UNIVERSIDADE DE SÃO PAULO

FACULDADE DE ARQUITETURA E URBANISMO

\title{
PROJETO FAUS
}

ensaios no campo ampliado do ensino de arquitetura em São Paulo

José Maria de Macedo Filho

tese apresentada à Faculdade de Arquitetura e Urbanismo da Universidade de São Paulo para obtenção do título de Doutor em Arquitetura e Urbanismo

área de concentração Projeto de Arquitetura

Prof $^{a}$. Dra. Helena Ayoub Silva orientadora

São Paulo 
Autorizo a reprodução e divulgação total ou parcial deste trabalho, por qualquer meio convencional ou eletrônico, para fins de estudo e pesquisa, desde que citada a fonte.

José Maria de Macedo Filho

(macedofilho@usp.br)

Macedo Filho, José Maria de

Projeto FAUS, ensaios no campo ampliado do ensino de arquitetura em São Paulo / José Maria de Macedo Filho; orientadora Helena Aparecida Ayoub Silva. São Paulo, 2020.

$350 \mathrm{p}$.

Tese (Doutorado) - Faculdade de Arquitetura e Urbanismo da Universidade de São Paulo. Área de concentração: Projeto da Arquitetura.

1. FAU-Santos. 2. Baixada Santista. 3. Arquitetura. 4. Pedagogia. 5. Política. 6. Ideologia. 7. atelier. I. Silva, Helena Aparecida Ayoub, orient.

II. Título. 


\section{RESUMO}

PROJETO FAUS, ensaios no campo ampliado do ensino de arquitetura em São Paulo Esta pesquisa apresenta como tema o ensino de arquitetura desde o processo de formação da Faculdade de Arquitetura e Urbanismo de Santos (FAUS). O contexto é o da expansão do ensino privatizado nos anos 1970 em São Paulo que, em um movimento de migração docente dirigido pela FAU-USP, escolas existentes e escolas em formação influenciaram umas às outras, simultaneamente e em todas as direções. Objetiva-se contribuir para o debate crítico e histórico a respeito da formação do arquiteto nas universidades brasileiras e seus reflexos na discussão da prática profissional do país. Investiga os meios de comunicação do processo de produção da arquitetura, entendido como uma operação que oscila entre a lógica e a intuição, tendo a cidade como principal campo de ação do arquiteto. Para tanto, apoia-se na coleta e observação de dados relativos à atuação acadêmica e da prática profissional de estudantes, egressos e professores da FAUS, centrado na Região Metropolitana da Baixada Santista e visando o conhecimento da conjuntura em que ocorreram e das estratégias que tornaram possível a sua realização. Dessa maneira, indica que o estabelecimento de alianças ideológicas, políticas e pedagógicas entre instituições e grupos de docentes e discentes na relação ensino-aprendizagem, focado na atividade prática do projeto em atelier, possivelmente consolidou o modo paulista de pensar e fazer arquitetura.

Palavras-chave: FAU-Santos; Baixada Santista; arquitetura; pedagogia; política; ideologia; atelier. 


\section{ABSTRACT}

FAUS PROJECT, essays in the expanded field of architecture education in São Paulo.

Teaching in Architecture, from the beginning of the Faculdade de Arquitetura e Urbanismo de Santos (FAUS), is the core theme of this work. During the expansion of the privatized education centers along the 1970's across the State of São Paulo, constant movements and migrations of teachers from the FAU-USP and diverse educational schools that were arising on these days - caused deep influences between all the members involved, simultaneously and in all directions. This work wants to achieve the most relevant climate to develop and stimulate a reviewing and historical debate about the educational process of Architecture in Brazilian universities and the direct reflections in the practice of the discipline. The means of communication of the productive process in Architecture were understood as an operation that oscillates between logic and intuition in a main field called city where architects act. In order to reach this comprehension, this work collected and analyzed the archive of the FAUS - the production of students, graduates and teachers based on the metropolitan region of Santos - elucidating the situation and the strategies that made these interactions possible. Therefore, it states the establishment of ideological, political and pedagogical alliances between institutions and groups of teachers and students in a teaching-learning relationship based on a practical activity of architectural design located in "the atelier", an open space in FAUS. It possibly consolidated the São Paulo way of thinking and practice in architecture.

Keywords: FAU-Santos; Baixada Santista; architecture; pedagogy; politics; ideology; studio. 


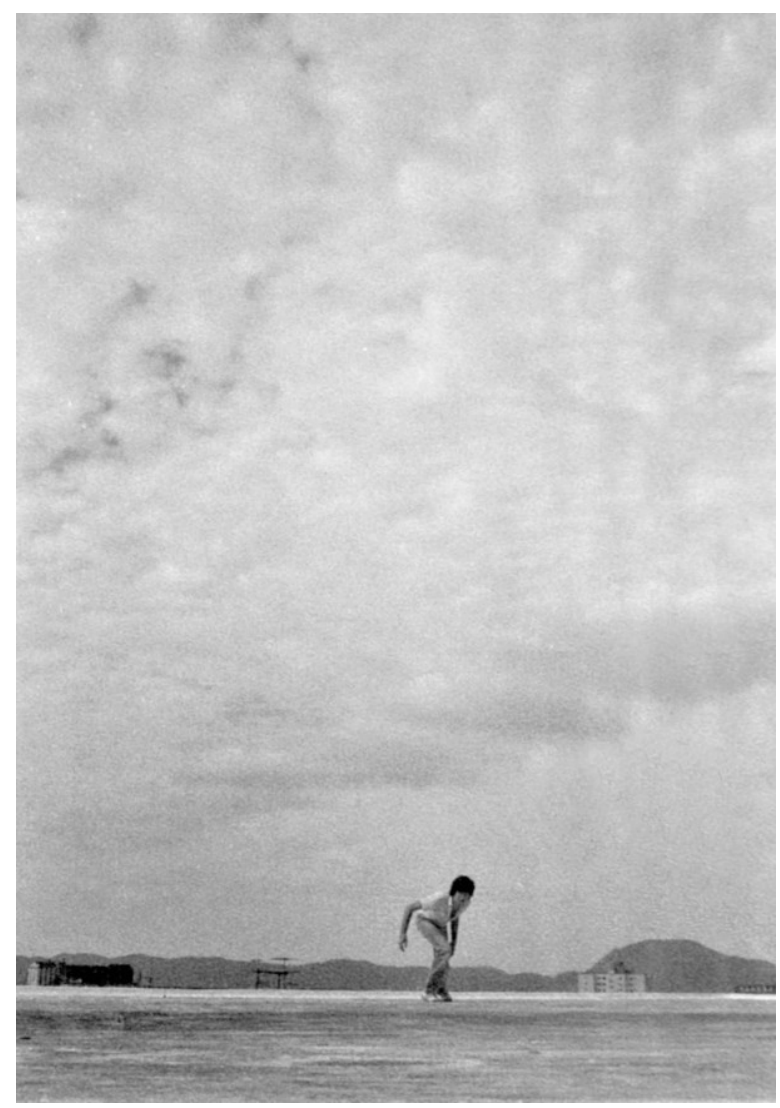

1981

O estudante na cobertura do prédio da FAUS percorre velozmente a cidade com seu skate. Sobre a linha do horizonte, a técnica o mantém equilibrado e a intuição o guia através do desconhecido. 


\title{
AGRADECIMENTOS
}

\author{
À Universidade de São Paulo. \\ À minha querida orientadora Helena Ayoub por todas as provocações. \\ Ao amigo Ragde Etned. \\ Aos professores Edgar Gonçalves Dente, Julio Katinsky, Jon Maitrejean, Artur Rozestraten, Maria Amélia Devitte Azevedo, \\ Antônio Carlos Barossi, Orestes Bortolli, Paulo Fonseca, Jorge Bassani, Luiz Américo Munari, Hugo Segawa, Mônica \\ Junqueira, Camila d'Otaviano, Miguel Pereira (in memorian) e aos colegas Sergio Matera, Luiz Junqueira e Erick Vicente.
}

Aos alunos e ex-alunos da FAUS. Aos colegas e professores da Universidade Católica de Santos Marcos Medina, Orpheu Zamboni, Gino Caldatto, Maria Helena Flynn, Francisco Petracco, Apoena Amaral, Juan Cabello Arribas, Moracy Amaral, Carlos Antunes, Fernando Cabral, José Claudio Paneque, Marcos Piffer, José Gomes Soutello, Fabio Serrano, Edison Eloy, Sergio Novita, Ruy Debs Franco, Leila Diêgoli, Ney Caldatto, Sebastian Beck, Denis Joelsons, Debora Blanco, Clarissa Souza, Denis Ferri, Fabio Onuki, Cléber Ferrão, Fernanda Britto, Ana Salvi, Alfred Talaat, José Marques Carriço, Mônica Viana, Lenimar Rios, João Meyer, Renato Carrieri, Marcos Acayaba, Ricardo Granata, Frédéric Lebois, Vera Domschke, Paulo Von Poser, Cassia Magaldi, César Luiz Mazacoratti, Márcio Brasil, Paulo Pignanelli, Ernesto Walter Theodor, Mauricio Azenha, Denise Alcântara, César Capasso, Levi Bucalem, Denise Ruprecht, Carlos Prates, Gustavo Maia Rodrigues, David Gheleter. Aos arquitetos da FAUS Lélio Kolhy, Luisa Alegria, Eber de Gois, Maria Orlando, Newma Bitencourt, Sergio Waissmann, Alexsandro Ferreira, Ricardo Andalaft, Juliana Azevedo, Fernando Arouca, Caetano Greco e Rafael Mendes. A todos os arquitetos egressos que responderam ao questionário. Às queridas Claudia Maciel, Marcia Leite, Dona Dirce, Viviane Santos, Franciele Oliveira, Raquel Nunes, Marilza e Mônica Assis.

Aos alunos, ex-alunos, colegas e professores da Escola da Cidade Guilherme Petrella, Eduardo Ferroni, Cristiane Muniz, José Paulo Gouvêa, Luiz Mauro Freire, Fernando Viegas, Álvaro Puntoni, Anália Amorim, Ciro Pirondi, Pablo Hereñu, Felipe Noto, Valdemir Rosa, Marta Moreira, Guilherme Paolielo, Geraldo Puntoni, Fabio Valentim, João Clark Sodré, Juliana Braga, Maira Rios, Flavia Torres, Anna Junni, Paola Ornaghi, Gustavo Utrabo, Carlos Ferrata, Cesar Shundi, Francisco Fanucci, Mariana Boghosian Al Assal, Pedro Tuma, Marco Artigas, Pedro Freire, Pedro Vada, Joaquim Gak e Roberto Pompéia.

À Alina del Castillo, professora de Teoria da Arquitetura da Universidad de la República (FAU-UDELAR). Aos professores Luciano Margotto, Carlos Hernandez Arriagada e Ruth Verde Zein, da Universidade Presbiteriana Mackenzie. Ao professor Ciro Miguel, do Swiss Federal Institute of Technology in Zurich (ETH-Zurich). Ao professor Jimmy Efrén Liendo, da Universidad Nacional de San Agustín de Arequipa (UNSA - Peru). Aos professores Reinaldo Ledgard, Paulo Dam Mazzi e Mariana Leguia, da Pontifícia Universidad Católica del Peru (PUCP). Ao professor Héctor Fernández Elorza, da Escuela Técnica Superior de Arquitectura - ETSAM (UPM-Madrid). À Gabrielly Silva e Marina Saboya.

Aos companheiros de escritório, pela imprescindível ajuda cotidiana, querido amigo Dhiego Torrano, Matheus Pardal, Bruna Tavares, Milena Santos, Rafael Pereira e Ricardson Ricardo.

Aos meus pais Nair Campos e José Maria de Macedo, e familiares: Fernando Macedo e Ellen, Pedro e Gabriel Malteze, Jorge Manuel Souza e Lygia Resende, Lia Sousa e Maria Cristina Costa (in memorian), Paulo Arbeli e Priscila Costa, Heraldo Prado e Viviane Costa, Lina.

Em especial, à Christiane, Manuela e Cecília. É a elas que dedico este trabalho. 


\section{SUMÁRIO}

INTRODUÇÃO

015

Capítulo 1

ENTRADA

023

1.1 A dimensão política e pedagógica do atelier

025

1.2 Processamento brasileiro

041

1.3 Contribuição paulistana

051

1.4

Uma escola necessária

063

Capítulo 2

DOBRA

073

2.1 Alianças estruturantes: a fundação da FAUS

079

2.2

Refugiados do ensino

091

2.3

Projeto como instrumento de sustentação política

107

2.4

Edifício como síntese pedagógica

Capítulo 3

\section{CONTINUIDADE}

145

$\begin{array}{ll}3.1 & \text { Resistência e afirmação } \\ 3.2 & \text { Fragmentação curricular e espacial } \\ 3.3 & \text { Identificação comunitária } \\ 3.4 & \text { A dimensão projetual do atelier }\end{array}$

149

175

199

215

Capítulo 4

MAPA

231

$\begin{array}{ll}4.1 & \text { Cidade como laboratório } \\ 4.2 & \text { Legitimidade e distinção } \\ 4.3 & \text { Devolução caiçara } \\ 4.4 & \text { Projeto FAUS: dilatentur spatia veritatis }\end{array}$

233

249

259

275

CONSIDERAÇÕES FINAIS 



\section{INTRODUÇÃO}

Uma das características mais importantes do rizoma é ter múltiplas entradas [...] não começa nem conclui, encontra-se sempre no meio, e estar entre as coisas significa unicamente aliança. ${ }^{1}$

O problema principal desta pesquisa é a verificação da relevância da Faculdade de Arquitetura e Urbanismo de Santos (FAUS) no ensino e na produção da arquitetura e do urbanismo na Região Metropolitana da Baixada Santista (RMBS). Fundada em 1970, resultou de uma série de alianças ideológicas, políticas e pedagógicas firmadas pelo engenheiro-arquiteto Oswaldo Corrêa Gonçalves (POLI-USP, 1941) com diferentes instituições, majoritariamente, com docentes e egressos da Faculdade de Arquitetura e Urbanismo da Universidade de São Paulo (FAU-USP). Desse modo, com o objetivo de formar quadros profissionais de arquitetos para atuarem nas cidades do litoral de São Paulo, o projeto para a FAUS foi elaborado sob a égide cultural da FAU-USP que, por sua vez, ao se emancipar da Escola de Engenharia Politécnica, em 1948, consolidava seu projeto pedagógico influenciada por outras escolas no Brasil e no exterior, sobretudo, pela Bauhaus de Weimar/Dessau e pelos VKhUTEMAS russos. Ambas difusoras do ideário da arquitetura moderna internacional do início

${ }^{1}$ Trata-se de um movimento transversal que carrega uma e outra coisa, "riacho sem início nem fim, que rói suas duas margens e adquire velocidade no meio". DELEUZE, Gilles. GUATTARI, Félix. Mil platôs, capitalismo e esquizofrenia. Vol. 01, 1995. p. 37. (grifo nosso). 
do século XX, pautadas pelo viés socialista e através do método do aprender fazendo, posicionaram o atelier como o lugar para o processamento da síntese entre a arte e a técnica.

A contextualização histórica do projeto para a FAUS remonta ao período da ditadura militar e do "milagre econômico" brasileiro, observado nas décadas de 1960 e 1970. Época de grande demanda pelo ensino superior que o Estado não foi capaz de suprir e que, amparado na reforma universitária idealizada no acordo MEC-USAID, autorizou o capital privado a oferecer cursos superiores. Assim sendo, em 1970, no estado de São Paulo foram fundadas a Faculdade de Arquitetura e Urbanismo de Santos (FAUS), a Faculdade de Arquitetura e Urbanismo da Universidade Brás Cubas (FAU-UBC) e a Faculdade de Arquitetura de São José dos Campos (FAU-SJC), todas com professores da FAU-USP, da FAU-Mackenzie e da FAU-UnB, envolvidos na elaboração dos seus projetos pedagógicos. Em linhas gerais, esses professores viram esse processo como uma real oportunidade de expansão dos horizontes didáticos observados até então.

Nesse sentido, a ideia é que muitos arquitetos formados pela FAU-USP lecionavam na própria FAU e foram fundadores e ou professores das novas escolas do estado de São Paulo, que também passaram a formar novos arquitetos e novos professores. Esses grupos, desde sua experiência de formação, ao repetirem, transformarem ou experimentarem metodologias de ensino, naturalmente, contribuíram na difusão do ideário da arquitetura moderna internacional, gerando uma espécie de campo expandido. Com efeito, pressupor a ampliação de um campo é o mesmo que confirmar sua abrangência ou espalhamento, no caso, o fazer e ensinar arquitetura. Interessa, portanto, verificar o processo contrário, de convergência, da observação de minúcias, especificidades desses fragmentos no âmbito do conhecimento coletivo, para identificar a contribuição do específico para o conjunto.

Indo nessa direção, a pesquisa procura investigar em que medida, através da migração dos grupos de professores pioneiros, os ideais políticos e ideológicos da FAU-USP, especialmente os polarizados no fórum de 1968 entre Vilanova Artigas e Sérgio Ferro, encontraram ou não campo de expansão fora da capital com a abertura dos novos cursos de arquitetura pela iniciativa privada. No que se refere ao objeto desta pesquisa, importa saber como se deu o desdobramento das alianças firmadas por Oswaldo Corrêa Gonçalves entre professores com visões heterogêneas e divergentes reunidos pelo mesmo objetivo, o ensino da arquitetura. Aprofundando a investigação, vale observar qual é a relevância do contexto social, geográfico e espacial, bem como do caráter político e administrativo institucional, na formação do estudante de arquitetura e seus possíveis reflexos na elaboração dos currículos e projetos pedagógicos dos cursos. Sobre esse ponto e indo além, acredita-se que a formação acadêmica, a prática profissional e a experiência individual de cada professor, aliadas à capacidade de adaptação e participação do corpo discente nos processos de ensino-aprendizagem, 
além de decisivos na elaboração das estratégias de educação, conferem identidade própria para o curso.

O que se pretende é oferecer insumos que possam ser cruzados com os de outras instituições, contextualizando e estabelecendo parâmetros comparativos para uma possível contribuição ao debate crítico e histórico a respeito da formação do arquiteto nas universidades brasileiras e seus reflexos na discussão da prática profissional do país. Assim como auxiliar na busca de novos meios de comunicação dos processos de produção da arquitetura que opera entre elementos intuitivos e analíticos, entre o geral e o particular, considerando o contexto territorial, histórico e cultural da cidade, como principal campo de ação do arquiteto.

No que se refere aos aspectos metodológicos, vale dizer que o trabalho foi elaborado a partir da perspectiva de quem produz o projeto de arquitetura no âmbito profissional ao mesmo tempo que exerce a docência. Resulta do esforço para imbricar elementos do universo acadêmico com as questões da prática do ofício em um processo de retroalimentação desejável para o seu ensino. Entretanto, o envolvimento pessoal com a FAUS - como estudante de 1995 a 1999 e, desde 2003, na condição de professor - somado à necessidade de expandir o campo de investigação, do específico para o universal apoiado em bases claras e bem delineadas, exigiram algumas ponderações mais cuidadosas sobre a relação entre objeto de estudo e pesquisador.

Assim, a primeira reflexão, de ordem cronológica, estabeleceu uma divisão temporal dos 50 anos de existência da FAUS em dois períodos distintos: de 1970 até 1995, relativo aos 25 anos iniciais de atividades da escola, aqui denominado como "circunstância histórica" e, de 1995 a 2020, referente ao decurso dos 25 anos de vivência pessoal, é admitido como "crítica narrativa". Tal proposição expõe uma questão de ordem metodológica, na medida em que identifica os termos "história" e "crítica", seguida por um problema de natureza comportamental, o compromisso "ético" em relação à essência dos valores, normas e prescrições presentes no contexto do objeto de estudo. Indo nessa direção, a segunda ponderação surgiu da reflexão acerca do comportamento ético determinando que a história fosse abordada como projeto, não como desvelamento de fatos, ou seja, uma operação de projeto entendida como pesquisa-crítica, capaz de reconstituir no presente, elementos da história com o propósito de construir caminhos para o futuro.

Essa argumentação, ao se apoiar na convicção de que toda ação projetual possui intenção, que não constitui uma operação neutra ou imparcial feita a partir de princípios de isenção, pretende equalizar a questão relacionada aos termos "história e crítica". Projeto é, antes de tudo, uma ação crítica, permite múltiplas entradas e, apresenta-se aqui como um instrumento de diálogo. Contudo, ainda restando alguns impasses para a melhor abordagem de um assunto com diversas aberturas e 
interpretações, recorreu-se, em favor da clareza e por cautela, ao que Waisman pensa sobre essa questão:

\begin{abstract}
A ciência histórica não é mera reprodução do que aconteceu. Não poderia sê-lo, mesmo a partir de um ponto de vista estritamente pragmático, pela impossibilidade de conter a totalidade dos fatos, objetos e acontecimentos. Uma seleção é indispensável, ainda que apenas para reduzir a totalidade a uma dimensão compreensível. Em seguida virão a organização, as articulações, as valorizações, por meio das quais se tentará dotar de sentido o panorama traçado. Porque a história não é simples narração: é uma sucessão de juízos. ${ }^{2}$
\end{abstract}

Isso posto, e com um pouco mais de segurança, é possível afirmar que a construção da circunstância histórica de um determinado objeto, mesmo com toda sua especificidade, ao aplicar com clareza e seguir com rigor procedimentos metodológicos pré-estabelecidos, pode gerar universais para o estudo de outros objetos similares. Por outro lado, constitui uma tarefa complexa com múltiplas e simultâneas formas de enfrentamento, cujo desdobramento, inevitavelmente, gera subtemas e, portanto, novas frentes de pesquisa.

Diante desse problema, como estratégia, primeiro se pensou em estabelecer um recorte de tempo centrando o esforço em um determinado período julgado relevante, mas ao considerar que se trata de uma escola em vias de completar cinquenta anos de atividade e que não dispõe de nenhuma publicação coesa sobre sua existência e produção, percebeu-se que isso enfraqueceria a questão central e, portanto, foram descartados recortes temporais. Ainda nessa direção, ao cogitar que a investigação pudesse focar no ensino do projeto, recaiu-se no mesmo dilema anterior: reconstituir e sistematizar ineditamente o percurso histórico de uma escola de arquitetura e abordar apenas a disciplina de projeto poderia reduzir o entendimento do conjunto. Mas, ao se apoiar na noção do projeto como pesquisa crítica-reflexiva, seguido de ações produtivas para a síntese dos conhecimentos adquiridos ao longo do seu processo de elaboração, percebeu-se que se trata de uma ciência universal, não apenas um saber disciplinar. Assim sendo, valendo-se de Naruto, o objetivo é entender "o ensino de arquitetura como ensino de projeto." ${ }^{3}$

Com o objetivo de dar organicidade ao encadeamento da pesquisa, foi proposto um axioma considerado inicialmente de fácil comprovação: "A FAUS é uma derivação da FAU-USP". Tal evidência poderia ser constatada com a observação da documentação pesquisada, no desenho da sua primeira estrutura curricular e na própria composição do quadro docente pioneiro. Contudo, o trabalho, no decorrer da sua elaboração, foi alimentado continuamente por novas questões apontadas nas orientações, nas disciplinas cursadas, na banca de qualificação, nos seminários de pesquisa ocorridos ao longo do programa e que, juntamente às análises do material pesquisado, exigiram algumas

\footnotetext{
2 WAISMAN, Marina. O interior da História: historiografia arquitetônica para uso de latino-americanos. São Paulo: Perspectiva, 2013. p. 3.

${ }^{3}$ NARUTO, Minoro. Repensar a Formação do arquiteto. 2006. 129p. Tese (doutorado em arquitetura e urbanismo) - Faculdade de Arquitetura e Urbanismo da Universidade de São Paulo. São Paulo, 2006. pp. 89 - 90.
} 
alterações. Nesse sentido, segundo a arquiteta Ruth Verde Zein, o processo de investigação para a construção de uma identidade, seja qual for, ao partir da noção de derivação, corre o risco de ser excludente e reducionista nas escolhas e sucessão de juízos e, portanto, a linha de pesquisa deve partir de um princípio aberto, autônomo, próprio e multidisciplinar. Nas suas palavras: "quando uma escola nasce, ela já é." ${ }^{4}$

A simplicidade e nitidez da expressão de Verde Zein expôs um problema que, provavelmente por falta de clareza, ao propor a FAUS como derivação da FAU-USP, fortuitamente, a FAU-USP posicionava-se como o objeto de estudo central e a FAUS, de maneira contraditória, era posta em segundo plano. Substituiu-se o termo derivação, atrelado à ideia de gênese, origem e filiação, pela noção de aliança, associada ao conceito de acordo para auxílio mútuo. Dessa maneira, a FAUS passou a ser o objeto de estudo da pesquisa e a FAU-USP o ponto de apoio para a verificação das relações políticas e ideológicas estruturantes do processo de expansão do ensino. A partir dessas formulações, e no âmbito desta pesquisa, admitiu-se que a realização do ensino institucional da arquitetura depende de quatro elementos fundamentais: do estudante, do professor, de uma pedagogia e de um espaço.

Tendo isso em vista, os procedimentos metodológicos estabelecidos foram pautados pela busca de caminhos mais do que respostas absolutas, pois essas correm o risco de serem conclusivas e fechadas, ao passo que o caminho é aberto, pressupõe escolhas formais e intuitivas simultaneamente, percorrer caminhos é o fazer do arquiteto, trata do imponderável, dificilmente descrito com precisão. Dessa maneira, a natureza epistemológica dessa abordagem se vale da produção, observação e leitura de material desde entrevistas, depoimentos, enquetes, documentos originais e inéditos em acervos particulares e públicos, fontes bibliográficas, ensaios e textos teóricos relacionados ao tema, para o reconhecimento do corpo docente, corpo discente, sedes da escola e sua estrutura pedagógica.

Assim, a noção geral que permeia a estrutura desta tese é a de que o ensino de arquitetura é dirigido por princípios políticos, pedagógicos e ideológicos que dependem de alianças entre diversos grupos, instituições e formações sociais, mas sobretudo àquela entre docentes e discentes para sua pesquisa, aprendizagem e produção. Nesse sentido, a consciência de que arquitetura se faz com muitas mãos oferece a oportunidade de recorrer, como ponto de apoio teórico, aos conceitos de conexão, heterogeneidade, multiplicidade, ruptura a-significante, cartografia e decalcomania que constituem os seis princípios do Rizoma. Trata-se de uma teoria pós-estruturalista do conhecimento que, formulada e escrita a dois, ou seja, a quatro mãos, pelos filósofos Gilles Deleuze e Felix Guattari,

\footnotetext{
${ }^{4}$ Em uma conversa informal com Ruth Verde Zein, pouco antes de iniciar um seminário organizado pelo HABITAFAUS (Laboratório de Habitação da Faculdade de Arquitetura e Urbanismo de Santos) "Conversas com estudantes" no dia 09 de outubro de 2017 , no prédio da FAUS.
} 
grosso modo, valoriza o múltiplo a partir de uma determinada entrada, uma raiz capaz de expandir, conectar, romper e não perder o vínculo com o uno inicial.

É preciso fazer o múltiplo, não acrescentando sempre uma dimensão superior, mas, ao contrário, da maneira simples, com força da sobriedade, no nível das dimensões de que se dispõe, sempre $n-1$ (é somente assim que o uno faz parte do múltiplo, estando sempre subtraído dele). Subtrair o único da multiplicidade a ser constituída; escrever $\mathrm{n}-1$. Tal sistema poderia ser chamado de rizoma. ${ }^{5}$

Vale dizer que formulações no campo da filosofia extrapolam os objetivos deste trabalho, por isso o modelo dos filósofos franceses foi tomado por empréstimo e utilizado como imagem para relacionar os seis princípios do rizoma descritos ao conteúdo aqui investigado. Em um esforço de síntese, esses princípios se converteram em quatro universais que dão nome, portanto identidade, aos quatro capítulos que compõem este trabalho, a saber: entrada, dobra, continuidade e mapa, contribuindo para o delineamento da teoria principal dessa tese, expressada através da fixação do seguinte paralelismo:

O primeiro capítulo, ao ser associado aos princípios de conexão e de heterogeneidade, é denominado Entrada, pretende configurar um ponto de apoio teórico para sustentação da argumentação desenvolvida no trabalho. Procede uma breve revisão das premissas pedagógicas praticadas no início do século XX na Europa, suficiente para iluminar de maneira geral o processo de constituição, consolidação e ensino da profissão de arquiteto no Brasil, especialmente em São Paulo, que culminou com a emancipação do ensino de arquitetura em relação às escolas de artes e de engenharia. Destaca-se a contribuição de Vilanova Artigas através de sua firme confiança no atelier como um lugar motivador das relações sociais, políticas e pedagógicas da escola e trata das premissas constituintes do projeto para a FAUS, elaborado ao longo dos anos 1960 pelo arquiteto Oswaldo Corrêa Gonçalves para formar quadros profissionais para a Região da Baixada Santista.

O segundo capítulo, nomeado Dobra está associado ao princípio da multiplicidade. Discorre acerca das alianças firmadas por Oswaldo Corrêa com a FAU-USP e com a Sociedade Visconde de São Leopoldo (SVSL), mantenedora das Faculdades Católicas de Santos. Aborda os processos, fundação e consolidação da FAUS no contexto da expansão do ensino superior nos anos 1970, observando a atuação ideológica e política do heterogêneo grupo pioneiro de docentes oriundos da FAU-USP na estruturação inicial do curso. A escola se desloca pela cidade até projetar e construir sua sede própria. A concepção desse edifício, do ponto de vista construtivo e conceitual, estava alinhada aos princípios da produção da escola paulista de arquitetura do início dos anos 1970.

O terceiro capítulo foi associado ao princípio da ruptura a-significante e intitulado Continuidade. Pretende demonstrar o gradual processo de consolidação política e pedagógica da FAUS em um 
cenário de vigilância militar controlando e reprimindo estudantes e professores. Foram anos de intensos debates, marcados por crises que se converteram em oportunidades, contribuindo para a formação da identidade da escola. Com a estruturação da Universidade Católica de Santos, em meados dos anos 1980, o caráter comunitário da instituição permitiu que a FAUS estendesse suas atividades do âmbito local para o regional. O prédio sofreu uma série de reformas, atreladas ou não, às constantes alterações e exigências curriculares promovidas pelo Ministério da Educação, e o atelier da FAUS se consolida como o centro de gravidade da escola por sua capacidade de produção.

O quarto e último capítulo, associado aos princípios de cartografia e decalcomania, como um Mapa e ao modo de um ensaio, pressupõe maior liberdade para a observação e experimentação, tanto do pensamento, como do projeto para, a partir da leitura dos dados coletados acerca da constituição e consolidação do perfil cultural da FAUS, delinear um panorama sobre a sua produção e consequente relevância da atuação profissional e do ensino de arquitetura de seus docentes e egressos no contexto da Região Metropolitana da Baixada Santista. Por último trata da relação entre espaço e pedagogia no contexto do ensino da arquitetura e do urbanismo contemporâneos.

Em síntese, devido à natureza do tema, marcado com idas e vindas no tempo, assuntos ramificados, configurando um caleidoscópio de difícil posicionamento das questões centrais da investigação, os capítulos estão organizados da seguinte maneira: abertura do tema; exame de significados e conceitos análogos ou contrapostos à ideia central; desenvolvimento dos assuntos, apoiado ou não em material empírico analisado; considerações finais e parciais ao capítulo.

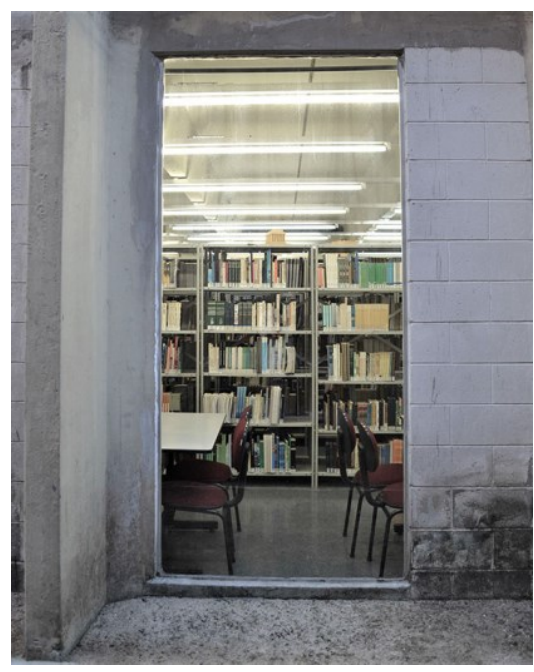


ENTRADA

O princípio de conexão e o princípio de heterogeneidade determinam que qualquer ponto de um rizoma pode ser conectado a qualquer outro ponto e deve sê-lo. ${ }^{1}$

Este capítulo pretende construir, a partir de subsídios históricos e conceituais, uma base teórica mínima para sustentar as reflexões desenvolvidas nesta pesquisa. Para tanto, busca identificar aberturas ou entradas que possibilitem revisar os impactos e desdobramentos no Brasil dos fundamentos pedagógicos praticados em duas escolas de arquitetura europeias, ambas criadas no início do século XX: os VKhUTEMAS na extinta União das Repúblicas Socialistas Soviéticas e a Staatliches-Bauhaus de Weimar, na Alemanha. Acredita-se que essa breve reavaliação histórica, grosso modo, centrada na investigação de metodologias de ensino próprias do complexo artetécnica, seja suficiente para iluminar questões que, indo um pouco além, estão relacionadas com o estabelecimento de alianças ideológicas e políticas para a prática didática e profissional da arquitetura.

${ }^{1}$ DELEUZE, Gilles; GUATTARI, Félix. Mil platôs, capitalismo e esquizofrenia. Vol. 01. São Paulo: Editora 34, 1995. p.15. 
Em São Paulo, os primeiros reflexos dessas experiências ocorreram no período de luta, no âmbito nacional pela conquista da autonomia da educação e da profissão do arquiteto, e influenciaram as reformas de ensino realizadas pela FAU-USP posicionando o atelier no centro de todas as atividades didáticas da escola a partir de 1962. Interessa verificar em que medida os debates entre professores e estudantes da FAU-USP foram capazes de gerar o lastro de sustentação ideológica, política e pedagógica que permitiu a associação com outras instituições como, por exemplo, a FAU-Mackenzie e o IAB/SP no processo de expansão do ensino privatizado de arquitetura a partir de 1970.

Nesse contexto, o projeto para o estabelecimento de uma faculdade de arquitetura e urbanismo em Santos, terceira escola no estado de São Paulo, foi elaborado ao longo dos anos de 1960 e tinha como principal objetivo formar quadros profissionais para a Região da Baixada Santista. Além de todo o empenho e esforço coletivo de arquitetos e professores da FAU-USP e da FAU-Mackenzie no desenho dessa nova escola, destaca-se a contribuição do arquiteto Oswaldo Corrêa Gonçalves que, a partir de sua fecunda amizade com o arquiteto João Baptista Vilanova Artigas, revelou-se um habilidoso agente motivador das relações sociais, políticas e pedagógicas oferecidas pela prática da arquitetura. 


\section{A dimensão política e pedagógica do atelier}

Ao admitir que o projeto de arquitetura é a síntese de um conjunto de elementos lógico-intuitivos, cuja complexa cadeia de decisões é demonstrada na prática, muitas vezes coletiva e em atelier, impõe-se um rápido recuo no tempo, uma vez que se apresentam como objeto de estudo duas experiências pedagógicas inovadoras nesse campo, praticadas no início do século XX na Europa oriental e ocidental. Ambas foram pioneiras na ruptura com o ensino tradicional acadêmico praticado em escolas de arte ou em institutos técnicos e tinham como objetivo comum a construçãoarquitetura como síntese entre arte e técnica, uma tentativa de recuperação dessa antiga unidade que, segundo o professor Vilanova Artigas, "a separação entre arte e técnica se dá quando surge o Renascimento, ou antes, na baixa idade média, da necessidade de dividir técnicas e artes mecânicas e as belas artes". ${ }^{1}$

A primeira experiência, talvez a mais radical, surgiu na extinta União das Repúblicas Socialistas Soviéticas (URSS) no epicentro do processo de emancipação social e política do povo contra o estado czarista, e tinha como propósito equiparar a Rússia à Europa Ocidental em termos de desenvolvimento, pois apesar da mudança de paradigma proposta pela revolução industrial, potencializada na virada do século XIX para o século XX, o país ainda não estava preparado para a grande transformação e adequação da sociedade russa aos novos tempos e às novas formas de vida e de produção. Por não ser um fato isolado, mas uma manifestação com representantes de todas as áreas e camadas da sociedade, em outubro de 1917, culminou na Revolução Bolchevique ${ }^{2}$ que acabou por derrubar o estado vigente de Nicolau II.

Logo após a revolução de outubro, o ministério da educação soviético, órgão básico de controle das atividades educacionais, artísticas, de preservação de monumentos e de políticas culturais, criou o NARKOMPROS Narodnyi Komissariat Prosveshcheniya (Comissariado do Povo para a Instrução Pública). O mandato para a educação de massa foi enquadrado dentro de um projeto soviético de industrialização mais amplo, reorganizando todas as áreas da vida, das práticas artísticas às práticas trabalhistas, com base científica. Nesse sentido, o ministério realizou uma ampla e radical reforma

\footnotetext{
${ }^{1}$ Para o professor Artigas “Belas artes é uma inovação linguística [...] e em latim não consegui encontrar a expressão 'belas-artes'. Essa diferenciação entre arte e técnica é decorrente de dois impactos que se deram sobre a técnica durante a história. 0 primeiro deles é no aparecimento, na Grécia, da teoria, [...] ou da epistêmico-herética, provocando um profundo impacto sobre a noção de téchne na Grécia. O segundo impacto ocorreu no momento em que, no Renascimento, surge a crença de que tudo o que é construído deve ser construído sob princípios científicos". ARTIGAS, João Batista Vilanova. Caminhos da Arquitetura. São Paulo: Cosac Naify, 2004. pp. 197-198.

2 Tradução do termo russo большевик (Bolchevique), era utilizado para designar os integrantes de uma facção do Partido Operário Socialdemocrata Russo, liderada por Vladimir llyich Ulyanov, mais conhecido pelo pseudônimo Lênin, naquele momento recém-chegado do exílio na Suiça. Sobre a revolução russa, ver "Dez dias que abalaram o mundo", um testemunho vivo de John Reed, jornalista norteamericano filiado à causa comunista que narra no calor da hora os acontecimentos revolucionários daqueles dias. REED, John. Dez dias que abalaram o mundo. São Paulo: Penguin Classics/Companhia das Letras, 2010.
} 
educacional, cujo objetivo principal era educar a classe proletária emergente e desenvolver uma nova cultura artística capaz de atender às crescentes necessidades da produção industrial. ${ }^{3}$

Segundo a pesquisadora russa Anna Bokov, a primeira fase dessa reforma foi iniciada em 1918, ainda em meio a um conturbado cenário político e social, com o estabelecimento dos SVOMAS, acrônimo russo de SGKhM, Svobodnie Gosudarstvenya Khudozhestvennya Masterskia (Ateliers Artísticos Estatais Livres). Pode-se dizer que a origem de seu inovador modelo de ensino tem sua base de sustentação ideológica no processo de implantação do comunismo na Rússia e, desde sua abertura, a instituição ofereceu educação gratuita admitindo candidatos de origens desprivilegiadas, independentemente de gênero, talento artístico ou qualquer tipo de formação acadêmica: bastava serem alfabetizados. $O$ ensino era distinto das escolas de belas artes russas no sentido de aproximar a arte da técnica, pois enfatizava o trabalho coletivo em oficinas. ${ }^{4}$

Em 1920, na cidade de Moscou, Vladimir Lênin assinou um decreto que converteu os SVOMAS nos VKhUTEMAS, acrônimo russo de Vysshie Khudozhestvenno Tekhnicheskie Masterskie (Ateliers Superiores de Arte e Técnica), criados para formar profissionais e artistas qualificados para a indústria moderna. Concebidos como uma escola interdisciplinar composta de faculdades artísticas e industriais que tinham como objetivo a síntese entre arte e técnica. Dispunham de oito departamentos de arte e produção subdivididos da seguinte forma: arquitetura, pintura, escultura, gráfica, têxtil, cerâmica, madeira e metalurgia. A interdisciplinaridade entre esses departamentos foi viabilizada pelo currículo preliminar que consistia em quatro cursos primários: gráficos, cor, volume e espaço. $O$ curso preliminar tornou-se o elemento unificador da escola.
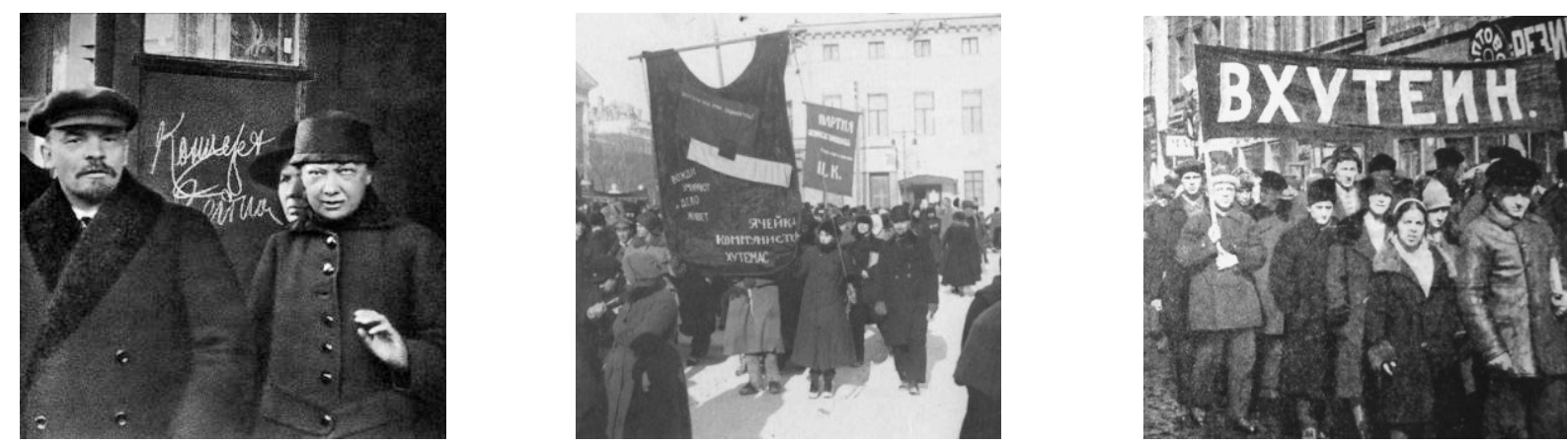

FIG. 01. Vladimir Lênin e sua companheira Nadezhda Krupskaya, feminista, pedagoga e dirigente bolchevique na Revolução Russa, criaram o novo sistema educativo soviético. Estudantes dos VKhUTEMAS - VKhUTEIN em manifestações pelas ruas de Moscou.

\footnotetext{
${ }^{3}$ Esse período também é estudado minuciosamente pelo historiador Jair Diniz Miguel em sua tese de doutorado sobre os Vkhutemas. MIGUEL, Jair Diniz. Arte, ensino, utopia e revolução: os ateliês artísticos Vkhutemas/Vkhutein (Rússia/URSS, 1920-1930). 2006. 404p. Tese (doutorado) - Faculdade de Filosofia, Letras e Ciências Humanas, Departamento de História, Programa de Pós-Graduação em História Social da Universidade de São Paulo. São Paulo, 2006. pp. 26-87.

${ }^{4}$ A arquiteta Anna Bokov é especialista no estudo das vanguardas russas do início do século XX e, como professora, tem feito uma série de experimentos aplicando os métodos dos VKhUTEMAS na Cooper Union - The Irwin S. Chanin School of Architecture, Nova York, NY. Tradução livre do texto BOKOV Anna. Institutionalizing the Avant-Garde: Vkhutemas 1920-1930. Walker Reader Magazine. Jun. 2017. não p. (tradução nossa). Disponível em: <https://walkerart.org/magazine/institutionalizing-the-avant-garde-vkhutemas-1920-1930>. Acesso em: 22 mar. 2019.
} 


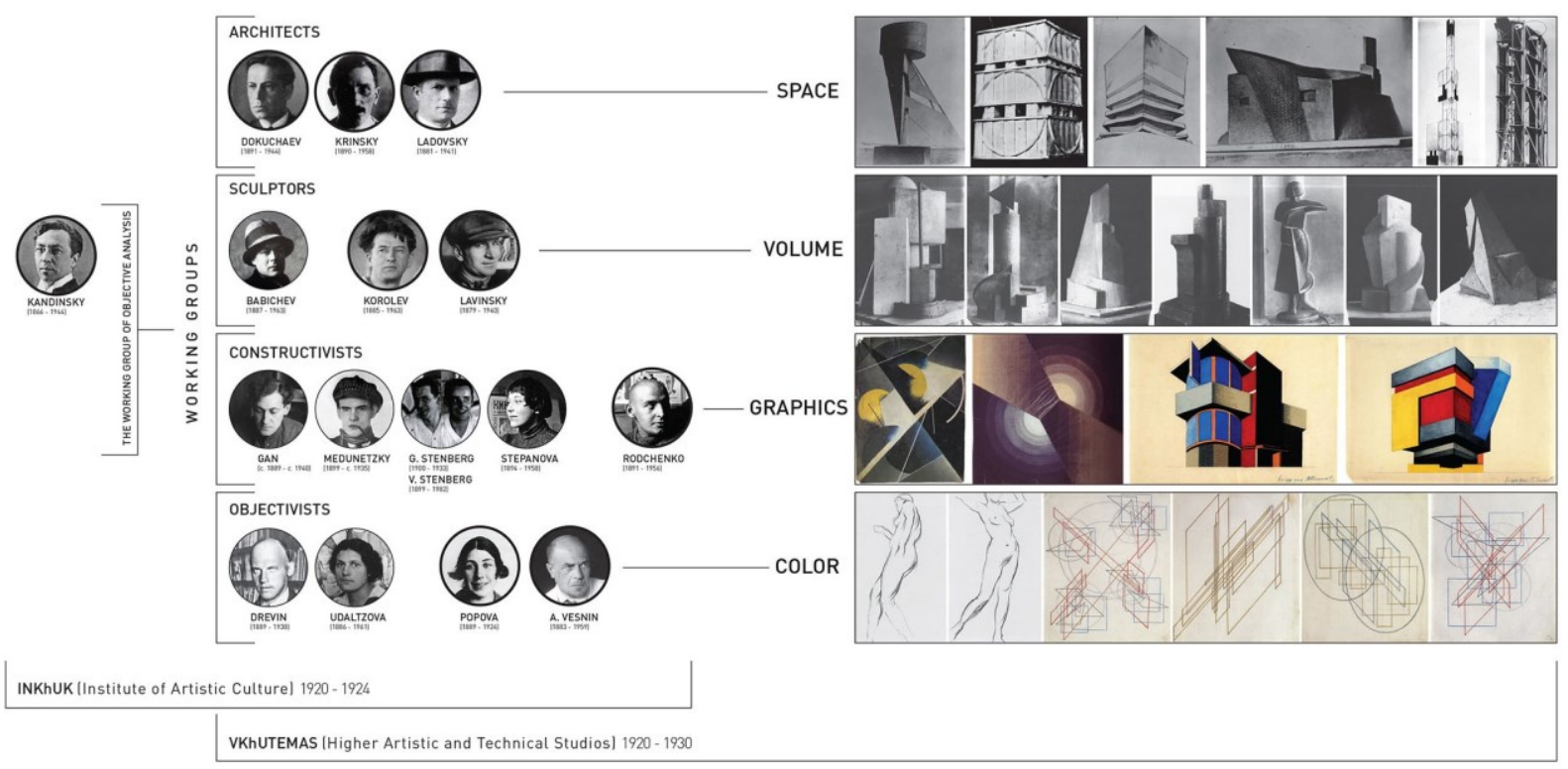

FIG. 02. Organização pedagógica dos VKhUTEMAS.

Segundo Komarova, a história dos VKhUTEMAS se divide em três fases distintas, com três reitores diferentes: Ravdel de 1920 até 1923, Favorsky de 1923 até 1926 e Pavel Novitsky a partir de 1926, momento em que a escola ganha o status de instituto e é denominada como VKhUTEIN. Pavel Novitsky ficou no comando dos institutos até a sua dissolução em 1930. Em seu quadro docente a escola contou com grandes nomes da vanguarda construtivista russa como Alexander Rodchenko e Varvara Stepanova, Alexander Vesnin e Lyubov Popova, Boris Korolev e Anton Lavinsky, Nikolai Ladovsky e Vladimir Krinsky, El Lissitzky e Vladimir Tatlin, Gustav Klutzis e Moisei Ginzburg. Os VKhUTEMAS introduziram um modelo de educação que constituiu um lugar para a vida coletiva, para o trabalho e para o desenvolvimento da criatividade. ${ }^{5}$

A segunda e mais conhecida experiência foi a praticada pela Staatliches-Bauhaus Weimar (Casa da Construção de Weimar), escola estatal de artes e arquitetura alemã, fundada pelo arquiteto Walter Gropius na República de Weimar em 1919. Ao longo de seus quatorze anos de atividade a Bauhaus teve suas sedes implantadas em três cidades distintas e, como diretores, três destacados arquitetos: o próprio Walter Gropius dirigiu a escola de 1919 até 1928, e foi quem permaneceu por mais tempo no comando e, inclusive durante o processo de mudança da cidade de Weimar, foi quem projetou a nova sede da escola, inaugurada em 1926, na cidade de Dessau. Dois anos mais tarde Gropius renunciou e foi sucedido pelo suíço Hannes Meyer, que permaneceu no cargo de 1928 a 1930 e, por último, de 1930 até a sua extinção em 1933, na cidade de Berlim, a escola alemã foi dirigida por Ludwig Mies van der Rohe.

${ }^{5}$ KOMAROVA, L. K. Die Archilektur-Fakultät der WCHUTEMAS und des W.CHUTEIN 1920 -1930. Weimar: Wissenschaftliche Zeitschrift / Hochschule für Architektur und Bauwesen, 1979. pp. 319-322. (tradução nossa). 
Gropius, logo depois de formado arquiteto, em 1907, apesar de não ter formação específica em pedagogia, constatou que "a formação do arquiteto, tal como praticada nas Escolas Técnicas Superiores e nas Academias de Arquitetura era insuficiente para prepará-lo para a solução dos problemas arquitetônicos do futuro" ${ }^{6} \mathrm{~A}$ inquietação provocada por essa constatação o levou a estudar esse assunto sistematicamente até perceber a dissonância entre o ensino enciclopédico e as exigências práticas que a ele se seguiam, e concluiu que era necessário aproximar as artes e a arquitetura das inovadoras tecnologias de construção oriundas das grandes transformações sociais daquele tempo. Em 1918, viajou para a URSS para divulgar a vanguarda expressionista alemã em uma exposição na cidade de Moscou e, nesse sentido, é provável que Gropius tenha conhecido os SVOMAS soviéticos que já haviam rompido com o ensino tradicional das escolas de artes.

Para compor o quadro docente da Bauhaus, entre 1919 e 1923, Gropius convidou artistas de renome internacional como Lyonel Feininger, Johannes Itten, Gerhard Marcks, George Muche, Oskar Schelemmer, Paul Klee, Wassily Kandinsky, László Moholy-Nagy, Lothar Schreyer, Walter Peterhans e Ludwig Karl Hilberseimer, além dos brilhantes ex-alunos Marcel Breuer, Herbert Bayer, Gertrud Arndt, Josef Albers, Joost Schmidt, Gunta Stölzl e Hinnerk Scheper. ${ }^{7}$ Como artistas livres, tinham a liberdade para expressar suas conviç̧ões e linguagens pessoais em suas oficinas.

Em 1919, o desejo de unificação da arte com a técnica estava descrito no manifesto de fundação da Bauhaus como um dos seus principais postulados: "O objetivo último de toda atividade artística é a construção". ${ }^{8}$ No que diz respeito ao conteúdo e à forma, esse princípio foi representado em um diagrama de organização pedagógica da escola sob a direção de Gropius, nele é possível verificar a divisão do ensino em três cursos: uma para aprendizes, outro para oficiais e o último para mestres. A forma concêntrica desse diagrama demonstrava o caminho que deveria ser percorrido pelo estudante ao ingressar no curso, tendo a construção como objetivo final, era obrigatório cursar o ensino preliminar - ministrado entre 1919 a 1923 por Johannes Itten e de 1923 a 1928 por Lásló Moholy-Nagy - com um semestre de duração. Ao término de três anos recebia o título de Oficial Artesão, o certificado era chancelado pela Câmara de Artesanatos e, eventualmente, pela própria Bauhaus. ${ }^{9}$

\footnotetext{
${ }^{6}$ Wick acredita que o despertar da vocação pedagógica de Gropius foi provocada por algum fator particular, não acadêmico, "uma experiência absolutamente pessoal”. WICK, Rainer. Pedagogia da Bauhaus. São Paulo: Martins Fontes, 1989. p. 95.

7 Extraído do quadro Cronologia da Bauhaus elaborado por Rainer Wick. Nesse quadro, além dos nomes dos professores, é possível observar o período de permanência de cada um deles na escola, as sedes de atuação e sua condição institucional, se era aluno, diretor, se estava licenciado ou sem regência de curso. O cruzamento desses dados com a biografia de cada deles, do ponto de vista metodológico, acabou por gerar material para Wick identificar, ou mesmo dimensionar, a sua relevância de atuação na construção da pedagogia da escola. WICK, Rainer. Pedagogia da Bauhaus. Op. cit. p.37.

${ }^{8}$ WICK, Rainer. Ibid. p.89.

${ }^{9}$ Gropius, "Idee und Aufbau des Staatlichen Bauhauses". In GROPIUS, Walter (ed) Staatliches Bauhaus Weimar 1919 - 1923 , Weimar/Munique, 1923. p.10. Apud. WICK, Rainer. Pedagogia da Bauhaus. Op. cit. p. 89.
} 
Os cursos nos VKhUTEMAS também eram organizados em ateliers interdisciplinares de arte e técnica, o curso preliminar durava dois anos, era claro e bem desenvolvido. A pedagogia do curso introdutório Espaço foi criada e ministrada por Nikolai Ladovsky desde a fundação da escola. Esse curso tornou-se tão importante que, a partir de 1923, passou a ser obrigatório para todos os ingressantes dos VKhUTEMAS, independente da especificidade do atelier escolhido pelo aluno. 0 curso Espaço, de maneira inovadora, suprimiu o programa e o lugar na proposição dos trabalhos do primeiro ano, os exercícios aplicados eram gramaticais com foco no desenvolvimento de habilidades básicas em arquitetura. Os estudantes produziam no atelier uma série de modelos de estudos a partir de instruções básicas explorando aspectos relacionados à materialidade e articulação da forma, espaço, volume, ritmo, estrutura, equilíbrio, massa e peso. Neste sentido, somente depois que estivessem familiarizados com a espacialidade abstrata, poderiam avançar para um nível mais complexo do curso que introduzia nos exercícios de projeto princípios de lugar e função. ${ }^{10}$

É notável a equivalência nas abordagens pedagógicas da Bauhaus e dos VKhUTEMAS, ambas tinham como objetivo comum fundir arte e técnica através de princípios construtivos em ateliers específicos. Estruturadas concentricamente, possuíam um curso preliminar de nivelamento e capacitação com ênfase na construção. Entretanto, ao comparar os diagramas de conteúdo dessas escolas, constatase que o atelier de arquitetura representa uma importante distinção. Desde o início de suas atividades, os VKhUTEMAS soviéticos tinham na sua estrutura curricular o curso de arquitetura junto aos demais ateliers específicos, apesar de o atelier de arquitetura, tanto o preliminar quanto 0 avançado, ser um dos mais fortes e inovadores da escola de Moscou. Ao passo que, na Bauhaus, apesar de todas as disciplinas artísticas serem consideradas componentes inseparáveis de uma nova arquitetura entendida como obra de arte unificada, permaneceu, como o próprio Gropius declarou, "um objetivo distante" posicionado no centro do seu diagrama de ensino, em vez de uma parte igual do currículo. O curso de arquitetura da Bauhaus foi iniciado somente em 1927.

Dentre os professores da Bauhaus, o pintor suíço Johannes Itten merece destaque por seu interesse em pedagogia e pelo caráter inovador de seus métodos aplicados no curso preliminar Vorkurs que, em síntese, consistiam em despertar a autonomia intelectual dos estudantes através da eliminação de todos os preconceitos acumulados em suas mentes ao longo da vida. Itten acreditava que somente despido de tais preconceitos o estudante estaria preparado para libertar todo o seu poder criativo através da abordagem intuitiva e sensível dos materiais e da natureza. 0 curso preliminar de Itten é considerado por muitos críticos como o eixo estruturante dos primeiros anos da Bauhaus e, segundo Reyner Banham, chegou a ser considerado a essência do método da Bauhaus.

${ }^{10}$ TSCHEPKUNOWA, Irina. WChUTEMAS - ein russisches Labor der Moderne: Architekturentwürfe 1920 - 1930. Berlim: Martin-Gropius-Bau, dez. 2014 / abr. 2015. Catálogo de exposição. pp. 6-14. (tradução nossa). 

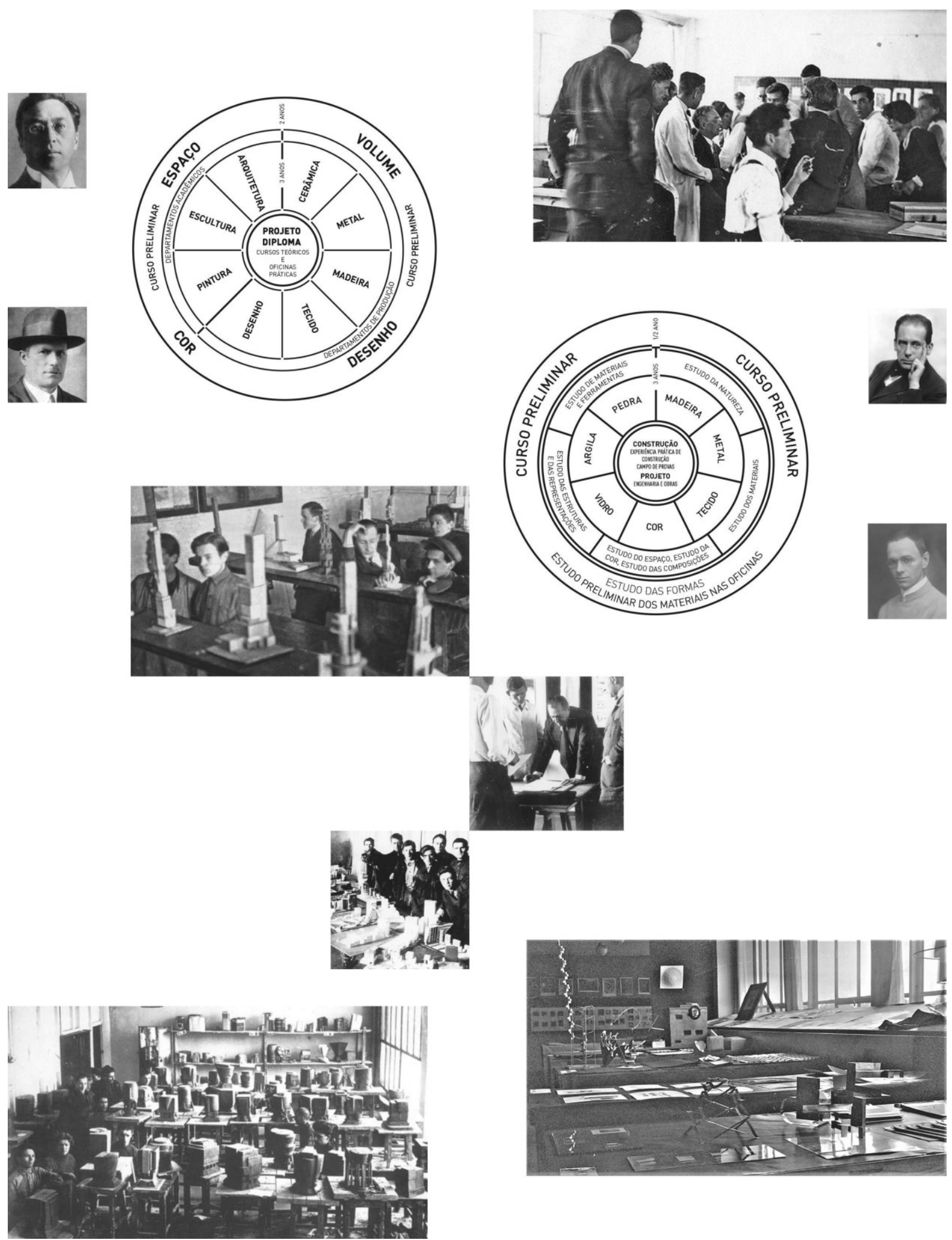

FIG. 03. À esquerda no topo, Wassily Kandinsky e Nicolai Ladovsky, ao lado, organização pedagógica dos VKhUTEMAS, URSS, 1923 e abaixo estudantes nos ateliers do curso espaço. À direita no topo, Wassily Kandinsky no centro com estudantes da Bauhaus, abaixo Walter Gropius e Johannes Itten, ao lado organização pedagógica da Bauhaus, Weimar, 1922, abaixo Mies Van der Rohe com estudantes e Atelier da Bauhaus. 
Seus objetivos foram descritos por Itten somente em 1922 por ocasião da exposição dos trabalhos dos aprendizes e oficiais da Bauhaus:

O curso preliminar diz respeito a toda a personalidade do aluno, uma vez que procura libertá-lo, fazer com que se erga sobre seus próprios pés, e lhe possibilita ganhar um conhecimento tanto do material quanto da forma através da experiência direta. Como questão de princípio, cada aprendiz tem de fazer seu próprio projeto. ${ }^{11}$

Por sua vez, no curso preliminar da escola Soviética, em oposição à visão espiritualizada de Itten, o professor Nicolai Ladovsky utilizava elementos racionais e psicanalíticos, baseados na percepção, na experiência e na economia de energia psíquica para desenvolver a fundamental necessidade humana de se orientar no espaço. Ladovsky sistematizou sua metodologia em um ensaio intitulado "Fundamentos da teoria da arquitetura", publicado em 1926, pela ASNOVA, acrônimo russo de Assotsiatsiya Novykh Arkhitektorov (Associação dos Novos Arquitetos), fundada por ele mesmo. Nesse texto, o arquiteto russo apresenta sua pedagogia como "racionalismo arquitetônico", um sistema análogo ao racionalismo técnico, mas operado a partir da percepção, ou seja, enquanto os racionalistas visavam criar um sistema autorreferente, uma nova gramática de arquitetura baseada em elementos abstratos, através do trabalho e investigação dos materiais, o sistema de Ladovsky propunha reconhecer a expressão e a qualidade da forma material através da percepção. Nesse sentido, listou quatro características formais que serviriam como premissas para uma nova ordem arquitetônica: Geometria: relação de superfícies, cantos, etc.; Física - peso, massa, etc.; Mecânica: estabilidade, mobilidade; Lógica: articulação da superfície como tal e do volume delimitador da superfície. $^{12}$

Apesar de formado na tradição clássica, Ladovsky estava convencido de que o conhecimento excessivo da história da arquitetura poderia impedir a liberdade criativa do estudante, e chegou a sugerir que, para a criação do novo, era necessário que todo estudante tivesse um "diploma de ignorância" para ingressar em seu curso. "Precisamos conhecer a história, mas não ao ponto de cheirarmos à naftalina. O Gótico foi o resultado do conhecimento aliado à liberdade e, assim como nós, sabemos algumas coisas, mas somos livres o suficiente para criar." ${ }^{13}$ Nesse sentido, Ladovsky contou com a vontade de muitos alunos, livre de preconceitos e do peso do conhecimento histórico, eram submetidos ao experimento pedagógico radical, praticando exercícios espaciais em ateliers

\footnotetext{
${ }^{11}$ BANHAM, Reyner. Teoria e projeto na primeira era da máquina. São Paulo: Perspectiva, 1975. p. 441.

12 Dependendo da articulação do tamanho e quantidade, esses elementos se desdobravam em três binômios: força e fraqueza; crescimento e invariabilidade e finito e infinito. BOKOV, Anna. VKhUTEMAS Training. Fair Enough, Venice Biennale, Nov 2014. pp. 109-111. (tradução nossa). Disponível em: <http://yale.academia.edu/AnyaBokov>. Acesso em: 28 mar. 2019.

13 Texto de 1919 de Nicolai Ladovsky ZhIVSKULPTARKh acrônimo russo para Zhivopis, Skulptura, Arkhitektura (Pintura, Escultura, Arquitetura) in KHAN-MAGOMEDOV, Selim. Architecture de avant-garde soviética. Livro 1, pp. 629-630. Apud. BOKOV, Anna. Rhythm and other elements: analysis and composition in soviet avant-garde architecture. New Haven: Actar Publisher/ Yale School of Architecture, 2016. pp. 47-55. (tradução nossa).
} 
deliberadamente desprovidos de qualquer referência histórica ou de representação, apenas estimulando o pensamento abstrato. ${ }^{14}$

Em síntese e, de maneira muito similar à Bauhaus como já observado, os principais aspectos da estrutura educacional que impactaram diretamente na pedagogia dos VKhUTEMAS incluíam a interdisciplinaridade entre campos do conhecimento; conectividade com unidades de pesquisas externas; o espírito colaborativo, enraizado no trabalho e na vida comunitária; associações profissionais de arquitetura e artes; cultura de oposição marcada pelos debates entre construtivistas, racionalistas e classicistas; organização de exposições nacionais e internacionais, e publicações, como a revista Arkhitektura VKhUTEMAS. ${ }^{15}$

Desde o início, o aspecto político permeou essas duas experiências. No caso da Bauhaus, logo nos anos iniciais e, segundo Argan, a visão fria e funcionalista de Gropius ${ }^{16}$ entrou em choque com a visão subcultural e quase religiosa do grupo de mestres e artistas ligados a Johannes Itten que, devido à autonomia com a qual conduziam os trabalhos em suas oficinas e a falta de coordenação entre elas, produziam um crescente distanciamento entre si e, sob a ótica de Gropius, poderiam impedir a concretização da "noção da obra de arte total sob as asas da construção", cujo objetivo de criação deveria estar comprometido socialmente e não apenas na obra de arte como disciplina autônoma. Em um texto de 1922, Gropius encontrou sua expressão máxima na afirmação "Arte e Técnica, uma nova unidade! A técnica não precisa da arte, mas a arte precisa, e muito, da técnica", ${ }^{17}$ Itten saiu da escola em 1923. Em um primeiro momento, essa mudança de orientação devolveu o caráter expressionista da Bauhaus e permitiu maior penetração dos ideais construtivistas através de Josef Albers e László Moholy-Nagy, que assumiram o curso preliminar.

Além disso, esta nova direção possivelmente estaria ligada às frequentes visitas do pintor holandês Theo van Doesburg a Weimar, representante do movimento De Stijl. Impedido por Gropius de lecionar na escola, proferia contundentes críticas acerca da pouca relação da Bauhaus com a

\footnotetext{
${ }^{14}$ KREIS, Barbara. WChUTEMAS - ein russisches Labor der Moderne: Architekturentwürfe 1920 - 1930. Berlin: Martin-Gropius-Bau, dez. 2014 / abr. 2015. Catálogo de exposição. pp. 28-31. (tradução nossa).

${ }^{15}$ Nesse sentido é fundamental a participação do INKhUK - Institut Khujestvennoi Kul'tury (Instituto de Cultura Artística de Moscou), fundado em 1920, que se deveu ao desejo de criar uma instância de debate sobre as ideias de Kandinsky sobre "cultura artística", "arte sintética monumental ou total" e estudo das técnicas e dos materiais na arte moderna. Foi um polo fundamental para o debate e a criação do Construtivismo soviético. De suas reuniões e debates saíram textos fundamentais para a vanguarda russa, além de ações e políticas gerais para as artes e o ensino artístico em Moscou, ou seja, para o VKhUTEMAS. MIGUEL, Jair Diniz. Arte, ensino, utopia e revolução: os ateliês artísticos VKhUTEMAS/VKhUTEIN (Rússia/URSS, 1920-1930). Op. cit. pp. 57- 58.

${ }^{16}$ Para Argan, isso se deve à formação de Gropius em arquitetura: "sua meta é operar no vivo de uma situação com a tempestividade e a exatidão de uma intervenção cirúrgica. A racionalidade torna-se uma técnica infalível, mas como toda técnica, válida somente no ato que a realiza. A constatação da crise, que é antes de tudo crise do sentimento é, portanto, a condição-base desta oscilante dualidade de racionalismo e pragmatismo, que repercute na postulada identidade de processo criativo e processo didático". ARGAN, Giulio Carlo. Projeto e destino. São Paulo: Editora Ática, 2004. pp. 235-236.

${ }^{17}$ Texto que tratava do conflito com Itten, Wingler observa que a ênfase dada à produção industrial acabou por configurar a primeira mudança operacional da Bauhaus, pois sinalizou a volta de Gropius às suas ideias básicas, de antes da guerra. Ver mais em: WINGLER, Hans M. Das Bauhaus. Bramanche, 1968. pp.26-27. Apud. WICK, Rainer. Pedagogia da Bauhaus. Op. cit. p. 42.
} 
indústria que, até aquele momento, insistia na elaboração individualizada da arte. ${ }^{18}$ Nesse sentido, com os novos professores, o curso preliminar da Bauhaus reposicionou os ateliers, passando a demonstrar maior interesse na produção mecanizada e nos problemas de projetar para ela. ${ }^{19}$

Além de impedir a abertura do curso de arquitetura, em meados de 1924, o governo conservador do Estado de Weimar, movido por questões ideológicas e políticas, reduziu os recursos direcionados para a escola, chegando ao ponto de seus "mestres decretaram a dissolução do instituto em 31 de março de $1925 " .{ }^{20}$ Essa situação extrema deflagrou um novo processo de atualização e reorganização interna que culminou na contratação de jovens mestres recém-formados pela própria escola, uma clara resposta, também com caráter ideológico e político, pois ao assumirem cargos de direção nas oficinas, naturalmente garantiram a continuidade dos objetivos da Bauhaus.

O cenário de instabilidade e incerteza em Weimar provocou a transferência da escola para a progressista cidade de Dessau, que inclusive financiou a construção de um prédio próprio projetado por Gropius e inaugurado em 1926. ${ }^{21}$ Essa mudança, aliada à construção da nova sede, conferiu um importante papel na consolidação da estrutura pedagógica da escola e fortaleceu o curso de arquitetura, visto que as características do novo edifício e sua relação com a cidade, além de conter os princípios necessários para a formação dos arquitetos do futuro, continham os elementos capazes de estabelecer a fusão das novas tecnologias da construção com as recentes demandas sociais exigidas pela modernidade. ${ }^{22}$

Em Moscou, a primeira fase do VKhUTEMAS, assim como a da Bauhaus, foi a mais fértil e otimista, pois seu caráter inovador era sustentado pelos debates e teorias acerca das práticas artísticas da época. Esses conteúdos eram levados para os ateliers que investigavam os fundamentos dos diversos campos da arte, retroalimentando as discussões e pesquisas através da contínua verificação do processo educacional. No caso da arquitetura, esse procedimento garantia o caráter inovador no ensino do projeto, ampliando a percepção das relações entre teoria e prática na produção do espaço e da forma modernos.

\footnotetext{
${ }^{18}$ Para Walter Dexel a transformação mais importante entre 1922 e 1923 se deu graças a Theo van Doesburg e sua crítica às tendências expressionistas e a produção individualizada da arte. O pintor holandês ainda dizia que não vira até então na Bauhaus a síntese entre arte e sociedade tão enfatizada por Gropius. DEXEL, Walter. Der Bauhausstil - ein Mythos. Texte 1921-1965, ed. por Walter Vitt, Starnberg, 1976. P.21. Apud WICK, Rainer. Pedagogia da Bauhaus. Op. cit. p. 42.

${ }^{19}$ BANHAM, Reyner. Op. cit. p. 439.

${ }^{20}$ WICK, Rainer. Op. cit. p. 49.

${ }^{21}$ Segundo Hans Wingler, o prefeito da cidade de Dessau Fritz Hesse, além de convidar a Bauhaus para se instalar na cidade, direcionou muitos recursos financeiros, "tutelou e protegeu a Bauhaus com diplomacia e habilidade e exemplar coragem cívica". WINGLER, Hans M. Das Bauhaus. Bramanche, 1968. p. 378. Apud. WICK, Rainer. Pedagogia da Bauhaus. Op. cit. p. 49.

22 Segundo Argan, a verdade histórica de uma possível estética de Gropius está fundamentada "nos edifícios que constrói, nas soluções urbanísticas que propõe, na revolução que realiza nos métodos de produção da arte aplicada e nos métodos do ensino da arte. É um temperamento essencialmente prático, que age sobre o terreno concreto da contingência. Sabe que a sua lógica formal encontra força de ultima ratio na crise total dos valores fundamentais da história, que nenhuma civilização é mais possível por força de certos princípios, mas apenas na clareza e na firmeza dos atos". ARGAN, Giulio Carlo. Projeto e destino. Op. cit. p. 235.
} 

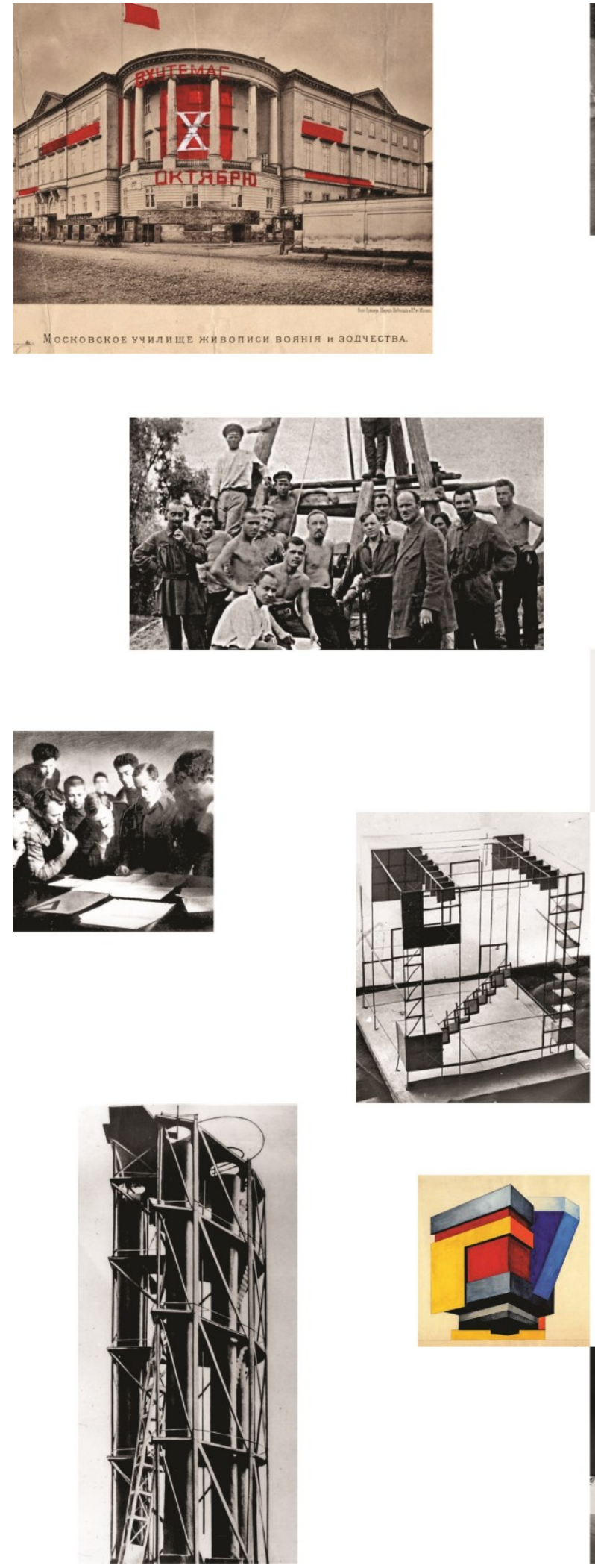
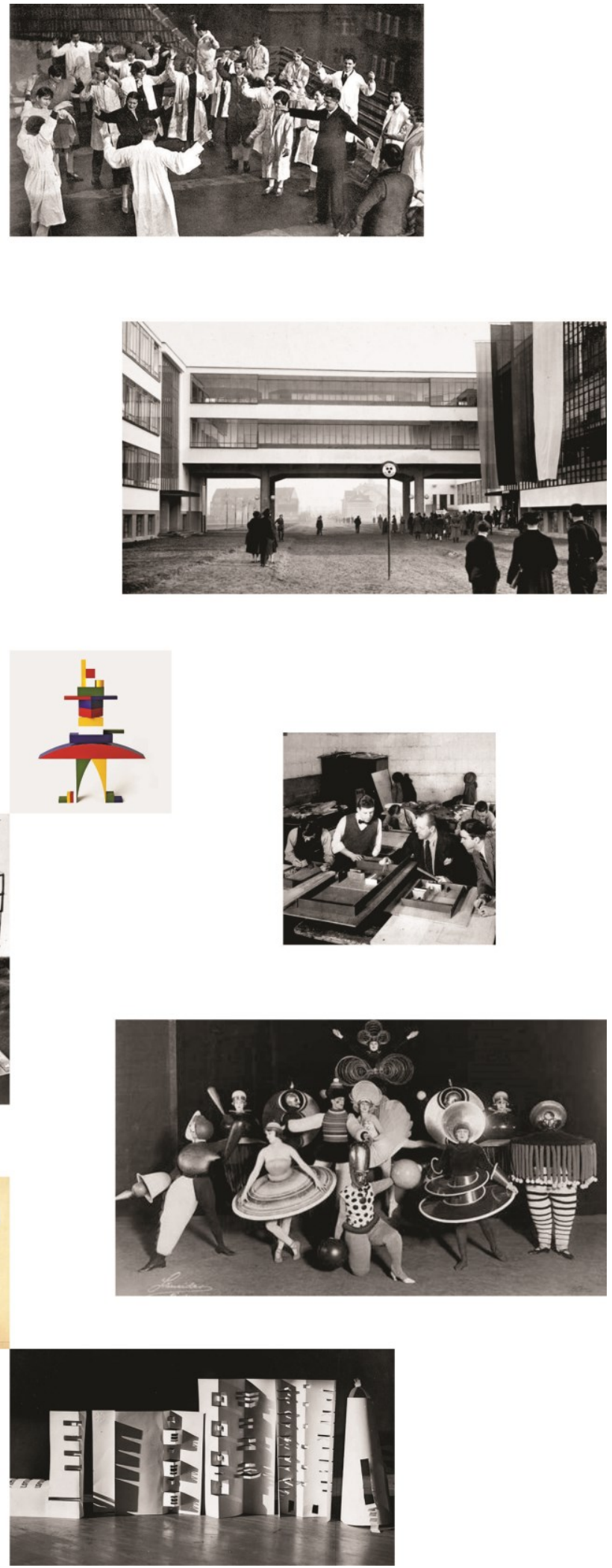

FIG. 04. À esquerda no topo, desenho na fachada da sede dos VKhUTEMAS, aquarela de Alexander Vesnin. Abaixo, Nikolai Ladovsky (em pé segurando um chapéu) com estudantes e membros da Sociedade de Construtores do Estádio Vermelho Internacional, 1925. Estudantes no atelier de Wladimir Krinski (ao centro), apoiado na mesa Michail Korshew e com o lápis Michail Turkus, 1920. Abaixo, trabalhos dos estudantes do curso espaço de Ladovsky. À direita no topo, aula ministrada por Johannes Itten em seu curso preliminar - Vorkurs, Itten iniciava suas aulas praticando ginástica e meditação com os estudantes, pois considerava a abertura espiritual e a paz de espírito como meio de liberdade de expressão, início de 1920. Abaixo, edifício da Bauhaus em Dessau 1926, nota-se que a passagem em nível sobre a rua estabelece um franco diálogo entre cidade e edifício, foto de Lucia Moholy. Ludwig Mies van der Rohe com os estudantes, a partir da esquerda: Anne Marie Wilke, Heinrich Neuy, Mies van der Rohe, Hermann Klumpp, Foto de Pio Pahl, Dessau 1930/1931. Trabalhos dos estudantes da Bauhaus, destaque para o Balé Triádico de Oskar Schelemmer. 
Porém, entre 1926 e 1928 foi iniciado um processo para a conversão dos VKhUTEMAS em Instituto, que passou a ser denominado como VKhUTEIN (Instituto Superior de Arte e Técnica). Inevitavelmente, o status de instituto refletiu diretamente na sua pedagogia, pois no lugar da organização artística horizontal, a nova estrutura de ensino era burocrática, formal, tecnocrática e impositiva. Apesar do currículo bem estruturado e dos processos de admissão simplificados, esta mudança provocou um retrocesso à tradição acadêmica conservadora, cada vez mais próxima do modelo da Escola de Belas Artes que, originalmente foi criado para se opor. ${ }^{23}$

Em Dessau, o processo de reorganização pedagógica encerrou-se em 1927 com a criação do departamento de arquitetura. Dirigido pelo arquiteto marxista Hannes Meyer, ${ }^{24}$ o curso tinha caráter funcionalista com abrangência social e urbana e seguia rigorosamente um modelo de estudo sistematizado e cientificamente embasado nos problemas reais. A ênfase atribuída aos aspectos construtivos da arquitetura dispensava qualquer esteticismo que conflitasse com o conceito de sua função social. Meyer resumiu da seguinte maneira o que eram as aulas de arquitetura sob seu comando na Bauhaus:

Em nosso ensino de arquitetura desenvolvemos uma construção funcional que, ao contrário da interpretação comum, suplantava o elemento puramente técnico, através de uma análise da situação social e de um estudo minucioso de todos os fatores biológicos, reservando-se especial atenção aos fatores psicológicos e à organização da vida, esperávamos chegar a um aprofundamento e a um enriquecimento da arquitetura. ${ }^{25}$

Walter Gropius renunciou ao cargo de diretor e encerrou suas atividades na Bauhaus em 1928, para trabalhar em seu escritório em Berlim. Simultaneamente à saída de Gropius, desligaram-se da escola Herbert Bayer, Marcel Breuer e Moholy-Nagy, e esse fato marcou o início de um gradual processo de desintegração. Hannes Meyer foi o indicado de Gropius e, ao assumir a direção, direcionou todos os esforços para a consolidação do curso de arquitetura, ameaçando a ideia inicial de arte unificada e provocando grande insatisfação dos professores artistas. Meyer acreditava que a arquitetura era a ciência da construção, construção não como uma questão de sentimento, mas de conhecimento,

\footnotetext{
${ }^{23}$ ARGAN, Giulio Carlo. Op. cit. p. 235.

${ }^{24}$ Membro do partido comunista alemão, Hannes Meyer foi um arquiteto suíço nascido na Basileia, integrante de uma família protestante que, desde o século XVII, tinha grande tradição no campo da arquitetura. O viés ideológico de esquerda o tornou membro do partido comunista alemão e membro do ABC Group, juntamente com Mart Stamm, El Lissitzky, Hans Schimdt, Emil Roth e Hans Wittewer, em Basel, Suíça. Nesse grupo, vale destacar o papel de El Lissitzky, propagandista incansável, publicou em Berlim a revista Vesh (Objeto), organizou visitas de estudantes e exposições em Moscou e Weimar, além de ser muito próximo de Hannes Meyer, com quem mantinha contato através de publicações e correspondências. DAL Co, Francesco (org). El arquitecto em la lucha de clases y otros escritos, Hannes Meyer. Barcelona: Gustavo Gili, 1972. p .11.

${ }^{25}$ Para tanto "pesquisou-se o espaço vital de algumas famílias de operários e trabalhadores, a fim de se conseguir uma melhor tipificação de seus núcleos de moradia. Por fim, procedeu-se a uma análise global de todo o complexo urbanístico da cidade de Dessau, que demonstrou claramente as deficiências e o aspecto classista desta cidade modelo. Os bairros de trabalhadores localizavam-se, sem exceção, nas nocivas imediações das indústrias, e as instalações culturais concentravam-se nas zonas residenciais da população de melhor renda." Em princípio, pode-se dizer que a ênfase dada ao papel social do arquiteto, que esteve presente desde cedo na trajetória de Meyer, remonta aos anos de 1912-1913, quando viajou para a Inglaterra para estudar as cooperativas de Londres e Birmingham, o que despertou seu interesse pelos assuntos relacionados à classe operária, norteando sua atividade como arquiteto. Viajou e trabalhou pela Europa, sempre envolvido nos movimentos cooperativos. MEYER, Hannes. Bauhaus Dessau - Erfahrungen einer polytechnischen erziehung. In Lena Meyer-Bergner apud WICK, Reiner. Pedagogia da Bauhaus. Op. cit. p. 55.
} 
portanto, não condicionada pela intuição, mas pela razão, um acontecimento técnico. Para o arquiteto suíço, a Bauhaus de Dessau não era um fenômeno artístico, mas sim um fenômeno social, a escola deveria estar a serviço do povo, sem esteticismos ou modismos. Tal pragmatismo dissolveu o que restava de espiritual na escola.

Em 1930, por razões políticas, Hannes Meyer foi substituído por Ludwig Mies van der Rohe que, como diretor da Bauhaus, deu continuidade ao programa de Meyer mantendo a ênfase no curso de arquitetura em detrimento dos demais. Entretanto, Mies abandonou as preocupações sociais e os métodos que aproximavam os exercícios da realidade, inclusive, dando ênfase na investigação de problemas técnicos e formais. Essa opção desmantelou a ideia de arte unificada e conferiu à escola um viés tecnicista, formando arquitetos especialistas em detrimento de uma formação generalista e criativa. Segundo Anatole Kop, essas ações criavam mais um estilo, "o estilo Bauhaus", sem relação com a "causa" defendida na Alemanha, principalmente no período de Dessau. ${ }^{26} \mathrm{~A}$ derrota dos socialdemocratas nesta mesma cidade, em 1932, fez com que a Bauhaus mudasse para um antigo galpão fabril em Berlin-Steglitze e, no dia 20 de julho de 1933, ela foi obrigada pelos nazistas a se autodissolver, acusada de ser uma escola comunista e degenerada.

No caso soviético, uma nova reforma iniciada em 1929 dividiu a escola em seis instituições menores, especializadas e separadas, priorizando as tarefas de industrialização em massa voltada para o comércio. A grande instituição interdisciplinar foi julgada "ineficiente" pelo governo de Josef Stalin, ${ }^{27}$ que considerava a produção dos VKhUTEIN "formalista", no sentido pejorativo e, em 1930, seu programa educacional foi encerrado. É provável que tais críticas procurassem desviar a atenção das reais preocupações do regime stalinista, pois a importância da escola como um dos centros do emergente movimento moderno, que propunha a emancipação cultural da classe proletária, era vista como uma ameaça ao Estado Soviético, um perigoso instrumento de manipulação política do Ocidente. Nesse sentido, em 1933, foi fundado o MARKhI (Instituto de Arquitetura de Moscou), resultado da fusão do departamento de arquitetura do VKhUTEIN com o currículo do Instituto Técnico de Engenharia Civil. Atualmente o MARKhl é a escola de arquitetura mais importante da Rússia. $^{28}$

Conforme o exposto, essas duas experiências apresentam extraordinárias semelhanças entre si. Além da prática didático-pedagógica do "aprender fazendo" no atelier e da ênfase no trabalho coletivo e social, ambas surgem praticamente ao mesmo tempo, os SVOMAS/VKhUTEMAS em 1918-1920 e a Bauhaus em 1919. Tanto uma quanto a outra funcionaram por um curto período de tempo, de um

\footnotetext{
${ }^{26}$ Para Kopp, essa opção de Mies refletirá nas futuras Bauhaus nos Estados Unidos, para onde foram a maioria dos professores exilados da Bauhaus. KOPP, Anatole. Quando o moderno não era um estilo, mas uma causa. São Paulo: Nobel, 1990. p. 64.

27 Josef Stalin assumiu o controle da URSS logo após a morte de Lênin, em 1924.

${ }^{28}$ BOKOV, Anna. VKhUTEMAS Training. Op. cit. pp. 101-102. (tradução nossa). 
lado os ateliers russos com doze anos de atividades e do outro a escola alemã com quatorze anos de atuação. Compartilhavam valores disseminados por organizações de esquerda além de contarem com alguns dos principais protagonistas das vanguardas expressionista e construtivista. Por fim, foram dissolvidas involuntariamente por questões de ordem ideológica e política, de um lado pelo realismo socialista de Josef Stalin, em 1930, e de outro pelo estado nazista de Adolph Hitler, em 1933.

Não obstante, apesar das semelhanças entre as duas escolas, algumas diferenças merecem destaque. Como visto, o curso de arquitetura é uma importante distinção, pois esteve presente desde o início do funcionamento da escola de Moscou, ao passo que o da Bauhaus foi iniciado oito anos após sua fundação. Do ponto de vista político a escola de Weimar, desde seu o início até a sua extinção, teve que se defender das reações dos nacionais-socialistas, ao passo que em Moscou, apoiados pelo estado desde sua fundação e, segundo Bokov, os VKhUTEMAS não eram somente uma instituição educacional, funcionavam mais como uma comuna do que como uma escola e, dessa maneira, se converteram em um poderoso condensador social difusor da cultura moderna.

Indo nessa mesma direção, o número de vagas oferecidas por ambas as escolas é outro aspecto a ser destacado. As matrículas da escola alemã eram estruturadas em função da relação professor-aluno, Gropius acreditava que escolas menores eram mais produtivas, pois a atmosfera intensiva e o vigor intelectual exigiam trabalho coletivo do estudante e do professor em todas as tarefas. Para Gropius a proporção ideal estava entre doze e dezesseis alunos por professor, dessa maneira a Bauhaus tinha entre cem e cento e cinquenta alunos. ${ }^{29}$ Já o número de estudantes e professores dos VKhUTEMAS era aproximadamente dez vezes maior que a Bauhaus. Por exemplo, no ano acadêmico de 19241925, a escola soviética tinha 1.445 estudantes matriculados, enquanto a Bauhaus inscreveu $127 .{ }^{30}$ Isso configura uma importante diferença ideológica, pois apesar de terem como objetivo comum a síntese entre arte e técnica, os VKhUTEMAS, apoiados pelo Estado, criaram uma versão proletária desse ideal e levaram a educação para as massas de maneira a atender a crescente produção industrial do país.

Não por acaso, as pedagogias de ambas as escolas, apesar dos evidentes cruzamentos, apresentam uma diferença essencial: o perfil do estudante diante do complexo arte-técnica. Em Weimar era feita uma avaliação preliminar e o candidato era selecionado pelo seu potencial de desenvolvimento, ou por seu talento já em evidência; além disso possuía satisfatório grau de instrução o que, muito provavelmente, Ihe proporcionava maior autonomia diante das pesquisas e projetos propostos na escola. Moholy-Nagy justificou que o modelo artesanal oferecia uma visão global e detalhada da

\footnotetext{
${ }^{29}$ GROPIUS, Walter. Bauhaus: novarquitetura. 2a Edição. São Paulo: Perspectiva, 1974. p. 96.

${ }^{30}$ BOKOV, Anna. VKhUTEMAS Training. Op. cit. p. 102. (tradução nossa).
} 
produção do objeto como um todo, desde a concepção e projeto até a sua construção final e, "desse modo, seu olhar está voltado para o todo orgânico". ${ }^{31}$

No caso soviético, não era possível educar os milhares de estudantes vindos do interior para a capital Moscou utilizando métodos didáticos individualizados e artesanais, como na Bauhaus criticada por Doesburg e "corrigida" por Nagy; isso só poderia ser alcançado através da experimentação de novos procedimentos educacionais. Desse modo, e como visto, centenas de estudantes semianalfabetos desprovidos de formação acadêmica facilitaram a investigação de como a arte e a arquitetura poderiam ser pensadas, produzidas e experimentadas. Os inúmeros exercícios de investigação tridimensional, feitos em argila, papel, metal ou madeira, configuraram um grande repositório de formas proto-modernistas, e eram metodicamente foto documentadas, testadas e analisadas, diretamente nos ateliers ou em laboratórios científicos. ${ }^{32}$

Pois bem, o evidente caráter racionalista verificado na pedagogia e sistematização investigativa da escola moscovita, mais especificamente no curso preliminar Espaço, refletia "um elevado grau de adestramento, além da permanência consideravelmente mais longa do principiante neste estágio", ${ }^{33}$ configurando uma metodologia de ensino instrumental, pois o ensino proposto para as massas baseava-se em um conjunto de operações prescritas que, segundo Bokov, constituía um algoritmo muito básico de instruções escritas passo a passo, distribuídas aos alunos do curso preliminar na forma de tarefas.

Quanto aos seus legados, essas duas experiências também apresentam significativa distinção, podese dizer que a herança soviética foi muito prejudicada, pois apesar de inicialmente apoiada pelo Estado, após a morte de Lênin, foi sistematicamente reprimida pela política de Stalin até a sua dissolução. Diante da impossibilidade do exílio, alguns de seus professores foram perseguidos e acabaram desaparecendo, como por exemplo, Nikolay Ladovsky, que morreu em 1941, sob circunstâncias desconhecidas, em Moscou. Inclusive seus arquivos foram supostamente perdidos no tumulto da Segunda Guerra Mundial. Fatos como esse foram responsáveis pelo sumiço de valioso material produzido pela escola, além de documentos e registros de atividades provocando,

\footnotetext{
${ }^{31}$ Com o objetivo de problematizar essa questão, Nagy faz uma pergunta, que ele mesmo responde: "por que a educação artesanal na Bauhaus?" Entretanto, fez uma ressalva que, em contraponto à visão espiritualizada de seu antecessor Johannes Itten, justificava o caráter racionalista de sua pedagogia, direcionado para a produção industrial: “O ensino artesanal devia ser considerado na Bauhaus predominantemente como fator educativo, não como um fim em si mesmo. É provável que este trabalho educativo da Bauhaus ainda possa ser levado mais adiante, no futuro, com base em uma técnica (máquina) mais amplamente desenvolvida. Caso o sentido de totalidade seja mantido, o resultado só será diferente do ponto de vista quantitativo, mas não qualitativo". MOHOLY-NAGY, László. Do material à arquitetura. Barcelona: Gustavo Gili, 2005. p. 18.

32 BOKOV Anna. Institutionalizing the Avant-Garde: Vkhutemas 1920-1930. Op. cit. não p. (tradução nossa).

${ }^{33}$ Apenas para lembrar, o curso preliminar da Bauhaus durava um semestre e o dos VKhUTEMAS durava dois anos e, segundo Christian Schädlich, "a unificação das artes com base em um trabalho comum interdisciplinar e orientado para a prática podia ser muito melhor executada na Bauhaus, com seus 150 estudantes, do que no WCHUTEMAS, dez vezes maior. Nele, apenas o curso básico tinha uma função de integração." SCHÄDLICH Christian. Bauhaus 1919-1930. Dessau: Wissenschaftl Kulturelles Zentrum Bauhaus, 1983. p. 475. Apud. WICK, Rainer. Pedagogia da Bauhaus. Op. cit. p. 81-82.
} 
inevitavelmente, grandes dificuldades de divulgação e difusão das práticas dos VKhUTEMAS. Anna Bokov lembra que dois anos depois, em 1943, Alexandr Rodchenko escreveu em seu diário:

\begin{abstract}
Os projetos que Ladovsky fazia em compensado no seu atelier agora estão se molhando na sua varanda. Ele era uma figura importante da arquitetura e tudo está se transformando em pó... minhas pinturas também se molharão, serão queimadas em um fogão... arte... vale a pena viver para você? Quem precisa disso? 0 que é necessário, aparentemente, é apenas guerra, pão e banha. O pobre sonhador Ladovsky morreu. Por toda sua vida quis construir algo novo. ${ }^{34}$
\end{abstract}

Por outro lado, os professores da Bauhaus, ao saírem da Alemanha nazista, encontraram exílio em países democráticos e tiveram a oportunidade de dar continuidade a seus trabalhos acadêmicos e profissionais, além de contar com grande liberdade e estímulo para difundir suas atividades como docentes. Para citar apenas alguns exemplos, Walter Gropius percorreu universidades e participou de diversos simpósios e congressos ao redor do mundo, debatendo a pedagogia aplicada na Bauhaus de 1919 até 1928, período em que foi diretor, além de produzir muitos escritos sobre a escola. Da mesma forma, Wassily Kandinsky difundiu em território francês sua experiência através de textos sobre suas aulas na Bauhaus e de suas pinturas desenvolvidas durante o período vivido na escola alemã. Mies Van der Rohe e Moholy-Nagy foram para os EUA e, na cidade de Chicago, consolidaram suas pesquisas no campo da arquitetura, da arte e do design. Nessa mesma cidade, Nagy foi diretor da New Bauhaus que, por motivos financeiros funcionou por apenas um ano, motivando o artista húngaro a fundar o Instituto de Design em Chicago.

Hannes Meyer por sua vez, foi para a URSS como consultor de diversos planos de desenvolvimento de cidades soviéticas e, assim como Gropius, Kandinsky e Moholy-Nagy, também escreveu sobre sua experiência didática na escola alemã. Destacou que a missão social da Bauhaus, sob sua direção, era caracterizada pela ampliação das disciplinas de ciências exatas e pela contenção da influência dos professores artistas. Pode-se dizer que essa visão marxista de Meyer constituiu uma legítima "pedagogia politécnica", o que não deixou de ser um retrocesso ao objetivo original da Bauhaus da unificação das artes com a técnica. A extensa divulgação do modelo de ensino baseado na autonomia e na produção coletiva praticada no atelier, em contraponto aos métodos de aprendizado baseados somente em leitura ou em aulas expositivas, mesmo com as modificações sofridas em diferentes períodos devido ao caráter distinto de intenções e convicções, ideológicas e políticas de seus professores, consolidou o "método da Bauhaus, convertendo-se em uma espécie de norma para treinamento arquitetônico avançado por todo o mundo"..$^{35}$

\footnotetext{
${ }^{34}$ BOKOV, Anna. Space: The Pedagogy of Nikolay Ladovsky. Walker Reader Magazine. Jun. 2017. não p. (tradução nossa). Disponível em: <https://walkerart.org/magazine/space-the-pedagogy-of-nikolay-ladovsky>. Acesso em: 22 mar. 2019.

${ }^{35}$ BANHAM, Reyner. Op.cit. p. 439.
} 
Contudo, é oportuno destacar a ressalva de William Curtis de que, apesar de ser evidente o aspecto ideológico e político nessas duas escolas, a Bauhaus sob o "espiritualizado socialismo apolítico" de Gropius seguido da "teimosia marxista" de Hannes Meyer, e os VKhUTEMAS emergidos de uma atmosfera pós-revolucionária defensora de uma suposta "verdade" da arquitetura da nova ordem social, deve-se evitar simplificações sobre ideologia e uso formal, imputando ao todo da arquitetura moderna desse período algum tipo de dogma rígido. Mesmo diante da impossibilidade de se compreender a produção da arquitetura dos anos 1920 fora dos ideais sociais que a impulsionaram, pois ainda segundo Curtis, havia uma rica variedade de valores disseminados por arquitetos como Le Corbusier, Gerrit Ritveld, Erich Mendelsohn, dentre outros. ${ }^{36}$

Sem a pretensão de oferecer respostas conclusivas, por enquanto importa pensar que a revisão dessas experiências constitua o ponto de apoio teórico necessário para a problematização desse trabalho, pois, como visto, tanto a Bauhaus quanto os VKhUTEMAS desenvolveram abordagens sem precedentes, nas quais o processo de ensino e aprendizagem abriram caminhos para a investigação do desconhecido, posicionaram o atelier como um inestimável instrumento de síntese técnicaartística para professores e estudantes, juntos, pensarem, experimentarem e produzirem arquitetura de diferentes maneiras, indefinidamente. Desse modo, apresentam-se como ações capazes de incomodar todo aquele insensível a qualquer forma de inquietação ideológica e cultural. ${ }^{37}$

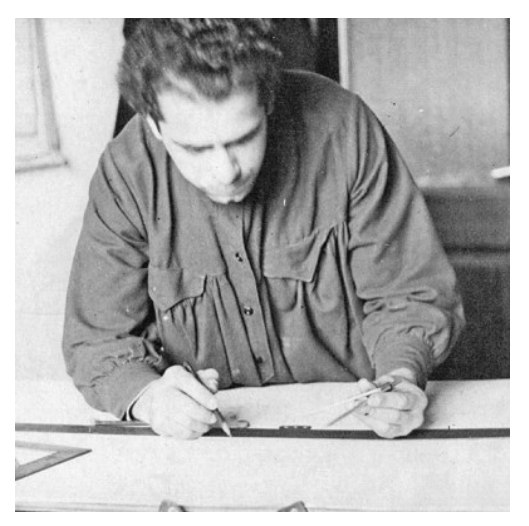

FIG. 05. Estudante dos VKhUTEMAS, URSS, 1923.

\footnotetext{
${ }^{36}$ Ver capítulo "Arquitetura e revolução na Rússia". O historiador William Curtis destaca a dificuldade de se entender o contexto da revolução de 1917 e seus desdobramentos no conjunto da produção da arquitetura dos anos 1920. p\Para Curtis "não existe um passo direto de um conjunto de ideias para um conjunto de formas". CURTIS, William J. R. Arquitetura moderna desde 1900 . 3 a edição. Porto Alegre: Bookman, 2008. pp. 201-215.

${ }^{37}$ Ver mais sobre este tema no capítulo "Arquitetura e ideologia" in ARGAN, Giulio Carlo. Projeto e destino. Op. cit. pp. 71-78.
} 


\section{Processamento brasileiro}

Em proporção absolutamente superior aos VKhUTEMAS, a repercussão dos modelos pedagógicos praticados pela Bauhaus nos anos 1920, desde muito cedo, estabeleceu novos paradigmas para o ensino da arquitetura no mundo inteiro, inclusive no Brasil que, nesse mesmo período, expressava significativa inquietação cultural, não só no campo da arquitetura, mas um desejo de mudança manifesto em todos os setores desde 1922. Apesar da profissão de arquiteto ainda não estar muito bem definida na década de 1920, já havia um movimento de luta pela autonomia profissional e do ensino em relação às escolas de belas artes e politécnicas de engenharia.

Nesse sentido, destaca-se a atuação pioneira de Lucio Costa que, em 1930, estava mergulhado nas discussões em prol de uma ampla reforma do ensino de arquitetura praticado na Escola Nacional de Belas Artes (ENBA) do Rio de Janeiro, destacando a importância de aproximar a arte do conhecimento técnico-científico para "orientar o ensino artístico no sentido de uma perfeita harmonia com a construção". ${ }^{38}$ Nota-se que, além da consonância aos já expostos modelos de ensino praticados nas escolas soviética e alemã, esse pensamento estava alinhado aos postulados do urbanismo e da arquitetura moderna, discutidos no primeiro Congresso Internacional de Arquitetura Moderna (CIAM) em 1928, imbuído da ideologia comunista de Hannes Meyer, ${ }^{39}$ e que haviam sido divulgados por Le Corbusier na ocasião de sua primeira visita ao Brasil em 1929, nas cidades de São Paulo e Rio de Janeiro.

Quando assumiu a direção da ENBA em 1930, aos 29 anos de idade, Lucio convidou para ajudá-lo nesta empreitada Gregori Warchavchik. Naquele momento o arquiteto russo era o único que havia projetado e construído duas casas com características modernas em São Paulo, ${ }^{40}$ teoricamente, uma grande contratação para a ENBA, entretanto, mesmo com todos os esforços, Lucio e seus aliados

\footnotetext{
${ }^{38}$ A ENBA era dirigida por José Mariano Filho, entusiasta do estilo neocolonial, e influenciava os jovens estudantes da época a praticarem esse tipo de arquitetura. Lucio Costa em resposta a essa orientação e, segundo ele mesmo, já desperto do estado alienante em que se encontrava, ressaltava que "o estudo dos clássicos deveria ser praticado como disciplina e servirem de orientação crítica e não para aplicação direta”. COSTA, Lucio. Registro de uma vivência. São Paulo: Edições SESC São Paulo/Editora 34, 2018. p. 68.

${ }^{39}$ Apesar de ter a frente figuras como Sigfried Giedion e Le Corbusier, identificados como os mentores ideológicos desses congressos, segundo Frampton, a ausência misteriosa dos humanistas liberais Mies Van der Rohe, Walter Gropius e Eric Mendelsohn abriu espaço para o polêmico grupo comunista $A B C$ group, que influenciou substancialmente esse primeiro congresso e que, ainda segundo Frampton, exerceu um importante papel ideológico na evolução da arquitetura europeia a partir desse primeiro congresso em 1928 até 1956 , data da última edição dos CIAM. Ver mais sobre os CIAM na obra de Eric Munford que, a partir da identificação de quatro períodos distintos, procede a uma análise extensa e minuciosa sobre cada edição. MUNFORD, Eric Paul. The CIAM discourse on urbanism, $1928-1960$. Massachusetts: The MIT press, 2000.

${ }^{40}$ A primeira delas é a residência do próprio arquiteto construída em 1927 na Rua Santa Cruz e a segunda, conhecida como Casa Modernista da Rua Itápolis, concluída em 1929, ambas na cidade de São Paulo. Segundo José Lira, a batalha da arquitetura internacional no Brasil, tem como um dos seus marcos principais a "Exposição de uma casa modernista" realizada em São Paulo entre 24 de março e 25 de abril de 1930, em uma das casas projetada e construída por Warchavchik. Trata-se da casa da Rua Itápolis, bairro do Pacaembu em São Paulo. Lira destaca que Oswald de Andrade escreveu na ocasião da exposição: "encerrava-se o ciclo de combate à velharia, iniciado por um grupo audacioso no Teatro Municipal, em fevereiro de 1922 (semana de 22). É a despedida de uma época de fúria demonstrativa”. LIRA, José. Warchavchik: fraturas da vanguarda. São Paulo: Cosac Naify, 2011. pp. 195-213.
} 
encontraram grande dificuldade para implantar tais ideias, pois, além de irem contra o academicismo anacrônico praticado na escola de belas artes, confrontavam diretamente com os interesses dos engenheiros que não aceitavam a emancipação ou distinção profissional. Lucio não conseguiu superar a postura resistente e atrasada desses acadêmicos, e foi obrigado a renunciar depois de apenas nove meses à frente do cargo. ${ }^{41}$

Em 1933 a profissão do arquiteto foi regulamentada no Brasil, através da Lei №. 23.569/1933, ${ }^{42}$ porém com atribuições profissionais ainda sob a égide pedagógica das Escolas de Belas Artes ou das Escolas Politécnicas de Engenharia, que ofereciam cursos seriados e organizados pela justaposição de disciplinas técnicas e artísticas. Essa junção esquemática de dois modelos distintos não foi suficiente para satisfazer a categoria de arquitetos, ao contrário, acirrou o conflito por continuar demonstrando o reduzido entendimento de acadêmicos e parte da sociedade acerca da profissão e dos métodos específicos para seu ensino. Em 1936, a segunda visita de Le Corbusier ao Brasil para colaborar com a equipe de arquitetos liderada por Lucio Costa no projeto do Ministério da Educação e Saúde (MES), ${ }^{43}$ na cidade do Rio de Janeiro, além de obter grande repercussão em todo o país e no mundo, revelou o jovem arquiteto recém-formado pela ENBA, em 1934, Oscar Niemeyer. A partir do contato com o mestre franco-suíço, Oscar desenvolveu extraordinário talento individual, caracterizado pela natureza plástica e poética de suas obras, provavelmente contribuindo para a formação da escola carioca de arquitetura e influenciando gerações de arquitetos.

O movimento emancipatório ganhou força com a criação do departamento autônomo do Instituto dos Arquitetos do Brasil (IAB-SP) ${ }^{44}$ na cidade de São Paulo em 1943, cujo objetivo principal era divulgar a profissão e a produção da arquitetura brasileira. Nesse sentido, foi empenhado um grande esforço para comprovar a complexidade de se fazer arquitetura, era preciso demonstrar que se tratava de uma disciplina que exigia melhor elaboração na sua definição conceitual e prática, além de mais clareza na determinação do papel do arquiteto junto à sociedade, que por sua vez, insistia em

\footnotetext{
${ }^{41}$ Wisnik lembra que Lucio Costa foi protagonista em duas situações decisivas para a nossa recente história arquitetônica: "na reviravolta do ensino na Escola Nacional de Belas Artes (ENBA), em 1930, que se desdobrou no importante "Salão de 31", dito "Salão revolucionário", fundamental para as os rumos das artes plásticas no Brasil, e no projeto para o Plano Piloto de Brasília, em 1957, de inegável relevância não só nacional como mundial”. WISNIK, Guilherme. Lucio Costa. São Paulo: Cosac Naify, 2001. p. 9.

${ }^{42}$ A Lei no. 23.569/1933, segundo seu artigo I regulamenta "o exercício das profissões de engenheiro, de arquiteto e de agrimensor será somente permitido, respectivamente”. Disponível em: <http://www.planalto.gov.br/ccivil_03/decreto/1930-1949/D23569.htm>. Acesso em: 15 abr. 2019.

${ }^{43}$ Essa segunda visita foi a convite do ministro Gustavo Capanema por indicação de Lucio Costa convicto de que Corbusier tinha o prestígio necessário para ajudar na afirmação da arquitetura moderna no país, participando da equipe composta pelos arquitetos brasileiros que, além de Lucio, contava com Carlos Leão (1906-1983), Affonso Eduardo Reidy (1909-1964), Jorge Machado Moreira (1904-1992), Ernani Vasconcelos e Oscar Niemeyer (1907-2012). Segundo Roberto Segre, Le Corbusier na ocasião vivia um momento difícil devido a uma série de críticas injustas e errôneas acerca da sua obra, sendo que os ataques mais duros proviam dos "arquitetos de esquerda, cujos objetivos essenciais não divergiam dos fundamentos sociais, econômicos, técnicos e funcionais do movimento moderno. Os membros da Nova Objetividade, liderados por Hannes Meyer (membro do partido comunista alemão) e o Tcheco Karel Teige acusaram-no de formalista e esteticista a serviço da burguesia europeia". Ver sobre o tema no item Academia, Política e ideologia in SEGRE, Roberto. Ministério da educação e saúde: ícone urbano da modernidade brasileira (1935-1945). São Paulo: Romano Guerra Editora, 2013, pp. 170-173.

${ }^{44}$ Herdeiro do Instituto Brasileiro de Arquitectura, fundado no Rio de Janeiro em 26 de janeiro de 1921, o IAB é a mais antiga das entidades brasileiras dedicadas aos temas ligados à arquitetura, à cidade e ao exercício da profissão. Disponível em: <http://www.iabsp.org.br/iabsao-paulo/>. Acesso em: 14 abr. 2017.
} 
demandar projetos "com caráter meramente decorativo resultando em construções em estilo". ${ }^{45}$ Essas reivindicações naturalmente evidenciavam a constante necessidade de aperfeiçoamento da formação do arquiteto e acabaram por ampliar as discussões para a criação de faculdades de arquitetura com autonomia pedagógica.

Esse processo culminou com a redação de um projeto de lei que, elaborado durante o Primeiro Congresso Brasileiro de Arquitetos em São Paulo, realizado entre os dias 26 a 30 de janeiro de 1945 com o tema "A Função Social do Arquiteto; o Ensino da Arquitetura; Arquitetura e Indústria", passou a vigorar no mesmo ano após ser promulgado o Decreto-Lei no 7.918 de 31 de agosto de 1945. Essa lei dispunha sobre a organização da Faculdade Nacional de Arquitetura (FNA) situada no Rio de Janeiro, com a finalidade de "ministrar o ensino de arquitetura e de urbanismo, visando à preparação de profissionais altamente habilitados e realizar estudos e pesquisas nos vários domínios técnicos e artísticos que constituem objeto de seu ensino". ${ }^{46}$ Seu currículo foi aplicado como modelo para as outras escolas de arquitetura existentes como a Escola de Arquitetura da Universidade de Minas Gerais, $1946 .{ }^{47}$ Bem como para as fundadas nos anos seguintes, em 1947 na FAU-Mackenzie e 1948 na FAU-USP, ambas em São Paulo; 1952 na FAU-UFRGS em Porto Alegre; 1959 na FAU-UFBA em Salvador e, também em 1959, na FAU-UFPE em Recife.

FIG. 06. Crachá de Oswaldo Corrêa do 1ํ Congresso Brasileiro de Arquitetos em São Paulo, 1945.

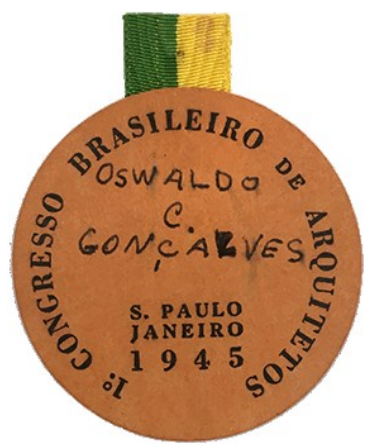

Entretanto, arrisca-se dizer que um dos pontos de inflexão decisivos para o futuro desenvolvimento do ensino de arquitetura no Brasil, grosso modo, tal como é conhecido hoje, remonta à década de 1940, quando o jovem arquiteto João Baptista Vilanova Artigas foi contemplado com uma bolsa de estudos ofertada pela Fundação Guggenheim para conhecer a arquitetura e as universidades norte-

\footnotetext{
45 Texto elaborado pelos professores da FAU - SJC para o IX Congresso Brasileiro de Arquitetos em São Paulo em 1976, teve como relator Ari Vicente que dissertou sobre a formação do arquiteto: "formavam arquitetos para um mercado ainda mal definido e incipiente, que exigia construtores de 'estilo' e 'bom gosto', que passam a projetar residências modernas e edifícios de alto gabarito artístico e estético". FERNANDES, Ary et al. Prática - Investigação. In Anais do IX Congresso Brasileiro de Arquitetos. São Paulo: IAB, 1976. p. 126.

${ }^{46}$ O Decreto-Lei no 7.918/1945 estabelecia que “A Escola Nacional de Arquitetura, criada pela lei no 452, de 5 de julho de 1937, denominarse-á Faculdade Nacional de Arquitetura da Universidade do Brasil”. Rio de Janeiro, 31 de agosto de 1945. Aprovada por Getúlio Vargas, Gustavo Capanema e A. de Souza Costa. Disponível em: <https://www2.camara.leg.br/legin/fed/declei/1940-1949/decreto-lei-7918-31agosto-1945-417265-publicacaooriginal-1-pe.html>. Acesso em: 14 abr. 2017.

${ }^{47} \mathrm{Em}$ 1946, foram reconhecidos os diplomas da Escola de Arquitetura da Universidade de Minas Gerais, emancipada do curso de engenharia fundado em 1930. SEGAWA, Hugo. Arquiteturas no Brasil 1900-1990. São Paulo: EDUSP, 2002. p. 130.
} 
americanas. ${ }^{48}$ Artigas embarcou em setembro de 1946 e retornou ao país mais de um ano depois, em novembro de 1947. Esse curto período de tempo foi suficiente para o arquiteto perceber o atraso no ensino de arquitetura brasileiro praticado segundo o modelo da FNA do Rio de Janeiro. $\mathrm{O}$ arquiteto Oswaldo Corrêa Gonçalves, sabendo que Artigas já havia visitado alguns cursos de arquitetura, em carta de 14 de dezembro de 1946, com o objetivo de manter Artigas informado sobre os desdobramentos do processo de emancipação da FAU-USP em relação à escola Politécnica, escreveu:

\begin{abstract}
Dois meses atrás mais ou menos, foi empossado como reitor da Universidade o prof. A. de Almeida Prado da Medicina. No dia seguinte ao de sua posse recebeu ele telegramas dos arquitetos de S. Paulo, do Instituto de Arquitetos do Brasil, dos alunos de arquitetura da Escola Politécnica e dos alunos do Mackenzie, pleiteando que entre os seus primeiros atos de reitor incluísse o da criação da Faculdade de Arquitetura e Urbanismo.

Com grande agrado para todos e surpresa, ele tomou imediatas providências nesse sentido. Solicitou urgência à congregação da escola Politécnica, de quem fora solicitado parecer e este foi, segundo me disse o Anhaia Mello, 'mudar no próximo ano todo o curso de arquitetura da escola Politécnica para a faculdade de arquitetura e abrir matriculas no 1을 ano somente dos cursos da Faculdade de Arquitetura e Urbanismo'.

Soube agora que o processo está de novo na Reitoria onde se procede a efetivação legal da doação. Estamos, pois, de parabéns. Sem dúvida começará a faculdade a funcionar em fevereiro ou março próximo.

Assim seria do máximo interesse que você mandasse dizer alguma cousa ao Anhaia pois mais de uma vez em conversa com ele, disse-me não ter recebido ainda nenhuma notícia sua, parecendo-me mesmo estar um pouco aborrecido com isso. Emprestei a ele o programa da Faculdade de Arquitetura do Rio de Janeiro a seu pedido para entender a composição de um programa para a Faculdade. Como você já tem dados sobre o ensino, é conveniente escrever-Ihe dizendo qualquer coisa para animar mais o homem. Ele não me parece tão entusiasmado como devia e como estamos nós. ${ }^{49}$
\end{abstract}

Em 27 de dezembro de 1946, Artigas respondeu a carta de Oswaldo Corrêa recomendando que divulgasse entre seus companheiros sua preocupação com a formulação do currículo da nova faculdade: “Não preste a mínima atenção ao programa estabelecido pelo pessoal do Rio. É simplesmente ridículo e superficial. Tremendamente. Quanto mais longe daquilo nós ficarmos, melhor." ${ }^{50}$ Apesar desse choque cultural ter explicitado a falta de espirito público e senso de comunidade da sociedade brasileira além de seu raso conhecimento do campo da arquitetura, Artigas verificou que naquele momento começava a aparecer algum espaço coletivo, e essa era a oportunidade para reverter esse quadro por meio de um movimento democrático, essencialmente organizado em conjunto para atingir o mesmo objetivo.

A inquietação de Artigas apenas aumentou diante da certeza de que não encontraria as respostas adequadas para nossa realidade se continuasse seguindo o roteiro inicial da viagem que previa um período de seis meses de pesquisa de métodos para a arquitetura moderna e seu ensino, entre Harvard University e Massachusetts Institute of Technology (MIT). Acabou por abandonar o roteiro inicial da viagem em busca de algo realmente novo, "riquíssimo e prometedor".

\footnotetext{
${ }^{48}$ Sobre a viagem de Artigas ver: SODRÉ, João Clark de Abreu: Roteiros americanos: as viagens de Mindlin e Artigas pelos Estados Unidos, 1943-1947. 2016. 256p. Tese (Doutorado em arquitetura e urbanismo) Faculdade de Arquitetura e Urbanismo da Universidade de São Paulo. São Paulo, 2016.

${ }^{49}$ Carta de Oswaldo Corrêa Gonçalves a João Batista Vilanova Artigas. São Paulo, 14 dez. 1946. Arquivo Biblioteca da FAUS.

${ }^{50}$ Carta de Vilanova Artigas a Oswaldo Corrêa Gonçalves. Nova York, 27 de dezembro de 1946, 3p. Arquivo Biblioteca da FAUS.
} 
Daqui a alguns dias vou viajar para o sul, para ver umas escolas progressistas que existem por lá. [...] por agora vi as universidades de Boston e de Columbia, aqui em N. York. Mas vi também um grande número de escolas livres, e algumas de grande importância. E conversei com gente que traça planos, gente que já ensinou e gente que sabe agora, o que deveria ter aprendido e de que maneira. ${ }^{51}$

Esse trecho da carta é um importante registro da natureza dos contatos de Artigas com arquitetos e artistas de prestígio internacional que residiam naquele momento nos EUA, muitos deles exilados, como por exemplo, Walter Gropius que estava em Boston, e o professor húngaro László MoholyNagy, no Instituto de Design de Chicago ${ }^{52}$ e que, como visto anteriormente, traziam consigo grande experiência adquirida no ensino das artes e arquitetura, diretamente através de suas práticas no curso na Bauhaus e, indiretamente, dos princípios praticados nos VKhUTEMAS, através de suas relações com os artistas e arquitetos construtivistas que também lecionavam na escola alemã. 0 próprio Artigas confirma esses contatos com professores da Bauhaus:

Tive contato com muitas pessoas, gente da Bauhaus que estava nos Estados Unidos lecionando. Nos primeiros meses de 1948, cheguei ao Brasil. Nessa época os herdeiros da família Penteado doaram à Politécnica o prédio da Rua Maranhão para que a Universidade de São Paulo montasse uma escola de arquitetura. A Politécnica não queria isso. [...] Cercar a arquitetura do significado cultural e artístico que ela tem não é tarefa muito fácil. [...] Ter a coragem de assimilar a condição de arquiteto como artista não é uma vaidade, mas necessidade de formação de uma consciência, de uma visão de mundo. ${ }^{53}$

Artigas, ao retornar ao Brasil, estava imbuído da estratégia pedagógica praticada pela Bauhaus nos anos 1920, principalmente da necessidade de aproximar a arquitetura da arte na formação do arquiteto. Para tanto era inevitável a ruptura com o ensino puramente técnico das escolas de engenharia, atualizando o ensino até então praticado no Brasil. Para Artigas a unidade entre interior e exterior, entre forma e conteúdo era precisamente uma das principais características da arquitetura moderna: "a de reunir a arte com sua finalidade funcional". ${ }^{54}$

Neste sentido, em 1947, enquanto Artigas encontrava os mestres vanguardistas da Bauhaus, Christiano Stockler das Neves, arquiteto com perfil conservador, articulava a emancipação da Faculdade de Arquitetura Mackenzie (FAM) da Escola de Engenharia Mackenzie, administradas pelo

\footnotetext{
${ }^{51}$ Carta de Vilanova Artigas a Oswaldo Corrêa Gonçalves. Nova York, 27 de dezembro de 1946. Op. cit.

52 Em depoimento dado ao autor Julio Katinsky lembrou que Artigas visitou o Instituto de Design em Chicago, que na época contava com a presença de László Moholy-Nagy e, segundo Katinsky, esse encontro foi importante para estruturar as novas pedagogias para a FAU-USP a partir de 1957. Entretanto, parece existir uma contradição nessas datas, pois segundo João Sodré, Artigas embarcou para os EUA no dia 27 de setembro de 1946, chegando a Nova York no dia 28. Após um período em Boston, iniciou no dia 6 de janeiro de 1947 sua viagem para o sul e, segundo o roteiro da viagem, Chicago era o último destino antes de voltar para a cidade de Nova York. Moholy-Nagy faleceu em 24 de novembro de 1946, portanto, a menos que tenham se encontrado entre 28 de setembro e 24 de novembro de 1946 , é provável que esse encontro nunca tenha ocorrido no âmbito dessa viagem. Ver o roteiro detalhado em: SODRÉ, João Clark de Abreu: Roteiros americanos: as viagens de Mindlin e Artigas pelos Estados Unidos, 1943-1947. Op. cit. pp. 166-231.

${ }^{53}$ Compilação de testemunhos in INSTITUTO LINA BO E P. M. BARDI. Vilanova Artigas, Coleção Arquitetos Brasileiros. São Paulo: Instituto Lina Bo e P.M. Bardi e Fundação Vilanova Artigas, 1997. p. 26.

${ }^{54} \mathrm{Na}$ ocasião do concurso para professor titular da disciplina de Projeto da FAU-USP em junho de 1984, Artigas começa suas arguições refletindo sobre a origem da função social do arquiteto proposta pela arquitetura moderna, apoiado em Tafuri reforça que a Revolução Bolchevique de 1917 ofereceu as saídas para um mundo novo: [...] "o arquiteto ficou impregnado, nessa altura dos acontecimentos, da necessidade de participar, com a própria arquitetura, das mudanças sociais do mundo de então". ARTIGAS, João Batista Vilanova. Caminhos da Arquitetura. São Paulo: Cosac Naify, 2004. p. 187-188.
} 
Instituto Presbiteriano Mackenzie, mantenedora privada, confessional e sem fins lucrativos que vinha formando engenheiros-arquitetos desde 1917. A FAM contribuiu decisivamente no processo de consolidação da prática profissional e do ensino de arquitetura em São Paulo, através da participação de seus professores na fundação e direção dos primeiros anos de atividades do IAB-SP. Nesse sentido, destaca-se o arquiteto Eduardo Kneese de Mello como o primeiro presidente do Instituto no cargo de 1943 a 1949. Kneese de Mello foi substituído por outro arquiteto da FAM, Oswaldo Artur Bratke na gestão de 1950 a 1951. Além do cargo de presidente, muitos arquitetos da FAM assumiram outras funções no departamento em defesa da profissão. Posteriormente, a FAU-USP contou com a fundamental participação de arquitetos e professores oriundos da FAM, apenas para citar alguns exemplos, nomes como Pedro Paulo de Melo Saraiva, Paulo Mendes da Rocha e Carlos Millan, coordenador do Grupo de Estudos do Ateliê e autor do relatório intitulado "O ateliê na formação do arquiteto" apresentado em 1962, ${ }^{55}$ além do próprio Eduardo Kneese de Mello.

Em 1948 a FAU-USP, instituição pública, laica e de perfil progressista, através de ações coordenadas por Luís Ignácio Romeiro de Anhaia Mello, tornou-se independente da Escola Politécnica da Universidade de São Paulo, que vinha formando engenheiros-arquitetos desde 1894. Ainda no edifício da Poli, a primeira turma do curso iniciou suas atividades no segundo semestre de 1948 e, para compor o quadro docente, Anhaia Mello convidou Vilanova Artigas que, após ser aprovado por meio de um concurso, ingressou na escola juntamente com outros engenheiros-arquitetos, como Ícaro de Castro Mello, Zenon Lotufo, Roberto Cerqueira César e Ernest Mange.

\footnotetext{
Oswaldo era um arquiteto formado na POLI-USP e encantado nitidamente com o Anhaia Mello, ele era do grupo do Anhaia Mello digamos assim, havia dois grupos, o grupo do Anhaia Mello e o grupo do Prestes Maia. São duas orientações importantes, nenhum dos dois era professor de urbanismo, mas estavam envolvidos com trabalhos de urbanismo, tanto Prestes Maia quanto o Anhaia Mello. ${ }^{56}$
}

A matriz curricular estava baseada no modelo federal implantado na FNA do Rio de Janeiro, em 1945, cumprindo a Lei no 7.918/1945. Incluía disciplinas artísticas, teóricas e técnicas, essas últimas, ministradas pelos catedráticos da Politécnica. É possível constatar, além de algumas disparidades nos cursos dessas duas escolas, a ênfase dada à plástica nos cinco anos do curso da FAU-USP. Grosso modo, que esse padrão curricular vigorou até 1962.

\footnotetext{
${ }^{55}$ MILAN, C.B. O ateliê na formação do arquiteto. Relatório apresentado pelo professor Carlos Barjas Millan, Coordenador do Grupo de Estudos do Ateliê. São Paulo: Setor de publicações. Faculdade de Arquitetura e Urbanismo da Universidade de São Paulo. 1962, 46p.

${ }^{56}$ KATINSKY, Julio Roberto. Entrevista com Julio Roberto Katinsky. São Paulo: 23 mai. 2016. Entrevista a José Maria de Macedo Filho. 


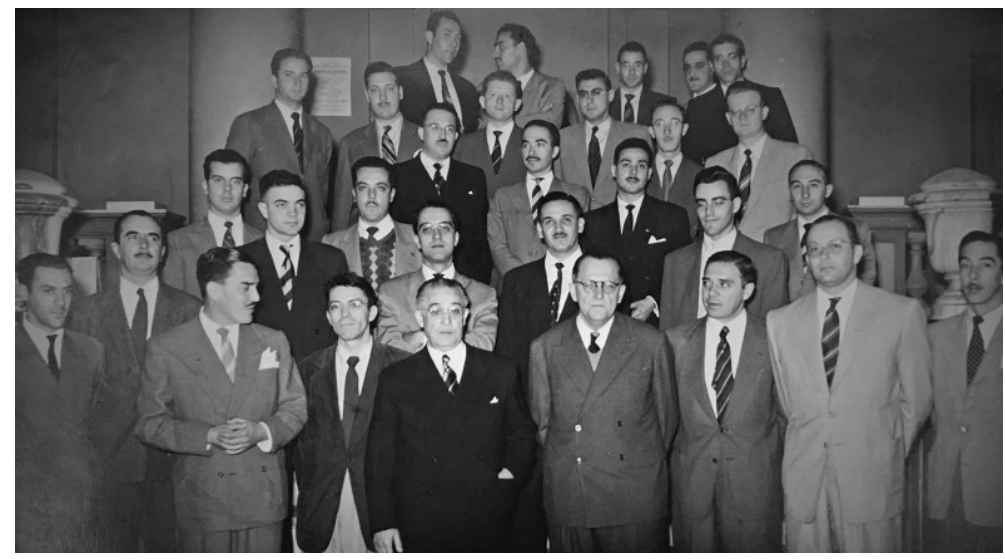

FIG. 07. Homenagem ao professor Luiz de Anhaia Mello em 26 de agosto de 1948. Oswaldo Corrêa é o terceiro da esquerda para a direita na segunda fila.

\begin{tabular}{|c|c|c|}
\hline $\begin{array}{r}\text { Matemática Superior } \\
\text { Geometria Descritiva e Aplicações } \\
\text { Arquitetura Analítica } \\
\text { Composição de Arquitetura - pequenas composições } \\
\text { Normografia } \\
\text { Desenho Artístico } \\
\text { Plástica }\end{array}$ & 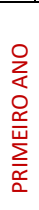 & $\begin{array}{l}\text { Matemática Superior } \\
\text { Geometria Descritiva } \\
\text { História da Arte } \\
\text { Arquitetura Analítica (1ap parte) } \\
\text { Desenho Artístico }\end{array}$ \\
\hline $\begin{array}{r}\text { Concreto simples e armado } \\
\text { Economia Política } \\
\text { Estatística aplicada } \\
\text { Organização Administrativa } \\
\text { Hidráulica: Urbana e Saneamento } \\
\text { Grandes estruturas } \\
\text { Composição de Arquitetura - grandes composições } \\
\text { Legislação e Contabilidade } \\
\text { Composição Decorativa } \\
\text { Plástica }\end{array}$ & 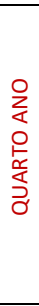 & $\begin{array}{l}\text { Concreto Armado } \\
\text { Legislação Econômica e Política } \\
\text { Higiene da Habitação e Saneamento das Cidades } \\
\text { Grandes Composições de Arquitetura (1ạ parte) } \\
\text { Arquitetura no Brasil }\end{array}$ \\
\hline
\end{tabular}

TAB. 01. Programas de ensino da FAU-USP e FNA-RJ.

Como já mencionado, o debate realizado no Primeiro Congresso Brasileiro de Arquitetos em São Paulo, em 1945, também repercutiu na esfera nacional e se estendeu ao II, III, IV e V Congressos, respectivamente, em Porto Alegre - 1953; Belo Horizonte - 1953; São Paulo - 1954 e Recife - 1955. 
Edgar Graeff sintetiza esse momento como "um verdadeiro movimento nacional pela reforma do ensino de arquitetura", ${ }^{57}$ fundamentalmente pautado pela discussão da prática profissional focada na função social do arquiteto, da reformulação do ensino de arquitetura em sintonia com o desenvolvimento tecnológico e com a qualidade da arquitetura produzida no país. Esse movimento contou com a colaboração de arquitetos de renome internacional como o próprio Walter Gropius que veio ao Brasil, em 1954, para o IV Congresso Brasileiro de Arquitetos em São Paulo.

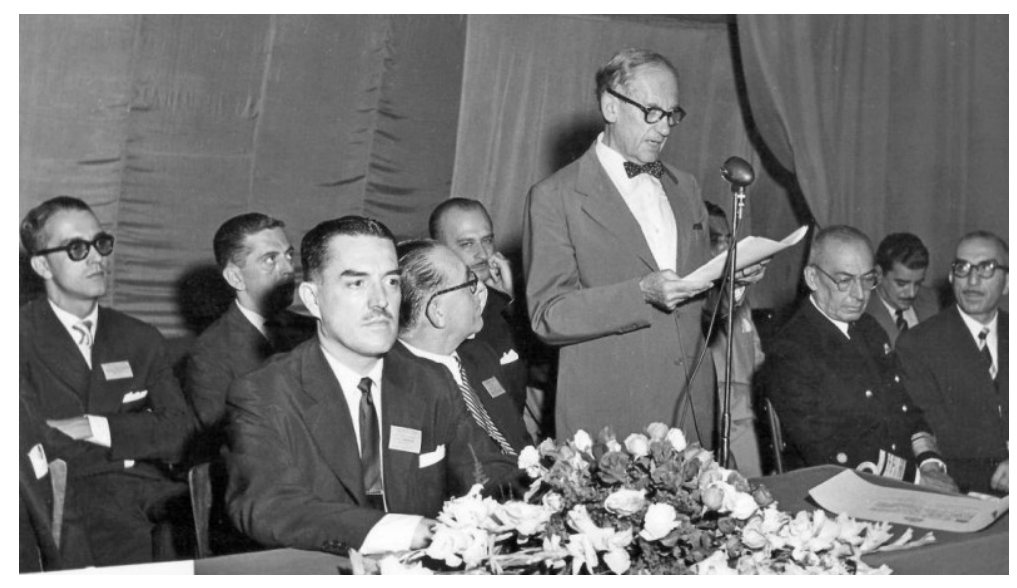

FIG. 08. Discurso de Walter Gropius na cerimônia de abertura do IV Congresso Brasileiro de Arquitetos em São Paulo, 1954. À esquerda de Gropius, Rino Levi, Leo Ribeiro de Moraes e Oswaldo Corrêa Gonçalves.

Além do congresso, Gropius participou de uma série de eventos organizados pelo IAB/SP e pelos seus associados, compartilhou sua experiência pedagógica desenvolvida na Bauhaus, difundindo sua visão de trabalho coletiva, não individualizada, praticada em oficinas ou ateliers. Nesse sentido, deve-se destacar a valorosa preocupação dos arquitetos brasileiros com os rumos da profissão e sua contribuição com o desenvolvimento tecnológico do país. A presença de nomes como o de Gropius não se deu por qualquer sentimento de inferioridade técnica ou artística, muito pelo contrário, mas por questões de experimentação e atualização pedagógica. O reconhecimento da qualidade e originalidade da produção brasileira de arquitetura no exterior, através de exposições como por exemplo, a Brazil Builds de Philip Goodwin ${ }^{58}$, somado a projetos de grande impacto, como a construção do Parque do Ibirapuera (1952-54) e o concurso do Plano Piloto de Brasília (1956), intensificou o movimento de afirmação do trabalho do arquiteto no país, baseado na formação de equipes para o trabalho conjunto da categoria no grande projeto da sociedade brasileira. "Com o

\footnotetext{
${ }^{57}$ Graeff, indo além, ressalta que "este trabalho específico na área de arquitetura ganha maior significado por ter-se mantido incorporado ao grande movimento nacional pela reforma geral do ensino superior e da universidade brasileira". GRAEFF, E. A. Arte e técnica na formação do arquiteto. São Paulo: Nobel, 1995. p. 44.

${ }^{58}$ A exposição Brazil Builds continha exemplares da arquitetura brasileira do período de 1652 a 1942, desde o legado histórico à produção moderna, dentre outras obras: o Ministério de Educação e Saúde; o Pavilhão Brasileiro na Feira Internacional de Nova York de 1939, a Residência João Arnstein etc. Após a exibição em Nova York, a exposição circulou entre 1943 e 1945 por cidades da América do Norte e também foi apresentada em Londres. No Brasil, foi exposta no Rio de Janeiro, Belo Horizonte, São Paulo, Santos, Campinas, Curitiba, Florianópolis, Porto Alegre e Jundiaí. Ver mais sobre o tema. SEGAWA, Hugo. Arquiteturas no Brasil 1900-1990. São Paulo: EDUSP, 2002. pp. 101-102. GOODWIN, Philip. Brazil Builds: Architecture New and Old 1652-1942. New York: The Museum of Modern Art, 1943.
} 
despontar do sentimento nacionalista, cresce a tese de uma arquitetura motor de transformações da sociedade, e o projeto passa a ser considerado instrumento dessa ação transformadora". ${ }^{59}$

Conforme o exposto, a constituição da profissão de arquiteto e urbanista no Brasil se deu através do debate acerca dos procedimentos pedagógicos para a formação desse profissional, centrado no processo de emancipação e autonomia do Curso de Arquitetura em relação aos cursos das Escolas de Belas Artes e das Escolas Politécnicas, através da atuação de professores, estudantes e entidades de classe como o Instituto dos Arquitetos do Brasil. Finamente, pode-se afirmar que arquitetura, ideologia e política são indissociáveis, inclusive Sylvia Fischer destaca o posicionamento político mais à esquerda daquele grupo de arquitetos do IAB-SP:

Desde o início dominava uma clara tendência de esquerda, sendo suas reuniões ocasião para levantar fundos para o Partido Comunista Brasileiro. Entidade considerada nos setores mais conservadores da classe (leia-se Instituto de Engenharia) como dominada pelos comunistas, o IAB/SP esteve sempre empenhado em lutas políticas de cunho democratizante e nacionalista. ${ }^{60}$

Oswaldo Bratke, um dos fundadores do Instituto, comentou sobre a postura e investidas dos arquitetos modernos do IAB-SP contra os arquitetos ainda presos à tradição clássica da arquitetura, “determinados arquitetos eram delicadamente afastados, uma vez que não eram reconhecidos por esse time como arquitetos de vanguarda. E o IAB era, sem dúvida nenhuma, para os de vanguarda." ${ }^{61}$ Assim, os membros que não estivessem alinhados com os princípios políticos e ideológicos da entidade e ao espírito social da arquitetura moderna, eram vistos como conservadores, antiquados e deixados em segundo plano no grupo.

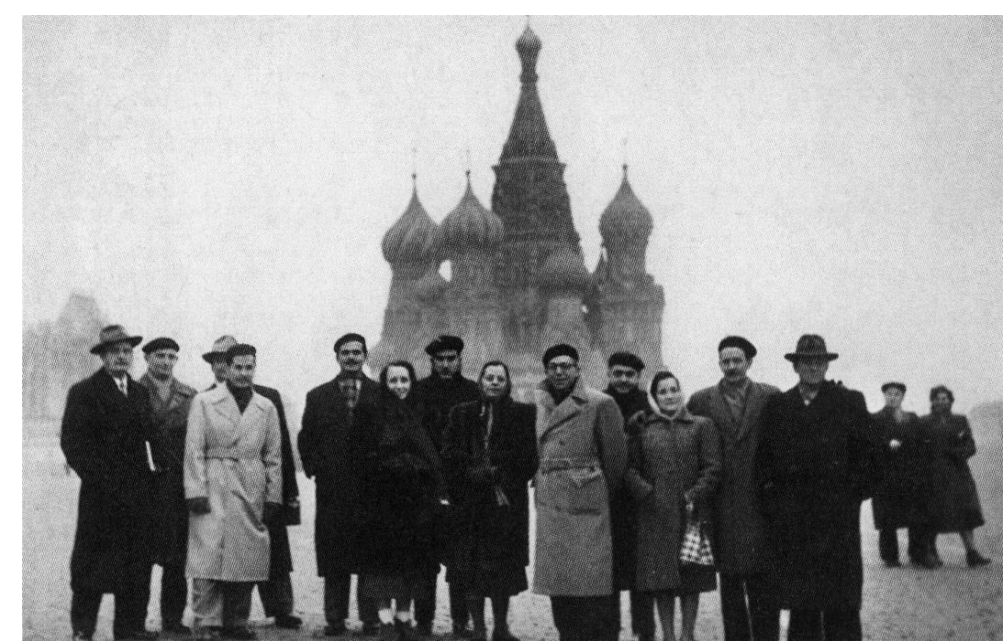

FIG. 09. Vilanova Artigas e o grupo de arquitetos brasileiros diante da catedral de São Patrício, na Praça Vermelha em Moscou. Destaca-se a presença de Lina Bo Bardi, Paulo Mendes da Rocha, Pedro Paulo de Melo Saraiva, dentre outros.

\footnotetext{
${ }^{59}$ FERNANDES, Ary et al. op.cit. p.126.

${ }^{60}$ FICHER, Sylvia. Os arquitetos da Poli: ensino e profissão em São Paulo. São Paulo: Edusp, 2005. p. 248.

${ }^{61}$ Ibid. pp. 247-248.
} 
ENTRADA 


\title{
Contribuição paulistana
}

\begin{abstract}
Quando eu estava no Brasil, o Neves me contou que eles estavam procurando levar para a escola de arquitetura os velhos professores que saíram da Politécnica por ocasião da lei de desacumulação [...] isso não tem importância, eles poderiam até servir. Mas o Neves me disse que eles achavam que, para a escola

de arquitetura, qualquer professor serviria - para as cadeiras tipicamente técnicas porque arquiteto não precisa conhecer muito isso. É errado. Exatamente o contrário deve ser o nosso ponto de vista. Para a nova Faculdade, o melhor. Insisto nisso, Oswaldo [...] o nosso slogan deve ser: para a Escola, o melhor. ${ }^{62}$
\end{abstract}

A consistente produção da arquitetura brasileira, de certa maneira, ainda dependia dos talentos individuais para ser reproduzida, o que demonstrava, na visão daqueles arquitetos, a necessidade de aperfeiçoamento do seu ensino, pois os cursos de arquitetura ainda eram um amálgama indefinido e compartimentado das escolas de belas artes e das escolas de engenharia. Não sendo uma exceção, a FAU-USP, mesmo instalada em seu prédio próprio desde 1950, na Rua Maranhão, permanecia vinculada às cátedras de ensino técnico e com professores da Politécnica ocupando esses cargos. Em 1957, a insatisfação com esse modelo motivou a escola a iniciar um processo de reformulação pedagógica para garantir aos novos arquitetos uma formação compatível com as necessidades do país, seguindo os pressupostos de autonomia estabelecidos pelos congressos e entidades de classe. Com esse objetivo foi criada uma comissão composta pelos professores João Vilanova Artigas, Rino Levi, Abelardo de Souza e Hélio Duarte, e essa comissão coordenou a elaboração do documento conhecido como Proposta de $1957 .{ }^{63}$

O projeto reconhecia a complexidade do ensino de arquitetura não só no Brasil, mas em todo o mundo, principalmente pelo desajuste entre os currículos universitários e a vida profissional do arquiteto. Esses professores perceberam que o problema não estava apenas relacionado aos processos de ensino, mas também à própria organização da sociedade e dos conflitos entre a técnica e a arte contemporânea, entretanto tinham clareza de que a responsabilidade de integrar o arquiteto à sua "missão social" cabia às organizações de ensino. O reconhecimento da pouca experiência no ensino de arquitetura frente às novas demandas emancipadoras da sociedade brasileira, além da responsabilidade de sustentar o elevado prestígio da arquitetura nacional no contexto internacional, abriu a possibilidade para o experimento.

Segundo a comissão, não bastava adaptar os currículos técnicos para a formação do arquiteto, pois são informativos, assim como as disciplinas de história, trata-se de uma formação muito mais

\footnotetext{
${ }^{62}$ Carta de Vilanova Artigas a Oswaldo Corrêa Gonçalves. Nova York, 27 de dezembro de 1946, 3p. Arquivo Biblioteca da FAUS.

63 "Se temos pouca experiência e pouca tradição no ensino da arquitetura, em compensação estamos menos comprometidos com métodos hoje mundialmente considerados antiquados e contraproducentes. Convém frisar que temos todas as condições para iniciar um novo ciclo de experiências em torno do ensino dentro de um espírito mais evoluído, longe das limitações características de um tradicionalismo que só à primeira vista é difícil de romper". Trecho do relatório da reforma de 1957. Ensino de arquitetura na FAU-USP - proposta de 1957. FORTI, Marco Artigas. FAUUSP - 50 anos da Reforma de 1962. não p. Disponível em: <http://www.dearquiteturas.com>. Acesso em: 11 nov. 2015.
} 
complexa do que a visão fragmentada dos conteúdos, ou seja, do arquiteto se exige uma síntese, "uma visão unitária do mundo contemporâneo", um conjunto de conhecimentos capaz de expressar com segurança o desenvolvimento cultural da sociedade em que se vive. Desse modo, com clara referência à Bauhaus, ressaltam a ênfase dada à formação do "arquiteto integral" por escolas estrangeiras progressistas conferindo ao futuro arquiteto uma visão universal e única do mundo que o envolve.

\begin{abstract}
Walter Gropius, que dos grandes arquitetos contemporâneos é talvez o que maior contribuição tem dado para o esclarecimento desses conceitos, assim se exprime: "o arquiteto é um coordenador cuja missão é unificar os numerosos problemas sociais, técnicos, econômicos e plásticos inerentes à construção". E sobre o ensino em particular: "o campo de ação do aluno deve ser universal e não fragmentário, compreendendo todos os conhecimentos e a experiência real. ${ }^{64}$
\end{abstract}

"A nossa escola tem todas as condições para aproximar-se dessas aspirações." ${ }^{65}$ Essa afirmação, contida no relatório de 1957, marca o ponto de inflexão para que a FAU-USP fortaleça e consolide os ideais de coletividade propostos por Gropius nos anos 1920 na Bauhaus, estabelecendo alianças e juntando forças no sentido de uma "maior integração de todos os valores em uma equipe harmônica e convicta das possibilidades que realmente temos de dar um passo à frente na solução da missão que assumimos." ${ }^{66}$ Portanto, a Proposta de 1957 não representava opiniões individuais, mas de todo o grupo e esse ideal de coletividade proporcionou ao atelier o status de organismo de convergência de todas as disciplinas do curso. Por sua importância no exercício da profissão, o atelier configura o lugar da relação horizontal entre professor e estudante e da síntese entre a prática profissional e o ensino.

Em 1960, na ocasião do Encontro Regional de Educadores Brasileiros, a comissão responsável por analisar o ensino de arquitetura era formada por professores da FAU-USP e o professor Roberto Cerqueira César, através de seu relatório intitulado "O Ensino da Arquitetura e do Urbanismo," demonstrava que as ideias contidas na proposta de 1957 amadureciam e ganhavam força e, apesar de não ter sido detalhada e posta em prática, recomendava que essa proposta deveria ser utilizada como ponto de partida para os trabalhos das comissões que estudavam a nova organização do ensino na FAU-USP. Assim, de acordo com a legislação federal, formalizaram uma proposta na qual o projeto, deveria ter dentro da escola, a mesma importância que ele tem no exercício da profissão, estabelecendo distinções de natureza e função educativa em cada matéria, criando grupos de pesquisa científica, cultural e de prática de atelier. ${ }^{67}$

\footnotetext{
${ }^{64}$ FORTI, Marco Artigas. FAUUSP - 50 anos da Reforma de 1962. Op. cit. não p.

${ }^{65} \mathrm{Ibid}$.

${ }^{66} \mathrm{Ibid}$.

${ }^{67}$ Em 1962, o relatório "O ensino da arquitetura e do urbanismo", do professor Roberto Cerqueira Cézar foi citado na íntegra por Carlos Millan. MILLAN, C.B. $O$ ateliê na formação do arquiteto. Op. cit. 46p.
} 
Sugestões em Estudo - 1957
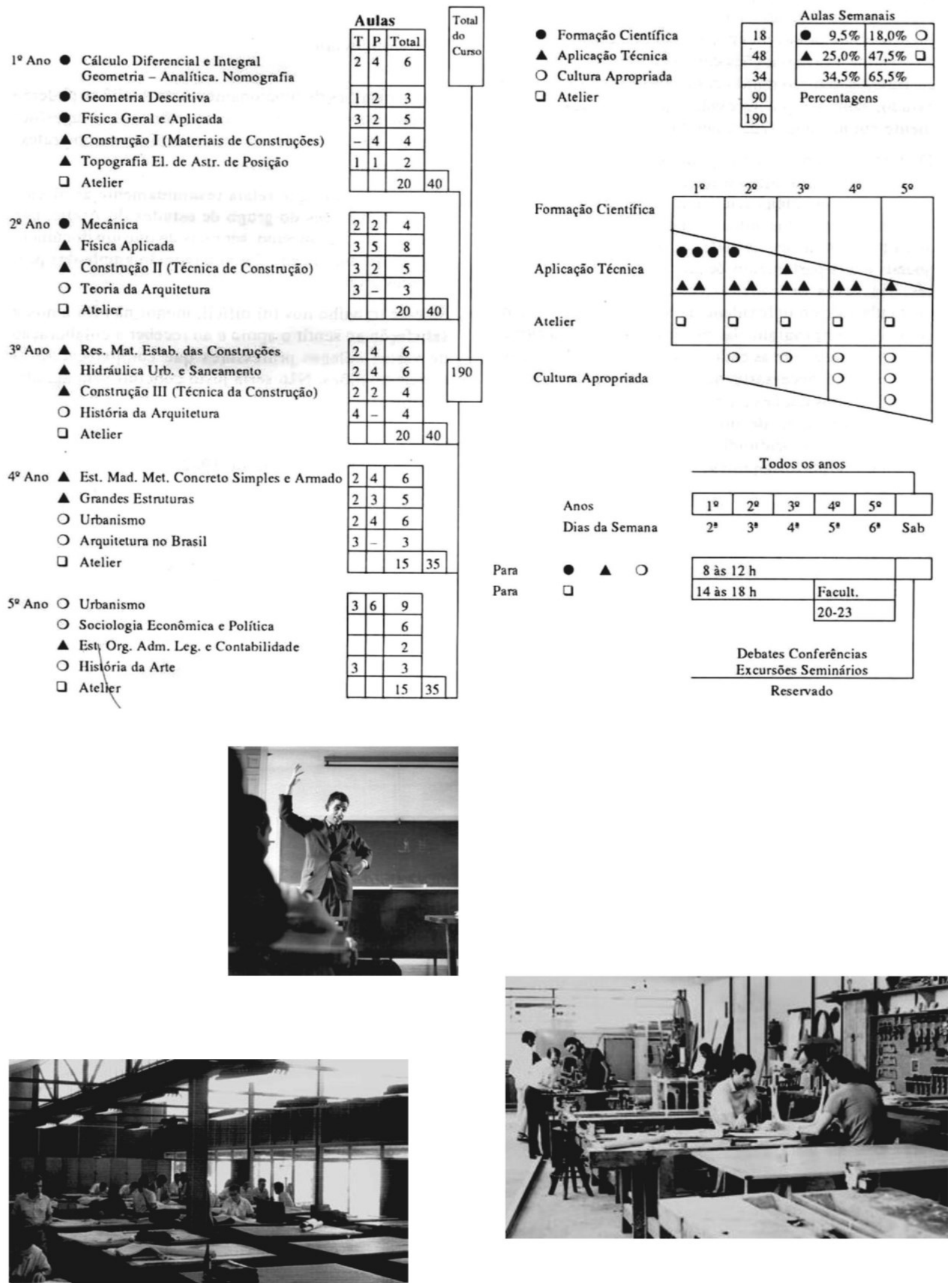

FIG. 10. Organograma do atelier da FAU-USP proposto em 1957. Flavio Motta em sala de aula na FAU-USP durante o 20 semestre de 1958 Atelier da FAU-USP na Vila Penteado nos anos de 1968, projeto de Ernst Mange e Ariaki Kato, 1956 e vista interna do "Galpão da Maquete". 
Em 1962, a FAU-USP criou um novo modelo pedagógico, conhecido como "Reforma de 62",68 resultado de uma série de debates que, liderados por Vilanova Artigas, envolveram professores e estudantes com o objetivo de consolidar um regulamento próprio e emancipatório dos currículos da FNA e da Poli. Segundo o professor Edgar Dente, a reforma de 1962 não alterou radicalmente a "estrutura curricular" até então vigente na FAU, existia quase uma total correspondência entre as disciplinas antigas e as novas, aparentemente tratava-se de uma simples alteração de nomenclatura, entretanto o que ocorreu foi uma verdadeira revolução no ensino da arquitetura: "A Lei de Diretrizes e Bases da Educação, aprovada pelo Congresso Nacional no ano anterior, extinguiu as cátedras e com elas foi-se a tirânica ditadura imposta à FAU pelos catedráticos da Politécnica". ${ }^{69}$ Nesse sentido, a principal reformulação aprovada foi a substituição das cátedras, que induziam à fragmentação dos conteúdos com consequente isolamento das disciplinas correlatas pelos departamentos que, de modo inverso, organizavam e reuniam as disciplinas afins adequando os programas de modo a garantir a unidade da formação do arquiteto.

\begin{abstract}
As nossas escolas superiores não têm vitalidade, elas não se transformam nunca; não são autônomas, dependem da politicagem e muito. E depois a coisa bárbara de os professores serem catedráticos e vitalícios. Eles envelhecem e morrem na cátedra; suam velhice nas barbas da gente. Já aqui, uma organização universitária pode mudar a rota da noite para o dia. É só despedir meia dúzia de professores e contratar novos que no mês seguinte a escola exibe os mais tentadores programas. E isso não é conversa fiada não. Eu venho de presenciar isso no MIT. Os nomes publicados no catálogo do ano passado já não representam nada hoje. E eram uns nomes pesados, pesadíssimos. ${ }^{70}$
\end{abstract}

O extraordinário feito da recém-inaugurada cidade de Brasília ampliou a convicção de que a atividade do arquiteto não se limitava apenas à construção de edifícios, certeza reforçada pela crescente demanda da administração pública e particular por desenvolvimento de planos urbanos e regionais com a presença de arquitetos, nas palavras de Millan: "Os arquitetos são chamados a assumir, e assumem, trabalhos e responsabilidades cada vez maiores, seja nas obras de Brasília, seja nas obras do Plano de Ação do governo do estado de São Paulo." ${ }^{71}$ Diante dessa constatação, o documento afirmou a necessidade de incluir as disciplinas de planejamento urbano e regional no currículo da faculdade. Outro setor carente de profissionais arquitetos estava relacionado à "demanda da indústria por profissionais capazes de intervir no campo do desenho industrial", ${ }^{72}$ assim foi criada a disciplina de desenho industrial para projeto de equipamentos, móveis, utensílios e fabricação de elementos de construção. Essa iniciativa estava diretamente ligada ao fato de a FAU

\footnotetext{
${ }^{68}$ Essa resenha foi elaborada a partir do texto "O sentido da Reforma de 1962", redigido no dia 20 de julho de 1962 e apresentado no III Encontro de Diretores, Professores e Estudantes das Escolas de Arquitetura, realizado em Belo Horizonte em agosto do mesmo ano. Arquivo Biblioteca da FAUS.

${ }^{69}$ DENTE, Edgar G. Estudo Crítico e Proposta para a Estrutura Curricular da FAU-USP. Edição do Autor. São Paulo, FAU-USP. 1987. não.p.

${ }^{70}$ Carta de Vilanova Artigas a Oswaldo Corrêa Gonçalves. Nova York, 27 de dezembro de 1946, 3p. Arquivo Biblioteca da FAUS.

${ }^{71}$ MILAN, C.B. $O$ ateliê na formação do arquiteto. Op.cit. 46p.

72 Ibid.
} 
estar localizada no centro industrializado mais importante do país, permitindo o caráter pioneiro nesse rumo.

Em linhas gerais, a Reforma de 1962 acompanhou o espirito da Proposta de 1957, concentrando nos primeiros anos as disciplinas de formação técnica e científica, substituídas gradativamente pelas disciplinas de caráter cultural conforme o estudante avançasse no curso, tendo o atelier, ou seja, as atividades de projeto ou composição, como elemento catalisador dos conteúdos aprendidos nessas disciplinas, permitindo que o estudante elaborasse a síntese dos conhecimentos adquiridos, através da materialização do próprio projeto. Considerada a importância do Departamento de Composição, foram criadas linhas de pesquisa dentro do departamento com o objetivo de flexibilizar a formação e tornar os arquitetos aptos para trabalhar nos campos do desenho industrial, no projeto de edifícios e no planejamento das cidades. Orientadas verticalmente com programas específicos para o desenvolvimento progressivo e condizente com os objetivos estabelecidos. Segundo Millan, através do atelier que a faculdade realizará seus objetivos fundamentais:

1. Realizar o aprendizado e domínio dos meios de representação e expressão gráficas; 2. Iniciar o aluno, egresso dos cursos médios de caráter geral, no mundo dos valores plásticos e estéticos, desenvolvendo nele pela experiência, a sensibilidade e a capacidade criadora, aliadas a uma necessária mentalidade de construtor; 3. Ser o lugar de estudo, de pesquisa e trabalho do planejamento do meio físico nas suas relações diretas com o homem, onde o aluno entrará em contato com os problemas vivos da Arquitetura e do Urbanismo, na forma mais próxima daquela em que os terá como profissional. ${ }^{73}$

Millan recomendou ainda o "treinamento" gráfico e plástico-construtivo individual nos dois primeiros anos, instrumentalizando o aluno para que pudesse enfrentar os problemas arquitetônicos com certa liberdade e possibilidade de penetração do terceiro ao quinto ano do curso. Além disso, frisava a importância do contato com os problemas reais em toda a sua complexidade e grandeza, nesse sentido, todos os alunos da faculdade deveriam frequentar simultaneamente o atelier, organizados da seguinte maneira: aprendizado gráfico e plástico-construtivo; mentalidade de construtor e formação do arquiteto. Os exercícios deveriam ser eminentemente práticos, com a intenção de fixar a nova linguagem e a nova sintaxe que começam a conhecer. Os temas de composição, nesses anos, deveriam se restringir a aspectos - muito particulares - da organização espacial, nos quais pudessem verificar as implicações de ordem construtiva.

A Reforma de 1962, apesar de não ter sido a única reforma no país naquele momento, delineou novos horizontes para o ensino e a prática profissional em São Paulo e no Brasil. De acordo com o professor Julio Katinsky, "foi um esforço de síntese de Vilanova Artigas, absorvendo tudo que havia de proposta de ensino de arquitetura na época" ${ }^{74}$ e desse modo, a Reforma estabeleceu diretrizes

\footnotetext{
${ }^{73}$ MILAN, C.B. $O$ ateliê na formação do arquiteto. Op.cit. 46p.

74 Depoimento do professor Julio Roberto Katinsky concedido ao autor em 23 de maio de 2016.
} 
para a criação de um currículo independente para a formação do arquiteto, notadamente influenciada pelos princípios da Bauhaus de Gropius, e pelos princípios do Construtivismo Russo que vislumbrou "as possibilidades de a arte se integrar com a vida, de forma a abrir uma idade de ouro que a Revolução Soviética ofereceu, e foi o que realmente determinou as saídas para a Arquitetura Moderna". ${ }^{75}$

Nesse ponto, importa dizer que dessa forma, esse novo modelo propôs que as atividades de tecnologia e os estudos das ciências humanas fundamentassem diretamente as práticas de atelier que detinham $50 \%$ da carga horária total do curso, destacando a importância do projeto como fator relevante na atuação do arquiteto e urbanista no contexto geográfico no qual está inserido, com sentido social e perfil generalista. ${ }^{76}$ Segundo Braga, em decorrência da reestruturação curricular foram criadas quatro linhas de desenvolvimento didático: 1 - expressão gráfica ou comunicação visual; 2 - desenho industrial; 3 - arquitetura de edifícios; 4 - planejamento. Foram criados e estruturados quatro departamentos: 1 - Composição; 2 - Histórico-crítico; 3 - Ciências Aplicadas; 4 Disciplinas Técnicas. Finalmente, como elemento coordenador e de integração interdisciplinar, foi criado o "Museu", órgão centralizador e difusor dos resultados dos trabalhos e pesquisas desenvolvidos dentro da faculdade na forma de exposições, conferências, seminários e publicações ${ }^{77}$ No que diz respeito aos fundamentos da arte, guardadas as devidas proporções, arrisca-se dizer que o professor Flavio Motta foi para a Faculdade de Arquitetura e Urbanismo da Universidade de São Paulo o que o artista Johannes Itten foi para a Bauhaus. Desempenhou importante papel no desenvolvimento do campo da arte na FAU-USP e, a partir de 1962, contou com a ajuda de dois exalunos na condição de professores assistentes, os arquitetos Julio Katinsky e Sérgio Ferro. ${ }^{78}$ Esse momento coincide com o interesse de aprofundamento e pesquisa, por parte de Flavio Motta, de temas relativos ao estudo da "arte popular", da "arte entre as crianças e os alienados", da "arte negra", etc. Em um verdadeiro esforço de consolidação e sistematização dos estudos de História da Arte no Brasil promoveu uma nova forma de olhar a cultura popular que, sem dúvida influenciou o

\footnotetext{
${ }^{75}$ ARTIGAS, João Batista Vilanova. Op. cit. p. 187-188.

${ }^{76}$ Termo difundindo por Gropius publicado pela primeira vez no Brasil pelos boletins do IAB no 11. nov. 1954 e no 12. dez. 1954. Disponível em: < http://www.iabsp.org.br/boletins/boletins_1954.pdf >. Acesso em: 08 jul. 2019. Para Gropius, "na educação do arquiteto criativo, importa mais procurar e menos o examinar. Acredito que um tal programa levará nossos futuros arquitetos da observação à descoberta, da descoberta à invenção e finalmente à configuração intuitiva de nosso mundo-ambiente". GROPIUS, Walter. Bauhaus: novarquitetura. Op. cit. pp. 79-96.

77 As reformas programadas em 1961 foram postas em prática. Assim é que se instalou o 'atelier' amplo, onde são ministradas as aulas das cadeiras ligadas ao departamento de Composição, assistidas por docentes de cadeiras técnicas, tais como física, hidráulica, materiais e técnica das construções. Segundo o relatório, nesse ano a FAU recebeu uma verba do Plano de Ação do Governo do Estado, o que possibilitou o aumento de pessoal administrativo e uma série de melhorias na biblioteca, que ampliou seu tamanho e aumentou consideravelmente o acervo. O relatório apresenta não somente as alterações no sistema de ensino, mas também as modificações na estrutura administrativa e física da Faculdade para comportar a nova organização. O corpo docente, que contava com 60 professores em 1961, foi expandido para 86 professores no ano seguinte. E segundo o relatório, o programa para o ano de 1963 era o de "consolidar as reformas já iniciadas", que estavam redigidas em um novo regulamento da Faculdade, "em fase adiantada de elaboração". Apud. COSTA, Juliana Braga. História, arte e arquitetura: Flávio Motta e o ensino como ofício. 2017. 362p. (Doutorado em arquitetura e urbanismo) Faculdade de Arquitetura e Urbanismo da Universidade de São Paulo. São Paulo, 2017. pp. 248-249.

${ }^{78}$ Formados pela Faculdade de Arquitetura e Urbanismo da Universidade de São Paulo, respectivamente, em 1957 e 1962.
} 
programa de 1962 e, consequentemente, norteou os futuros debates para relacionar a arte com a técnica nas escolas de arquitetura brasileiras. ${ }^{79}$

Em 1963, foi realizado na FAU-USP o seu primeiro Fórum de debates que, além de comemorar os primeiros quinze anos de fundação da FAU, deu continuidade ao debate acerca do ensino e da prática profissional com a consolidação da Reforma de 1962. Tratou da transferência da escola para o novo edifício na cidade universitária e da aprovação da regulamentação profissional das atividades de arquiteto, engenheiro e agrônomo pelo congresso nacional. Esse processo foi interrompido pelo golpe militar de $1964 .{ }^{80}$

Em junho de 1964 o Ministério da Educação brasileiro (MEC) firmou o primeiro de uma série de acordos com a United States Agency for International Development (USAID), os conhecidos acordos MEC-USAID. ${ }^{81}$ Grosso modo, esses acordos estabeleceram convênios de assistência técnica e cooperação financeira à educação brasileira, seu caráter instrumental claramente visava atender aos interesses do capital internacional, principalmente aos interesses norte-americanos. Os MEC-USAID passaram a nortear as formulações e orientações da política educacional nacional que, posteriormente, conduziram o processo de reforma da educação brasileira ao longo da ditadura militar. ${ }^{82}$ Inevitavelmente, as universidades reagiram e passaram a constituir importantes pontos de resistência e inconformismo com a situação, na busca de um novo projeto de universidade nacional, além da defesa das conquistas alcançadas na Reforma de $1962 .{ }^{83}$

Em 1966, o diretor da FAU-USP, indicado ao cargo em 1964 pelo governo, sistematicamente procurava reestabelecer os padrões de ensino politécnicos, interferiu no projeto de Artigas para o

\footnotetext{
${ }^{79}$ Segundo Braga, Julio Katinsky que havia sido membro do Centro de Estudos Folclóricos do GFAU, foi quem sugeriu a incorporação do estudo do artesanato popular ao conjunto de temas a serem pesquisados na disciplina, propondo como tema a produção dos artesãos do Vale do Paraíba. Sobre o legado de Flavio Motta ver COSTA, Juliana Braga. História, arte e arquitetura: Flávio Motta e o ensino como ofício. 2017. 362p. (Doutorado em arquitetura e urbanismo) - Faculdade de Arquitetura e Urbanismo da Universidade de São Paulo. São Paulo, 2017. pp.255-270. Ver também COSTA, Juliana Braga. Ver não é só ver: dois estudos a partir de Flávio Motta. 2010. 250p. (mestrado em arquitetura e urbanismo) - Faculdade de Arquitetura e Urbanismo da Universidade de São Paulo. São Paulo, 2010.

${ }^{80}$ No contexto internacional, esse mesmo período foi marcado por uma série de golpes militares na América Latina, sucederam ao Brasil a Argentina em 1966, Chile e Uruguai em 1973. Sobre o Golpe de 1964 ver mais em MOTA, C. G.; LOPEZ, A. História do Brasil, uma interpretação. 4a Edição. São Paulo: Editora 34, 2015 e REIS, Daniel Aarão. Ditadura e democracia no Brasil: do golpe de 1964 à constituição de 1988. Rio de Janeiro: Zahar, 2014.

${ }^{81}$ Para aprofundar o entendimento sobre estes acordos ver os seguintes trabalhos: ARAPIRACA, José Oliveira. A USAID e a educação brasileira: um estudo a partir de uma abordagem crítica do capital humano. 1979. 273p. (Dissertação de mestrado em educação) Instituto de Estudos Avançados em Educação, Fundação Getúlio Vargas. Rio de Janeiro, 1979 e GAIO, Daniel Machado. A concepção de modernização na política de cooperação técnica entre o MEC e a USAID. 2008. 162p. Dissertação (Mestrado em educação) Universidade de Brasília. Brasília, 2008.

82 "Parte das políticas que visavam garantir a expansão do capital, tinham também sua expressão no plano educacional, cumprindo uma função preparatória das condições econômicas, culturais e sociais contemporâneas, definidas por Francisco de Oliveira como o 'monstrengo social' em que nos transformamos". PRONSATO, SYLVIA A. DOBRY. Para quem e com quem: ensino de arquitetura e urbanismo. 2008. 321p. Tese (Doutorado em arquitetura e urbanismo) - Faculdade de Arquitetura e Urbanismo da Universidade de São Paulo. São Paulo, 2008. pp. 52-53.

${ }^{83}$ A situação econômica do país se deteriorava rapidamente devido à política de contenção inflacionária do governo que, além de contribuir para o descontentamento das classes operárias em razão da contenção salarial estimulando sucessivos focos de greve em todo o território, refletia diretamente na profissão do arquiteto retraindo significativamente a demanda por projetos, que, por consequência, reprimia a indústria da construção e ao mesmo tempo reduzia a qualidade dos produtos elaborados. FERNANDES, Ary et al. Prática Investigação. Op. cit. p. 126.
} 
prédio da FAU e solicitou o imediato início da sua construção na cidade universitária. Enquanto isso, na FAU Maranhão, ele fechou o Museu, o Laboratório Fotográfico e o Centro de Estudos Brasileiros e transformou o atelier em salas menores. Esses fatos somados irritaram os estudantes de tal forma que, além de desmontarem as divisórias do atelier, paralisaram as atividades didáticas instaurando um processo de crise. "Antes de os colegas franceses abrirem as barricadas em Paris, os alunos da FAU, cumprindo o rito tradicional e consolidando o símbolo, demoliram as paredes do atelier reconstruídas pelo diretor e instauraram o Fórum célebre" ${ }^{84} \mathrm{O}$ diretor reagiu solicitando a imediata mudança para o novo prédio:

Sabe V. Exa. que a Faculdade de Arquitetura e Urbanismo, na atual conjuntura, é uma mentira à sã política universitária. É uma Faculdade tumultuada, perdida, no meio da massa estudantil do bairro de Higienópolis. Difícil a sua administração eficiente. Praticamente impossível o seu disciplinamento: quer do corpo discente, quer do corpo docente, quer do corpo administrativo. [...] É urgente o início das obras, para que se possa transferir, o mais breve possível, integralmente, toda a Faculdade. ${ }^{85}$

De acordo com o professor Edgar Dente, Pedro Moacir afastou-se por problemas de saúde e foi substituído pelo Prof. Eurípedes Simões de Paula, historiador da Faculdade de Filosofia e um dos "pais da segunda era da USP". Posteriormente, Ariosto Mila foi eleito seu sucessor pela primeira Congregação própria da FAU e, pela primeira vez, um arquiteto. A obra do novo prédio da FAU avançava e havia um clima de grande expectativa acerca da futura da escola. Nesse sentido, Sérgio Ferro, Rodrigo Lefèvre, Flávio Império e o então estudante Edgar Dente, preocupados com um eminente retrocesso, arquitetaram toda a agitação que redundou na eclosão de um Fórum para reestabelecer e atualizar as diretrizes de ensino elaboradas na Reforma de $1962 .{ }^{86} \mathrm{O}$ desfavorável contexto político desse período ditatorial, no qual o governo do regime militar perseguia os militantes de esquerda com a justificativa de que estes eram uma ameaça ao país, influenciou radicalmente o foco das discussões.

Em síntese, no Fórum de 1968 havia duas posições: de um lado, Vilanova Artigas que, diante do controverso cenário político, reafirmava a proposta de 1962 e argumentava que diante do grande processo de expansão industrial e urbano, o projeto deveria ser visto como instrumento político, utilizando o governo (mesmo o militar) como suporte para a elaboração de projetos e construções com fins sociais, afinal esse deveria ser o papel natural do Estado, evitando qualquer tipo de confronto armado e o desnecessário derramamento de sangue de jovens estudantes. Do outro lado, os jovens Sérgio Ferro, Flávio Império e Rodrigo Lefèvre que sustentavam que a prática profissional

\footnotetext{
${ }^{84}$ DENTE, Edgar G. Op. cit. não p.

${ }^{85}$ Ofício datado de 7 de dezembro de 1966, do Diretor Pedro Moacyr do Amaral Cruz ao diretor Executivo do FUNDUSP, Adalberto M. dos Santos, saudando o contrato lavrado para a edificação do edifício da Faculdade no campus do Butantã. JUNQUEIRA, Luiz Eduardo Vasconcellos. Os anexos da FAU-USP: do ateliê da Vila Penteado ao concurso de 1989. 2016. 451p. Dissertação (Mestrado em arquitetura e urbanismo) - Faculdade de Arquitetura e Urbanismo da Universidade de São Paulo. São Paulo, 2016. p. 129.

${ }^{86}$ DENTE, Edgar Gonçalves. Entrevista com Edgar Gonçalves Dente. São Vicente, 06 jun. 2016. Entrevista a José Maria de Macedo Filho.
} 
da arquitetura não era suficiente para fazer frente ao regime militar, defensores da luta armada, ficaram conhecidos como Grupo Arquitetura Nova. ${ }^{87}$

No Fórum de 1968, foram criadas três comissões mistas, uma para cada Departamento: Projeto, História e Ciências Aplicadas. Sérgio Ferro e Rodrigo Lefèvre eram professores do Departamento de História e ficaram quase como relatores das comissões dos departamentos de Ciências e Projeto. Esses professores eram muito críticos à divisão do trabalho no canteiro de obras e à separação decorrente entre trabalho intelectual e manual, defendiam uma pedagogia que oferecesse maior autonomia ao estudante, propunham uma estrutura que, aos moldes de disciplinas eletivas, ${ }^{88}$ permitiria que o aluno trilhasse seu próprio caminho a partir de seus interesses. Essas unidades seriam integradas por um atelier interdepartamental. Entretanto, essa proposta encontrava cada vez mais resistência dos engenheiros da Poli. O Professor Artigas fez uma explanação acerca da Reforma de 1962 e da necessidade de continuidade do processo de revisão do ensino:

O mérito da Reforma de 1962 foi a diferença metodológica entre arte, ciência e técnica. Surgiu uma angulação nova de análise de uma série de problemas. A necessidade de racionalizar a arquitetura de um lado e a técnica de outro, a Reforma colocou para a FAU a conceituação dos aspectos modernos da problemática do objeto do planejamento urbano e do projeto, propondo sobre um ângulo mais moderno a pesquisa do real artístico, a metodologia artística [...] A Reforma não foi algo que surgiu do nada, mas foi o prosseguimento de um processo, esse processo deve ser continuado, pois nenhuma reforma é reforma enquanto imobiliza. ${ }^{89}$

Venceu a proposta da forte figura de Vilanova Artigas frente às dificuldades impostas pelos catedráticos, reafirmando a Reforma de 1962 e incorporando uma revisão dos métodos de ensino dos Departamentos de Construção e Ciências, o que, de certa maneira, contemplava alguns princípios do grupo de Sérgio Ferro. Essa divisão ideológica estabelecida durante o Fórum de 1968 desdobrou-se ao longo do processo de expansão do ensino em São Paulo, assunto que será abordado mais adiante. Para o professor Edgar Dente, o relatório da comissão de projeto do Fórum de 1968 estabeleceu um novo significado para o atelier paulista:

\footnotetext{
Opinião frequente entre os professores do Departamento de Projeto é a de afirmar que o atelier deveria ser estruturado num esquema real de pesquisa, levantamento, processamento, etc. por meio de metodologia adequada apta a fornecer os dados para o trabalho de projeto, tarefa essa que não pode ser realizada pelo profissional; nesse caso o escritório-atelier funcionaria como o laboratório de experiência e formulação prática. ${ }^{90}$
}

\footnotetext{
${ }^{87}$ Os professores Sérgio Ferro e Rodrigo Lefèvre, em 1967 haviam deixado o Partido Comunista do Brasil - PCB e na Ação Libertadora Nacional - ALN, fundada por Carlos Marighella, junto com a VPR (Vanguarda Popular Revolucionária) que, paralelamente às passeatas estudantis e sem ligação orgânica com elas, já atuavam atacando bancos e instituições comprometidas com o regime, realizando operações de agitação e propaganda protegidas pelas armas (propaganda armada). ARANTES, Pedro Fiori. Arquitetura Nova: Sérgio Ferro, Flávio Império e Rodrigo Lefèvre, de Artigas aos mutirões. 2ạed. São Paulo: Editora 34, 2011. pp. 92. Sobre Carlos Marighella ver: MAGALHÃES, Mario. Marighella - o guerrilheiro que incendiou o mundo. São Paulo: Companhia das Letras, 2012.

88 "Gavetas de conhecimento", segundo Edgar Dente, termo utilizado por Sérgio Ferro para designar a estrutura proposta. Depoimento do professor Edgar Dente concedido ao autor em maio de 2018.

89 Depoimento do professor Edgar Dente concedido ao autor em maio de 2018.

90 DENTE, Edgar G. Estudo Crítico e Proposta para a Estrutura Curricular da FAU-USP. Op. cit. não p.
} 


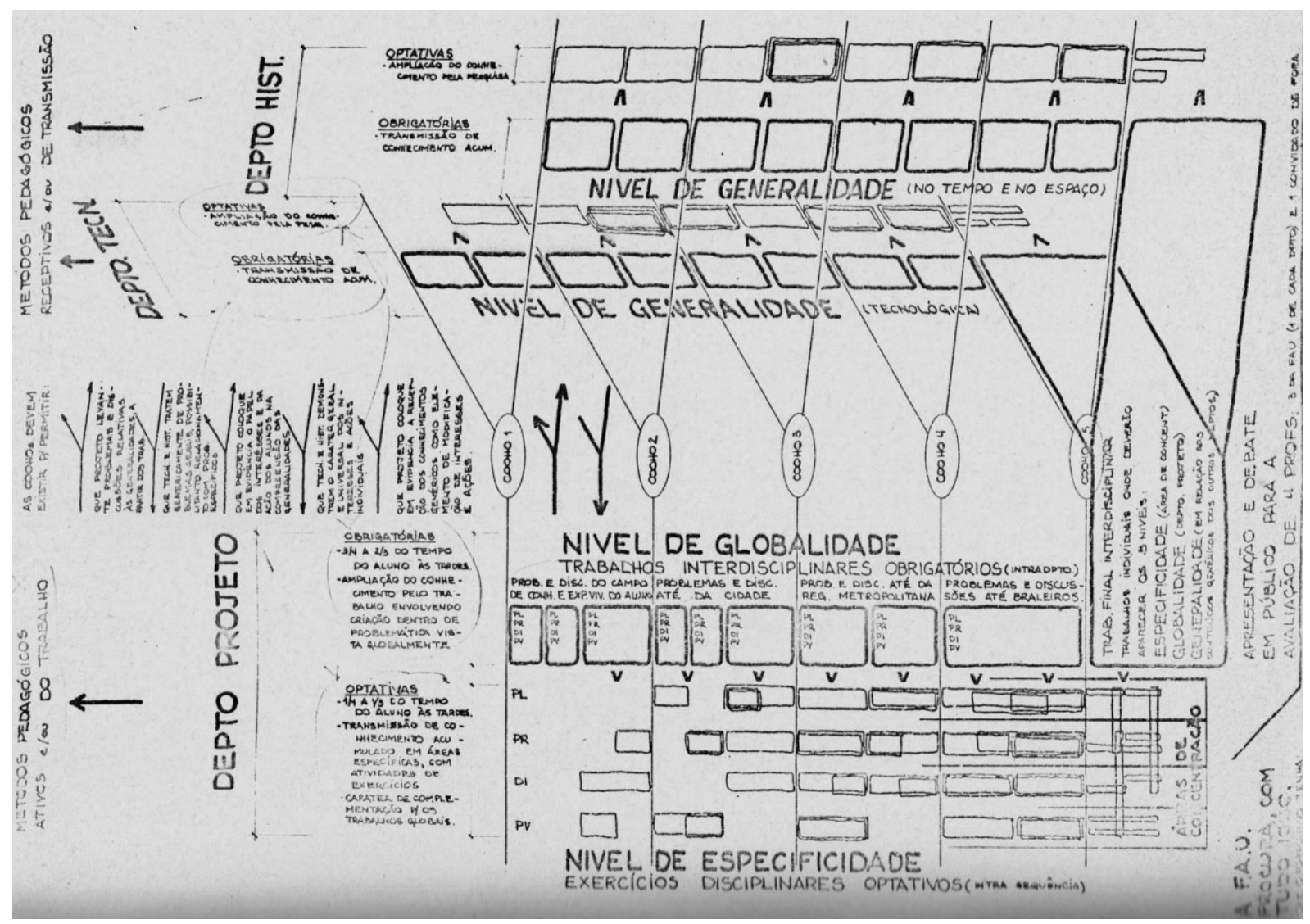

FIG. 11. Proposta de Rodrigo Lefèvre para o curso de projeto da FAU-USP apresentada no Fórum de 1968. Relatório da comissão de projeto do Fórum de 1968, 4 de junho de 1968.

Passados quatro anos do golpe, o cenário político no país era muito conturbado e o ano de 1968 foi marcado por sucessivos protestos em âmbito nacional e internacional, a população passou a cobrar as promessas de abertura democrática do então presidente Artur da Costa e Silva, e os estudantes iniciaram diversos movimentos de ocupação das ruas em diversas capitais do país. ${ }^{91}$ Como resposta ao cenário de crise social, em 13 de dezembro de 1968 o Congresso Nacional foi fechado e o Al-5 decretado. Esse ato definiu o momento mais duro da ditadura militar, dando poder de exceção aos governantes para punir arbitrariamente os que fossem inimigos do regime ou como tal considerados. A Lei no 4.464 de 9 de novembro de 1964, conhecida como Lei Suplicy para repressão da participação estudantil nas universidades brasileiras, foi reforçada com o Decreto Lei no 477 de 26 de fevereiro de 1969, que dava poderes ao Estado para expulsar e processar alunos das escolas públicas. Foi criada a Operação Bandeirantes (OBAN), órgão de repressão clandestino mantido pelas forças armadas na

\footnotetext{
91 “Estudantes e operários participaram intensamente de greves e protestos contra o regime militar. O 1o de maio de 1968 em São Paulo também foi violento, tendo o governador Abreu Sodré sido atingido por uma pedrada. Os secundaristas começavam também a participar dos movimentos. Em 3 de outubro, nos violentos conflitos na Rua Maria Antônia - onde, em um lado, estava instalada a Faculdade de Filosofia, escola da Universidade de São Paulo, em que predominava a esquerda universitária, e, na calçada oposta, a Universidade Mackenzie, escola em que predominavam as lideranças estudantis de direita então denominadas pelo Comando de Caça aos Comunistas (CCC) e protegidas pela reitoria -, morreu José Carlos Guimarães, um estudante secundarista”. MOTA, C.G.; LOPEZ, A. Op. cit. p. 812.
} 
cidade de São Paulo e, por fim a junta militar decretou o Al-14, que instituiu a pena de morte e prisão perpétua para os casos de guerrilha revolucionária e subversiva. ${ }^{92}$

Com coragem, disposição, juventude e um mundo melhor como desejo na cabeça, seguimos em frente. As brecadas se sucedem a partir dos anos violentos. E, em 1968 o sonho perdeu espaço para a realidade. A reforma de 1962 durou até 1969. "Sete anos". Não é pouco. A matriz (Bauhaus) durou quatorze. ${ }^{93}$

Em 1969, a FAU-USP deixou a Rua Maranhão e se mudou para o seu novo edifício na Cidade Universitária, projetado por Vilanova Artigas, constituía a síntese pedagógica proposta na Reforma de 1962. Muito maior que o prédio da Vila Penteado, ampliou a capacidade de 80 para 150 estudantes. Entretanto, a ocupação desse novo espaço, por ser afastado da área central da cidade, inicialmente provocou um sensível esvaziamento político na escola. Por força do Al-5, Artigas foi aposentado compulsoriamente, juntamente com Paulo Mendes da Rocha e Jon Maitrejean. O Reitor da Universidade de São Paulo foi cassado e os direitos políticos de professores, agentes públicos e intelectuais foram suspensos, ocorrendo o mesmo em outras universidades públicas do país. 0 ensino superior passou a sentir os efeitos do acordo MEC-USAID, firmado em 1965 entre o governo brasileiro e o governo norte-americano, que impunha a reforma da universidade brasileira, seguiramse algumas alterações curriculares e foram feitas novas contratações. ${ }^{94}$ Esses fatores, somados ao cenário político vigente, acabaram deflagrando um processo de crise no ensino superior.

FIG. 12. Ateliers da FAU-USP na Cidade Universitária.

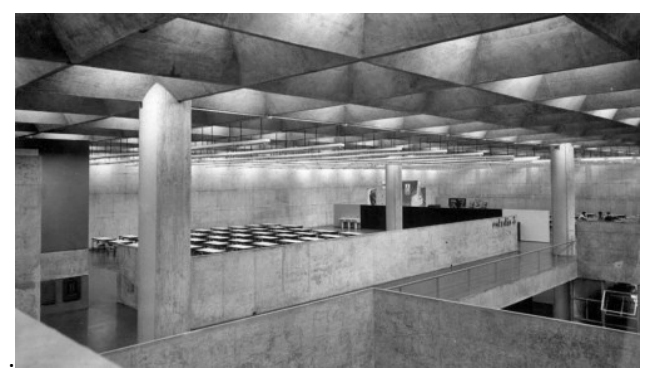

Do ponto de vista econômico, esse momento se destacou pela forte atuação do Estado depois do golpe de 1964, que passou a atuar no planejamento urbano, com expressivos investimentos em prol do desenvolvimento da infraestrutura do país, ampliando a demanda por profissionais engenheiros e arquitetos. Esse fenômeno ficou conhecido por "milagre econômico brasileiro" ${ }^{95} \mathrm{~A}$ necessidade de

\footnotetext{
92 “No esforço de repressão, logo se deu a junção das forças armadas, sendo criados o CIEX do exército, seguidos de outros órgãos, como a OBAN, O DOI-CODI, o CENIMAR da Marinha (que chegou a ter uma escola de tortura na llha das Flores, na baía da Guanabara, com assistência dos americanos) e o CISA da aeronáutica". MOTA, C. G.; LOPEZ. Op. cit. pp. 820-821.

${ }^{93}$ Texto de Abrahão Sanovicz, sistematização crítica da obra de arquitetura para obtenção do título de livre docente junto à FAU-USP, 1997, p. 226. Apud. SILVA, Helena A. Ayoub. Abrahão Sanovicz: o projeto como pesquisa. 2004. 610p. Tese (Doutorado em arquitetura e urbanismo) Faculdade de Arquitetura e Urbanismo da Universidade de São Paulo. São Paulo, 2004. pp. 108-109.

${ }^{94}$ WISSENBACH, Vicente (org.). Siegbert Zanettini. Cadernos Brasileiros de Arquitetura, no 8. São Paulo: Projeto, s/d. pp. 6-7.

${ }^{95}$ Segundo Caio Prado, esse momento da economia brasileira deveria ser caracterizado como "comportamento imprimido à economia brasileira em sua fase mais recente e atual", pois o termo "milagre econômico" é equivocado por não demonstrar a dependência e subordinação da economia brasileira no contexto internacional do capitalismo, comandado essencialmente pelas multinacionais imperialistas há pelo menos 75 anos. PRADO JR, Caio. História econômica do Brasil. São Paulo: Brasiliense, 2008. pp. 345-346.
} 
formação de novos quadros profissionais já havia sido identificada na Reforma de 1962, com o debate acerca da inclusão das disciplinas de desenho industrial e de planejamento urbano no currículo da FAU-USP, e tinha como objetivo atender a demanda por desenvolvimento das diversas cidades-chave no processo de metropolização da cidade de São Paulo, que vinha ampliando rapidamente sua mancha urbana desde os anos 1940 e, mais expressivamente, nos anos 1960 a 1980. Desse modo, o Ministério da Educação e Cultura, através do parecer no 384/69 de 23 de junho de 1969, determinou um currículo mínimo e autorizou instituições privadas a oferecerem cursos superiores de graduação em diversas áreas do conhecimento. Nesse sentido, estabeleceu para o curso de arquitetura e urbanismo uma divisão em dois eixos estruturantes: matérias básicas e matérias profissionais. A duração mínima do curso deveria ser de 3.600 horas, ministradas no mínimo em quatro anos e no máximo em seis anos letivos.

\begin{tabular}{r|l} 
MÁTERIAS BÁSICAS & MATÉRIAS PROFISSIONAIS \\
ESTÉTICA, HISTÓRIA DAS ARTES E ARQUITETURA & TEORIA DA ARQUITETURA, ARQUITETURA BRASILEIRA \\
MATEMÁTICA & RESISTÊNCIA DOS MATERIAIS E ESTABILIDADE DAS CONSTRUÇÕES \\
ESTUDOS SOCIAIS & MATERIAIS DE CONSTRUÇÃO E DETALHES TÉCNICOS DE CONSTRUÇÃO \\
DESENHO E OUTROS MEIOS DE EXPRESSÃO & INSTALAÇÕ̃ES E EQUIPAMAMENTOS \\
PLÁSTICA & HIGIENE DE HABITAÇÃO \\
& PLANEJAMENTO ARQUITETÔNICO
\end{tabular}

TAB. 02. Estrutura do currículo mínimo proposto pelo MEC em 1969.

De acordo com as decisões de cada escola, a grade mínima poderia ser ampliada configurando um currículo pleno. A resolução fazia algumas recomendações sobre a natureza de cada disciplina, destacando que planejamento arquitetônico deveria contemplar o projeto do objeto, edifício e interior, bem como do planejamento urbano, com ênfase nos problemas de maior interesse social. Determinava que o curso deveria promover estágio dos seus alunos em escritórios de arquitetura credenciados, em serviços públicos e nas indústrias. Além disso, os cursos deveriam oferecer excursões - com obrigação de relatório crítico - a obras fundamentais, cidades históricas, etc. Assim, merece destaque a atuação da FAU-USP que, apoiada pelo IAB-SP e a partir da Reforma de 1962, sistematizou diretrizes curriculares capazes de atender o processo de expansão das escolas de arquitetura vivido nos anos de 1970, amplamente disseminadas pela migração de seus docentes para todo o estado de São Paulo. Essa proposta posicionou o atelier no centro de gravidade dos novos cursos.

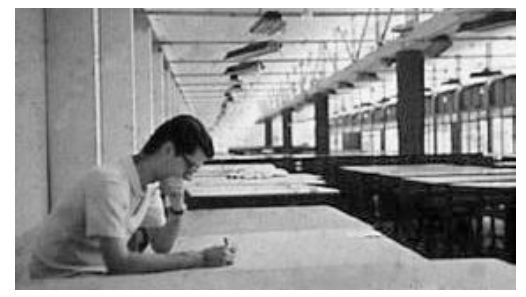


Uma escola necessária

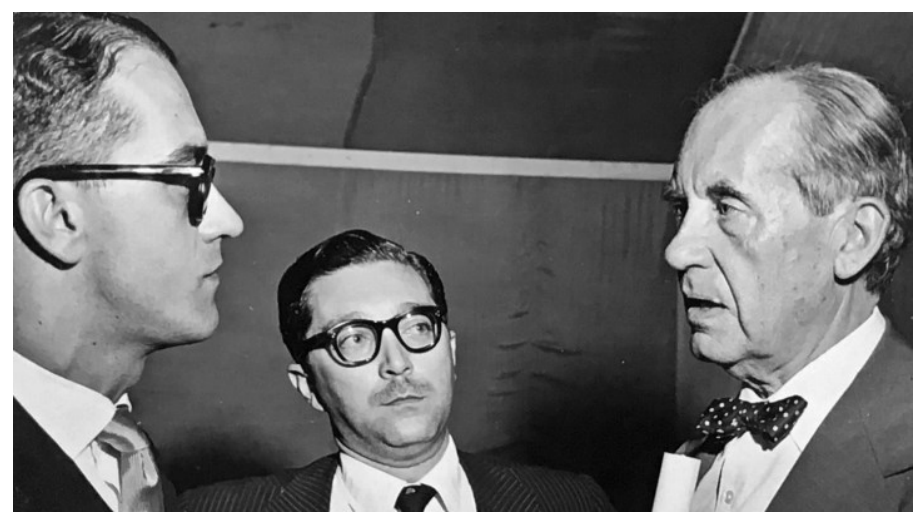

FIG. 14. Oswaldo Corrêa Gonçalves, Eduardo Corona e Walter Gropius em 1954.

O projeto para a instalação da Faculdade de Arquitetura e Urbanismo de Santos foi idealizado, coordenado e implantado pelo arquiteto Oswaldo Corrêa Gonçalves, representante da primeira geração de arquitetos modernos de São Paulo. Através de sua obra e de sua atuação na FAU-USP, no IAB/SP e na Bienal Internacional de Artes e de Arquitetura, contribuiu para a divulgação dos princípios da arquitetura modernista e para a consolidação da profissão de arquiteto no país. Para o desenvolvimento dos assuntos aqui abordados, interessa, mais do que analisar sua obra, ${ }^{96}$ evidenciar a sua capacidade de articulação política através das alianças profissionais e acadêmicas firmadas com indivíduos e entidades, que mesmo com visões ideológicas opostas, trabalharam juntos no projeto da faculdade de Santos. Portanto, serão destacadas em momentos oportunos algumas obras chave e alguns pontos que reforcem os argumentos tratados nessa tese. Isso posto, para contextualizar Oswaldo nos assuntos até então abordados, vale traçar um breve panorama biográfico da vida profissional e acadêmica do arquiteto.

Nascido em Santos no dia 27 de fevereiro de 1917, filho de família tradicional e abastada da cidade, passou a infância em um casarão em frente a um dos canais de drenagem projetados por Saturnino de Brito no início do século XX. Formou-se engenheiro-arquiteto na Escola Politécnica da Universidade de São Paulo em 1941 e engenheiro civil em 1945. Em 1942, Oswaldo foi contratado pela Prefeitura de São Paulo para trabalhar no Setor de Aprovação de Plantas, onde permaneceu até

\footnotetext{
${ }^{96}$ Julgou-se desnecessário investigar e analisar o conjunto da obra de Oswaldo Corrêa Gonçalves nos mais de sessenta anos de sua vida profissional e acadêmica, pois além de extrapolar os objetivos desse trabalho, já existe literatura que versa sobre o assunto ver: FICHER, Sylvia. Os arquitetos da Poli: ensino e profissão em São Paulo. São Paulo: Edusp, 2005. SEGAWA, Hugo. Arquiteturas no Brasil. $1900-1990$. 3a..ed. São Paulo: Edusp, 2010. OLIVEIRA, Elaine Rodrigues. A contribuição de Oswaldo Corrêa Gonçalves para a arquitetura moderna brasileira. 1999. 171p. Dissertação (Mestrado em Arquitetura) - Departamento de Arquitetura e Urbanismo da Escola de Engenharia de São Carlos da Universidade de São Paulo. São Carlos, 1999; MACEDO. Christiane Costa Ferreira. Teatro Municipal de Santos: (re)apropriação do espaço moderno. 2008. 212p. Dissertação (Mestrado em arquitetura e urbanismo) Faculdade de Arquitetura e Urbanismo da Universidade de São Paulo. São Paulo, 2008; GATI, Catharine. Oswaldão: construindo a profissão. Documento Oswaldo Corrêa Gonçalves. Revista AU, São Paulo, no 59, abril de 1995.
} 
1953. Entre 1945 e 1946, publicou no Jornal de São Paulo a coluna semanal "Urbanismo", nesse ínterim, participou da criação do $\mathrm{IAB} / \mathrm{SP},{ }^{97}$ foi membro da primeira direção e, posteriormente, presidente na gestão de 1961 a 1963, mesma época em que dirigiu com Fábio Penteado e Eduardo Kneese de Mello o programa Arquitetos na TV, exibido pela TV Excelsior entre 1961 e 1962.

Foi professor na FAU-USP entre 1954 e 1955, lecionou com Ícaro de Castro Mello a disciplina de plástica, ${ }^{98}$ ao mesmo tempo em que participava da organização da II Bienal Internacional de Artes de São Paulo. Em 1961, assumiu a direção da sessão de arquitetura da Bienal e, em 1973, realizou sob a sua coordenação a I Bienal Internacional de Arquitetura e, segundo o professor Julio Katinsky, "em uma época de repressão violenta ele foi procurar justamente o Artigas, que acabou sugerindo o tema da exposição: $O$ ambiente que o homem organiza". ${ }^{99}$ Oswaldo era uma pessoa de postura política progressista, de centro-esquerda, fez um grande esforço para inserir nessa mostra a produção das escolas de arquitetura da época, abrindo espaço para os jovens estudantes que, além de apresentarem sua produção, tomavam contato com a prática profissional de importantes arquitetos.

Oswaldo lecionou na FAU de São Paulo e esse é um aspecto pouco valorizado, mas é importante, ele foi um arquiteto de São Paulo que lutou pela criação da Faculdade de Arquitetura e Urbanismo de São Paulo e chegou a ser professor assistente do Ícaro [...] A vocação do Oswaldo não era apenas para ser um bom arquiteto, ele lutou muito para ser um bom arquiteto, mas também ser professor. ${ }^{100}$

Oswaldo apesar de admirador de Le Corbusier e Oscar Niemeyer - conhecidos pelo forte personalismo de suas obras - talvez influenciado por Walter Gropius, criticou a postura individualista dos arquitetos brasileiros no VIII Congresso Pan-Americano de Arquitetos realizado no México, em 1952, passando a defender o trabalho em equipe. Nesse sentido, em 1946, iniciou sua atividade profissional particular associando-se aos arquitetos Paulo Ballario e José Ferreira. Em 1971, fundou com os arquitetos Benno Perelmutter, Carlos Ferro, Décio Tozzi, Franco Petrich, João Walter Toscano e Ubirajara Giglioli o Escritório Pluricurricular de Projetos (PLURIC), onde trabalhou até meados dos anos 1980. ${ }^{101}$

\footnotetext{
${ }^{97}$ Oswaldo foi um dos dez arquitetos a ter seu escritório instalado no 3o andar da recém-inaugurada sede do IAB/SP, os demais arquitetos que lá se instalaram foram: no 3o andar, Alfredo Becker; no 4ㅇandar, Ítalo Mauro; no 5o andar, Ariosto Mila, David Otoni, Gastão Rachou Filho, Heitor Souza, João Cacciola e Vilanova Artigas; no 7o andar, Hélio Pasta. DEDECCA, Paula Gorenstein. Sociabilidade, crítica e posição: o meio arquitetônico, as revistas especializadas e o debate do moderno em São Paulo (1945-1965). 2012. 403f. Dissertação (Mestrado) Faculdade de Arquitetura e Urbanismo - Universidade de São Paulo, São Paulo. 2012, p. 40.

98 Oswaldo Corrêa participou do processo seletivo para docente na disciplina de grandes composições no ano de 1952 e foi aceito como assistente na disciplina de plástica em 1953. Ministrou essa disciplina nos anos de 1954 e 1955. Arquivo da Biblioteca da FAUS.

${ }^{99}$ KATINSKY, Julio Roberto. Entrevista com Julio Roberto Katinsky. São Paulo: 23 mai. 2016. Entrevista a José Maria de Macedo Filho.

100 Ibid.

${ }^{101}$ OLIVEIRA, Elaine Rodrigues. Op.cit. passim.
} 

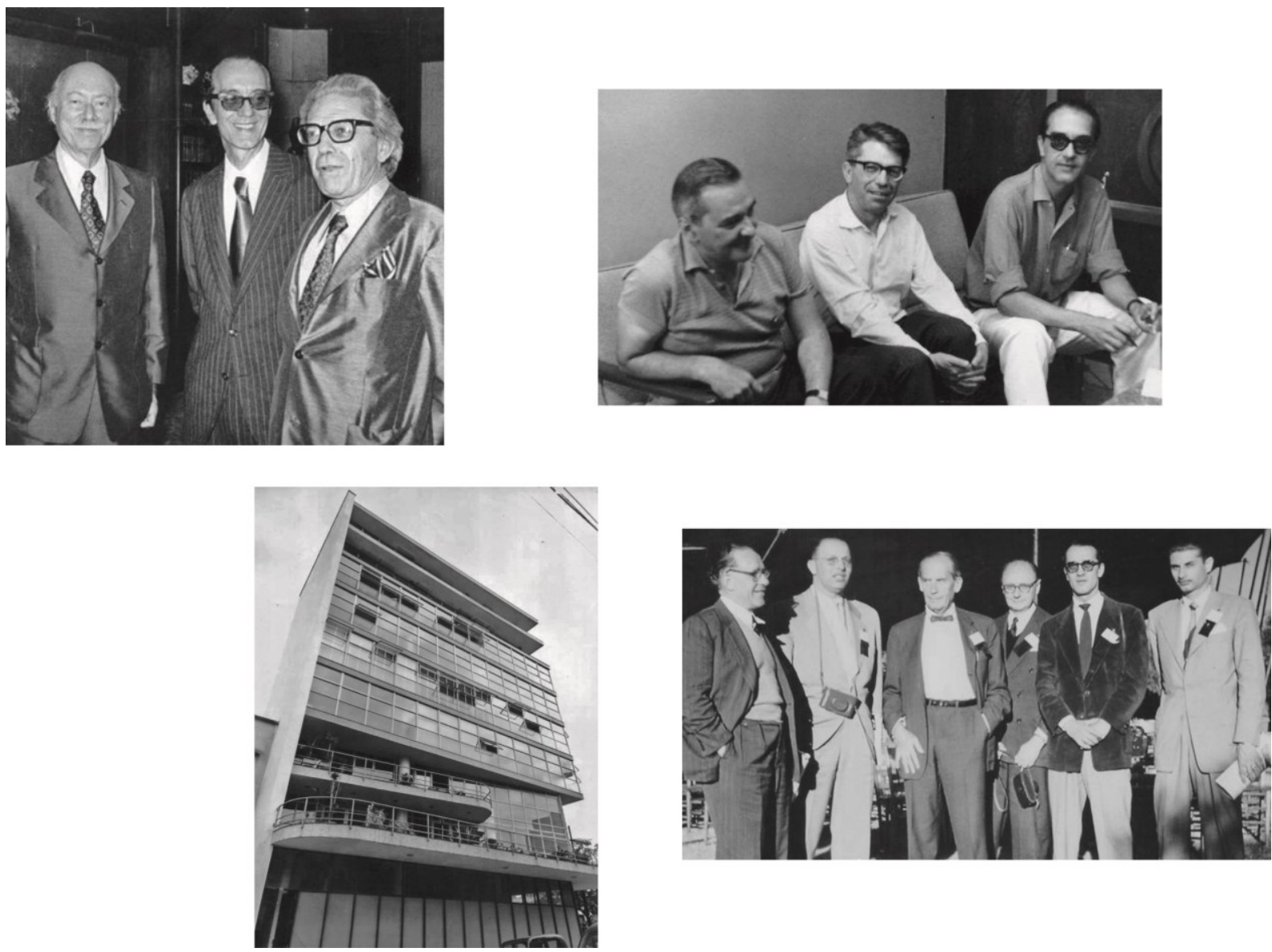

FIG. 15. Acima à esquerda, Eduardo Kneese de Mello, Oswaldo Corrêa e Vilanova Artigas na abertura da I Bienal Internacional de Arquitetura em 1973. Ao lado, Flávio da Silveira, Vilanova Artigas e Oswaldo Corrêa em Havana em 6 de junho de 1963 . Abaixo, sede do IAB/SP dos arquitetos Rino Levi, Roberto Cerqueira Cesar, Jacob Ruchti, Miguel Forte, Galiano Ciampaglia, Zenon Lotufo, Abelardo de Souza e Hélio Duarte, 1950. VIII Congresso Pan-Americano de Arquitetos realizado no México em 1952, da esquerda para a direita: Rino Levi, Ícaro de Castro Mello, Walter Gropius, Lucjan Korngold e Oswaldo Corrêa.

Ao longo de sua carreira contou com a colaboração de diversos colegas arquitetos em distintos projetos, como, por exemplo, Jayme Fonseca Rodrigues; Ícaro de Castro Mello; Roberto Milliet; Osmar Tosi; Heitor Ferreira; Abrahão Sanovicz; Julio Katinsky; Benno Perelmuter, José Arduim Filho; Marciel Peinado; Michail Lieders; Claudio Paneque, Aníbal Martins Clemente, Rubens Vianna, Ricardo Sievers, dentre outros. Influenciado pela escola de arquitetura do Rio de Janeiro, buscou a integração da arquitetura com as artes plásticas e contou em suas obras com o trabalho de artistas como Marcelo Grassmann, Clóvis Graciano e Irênio Maia. Oswaldo Corrêa, além dos projetos para edifícios público e privados, realizou diversos projetos urbanos, experimentando, fundindo e adaptando estratégias urbanísticas desde os princípios da cidade-jardim, idealizada por Ebenezer Howard, da Carta de Atenas, dos ideais de Le Corbusier até os conceitos do urbanismo norte-americano aprendidos na FAU-USP com o professor Luiz de Anhaia Mello. ${ }^{102}$

102 “O Anhaia Mello era mais ligado ao pensamento inglês, e, portanto ele era um admirador da cidade jardim em primeiro lugar e, em segundo lugar, era admirador dos estudos americanos sobre urbanismo (que nós não dávamos a mínima atenção), um país avançado tecnicamente tinha que ter uma reflexão sobre a cidade, e tinha muito boa por sinal, e nós não soubemos entender os únicos arquitetos 
Em síntese, o trabalho em equipe, de certa maneira, explica a variação e evolução de sua obra, inclusive é possível verificar dois momentos distintos na produção de Oswaldo, o primeiro compreendido entre meados da década de 1940 e 1950, ou seja, seus primeiros anos de atuação revelam sua admiração pela arquitetura carioca, leve, aberta à paisagem, integrando as artes plásticas à arquitetura. Dentre outros exemplares, destacam-se o Edifício Sobre as Ondas, 1946 e o Posto de Serviços Texaco, 1956. A associação com outros colegas arquitetos a partir de 1957 até 1980 marca o segundo momento da produção de Oswaldo. As obras passam a ser definidas pela verdade estrutural, com ênfase na estrutura de concreto armado aparente, rigor técnico e caráter funcionalista, claramente alinhada ao modo de fazer da arquitetura moderna paulista. Nesse sentido, dentre outros exemplares, destacam-se o Teatro Municipal de Santos, $1961-1979,{ }^{103}$ e o Pronto Socorro de Santos em 1976, posteriormente Abrahão Sanovicz declarou que o aspecto multidisciplinar e o rigor da técnica foram de suma importância em sua formação.
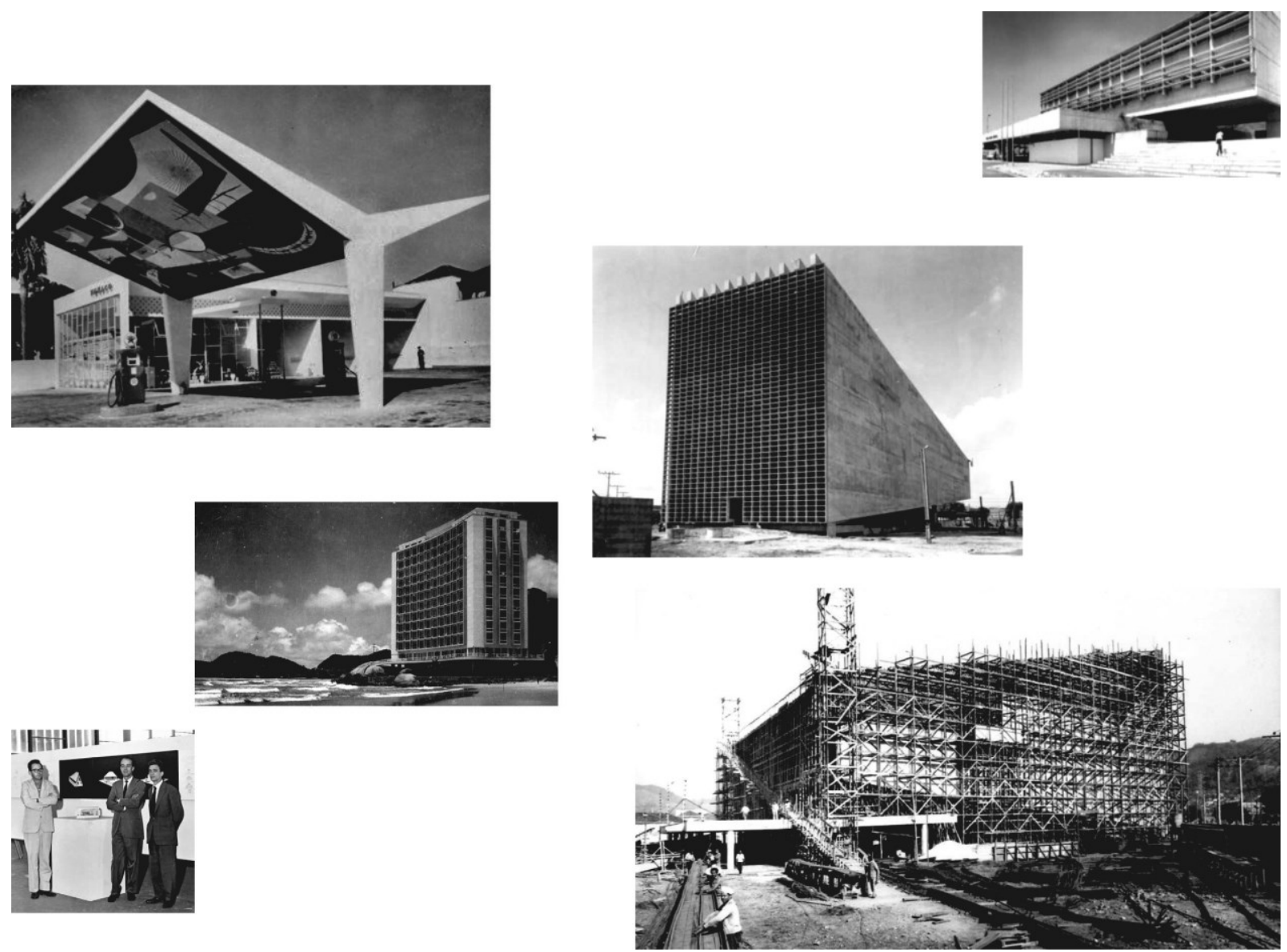

FIG. 16. À esquerda no topo, Posto Texaco em Santos, Oswaldo Corrêa e Osmar Tosi, painel de Irênio Maia, 1956. Abaixo, Edifício Sobre as Ondas no Guarujá, Jayme Fonseca e Oswaldo Corrêa, 1946. Abrahão Sanovicz, Oswaldo Corrêa e Julio Katinsky diante do projeto para o Teatro Municipal de Santos exposto na VI Bienal de São Paulo em 1961. À direita no topo, Pronto Socorro Municipal de Santos, Oswaldo Corrêa, Benno Perelmuter, José Arduim Filho e Marciel Peinado, 1976. Abaixo, volume principal do Teatro Municipal de Santos acabado e sua construção por volta de 1969, Oswaldo Corrêa, Julio Katinsky e Abrahão Sanovicz, 1961-1979.

que penetravam profundamente no pensamento norte-americano de urbanismo; na Europa, Le Corbusier; no Brasil, Lúcio Costa e Anhaia Mello." Depoimento do professor Julio Katinsky concedido ao autor em 23 de maio de 2016.

${ }^{103}$ Sobre o teatro ver: MACEDO, Christiane Costa Ferreira. Teatro Municipal de Santos: (re)apropriação do espaço moderno. Op. cit. 
Para o Teatro de Santos, além das referências e dos esclarecimentos sobre o processo do projeto, sempre destacou a maneira como se deu a apropriação de novas áreas de conhecimento (mecânica cênica, estruturas protendidas, sofisticado sistema de ar condicionado). Outro importante aspecto ressaltado nos textos sobre o projeto refere-se ao aprendizado na convivência com um profissional mais experiente, o arquiteto Oswaldo Corrêa Gonçalves. ${ }^{104}$

A partir dos anos 1980, Oswaldo Corrêa se dedicou exclusivamente à docência, foi desligado do quadro de professores da FAUS somente após seu falecimento no dia 28 de agosto de 2005.

Enfim, o que se pretende demonstrar é que Oswaldo, naquele momento, estava preparado para o desafio de implantar uma Faculdade de Arquitetura em Santos, apesar da dificuldade em montar um curso de arquitetura nas condições políticas e ideológicas que o país vivia na década de 1960, pois todo o processo de gestação e estruturação do currículo mínimo, os modelos de ensino e mesmo a contratação do corpo docente envolviam grandes desafios. Nesse sentido, pode-se dizer que Oswaldo desempenhou mais o papel de agenciador do que de pedagogo na estruturação da escola de Santos. Estudioso, foi um arquiteto muito competente e interessado nos assuntos referentes à prática profissional e acadêmica, seu carisma e generosidade no trato com as pessoas revelaram um talentoso perfil político e, nesse sentido, independente do antagonismo ideológico, transitava com a mesma facilidade pelos grupos de arquitetos e professores relacionados a Vilanova Artigas e Sérgio Ferro na FAU-USP, assim como entre os arquitetos e docentes da FAU-Mackenzie.

Desde as trocas de correspondência com Artigas em 1946 que, como visto anteriormente, demonstraram as ideias seminais que seriam implantadas mais tarde na FAU-USP, Oswaldo Corrêa, através dessa relação de amizade que mantinha com Artigas e com o próprio Anhaia Mello, observou de perto o processo de emancipação dessa escola e sua fundação em 1948. Na ocasião da Reforma de 1962, era presidente do IAB-SP e detinha uma cópia desse documento na sede do Instituto e, a partir de 1964, com a mencionada demanda de trabalho oferecida pelo Estado, Oswaldo iniciou a preparação do Projeto FAUS. Em 1966, tinha em mãos a minuta para o Estatuto da FAU-USP e estabeleceu contato com o jovem professor Sergio Ferro para conhecer suas inovadoras propostas para a não implantada escola de Taubaté, mas que mereceram destaque durante o Fórum de 1968 na FAU-USP, essas ideias foram depuradas até o início de 1970, sendo parcialmente implantadas na FAUS e integralmente na FAU-SJC.

Segundo o Engenheiro chefe das obras da PRODESAN, o professor Sérgio Novita Fortis, eram feitas reuniões semanais entre os arquitetos Oswaldo Corrêa, Abrahão Sanovicz e Julio Katinsky, responsáveis pelo projeto e acompanhamento da construção do Teatro Municipal de Santos, iniciada em 1967. Essas discussões estavam relacionadas, naturalmente, ao que diz respeito a detalhes técnicos-construtivos, entretanto, aproveitando a oportunidade de estarem juntos, muitas vezes

104 SILVA, Helena A. Ayoub. Op. cit. p. 291. 
estendiam essas reuniões do campo prático para o campo do ensino da profissão, lançando bases para o estabelecimento de alianças com professores e ex-alunos da FAU-USP. ${ }^{105}$

Além das cartas de Vilanova Artigas em 1946, Oswaldo Corrêa Gonçalves detinha um documento com quatro páginas descrito por ele próprio como: "Sugestão Artigas, 1969". Nesse documento é possível verificar que a organização da FAUS seria feita a partir de duas partes. A primeira parte foi denominada como "Parte fundamental", representada pela experiência criativa em atelier durante os cinco anos através dos cursos de comunicação e linguagem (desenho de mensagem); desenho do objeto (desenho industrial); desenho do edifício e urbanismo (desenho da paisagem). A segunda parte foi dividida em dois grupos: "Parte informativa (1)", representada pelas ciências da natureza e subdividida pelos cursos de Ciência Aplicada, Tecnologia de Materiais e Tecnologia da Construção, e "Parte Informativa (2)", representada pelas ciências históricas e expressa nos cursos de História da Arte (comunicação e objeto); História da Arquitetura e do Urbanismo; Estética e Sociologia e Economia Aplicada. No documento encontrado não é possível verificar a carga horária prevista para esse grupo de disciplinas.

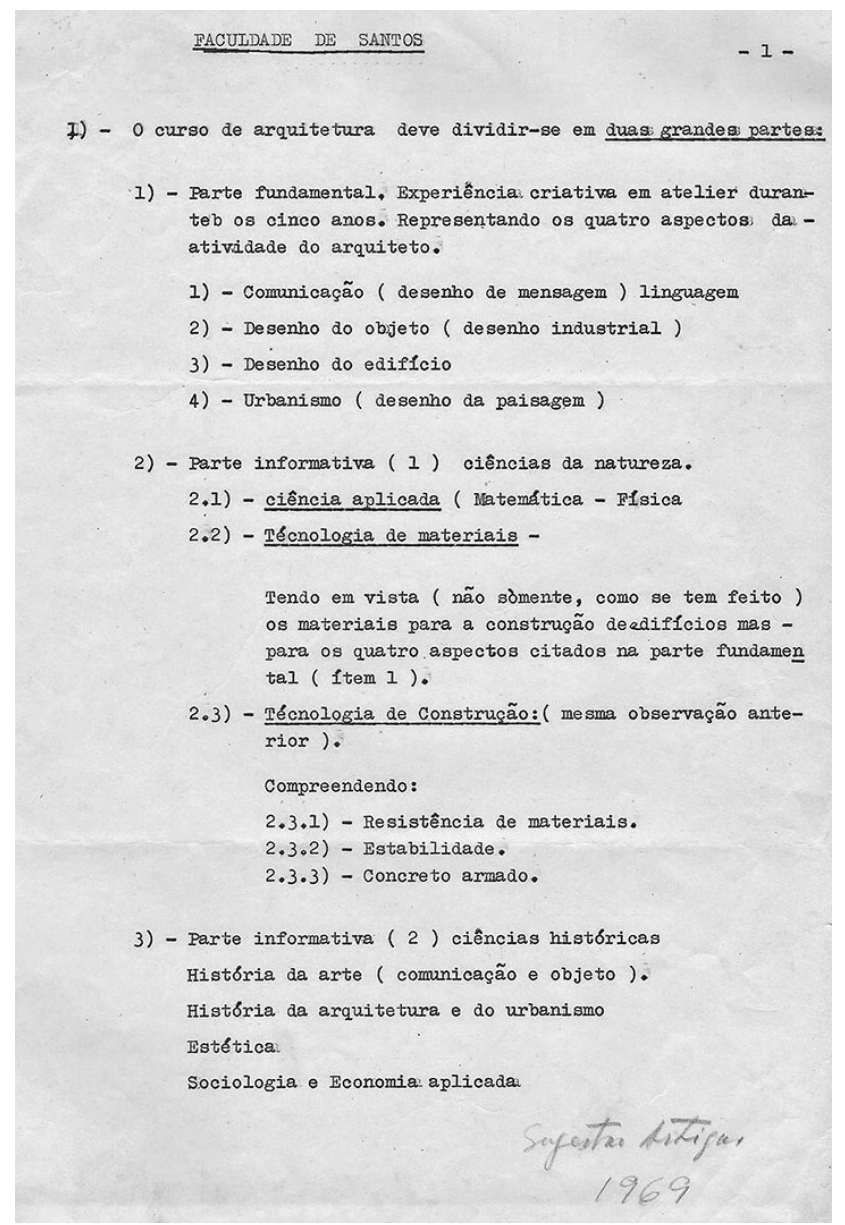

FIG. 17. Sugestão para a Faculdade de Santos.

\footnotetext{
${ }^{105}$ Entrevista com o professor Sérgio Novita Fortis concedida ao autor em 22 de setembro de 2016.
} 


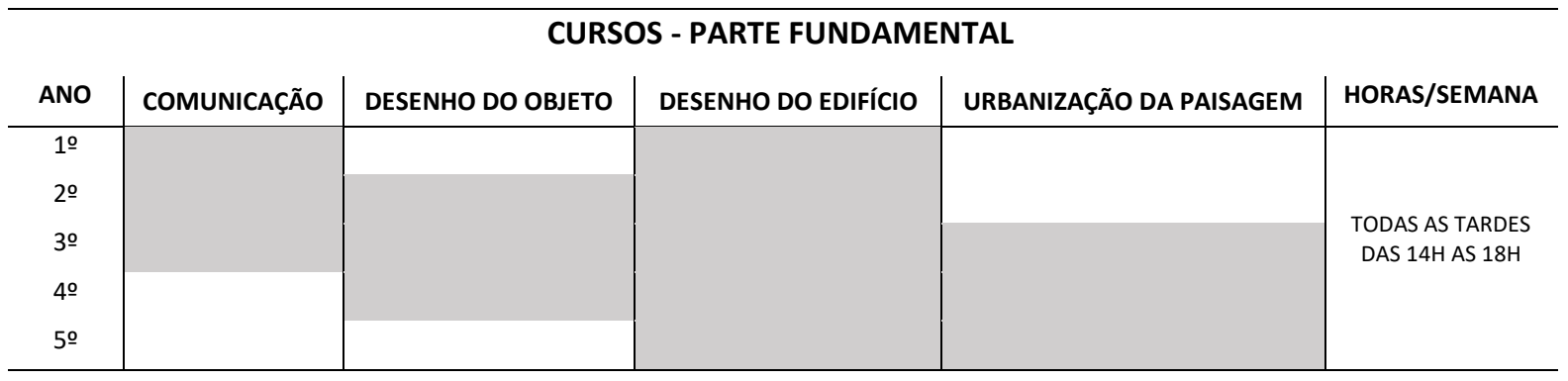

PROPOMOS EM HORAS DE TRABALHO - SEMPRE AS MESMAS NO ATELIER E OFICINA DE MODELOS

\section{CURSOS - PARTE INFORMATIVA 1 E 2}

\begin{tabular}{c|c|c|c} 
ANO & CIÊNCIAS HISTÓRICAS & CIÊNCIAS APLICADAS & TECNOLOGIAS \\
\hline 19 & HISTÓRIA DA ARTE & MATEMÁTICA / FÍSICA & TECNOLOGIA DE MATERIAIS \\
2 & HISTÓRIA DA ARQUITETURA E DO URBANISMO & FÍSICA / RESISTÊNCIA & TECNOLOGIA DE MATERIAIS \\
3 & SOCIOLOGIA ECONÔMICA & ESTABILIDADE & TECNOLOGIA DE CONSTRUÇÃO \\
40 & SOCIOLOGIA ECONÔMICA & CONCRETO ARMADO & TECNOLOGIA DE CONSTRUÇÃO \\
\end{tabular}

TAB. 03. Sugestão para a Faculdade de Santos.

Esse projeto pedagógico determinava que as atividades de atelier, com a oficina de modelos anexa, deveriam se estender ao longo dos cinco anos do curso, sendo a prancheta ou mesa de desenho a unidade básica de organização. A "parte fundamental" é retomada ao final do documento, com caráter de conclusão, ou mesmo como uma tentativa de síntese possível entre as disciplinas de projeto, ao modo de um Trabalho de Graduação Interdisciplinar, o TGI. Na conclusão dessa proposta pedagógica, Artigas propõe os seguintes universais:

\section{Comunicação, linguagem do espaço | Desenho industrial, objeto no espaço}

\section{Edifício construção, espaço | Urbanismo paisagem, espaço}

Não é possível afirmar, de maneira definitiva, que o documento é realmente uma proposta elaborada por Vilanova Artigas, pois foi datilografado e não está assinado pelo autor, mas como visto, existem traços muito particulares do seu pensamento que, inclusive, já haviam sido postos em prática no projeto do edifício da FAU na cidade universitária em 1961, instituídos na Reforma 1962 e consolidados no Fórum de 1968 na FAU-USP. Por exemplo, a prancheta como unidade básica de organização dos ateliers e a proposta do desenho industrial como disciplina no curso de projeto. Fazse necessário lembrar que toda essa elaboração remonta aos pressupostos estabelecidos pelos VKhUTEMAS e pela Bauhaus em seus aspectos ideológicos e políticos, mas principalmente, no que diz respeito à pedagogia e ao esforço em unificar os conceitos de arte e técnica na formação do arquiteto paulista.

Ao organizar o projeto para a FAUS seguindo a mesma metodologia da estrutura concêntrica da Bauhaus e dos VKhUTEMAS, é possível constatar que os universais linguagem, construção, paisagem 
e objeto, entremeados por espaço, são conceitos que sustentam as bases para o aprendizado teórico e técnico, oferecidos pelas disciplinas de Ciências Históricas, Ciências Aplicadas e Tecnologia. Esse sistema alimenta as atividades práticas dos ateliers de Projeto do Edifício, Urbanismo, Desenho Industrial e Mensagem, entendidos como o lugar de processamento da síntese dos conhecimentos adquiridos pelo estudante, feita através da tríade crítica-reflexão-ação. Ao longo do último ano, o aluno deve demonstrar domínio técnico e autonomia crítica para propor, desenvolver e demonstrar um problema através de um projeto, entendido no seu sentido mais amplo e representado pelo Trabalho de Graduação Interdisciplinar - TGI.
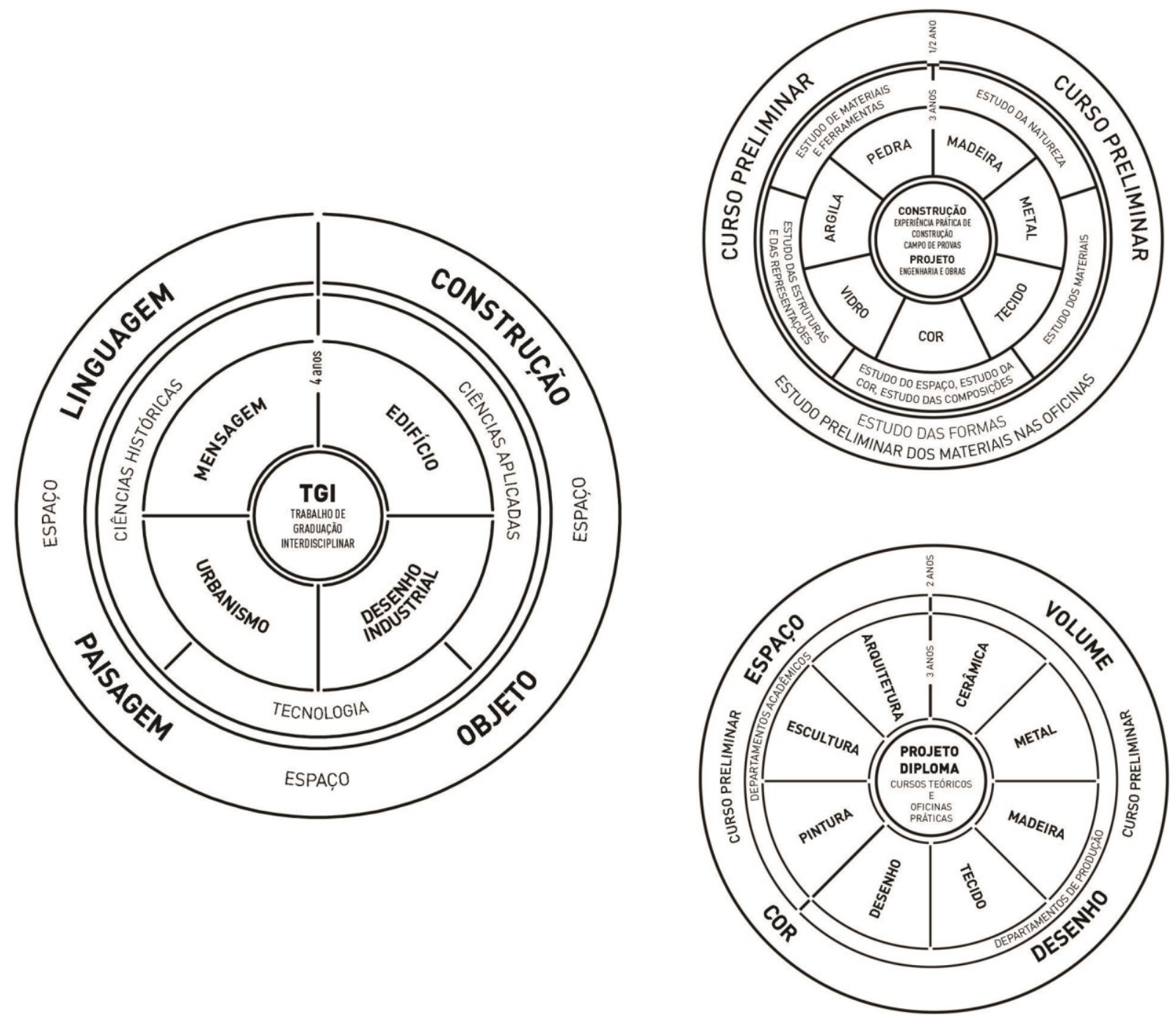

FIG. 18. Organização pedagógica para a FAUS baseada na sugestão de Artigas de 1969. Acima à direita, organização pedagógica da Bauhaus, Weimar, 1922. Abaixo, organização pedagógica dos VKhUTEMAS, 1923. 
Em resumo, pode-se dizer que existem múltiplas entradas para abordar o problema do ensino de arquitetura e do urbanismo. No âmbito desse trabalho, a contextualização histórica com a revisão das influências das pedagogias praticadas pela Bauhaus e pelos VKhUTEMAS configura um importante ponto de apoio para entender o período que antecedeu a fundação da FAUS. Um momento de luta pela constituição, autonomia e consolidação da profissão de arquiteto e urbanista no Brasil, marcado por uma série de debates para a reformulação do seu ensino.

\begin{abstract}
Um primeiro tipo de livro é o livro-raiz. A árvore já é a imagem do mundo, ou a raiz é a imagem da árvoremundo. É o livro clássico, como bela interioridade orgânica, significante e subjetiva (os estratos do livro). 0 livro imita o mundo, como a arte, a natureza: por procedimentos que lhes são próprios e que realizam o que a natureza não pode ou não pode mais fazer. A lei do livro é a reflexão, o Uno que se torna dois. [...] A natureza não age assim: as próprias raízes são pivotantes com ramificação mais numerosa, lateral e circular, não dicotômica. $O$ espírito é mais lento que a natureza. Até mesmo o livro como realidade natural é pivotante, com seu eixo e as folhas ao redor. Mas o livro como realidade espiritual, a Árvore ou a Raiz como imagem, não para de desenvolver a lei do Uno que se torna dois, depois dois que se tornam quatro... ${ }^{106}$
\end{abstract}

O agenciamento ideológico e político processado por docentes e discentes da FAU-USP a converteram na raiz capaz de discutir, sistematizar e documentar o próprio processo de emancipação pedagógica e cultural. Forjou novos vetores, seguimentos e ramificações através do estabelecimento de alianças políticas, ideológicas e pedagógicas com outras instituições. Essa inequívoca contribuição, no plano teórico-acadêmico, esteve atrelada à prática profissional da arquitetura, desenvolveu o pensamento crítico e tornou claro para o estudante qual era seu papel na sociedade. ${ }^{107}$ Nesse sentido, arrisca-se dizer que a pedagogia da FAU-USP, centrada no atelier e apoiada na convicção da prática de projeto como pesquisa e instrumento de emancipação política, alinhou o ensino da arquitetura em São Paulo às discussões nacionais e internacionais daquele momento.

Portanto, constata-se que o projeto para a FAUS foi elaborado essencialmente por docentes da FAUUSP através de um processo coletivo e dialético, teoricamente embasado e fortalecido pela experiência prática e individual de cada professor. Oswaldo Corrêa Gonçalves, ao aproximar todos esses agentes, firmou uma aliança com a FAU de Artigas forte o bastante para que o projeto da Faculdade de Santos ganhasse corpo e revelasse a Região da Baixada Santista como um possível laboratório de investigação e atuação para os futuros arquitetos por ela formados.

\footnotetext{
${ }^{106}$ DELEUZE, Gilles. GUATTARI, Félix, op. cit. p. 13.

${ }^{107}$ Esta construção coletiva da FAU foi marcada por conflitos ideológicos e interesses políticos dentro da própria comunidade acadêmica da USP, segundo Hugo Segawa "o embate ideológico do momento não se circunscreve aos poucos exemplos mencionados, mas as contingências políticas e econômicas que conduziam a uma aliança implícita de grupos políticos conflitantes, numa coexistência de antagonismos sob as estratégias de desenvolvimento nacional. "Ver capítulos 6 e 7 da obra SEGAWA, Hugo. Arquiteturas no Brasil 19001990. Op. cit. pp. 103-157.
} 
ENTRADA 


\section{2}

DOBRA

O princípio da multiplicidade afirma que somente quando o múltiplo é efetivamente tratado como substantivo, multiplicidade, que ele não tem mais nenhuma relação com o uno como sujeito ou como objeto, como realidade natural ou espiritual, como imagem e mundo. ${ }^{1}$

Ainda no contexto do final da década de 1960, era necessário consolidar e ampliar o campo de atuação dos arquitetos a partir da abertura de novas faculdades de arquitetura que, do ponto de vista ideológico e político, refletiriam a ação profissional da categoria. Nesse sentido, o ensino e a prática da arquitetura, inexoravelmente, configuraram ações ideológicas e políticas, desde os exemplos inovadores russos e alemães do início do século $X X$, até seus desdobramentos e desenvolvimento a duras penas aqui no país. A elaboração de um projeto pedagógico implicava no estabelecimento de alianças com diferentes agentes, uma equação de complexa resolução no campo da arquitetura, por não ter suas bordas muito bem definidas, ser amplo, subjetivo e depender do trabalho coletivo, apesar de também configurar um trabalho técnico. Alianças que não dependem apenas dos interessados diretos, arquitetos, professores, estudantes e mantenedoras, mas

\footnotetext{
${ }^{1}$ DELEUZE, Gilles; GUATTARI, Félix. Mil platôs, capitalismo e esquizofrenia. Vol. 01. São Paulo: Editora 34, 1995. pp. 14-16
} 
fundamentalmente da sociedade que constrói a ideia do que pode ser sua arquitetura, da forma como reconhece e valoriza o processo de concepção e materialização das coisas, dos edifícios, das cidades, do seu habitat.

O reconhecimento desse fazer demanda um contínuo empenho dos arquitetos brasileiros desde os anos 1920 até os dias de hoje. O valoroso esforço de estudantes e professores da FAU-USP para estabelecer um currículo adequado à formação do arquiteto, possível de ser cientificamente experimentado, testado, revisado, acabou servindo com o modelo geral e sistematicamente reproduzido diante da grande demanda profissional e da carência de vagas nas faculdades existentes a partir da segunda metade dos anos 1960. Em 1968 existiam, em todo o Brasil, oito cursos de arquitetura e urbanismo oferecidos por universidades públicas e dois cursos oferecidos por mantenedoras privadas. Os cursos públicos e gratuitos eram oferecidos pela Escola de Arquitetura de Minas Gerais (EA-MG), 1930; Faculdade Nacional de Arquitetura (FNA), 1945; Faculdade de Arquitetura e Urbanismo da Universidade de São Paulo (FAU-USP), 1948; Faculdade de Arquitetura da Universidade Federal do Rio Grande do Sul (FAU-UFRGS), 1952; Faculdade de Arquitetura da Universidade Federal da Bahia (FAU-UFBA), 1959; Faculdade de Arquitetura da Universidade Federal de Pernambuco (FAU-UFPE), 1959; Faculdade de Arquitetura e Urbanismo da Universidade Federal do Paraná (FAU-UFPR), 1961; Faculdade de Arquitetura e Urbanismo da Universidade de Brasília (UnB), 1962; Escola de Arquitetura da Universidade Federal do Ceará (EA-UFC), 1964; Curso de Arquitetura da Universidade Federal do Pará, 1964. As escolas privadas eram representadas pela Faculdade de Arquitetura Mackenzie (FAU-MACK), 1947 e a Faculdade de Arquitetura e Urbanismo da Universidade Católica de Goiás (FAU-UCG). ${ }^{1}$

Entretanto, convém advertir mais uma vez que, na contramão dos altos ideais propostos pelos arquitetos engajados na discussão da melhor formação profissional, a Reforma Universitária de 1968/69, proposta pelo governo militar, como parte do acordo MEC-USAID e baseada no Plano Atcon - elaborado pelo professor norte-americano Rudolf Atcon - intitulada “Concentração da Política Norte-Americana na América Latina para Reorganização da Universidade e a Integração da Economia", tinha como objetivo, além da abertura do ensino superior para o setor privado, transformar a universidade pública em universidade privada com caráter empresarial, ou seja, com a finalidade do lucro. Essa nova estrutura limitava a ação dos docentes que poderiam ser demitidos, como em qualquer empresa privada, e eliminava a interferência estudantil na administração da

\footnotetext{
${ }^{1}$ UNIVERSIDADE DE SÃO PAULO. Faculdade de Arquitetura e Urbanismo. União Internacional de Arquitetos - UIA. Relatório sobre o ensino de arquitetura no Brasil, outubro de 1974. In: ASSOCIAÇÃO BRASILEIRA DE ESCOLAS DE ARQUITETURA. Sobre o ensino de arquitetura no Brasil. São Paulo: ABEA, 1977. Apud. MONTEIRO, Ana M. R. G. (ORG). A construção de um novo olhar sobre o ensino de arquitetura e urbanismo no Brasil: os 40 anos da Associação Brasileira de Ensino de Arquitetura e Urbanismo. Brasília: ABEA, 2013. pp. 21-23.
} 
universidade inibindo, desse modo, ações subversivas. ${ }^{2}$ Essa reforma estava baseada na Lei federal 5.540 de 1969 que determinava o currículo mínimo do curso de arquitetura. ${ }^{3}$

O resultado dessa política foi a proliferação desordenada de cursos superiores no setor privado, realizado sem nenhuma preparação quanto às instalações, aos equipamentos e à qualificação dos professores, pois diferentemente das razões dos arquitetos-intelectuais que discutiam o ensino da arquitetura desde o currículo desenvolvido na reforma de 1962, as mantenedoras privadas vislumbravam o ensino como um negócio, bastando seguir uma receita pronta e chancelada pelo governo. Nesse sentido, em um documento escrito por alunos e professores da Faculdade de Arquitetura de São José dos Campos (FAU-SJC) e, apresentado no IX Congresso Brasileiro de Arquitetos em $1976,{ }^{4}$ demonstrava que esses cursos apresentavam as mesmas características naquele momento:

- Procuram absorver a demanda excedente dos vestibulares das escolas mais antigas;

- Constituem-se em escolas isoladas, mantidas por entidades privadas com fins lucrativos, mesmo que seus estatutos afirmem o contrário;

- O corpo docente inicial é mínimo, para funcionamento da primeira série do curso, formado a partir de um grupo de "pioneiros" e se amplia de acordo com a necessidade prática a cada ano;

- A grande maioria dos professores reside na capital, viajando semanalmente para dar aulas no local em que funciona a escola - geralmente em cidade próxima dessa capital;

- As entidades mantenedoras pouco ou nada sabem de ensino de arquitetura, assumindo o novo curso dentro dos modelos convencionais de outros cursos superiores;

- Ocupam-se prédios existentes, geralmente construídos para outros fins, sem realizar sequer as adaptações de ambientes necessárias;

- A infraestrutura administrativa, as instalações especiais mínimas, o equipamento básico de oficinas e laboratórios são considerados pelas mantenedoras “investimentos de longo prazo" e só começarão a ser realizados decorridos alguns anos de funcionamento do curso, comprovada sua lucratividade. ${ }^{5}$

Os professores "migrantes do ensino" imbuídos com o espirito idealista para construir uma pedagogia crítica, contra o modelo instrumental imposto pelo governo baseado no acordo MECUSAID, muitas vezes frustrados por não conseguirem viabilizar seus ideais nas instituições de origem, vislumbraram a possibilidade de criar cursos experimentais, acreditaram na possibilidade de pôr em

\footnotetext{
${ }^{2}$ Segundo o professor Edgar Graeff, entre 1964 e 1969, dezenas de professores engajados no aperfeiçoamento do ensino foram censurados por atos de repressão e milhares de estudantes foram suspensos, presos e expulsos das escolas, condenados por questionarem e duvidarem do poder das armas sobre o direito e a dignidade das pessoas. GRAEFF, Edgar Albuquerque. Arte e técnica na formação do arquiteto. São Paulo: Nobel, 1995. pp. 45-49.

${ }^{3}$ Parecer no 384/69, aprovado em 10 de junho de 1969. Relator Conselheiro Celso Kelly. Cf. capítulo 1, Contribuição Paulistana.

${ }^{4}$ Este documento contou com a colaboração de professores que nessa mesma época lecionavam na FAUS, Paulo Bastos, Sérgio Ferro, Rodrigo Lefèvre, Mayumi Watanabe de Souza Lima, Sérgio de Souza Lima e Francisco de Oliveira. LIMA, Sérgio de Souza (org.). Mayumi Watanabe de Souza Lima: arquitetura e educação. São Paulo: Studio Nobel, 1995. p. 63. Sylvia Dobry em sua tese completa a equipe: Fernandes, Ari Vicente, arquiteto; Nogueira, Cristina Wickerhauser, estudante; Morita, Horácio M., arquiteto; Ives Freitas, estudante; Maffezoli, Lineu Carlos, economista; Oliveira, Márcio Romero de estudante; Cunha, Maria C. Pereira, historiadora; Nucci, Marizabel Penteado, estudante; Nador, Mônica P., estudante; Fernandes, Yara Vicentini, arquiteta. PRONSATO, Sylvia A. Dobry. Para quem e com quem: ensino de arquitetura e urbanismo. 2008. 321p. Tese (Doutorado em arquitetura e urbanismo) - Faculdade de Arquitetura e Urbanismo da Universidade de São Paulo. São Paulo, 2008. p. 58.

${ }^{5}$ LIMA, Sérgio de Souza (org.). Op. cit. p. 63.
} 
prática modelos avançados de ensino sem os entraves burocráticos de estruturas viciadas. Nesse sentido, ao longo do ano de 1969 firmaram contatos com mantenedoras de faculdades privadas, localizadas em cidades próximas aos grandes centros urbanos, com características de polo de desenvolvimento. Ao ser aceita a proposta, esses professores formavam grupos de trabalho para estruturar os novos cursos. Entretanto, segundo o documento de 1976:

\begin{abstract}
Em poucos meses de funcionamento do curso, após o primeiro vestibular, a realidade empresarial dessas instituições acabaria com o sonho inicial. Realmente inexistiam os entraves burocráticos das tradicionais universidades, mas existia efetivamente o entrave empresarial: a aspiração ao lucro máximo, imediato e a redução do investimento ao mínimo necessário à subsistência do curso - característica de todas as mantenedoras. ${ }^{6}$
\end{abstract}

Em 1974 o sistema MEC-USAID demonstrava seus efeitos. A situação foi invertida e entraram em funcionamento doze escolas na rede particular e somente duas na rede pública e gratuita. Em 1970, no estado de São Paulo foram fundadas a Faculdade de Arquitetura e Urbanismo de Santos (FAUS), a Faculdade de Arquitetura e Urbanismo da Universidade Brás Cubas (FAU-UBC) e a Faculdade de Arquitetura de São José dos Campos (FAU-SJC), no estado do Rio de Janeiro abriram a Faculdade de Arquitetura e Urbanismo da Universidade Santa Úrsula (FAU-USU) e a FAU de Barra do Piraí. Em 1971 a Faculdade de Arquitetura e Urbanismo da Universidade de Rio dos Sinos (FAU-UNISINOS), em São Leopoldo, no Rio Grande do Sul e Faculdade de Arquitetura e Urbanismo das Faculdade Integradas Silva e Souza (FAU-SILVAESOUZA), na Guanabara. Em 1972, foram instaladas a Faculdade de Arquitetura e Urbanismo Bennett (FAU-BENNETT) e a Faculdade de Arquitetura e Urbanismo da Universidade Gama Filho (FAU-UGF), as duas no Rio de Janeiro. Em 1973, Faculdade de Arquitetura e Urbanismo Farias Brito (FAU-FB), em Guarulhos, São Paulo. Em 1974, a Faculdade de Arquitetura e Urbanismo da Universidade Católica de Campinas (FAU-PUCCAMP) e a Faculdade de Arquitetura e Urbanismo da Universidade de Mogi das Cruzes (FAU-UMC), ambas em São Paulo. Os dois cursos públicos foram oferecidos pela Faculdade de Arquitetura e Urbanismo da Universidade Federal de Pelotas (FAU-UFPEL), no Rio Grande do Sul, fundado em 1971 e pela Faculdade de Arquitetura e Urbanismo da Universidade Federal Fluminense (FAU-UFF), em 1972. ${ }^{7}$

\footnotetext{
${ }^{6}$ LIMA, Sérgio de Souza (org.). Op. cit. p. 63.

${ }^{7}$ Existe uma confusão quanto às datas de abertura das Faculdades de Santos, a FAUS, e de Mogi, a FAU-UBC, que iniciaram as suas atividades em 1970, não em 1971. Ao longo desta pesquisa serão apresentados documentos que comprovam esses registros. UNIVERSIDADE DE SÃO PAULO. Faculdade de Arquitetura e Urbanismo. União Internacional de Arquitetos - UNESCO. Relatório sobre o ensino de arquitetura no Brasil. Outubro de 1974. In: ASSOCIAÇÃO BRASILEIRA DE ESCOLAS DE ARQUITETURA. Sobre o ensino de arquitetura no Brasil. São Paulo: ABEA, 1977. Apud. MONTEIRO, Ana M. R. G. (org.). A construção de um novo olhar sobre o ensino de arquitetura e urbanismo no Brasil: os 40 anos da Associação Brasileira de Ensino de Arquitetura e Urbanismo. Op. cit. pp. 21-23.
} 


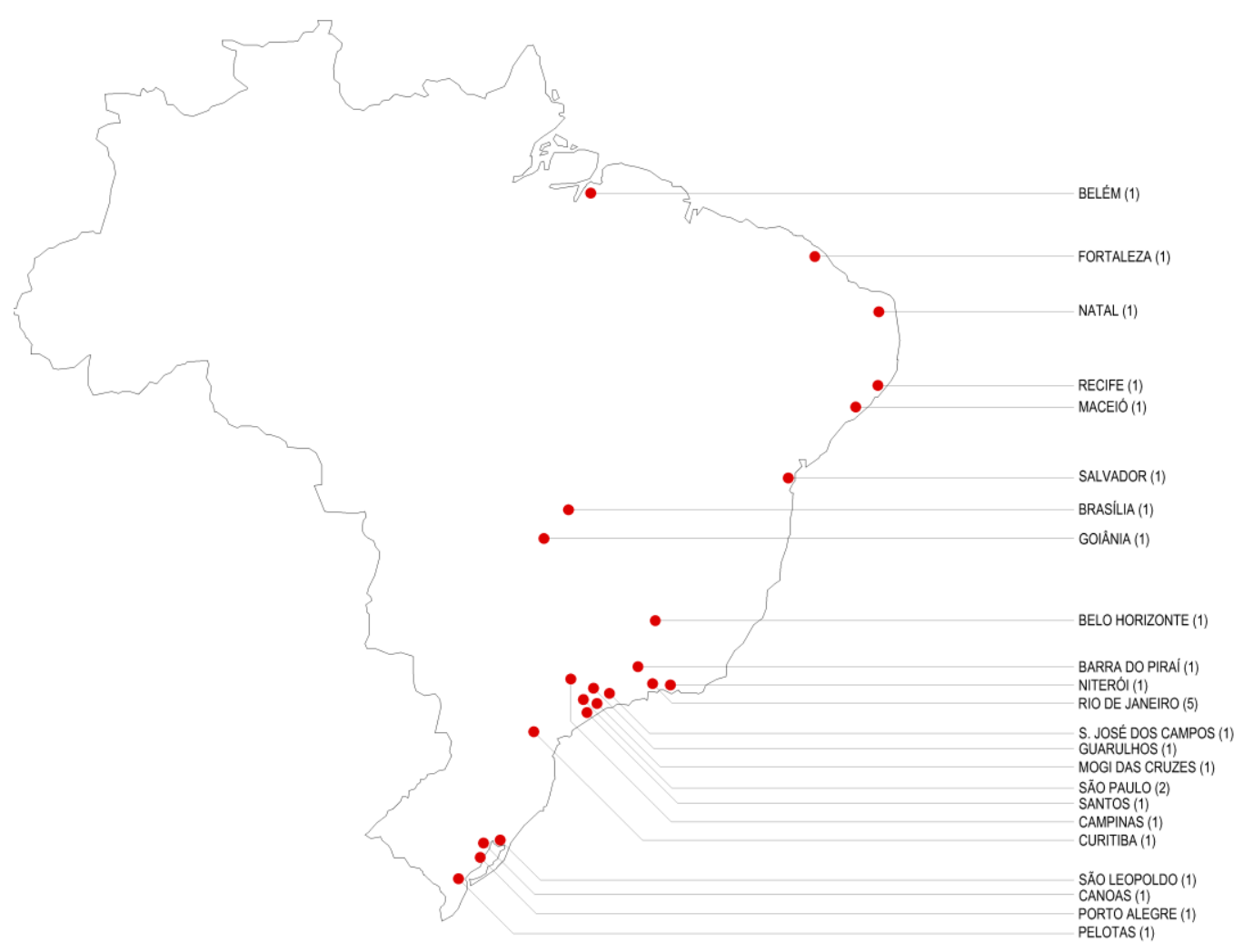

FIG. 19. Distribuição de cursos por cidades em 1974.

\begin{abstract}
À época, existiam no município de São Paulo dois cursos. Um na USP, a FAU, o outro no Mackenzie. O primeiro se apresentava como uma trincheira abrangente de resistência cultural, o outro abrigado em um enclave reconhecidamente reacionário, se mostrava pragmático e formador de profissionais para o mercado. Em torno deles, na expansão metropolitana surgiam outros cursos. O de Santos, configurado por professores da FAU-USP, como uma redução do modelo adaptado às possibilidades de uma associação religiosa local; os dois de Mogi, sendo um deles coordenado por professores da FAU-USP e o outro configurando um curso de curta duração, o de São José dos Campos, idealizado por professores de Brasília, como uma potencialização daquela experiência abortada pelo regime militar. ${ }^{8}$
\end{abstract}

Esse era o cenário no qual a fundação da FAUS ocorreu, de um lado a circunstância do governo militar que, dissolvendo direitos e liberdade de expressão, influenciava diretamente os meios acadêmicos a partir da imposição de pedagogias instrumentais e desenvolvimentistas com a justificativa de suprir a falta de vagas nas universidades públicas. Por outro lado, a presença das teorias marxistas nos meios intelectuais e estudantis desse período ganhou força como possibilidade crítica e resistência às metodologias puramente tecnicistas determinadas pelo governo como forma de padronizar o ensino superior, tanto na universidade pública quanto nas novas faculdades privadas. Contudo, essa polarização foi mediada através da articulação política entre grupos de professores e estudantes que enfatizavam o papel social do arquiteto ao mesmo tempo que buscavam novas formas de atender as demandas sociais por infraestrutura, equipamento e habitação.

\footnotetext{
${ }^{8}$ CARON, Jorge. Memorial de atividades acadêmicas. São Carlos: FAU/EESC-USP, 1999. p. 11 Apud. RUGGIERO, Amanda Saba. Jorge Caron: uma trajetória. 2006. 183p. Dissertação (Mestrado em arquitetura e urbanismo) Escola de Engenharia de São Carlos, Universidade de São Paulo. São Paulo, 2006. p. 63.
} 
DOBRA 


\title{
Alianças estruturantes: a fundação da FAUS
}

\begin{abstract}
Uma escola de arquitetura deve estar intimamente ligada com a indústria e o povo e tudo o mais, do país a que serve. [...] E o que é mais importante, como organizar uma escola para nós de maneira que se adapte às nossas possibilidades, ao nosso meio. ${ }^{1}$
\end{abstract}

A relação entre o homem e o mar é o principal elemento que marca a identidade dos municípios da Baixada Santista. O Porto de Santos é o agente estruturador do desenvolvimento regional. Assim, as nove cidades que compõem a atual Região Metropolitana da Baixada Santista (RMBS), ${ }^{2}$ Bertioga, Cubatão, Guarujá, Itanhaém, Mongaguá, Peruíbe, Praia Grande, Santos e São Vicente, nasceram e se desenvolveram em consequência da facilidade de acesso ao mar e continuam dependendo, direta ou indiretamente, dele. ${ }^{3}$ Localizada na região Sudeste, no litoral central do estado de São Paulo, limitada pela serra do Mar e o Oceano Atlântico, se estende de Norte a Sul tendo como limites continentais administrativos a Região Metropolitana de São Paulo (RMSP) a oeste, ao norte os municípios da Região de Caraguatatuba, e o Vale do Ribeira ao sul e sudoeste. Segundo dados do IBGE de 2015, a região ocupa a área de $2.373 \mathrm{~km}^{2}$ com uma população de 1.668 .428 habitantes. Santos é o município mais populoso, com 433.966 habitantes, e sede do principal porto brasileiro.

A estreita relação da Baixada Santista com o Planalto Paulista existe desde os quadros do povoamento indígena e, apesar de configurarem regiões independentes, a presença do Porto de Santos a partir do processo de colonização iniciou um processo de interdependência implícita entre São Paulo e Santos, conferindo aos dois municípios a característica de "cidades conjugadas". ${ }^{4}$ A consolidação dessas relações veio a partir de meados do século XIX, com a necessidade de escoamento da produção cafeeira oriunda do interior paulista, fenômeno que provocou o exponencial crescimento das atividades portuárias e o inevitável crescimento da cidade de Santos, e culminou com a construção, em 1865, da São Paulo Railway: a ligação ferroviária entre Santos e Jundiaí, passando pela cidade de São Paulo. O histórico problema geográfico representado pela Serra do Mar ofereceu grande dificuldade técnica e econômica para a implantação da ferrovia, fator determinante para a construção de uma única linha, um único segmento entre o mar e as fazendas de café.

\footnotetext{
${ }^{1}$ Carta de Vilanova Artigas a Oswaldo Corrêa Gonçalves. Nova York, 27 de dezembro de 1946, 3p. Arquivo Biblioteca da FAUS.

${ }^{2}$ A Baixada Santista foi considerada região metropolitana em 1996.

${ }^{3}$ A análise do processo histórico de formação dos municípios da Baixada Santista, a partir da antiga Capitania de São Vicente, revela que a emancipação dos municípios da RMBS ocorreu da seguinte maneira: São Vicente (1532), Santos (1545), Itanhaém (1561); Guarujá (1934); Cubatão (1948); Mongaguá (1959); Peruíbe (1959); Praia Grande (1964); Bertioga (1991). Cf. AGÊNCIA METROPOLITANA DA BAIXADA SANTISTA. Disponível em: <http://www.agem.sp.gov.br/indicadores/default.htm>. Acesso em: 03 nov. 2016.

${ }^{4}$ PETRONE, Pasquale. Aldeamentos paulistas. São Paulo: Edusp, 1995. p. 48
} 


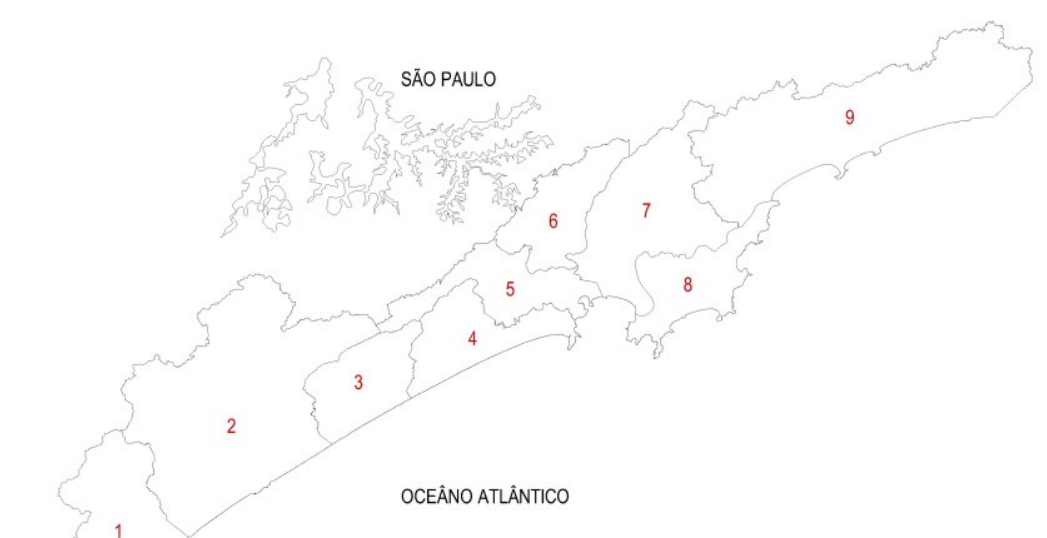

A FERROVIA SOROCABANA

B RODOVIA IMIGRANTES

C RODOVIA ANCHIETA

D CALÇADA DO LORENA

E FERROVIA SÃO PAULORAILWAY

F RODOVIA MOGI-BERTIOGA

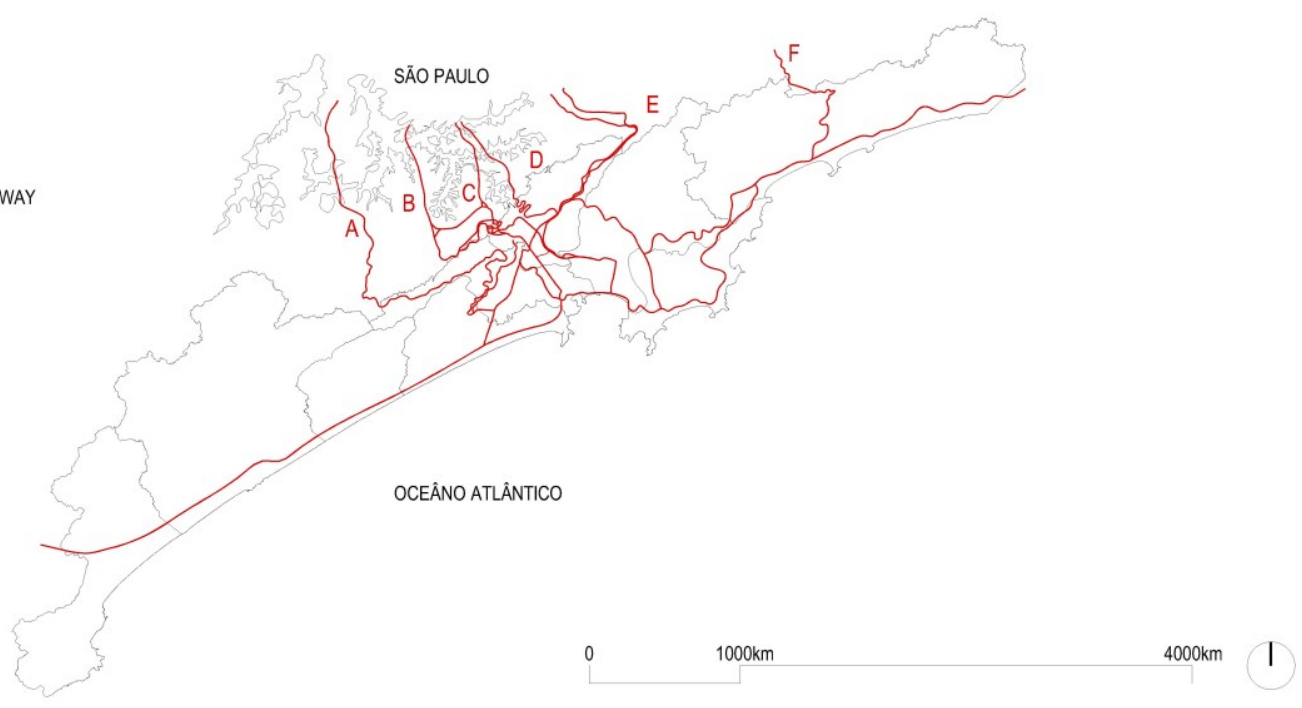

CIDADES DA REGIÃO METROPOLITANA DA BAIXADA SANTISTA E INFRAESTRUTURAS DE MOBILIDADE

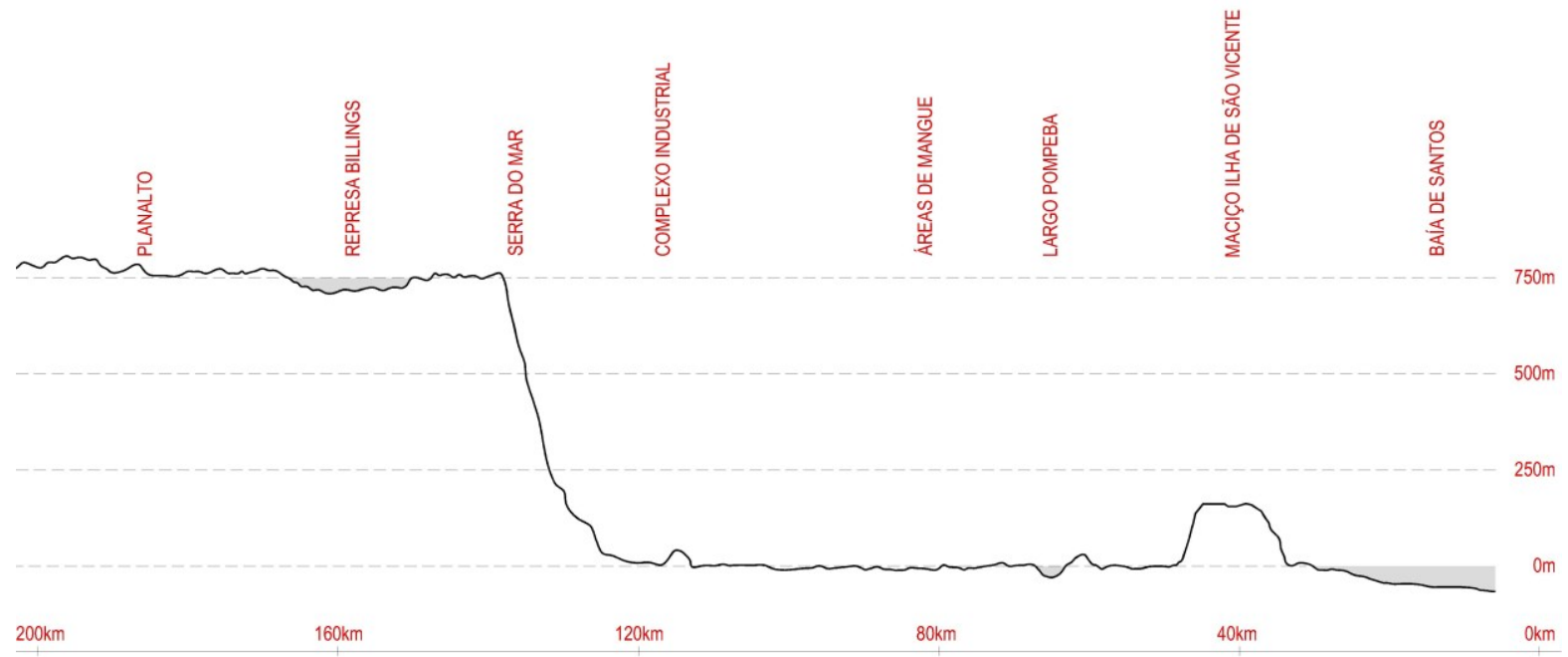

RELAÇÃO ALTIMÉTRICA ENTRE O PLANALTO E O LITORAL PAULISTA.

FIG. 20 
Essa condição permitiu que a cidade de São Paulo assumisse a função de local de transbordo, uma espécie de porto seco, funcionando como uma extensão do porto de Santos. Dessa maneira, configurou um centro, a partir do qual os caminhos se abriam para todas as direções rumo ao interior. Não obstante, no final do século XIX, o surto de desenvolvimento econômico naturalmente trouxe consigo um substancial adensamento populacional da área urbanizada da cidade de Santos, principalmente junto ao porto. Tal processo, atrelado à falta de planejamento urbano e incremento da infraestrutura existente, resultou na proliferação de uma série de epidemias que rapidamente se alastraram e passaram a ameaçar São Paulo e as cidades do interior, ironicamente, através da mesma ferrovia. Com o objetivo de resolver esse problema, o Estado criou a Comissão de Saneamento de Santos e, no início do século XX, um amplo projeto urbano e sanitário foi realizado pelo Engenheiro Sanitarista Saturnino de Brito, ${ }^{5}$ visando o saneamento e a ocupação de todas as áreas desabitadas dos arredores de Santos, aliviando a densa ocupação da área central.

Santos em São Paulo: aquilo era um lamaçal [...] para resolver essa situação, o Engenheiro Saturnino de Brito, um grande especialista em saneamento, soube como estabelecer canais de drenagem das águas, muralhas de cais, aterros, consolidando assim o território para fazer uma cidade onde a princípio seria impossível. O esforço se justifica no caso de Santos porque há outros desejos para que a cidade esteja ali, que impõem a condição daquele lugar. Quais são? Antes de mais nada, o porto. Então alguém diz: "aqui eu pretendo fazer um porto; mas há muita lama... então farei as casas um pouco mais altas... e assim vai. ${ }^{6}$

O plano de Saturnino de Brito previa a drenagem de áreas alagadiças a partir de um sistema de canais a céu aberto que também deveriam ser capazes de escoar as águas pluviais e regular os níveis do lençol freático da cidade. Foi elaborado em conjunto um sistema elevatório de esgoto, separado das águas pluviais e escoados através de uma extensa malha de tubulações subterrâneas, sendo o alto mar seu destino final. Além do caráter profilático, o plano de Saturnino visava a ocupação da ilha, pois os canais implantados naturalmente configuraram potentes estruturas de viabilização do desenho urbano das áreas recém conquistadas e, do ponto de vista cultural, converteram-se na principal referência paisagística e simbólica da malha urbana da cidade de Santos. Nesse sentido, essas ações foram suficientes para orientar a expansão e a ocupação das porções sul e leste da ilha, junto à orla da praia, invertendo o antigo vetor oeste de crescimento que, devido à proximidade com o planalto, avançava na direção de Cubatão. ${ }^{7}$

\footnotetext{
${ }^{5}$ Francisco Saturnino Rodrigues de Brito nasceu em Campos, no Estado do Rio de Janeiro em 14 julho de 1864 . Formou-se engenheiro civil pela Escola Politécnica do Rio de Janeiro em 6 de abril de 1886. Profissionalmente, atuou em inúmeras cidades brasileiras sempre com projetos direcionados ao saneamento e a melhoria da qualidade de vida, como em Recife, Belém, Paraíba, Belo Horizonte, Espírito Santo, Rio de Janeiro, Petrópolis, Paraíba do Sul, Itacoara, Campos, Santos, Campinas, Ribeirão Preto, Limeira, Sorocaba, Amparo, Paraná e Rio Grande do Sul. In: SABESP. O saneamento na Baixada Santista e seu legado cultural. São Paulo, 1995. Sobre os planos de intervenção urbana na cidade de Santos, ver o trabalho do arquiteto formado pela FAUS Sidney Piochi: BERNADINI, Sidney Piochi. Os Planos da cidade: As políticas de intervenção urbana em Santos - de Estevan Fuerts a Saturnino de Brito (1892-1910). 2007. São Carlos: RIMA/FAPESP, 2006.

${ }^{6}$ ROCHA, Paulo Mendes da. Maquetes de papel. São Paulo: Cosac\&Naify, 2007. p. 20.

7 LANNA, Ana L. Duarte. Uma cidade na transição. Santos: 1870-1913. São Paulo-Santos: Hucitec, 1996. p. 99.
} 

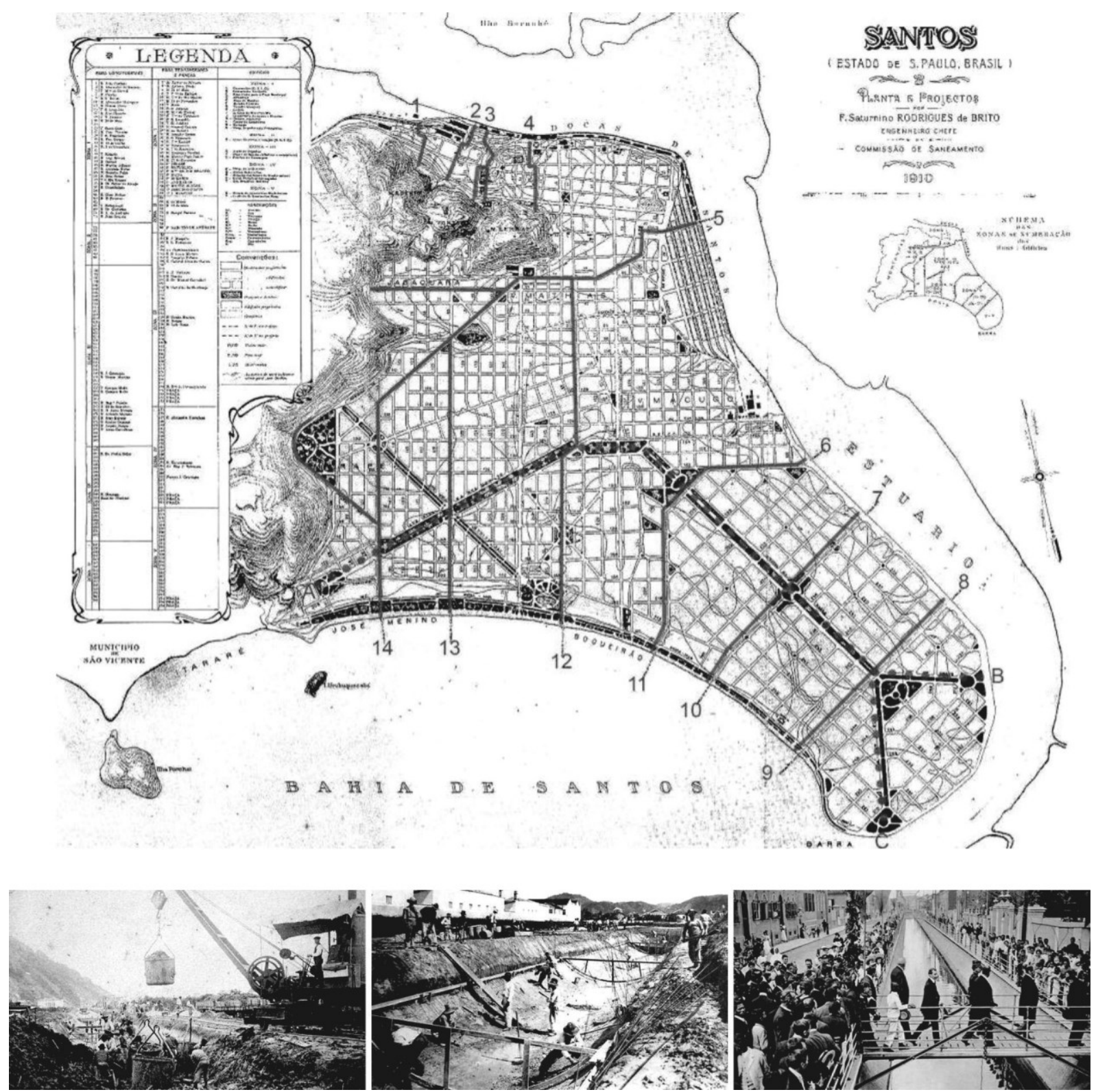

FIG. 21. O projeto previa uma rede de drenagem superficial para recolher as águas dos rios e das áreas encharcadas sujeitas a inundações; um sistema separador absoluto - que separa o esgoto das águas pluviais; esgotamento dos despejos pelo sistema de elevação; destino dos despejos localizado fora da ilha, levados por tubulações que atravessam o mar. Construídos em concreto armado, a céu aberto e com gramado na parte superior, os canais seriam responsáveis por captar as águas pluviais e seriam no número total de nove, ocupando o espaço central das avenidas, facilitando a circulação e o arejamento urbano. Dessa forma, atendendo a três conceitos urbanos muito preconizados na época: a higiene, a valorização do espaço público e o embelezamento.

Concluídas as obras, o conjunto de canais de Saturnino funcionou como uma gigantesca e eficiente máquina hidráulica de drenagem e, naturalmente, com o passar dos anos a cidade se transformou. As atividades portuárias, o comércio e os serviços cresceram mais qualificados e a vida cultural foi incrementada com a construção de novos equipamentos importantes como teatros, clubes e hotéis. Ao mesmo tempo em que a cidade avançava em direção à orla das praias, lugar mais agradável para se viver, o centro passava a ser visto exclusivamente como local de trabalho, para realização das atividades comerciais e administrativas. Em 1947, a inauguração da Rodovia Anchieta constituiu outro importante vetor de desenvolvimento do litoral de São Paulo na medida em que encurtou, 
ainda mais, as distâncias entre a Baixada Santista, a cidade de São Paulo e o interior do estado. ${ }^{8}$ Naquele momento, a região, além de reforçar seu potencial de desenvolvimento econômico, passou a ser vista como um lugar para o descanso e lazer, tendo o mar como grande fonte de recursos terapêuticos para a população do estado de São Paulo.

\begin{abstract}
A significação dessa extensa área recreativa assume uma importância que pouca gente compreende agora. Presentemente a nova rodovia facilitará aos moradores do Planalto a que venham usufruir os benefícios do mar. Mais tarde, porém, dentro de cinco a dez anos, um novo meio de condução porá essa admirável faixa litorânea quase às mãos dos paulistanos. [...] com os helicópteros, milhões de pessoas procurarão as praias de Santos, inclusive como alternativa de residência dessa imensa população de commuters que se formaria em São Paulo. ${ }^{9}$
\end{abstract}

Nesse novo vetor surgiram bairros dotados de infraestrutura suficiente para permitir a construção de grandes casarões, em um primeiro momento, implantados ao longo das Avenidas Ana Costa e Conselheiro Nébias e em seguida em frente ao mar, ao longo da Avenida da Praia. Na década de 1940, com o aumento do turismo e da população nos fins de semana, apareceram os primeiros edifícios com até dez pavimentos, ${ }^{10}$ o que incentivou o setor da construção civil a fazer grandes investimentos nessas áreas privilegiadas. As empresas que atuavam na capital perceberam a oportunidade e construíram grande parte dos edifícios desse período. Vale destacar que as construtoras paulistanas, inexoravelmente, contratavam os escritórios de arquitetura também originários da capital, a exemplo de Franz Heep, Ícaro de Castro Mello, Pedro Paulo de Mello Saraiva, Botti \& Rubin, Zenon Lotufo, entre outros. ${ }^{11}$ As cidades de São Vicente e Guarujá não ficaram fora desse processo e também experimentaram um grande desenvolvimento imobiliário em suas orlas, um verdadeiro processo de valorização das praias "como franja de veraneio da metrópole que se estruturava a partir de São Paulo". ${ }^{12}$

\footnotetext{
${ }^{8} \mathrm{~A}$ Via Anchieta beneficiará extraordinariamente a cidade de Santos, principal balneário do Estado de S. Paulo, atraindo para suas praias grande número de veranistas da capital e do interior, maltratados pela rudeza de uma rodovia impraticável." In: Jornal A Tribuna de 6/11/1946. Apud. MACEDO. Christiane Costa Ferreira. Teatro Municipal de Santos: (re)apropriação do espaço moderno. Dissertação de Mestrado FAUUSP. São Paulo, 2008. p. 36.

9 Observação feita pelo arquiteto Richard Neutra em 1945 depois de visitar as praias do Guarujá. "A grande extensão", Diário da Noite, São Paulo, 17/11/1945. Apud. LIRA, José. Warchavchik: fraturas da vanguarda. São Paulo: Cosac Naify, 2011. p. 456.

${ }^{10}$ Os anos 1930 também são caracterizados pela popularização dos edifícios de apartamentos, como expõe Lemos: “Essa década de 1930 foi o tempo da propagação do concreto armado e em que se aceitou definitivamente o prédio de apartamentos, a solução de moradia coletiva até então altamente rejeitada pelo gosto popular, especialmente pela classe média que não admitia "promiscuidades" semelhantes aos cortiços das classes baixas". LEMOS, Carlos. A arquitetura brasileira. São Paulo: Melhoramentos e Universidade de São Paulo, 1979, p. 137.

${ }^{11}$ Segundo Christiane Macedo, a cidade de Santos foi tomada por novas construções, um verdadeiro surto imobiliário que, iniciado na década de 1950, teve seu auge na década de 1960. Na orla da praia, no lugar dos antigos palacetes, foram erguidos edifícios residenciais, a maioria de apartamentos para alta temporada, iniciando o processo de verticalização da cidade de Santos. Os santistas, com o desejo de manter o seu "lugar ao sol", também procuravam os edifícios com vista para o mar ou se fixavam nas adjacências. MACEDO, Christiane Costa Ferreira. Teatro Municipal de Santos: (re)apropriação do espaço moderno. Op. cit. pp. 36 - 76.

12 LIRA, José. Op. cit. p. 456.
} 


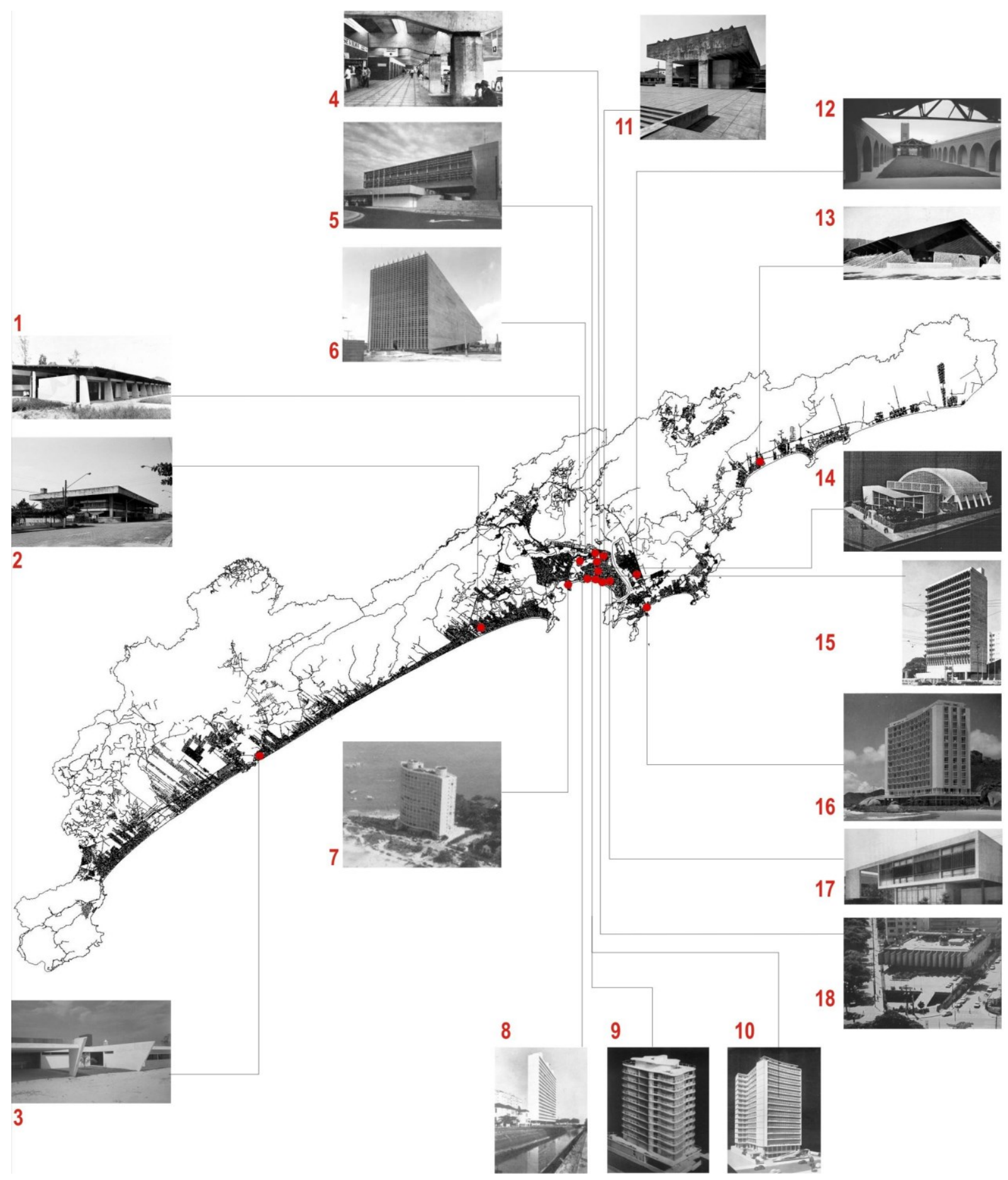

FIG. 22. Alguns exemplares da arquitetura moderna existentes na região da Baixada Santista nos anos 1970.1 Escola Morro Nova Cintra, 1969 - Walter Maffei. 2 Colônia de férias do Sindicato dos Têxteis, 1970 - Vilanova Artigas. 3 Ginásio de Itanhaém, 1959 - Vilanova Artigas. 4 Rodoviária de Santos, 1967 - Flávio Pastore e Luigi Villavecchia. 5 Pronto Socorro Municipal, 1976 - Oswaldo Corrêa Gonçalves. 6 Teatro Municipal de Santos, 1961 - Julio Katinsky, Oswaldo Corrêa Gonçalves e Abrahão Sanovicz. 7 Edifício Maraú, 1955 - Lauro da Costa Lima. 8 Edifício Porto Fino, 1961 - Pedro Paulo Saraiva. 9 Edifício Arco Iris, 1957 - Zenon Lotufo. 10 Parque Verde Mar, 1953 - Artacho Jurado; 11 Grupo Escolar 7 de setembro, Colégio Acácio, 1960 - Decio Tozzi. 12 Escola Conceiçãozinha, 1976 - Vilanova Artigas. 13 SESC de Bertioga, 1968 - Ícaro de Castro Mello. 14 Clube Atlético Santista, 1947 - Ícaro de Castro Mello e Oswaldo Corrêa Gonçalves. 15 Edifício da PRODESAN, 1960 - Flávio Pastore e Luigi Villavecchia. 16 Edifício Sobre as Ondas, 1951 - Jayme Rodrigues e Oswaldo Corrêa Gonçalves. 17 Casa Heitor Almeida, 1949 - Vilanova Artigas. 18 Clube XV, 1964 - Francisco Petracco e Pedro Paulo Saraiva. 
Em 1956, Juscelino Kubitschek, ao assumir a presidência da República com seu lema '50 anos em 5', deu início à implantação da indústria automobilística na região do $A B C$ paulista, ao mesmo tempo em que instalava o parque industrial de Cubatão com a implantação do polo petroquímico e do parque siderúrgico, obras de grande porte e valor estratégico nacional. Segundo Carriço, a grande demanda oferecida pelo setor da construção civil nas décadas de 1950 e 1960 que, juntamente com o parque industrial de Cubatão, atraíram grande contingente de trabalhadores para a região. Essa época foi marcada pela estatização dos serviços públicos, como por exemplo, o setor ferroviário, as obras de saneamento básico, o fornecimento de gás e transporte público urbano. ${ }^{13}$

Até a década de 1950, o porto de Santos desempenhava um papel de excepcional importância no intercâmbio entre a indústria paulistana e a o restante do país e mesmo do mundo. Até essa época, assemelhava-se o Brasil a um arquipélago, tamanha a autonomia que tinham suas diferentes regiões, que na verdade eram 'cercadas de água por todos os lados', pois quase todo o transporte que se fazia entre elas se dava pelo mar. A área metropolitana de São Paulo comerciava com o Brasil através de Santos, tanto na importação de matérias primas como na exportação de produtos industrializados. Os fluxos de transporte entre Santos e a metrópole eram excepcionalmente intensos. Junto as vias que atendiam a estes fluxos, as indústrias procuravam acesso ao país todo. ${ }^{14}$

Nesse período, no âmbito nacional, as pressões políticas e sociais eram intensas, causadas principalmente pelo alto déficit habitacional e pela falta de acesso às melhorias urbanas, por parte da população que migrava de forma significativa de outras cidades e de áreas rurais. Com o objetivo de promover o desenvolvimento de regiões estratégicas, o estado autorizou a abertura de empresas públicas nas cidades-chave desse processo que tinham como principal tarefa a elaboração e implantação de planos diretores com a finalidade de ordenar e sistematizar a ocupação de suas áreas urbanas. Em São Paulo, por exemplo, foram criadas a Empresa Paulista de Planejamento Metropolitano S.A (EMPLASA), a Empresa Municipal de Urbanização de São Paulo (EMURB), a Coordenadoria Geral do Planejamento (COGEP) e o METRO. Segundo Wisnik, a atuação do arquiteto era cada vez mais requerida, a sociedade finalmente reconhecia o arquiteto como um profissional independente em relação ao engenheiro, levando a profissão a ser finalmente reconhecida pela sociedade, "o mercado para arquitetos e urbanistas assumia proporções gigantescas." ${ }^{15}$ Nesse sentido, a cidade de Santos, pela sua importância no sistema de metropolização da cidade de São Paulo conforme o exposto, deveria preparar seu plano diretor que, além do ordenamento da própria cidade, iria servir como um modelo para os outros municípios da região da baixada.

\footnotetext{
${ }^{13}$ CARRIÇO, José M. Legislação urbanística e segregação espacial nos municípios centrais da região metropolitana da Baixada Santista. Dissertação (mestrado em arquitetura e urbanismo) Faculdade de Arquitetura e Urbanismo da Universidade de São Paulo. São Paulo, 2002. p. 56.

${ }^{14}$ VILLAÇA, Flavio. Espaço interurbano no Brasil. São Paulo: Nobel, 1998. pp. 136-138.

${ }^{15} \mathrm{O}$ artigo 79 da Lei Orgânica dos Municípios do Estado de São Paulo passou a exigir a elaboração dos Planos Diretores de Desenvolvimento Integrado - PDDI das cidades do estado, sendo necessária a criação de empresas públicas que, por sua vez, favoreceram o surgimento de grandes empresas de projeto e consultoria e, com elas, os grandes escritórios de arquitetura. WISNIK, Guilherme et al. Fórum, o percurso do ensino na FAU. Revista Caramelo, no 6, jun. 1993. p. 15.
} 
Em 1965, o prefeito de Santos, Silvio Fernandes Lopes, ${ }^{16}$ engenheiro formado pela Escola de Engenharia Mackenzie em 1947, fundou a Progresso e Desenvolvimento de Santos S.A. (PRODESAN), empresa pública com mais de $90 \%$ dos ativos pertencentes à municipalidade, cujo objetivo principal era o planejamento e a elaboração de projetos e execução de obras públicas para a cidade de Santos. O primeiro presidente nomeado da PRODESAN foi o engenheiro-arquiteto Aníbal Martins Clemente, formado pela Escola Politécnica da USP em $1940 .{ }^{17}$ Ao ser empossado, ele imediatamente organizou um concurso público para a formação do primeiro quadro profissional composto por arquitetos e engenheiros - mesmo depois de aprovados em concurso e, antes de tomar posse, esses profissionais precisaram do "aval técnico" do prefeito. Segundo o professor Sergio Novita Fortis, engenheiro também formado pela Escola de Engenharia Mackenzie em 1963 e um dos contratados, "esse grupo não deveria ser grande para não correr o risco de se transformar em um organismo público inchado e inoperante". ${ }^{18}$

Em 1966, o compacto quadro técnico da PRODESAN era composto pelos engenheiros-arquitetos Oswaldo Corrêa Gonçalves e Heitor Ferreira de Souza, ${ }^{19}$ e tinha como principal tarefa a elaboração do Plano Diretor Físico de Santos. Entretanto, mesmo com a participação do presidente da empresa, Aníbal Martins Clemente, e do próprio prefeito da cidade, o plano foi concluído somente em 1968, como uma espécie de dossiê. O grupo percebeu a grande oportunidade que se revelava, mas também uma complexa e extensa tarefa para ser elaborada por um quadro profissional tão reduzido.

\begin{abstract}
Fizemos o plano que, até aquela data (1966), era um amontoado de retalhos de leis. Nós levantamos toda a posição da cidade naquela época, fizemos o diagnóstico, uma série de propostas para a solução urbanística da cidade e, ao mesmo tempo, apresentamos e discutimos com o prefeito Silvio Lopes os projetos de lei da criação do Plano Diretor Físico de Santos, do Código de Edificações, do Código de Posturas, de um Plano diretor Físico para Bertioga e da preservação dos morros de Santos. ${ }^{20}$
\end{abstract}

O Plano Diretor de Santos foi implantado através da Lei no 3529 de 16 de abril de 1968 e vigorou por cerca de 32 anos, um longo período ordenando as transformações urbanas da cidade no qual sofreu poucas alterações e só foi substituído no ano 2000.

\footnotetext{
${ }^{16}$ Silvio Fernandes Lopes nasceu no dia 10 de dezembro de 1927 em Santos, foi prefeito da cidade por duas gestões 1957-1961 e 19651969 (nesta última foi indicado pelo governo militar), acumulou mandatos legislativos como vereador, deputado estadual e federal. Também foi secretário de Estado nos governos de Adhemar de Barros e Paulo Maluf, sua saída da vida pública ocorreu em 1982. Faleceu em 6 de dezembro de 2005, na cidade de São Paulo. Fonte: Carlos Pimentel Mendes. Disponível em: < http://www.novomilenio.inf.br/santos/poli1957.htm.>. Acesso em: 14 de out. 2015.

${ }^{17}$ Natural de Vila Nova de Gaia, Portugal, 9/08/1916-? Atuou profissionalmente nas esferas pública e privada com seu escritório técnico de projetos. Ver FICHER, Sylvia. Os arquitetos da Poli: ensino e profissão em São Paulo. São Paulo: Edusp, 2005. pp. 318 - 319.

${ }^{18}$ FORTIS, Sergio Novita. A formação do arquiteto na Faculdade de Arquitetura e Urbanismo da Unisantos - Universidade Católica de Santos: trajetória, organização curricular e condições de funcionamento no período de 1970 a 2003. Dissertação (Mestrado em Educação) - Universidade Católica de Santos. Santos, 2004. pp. 15-16.

${ }^{19}$ Formados respectivamente pela Escola Politécnica da USP em 1941 e 1956. FICHER, Sylvia. Op. cit. p. 324-327.

${ }^{20}$ GONÇALVES, Oswaldo Corrêa. Entrevista com o Professor Arquiteto Oswaldo Corrêa Gonçalves. Santos, 21 nov. 1982, entrevista a Edison Gloeden e Eugênio Lara. p. 6
} 
Santos é uma cidade que se caracteriza pela multiplicidade de suas funções. Sua posição geográfica privilegiada assegurou-lhe o papel de porta e escoadouro de uma rica e vasta área do território nacional. Destacando-se a importância da função portuária que Santos exerce e que vem contribuindo decisivamente para seu desenvolvimento, essa função esteve sempre ligada à de grande empório comercial, incluindo uma intensa atividade atacadista e varejista que alcança dimensões regionais. Mais recentemente, Santos passou a se projetar como centro turístico e recreativo. Não são menos significativas as suas funções cultural e de prestação de serviço, que ultrapassam os limites do território [...]. ${ }^{21}$
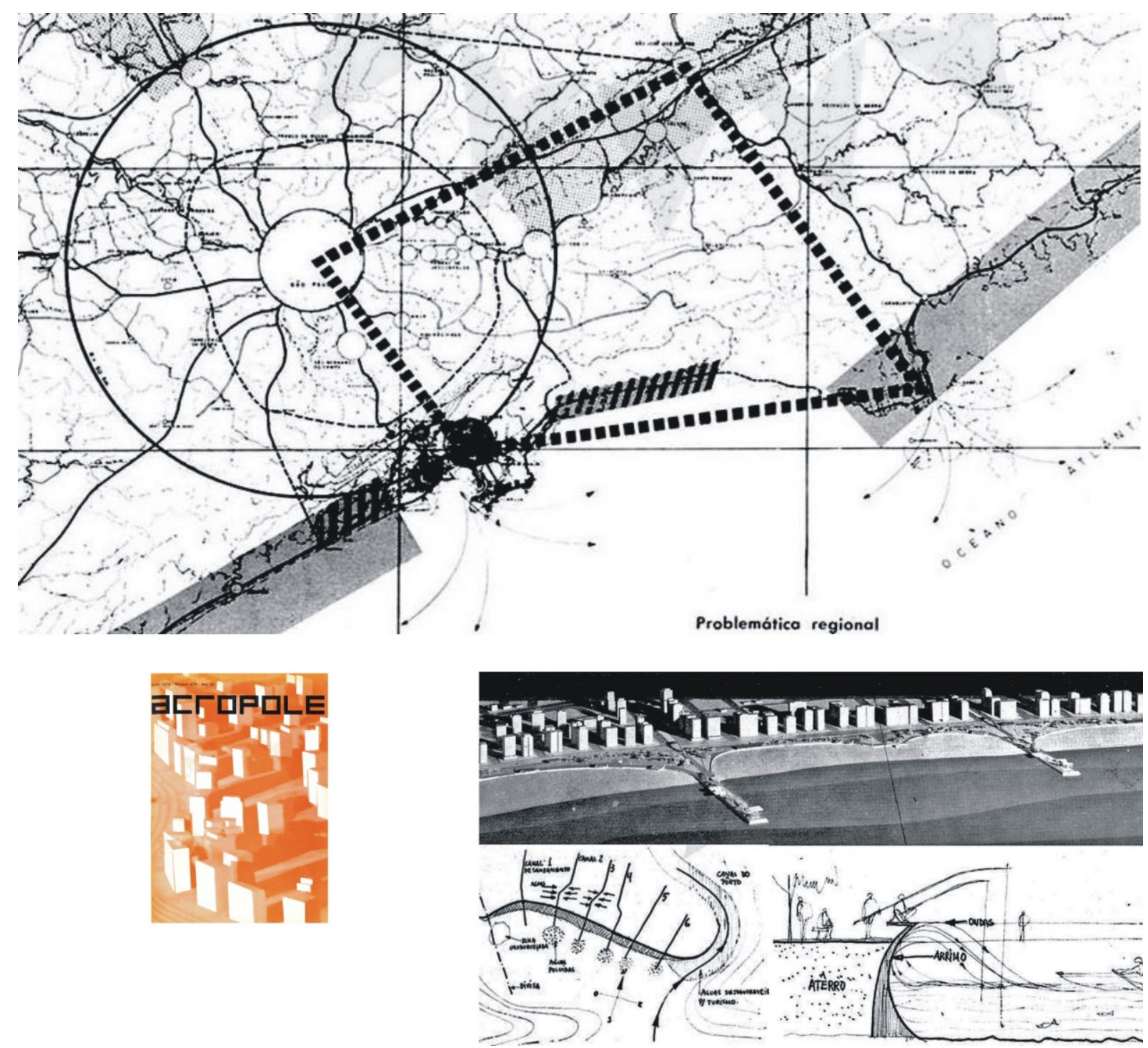

FIG. 23. Acima, mapa ilustrativo do Relatório do Plano de 1968 para Santos elaborado pela equipe de Oswaldo Correa Gonçalves na PRODESAN. Capa da Revista Acrópole no 374 e "Plano turístico das praias de Santos", solicitado pela PRODESAN, que "procura dar as praias de Santos, a atualização dos atendimentos dentro de um planto adequado para o recebimento dos turistas que a ela convergem [...] Para que se tenha ideia da importância dessa afluência de pessoas e da sua contribuição para a incrementação cada vez maior do turismo, pode-se dizer que Santos possui, em média diária, uma população flutuante que varia entre 12.000 e 15.000 pessoas. Nas épocas de veraneio, além dos turistas que permanecem em Santos para a temporada, devem ser somados aqueles que vêm passar o fim de semana, tendo-se então, um total de 160.000 turistas que frequentam a cidade num fim de semana nos meses de veraneio. Essa cifra é bastante expressiva levando-se em conta que a população fixa de Santos em 1965 era da ordem de 280.000 habitantes". Arquitetos Flavio Pastore e Luigi Villavecchia.

\footnotetext{
${ }^{21}$ Trecho do Relatório do Plano de 1968 para Santos elaborado pela equipe de Oswaldo Corrêa na PRODESAN. GONÇALVES, Oswaldo Corrêa. O plano diretor físico de Santos. Revista Acrópole, São Paulo, no 374, junho de 1970. p. 15.
} 
O plano reforçou a existência de um promissor mercado de trabalho para os arquitetos e urbanistas de São Paulo e, em 1970 a Revista Acrópole dedicou a edição de número 374 à "Região Santista", publicando diversos projetos e obras de arquitetos renomados da capital executados nas cidades litorâneas da Baixada. Importa dizer que, nesse mesmo período, extrapolando o universo da arquitetura, Santos também se destacava em outros campos artísticos e intelectuais como, por exemplo, no teatro amador de Plínio Marcos, no ativismo político da artista e escritora Patrícia Rehder Galvão, a Pagu, que ajudou o teatro e a cultura a se desenvolver na cidade, com o Festival de Música Nova, evento internacional de música contemporânea, criado em 1962 por Gilberto Mendes, dentre outros.

Era de se esperar que a efervescência gerada pelo conjunto desses fatores resultasse em uma grande demanda por projetos, não só os urbanísticos determinados pelo Plano Diretor de Santos, mas também projetos de edificações para habitação, educação, saúde, cultura etc., ou seja, a PRODESAN precisava ampliar seu quadro técnico. Entretanto, diante da escassez de profissionais arquitetos residentes na Baixada, contava quase que exclusivamente com a disponibilidade dos arquitetos e urbanistas oriundos da capital, e isso, de certa maneira, dificultava a contratação imediata desses profissionais. Os problemas para suprir esses cargos estavam relacionados a fatores como a distância que exigia deslocamento diário ou mudança de suas cidades de origem e a falta de conhecimento específico da cidade de Santos e a adaptação do profissional às questões regionais. Nesse sentido, tornou-se evidente a necessidade de formar quadros profissionais com conhecimento local. Oswaldo Corrêa Gonçalves percebeu que essa era a oportunidade para propor o estabelecimento de uma faculdade de arquitetura na cidade, capaz de fornecer os quadros técnicos necessários para a PRODESAN que, como gerenciadora, absorveria os profissionais formados pela futura escola, e intermediaria a contratação de serviços dos futuros escritórios de arquitetura e urbanismo que surgiriam na cidade.

É oportuno destacar que o aumento significativo do número de estudantes interessados na profissão, ao mesmo tempo que valorizava a categoria, esbarrava na falta de vagas nas escolas existentes, nesse caso, a FAU-USP e a FAU-Mackenzie que, incapazes de absorver essa demanda, deflagraram o problema do aluno excedente, ou seja, muitos candidatos eram aprovados no vestibular, mas acabavam nas listas de espera pela indisposição de vagas. ${ }^{22}$

Em 1967, apesar do desejo de criar uma escola de arquitetura autônoma, Oswaldo precisou do apoio das Faculdades Católicas de Santos e, desse modo, junto ao arquiteto Aníbal Martins entraram em

\footnotetext{
${ }^{22}$ A Lei 1.392 de 11 de julho de 1951 normatizava o aproveitamento dos candidatos excedentes por escolas particulares, levando em conta a infraestrutura e a possibilidade de atendimento de seu corpo docente. Seguindo esse princípio, o IAB/SP encarava com grande preocupação o problema do aluno excedente, visto como demanda reprimida a ser solucionada com a abertura de novos cursos de arquitetura. BARBOSA, G. C.; FRANCO, R. E. D. (ORG). Oswaldo Corrêa Gonçalves, arquiteto cidadão. Santos: edição do autor, 2019. p. 377.
} 
contato com o bispo diocesano de Santos e presidente da mantenedora Sociedade Visconde de São Leopoldo (SVSL) Dom David Picão ${ }^{23}$ e propuseram a criação de uma Faculdade de Arquitetura e Urbanismo para fazer parte do conjunto das Faculdades Católicas de Santos, que até então eram constituídas pela Faculdade de Direto, pela Faculdade de Filosofia, Ciências e Letras e pela Faculdade de Ciências Econômicas e Comerciais.

\begin{abstract}
Achamos que o município de Santos tinha uma série de elementos necessários e suficientes para que estudantes de arquitetura pudessem trabalhar, manipular, propor, enfim, realizar trabalhos sobre a cidade de Santos que, evidentemente, naquele momento estava em desenvolvimento e a cada instante surgia uma nova diretriz que deveria ser reestudada. Diante da quantidade de material existente, me pareceu muito importante que fosse utilizado por uma faculdade de arquitetura, razão pela qual propus ao Aníbal e ao Dom David, a criação de uma escola de arquitetura em Santos. ${ }^{24}$
\end{abstract}

A SVSL planejava a expansão das Faculdades Católicas com a criação dos cursos de Serviço Social e Comunicação e recebeu bem a ideia de estabelecer um curso de arquitetura, desse modo Dom David Picão consultou o Instituto dos Arquitetos do Brasil, departamento de São Paulo, pois segundo o próprio Oswaldo, o IAB/SP já havia se posicionado contra a proliferação indiscriminada de novas escolas de arquitetura. Em resposta, o IAB/SP enviou um oficio ao presidente da Sociedade Visconde de São Leopoldo:

[...] vimos a sua presença externar o ponto de vista do Instituto dos Arquitetos do Brasil - Departamento de São Paulo - expedido em carta ao Magnífico Reitor da Universidade de São Paulo por ocasião do problema do aluno excedente criado junto à Faculdade de Arquitetura e Urbanismo da Universidade de São Paulo, cuja cópia anexamos à presente. Verificará Vossa Reverendíssima, que somos favoráveis à criação de novos quadros de profissionais arquitetos para participarem do processo de desenvolvimento que nosso país enfrenta; estamos certos que a cidade de Santos, uma das maiores em nosso estado pelo seu crescimento demográfico, já teria condições de merecer sua Faculdade de Arquitetura e Urbanismo. ${ }^{25}$

A fundação da FAUS ocorreu em 1968 com o registro de seu estatuto no cartório das pessoas jurídicas da comarca de Santos, definida como "instituição não governamental de ensino superior, de pesquisa e estudo no campo da arquitetura e do urbanismo, e de divulgação científica, técnica e cultural", tendo a Sociedade Visconde de São Leopoldo como mantenedora. ${ }^{26}$ Após grande expectativa, o governo federal autorizou a abertura de novos cursos superiores pelo setor privado, a partir de $1969 .{ }^{27}$

\footnotetext{
${ }^{23}$ Dom David Picão assumiu a presidência da Sociedade Visconde de São Leopoldo em dezembro de 1966, substituiu Dom Idílio José Soares fundador dessa instituição em 1951. A cidade de Santos, no início dos anos 1950, contava com cerca de 250.000 habitantes e era deficitária no que dizia respeito ao ensino superior, assim em 1952, a SVSL implantou a Faculdade de Direito, em 1954, a Faculdade de Filosofia Ciências e Letras (FAFIS), com os cursos de Pedagogia, Letras e Jornalismo e, em 1959, a Faculdade de Ciências Econômicas e Comerciais (FACECS). UNIVERSIDADE CATÓLICA DE SANTOS. Projeto Pedagógico de Curso - Arquitetura e Urbanismo. Op.cit. p. 4.

${ }^{24}$ GONÇALVES, Oswaldo Corrêa. Entrevista com o Professor Arquiteto Oswaldo Corrêa Gonçalves. Op. cit. p. 6.

${ }^{25}$ IAB/SP. Ofício enviado a Dom David Picão. 8 ago. 1967. BARBOSA, G. C.; FRANCO, R. E. D. (org.). Op. cit. p. 378.

${ }^{26}$ FORTIS, Sergio Novita. Op. cit. p. 17.

${ }^{27}$ A perspectiva aberta pela política educacional do MEC foi recebida como a oportunidade tão esperada de se ampliar o número de cursos de arquitetura e urbanismo no país. LIMA, Sérgio de Souza (org.). Mayumi Watanabe de Souza Lima: arquitetura e educação. Op. cit. p. 63.
} 
A câmara de ensino superior, na sessão plenária de 29 de janeiro de 1970, pelo parecer no 5 e homologado posteriormente pelo Decreto no 66.568, de 14 de maio de $1970,{ }^{28}$ aprovou o curso de Arquitetura e Urbanismo da Faculdade de Arquitetura e Urbanismo de Santos e, dessa maneira, em 6 de fevereiro de 1970 a FAUS publicou o edital do seu primeiro vestibular. Os exames tiveram início em 9 de março de 1970 e terminaram no dia 12 do mesmo mês.

Em um artigo publicado pela revista Acrópole em janeiro de 1970, o professor Eduardo Corona refletia os modelos vestibulares praticados pela FAU-USP e pela FAU-Mackenzie, ressaltando a importância dos aspectos técnicos e artísticos, inerentes à profissão, estarem contemplados na avaliação do candidato ao curso de arquitetura na mesma proporção. A tendência já era de unificação desses aspectos, mas Corona, indo além, propunha a unificação dos vestibulares para todas as faculdades de arquitetura em São Paulo, existentes e novas.

Temos atualmente, depois da FAU e do Mackenzie, a Fac. de arquitetura de São José dos Campos, a de Santos e dentro em pouco a de Mogi das Cruzes. Façamos então, para 1971 um vestibular único para todas, adotando o critério das opções individuais e, depois, um critério de exames inteiramente novo, que dure 15 ou 20 dias, ou 1 mês, mas que os candidatos tenham condições de demonstração de sua capacidade, através de muitas provas e diferentes, como se fez este ano na FAU com a Linguagem da Arquitetura (seis provas). Assim, vários testes na área da arte, vários na área de conhecimentos gerais e vários na área técnica, poderão avaliar melhor e com mais certeza da capacidade de cada candidato e das condições particulares que deve possuir para ser arquiteto. ${ }^{29}$

Seguindo o modelo da FAU-USP, os exames contemplaram disciplinas técnicas, de ciências históricas e de Linguagem da Arquitetura em quatro partes. Dos 183 candidatos inscritos, 131 eram do sexo masculino e 52 do sexo feminino, 63\% eram provenientes da cidade de São Paulo, 27\% da cidade de Santos e o restante de diversas cidades do estado. As setenta vagas ofertadas foram preenchidas restando alguns candidatos em uma lista de espera. A aula inaugural do Curso de Arquitetura e Urbanismo da FAUS foi ministrada no dia 10 de abril de 1970 às 21 h no auditório da Faculdade de Filosofia das Faculdades Católicas de Santos por Luís Saia, formado engenheiro-arquiteto pela POLIUSP e diretor do 4을 distrito do Patrimônio Histórico e Artístico Nacional, Saia versou sobre problemas da arquitetura brasileira e da colaboração do arquiteto no desenvolvimento do país. ${ }^{30}$

\footnotetext{
28 "Fica autorizado o funcionamento da Faculdade de Arquitetura e Urbanismo de Santos, mantida pela Sociedade Visconde de São Leopoldo, em Santos, Estado do São Paulo. Brasília, 14 de maio de 1970. Emílio Médici e Jarbas Passarinho". UNIVERSIDADE CATÓLICA DE SANTOS. Relatório do ano letivo de 1970. Santos, 1970. p. 1.

${ }^{29}$ CORONA, Eduardo. Considerações sobre o vestibular. Revista Acrópole, no 369, set. 1970. p. 12.

${ }^{30}$ UNIVERSIDADE CATÓLICA DE SANTOS. Relatório do ano letivo de 1970 da FAUS. p. 5.
} 


\title{
Refugiados do ensino
}

\begin{abstract}
Uma escola de arquitetura pode ser um importante centro formador e disseminador de ideias. Mas não basta apenas a sua existência. Sua consistência intelectual deriva das pessoas que nela militam - estudantes e professores, principalmente -, suas interações com o meio profissional e suas relações com a sociedade que se insere. ${ }^{31}$
\end{abstract}

Conforme o exposto no capítulo anterior, o projeto para a FAUS foi resultado de uma série de alianças estruturadas por Oswaldo Corrêa Gonçalves através de suas relações com os grupos de intelectuais, artistas e arquitetos atuantes em São Paulo. Sua extraordinária capacidade de agenciar pensadores, com visões ideológicas e políticas distintas, para trabalharem juntos em um projeto sob a tutela da Igreja Católica, sem dúvida, merece destaque. Entretanto, e a bem da verdade, assim como a igreja, do ponto de vista político, o presidente da SVSL Dom David Picão tinha orientação ideológica e política alinhada à esquerda, e acolheu os professores da FAU-USP que tinham o mesmo viés ideológico, o que lhe rendeu a alcunha de "Bispo Vermelho". O critério de seleção utilizado por Oswaldo para a contratação desses docentes e amigos era a confiança e, nesse sentido, o corpo docente da FAUS foi composto, em grande número, por professores e ex-alunos vindos da FAU-USP, muitos impossibilitados de lecionarem na Universidade de São Paulo devido às dificuldades impostas pelo regime militar.

Como já se teve ocasião de dizer, além das exigências do currículo mínimo proposto pelo MEC em 1969, da troca de cartas, em 1946, com Vilanova Artigas, do acompanhamento da Reforma de 1962 da FAU-USP, a partir do IAB/SP, seguida do Fórum de 1968 e das conversas com o grupo de Sérgio Ferro até a sugestão para a "Faculdade de Santos" de Artigas, em 1969, juntos, esses fatos levaram Oswaldo a implantar na FAUS o mesmo sistema de disciplinas organizadas em três departamentos: Projeto, Tecnologia e Ciências Históricas.

\footnotetext{
Inicialmente participamos eu e o Aníbal. Depois comecei a convidar outros profissionais para participarem, entre eles o Sérgio Souza Lima, o Abrahão Sanovicz, Julio Katinsky, a Mayumi e o Sérgio Ferro. Foram os primeiros professores da faculdade, porque cada dois passaram a responder por um dos três departamentos sob os quais foi montada a faculdade: o de Projeto, o de História e o de Tecnologia, segundo as exigências do MEC. ${ }^{32}$
}

O Departamento de Projeto foi dividido em sequências, sendo a disciplina de Planejamento Arquitetônico composta por Desenho do Urbanismo e por Desenho de Edificação; Desenho do Objeto e Plástica, que correspondia à disciplina de Desenho de Mensagem. O Departamento de Ciências Históricas foi subdividido em Estética, História da Arte e Estudos Sociais e, finalmente, o

\footnotetext{
${ }^{31}$ SEGAWA, Hugo. Arquiteturas no Brasil. 1900-1990. 3a.ed. São Paulo: Edusp, 2010. p. 131.

32 GONÇALVES, Oswaldo Corrêa. Entrevista com o Professor Arquiteto Oswaldo Corrêa Gonçalves. Op. cit. p.12.
} 
Departamento de Tecnologia estava organizado pelas disciplinas de Geometria Descritiva, Matemática, Cálculo e Física. Aníbal Martins Clemente foi o primeiro diretor, Oswaldo Corrêa Gonçalves chefe do Departamento de Projeto, Sérgio Ferro chefe do Departamento de História e Sérgio Souza Lima chefe do Departamento de Tecnologia.

A preocupação em formar quadros profissionais voltados para os contextos social, geográfico e urbano da região norteou os primeiros anos de atividade do curso. Foram movidos pela ênfase no ensino da arquitetura que refletia a prática profissional do corpo docente, na tentativa de alinhar as diversas escalas do projeto de arquitetura com o desenvolvimento cultural, social, industrial e tecnológico do país. Seguindo nessa trilha, conforme já visto, Oswaldo Corrêa tinha naquele momento, entre seus projetos em execução, a obra do Teatro Municipal de Santos, em parceria com os arquitetos Abrahão Sanovicz e Julio Katinsky. Desse modo, pode-se dizer que, não por acaso, três das quatro sequências do Departamento de Projeto foram inicialmente ocupadas pelos arquitetos do Teatro Municipal: Oswaldo em Urbanismo, Abrahão em Mensagem e Julio em Objeto. Dos vinte docentes contratados, dezessete eram formados na USP, ou seja, $85 \%$ do quadro de professores pioneiros da FAUS; dois professores eram oriundos da Universidade Presbiteriana Mackenzie e um professor da Universidade Federal de Pernambuco. A situação do corpo docente no final do ano letivo de 1970 era a seguinte:

PROFESSORES PIONEIROS DA FAUS EM 1970

\begin{tabular}{|c|c|c|c|c|}
\hline SEQ. & PROFESSOR & ORIGEM & DISCIPLINA & PARECER \\
\hline 1 & ABRAHÃO VELVU SANOVICZ & FAU-USP & DESENHO DA MENSAGEM & №. 5 de $27 / 01 / 1970$ \\
\hline 2 & ANÍBAL MARTINS CLEMENTE & POLI-USP & DIRETOR & - \\
\hline 3 & ARNALDO ANTONIO MARTINO & FAU-USP & DESENHO DA MENSAGEM & - \\
\hline 4 & BENNO PERELMUTTER & FAU-USP & DESENHO DO URBANISMO & - \\
\hline 5 & DANIELLE ARDAILLON & FFCL-USP & ESTUDOS SOCIAIS & - \\
\hline 6 & DAVID ARAÚJO BENEDICTO OTTONI & POLI-USP & DESENHO DA EDIFICAÇÃO & - \\
\hline 7 & FRANCISCO DE OLIVEIRA & CFCH UFPE & ESTUDOS SOCIAIS & - \\
\hline 8 & GABRIEL BOLAFFI & FFCL-USP & ESTUDOS SOCIAIS & №. 5 de $27 / 01 / 1970$ \\
\hline 9 & JULIO ROBERTO KATINSKY & FAU-USP & DESENHO DO OBJETO & №. 5 de $27 / 01 / 1970$ \\
\hline 10 & MARINA DE CAMARGO & FFCL-USP & HISTÓRIA DA ARTE & - \\
\hline 11 & MASSASHI RUY OHTAKE & FAU-USP & DESENHO DO OBJETO & - \\
\hline 12 & MAYUME WATANABE SOUZA LIMA & FAU-USP & FÍSICA & - \\
\hline 13 & ORPHEU ZAMBONI & FAU-USP & FÍSICA & - \\
\hline 14 & OSWALDO CORRÊA GONÇALVES & POLI-USP & DESENHO DO URBANISMO & №. 5 de $27 / 01 / 1970$ \\
\hline 15 & ROBERTO LOEB & FAU-MACK & GEOMETRIA DESCRITIVA E CALCULO & - \\
\hline 16 & RODRIGO BROTERO LEFÈVRE & FAU-USP & HISTÓRIA DA ARTE & - \\
\hline 17 & RONALDO DUSCHENES & FAU-USP & GEOMETRIA DESCRITIVA E CALCULO & - \\
\hline 18 & SÉRGIO FERRO PEREIRA & FAU-USP & HISTÓRIA DA ARTE & №. 5 de 27/01/1970 \\
\hline 19 & SÉRGIO PEREIRA DE SOUZA LIMA & FAU-USP & GEOMETRIA DESCRITIVA E CALCULO & №73 de 30/01/1970 \\
\hline 20 & TELÉSFORO GIÓRGIO CRISTOFANI & FAU-MACK & DESENHO DA EDIFICAÇÃO & - \\
\hline
\end{tabular}

TAB. 04. A nomenclatura Desenho do Urbanismo consta somente no primeiro semestre de 1970, a partir do segundo semestre é denominada apenas como Urbanismo. 
A grade curricular inicial da FAUS estava organizada da seguinte maneira:
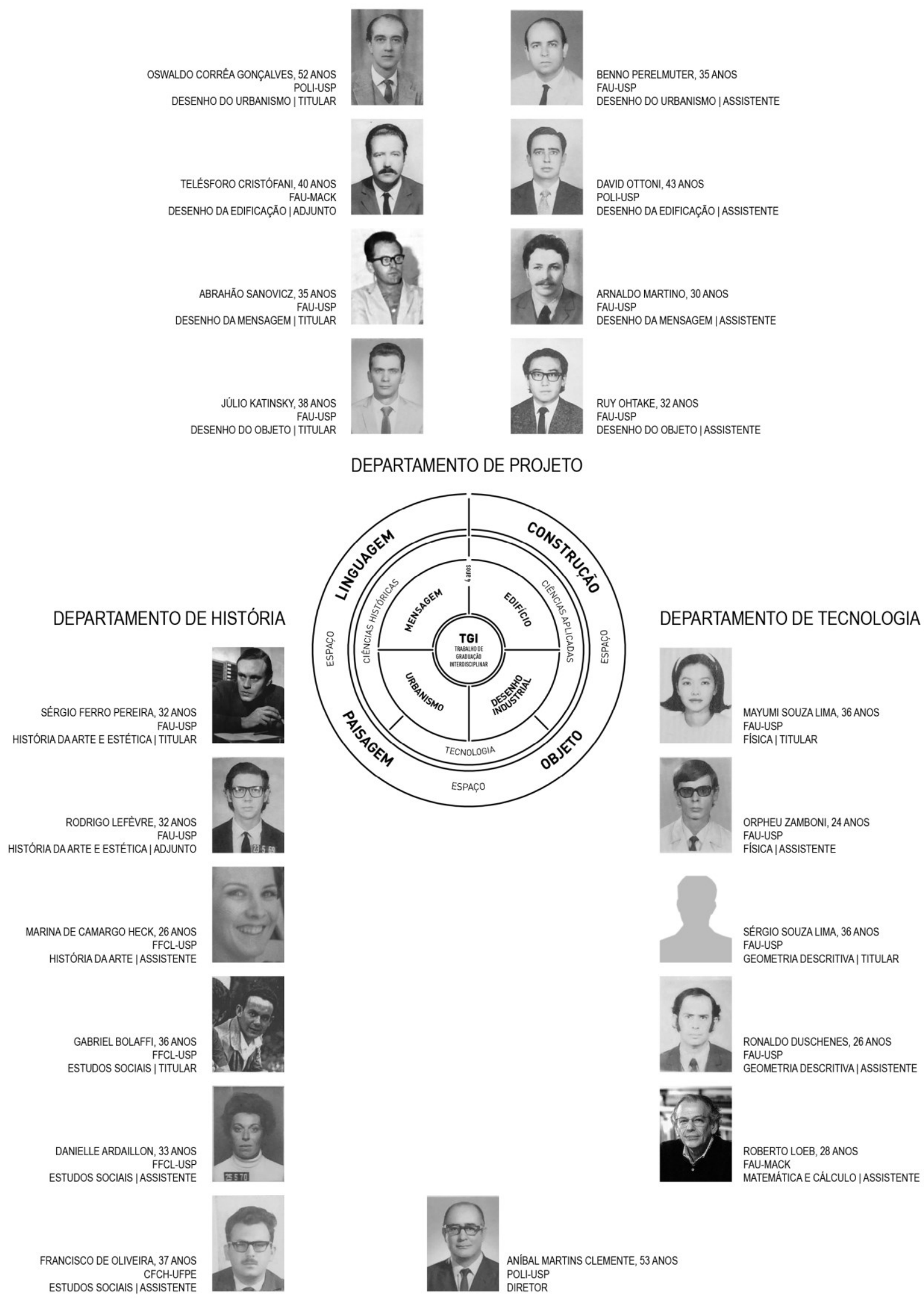

FIG.24. Distribuição dos professores fundadores na grade curricular inicial da FAUS. 
Contudo, apesar da clara hegemonia da FAU-USP no quadro docente da FAUS, segundo um dos professores fundadores da escola, Orpheu Zamboni, a essência da faculdade de Santos não era a da FAU, mas a da Escola de Brasília, estruturada por Darcy Ribeiro e outros intelectuais. Essência difundida em Santos pelo casal de professores Mayumi e Sérgio Souza Lima que, em 1962, ajudaram na estruturação do ICA-FAU da UnB. ${ }^{33}$ "O grupo de professores formadores da FAUS é egresso da FAU, nesse sentido muito acostumado ao nosso atelier, acredito que a experiência de Brasília foi muito importante para esse grupo. Acho que foi a coisa mais significativa na formação da escola." ${ }^{34}$

Ainda segundo o professor Zamboni, ao chegar na FAUS em 1970, esse grupo teve papel relevante na formação dos conceitos da escola, principalmente pela proposta de libertação dos modelos convencionais, dando maior autonomia e liberdade de participação aos estudantes na escolha de seus caminhos, inclusive na formulação dos exercícios e do curso. "Mas tenho a impressão de que esse grupo que se formou lá tentou fazer uma escola aos moldes daquilo que eles pensavam, no caso, um pouco diferente do que o Oswaldão havia imaginado." ${ }^{35}$ Essa tese, de certo modo, corrobora com a declaração do professor Ubyrajara Giglioli que, na ocasião de uma entrevista para as comemorações do cinquentenário da FAU-USP, afirmou: "Gonçalves pretendia criar uma síntese de diferentes correntes de pensamento ligadas ao ensino de arquitetura, juntando professores da USP, do Mackenzie e de Brasília". ${ }^{36}$

Apesar de Mayumi e Sérgio Souza Lima trabalharem em Brasília com Oscar Niemeyer e João Filgueiras Lima (Lelé), utilizando sistemas construtivos racionalizados e pré-fabricados, e trazendo essa experiência para Santos, curiosamente, em 1976, ocorreu um movimento contrário: o curso de Desenho Industrial desenvolvido para a FAUS pelos professores Abrahão Sanovicz e Julio Katinsky foi implantado na FAU-UnB com poucas alterações. Posteriormente, com sua publicação em 1977,37 serviu como modelo de curso para todas as escolas de arquitetura do país.

\begin{abstract}
Abrahão e o amigo Julio Katinsky participaram da estruturação da Faculdade de Arquitetura e Urbanismo de Santos - FAUS; o primeiro conceituando o curso de Programação Visual e o segundo o curso de Desenho Industrial. Nessa Faculdade foi titular da Cadeira de Mensagem. A experiência na estruturação e as atividades didáticas realizadas na FAUS resultaram no convite pelo Instituto de Arquitetura da Universidade de Brasília, em 1976, para que esses dois professores conceituassem os cursos de Desenho Industrial e
\end{abstract}

\footnotetext{
${ }^{33} \mathrm{O}$ grupo de Mayumi tinha grande conhecimento em pedagogia, sua experiência enfatizava a educação do primário à universidade. Sobre Mayumi, ver LIMA, Sérgio de Souza (org.). Mayumi Watanabe de Souza Lima: arquitetura e educação. São Paulo: Studio Nobel, 1995. BUITONI, Cássia Schroeder. Mayumi Watanabe Souza Lima: a construção do espaço para a educação. 2009. 226p. Dissertação (Mestrado em arquitetura e urbanismo) - Faculdade de Arquitetura e Urbanismo da Universidade de São Paulo. São Paulo, 2009.

${ }^{34}$ ZAMBONI, Orpheu. Entrevista com Orpheu Zamboni. São Paulo, 06 jun. 2016. Entrevista a José Maria de Macedo Filho.

${ }^{35} \mathrm{Ibid}$.

${ }^{36}$ GIGLIOLI, Ubyrajara. Cinquentenário da FAUUSP. Revista Projeto, São Paulo, o 228, jan. / fev. 1999. p.72.

${ }^{37} \mathrm{O}$ documento elaborado por Abrahão e Julio - resultante da conceituação realizada - foi publicado, em 1977, pela Associação Brasileira de Escolas de Arquitetura ABEA, sob o título Desenho Industrial e Programação Visual para Escolas de Arquitetura. Foi considerado pela Comissão de Ensino de Arquitetura e Urbanismo - CEAU, órgão do Ministério da Educação, documento de referência para discussão nas escolas de arquitetura do país. Ver SANOVICZ, Abrahão; KATINSKY, Julio Roberto. Desenho industrial e programação visual para escolas de arquitetura. Brasília: ABEA/ MEC, 1977.
} 
Comunicação Visual dessa instituição. Nesse estudo, Abrahão introduz sua proposta delimitando, em relação à formação do arquiteto, a área de atuação da programação visual numa faixa compreendida pela sinalização viária ou rodoviária, de um lado e, de outro, a propaganda. A partir dessa visão geral do problema, desenvolve e conceitua o curso e ementas para cinco disciplinas. ${ }^{38}$

Em linhas gerais, ao longo dos 47 anos de atividades didáticas no campo da arquitetura e do urbanismo, a FAUS contou com aproximadamente 347 professores, muitos arquitetos, engenheiros, historiadores, filósofos, cientistas sociais, matemáticos, artistas plásticos, geólogos, etc. Com o objetivo de organizar e sistematizar os dados coletados, foi elaborado um quadro que possibilita a identificação do docente, a disciplina ministrada, o ano de sua admissão, o ano do seu desligamento, além da identificação da instituição de sua graduação. ${ }^{39}$ Com essa classificação e organização, foi possível verificar o tempo de permanência na FAUS, o eixo temático trabalhado, além da identificação da instituição de graduação do professor, oferecendo assim a possibilidade de reflexão acerca dos aspectos ideológicos, políticos e didáticos vivenciados na FAUS por esse grupo.

Para uma rápida leitura, foi elaborado um diagrama síntese dessas informações, destacando os professores notáveis, longevos e professores egressos da própria FAUS, estes últimos apresentam-se com mais frequência a partir dos anos 1980. No diagrama é possível verificar as disciplinas ministradas, o tempo em que o docente permaneceu na escola e sua instituição de formação. Destacados em vermelho estão os professores da FAU-USP; em preto, professores formados em outras instituições; e abaixo, na cor cinza, os arquitetos docentes egressos da FAUS. Para melhor entendimento da relação entre o período de formação profissional e o início das atividades didáticas, os dados do quadro a seguir podem ser cruzados com o quadro geral de docentes e com a lista de arquitetos egressos da FAUS. ${ }^{40}$

Em um primeiro recorte, com o objetivo de estabelecer parâmetros comparativos e quantitativos entre as instituições de origem dos docentes da FAUS, foi considerado apenas o número total de professores arquitetos identificados no quadro docente geral. Desse modo, a FAUS dispôs de 198 arquitetos professores ao longo de sua história; desses, 106 são professores oriundos da FAU-USP (39\%), 42 são formados na FAUS (21\%) e 25 têm a FAU-Mackenzie como origem (13\%). Ampliando o espectro para o universo de todas as disciplinas, ou seja, do quadro completo dos docentes, descartando apenas os professores sem identificação de sua instituição de origem, resulta um total de 272 docentes identificados.

\footnotetext{
${ }^{38}$ SILVA, Helena A. Ayoub. Abrahão Sanovics: o projeto como pesquisa. 2004. 610p. Tese (Doutorado em arquitetura e urbanismo) Faculdade de Arquitetura e Urbanismo da Universidade de São Paulo. São Paulo, 2004. p. 278.

${ }^{39} \mathrm{O}$ quadro com todos os nomes dos professores da FAUS, encontrados ao longo da pesquisa, está disponível no Apêndice deste trabalho.

${ }^{40}$ A lista completa de formandos da FAUS está disponível no Apêndice deste trabalho.
} 


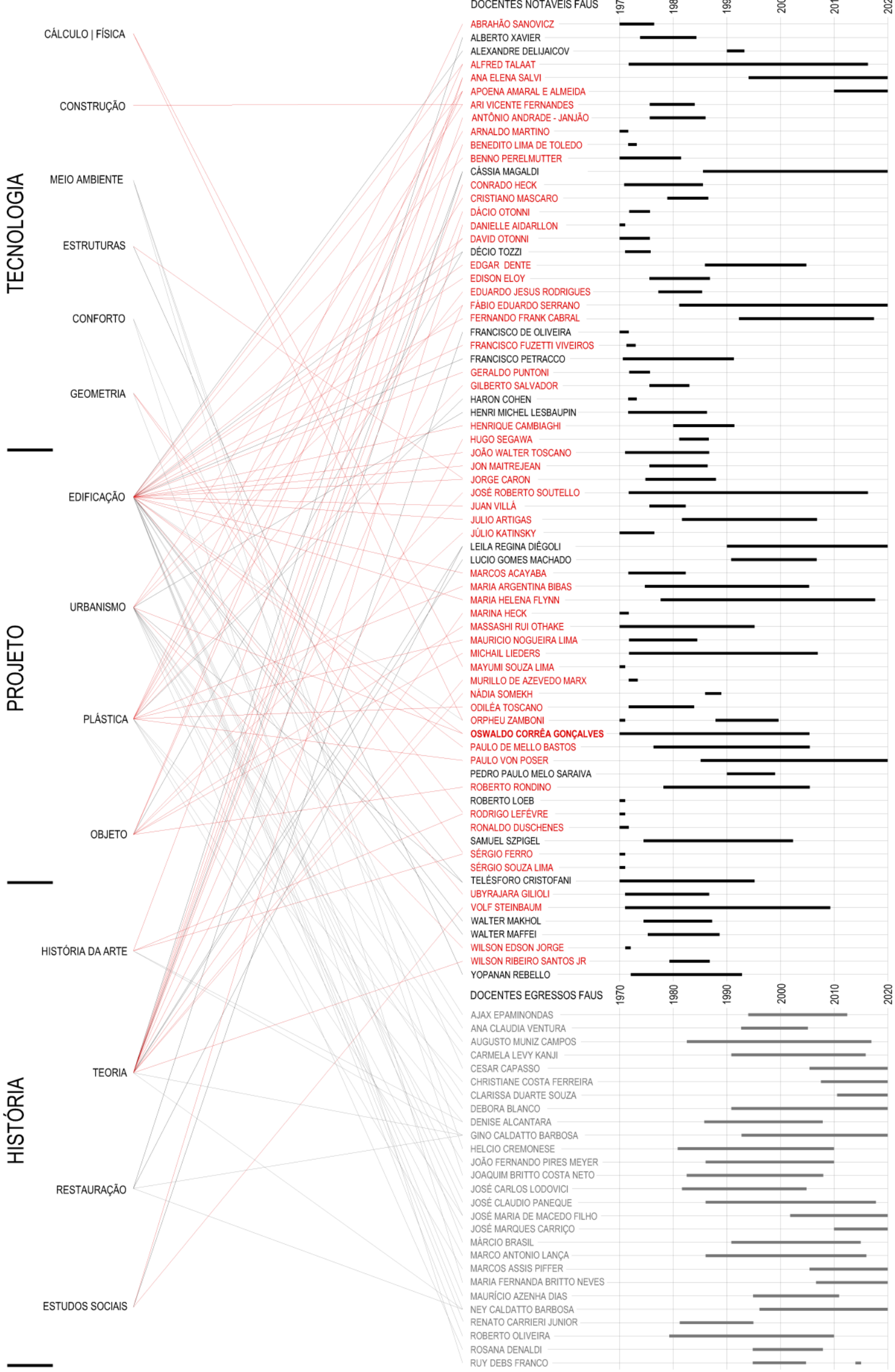

FIG. 25. Quadro síntese dos professores notáveis, longevos e egressos da FAUS. 
Desse total, 120 professores têm sua formação na Universidade de São Paulo (44\%), 51 são formados na própria Universidade Católica de Santos (19\%) e 30 são graduados pela Universidade Presbiteriana Mackenzie (11\%).

O reconhecimento e identificação do grupo de professores fundadores e formadores da FAUS, a partir do mapeamento de seus fluxos migratórios pelos novos cursos abertos nos anos 1970, oferece a oportunidade para futuras pesquisas sobre as escolas de arquitetura implantadas nesse mesmo momento. Também localizadas em regiões estratégicas dos pontos de vista do desenvolvimento urbano, econômico, industrial e turístico do estado de São Paulo, como a FAU-UBC e a FAU-SJC e, posteriormente, a FAU-FB, a FAU-PUCCAMP e a FAU-UMC. Essas escolas contaram, em seus quadros docentes, com professores em atividade na FAUS, e juntas constituíram um fértil campo de investigação de novos procedimentos didáticos-pedagógicos.

É oportuno destacar que a prática profissional do grupo pioneiro possivelmente tenha gerado subsídios seminais para a elaboração de procedimentos para o ensino de arquitetura no âmbito acadêmico, funcionando como um laboratório de experimentações capaz de retroalimentar a própria atividade prática, sendo o projeto entendido como pesquisa, a pesquisa entendida como extensão, cuja demonstração é o próprio projeto. Dessa maneira, julgou-se pertinente observar a produção desses arquitetos em um recorte temporal que compreende os cinco anos de germinação e desenvolvimento do projeto da FAUS, entre 1965 a 1970, o ano da sua fundação, em 1970, e os primeiros cinco anos de funcionamento da escola, de 1970 a 1975.

Esses dez anos constituem uma compilação muito específica da produção arquitetônica desenvolvida paralelamente às atividades didáticas desses arquitetos e se apresenta como um possível instrumento de análise das relações entre os aspectos que envolvem a produção do projeto e a obra edificada com o ensino, justamente por conter características e fundamentos importantes da arquitetura produzida pela escola paulista de arquitetura nos anos 1970. É evidente que essas provocações extrapolam os objetivos deste trabalho, mas oferece oportunidades de investigação e novas pesquisas, ampliando o campo de compreensão das fronteiras entre teoria e prática profissional. $^{41}$

\footnotetext{
${ }^{41} \mathrm{O}$ estudante da FAUS Rafael Mendes elaborou um trabalho de iniciação cientifica, sob a minha coordenação, resultando em uma pesquisa que apresenta um roteiro metodológico muito simples, composto por um processo de investigação, classificação e sistematização de dados com o objetivo de melhorar a compressão dos aspectos que envolvem a produção do projeto e seu ensino na Faculdade de Arquitetura e Urbanismo de Santos. SANTOS, Rafael Mendes. A produção arquitetônica dos professores pioneiros da Faculdade de Arquitetura e Urbanismo de Santos. 2019. 114p. Relatório final de atividades de pesquisa. Instituto de Pesquisas Científicas e Tecnológicas - IPECI. Universidade Católica de Santos, Santos, 2019.
} 


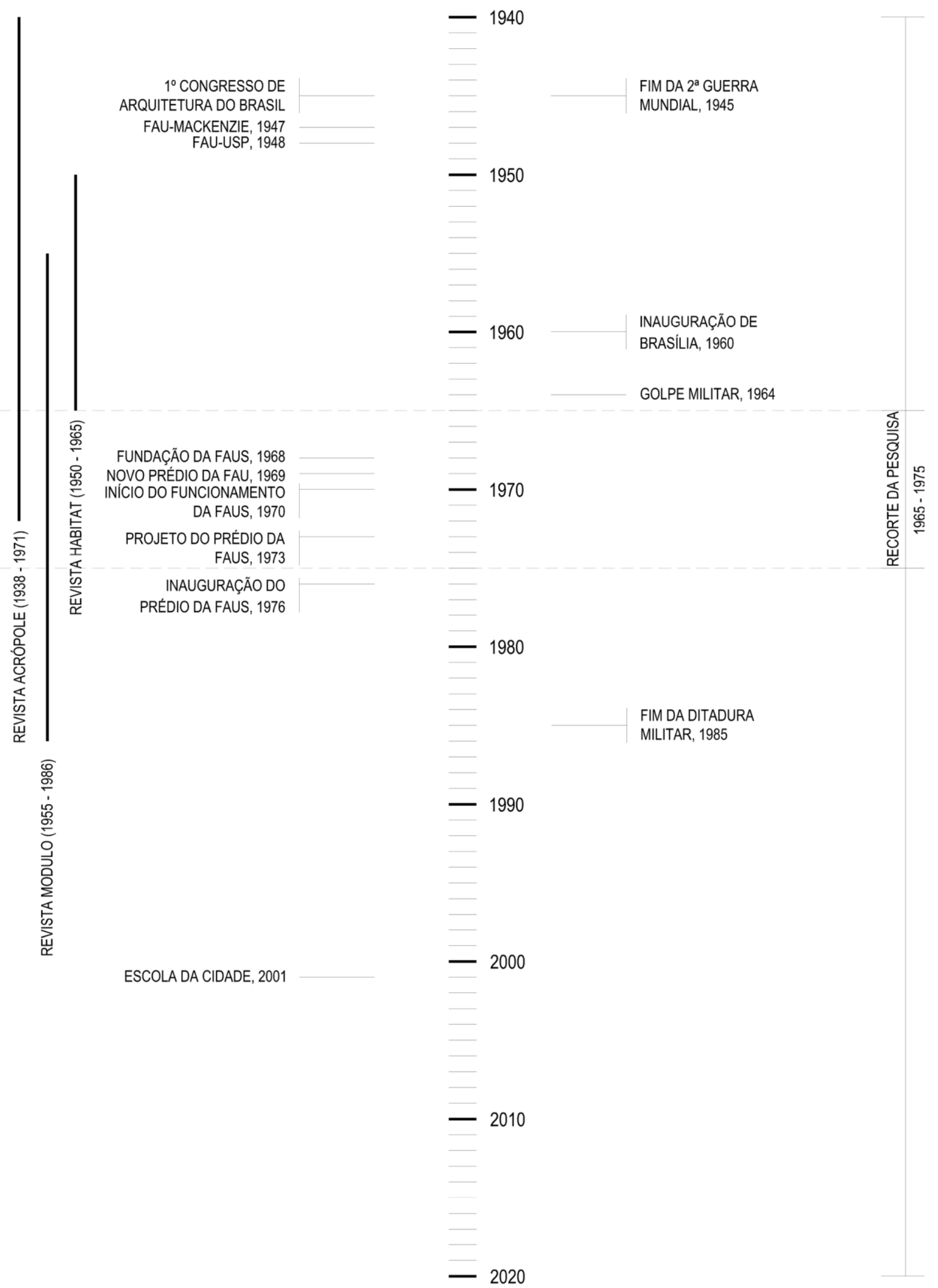

FIG. 26. Contextualização da produção dos professores da FAUS de acordo com o recorte proposto, entre 1965-1970. 

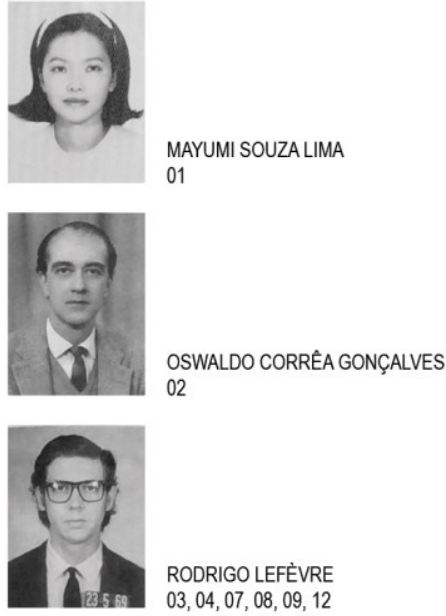

RODRIGO LEFĖVRE $03,04,07,08,09,12$

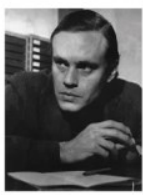

SÉRGIO FERRO PEREIRA $03,05,06,07,08,11$
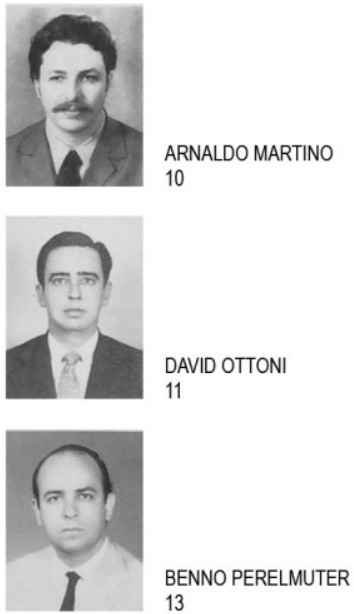

13

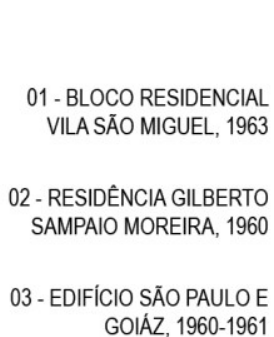

04 - RESIDÊNCIA MARIETTAE RUTH VAMPRÉ, 1962

05 - RESIDÊNCIA BORIS FAUSTO, 1961

06 - RESIDÊNCIA BERNARDO ISSLER, 1961

07 - RESIDÊNCIA SYLVIO BRESSER PEREIRA, 1964

08 - RESIDÊNCIAALBERTINA PEDERNEIRAS, 1964

09 - RESIDÊNCIA CLEOMENES DIAS BATISTA

1964

10 - RESIDÊNCIA TEREZA MARTINO, 1965

1960

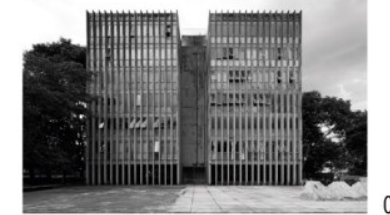

01
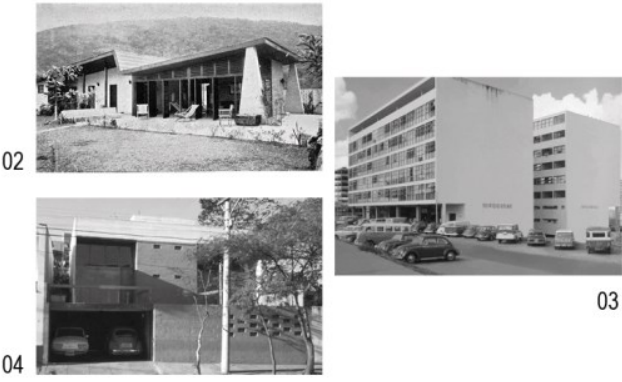

04

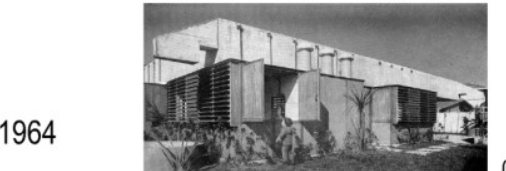

1964

05

07
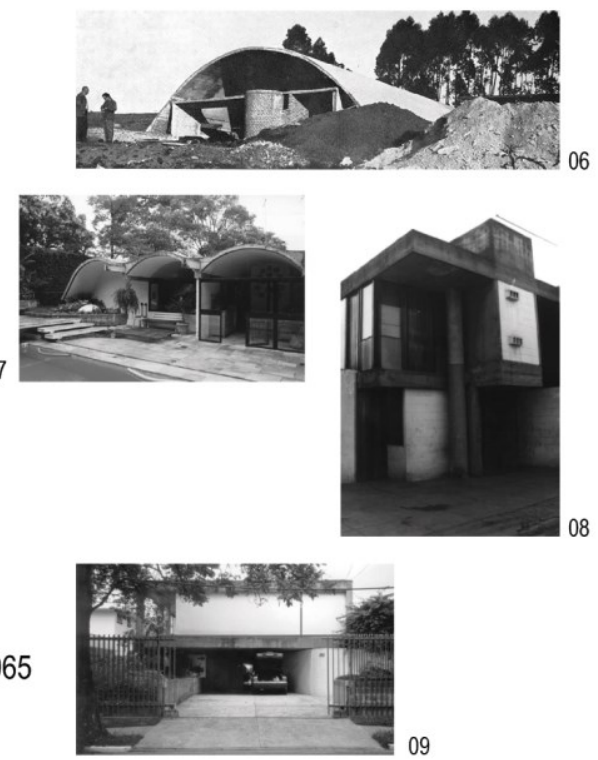

11 - RESIDÊNCIA JOSÉ CHAMIS, 1965

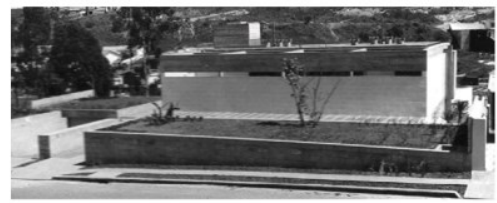

12 - RESIDÊNCIA HELLADIO CAPISANO, 1962-1965

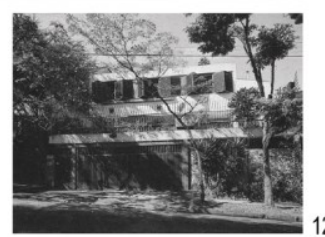

13 - ASS. DOS

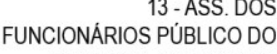
EST. DE S. PAULO, 1965

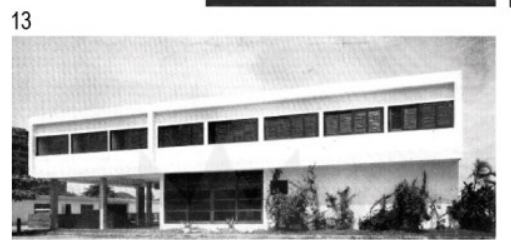

FIG. 27. Produção dos professores da FAUS. 

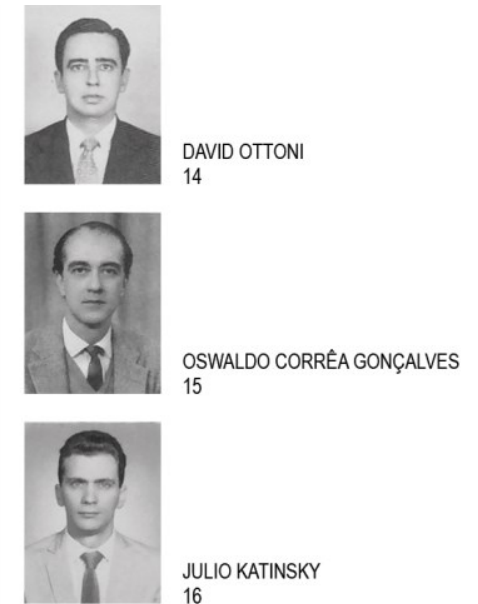

JULIO KATINSKY
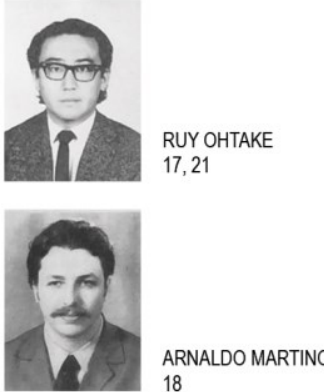

18
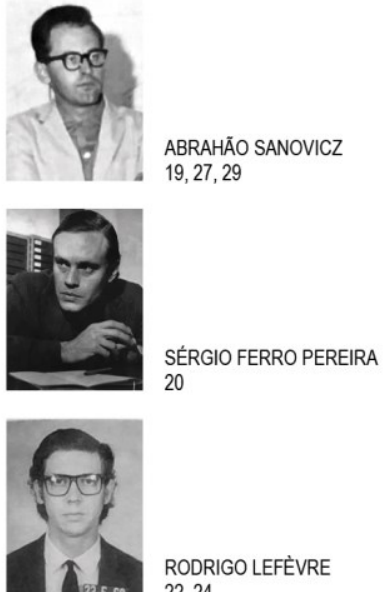

22. 24
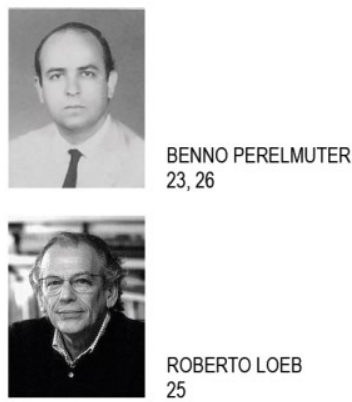

23,26

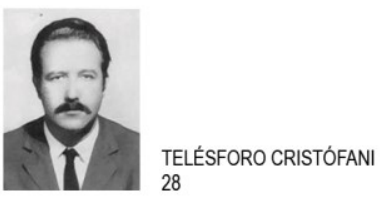

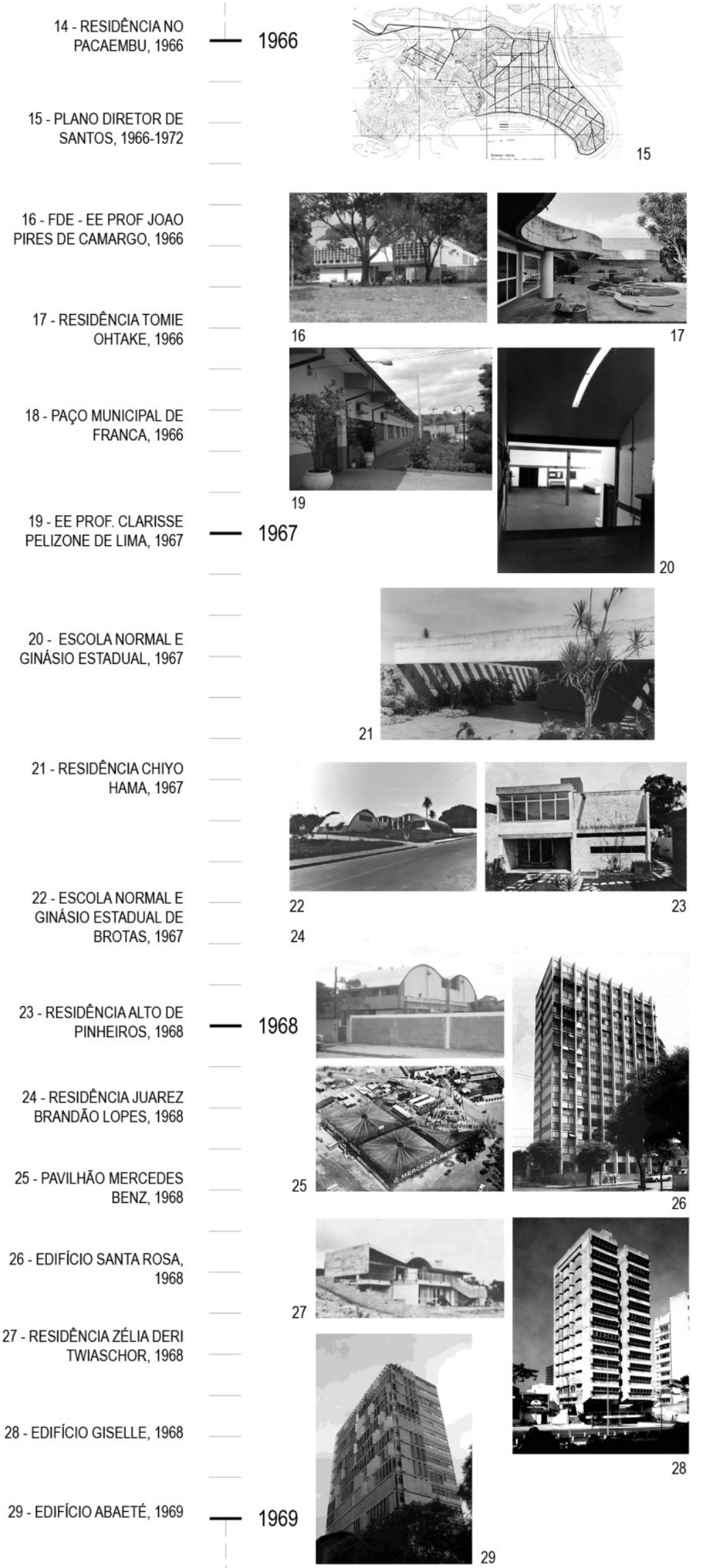

FIG. 28. Produção dos professores da FAUS 


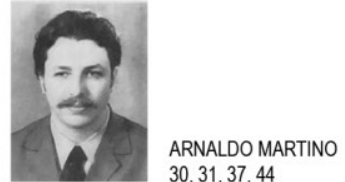

$30,31,37,44$
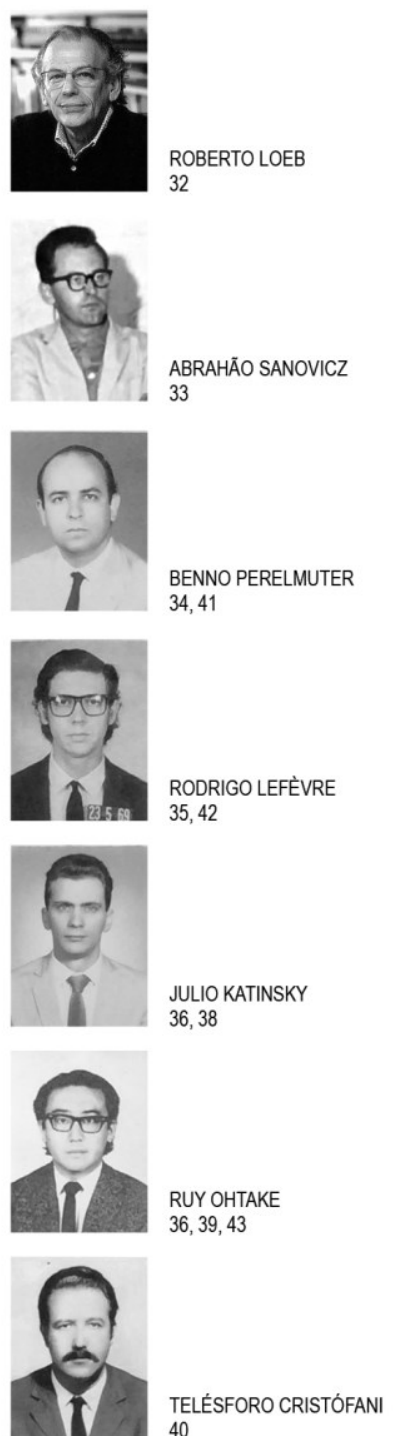

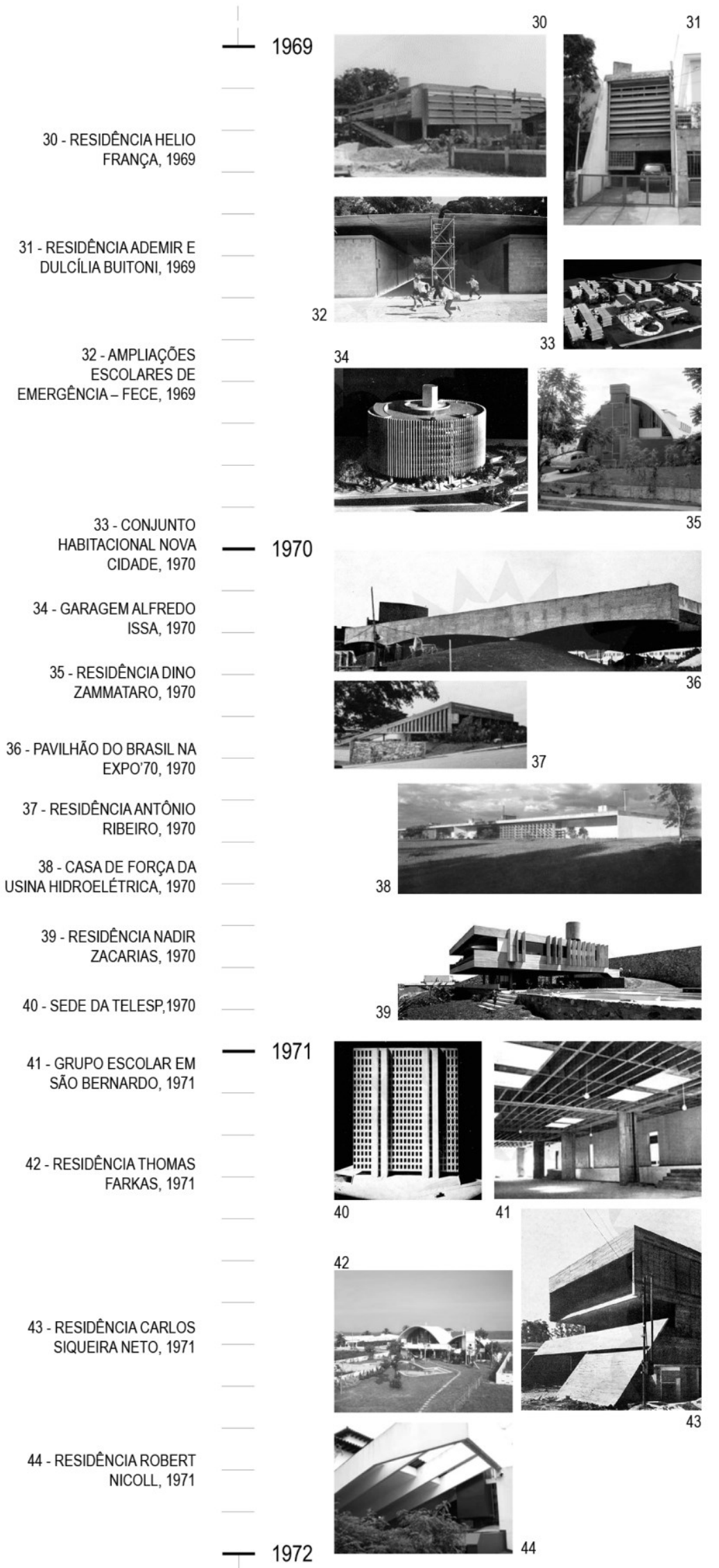

FIG. 29. Produção dos professores da FAUS. 


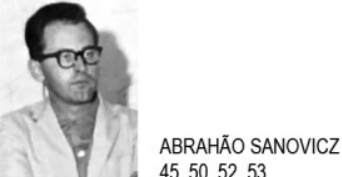

$45,50,52,53$

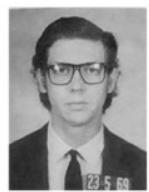

RODRIGO LEFĖVRE

$46,47,54$
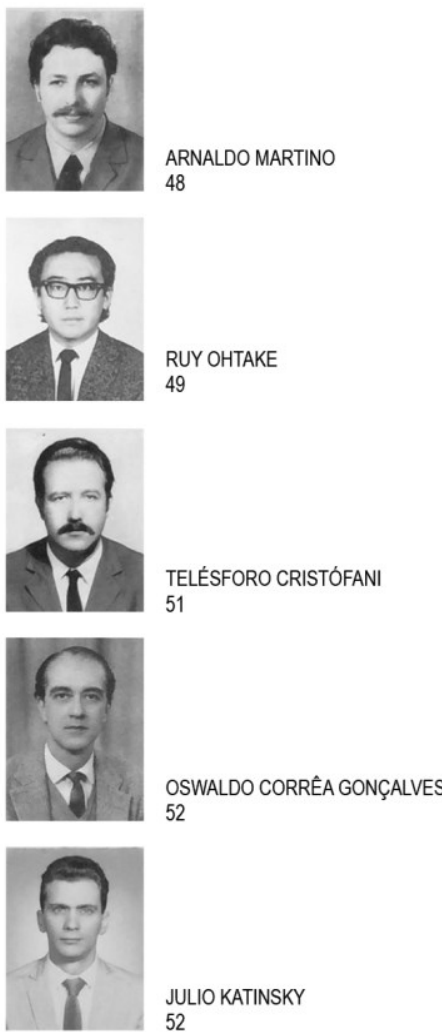

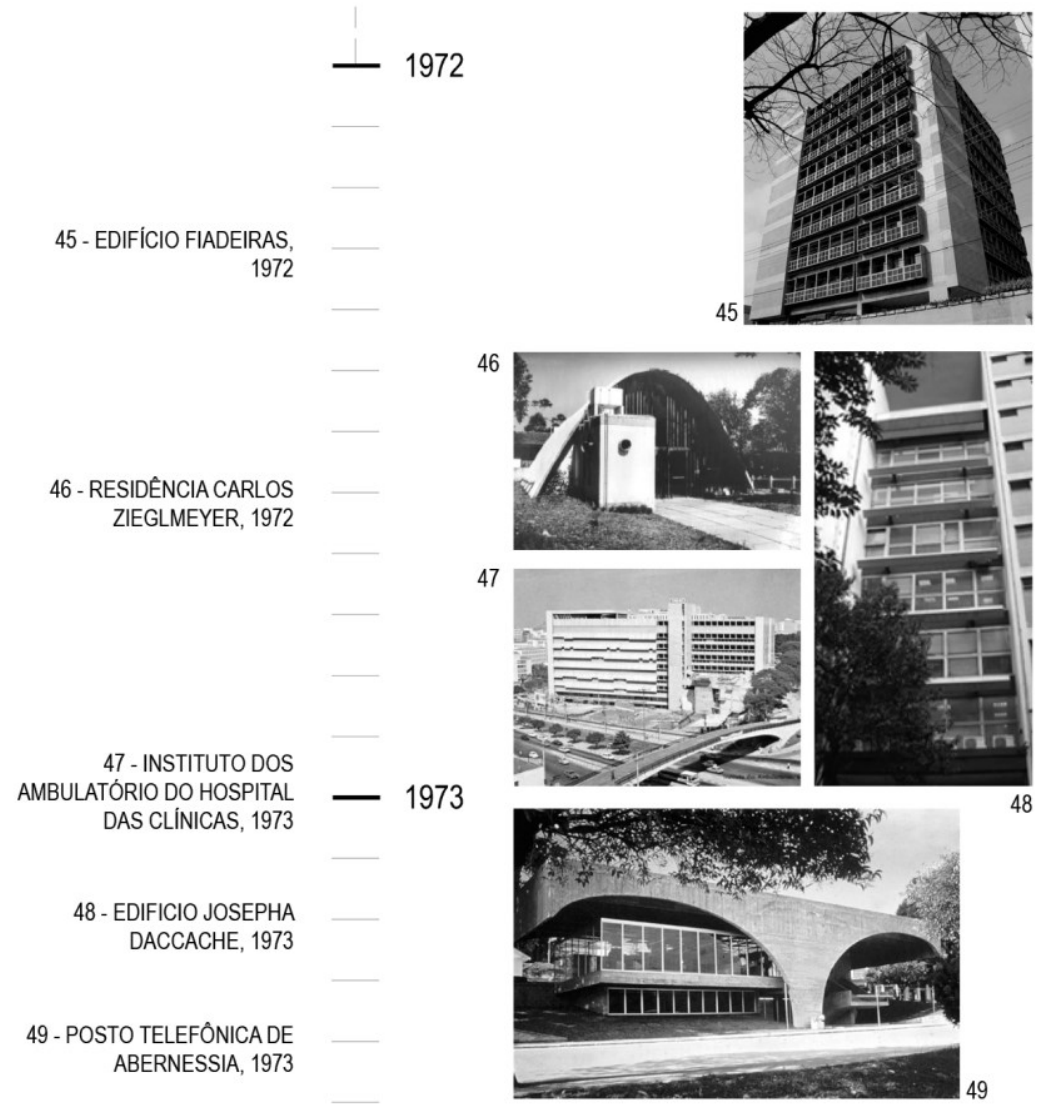

50 - RESIDÊNCIAANDRÉ MEHES, 1973

51 - EDIFICIO PAULISTAI, 1973

52 - CENTRO CULTURAL E TEATRO MUNICIPAL DE SANTOS, 1973

53 - EDIFICIO TEIXEIRADA SILVA, 1974

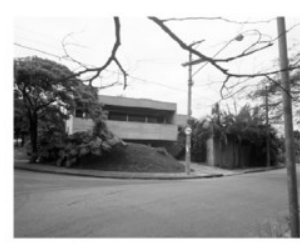

50

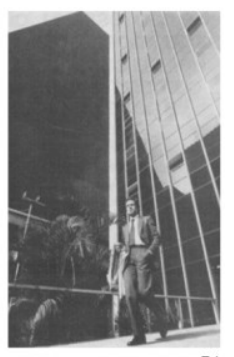

51

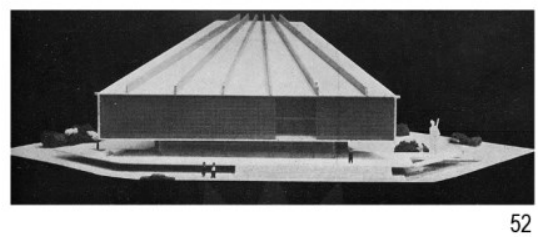

- EDIFICIO SEDE DO EEPARTAMENTO NACIONAL DE ESTRADAS E RODAGEM DNER - DNIT, 1974
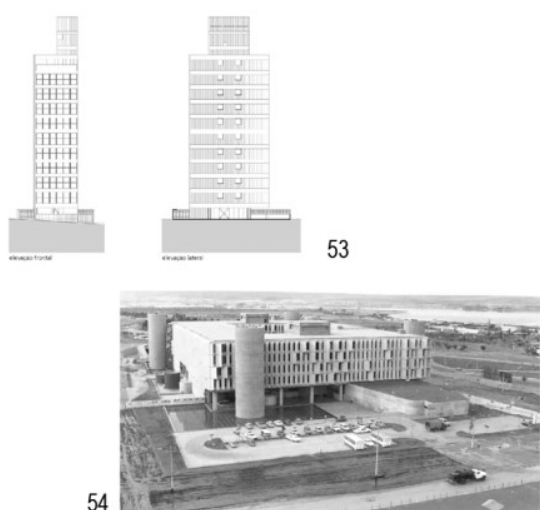

FIG. 30. Produção dos professores da FAUS. 

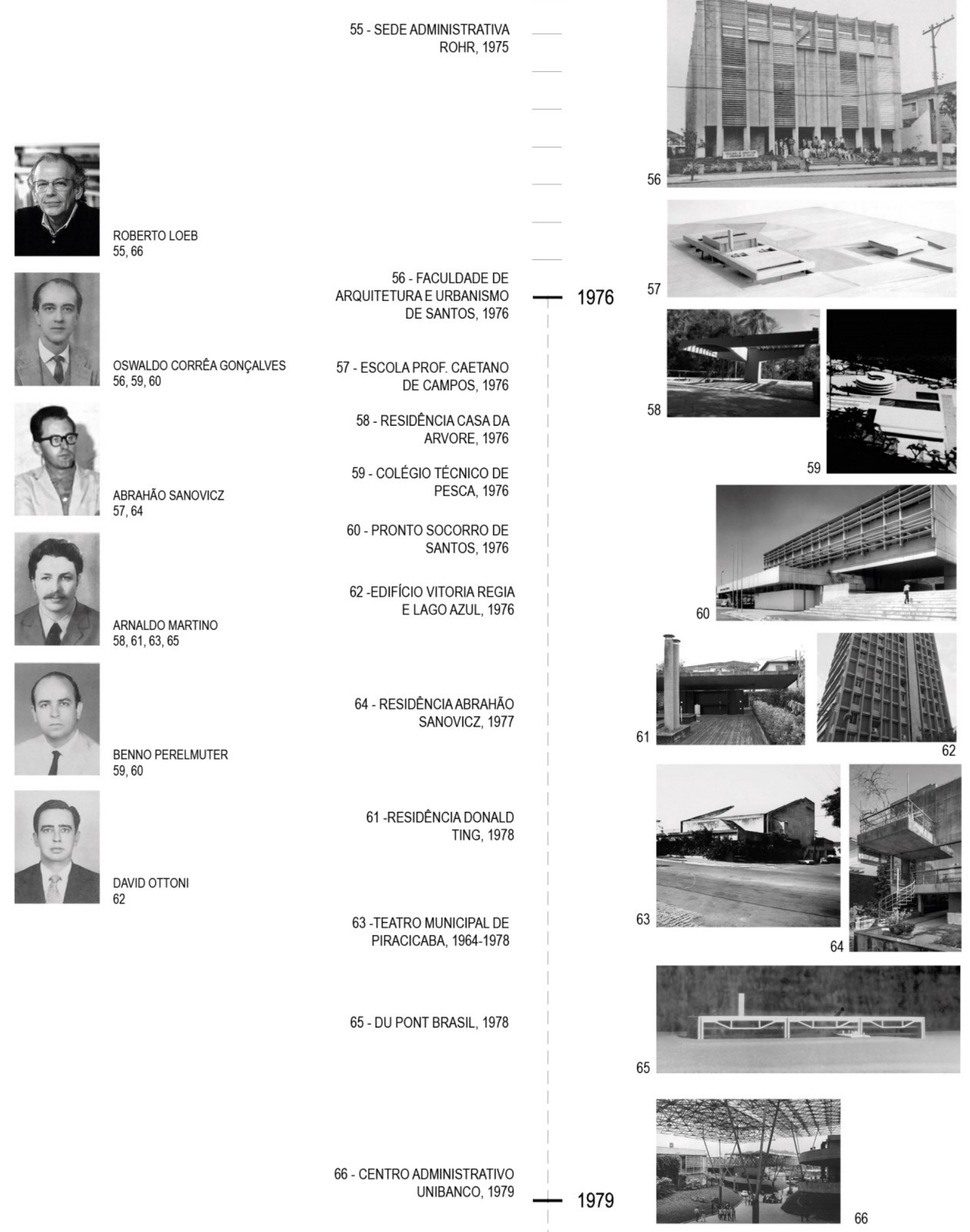

FIG. 31. Produção dos professores da FAUS. 


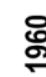

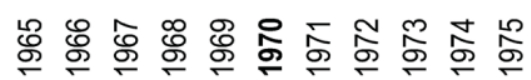

蝠
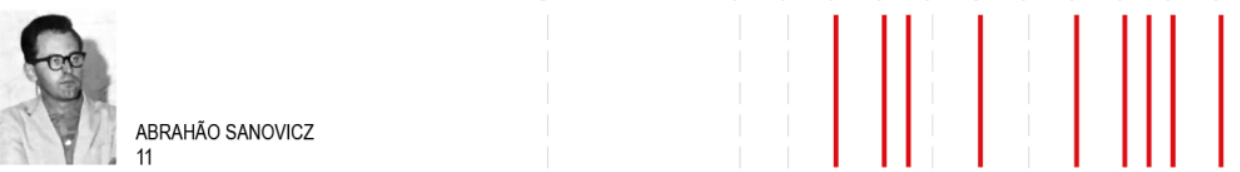

$\mid$
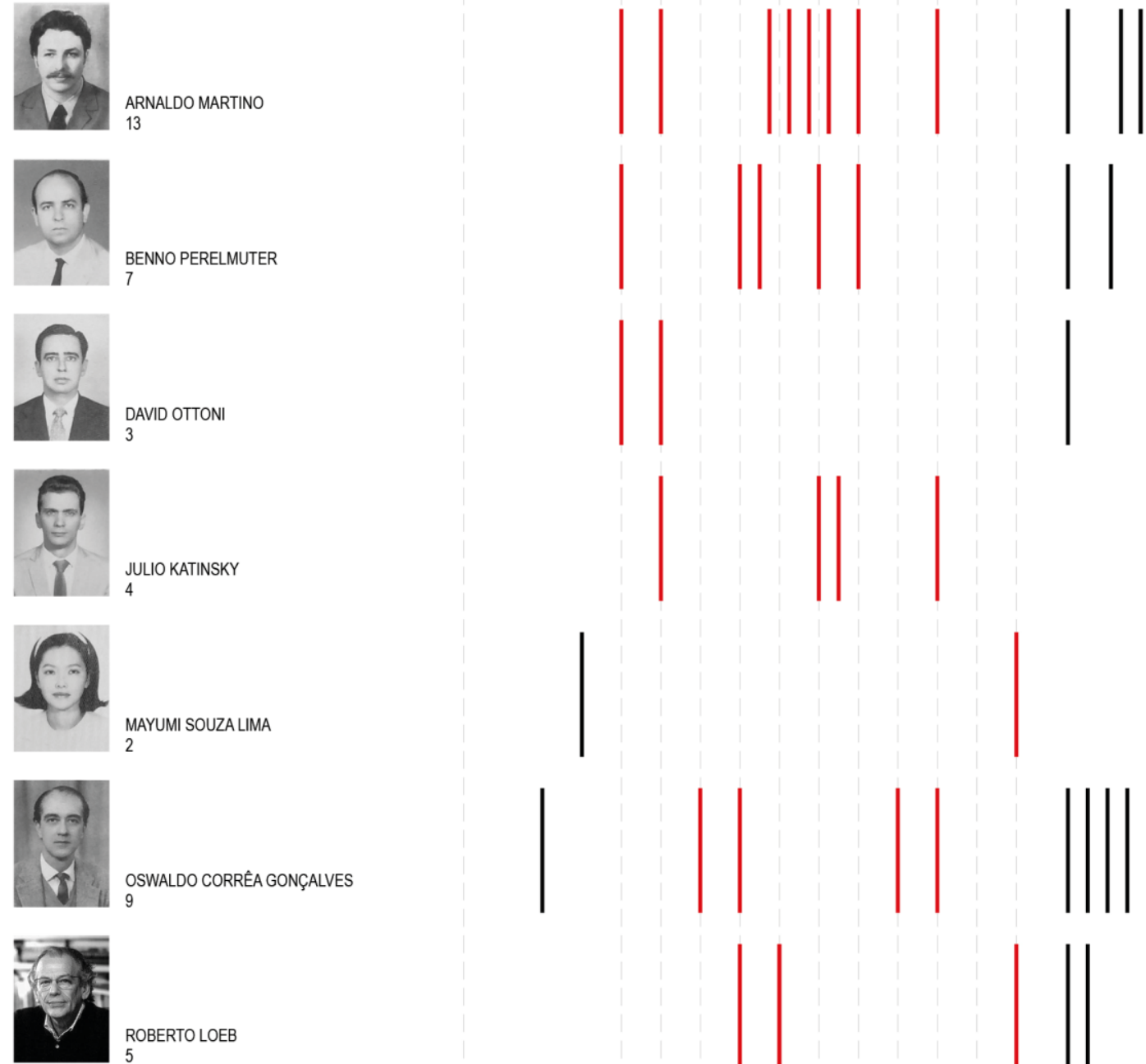

ROBERTO LOEB
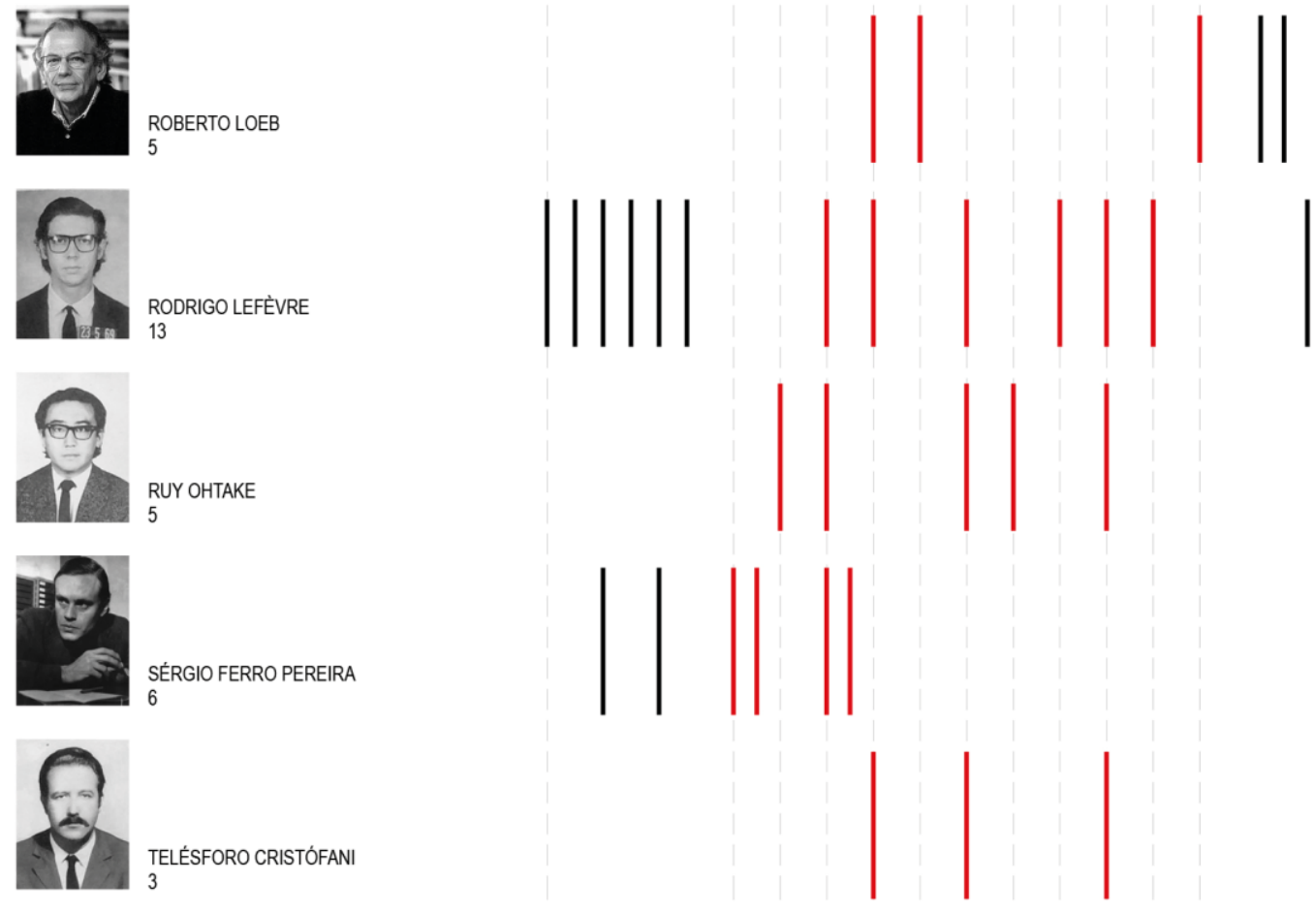

FIG. 32. Produção individual dos professores da FAUS no recorte de tempo proposto. 
Do ponto de vista político-administrativo, a FAUS foi dirigida por nove diretores e seis coordenadores de curso. Oswaldo Corrêa Gonçalves foi o que mais tempo permaneceu no cargo, um total de dezenove anos, alternando o comando com seus colegas, principalmente quando foi necessário, por sua reconhecida habilidade política, em resolver situações de crise, como as de 1972 e 1982. Posteriormente, em 1994, Oswaldo novamente assume a direção da FAUS, porém, com a saúde muito debilitada, acaba dependendo muito do seu vice-diretor, o professor Augusto Muniz Campos, que assumiu grande parte de seu trabalho.

Em contraposição à longevidade de Oswaldo Corrêa Gonçalves na direção da escola, verificamos que alguns diretores tiveram uma passagem muito rápida pelo comando, e isso pode ser explicado de algumas formas, mas a principal e mais recorrente é a questão política, relacionada diretamente com a forma de ingresso do candidato no cargo. No quadro abaixo é possível verificar que os diretores com rápida passagem são Noêmio Xavier da Silveira Filho e David Gelehrter Lopes. Ambos foram indicados pela reitoria e ambos enfrentaram resistência do colegiado de professores e corpo discente, e acabaram se tornando pivôs das crises de 1982 e 2000, respectivamente, assunto que será abordado adiante.

\section{DIRETORES DA FAUS}

\begin{tabular}{|c|c|c|c|}
\hline PERÍODO & DIRETOR & INGRESSO & FORMAÇÃO \\
\hline $1970-1971$ & ANÍBAL MARTINS CLEMENTE & NOMEADO PELO DIRETOR GERAL DA SVSL & POLI-USP \\
\hline $1972-1980$ & OSWALDO CORRÊA GONÇALVES & NOMEADO PELO DIRETOR GERAL DA SVSL & POLI-USP \\
\hline $1980-1981$ & JON MAITREJEAN & NOMEADO PELO DIRETOR GERAL DA SVSL & FAU-USP \\
\hline $1982-1982$ & NOÊMIO XAVIER DA SILVEIRA FILHO & NOMEADO PELO DIRETOR GERAL DA SVSL & FAU-MACKENZIE \\
\hline $1982-1985$ & OSWALDO CORRÊA GONÇALVES & NOMEADO PELO DIRETOR GERAL DA SVSL & POLI-USP \\
\hline $1986-1989$ & FABIO EDUARDO SERRANO & ELEITO PELO COLEGIADO DE PROFESSORES & FAU-USP \\
\hline $1990-1999$ & OSWALDO CORRÊA GONÇALVES $\left({ }^{*}\right)$ & ELEITO PELO COLEGIADO DE PROFESSORES & POLI-USP \\
\hline $2000-2000$ & DAVID GELEHRTER LOPES & NOMEADO PELO REITOR DA UNISANTOS & FAU-USP \\
\hline $2000-2001$ & JÚLIO CAMARGO ARTIGAS & ELEITO PELO COLEGIADO DE PROFESSORES & FAU-USP \\
\hline $2002-2005$ & CLAUDIO QUERIDO ABDALA & NOMEADO PELO REITOR DA UNISANTOS & FAU-MACKENZIE \\
\hline $2006-2009$ & ROBERTO HAGE CHAIN & ELEITO PELO COLEGIADO DE PROFESSORES & FAU-UBC \\
\hline $2010-2013$ & LEILA REGINA DIÊGOLI & ELEITA PELO COLEGIADO DE PROFESSORES & FAU-UBC \\
\hline $2014-2015$ & NELSON TREZZA & ELEITO PELO COLEGIADO DE PROFESSORES & FAU-USP \\
\hline $2016-2016$ & CLÉBER FERRÃO CORRÊA $(* *)$ & MOTIVO REGIMENTAL & ENG-UNESP \\
\hline $2016-2017$ & ANA ELENA SALVI & ELEITA PELO COLEGIADO DE PROFESSORES & FAU-USP \\
\hline 2018 - & FERNANDA BRITTO NEVES & NOMEADA PELO REITOR DA UNISANTOS & FAUS \\
\hline
\end{tabular}

TAB. 05. $\left(^{*}\right)$ O professor Augusto Campos Muniz, vice-diretor, ficou à frente da direção por grande parte do período devido a problemas de saúde de Oswaldo Corrêa Gonçalves. $\left(^{* *}\right)$ O professor Cleber Ferrão assumiu interinamente a coordenação da FAUS por curto período, durante o recesso de janeiro a fevereiro de 2016, e, por já ocupar a direção do Centro de Ciências Exatas, Arquitetura e Engenharia, permaneceu no cargo para organizar a eleição que colocou a professora Ana Elena Salvi na coordenação.

Nos primeiros anos de funcionamento, os diretores eram indicados pela direção geral da mantenedora das Faculdades Católicas de Santos, a Sociedade Visconde de São Leopoldo (SVSL). Posteriormente, por reivindicações do corpo docente e discente, foi implantado um sistema de eleição por lista sêxtupla, lista esta que era votada pelo colegiado de professores e por uma fração 
do conjunto de alunos. Seis nomes eram indicados e um deles escolhido pelo reitor. Esse sistema foi alterado com a criação da Universidade Católica de Santos (UNISANTOS) em 1986 e, a partir do novo plano institucional, a lista sêxtupla passou a ser tríplice. No entanto, mesmo com os princípios democráticos teoricamente consolidados, alguns dos diretores da FAUS foram nomeados diretamente pela reitoria da universidade, sem consultar o colegiado de professores e as representações estudantis.

O quadro acima demonstra que, dos quinze nomes, independentemente do tempo de permanência no cargo, dez diretores eram oriundos da FAU-USP e da POLI-USP, ou seja, $66 \%$ do total. Do ponto de vista cronológico, é possível verificar que a permanência de arquitetos oriundos da Universidade de São Paulo no comando da FAUS foi de 34 anos, ou seja, $72 \%$ do período de 47 anos de funcionamento da escola. Vale observar que os doze anos iniciais de influência política da USP foram interrompidos por apenas alguns meses, na curta gestão do professor Noêmio Xavier, formado na FAU-Mackenzie. Os 32 anos consecutivos de hegemonia ideológica, política e pedagógica da USP foram interrompidos somente em 2002 por outro arquiteto formado na FAU-Mackenzie. Nomeado pela reitoria no mesmo ano em que, devido a alterações na hierarquia da universidade, o cargo de diretor passou a ser de coordenador. Após 48 anos de sua fundação, pela primeira vez, uma arquiteta formada na FAUS assumiu a coordenação da escola.
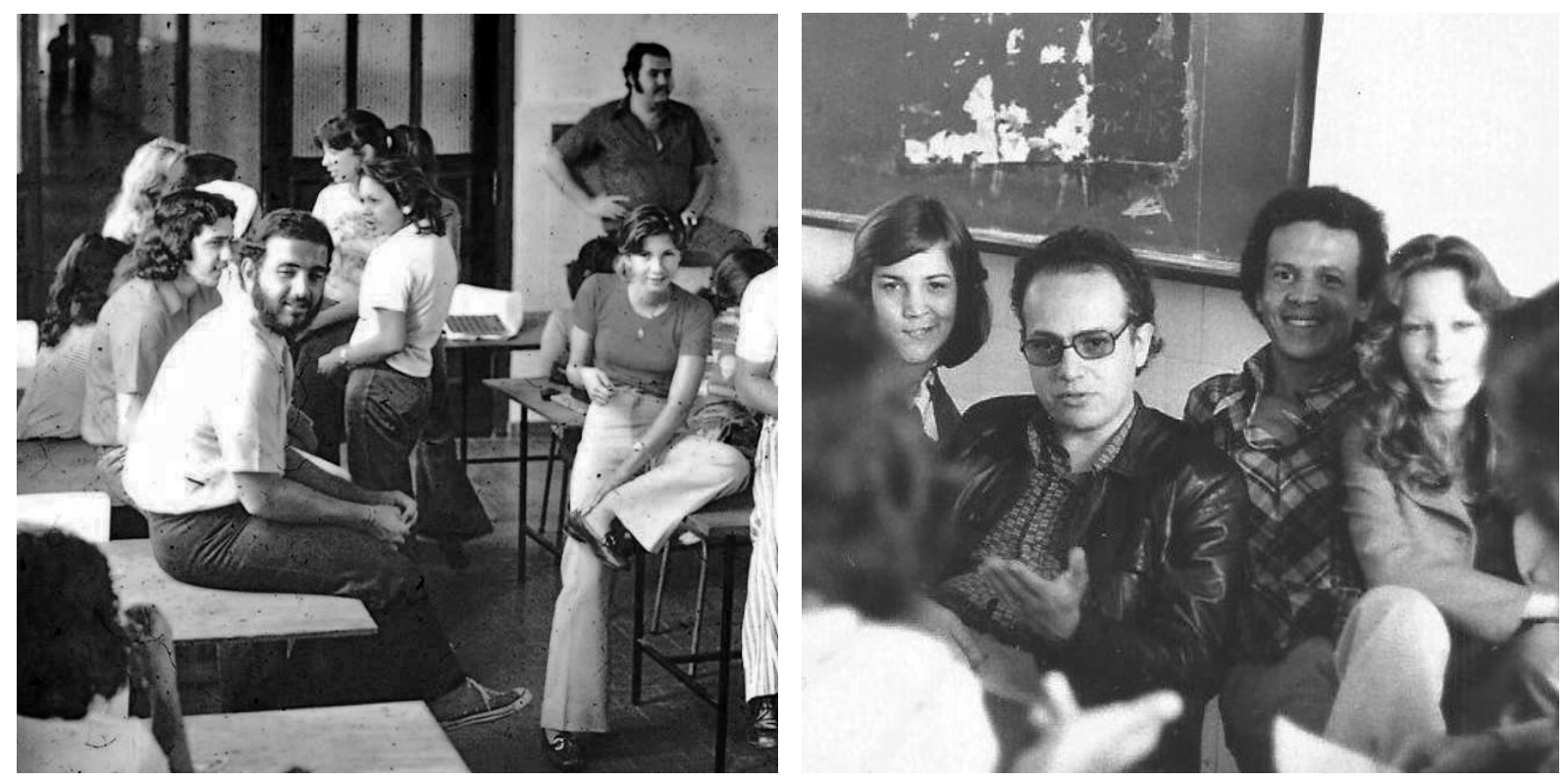

FIG. 33. FAUS 1973. À esquerda, os estudantes Hoover Frade, Reynaldo Amiky, Anne Buchert, Tibor Hari. À direita, aula do professor Lucio Gomes Machado com alunos, na época a FAUS estava instalada no Colégio Santista. 


\section{Projeto como instrumento de sustentação política}

Inevitavelmente, o caráter heterogêneo das alianças firmadas por Oswaldo Corrêa Gonçalves durante o processo de implantação e estruturação da FAUS gerava uma série de conflitos de natureza política, ideológica e pedagógica nos primeiros anos de atividade da escola, mas esses problemas eram superados à medida que o curso recebia novas turmas e novos professores. Apesar de a escola conquistar espaço junto à SVSL e importância na cidade e região, a conturbada cena política dos anos 1970 tornava muito tênue a linha de paz entre esses agentes e, nesse sentido, os conflitos na FAUS ganharam maior expressão.

Nos primeiros meses de funcionamento da FAUS, os professores Sérgio Ferro, Rodrigo Lefèvre, Sérgio Souza Lima e Mayumi Watanabe, juntamente com seus assistentes Orpheu Zamboni, Ronaldo Duschenes e Roberto Loeb, encontraram um fértil campo de experimentação e colocaram em prática algumas ideias que haviam sido derrotadas no Fórum de 1968 na FAU-USP. Queriam que os alunos percebessem as diferenças sociais existentes no país a partir do engajamento do arquiteto nos processos produtivos da arquitetura. Para tanto, propuseram aos alunos da primeira turma trabalhos cuja temática tinha como objeto de estudo uma favela da região, abordavam questões sobre a participação do arquiteto junto às classes menos abastadas da sociedade, propondo análises socioeconômicas, entrevistas e técnicas de autoconstrução. O que Mayumi definiu como "um banho de realidade", é mais bem explicado por Sérgio Ferro:

\footnotetext{
Nossa atuação em Santos foi bastante inovadora. Basicamente aplicamos as propostas que haviam sido derrotadas no Fórum da FAUUSP em 1968. Propúnhamos um ensino ancorado em questões atuais de uma arquitetura socialmente engajada. Tomamos, por exemplo, uma favela próxima como objeto de estudo de todas as matérias do primeiro ano. Sérgio e Mayumi eram professores de estrutura, e todos os conceitos básicos dessa matéria surgiam e eram desenvolvidos a partir de uma análise socioeconômica da favela, de enquetes sociológicas precisas, de suas condições de produção e da forma resultante etc. Enfim, todas as matérias tomavam como suporte uma realidade presente, e construíam seus conceitos a partir dela, inclusive, evidentemente, o projeto. Infelizmente, a experiência durou apenas um ano - com a prisão de boa parte dos professores (Sérgio, Mayumi, Rodrigo e eu) os outros tiveram que se afastar ou pôr as barbas de molho. ${ }^{42}$
}

Essa foi a primeira tentativa de integração departamental da FAUS, no primeiro semestre de 1970, fundindo as disciplinas de História e Tecnologia em prol de uma atividade única de pesquisa, envolvendo professores e estudantes. A importância dessa experiência foi lembrada pelo professor Francisco de Oliveira em uma conferência sobre políticas habitacionais, na FAU-USP, em 2004. Na

\footnotetext{
42 Depoimento de Sérgio Ferro, enviado por e-mail no dia 1 de abril de 2009 a Cassia Schroeder in BUITONI, Cássia Schroeder. Mayumi Watanabe Souza Lima: a construção do espaço para a educação. Op. Cit. p. 29.
} 
ocasião, Chico de Oliveira remeteu ao grupo de Sérgio Ferro a importante contribuição para a elaboração do seu livro Crítica à razão dualista:

\begin{abstract}
Esse contato surgiu ainda quando estávamos numa fase missionária: começamos - um grupo da Faculdade de Arquitetura e Urbanismo (FAU-USP) e mais alguns sociólogos - a fundar escolas de arquitetura e urbanismo por todo o estado de São Paulo. Santos foi objeto dessa investida. Havia um grupo muito interessante, com Sérgio Ferro, Rodrigo Lefèvre, Sérgio e Mayumi Souza Lima e dois sociólogos intrometidos como eu e Gabriel Bolaffi, que logo depois saiu, e Danielle Ardaillon ficou como minha assistente. Na ocasião os arquitetos haviam realizado uma pesquisa em Cubatão e Santos sobre habitação popular, a eterna dor de cotovelo desse grupo. Uma pesquisa bem feita; não sei se tinha representatividade estatística, mas isso não era muito importante. $O$ fato é que eles me deram os resultados tabulados para ler e comentar. Aí caiu a ficha: a maior parte das habitações era própria. No quesito casa própria, alugada ou cedida, "casa própria" era a enorme maioria. Pensei: "Esse treco não bate, alguma coisa está errada. Isso não é um país socialista, então deve ter alguma coisa errada". ${ }^{43}$
\end{abstract}

A precisão e assertividade desse exercício integrado despertou o interesse de boa parte dos estudantes que, imbuídos da ideologia do grupo de história e tecnologia, perceberam que poderiam contribuir não apenas com a participação nos exercícios didáticos, mas também com a estruturação pedagógica do novo curso, "um ensino ativo e participante, em que o professor é apenas mais um membro de uma equipe de pesquisa". ${ }^{44}$ Nesse sentido, os alunos passaram a pressionar a direção para que os departamentos fossem integrados, ou seja, agregar nesse modelo o Departamento de Projeto. Em maio de 1970, durante a primeira plenária da FAUS, a professora Mayumi Watanabe havia sugerido que fossem feitas reuniões interdepartamentais com o objetivo de integração "adequada e total", pois o calendário de reuniões do Departamento de Projeto estava organizado de maneira distinta do calendário dos Departamentos de História e Tecnologia. Na segunda plenária, no mês de julho de 1970, foram criadas comissões dentro dos três departamentos, compostas por professores e alunos, que tinham como tarefa analisar, durante as férias, as falhas ocorridas no primeiro semestre e suas possíveis soluções. As comissões deveriam também propor instrumentos didáticos e estratégias pedagógicas para a melhor integração possível. As reuniões deveriam ocorrer às quintas-feiras na sede do IAB/SP em São Paulo, nos dias 23 e 30 de julho e nos dias 06 e 13 de agosto. $^{45}$

Entretanto, o segundo semestre de 1970 foi marcado por dificuldades financeiras e políticas, e a terceira plenária só foi realizada em 21 de dezembro de 1970, quando foram recebidos os relatórios das comissões dos Departamentos de Projeto e Tecnologia. Os relatórios não foram debatidos, a preocupação central foi a continuidade das atividades da escola no próximo ano, com a indicação de

\footnotetext{
${ }^{43}$ Conferência apresentada no seminário de pesquisa "Políticas Habitacionais, Produção de Moradia por Mutirão e Processos Autogestionários: Balanço Crítico de Experiências em São Paulo, Belo Horizonte e Fortaleza", realizado na FAU-USP em outubro de 2004. A organização do ciclo de debates coube à Usina - Centro de Trabalho para o Ambiente Habitado, ao Centro de Estudos dos Direitos da Cidadania (CENEDIC) e ao Núcleo de Apoio à Pesquisa, Produção e Linguagem do Ambiente Construído (NAP-PLAC). OLIVEIRA, Francisco. $O$ Vício da virtude: autoconstrução e acumulação capitalista no Brasil. Revista Novos Estudos. CEBRAP. São Paulo, no. 74, mar. 2006.

${ }^{44}$ Relatório do estudante e presidente do Diretório Acadêmico da FAUS, Décio Roberto Ambrósio. DIRETÓRIO ACADÊMICO LUCIO COSTA. Dossiê da Crise de 1972. Santos, 1972. p. 09.

45 UNIVERSIDADE CATÓLICA DE SANTOS. Registro de "atas plenárias". Santos, 1970. pp. 2-5.
} 
novos professores que deveriam ser aprovados pelo MEC. Na ata dessa plenária não existe nenhuma menção ao Departamento de História, pois em dezembro de 1970 o professor Sérgio Ferro e seus amigos Rodrigo Lefèvre e Sergio Souza Lima foram presos pelo regime militar, acusados de explodir uma bomba em frente à embaixada norte-americana. Eles permaneceram um ano no Presídio Tiradentes juntamente com os também professores da FAUS, os arquitetos Júlio Barone e Carlos Henrique Heck. ${ }^{46}$ Segundo o professor Orpheu Zamboni, com a prisão desses professores foi desmontado todo o processo de ensino imaginado e em implantação na FAUS.

Tecnologia, por exemplo: não tinha disciplina de cálculo, concreto, grandes estruturas, nada. A Tecnologia era entendida como um bloco do processo de projeto de arquitetura, ensinada no atelier, local de semear questões para a compreensão dos processos tecnológicos que envolvem a arquitetura, e no momento que o projeto precisasse gerar algum cálculo, chamaríamos o Mário Franco para ministrar um curso de concreto. Quando isso gerava outras questões, como por exemplo, um problema de conforto acústico, nós chamaríamos um especialista e ele viria aqui e faria esse curso. Segundo o conceito de Brasília, o departamento constrói essa estrutura [...] era um grupo único, inclusive a gente queria dar mais suporte para a área de projeto, mas nunca funcionou, não nos encontrávamos. Na minha opinião, esse é o papel da Tecnologia e da História, talvez isso venha mais de Brasília do que da FAU, no meu entender, como o Artigas também passou a entender com o resultado do Fórum de 1968, o ensino unificado. ${ }^{47}$

Por outro lado, o Departamento de Projeto da FAUS seguia a linha de Vilanova Artigas que, sem espaço na FAU-USP devido à cassação de Jon Maitrejean, Paulo Mendes da Rocha e do próprio Artigas, segundo o professor Julio Katinsky, a escola de Santos era uma oportunidade para novas experimentações.

O Abrahão Sanovicz era nascido em Santos, como o Oswaldo, meu cunhado também é santista, portanto, tínhamos uma relação com a cidade que não era exclusivamente turística e, quando ele nos convidou para fundar a faculdade, nós aceitamos, claro, por dois motivos: primeiro, para criar uma escola de arquitetura que pudesse servir de contraponto para a FAU-USP, que estava ocupada pelo grupo de oposição ao Artigas. O segundo motivo é que queríamos não só criar uma faculdade de arquitetura, mas também era uma oportunidade para fazermos experiências com a área de projeto que estava à deriva na FAU, pois o Artigas, o Jon Maitrejean e o Paulo Mendes da Rocha tinham sido caçados pelo regime [...] então resolvemos aproveitar para testar uma nova postura em relação à essa postura da FAU. ${ }^{48}$

Katinsky estava apoiado na tese de que a responsabilidade social do arquiteto se sustentava no conceito do projeto como um instrumento de emancipação política e ideológica. Esse princípio surgiu no início de 1967, da preocupação de Vilanova Artigas e Flávio Motta sobre o significado das palavras "desenho" e "projeto", e resultou no poderoso texto de Flávio Motta "Desenho e Emancipação", que atribuiu uma forte carga ideológica a esses termos, e posicionou o projeto como desejo, como demonstração de soberania, e o desenho como emancipação. ${ }^{49}$

\footnotetext{
${ }^{46}$ BUITONI, Cássia Schroeder. Op. cit. p. 29.

${ }^{47}$ ZAMBONI, ORPHEU. São Paulo, 06 jun. 2016. Entrevista a José Maria de Macedo Filho.

${ }^{48}$ KATINSKY, Julio Roberto. Desenho industrial e programação visual para escolas de arquitetura. Brasília: ABEA/ MEC, 1977.

${ }^{49}$ Ver o capítulo Afirmação de uma Hegemonia - Vilanova Artigas e a linha paulista. SEGAWA, Hugo. Arquiteturas no Brasil. 1900-1990. Op. cit. pp. 144-146.
} 
O problema do desenho tem muito a ver com a nossa emancipação política. Ele se confunde com o desígnio de forjarmos uma cultura humanística. Bem sabemos que a palavra "desenho" tem, originalmente, um compromisso com a palavra "desígnio". Ambas se identificavam. Na medida em que reestabelecemos, efetivamente, os vínculos entre as duas palavras, estaremos também recuperando a capacidade de influir no rumo do nosso viver. Assim, o desenho se aproximara da noção de "projeto" (pro-jet), de uma espécie de lançar-se para a frente, incessantemente, movido por uma "preocupação". Essa "pré-ocupação" compartilharia da consciência da necessidade. Num certo sentido, ela já assinala um encaminhamento no plano da liberdade. Desde que se considere a preocupação como resultante de dimensões históricas e sociais, ela transforma o projeto em "projeto social". Na medida em que uma sociedade realiza suas condições humanísticas de viver, então o desenho se manifesta mais preciso e dinâmico em seu significado. Vale dizer que através do desenho podemos identificar o projeto social. E com ele encontraremos a linguagem adequada para conduzir a emancipação humana. ${ }^{50}$

A metodologia de ensino participativo aplicada pelo Departamento de Tecnologia e História, baseada na pedagogia da autonomia de Paulo Freire, ${ }^{51}$ surtia efeito e mobilizava cada vez mais os estudantes nas questões críticas sobre a profissão e formação, ao passo que o Departamento de Projeto pouco inovava em termos de ensino e avaliação e relações professor-aluno. Após insistentes pedidos de revisão de reprovações promovidas pelas disciplinas de projeto, junto à direção da escola, no início de 1971, os estudantes enviaram um relatório analítico das atividades acadêmicas realizadas na FAUS, no período entre 1970 e 1971, para a Inspetora Federal de Ensino Dr $^{\text {a }}$. Ruth Wolff denunciando os procedimentos pedagógicos, metodológicos e avaliativo dos professores do Departamento de Projeto. Esse documento foi seguido de um ofício com o mesmo teor.

Após a visita da Inspetora Federal à FAUS, em reunião entre os professores Oswaldo Corrêa, Julio Katinsky, Abrahão Sanovicz, Ruy Ohtake, Renato Nunes e os estudantes reprovados, foram encaminhadas algumas propostas para solucionar o problema, sendo a mais razoável a abertura de classes especiais para os reprovados. Entretanto, sem obter sucesso na reversão das reprovações e na abertura das classes de recuperação, mesmo diante da Intervenção da Inspetoria Federal, foi enviado um novo relatório em 2 de julho de 1971, dessa vez para ao Ministro da Educação e Cultura, o Coronel Jarbas Passarinho, denunciando que o encaminhamento proposto pela $\mathrm{Dr}^{\mathrm{a}}$. Ruth Wolff não havia surtido efeito devido à falta de interesse da Direção em resolver a questão. ${ }^{52}$

A quarta reunião plenária da FAUS, realizada no dia 18 de setembro de 1971 no auditório da PRODESAN, tinha como pauta principal o balanço didático de tudo o que tinha sido feito na FAUS até aquela data e, posteriormente, a apresentação de proposições para o estabelecimento de instrumentos didáticos e diretrizes capazes de operacionalizar a integração dos departamentos e melhorar o ensino na FAUS. Foram apresentados os relatórios das comissões sobre as experiências

\footnotetext{
${ }^{50}$ MOTTA, Flávio L. Desenho e emancipação. Ensaio publicado originalmente no jornal Correio Braziliense, em 16 de dezembro de 1967. In SERAPIÃO, Fernando. Vilanova Artigas e a FAUUSP. Coleção Monolito no 27. São Paulo: Monolito, 2015. pp. 84-86.

${ }^{51}$ Educador e intelectual brasileiro, propunha a emancipação dos estudantes através das relações entre discentes e docentes baseadas nos diálogos políticos-pedagógicos a partir de premissas e virtudes éticas, de modo que ambos, professores e estudantes cumprissem seu papel de cidadãos na apropriação crítica do conhecimento e suas ramificações. FREIRE, Paulo. Pedagogia da autonomia: saberes necessários à prática educativa. 52 a edição. Rio de Janeiro/São Paulo: Paz e terra, 2015.

52 Documentos no 2, 3, 4 e 5. DIRETÓRIO ACADÊMICO LUCIO COSTA. Dossiê da Crise de 1972. Santos, 1972. pp. 15-24.
} 
de cada um dos departamentos. Seguindo-se extenso debate sobre as proposições que, dentre os diversos grupos, transitavam sobre questões muito similares, grosso modo, propunham discussões coletivas quinzenais, mensais e plenárias semestrais de verificação para revisões e novas proposições. Além disso pretendiam organizar comissões com arquitetos-professores, estudantes e profissionais de pedagogia com o objetivo de integração dos departamentos.

Nesse ponto, verifica-se um conflito de ordem conceitual, os grupos divergiam quanto à intepretação do termo "integração", alguns professores acreditavam ser possível que esta ocorresse a partir de temas comuns entre os departamentos, ao passo que outros professores defendiam a fusão de todos os departamentos num único órgão formado por membros do corpo docente e discente da escola. Essa hipótese não foi unânime. Integrantes do Departamento de Projeto, baseados no já mencionado Decreto Federal 477 que restringia a atuação dos estudantes nas universidades, não haviam chegado a "um acordo sobre o que significa a participação ativa e crítica dos alunos, o que para uns era participação ativa, para outros não era". ${ }^{53}$ Sobre esse ponto, o professor Francisco de Oliveira afirmou que as conclusões dos grupos de trabalho se resumiam a técnicas de grupos de jovens, pois pensavam que reunir pessoas em um mesmo grupo e fazê-los discutir, significava integrar.

\footnotetext{
Na verdade, isto é um consenso apenas aparente. Na prática, quando colocarmos as diversas pessoas, professores e alunos num mesmo grupo, as divergências entre teoria e prática vão aparecer no primeiro momento. Uma divergência fundamental existe neste ponto que foi tocado por dois dos presentes: $O$ que significa a participação do aluno? Parece-me que uma das conclusões que essa plenária poderia tirar, era a de que a participação do aluno significa deliberação, sem o que nós estaremos construindo grupos de jovens que não resistirão ao primeiro embate ante as divergências metodológicas. Esse é o fulcro da questão, o grande ausente dessas propostas. O que está sendo proposto aqui são apenas formas de relacionamento, sendo que o problema fundamental a ser abordado é o metodológico de ensino [...] entendido como técnica de aprender e não como técnica de apresentar resultados. ${ }^{54}$
}

As reivindicações estudantis, amparadas pelos Departamentos de História e Tecnologia que ainda contavam com os professores Francisco de Oliveira e com a professora Mayumi, conduziram, juntamente com o Departamento de Projeto, a elaboração das diretrizes das comissões de estudos para efetivar a desejada integração departamental, e a sugestão dos estudantes deveria seguir os critérios de programação integrada dos cursos, os processos de desenvolvimento dos mesmos, bem como os sistemas de avaliação. ${ }^{55}$

\footnotetext{
53 UNIVERSIDADE CATÓLICA DE SANTOS. Registro de "atas plenárias". Santos, 1970. p. 14.

${ }^{54}$ UNIVERSIDADE CATÓLICA DE SANTOS. Registro de "atas plenárias". Santos, 1971. p. 15.

${ }^{55}$ Documento no17. DIRETÓRIO ACADÊMICO LUCIO COSTA. Dossiê da Crise de 1972. Santos, 1972. p. 49.
} 


\begin{tabular}{|c|c|c|}
\hline \multicolumn{3}{|c|}{ QUADRO SUGERIDO PELOS ALUNOS PARA COMPOSIÇÃO DAS COMISSÕES DE INTEGRAÇÃO } \\
\hline GRUPO & PROFESSORES & ESTUDANTES \\
\hline GRUPO 1 & $\begin{array}{l}\text { ROBERTO LOEB (coordenador), DAVID OTTONI, BENNO PERELMUTTER, FRANCISCO } \\
\text { PETRACCO, JULIO KATINSKY, CONRADO HECK E FRANCISCO DE OLIVEIRA. }\end{array}$ & $\begin{array}{l}\text { NEWTON CORRALDI (expositor), CARMELA LEVY } \\
\text { (secretária), LÚCIO LEAL, LUCINO ALVES, AUGUSTO } \\
\text { SANTOS, EDUARDO SABBATINI E JORGE LODY. }\end{array}$ \\
\hline GRUPO 2 & $\begin{array}{l}\text { LUIZ CARLOS DAHER (coordenador), TELÉSFORO CRISTOFANI (SECRETÁRIO), PAULO } \\
\text { SOUZA E SILVA, ARNALDO MARTINO, RUY OHTAKE, RONALDO DUSCHENES E } \\
\text { FLÁVIO MINDLIN. }\end{array}$ & $\begin{array}{l}\text { LUIZ ACKEL (expositor), ELIANI PENTEADO, ANTÔNIO } \\
\text { RAGO, PAULO PARRI, JOSÉ ARDUIN E LEONEL FILHO }\end{array}$ \\
\hline GRUPO 3 & $\begin{array}{l}\text { RENATO NUNES (coordenador), GABRIEL BORBA (secretário), OSVALDO CORRÊA, } \\
\text { ABRAHÃO SANOVICZ, JOÃO WALTER TOSCANO, MAYUMI WATANABE E ORPHEU } \\
\text { ZAMBONI. }\end{array}$ & $\begin{array}{l}\text { AVELINO JÚNIOR (expositor), LENIMAR RIOS, } \\
\text { MARCAINO, PASCHOAL NETO, MARGARIDA } \\
\text { MINCHERIAN, NEIDE CUNHA E ENEIDA HECK. }\end{array}$ \\
\hline
\end{tabular}

TAB. 06. Quadro sugerido pelos alunos para composição das comissões de integração para apresentação dos relatórios e propostas na 5ạ plenária da FAUS.

Nesse sentido, durante a 5ạ plenária da FAUS, ocorrida no dia 02 de novembro de 1971, foi proposta a criação de um Grupo Assessor de Programação Interdepartamental (GAPI). ${ }^{56}$ Esse grupo deveria ser composto por três membros de cada Departamento e nove estudantes integrantes do Diretório Acadêmico, garantindo, dessa maneira, o caráter paritário nas decisões da escola. Após amplo debate, o coletivo da escola aprovou o imediato início de funcionamento do GAPI que, a partir de reuniões internas nos departamentos, deveria agendar reuniões em caráter de urgência, pois o objetivo era pôr em prática as novas propostas no início do próximo ano. Nessa mesma direção, o Professor Luiz Carlos Daher sugeriu que o GAPI elaborasse um plano de ação que viabilizasse a participação docente e discente sem que as atividades didáticas fossem prejudicadas; o professor Arnaldo Martino reforçou essa preocupação e alertou que qualquer outra atividade extracurricular deveria ser bem ponderada para que não configurasse mais uma semana de "inatividade".

Evidentemente, esse virtuoso processo de autoavaliação e ajustes pedagógicos, com a participação de alunos e professores, demandava tempo para pesquisas, elaboração de textos e propostas que alimentariam as próximas discussões dos grupos de estruturação. Os Departamentos de Tecnologia e História entendiam que esse era um profícuo momento de aprendizado e consideraram todo o processo como atividade acadêmica válida para o semestre; entretanto, mesmo com a participação efetiva dos professores do Departamento de Projeto nas reuniões de integração departamental, seus integrantes não desconsideraram o andamento das atividades didáticas de suas disciplinas e, ao final do semestre, cobraram as entregas dos projetos e trabalhos. A insuficiência de conteúdo e desenvolvimento dos produtos entregues resultaram em reprovações, surpreendendo os alunos.

A resposta discente veio na forma de um dossiê elaborado pelo Diretório Acadêmico Lucio Costa, ${ }^{57}$ enviado para o presidente da Sociedade Visconde de São Leopoldo, Dom David Picão, em 03 de maio

\footnotetext{
56 UNIVERSIDADE CATÓLICA DE SANTOS. Registro de "atas plenárias". Santos, 1971. pp. 18-40.

57 Oculto por cerca de quarenta anos, o "Livro Negro da FAUS" é um dossiê sobre os dois primeiros anos de funcionamento da escola que, sob a ótica dos estudantes, registra os debates ideológicos e políticos na estruturação do novo curso. Contém 107 páginas, numeradas, carimbadas e rubricadas pelo presidente do Diretório Acadêmico Décio Ambrozio. Citado como: DIRETÓRIO ACADÊMICO LUCIO COSTA. Dossiê da Crise de 1972. 107p. Santos, 1972.
} 
de 1972, constituindo uma compilação de documentos, atas das plenárias e das reuniões de departamento, além de correspondências entre a direção, corpo docente e diretório acadêmico. Tudo cuidadosamente organizado, criticado e sintetizado em sete quadros, comprovando a dissonância metodológica, pedagógica e institucional entre os Departamentos de Projeto, História e Tecnologia. O documento destacava, além da falta de entrosamento departamental, a falta de integração dentro do próprio Departamento de Projeto, que apresentava temas distintos e desconectados, descumprindo os acordos firmados nas reuniões departamentais, propondo exercícios isolados para os estudantes. A falta de clareza nos critérios de avaliação provocou, da mesma forma que no final do segundo semestre de 1970, uma série de reprovações nas diversas disciplinas de projeto, sem que os alunos pudessem entender os motivos de tal desastre.

\begin{abstract}
Antes, entendemos ter havido conflito de objetivos entre pessoas com visões totalmente contrária sobre o ensino universitário no Brasil. Após estas se desgastarem por inteiro, sob as vistas complacentes da direção da escola, assistimos hoje às manobras do radicalismo, repudiando frontalmente a estrutura da FAUS, no nosso entender, intocável. São palavras da direção da escola: "ou vocês se contentam com fragmentos de arquitetura ou terão que procurar outra escola". Ora, apenas a título de comentário, receber fragmentos de arquitetura ao longo de cinco anos e ao custo de $\mathrm{Cr} \$ 40.000,00$ (quarenta mil cruzeiros) ou mais, não é o melhor investimento que certamente alguém pode fazer. Por outro lado, o problema de integração que antes se apresentava a nível dos Departamentos, hoje se apresenta muito pior, a nível das disciplinas, isso devido à contratação indiscriminada de professores por parte da Diretoria, contrariando o próprio Regimento da FAUS, segundo o qual a unidade básica de ensino e pesquisa são os Departamentos e não as disciplinas isoladas e estanques. ${ }^{58}$
\end{abstract}

Em síntese, a divisão política-pedagógica do Fórum de 1968 na FAU-USP teve seus reflexos na FAUS, provocou a polarização do corpo docente e trouxe consigo a mobilização do corpo discente. De um lado, estavam Sérgio Ferro, Sergio Souza Lima e Rodrigo Lefèvre que, como visto, haviam sido presos e afastados da escola, traziam suas convicções ideológicas baseadas nas críticas das relações de produção e exploração dos operários no canteiro de obras. Além de serem membros da Ação Libertadora Nacional (ALN), de Carlos Marighella, acreditavam que "a saída no Brasil só pode ser a luta armada, o caminho revolucionário, a preparação da insurreição armada do povo, com todas as consequências e implicações que daí resultam". ${ }^{59}$

Pode-se dizer que os relatórios produzidos pelos estudantes e enviados à Inspetoria Federal de Ensino e ao Ministro do MEC, representado pelo coronel Jarbas Passarinho, de certo modo, despertaram a atenção destes órgãos para o que ocorria na FAUS. Apesar do caráter emancipatório e político da pedagogia participativa se mostrar mais atrativo para os estudantes, no Departamento de Tecnologia a situação se degradava. Mayumi Watanabe e seus assistentes, Ronaldo Duschenes e

\footnotetext{
${ }^{58}$ Convertendo para valores atuais, a partir da cotação do dólar americano em maio de 1972, que valia CR\$ 5,91, portanto U\$ 6.768,18, hoje, agosto de 2019, com o dólar a $\mathrm{R} \$ 3,76$, o custo do curso da FAUS giraria em torno de $\mathrm{R} \$ 25.448,39$, equivalente a dois semestres atualmente. Relatório de Décio Ambrozio. DIRETÓRIO ACADÊMICO LUCIO COSTA. Dossiê da Crise de 1972. Santos, 1972. pp. 1-12. (sic).

${ }^{59}$ Trechos da carta de dezembro de 1966, reproduzidos no livro Foto biografia de Carlos Marighella. In ARANTES, Pedro Fiori. Arquitetura Nova: Sérgio Ferro, Flávio Império e Rodrigo Lefèvre, de Artigas aos mutirões. 2ªed. São Paulo: Editora 34, 2011. p. 92.
} 
Orpheu Zamboni, sofriam pressões políticas externas e se encontravam, no âmbito da faculdade, isolados diante da grande resistência ideológica e pedagógica para a integração departamental garantidora de um ensino não instrumental, e também acabaram pedindo demissão em carta enviada ao diretor em 22 de agosto de $1971 .{ }^{60}$

No final de 1970, esse pessoal todo foi preso, o Sergio, a Mayumi, o Ferro e o Rodrigo, portanto acabaram com o Departamento, sobrando a garotada que, durante esse período, manteve as disciplinas. A Mayumi foi solta e voltou. Mas, em 1971, começou uma perseguição política, recebi ameaças veladas que chegavam por caminhos escusos, alguns amigos que trabalhavam em Santos mandaram o seguinte recado para meu pai: "Manda o menino sair de lá que ele está na mira, logo os comunas da faculdade vão ser presos". Acabamos saindo em bloco, todo o Departamento de Tecnologia e a maior parte do Departamento de História. ${ }^{61}$

\begin{tabular}{|c|c|c|c|c|c|c|c|}
\hline & \multicolumn{6}{|c|}{ II - DA EXPOSISTRO CROMOOOOGICA DOS FATOS } & \multirow[b]{2}{*}{ aruvios } \\
\hline PERIODO & FATO & CONS. DEPARTAMEN- & DIRETORIA & DEP. PROJETO & DEP. PECNOIOGIA & DEP. HISTORIA & \\
\hline \multirow[t]{3}{*}{$\begin{array}{l}\text { Ie semestre de } \\
1970\end{array}$} & Vestibular & - & - & $\operatorname{nos} \frac{\text { moldes da }}{P_{A V}}$ & \multicolumn{2}{|c|}{ 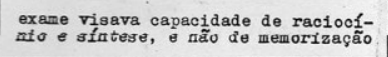 } & - \\
\hline & $\underset{\text { PAUS }}{\text { Objetivos da }}$ & \multicolumn{5}{|c|}{ A escola se propunha a inovar o ensiro ea Arquitetura e do Urbanismo } & $\begin{array}{l}\text { entugiagmados com } \\
\text { e. orientag âo nova } \\
\text { da PAUS }\end{array}$ \\
\hline & $\begin{array}{l}\text { Desenyolvimen- } \\
\text { to didático }\end{array}$ & - & - & 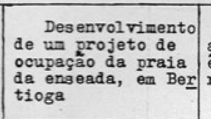 & \begin{tabular}{|l|} 
Písica aplicada \\
através de experri- \\
ênoila com extrutu- \\
ra em madeira
\end{tabular} & \begin{tabular}{|c|} 
Pesquiga sobre \\
habitacâa popauar ar \\
na baixada gantig \\
ta
\end{tabular} & - \\
\hline \multirow{3}{*}{22 semestre de } & $\begin{array}{l}\text { Não realiza- } \\
\text { çấ do Veati- } \\
\text { bular }\end{array}$ & $\begin{array}{l}\text { Omisio em face } \\
\text { do inciso 10, do } \\
\text { art. IX do R.I. }\end{array}$ & $\begin{array}{l}\text { Omissa na esco- } \\
\text { hha do prédio }\end{array}$ & - & - & - & - \\
\hline & $\begin{array}{l}\text { Plenária esco- } \\
\text { lhe tema único, } \\
\text { em vista da des- } \\
\text { conexão do semea } \\
\text { tre anterior }\end{array}$ & - & - & \multicolumn{3}{|c|}{ 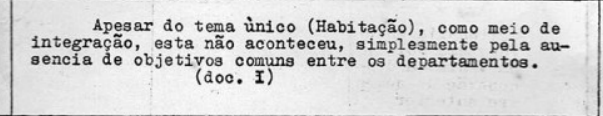 } & - \\
\hline & $\begin{array}{l}\text { Diferença de } \\
\text { oritérios de ava } \\
\text { liaģão dos trabâa } \\
\text { lhos }\end{array}$ & omisso & - & $\begin{array}{l}\text { Reprovacõoes } \\
\text { parciais }\end{array}$ & $\begin{array}{l}\text { aprovaçöes to- } \\
\text { tais }\end{array}$ & $\begin{array}{l}\text { Aprovaçöes to- } \\
\text { tais }\end{array}$ & $\begin{array}{l}\text { Rão concoraam } \\
\text { oom oritíríos de } \\
\text { aval ią̧ẫo. }\end{array}$ \\
\hline \multirow{3}{*}{$\begin{array}{l}12 \\
\text { Semestre de } \\
1971\end{array}$} & Ves tibular & - & - & \multicolumn{3}{|c|}{ Nos mesmos moldes do ano anterior. } & - \\
\hline & $\begin{array}{l}\text { Formagão de } \\
\text { cursos para os } \\
\text { reprovados }\end{array}$ & $\begin{array}{l}\text { Discussoẽs es- } \\
\text { téreis. }\end{array}$ & $\begin{array}{l}\text { Promessas que en } \\
\text { volviam o Departa- } \\
\text { mento de Projeto. }\end{array}$ & $\begin{array}{l}\text { Promessas que en } \\
\text { volviam a Direto } \\
\text { ri玉. }\end{array}$ & \multicolumn{2}{|c|}{ Solidários com os alunos. } & 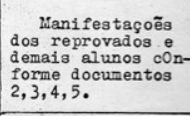 \\
\hline & $\begin{array}{l}\text { Desenvolvimen- } \\
\text { to didátioo }\end{array}$ & - & - & 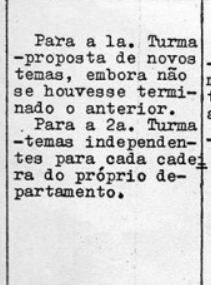 & 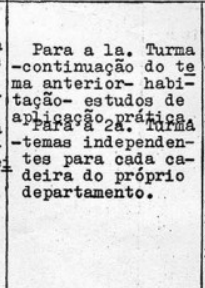 & 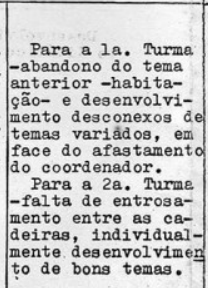 & 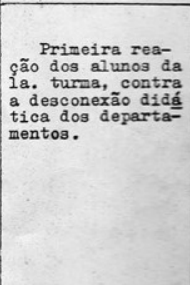 \\
\hline
\end{tabular}

FIG. 34. Resumo dos fatos ocorridos entre 1970 e 1971. Folha 2/8 do Livro Negro da FAUS.

Do outro lado, os professores do Departamento de Projeto, alinhados com a visão de Artigas do desenho como emancipação que, mesmo sob o regime autoritário, poderia seguir construindo uma sociedade mais justa, necessariamente dependiam da demonstração, da materialização do desejo de cada estudante na forma de desenho e projeto que refletisse essa posição. Esse grupo também estava insatisfeito com os rumos e resultados dos trabalhos produzidos na escola, além de

\footnotetext{
${ }^{60}$ Documento no 6. DIRETÓRIO ACADÊMICO LUCIO COSTA. Dossiê da Crise de 1972. Santos, 1972. pp. 25-26.
}

${ }^{61}$ ZAMBONI, Orpheu. São Paulo, 06 jun. 2016. Entrevista a José Maria de Macedo Filho. 
desgastado devido aos embates ideológicos contra os alunos "influenciados" por docentes dos Departamentos de História e Tecnologia. Esse grupo de alunos apresentou um documento ${ }^{62}$ que questionava as metodologias didáticas e de avaliação dos professores do Departamento de Projeto.

Essa apreciação que fizeram é de uma maneira fútil; para se ter uma ideia, a Cadeira de Desenho da Mensagem atribuiu nota seis para os trabalhos que tinham em mãos e não atribuíram nota para os que não tinham. $O$ que não é muito diferente das outras cadeiras desse departamento. Não se diferencia pelo seguinte: eles simplesmente deram números diferentes como se fossem notas para os alunos, não levando a nada, quando é fundamental o critério que a faculdade impõe em termos de avalição para com os trabalhos, por nós alunos, desenvolvidos. ${ }^{63}$

Vale destacar que, junto ao documento dos estudantes, foi enviado o pedido de retorno às atividades docentes na FAUS dos professores Mayumi Watanabe e Ronaldo Duschenes, assinados na mesma data da carta dos estudantes, ambos justificando que "dadas as contingências extraordinárias de acefalia em que se encontra o Departamento de Tecnologia, vimos por meio desta comunicar-Ihe estarmos à vossa disposição para reassumir nossos trabalhos." ${ }^{64}$

Em 02 de dezembro de 1970, os professores Rodrigo Brotero Lefèvre e Sérgio Ferro são presos pela OBAN. Uma comissão composta por representantes do IAB, da FAUS (da qual os dois professores são também fundadores) e da FAU-USP dirige-se à OBAN para informar-se sobre as prisões. Apesar dos evidentes sinais de tortura praticada nos dois professores, a comissão retira-se sem nada comentar, nem então, nem depois. Em 02 de dezembro de 1971, os professores Rodrigo Brotero Lefèvre e Sérgio Ferro são liberados sob condições. Apesar de ainda serem oficialmente professores da FAU-USP e da FAUS, não são inscritos no programa de ensino do ano de 1972. Não são nem "aposentados", nem encarregados de nenhuma atividade pela FAU-USP. 65

Por sua vez, o grupo de professores de projeto respondeu com um documento esclarecendo todos os pontos questionados pelos estudantes e, ao mesmo tempo, solicitando apuração dos fatos. Mesmo sendo encaminhadas e apuradas pelo diretor, julgaram insuficientes as ações reparadoras da instituição e, dessa forma, apresentaram um pedido de demissão coletiva, pressionando ainda mais a

\footnotetext{
${ }^{62}$ Documento de 23 de fevereiro de 1972. O Diretório Acadêmico Lucio Costa apresentava reclamações quanto aos critérios de avaliação utilizados pelo departamento de projeto e acusaram uma série de professores de não ter comprometimento com a FAUS. Demonstravam indignação por, ao retornarem das férias, encontrarem os trabalhos sem avaliação na secretaria da escola. Documento 23 . DIRETÓRIO ACADÊMICO LUCIO COSTA. Dossiê da Crise de 1972. Santos, 1972. pp. 64-67.

63 Ibid. pp. 65.

${ }^{64}$ Ibid. pp. 68-69.

${ }^{65}$ Depoimento de Sérgio Ferro à Comissão da Verdade da USP, seguido de uma declaração realizada por ocasião do lançamento do seu livro Artes plásticas e trabalho livre - de Dürer a Velázquez no Centro Universitário Maria Antônia. COMISSÃO DA VERDADE DA UNIVERSIDADE DE SÃO PAULO. Depoimento de Sérgio Ferro. Disponível em: <http://sites.usp.br/comissaodaverdade/informacoesdisponiveis/depoimentos/faculdade-de-arquitetura-e-urbanismo/professores/>. Acesso em: 04 jul. 2016. (grifo nosso). O mesmo ocorreu no âmbito da FAUS, mas com o agravante do envio de um ofício (FAUS-004/72), por parte do seu diretor Aníbal Martins Clemente, em 14 de janeiro de 1972, "consultando" o delegado titular do DOPS-SP quanto à situação dos professores Sérgio Ferro, Rodrigo Lefèvre e Sérgio Souza Lima perante a justiça militar, pois, "sendo certo pretenderem para o início do novo ano letivo reassumir as cadeiras de que são titulares, solicito esclarecimentos sobre a posição deste estabelecimento de ensino superior frente a esta situação, e junto ao Ministério de Educação e Cultura." Esses professores nunca voltaram para a FAUS. DELEGACIA DE ORDEM POLÍTICA E SOCIAL DE SANTOS (DOPS-Santos). Faculdade de Arquitetura e Urbanismo de Santos. Prontuário no 1359. Santos, 1972. p. 135.

Disponível em: <http://www.arquivoestado.sp.gov.br/upload/Deops/Prontuarios/BR_SP_APESP_DEOPS_SAN_P001359_01.pdf.>. Acesso em: 05 ago. 2016.
} 
direção. ${ }^{66} \mathrm{O}$ afastamento do restante de professores ligados ao grupo de Sérgio Ferro, a não recondução de Mayumi e Ronaldo ao Departamento de Tecnologia, o esvaziamento do Departamento de História somado ao demissionário Departamento de Projeto criaram uma situação crítica no corpo docente, agravada pela insatisfação dos estudantes que não concordavam com os critérios estabelecidos pela direção para a contratação de novos professores para a escola.

Ao longo do mês de março daquele ano, o Diretor Aníbal Martins Clemente enviou uma série de cartas convocatórias para os professores do Departamento de História, solicitando o retorno às atividades didáticas e posicionamento quanto às representações ofensivas e inapropriadas do diretório acadêmico contra a direção da escola e contra o Departamento de Projeto. Aníbal não convocou nenhum membro do Departamento de Tecnologia. No dia 3 de abril os estudantes enviaram ao Conselho Departamental um documento com nove páginas, intitulado "Resolução nำ1/72", ${ }^{67}$ que, em quatorze artigos, dispunha sobre a coordenação interdepartamental, critérios de avaliações, comissões e outras providências. Em síntese, era o produto final dos trabalhos iniciados no ano anterior com a criação do GAPI.

No dia 4 de abril de 1972, o Diretor Aníbal Martins convocou uma reunião do Conselho Departamental ${ }^{68}$ para o dia seguinte, 5 de abril de 1972, na sede do IAB/SP, sem mencionar a "Resolução no 1/72", com a seguinte ordem do dia: 1. Conhecimento de recomendação da Secretaria de Segurança Pública a respeito de posição de professores na Faculdade; 2. Exame da Situação dos departamentos face aos pedidos de demissão havidos; 3. Reinício das aulas e calendário escolar; 4. Assuntos de interesse geral. Entre os dias 10 e 13 de abril, como resultado dessa reunião, o dossiê registra a grade horária para os semestres I, III e V, sem professores no Departamento de Projeto e com novos professores nos Departamentos de Tecnologia e História, cada um deles destacados pelos alunos como: "Indicado pela Direção infringindo o Art. 9 e o item 6 do Art. 19 do Regimento Interno". Consta a proposta do Departamento de História para a distribuição de suas disciplinas e uma convocação de Reunião do Conselho Departamental, feita pelo Diretório Acadêmico. Os últimos registros desse documento são duas matérias publicadas no Jornal Cidade de Santos nos dias 12 e 13 de abril de 1972, respectivamente com as manchetes: "Faculdade de Arquitetura: alunos alegam que as aulas são ilegais" e "Diretor da FAUS afirma: não fui causador da crise na faculdade". o último

\footnotetext{
${ }^{66}$ Em um documento de 3 de março de 1972, o Departamento de Projeto esclareceu, detalhadamente, todos os pontos questionados pelos estudantes, revelando mal-entendidos e falhas na comunicação entre estudantes, professores e administração, o que posteriormente, foi confirmado em uma carta do Diretório Acadêmico em resposta ao pedido de esclarecimento do Diretor. O reconhecimento desse fato por parte dos estudantes fortaleceu politicamente o Departamento de Projeto, que passou a pressionar ainda mais a Direção. Documento 25. DIRETÓRIO ACADÊMICO LUCIO COSTA. Dossiê da Crise de 1972. Santos, 1972. pp. 71-74.

${ }^{67}$ Documento 32. DIRETÓRIO ACADÊMICO LUCIO COSTA. Dossiê da Crise de 1972. Santos, 1972. pp. 88-96.

${ }^{68}$ Documento 33. DIRETÓRIO ACADÊMICO LUCIO COSTA. Dossiê da Crise de 1972. Santos, 1972. p.97.
} 
documento é o pedido de demissão dos professores do Departamento de História, José Gabriel Borba Filho e Luiz Carlos Daher. ${ }^{69}$

\begin{tabular}{|c|c|}
\hline & $\begin{array}{l}\text { Seguindo ainda a linha de exposição anterior, daremos agora um quadro geral dos últimos acontecimentos ocorridos } \\
\text { nas diversas areas da FAUS; }\end{array}$ \\
\hline - & III- DA SITUAÇZO ATVAL \\
\hline DOS FATOS & Resumo dos últimos acontecimentos \\
\hline $\begin{array}{l}\text { CONSELHO } \\
\text { DEPARTAMENTAL }\end{array}$ & Negada a sua existência pelo diretor. \\
\hline DIRETORIA & 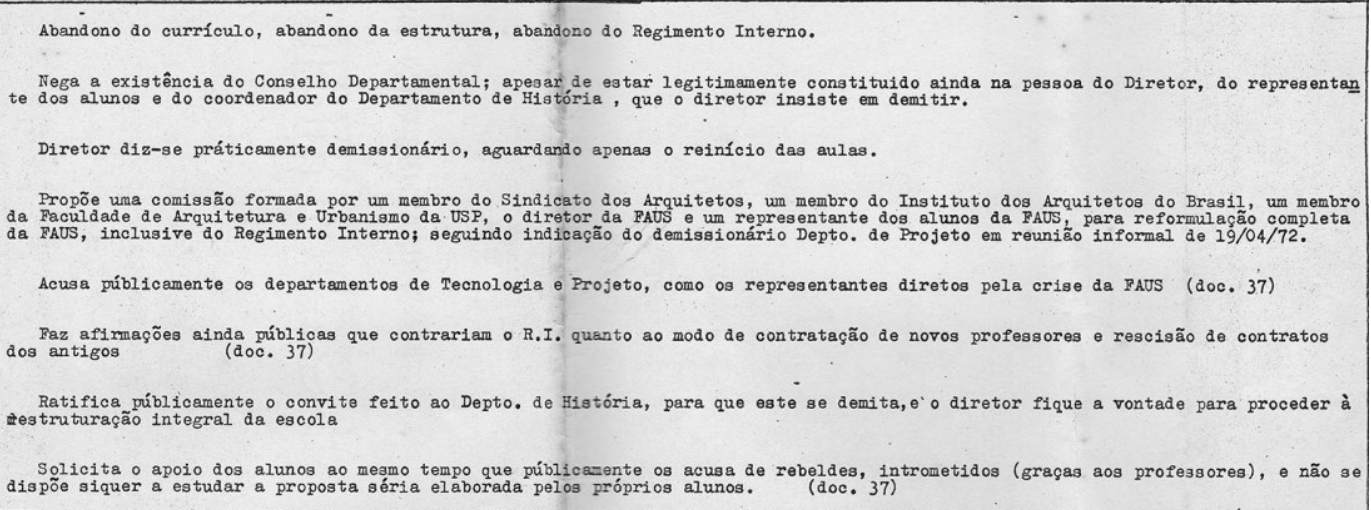 \\
\hline DEPTO. PROJETO & Inteiramente demissionário \\
\hline DEPTO; TECMOLOGIA & Inteiramente demissionário \\
\hline DBPTO. HISTORIA & $\begin{array}{l}\text { Tem seu coordenad or convidado a demitir-se } \\
\text { Professor isolado, indicado pelo coordenador, ministra aulas }\end{array}$ \\
\hline ALUNOS & $\begin{array}{l}\text { Ignora-se a formação dos alunos nos últimos dois anos e se lhes ministra aulas que nada se identificam, quer com sua formação, quer } \\
\text { com o espírito da FAUS. } \\
\text { Mnobilizam-se legitima e disciplinadamente no sentido de levarem às autoriades competentes um estudo sério sobre a situação da es } \\
\text { cola, propondo soluços que podem ser resumidas em duas palavras: Cumpram-se a lei e o Regimento Interno. }\end{array}$ \\
\hline $\begin{array}{l}\text { MOVOS } \\
\text { PROFESSORES }\end{array}$ & $\begin{array}{l}\text { Contratados às pressas ministram aulas isoladamente, sem que haja qualquer identidade entre as disciplinas. } \\
\text { Cada Professor dá o que bem entende, desaparecendo assim a sentido da Programação Geral. }\end{array}$ \\
\hline DISCIPLINAS & $\begin{array}{l}\text { Não há o mínimo entrosamento e coordenação entre os deptos.e não se identificam as disciplinas de cada departam into. } \\
\text { Desenho Arquitetonico: disciplina que não consta do ourrículo. }\end{array}$ \\
\hline
\end{tabular}

FIG. 35. Resumo dos fatos ocorridos entre 1970 e 1971 . Folha $8 / 8$ do Livro Negro da FAUS.

A resposta da Sociedade Visconde de São Leopoldo ao Dossiê enviado chegou no dia 19 de maio de 1972 às mãos do presidente em exercício do Diretório Acadêmico, o estudante Décio Ambrozio, assinada pelo presidente da mantenedora Dom David Picão, e constitui um documento que, inicialmente, concorda com as reivindicações metodológicas e pedagógicas, no sentido da emancipação e participação discente, reconhecendo que as causas da crise em andamento não são devidas à estrutura regimental da FAUS. Posteriormente, a SVSL defende as ações do Diretor, reforçando que ele estava autorizado pelos Departamentos e pela própria Mantenedora.

\begin{abstract}
Não é verdade que a direção queira acabar com a integração a nível dos departamentos. O que a diretoria faz é observar a hierarquia de valores na maneira de conduzir a escola. Em circunstâncias de colapso total, mediante a demissão coletiva de professores por motivos plenamente aceitáveis, e diante da pressão superior de não paralização e não adiamento do início das aulas, a Direção não iria pensar na "integração" porque, no momento, não era o mais urgente. Isso ficaria para uma segunda e posterior etapa. Nem entendemos que nessa solução prioritária estivesse o Diretor violando o Regimento. ${ }^{70}$
\end{abstract}

\footnotetext{
69 Documentos 34, 35, 36, 37, 38 e 39. DIRETÓRIO ACADÊMICO LUCIO COSTA. Dossiê da Crise de 1972. Santos, 1972. pp. $98-107$.

70 SOCIEDADE VISCONDE DE SÃO LEOPOLDO. Memorial no 85-72. 1972. 4p. Faculdades de Católicas de Santos. Santos, 1972. p. 2. (sic).
} 
A SVSL endureceu o tom de suas considerações ao se posicionar contra "algumas atitudes de alguns alunos encobertas pelo D.A.". Não reconheceu a legitimidade de paralização das aulas promovida pelos alunos, não admitiu que os estudantes recorressem às autoridades públicas antes de respeitar o escalonamento administrativo competente, ou seja, acima da direção da FAUS estava a Mantenedora e não a Inspetoria Federal de Ensino e muito menos o Exmº Sr. Ministro de Estado. Além disso, a SVSL repudiou a forma como os estudantes se referiram aos professores do Departamento de Projeto, configurando real falta de respeito para com eles, e lamentou que a "resolução no 1/72" do D.A. falseava a verdade dos fatos ocorridos na reunião, pois representantes da Mantenedora atestavam terem sido aceitas as duas reivindicações dos alunos e recomendou que isso não se repetisse. Finalmente concluía o documento da seguinte maneira:

Esta Sociedade Visconde de São Leopoldo preocupa-se profundamente em sanar a crise que atualmente afeta a FAUS, para o que adotará medidas que atingirão a raiz do mal, esperando extirpá-lo. Espera, igualmente, contar com a colaboração e maturidade dos Senhores Alunos. Por isso faz um apelo no sentido de que evitem indisciplinas, desobediências, desrespeito. ${ }^{71}$

Apesar do apoio Institucional, inexoravelmente, juntos, esses fatores fizeram com que o Diretor Aníbal Martins, não suportando as pressões, renunciasse ao cargo no dia 31 de maio de 1972 . 0 professor Oswaldo Corrêa Gonçalves foi indicado pela SVSL para ser o novo diretor da FAUS e, como vice-diretor, o professor Telésforo Cristofani. O aceite imediato de Oswaldo Corrêa para dirigir a escola, cujas plenárias ele inclusive já vinha presidindo em substituição ao diretor Aníbal, foi determinante para o futuro da FAUS, pois quando assumiu a direção Oswaldo já tinha percebido que "havia duas ideologias diversas que não poderiam conviver sem estraçalhar a escola." ${ }^{72}$ Nesse sentido, o novo diretor realinhou o sistema ideológico da FAUS, prevalecendo "oficialmente" o ideal da prática profissional defendido por Artigas, que tinha a seguinte resposta para os movimentos de guerrilha dentro das faculdades:

\begin{abstract}
Fechemos as escolas, vamos fazer guerrilhas. Temos colegas numerosamente classificados que elaboram essa tese e não aceitam que se entre na Faculdade de Arquitetura para fazer um curso de Arquitetura, mas aprender a ser guerrilheiro. Como pode ser isso? No fim não sai nem guerrilheiro e nem arquiteto. A revolução que vamos fazer prescindirá do conhecimento técnico e de uma visão artística de mundo? Se ela puder prescindir, então vamos fechar todas as escolas. ${ }^{73}$
\end{abstract}

Com evidente teor político, Oswaldo fez novas contratações e redirecionou o curso para a sua diretriz inicial: "formar arquitetos para atender às necessidades de desenvolvimento da região,

\footnotetext{
${ }^{71}$ SOCIEDADE VISCONDE DE SÃO LEOPOLDO. Memorial no 85-72. 1972. 4p. Faculdades de Católicas de Santos. Santos, 1972. p. 4. (sic).

72 Para Oswaldo, havia duas razões para a primeira crise da FAUS: a primeira, com caráter administrativo, era a de que o diretor Aníbal Clemente comparecia à escola das $8 \mathrm{~h}$ as $9 \mathrm{~h}$ da manhã, gerando uma série de problemas, pois o curso era vespertino e o diretor nunca estava presente ao mesmo tempo que os alunos. A segunda razão era ideológica. GONÇALVES, Oswaldo Corrêa. Entrevista com o Professor Arquiteto Oswaldo Corrêa Gonçalves. Op. cit. p. 7.

${ }^{73}$ Dalva Thomaz apud ARANTES, Pedro Fiori. Arquitetura Nova: Sérgio Ferro, Flávio Império e Rodrigo Lefèvre, de Artigas aos mutirões. 2ªed. São Paulo: Editora 34, 2011. p. 93.
} 
inclusive o Plano Diretor Físico de Santos de 1968, sem sofrer injunções políticas." ${ }^{74}$ Além disso, e de forma um tanto quanto pragmática, deixou claro que "o arquiteto tem que fazer projeto, é próprio do arquiteto, o projeto. Projeto para a cidade, para as casas e para as coisas, mas fazer projeto."75 Pode-se dizer que essa ação garantiu a continuidade de funcionamento da FAUS na cidade de Santos, visto que naqueles anos obscuros qualquer movimento em falso poderia ser decisivo e significar o encerramento das atividades da escola.

A 6o plenária da FAUS ocorreu somente em 31 de março de 1973, sem entrar em detalhes acerca da crise vivida ao longo dos anos anteriores e, além de assuntos de ordem administrativa, sinalizou a continuidade dos trabalhos de integração departamental. Nas plenárias seguintes o assunto foi perdendo força, até ser completamente esquecido, a partir do momento em que os integrantes das comissões manifestaram a importância da remuneração docente para operacionalização efetiva das reuniões, realizadas fora do horário das aulas.

Nesse ponto, é oportuno dizer que o interessante grupo de professores ligados a Sérgio Ferro, ao ser afastado da FAUS, migrou para a FAU-SJC a convite do professor Paulo de Mello Bastos, que considerava seus integrantes arquitetos e docentes altamente capacitados, devido à sua experiência efetiva na formação do ICA-FAU da UnB. Com exceção de Sérgio Ferro que foi para Grenoble na França, Rodrigo Lefèvre, Mayumi e Sérgio Souza Lima, juntamente com Francisco de Oliveira, continuaram suas investigações iniciadas na FAUS em 1970, até o momento em que suas propostas de renovação no ensino de arquitetura se depararam com as mesmas dificuldades de Santos. Pois, havia alguns professores no Departamento de Projeto da FAU-SJC que acreditavam no projeto como emancipação e no desenvolvimento da indústria da construção, mesmo sob um regime autoritário.

Por outro lado, a maioria dos professores que compunham os Departamentos de História e Tecnologia não acreditava no processo de industrialização da construção civil diante da grande disponibilidade de mão de obra barata. ${ }^{76}$ Segundo Dobry, esses departamentos alinhavam-se "com uma visão que, no Brasil, vinha sendo elaborada principalmente na FAU-USP e na FAUS e estava inserida no debate latino-americano revelado já em 1963, na reunião da União Internacional de Arquitetos (UIA), realizada em Cuba". ${ }^{77}$ Notavelmente, na FAU-SJC não havia a polarização ideológica entre os docentes dos seus departamentos como na FAUS, esses professores caminhavam juntos em prol de um ensino de arquitetura inovador. Entretanto, e ainda segundo Dobry, "a capacidade de

\footnotetext{
74 Trecho do depoimento de Oswaldo Corrêa Gonçalves em 12 de novembro de 2001 coletado pelo Professor Sergio Novita Fortis. in FORTIS, Sergio Novita. A formação do arquiteto na Faculdade de Arquitetura e Urbanismo da Unisantos - Universidade Católica de Santos: trajetória, organização curricular e condições de funcionamento no período de 1970 a 2003. Op. cit. p. 20.

75 Ibid. p. 68.

${ }^{76}$ Ver OLIVEIRA, Francisco. O Vício da virtude: autoconstrução e acumulação capitalista no Brasil. Op. cit.

${ }^{77}$ Ver parte III, capítulo III - FAU-SJC: o IPC, instituto de projeto e comunicação. Neste capítulo Sylvia Dobry descreve minuciosamente a pedagogia inovadora e polêmica que, por falta de competência da mantenedora em entender o que tinha em mãos, acabou por provocar o fechamento da escola. PRONSATO, Sylvia A. Dobry. Para quem e com quem: ensino de arquitetura e urbanismo. Op. cit. pp. $233-300$.
} 
sobrevivência da FAU-SJC sob pressões externas atingiu o limite da Mantenedora Vale-paraibana, que esperava uma autodissolução da escola"78 e, em 1976, após uma série de demissões de professores e funcionários, transferiu seus estudantes para outras escolas e suspendeu, com o consenso do MEC, as atividades da mais experimental das faculdades privadas em atividade naquela época, "até que os ânimos estivessem serenados."

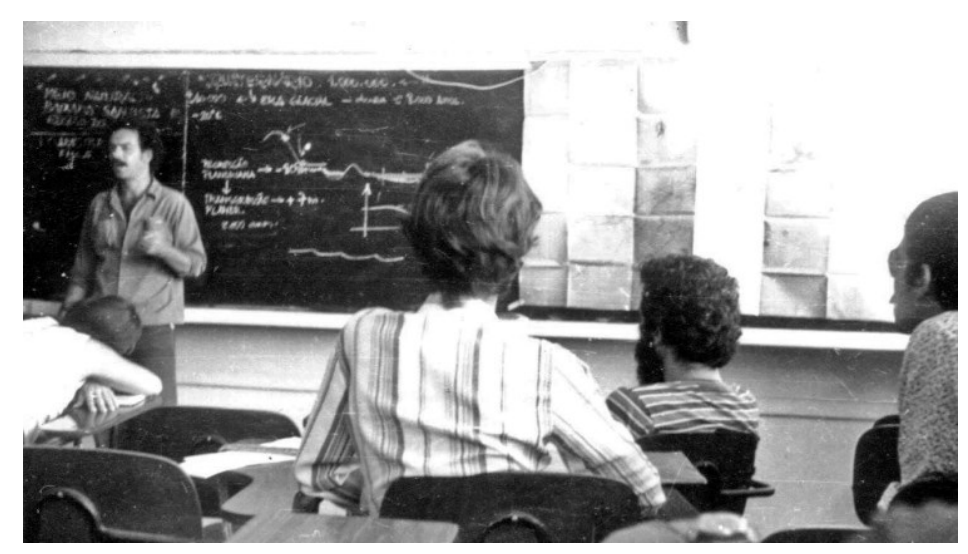

FIG. 36. Aula do professor Ari Vicente Fernandes na sede da FAUS no Colégio Santista, 1975.

Nesse mesmo ano, Lenimar Gonçalves Rios, na ocasião no IX Congresso Brasileiro de Arquitetos em 1976, locada no Grupo de Trabalho 4, cujo tema para discussão e formulação de teses era: “A formação do arquiteto", apresentou no seu relatório final duas hipóteses, cujo objeto, revela, por um lado, a influência ideológica dos seus antigos professores Sérgio Ferro, Rodrigo Lefèvre, Mayumi e Sergio Souza Lima, além do professor Francisco de Oliveira, no que diz respeito às formas de produção participativa no âmbito da prática profissional e do ensino e, por outro, das relações de dependência cultural estabelecidas pela "instrumental" reforma universitária. Segundo Rios, essas duas posições divergentes aparecem claramente na FAUS e, desde o princípio de seu funcionamento em 1970, estavam centradas na formulação de pedagogias para o ensino da arquitetura.

De um lado, os humanistas, que ainda pautavam sua orientação em função de um modelo ideal de profissional de acordo com uma perspectiva desenvolvimentista que já não existia mais - desvinculado, portanto da realidade [...] a ênfase é dada aos aspectos da instrumentação profissional (o desenho como síntese, a preocupação com os aspectos formais e a proposta-produto acabado colocada como finalidade de trabalho). De acordo com essa colocação, os alunos eram pressionados a dar respostas que já estavam préestabelecidas pelos professores. [...] De outro, propunha-se uma formação voltada para o desenvolvimento de uma consciência crítica que, levando em consideração as condições objetivas dentro das quais se insere a prática profissional e a própria formação universitária, colocava-se como saída possível para a crise estrutural e conjuntural que atinge a universidade [...] a instrumentação profissional era colocada não como um fim, mas como consequência da formação do arquiteto - entendida como um processo contínuo de apreensão de conhecimentos. ${ }^{79}$

\footnotetext{
${ }^{78}$ PRONSATO, Sylvia A. Dobry. Op. cit. p. 300.

${ }^{79}$ Aluna da primeira turma da FAUS, Lenimar vivenciou os primeiros anos de atividade da escola, hoje é professora das disciplinas de Urbanismo e Planejamento Urbano e Regional. RIOS, Lenimar G.; LEAL, Lucio; MINCHERIAN, Margarida. Formação do arquiteto: uma crítica possível e necessária. In Anais do IX congresso Brasileiro de Arquitetos. São Paulo: IAB, 1976. pp. 158-159.
} 
Rios concluiu seu relatório confirmando que a posição humanista era a mais adequada para a mantenedora, na medida que ela própria era contrária a qualquer tipo de atitude crítica efetiva, e, para garantir o pleno funcionamento da FAUS, eliminou o grupo mais radical, assumiu o controle financeiro da escola e criou dispositivos de repressão através de mudanças no regimento interno. Por último recomendou que fossem estudadas experiências similares para enriquecimento do debate e intercâmbios de informações para um melhor conhecimento da conjuntura em que essas experiências ocorreram. ${ }^{80}$

Pois bem, a decisão da nova direção da FAUS pelo projeto como instrumento de emancipação e sustentação política foi sedimentada com a proposta para a elaboração do projeto para a construção de sua sede própria, "O prédio da FAUS", projetado pelo professor Michail Lieders com a participação de Oswaldo Corrêa. Esse projeto deveria seguir os preceitos de industrialização propostos na Reforma de 1962 da FAU-USP, consolidados no Fórum de 1968. Além disso, essa mesma decisão, do ponto de vista pedagógico, determinou o perfil do egresso com ênfase no projeto, verificada até os dias atuais, assunto que será tratado adiante. A fé de Artigas no projeto como resposta possível do arquiteto para a superação do autoritarismo demonstra antes de tudo a visão generosa que ele tinha sobre o ensino. Anos mais tarde ele faria a seguinte declaração:

Vi rapazes em 1968 tentarem seguir a luta armada. Eu os impedi, apesar de na época 'ter transformado alguns deles em meus inimigos'. Mas tenho a impressão de que, com isso, salvei uma centena de jovens, que, hoje, estariam nas listas dos desaparecidos do período da repressão. Isso está no meu coração como a melhor contribuição política que dei à juventude de minha pátria. Digo isso com uma profunda emoção. Do sofrimento do nosso povo, posso dizer que participei profundamente. Alguém terá olhos para um dia ler, nas formas que projetei, todo esse sofrimento. Ver-se-á uma poética traduzida. Enfim, os arquitetos não dormiram, eles velaram. ${ }^{81}$
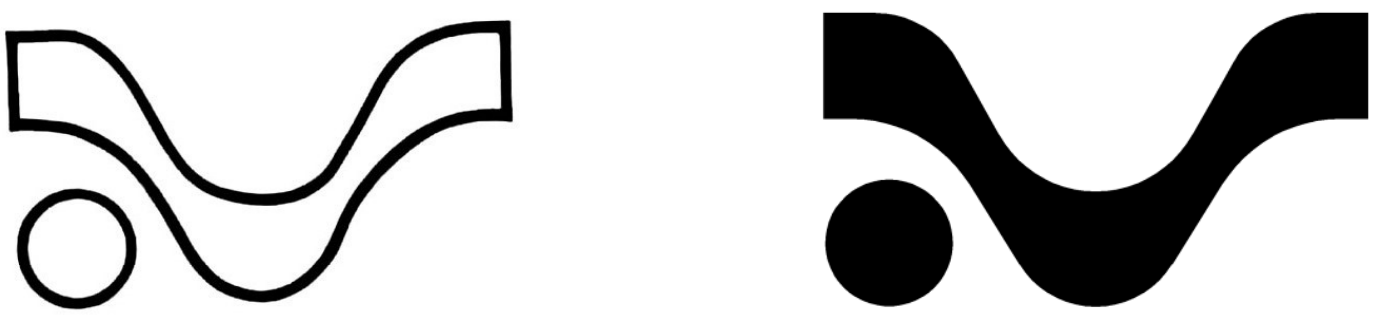

FIG. 37. Símbolo da FAUS. Proposta vencedora de um concurso interno promovido pelo Diretório Acadêmico Lucio Costa, entre 1973 e 1974. O vencedor foi o estudante Newmar Meirelles, FAUS 1977, que recebeu como premiação um jogo de compassos doado pela Casa da Vinci. A ideia consistia em representar a "onda do mar" ao mesmo tempo que as letras "A U S" (Arquitetura/Urbanismo/Santos). À esquerda arte final original do estudante Eber de Gois, FAUS 1977. À direita, redesenho do autor.

${ }^{80}$ RIOS, Lenimar G.; LEAL, Lucio; MINCHERIAN, Margarida. Op. cit. p. 159.

${ }^{81}$ Trecho da entrevista de Vilanova Artigas a Lívia Pedreira, in XAVIER, Alberto. Depoimento de uma geração: arquitetura moderna brasileira. São Paulo: Cosac Naify, 2003. p. 222. 
DOBRA 


\section{Edifício como síntese pedagógica}

O inicial caráter itinerante da FAUS configura um poético reconhecimento da cidade ao ocupar diversos locais antes de construir sua sede definitiva, conhecida como o Prédio da FAUS. Projetado por seus professores e estudantes e construído por um arquiteto, esse edifício, feito para abrigar um curso de arquitetura, ao utilizar o sistema construtivo de pré-moldados de concreto armado, inédito em Santos, destacou-se não apenas no âmbito da inovação tecnológica da construção, mas também se apresentou como um promissor agente de transformação cultural da cidade. Nesse sentido, pretende-se demonstrar que a concepção do edifício, do ponto de vista construtivo e conceitual, estava alinhada aos princípios da produção da escola paulista de arquitetura do início dos anos de 1960 e 1970.

Como visto, a FAUS iniciou suas atividades nas instalações oferecidas pela mantenedora no antigo prédio da Faculdade de Filosofia, Ciências e Letras. Essa primeira sede era situada na Rua Euclides da Cunha, 247 no Bairro da Pompéia, em Santos. A segunda sede foi ocupada já no segundo semestre de 1970, e era destinada aos semestres I e II. Situada na Avenida Ana Costa 378, era um galpão existente em um conjunto residencial projetado por Francisco Petracco, e dispunha de um atelier $244,65 \mathrm{~m}^{2}$, duas salas de aula, uma para aulas teóricas e outra para aulas práticas, sala para modelagem e artes gráficas e salas para diretoria e secretaria. Em conjunto com as outras Faculdades mantidas pela Sociedade Visconde de São Leopoldo, a Faculdade de Arquitetura utilizou, a título provisório, o auditório para palestra, o laboratório de Física e a biblioteca da Faculdade de Filosofia. Possuía nessa época um total de 580 livros e periódicos. ${ }^{82}$

Conforme os semestres avançavam, além da contratação de novos professores, a demanda por espaço aumentava. Dessa forma, a terceira sede da FAUS estava situada em 1972 na Avenida Senador Feijó 219, no centro da cidade, e ocupava algumas salas no pavimento superior de um edifício com lojas comerciais no pavimento térreo. Essa sede estava destinada ao funcionamento dos semestres I e III - II e IV, com as seguintes dependências: Atelier $1-126,69 \mathrm{~m}^{2}$ (utilizado pelos semestres III e IV); Atelier 2 - 156,26m² (utilizado pelos semestres I e II); Sala da diretoria e professores $-21,85 \mathrm{~m}^{2}$; Sala de secretaria e tesouraria $-17,75 \mathrm{~m}^{2}$; Oficina $-20,44 \mathrm{~m}^{2}$ (mimeografia e maquetes) e uma Biblioteca com quatro estantes abertas, ocupando o espaço de 0,35 x 3,60 com cinco prateleiras, perfazendo um total de $18,00 \mathrm{ml}$ de prateleiras, e 821 livros e periódicos. ${ }^{83}$ No final do ano letivo de 1972, a sede da Avenida Senador Feijó 219 abrigava as seguintes instalações: Atelier

\footnotetext{
82 UNIVERSIDADE CATÓLICA DE SANTOS. Relatório do ano letivo de 1970. pp. 5-6 e pp. 12-32.

83 UNIVERSIDADE CATÓLICA DE SANTOS. Relatório do ano letivo de 1971. pp. 3-4.
} 
$4-142,80 m^{2}$ (70 Alunos); Laboratório Fotográfico $-24 m^{2}$; Escritório Piloto $-55 m^{2}$; Oficina de maquetes $-70,60 \mathrm{~m}^{2}$ e Subsecretaria $-26,00 \mathrm{~m}^{2} .{ }^{84}$

Segundo Fortis, essa última localidade era muito próxima de outra instituição católica, o Colégio Santista na Rua Sete de Setembro 34, administrado pela ordem Marista, e logo foi firmado um convênio que autorizava a utilização de suas salas pela FAUS no período vespertino, já que as aulas do colégio ocorriam majoritariamente no período da manhã. Em pouco tempo a FAUS estava completamente instalada naquele colégio, ${ }^{85}$ e dispunha dos seguintes espaços: Atelier $1-112,00 \mathrm{~m}^{2}$ (70 alunos); Atelier $2-103,00 \mathrm{~m}^{2}$ (70 alunos); Atelier $3-80,50 \mathrm{~m}^{2}$ (70 alunos); Biblioteca 42,00m², com 1249 livros e periódicos; Sala de projeção com 120 lugares (aproximadamente 144,00m²); 2 salas para aulas teóricas com 80 lugares cada (aproximadamente 192,00m²); 1 laboratório de física;

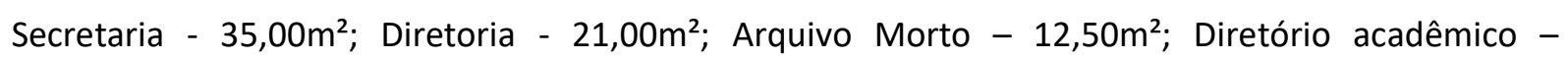
$10,00 \mathrm{~m}^{2} .{ }^{86}$

Oswaldo Corrêa manteve no cotidiano da Faculdade as plenárias mensais com o objetivo de reunir o corpo docente e discente para discussão e aperfeiçoamento didático do curso, além de abordar problemas relativos à cidade e à região. Segundo o professor Sergio Novita Fortis, ${ }^{87}$ Oswaldo, preocupado com a necessidade de ampliação dos espaços da FAUS, devido a urgência em atender as exigências do Conselho Federal de Educação para reconhecimento do curso, incorporou, além das plenárias oficiais, reuniões que ocorriam geralmente aos sábados pela manhã e que, durante o primeiro semestre do ano de 1973, tiveram como pauta principal o projeto para a construção de um edifício para a FAUS. O edifício deveria ser capaz de abrigar adequadamente as instalações específicas de um curso de arquitetura e, ao mesmo tempo, investigar e pôr em prática novos processos construtivos de acordo com os avanços técnicos da indústria da construção civil.

Esses profissionais, ao alinharem sua produção aos processos de industrialização e racionalização da construção, expandiram seu campo de atuação seguindo o mestre Vilanova Artigas que, em 1967, associado aos arquitetos Fabio Penteado e Paulo Mendes da Rocha, elaborou o projeto do Conjunto Habitacional Zezinho Magalhães para atender 60 mil pessoas em Guarulhos. ${ }^{88}$ Participaram como

\footnotetext{
${ }^{84}$ UNIVERSIDADE CATÓLICA DE SANTOS Relatório do ano letivo de 1972. p. 3.

${ }^{85}$ FORTIS, Sergio Novita. Op. cit. p. 19.

${ }^{86}$ Tratam-se de edifícios particulares com acesso restrito, desse modo os dados apresentados constam nas atas das plenárias e livros de registro de atividades da escola enviados ao MEC nos anos de 1970, 1971 e 1972, como pré-requisito da manutenção da autorização de funcionamento FAUS. UNIVERSIDADE CATÓLICA DE SANTOS. Relatório do ano letivo de 1972. p. 4.

${ }^{87}$ Texto elaborado a partir do depoimento do professor e engenheiro responsável pela obra da FAUS em 1973, Sérgio Novita Fortis, coletado pelo autor em 22 de setembro de 2016.

${ }^{88}$ Segundo Arantes, "não é apenas uma obra que Artigas realiza para o Estado, mas dezenas, como hospitais, estações rodoviárias, escolas, ginásios, sete conjuntos habitacionais para o CECAP: em Cubatão (1970), Americana (1972), Jundiaí (1973), Mogi-Guaçu (1975), Marília (1976) e Jaú (1976). In ARANTES, Pedro Fiori. Op.cit. p. 98.
} 

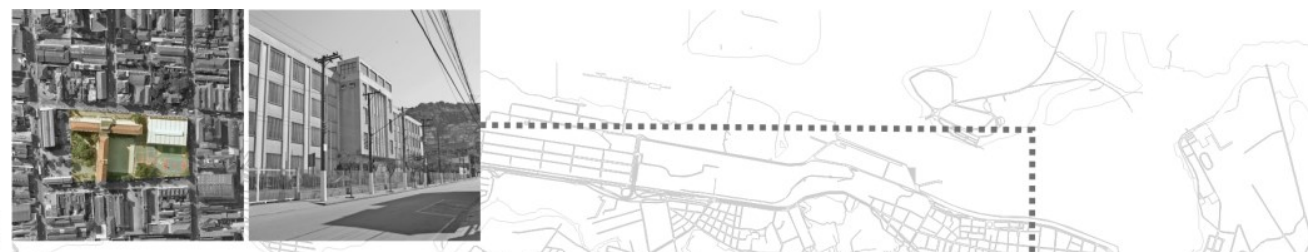

1972

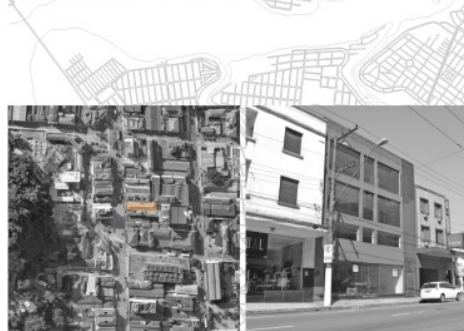

1971
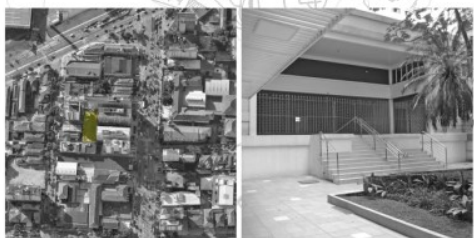

1970
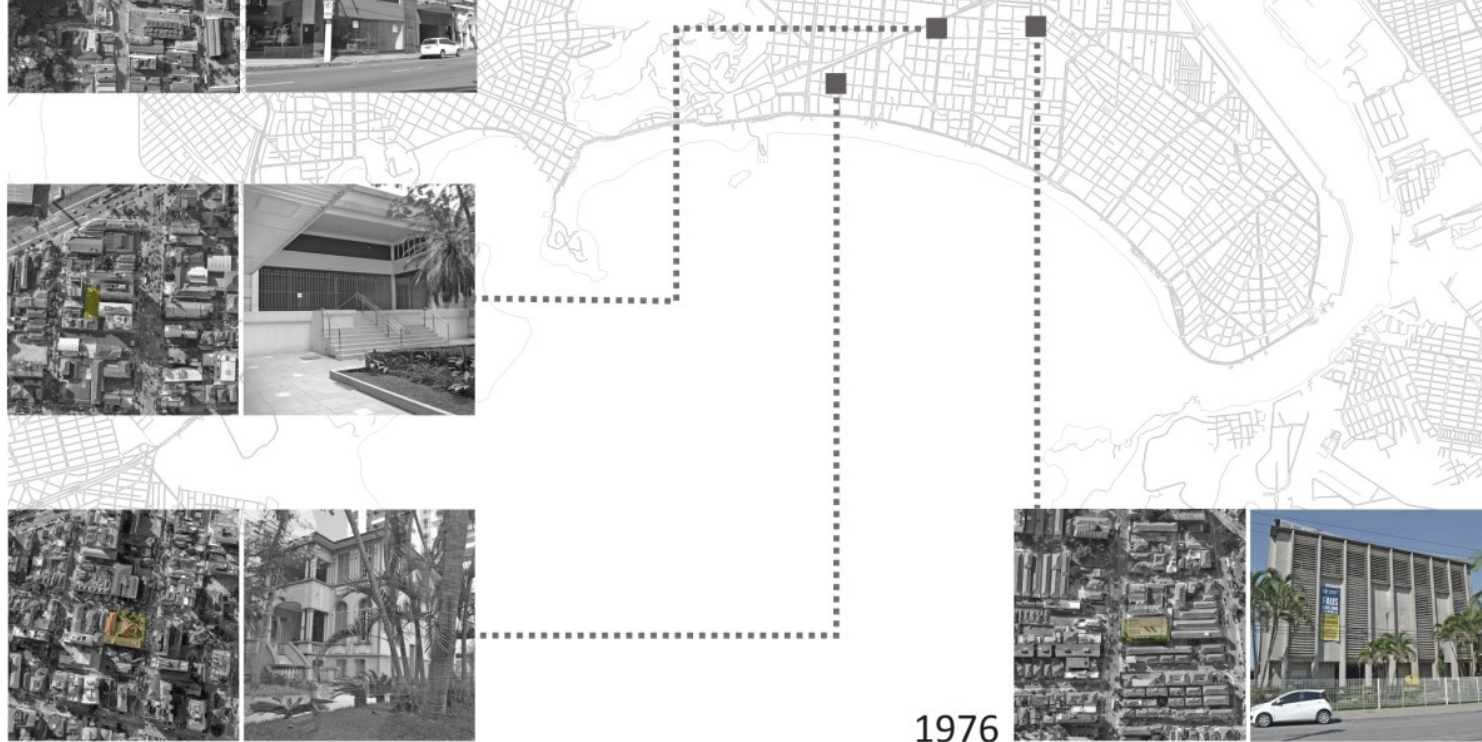

FIG. 38. Escola itinerante, percurso da FAUS pela cidade de Santos: 1970 - primeira sede na Rua Euclides da Cunha. 1971 - Galpão na Avenida Ana Costa. 1972 - Edifício comercial na Avenida Senador Feijó, 219 e no colégio Santista. 1976 - Sede definitiva na Avenida Conselheiro Nébias, 595.

\section{SEDES DA FAUS}

\begin{tabular}{c|c|c|c} 
SEQUÊNCIA & LOCAL & PERÍODO & ÁREA $\left(\mathbf{m}^{\mathbf{2}}\right)$ \\
\hline PRIMEIRA SEDE & RUA EUCLIDES DA CUNHA & 1970 & NÃO DISPONÍVEL \\
SEGUNDA SEDE & AVENIDA ANA COSTA & $1970-1971$ & 244,65 \\
TERCEIRA SEDE & AVENIDA SENADOR FEIJÓ & $1972-1973$ & 342,99 \\
QUARTA SEDE & RUA SETE DE SETEMBRO & $1972-1975$ & 752,00 \\
PRÉDIO DA FAUS & AVENIDA CONSELHEIRO NÉBIAS & $1976-$ ATUAL & $3.920,00$ \\
& & &
\end{tabular}

TAB. 07. Quadro síntese de áreas das sedes da FAUS.

colaboradores desse trabalho os arquitetos Ruy Gama, Geraldo Puntoni, Maria Visconti, Arnaldo Martino, Renato Nunes, Alfredo Paesani, Eugênia Paesani, Stipan Milic e Sylvia Ficher. A encomenda foi feita pela Caixa Estatual de Casas para o Povo (CECAP), autarquia ligada à Secretaria do Trabalho, Indústria e Comércio, e destinava-se a promover moradia para a população operária sindicalizada do estado. Nesse projeto, Artigas viu a oportunidade de aproximar o desenho da habitação ao desenho industrial e estudou exaustivamente sistemas industrializados para a execução da obra, convicto de 
que a incorporação de novas tecnologias permitiria a construção em massa das unidades habitacionais. Como visto, essa visão contrapunha frontalmente as posições de Sérgio Ferro, Rodrigo Lefèvre e Flávio Império que acreditavam em soluções simplificadas, com viés artesanal, permitindo a construção de habitações populares em sistema de mutirões.

Com efeito, Artigas seguia demonstrando sua tese de "que a responsabilidade social do arquiteto se sustentava no conceito do projeto como um instrumento de emancipação política e ideológica" ${ }^{89} \mathrm{e}$, apesar de não ter sido construído obedecendo a integralidade dos sistemas industrializados propostos, o Conjunto Zezinho Magalhães ampliou o campo da ação projetual dos arquitetos paulistas naquele momento. Essa visão de futuro e a crença no rigor da técnica são claras na descrição do projeto feita por Paulo Mendes da Rocha:

O objetivo foi, através das novas possibilidades dadas pela pré-fabricação, atingir um nível de excelência que demonstrasse que a qualidade de uma habitação não deveria corresponder ao padrão econômico de uma determinada classe social, mas aos conhecimentos técnicos do seu momento histórico, que permitissem uma construção racionalizada, honesta e acessível a todos. ${ }^{90}$

Indo além, durante os anos 1960, para atender a expansão do ensino público e abrigar os diversos cursos que seriam instalados e alojar estudantes e docentes em unidades habitacionais, a Universidade de São Paulo e a Universidade de Brasília, por exemplo, construíram edifícios projetados por seus arquitetos-professores utilizando processos racionalizados de construção com a aplicação de elementos pré-fabricados de concreto e aço. Indo nessa direção, em 1973 Paulo Bruna defendeu sua tese de doutorado na FAU-USP que tratava das questões do projeto de arquitetura e processos industriais de construção visando o desenvolvimento nacional. As afirmações de Bruna, no que diz respeito à necessidade e urgência da industrialização da construção no país, desde a escala do objeto até a escala do território, estão fundadas na ideia de que esses princípios deveriam ser incorporados efetivamente ao ensino da arquitetura:

Às Faculdades de Arquitetura caberia a formação de arquitetos especialmente preparados para atuar nos três níveis em que o projeto deverá atingir: do desenho industrial, do projeto arquitetônico e do planejamento territorial. Partindo da análise fenomenológica das tipologias existentes, o aluno deverá ser ensinado a individualizar as partes, decompondo o todo arquitetônico em elementos construtivos que sejam caracterizados por três qualidades fundamentais, isto é: funcionalmente definidos, formalmente e tecnicamente componíveis, tecnicamente e economicamente fabricáveis em série. Uma vez definidos os elementos construtivos, os alunos deverão ser capazes de efetuar a recomposição do organismo arquitetônico para verificar a organicidade das partes. E, finalmente, a última etapa será a planificação do território, uma vez que a escala das intervenções ultrapassa a unidade compositiva. ${ }^{91}$

\footnotetext{
${ }^{89}$ SEGAWA, Hugo. Op.cit. p. 144.

90 Texto de Guilherme Wisnik in. ARTIGAS, Rosa (org.). Paulo Mendes da Rocha. São Paulo: Cosac Naify, 2000. p. 184.

${ }^{91}$ A publicação da tese de Bruna em 1976, além da contribuição teórica e bibliográfica, converteu-se em uma influente referência para profissionais e estudantes sobre o assunto. BRUNA, Paulo J. V. Arquitetura, industrialização e desenvolvimento. 2a. Edição. São Paulo: Editora Perspectiva, 2002. pp. 143-144. (grifo nosso).
} 
Isto posto e conforme já demonstrado, no início dos anos 1970, além dos professores da FAU-USP e FAU-Mackenzie, o corpo docente da FAUS contava com professores oriundos da UnB, entre eles Alberto Xavier, Eduardo Fontes Hotz, Mayumi Watanabe e Sergio Souza Lima, estes dois últimos trabalharam no Centro de Planejamento da Universidade de Brasília (CEPLAN/UnB) diretamente com Oscar Niemeyer, Edgar Graeff e João Filgueira Lima, o Lelé. Pode-se dizer que a experiência desses docentes na pesquisa, projeto e aplicação prática dos sistemas construtivos industrializados nos canteiros das obras pré-fabricadas de Brasília naturalmente alimentaram as discussões entre professores e estudantes da FAUS para a determinação das premissas do projeto para a construção do seu prédio próprio.
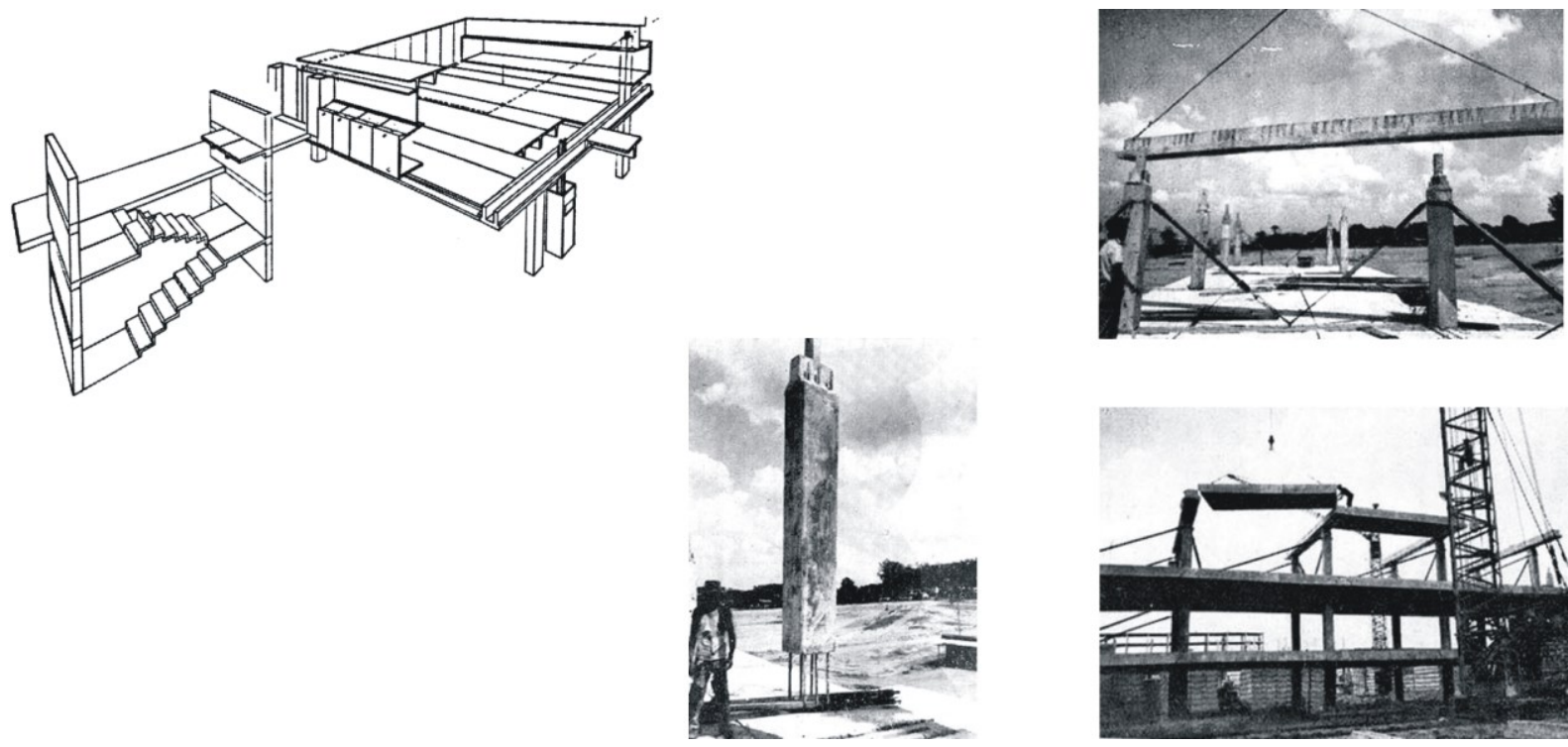

FIG. 39. Desenho das peças pré-fabricadas do conjunto CECAP, 1967 e construção industrializada do Conjunto Residencial da Universidade de São Paulo CRUSP, 1961-1964. Arquitetos Eduardo Knesee de Mello, Joel Ramalho Jr. e Sidney de Oliveira.

Em setembro de 1972, Oswaldo Corrêa apresentou o Regimento Interno do Centro de Assessoramento, Pesquisa e Documentação de Arquitetura e Urbanismo da FAUS, que além de propiciar a pesquisa e o aprimoramento didático profissional do quadro docente da FAUS, deveria funcionar como um escritório modelo com a participação de professores e estudantes para, juntamente com os demais órgãos das Faculdades Católicas de Santos, "programar obras, manter atualizado o Plano Físico e elaborar projetos e acompanhar a execução das obras no Campus." 92 Desse modo, seguindo o regimento do novo Centro, Oswaldo Corrêa Gonçalves, junto com o colegiado de professores da FAUS, estabeleceu algumas diretrizes e condições que deveriam orientar os arquitetos professores interessados em elaborar o projeto para o novo prédio da FAUS. As mais relevantes demonstravam um claro desejo de seguir a linha conceitual e construtiva da arquitetura

\footnotetext{
92 Capítulo 1 - Objetivos; Artigo 3; Alíneas A-T. In UNIVERSIDADE CATÓLICA DE SANTOS. Regimento interno do Centro de Assessoramento, Pesquisa e Documentação de Arquitetura e Urbanismo da FAUS. 8p. Santos, 1972. pp. 1-3.
} 
produzida pelos mestres de São Paulo, a saber: 1. A estrutura deveria ser pré-fabricada e em concreto aparente; 2. O arquiteto responsável pelo projeto seria escolhido por meio de concurso interno; 3. O arquiteto vencedor teria como remuneração somente os custos para elaboração do trabalho; 4. 0 acompanhamento da obra deveria ser gratuito. 0 professor arquiteto Michail Lieders ${ }^{93}$ foi o único que aceitou essas condições, de modo que não foi necessário realizar um concurso interno.

Paralelamente ao processo de definição programática e conceitual desse projeto, a Sociedade Visconde de São Leopoldo adquiriu um terreno ${ }^{94}$ com 30,00 metros de frente e 60,00 metros de profundidade, com área de 1.806,85 $\mathrm{m}^{2}$. Com localização privilegiada, ficava no centro da porção Leste da Ilha de São Vicente, na Avenida Conselheiro Nébias, no Bairro do Boqueirão, cidade de Santos. Definido o lugar e diante da urgência para o início das obras, Lieders começou os estudos e apresentou uma primeira hipótese de projeto que utilizava, parcialmente, o sistema de préfabricação, limitando-se ao desenho dos painéis de fechamento do edifício. A implantação dessa primeira proposta explorou ao máximo as reduzidas dimensões do lote, determinando que o programa fosse disposto em quatro pavimentos. Apesar desse adensamento, é possível verificar que o compacto bloco de serviços e circulação vertical, localizado na porção norte e no sentido longitudinal do terreno, além de servir todos os pavimentos, liberava as áreas servidas oferecendo maior flexibilidade programática para cada laje. Nesse sentido, a preocupação com as atividades de ensino, pesquisa e produção eram permeadas por generosas áreas de convívio.

A distribuição modular dos pilares somada ao exíguo programa do pavimento térreo proporcionava um pátio coberto que, ao modo de uma praça pública e da mesma maneira que o edifício da FAUUSP recém-inaugurado na Cidade Universitária, não possuía porta na entrada, era completamente aberto. Sob os pilotis, utilizando fechamentos independentes da estrutura, foram dispostas a biblioteca, a maquetaria, a secretaria, administração, núcleos de circulação vertical, sanitários e laboratório fotográfico.

\footnotetext{
${ }^{93}$ Nascido na cidade de Praga na Tchecoslováquia no dia 14 de outubro de 1944, filho de Alexandre Lieders e Helena Prochazka Lieders, veio para o Brasil e se formou na FAU-USP em 1968. Foi sócio de Carlos Ferro e Alfred Talaat, cujo escritório teve como colaboradores os destacados arquitetos André Vainer, Guilherme Paoliello e Anselmo Turazzi. Foi vencedor junto com o arq. Marcos Acayaba dos Concursos Públicos Estaduais para a construção dos Escritórios Regionais de Planejamento das cidades de Araçatuba, Bauru e Marília, promovidos pela Secretaria de Estado do Planejamento do Estado de São Paulo e Instituto de Arquitetos do Brasil - Departamento de São Paulo - em 1976. A execução das mencionadas obras industrializadas na Cidade Universitária ao longo nos anos 1960 e 1970 coincidiram com o período de formação do arquiteto Michael Lieders, que estudou na FAU-USP de 1964 a 1968 e teve como professores os mesmos arquitetos que ali construíam. Informações obtidas através de depoimentos de professores da FAUS, FAU-USP e da Escola da Cidade Arquitetura e Urbanismo.

${ }^{94} \mathrm{O}$ terreno foi adquirido a pedido do Diretor Geral das Faculdades Católicas, o Padre Américo Soares ao lado da "Casa Amarela", prédio próprio da mantenedora, onde funcionava a Faculdade de Direito de Santos, primeiro curso da Sociedade Visconde de São Leopoldo, fundado em 1952. Esse edifício era pintado de amarelo, daí sua denominação popular. A casa amarela foi substituída pelo prédio atual na década de 1970 .
} 


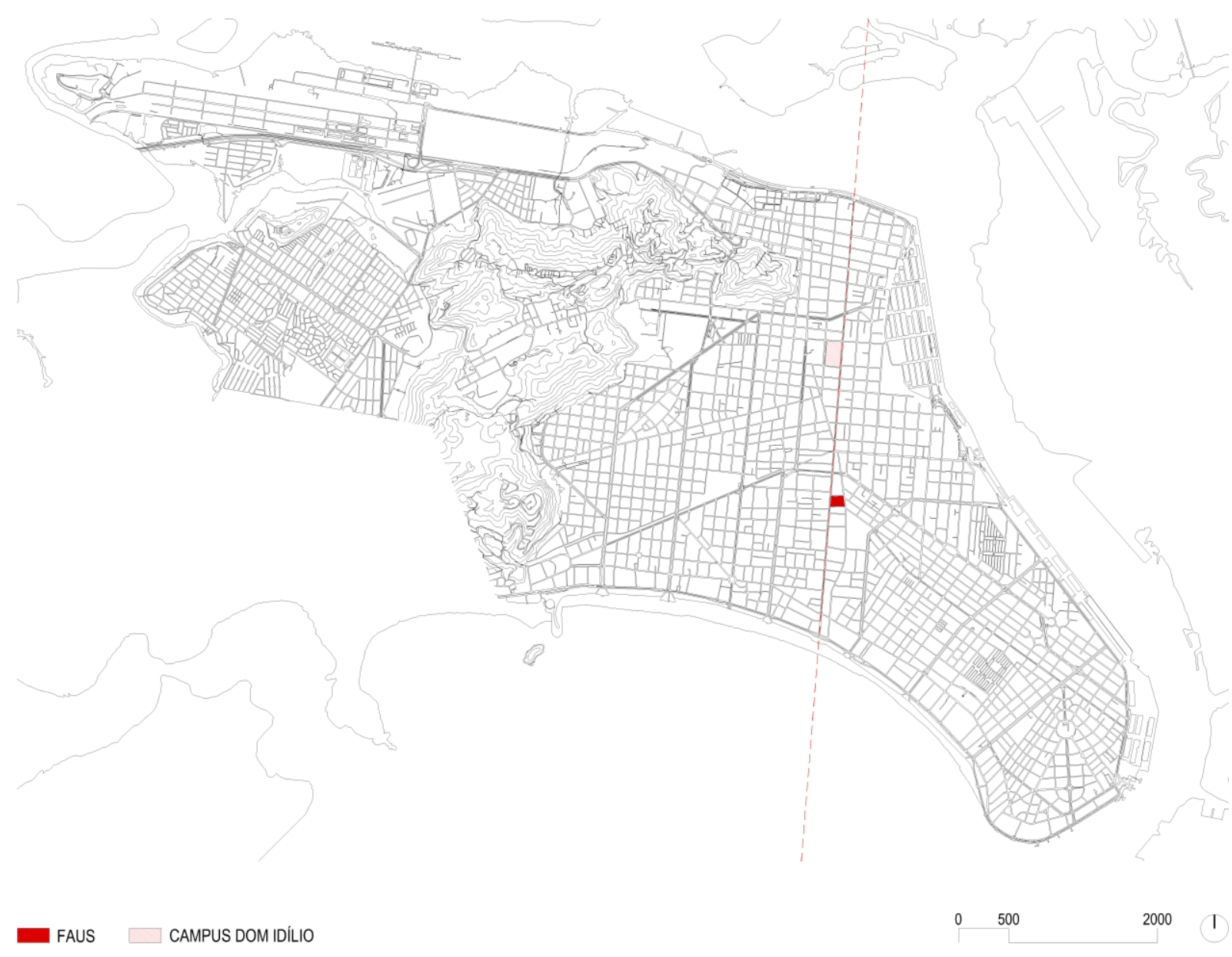

SITUAÇÃO DA FAUS E CAMPUS DOM IDÍLIO NA AVENIDA CONSELHEIRO NÉBIAS EM SANTOS

FIG. 40

Situados na porção sul do lote, os dez ateliers propostos estavam distribuídos em dois andares, cinco no segundo pavimento e cinco no terceiro pavimento. Esses espaços eram destinados a aulas teóricas e à prática de projeto e, para tanto, contavam com aproximadamente 150,00 $\mathrm{m}^{2}$ cada um, somando uma área total de $1.100,00 \mathrm{~m}^{2}$ em cada um dos pisos. Na cobertura, o professor Michail Lieders desenhou uma área de convívio com cantina e apoio cobertos e um terraço descoberto. A área total desse estudo era de $3.637,62 \mathrm{~m}^{2}$.

Apesar das restrições impostas pelas dimensões do terreno, essa versão já possuía as premissas que orientariam os estudos seguintes: a generosidade e fluidez espacial, e principalmente a valorização dos espaços coletivos de produção e de convivência. Essa primeira hipótese foi apresentada e discutida com outros professores da escola, que propuseram algumas alterações e, desse modo, o professor Oswaldo Corrêa se associou ao professor Michail Lieders para o desenvolvimento do projeto. 


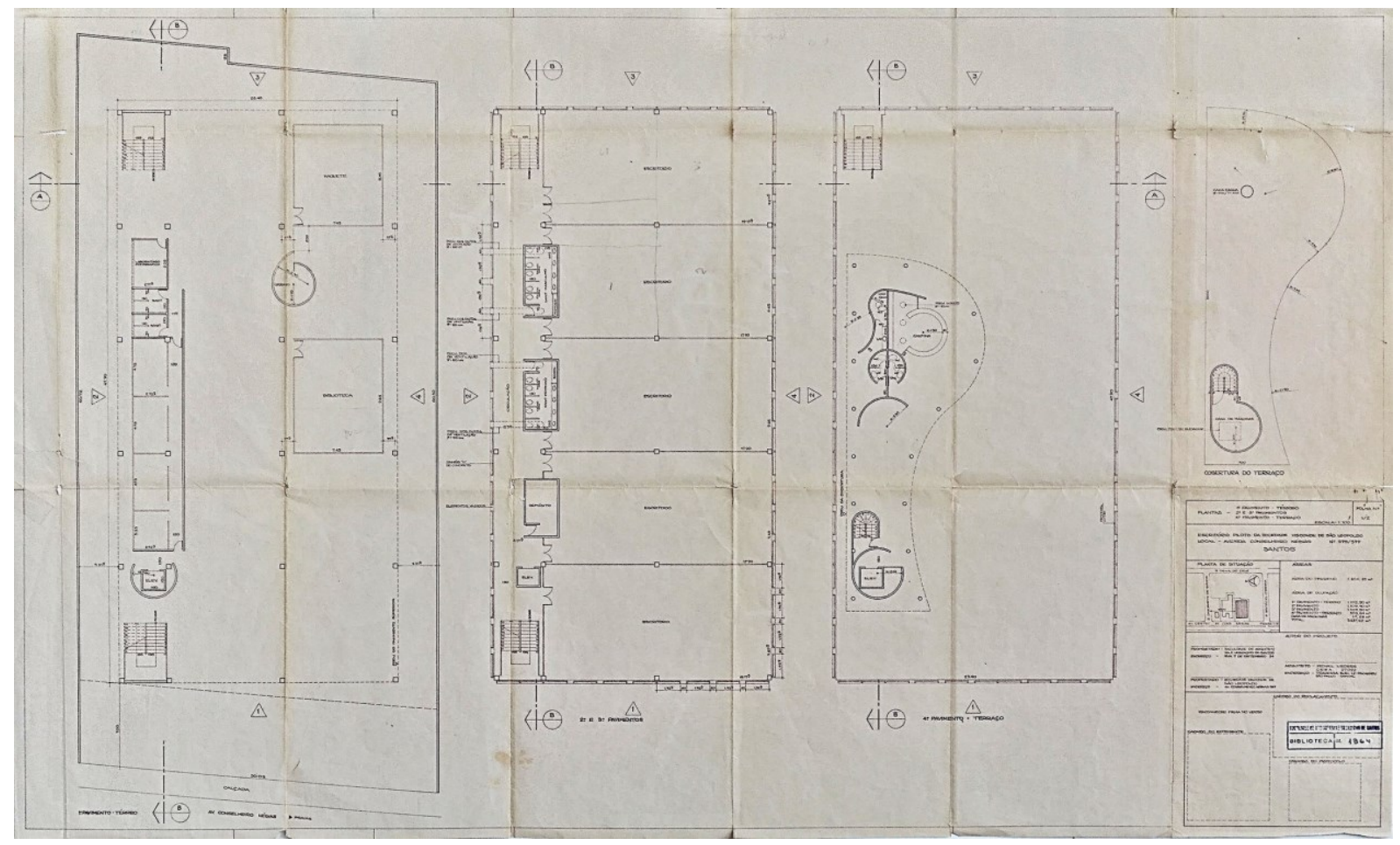

FIG. 41. Primeira versão do projeto para o prédio da FAUS.

O primeiro contato com os problemas técnicos e econômicos, inerentes ao sistema construtivo de pré-fabricados, além das discussões com os outros arquitetos da escola, geraram novas questões que precisavam ser verificadas. Nesse sentido, no estudo seguinte o sistema construtivo industrializado do projeto foi amplamente elaborado e passou a ter papel norteador no processo. A estrutura era integralmente composta por elementos em concreto pré-moldado com vigamento protendido e peças de fechamento desenhadas na mesma modulação dos painéis das lajes: 2,50 metros, totalizando 259 elementos pré-fabricados. Os demais componentes construtivos industrializados foram projetados de acordo com esse mesmo sistema modular, integrando assim estrutura, fechamentos, divisórias, caixilhos e elementos de proteção solar.

Com aproximadamente 3.920,00 metros quadrados de área construída, o aproveitamento do terreno segue a lógica do primeiro estudo, com a mesma implantação e distribuição do programa em quatro pavimentos, a entrada livre, sem portas. No entanto, o arranjo dos usos sofreu alterações consideráveis tanto do ponto de vista da sua localização quanto de suas dimensões. $\mathrm{O}$ sistema de circulação e os programas de apoio mantiveram-se implantados na face norte, no entanto, as escadas são rotacionadas mudando o sentido de acesso e o elevador é suprimido nessa versão.

No pavimento térreo podemos verificar que a biblioteca é ampliada e posicionada junto ao acesso frontal e um eixo central de circulação leva o usuário da frente ao fundo do terreno sem obstáculos. Há uma espécie de rua, capaz de organizar o acesso às salas de protocolo, tesouraria, conselho departamental, secretarias dos departamentos, diretoria, oficina de modelos, laboratório 
fotográfico, sanitários e escadas, configurando endereços independentes sob os pilotis. Ao centro, os arquitetos Michail Lieders e Oswaldo Corrêa reservaram um espaço de múltiplo uso que também funcionava como uma praça coberta.

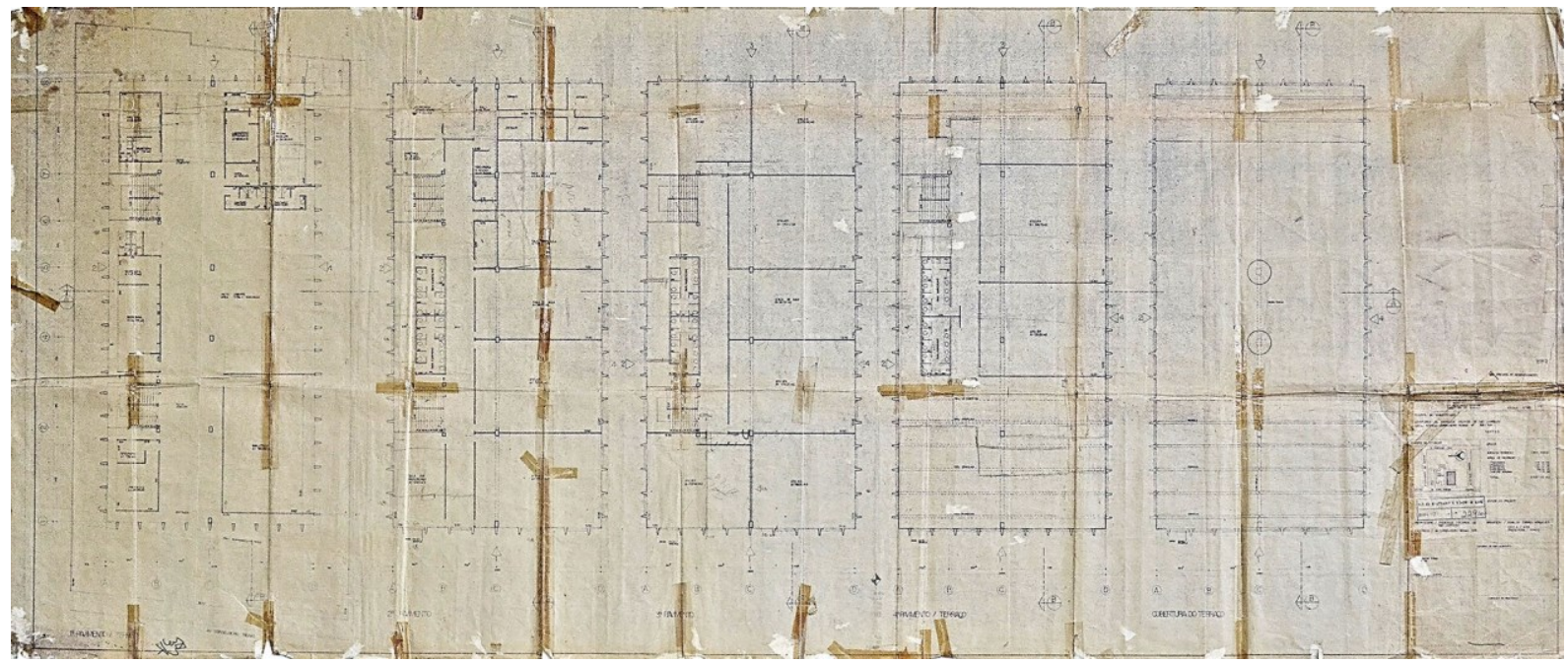

FIG. 42. Versão do projeto para o prédio da FAUS apresentada na Prefeitura Municipal de Santos.

No primeiro pavimento, a exigência da mantenedora em prever espaços para o curso de Serviço Social fez com que Michail Lieders e Oswaldo Corrêa desenhassem somente dois ateliers e três salas de aula menores, moduladas de acordo com a estrutura principal. No mesmo piso foi prevista a sala dos professores, diretoria e secretaria do curso de Serviço Social, além de salas menores definidas como estágio.

No segundo pavimento, além da circulação vertical e sanitários, foram desenhados sete ateliers independentes, que nunca funcionaram dessa forma. O prédio foi entregue com um único atelier, conforme desenho abaixo. Posteriormente os próprios estudantes auxiliados pelos professores instalaram algumas divisórias de madeira. A cobertura é constituída por um terraço jardim com pergolado, sempre obedecendo ao módulo estrutural principal, sanitários, apenas uma escada de acesso e dois ateliers para auxiliar as atividades que poderiam ser realizadas naquele lugar.

Essa segunda proposta foi apresentada e aprovada pelos professores e representantes da Sociedade Visconde de São Leopoldo, mantenedora das Faculdades Católicas de Santos. O projeto final pode ser visto apenas nas pranchas do projeto legal aprovado pela Prefeitura Municipal de Santos, através do processo 30.294 em 1973 no qual, talvez por questões operacionais e facilidade para aprovação, consta somente o nome de Oswaldo Corrêa como autor, por ser um arquiteto estabelecido na cidade. Os processos de concepção e desenvolvimento das duas propostas apresentadas para o colegiado de professores, alunos e mantenedora da FAUS não foram encontrados. 
A elaboração do projeto executivo de arquitetura compatibilizado com os projetos complementares, além da construção do edifício, ficou a cargo da construtora contratada. Apesar do modelo de contratação por concorrência pública, Michail Lieders e Oswaldo Corrêa Gonçalves deram preferência à empresa Construtora Rodrigues Lima Industrial Ltda. por ela ter como proprietário o arquiteto Otacílio Rodrigues Lima. Acreditavam que ele seria capaz de fazer as compatibilizações entre os projetos complementares e o sistema pré-fabricado respeitando os conceitos do projeto de arquitetura. A Sociedade Visconde de São Leopoldo assumiu todos os custos da empreitada, desde a compra do terreno, a construção do edifício e sua posterior manutenção, que ocorre até os dias de hoje.
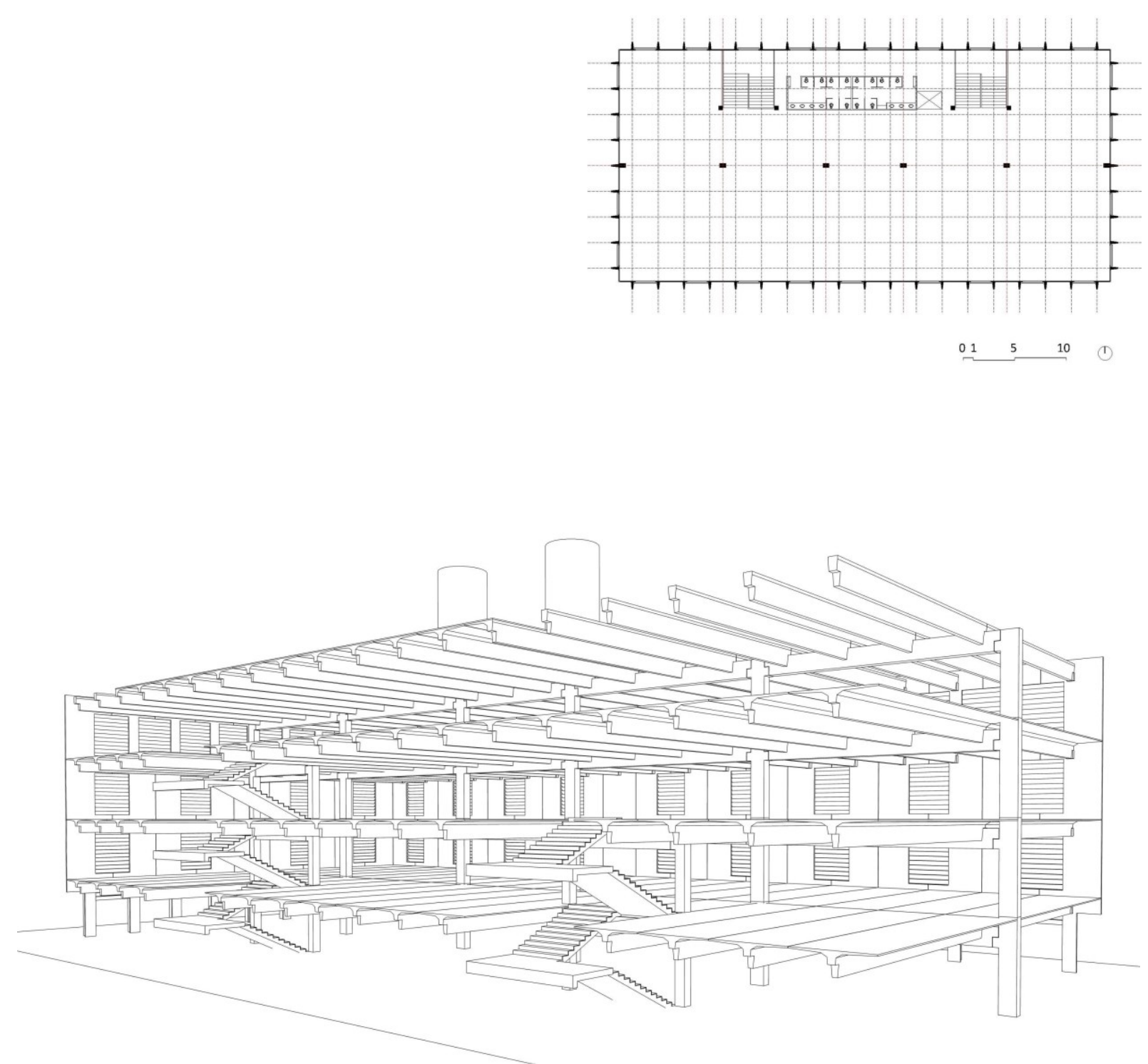

FIG. 43. Planta com a geometria do módulo estrutural e perspectiva em corte com os elementos estruturais do prédio da FAUS. 


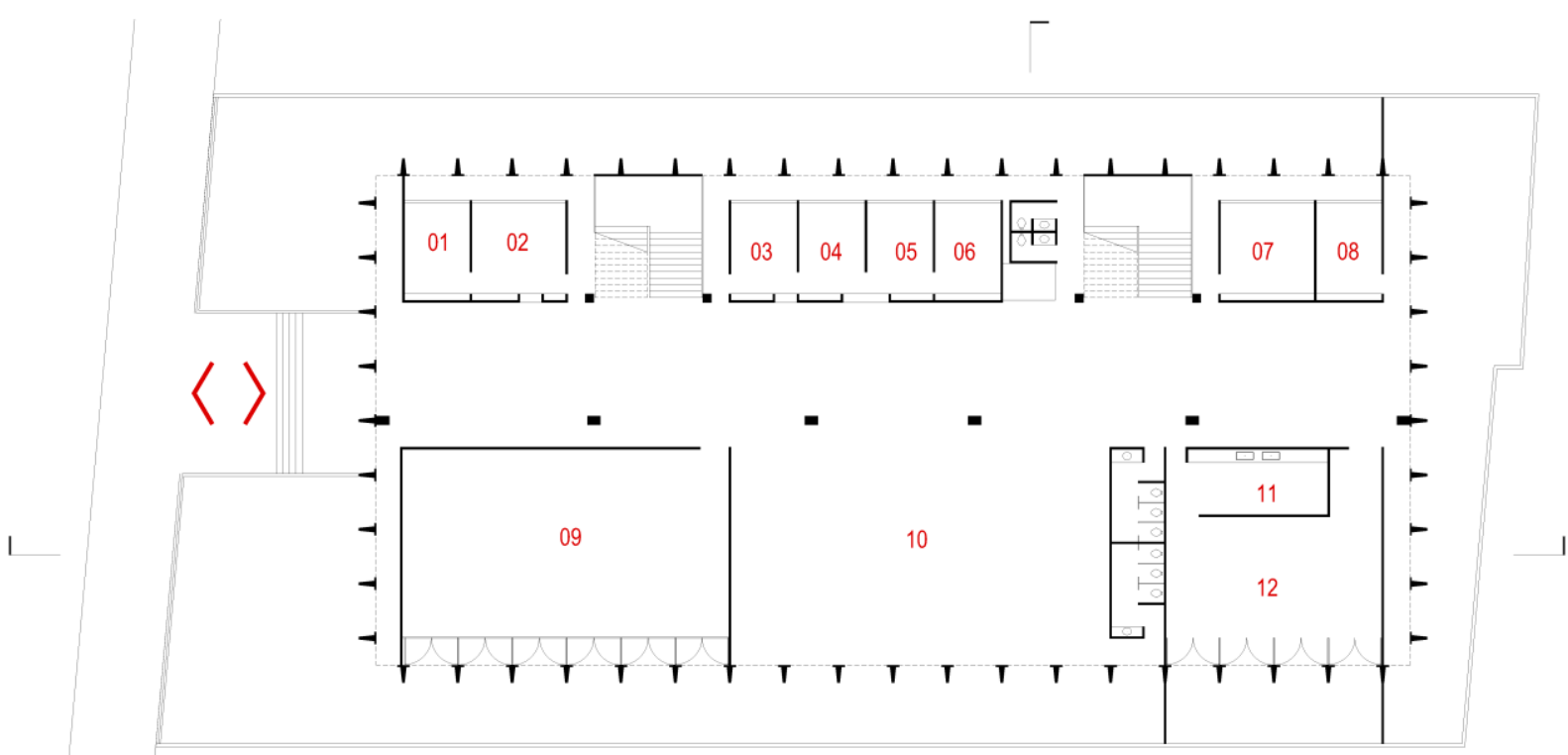

NIVEL +0.90m. PLANTA DO PAVIMENTO TÉRREO

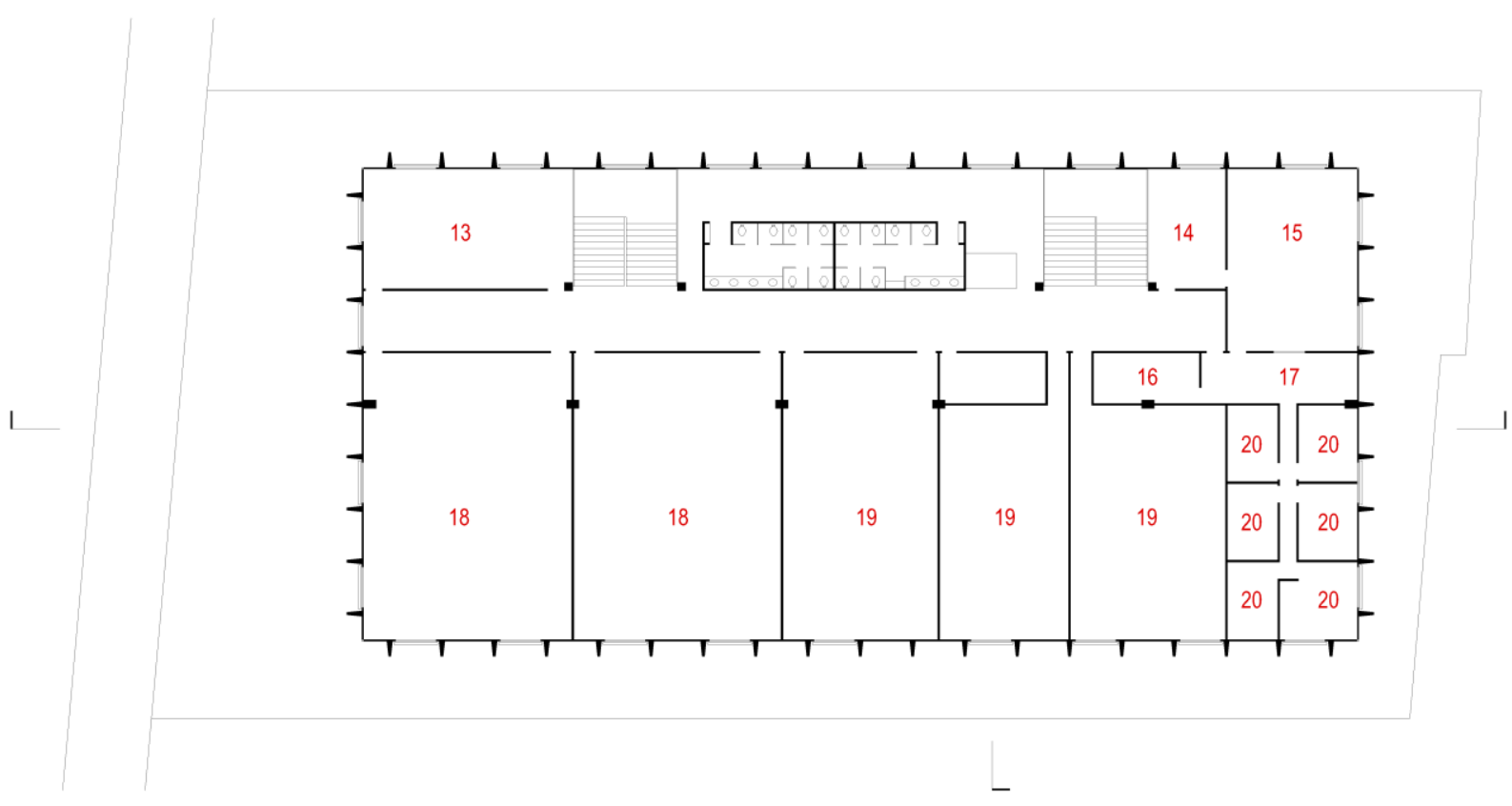

NIVEL + 4.90m. PLANTA DO $1^{\circ}$ PAVIMENTO

01 TESOURARIA 02 SECRETARIA GERAL 03 SECRETARIA DE CIÊNCIAS HISTÓRICAS 04 SECRETARIA DE TECNOLOGIA 05 SECRETARIA DE PROJETO 06 DIRETORIA 07 CONSELHO DEPARTAMENTAL 08 MECANOGRAFIA 09 BIBLIOTECA 10 MÚLTIPLO USO|PRAÇA COBERTA 11 LABORATÓRIO FOTOGRÁFICO 12 MAQUETARIA 13 SALA DOS PROFESSORES 14 DIRETORIA 15 SECRETARIA SERVIÇO SOCIAL 16 TESOURARIA 17 CIRCULAÇÃO 18 ATELIER 19 SALA DE AULA 20 ESTÁGIO 


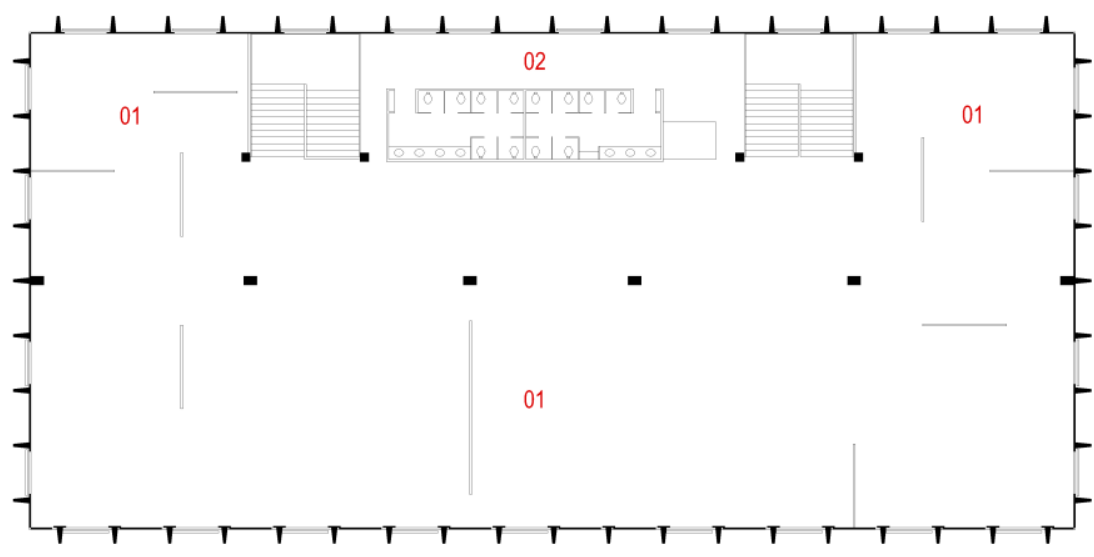

NIVEL +8.90m. PLANTA DO $2^{\circ}$ PAVIMENTO

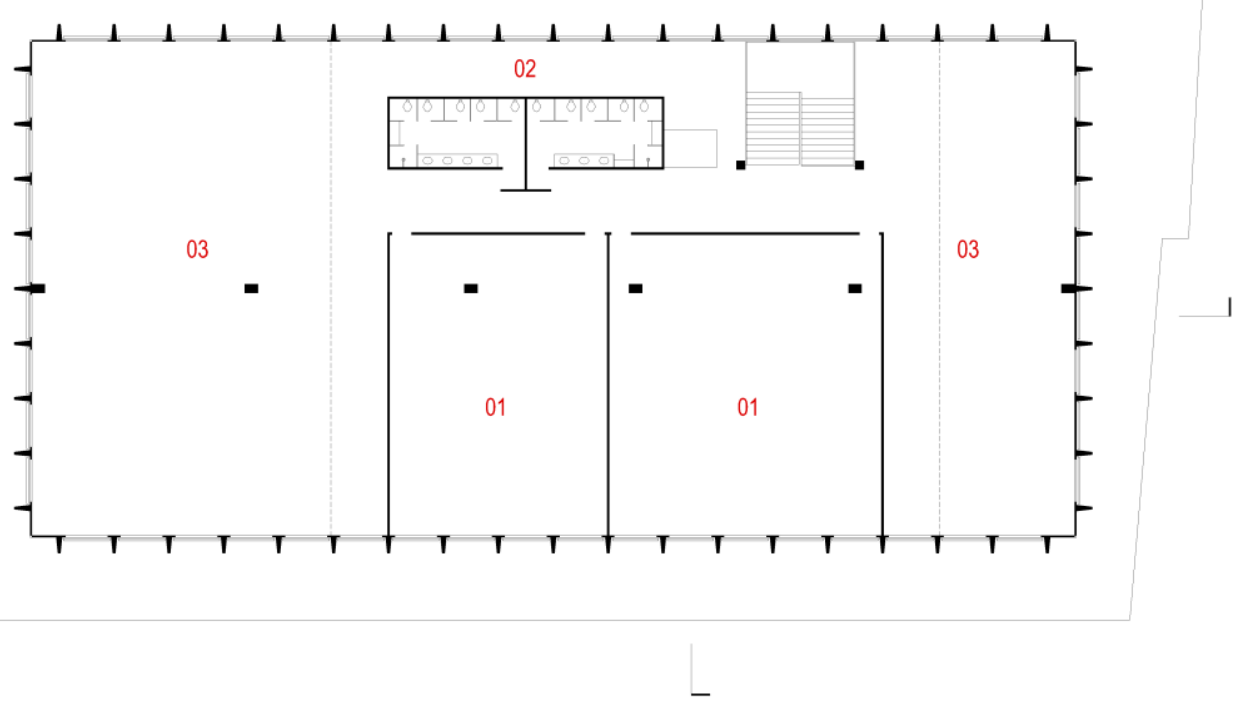

NIVEL $+12.90 \mathrm{~m}$. PLANTA DO $3^{\circ}$ PAVIMENTO

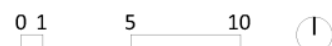

01 ATELIER 02 APOIO 03 PERGOLADO

FIG. 45. Projeto executado em 1976. 


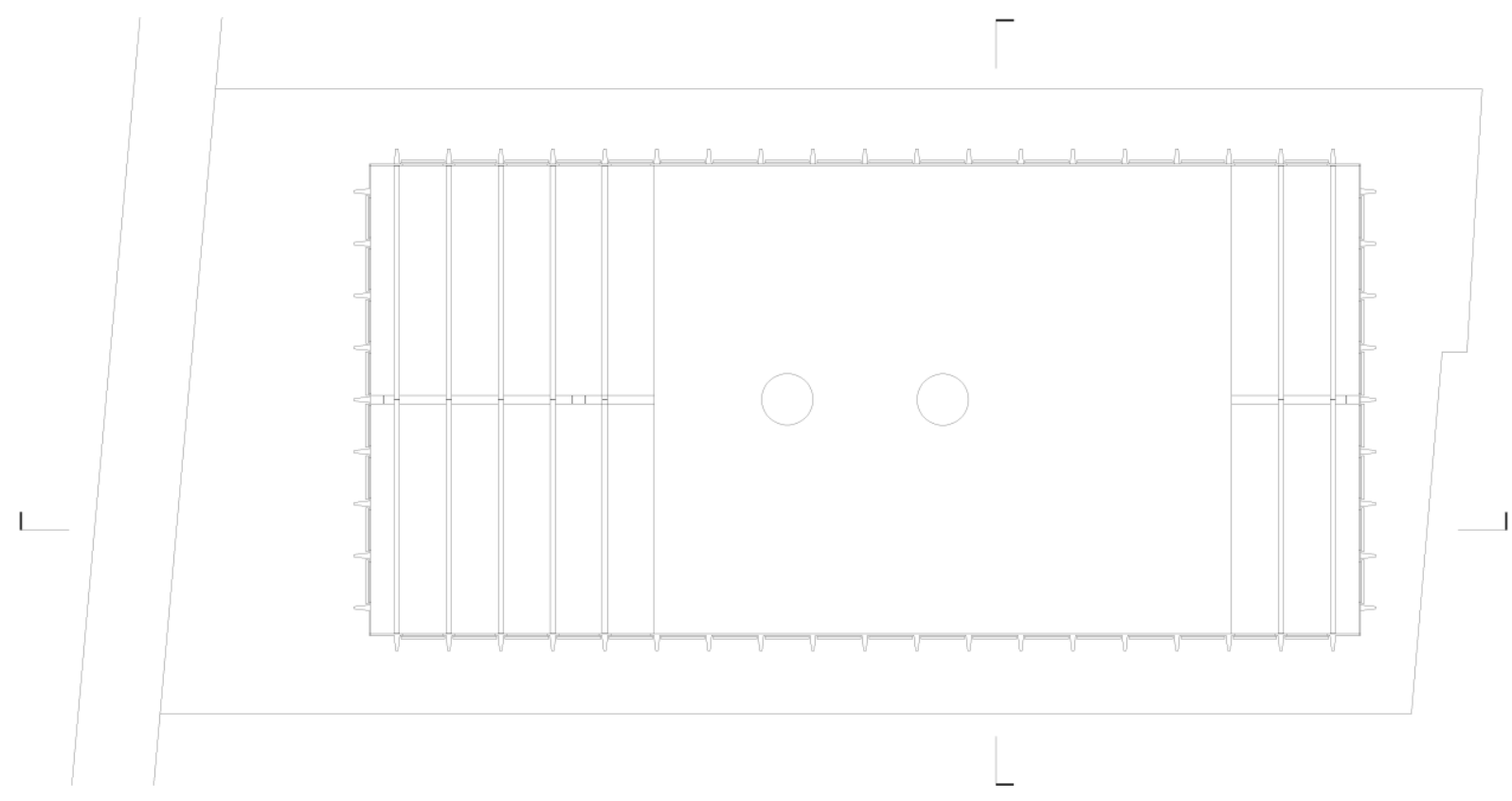

NIVEL +16.90m. PLANTA DA COBERTURA

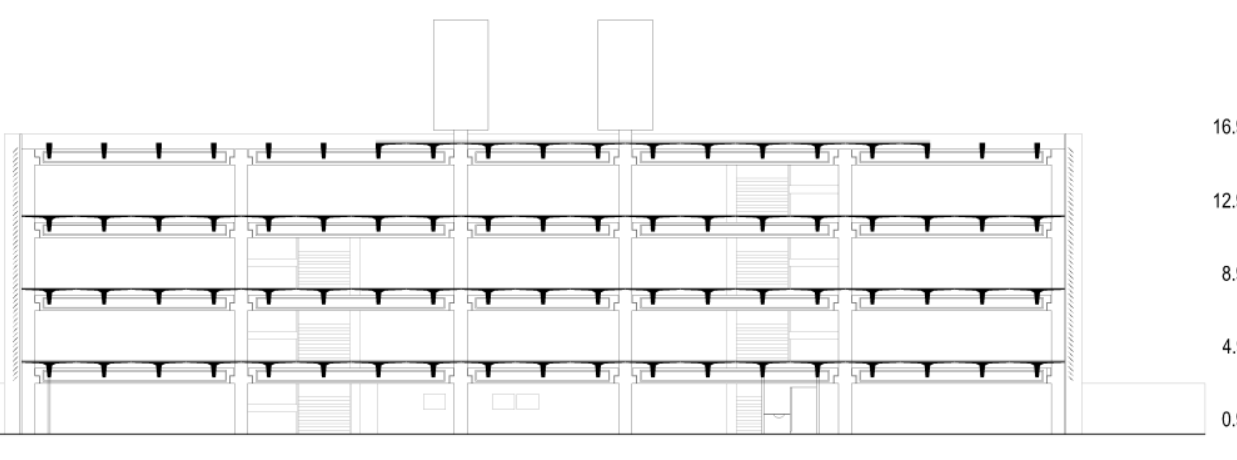

CORTE LONGITUDINAL

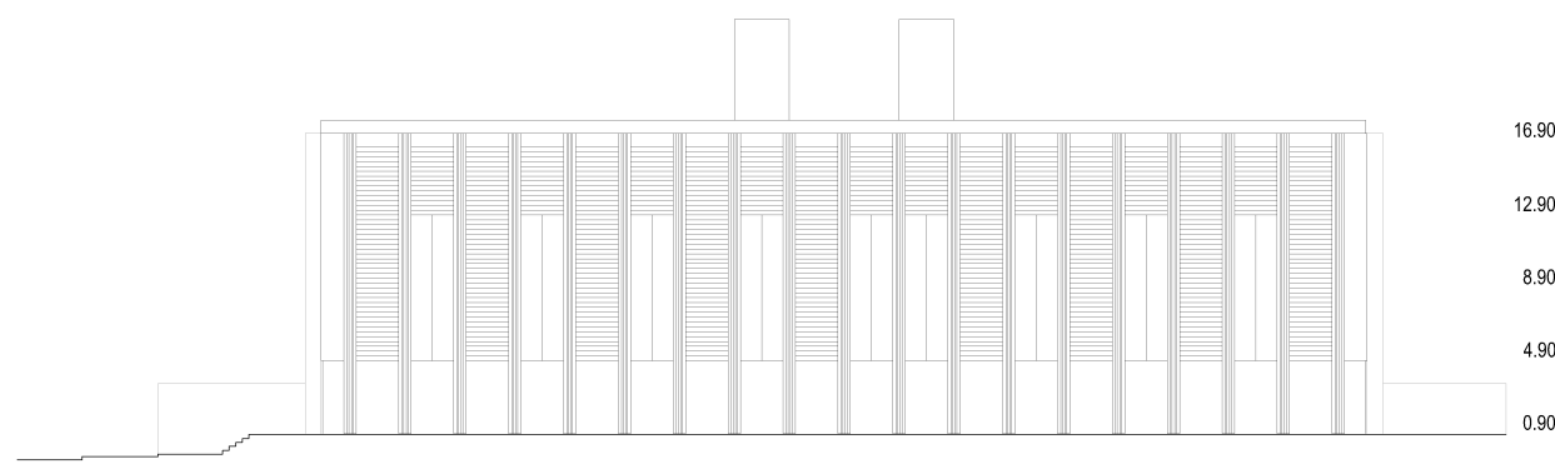

ELEVAÇÃO SUL 


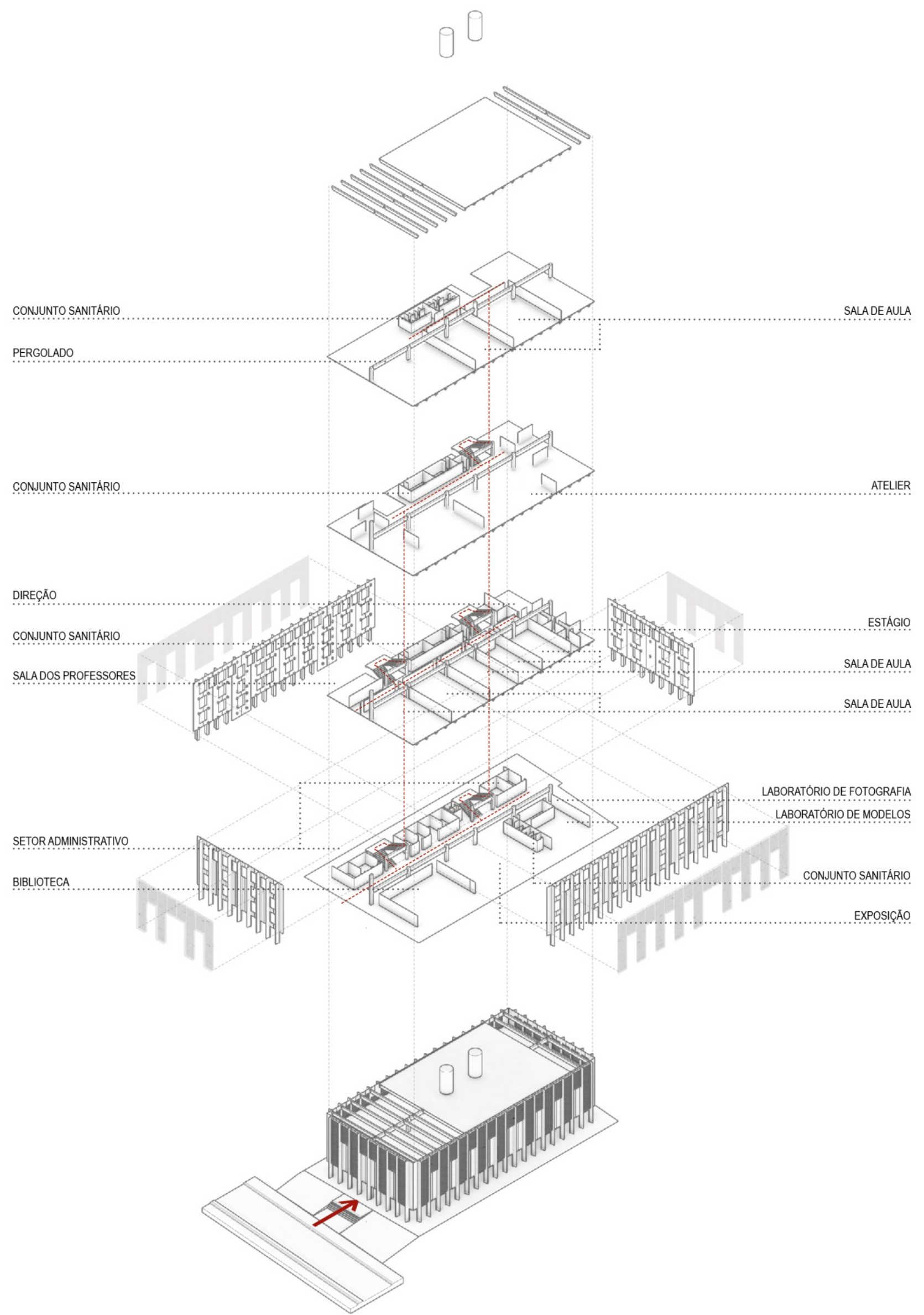

FIG. 47. Usos e circulações do projeto executado em 1976. 


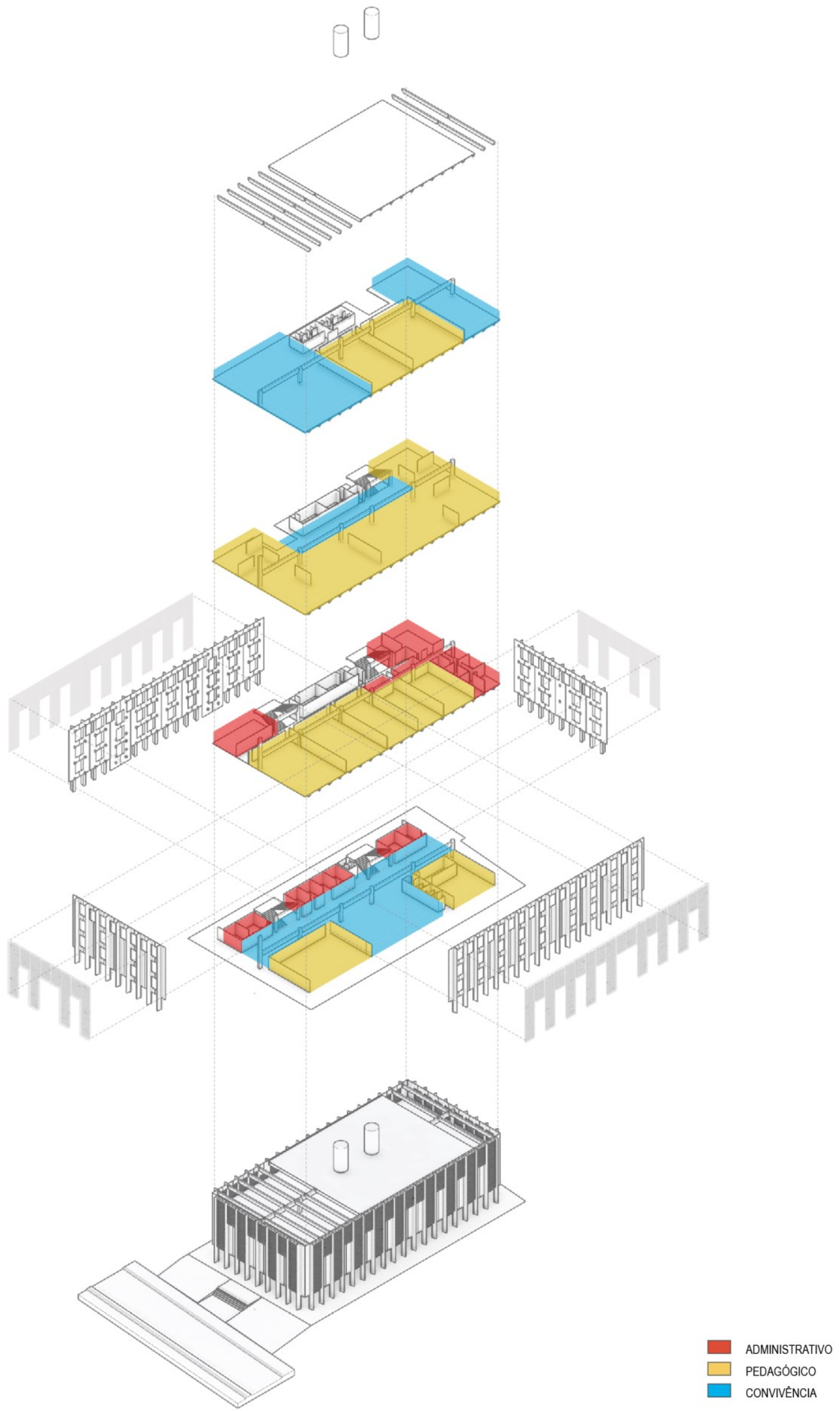

FIG. 48. Zoneamento do projeto da FAUS em 1976. 


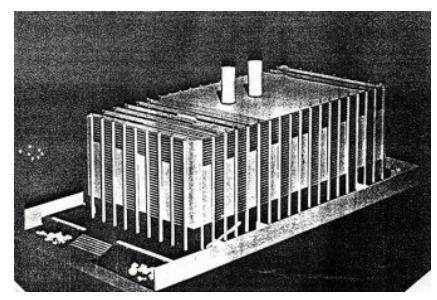

FIG. 49. Maquete do prédio da FAUS.

O contrato para a construção da FAUS foi assinado em 12 de julho de 1973, durante um evento da I Bienal Internacional de Arquitetura realizada no pavilhão de exposições do Ibirapuera, em São Paulo. Oswaldo Corrêa Gonçalves pretendia que as novas instalações estivessem prontas antes da diplomação da primeira turma em 1974, devido ao já mencionado processo de reconhecimento do curso junto ao MEC. Nesse sentido, a previsão inicial era de 150 dias para a conclusão da obra, a um custo de CR\$ 2.548 mil $^{95}$ ou CR\$ 650,00 por metro quadrado, custo inferior ao de uma construção tradicional, que era de CR\$ 850,00 por metro quadrado. Segundo matéria publicada em um jornal local, a construção teve início em 31 de julho de $1973 .^{96}$

Apesar de o projeto executivo de arquitetura compatibilizado com as demais disciplinas não ter sido localizado, uma análise um pouco mais cuidadosa das partes de alguns projetos complementares encontrados demonstra que existem muitas diferenças entre o projeto aprovado pela prefeitura e o que foi realmente realizado. Além de pequenas alterações na distribuição de alguns itens do programa, como, por exemplo, a recolocação do elevador no projeto, merece destaque a retirada das divisórias do segundo piso, que converteu os sete ateliers independentes em um único e generoso espaço. Esse lugar se tornou o coração da escola. Portanto, os desenhos e diagramas produzidos para auxiliar a leitura e entendimento do projeto e da construção da obra resultaram do cruzamento das informações disponíveis nesses fragmentos de desenho com as datas de sua elaboração, quando disponíveis nas legendas e carimbos dessas peças gráficas.

A postura pioneira dos profissionais envolvidos na obra trouxe consigo a inexperiência, tanto do construtor quanto dos arquitetos do projeto, que aprenderam sobre o sistema com a sua execução e, ao contrário das otimistas expectativas, a construção do edifício se estendeu até 1976. Além de fatores de ordem econômica, resultante de imprevistos e problemas técnicos, a logística de fabricação, transporte e montagem dos elementos pré-moldados de concreto foi determinante para o atraso na entrega do edifício.

\footnotetext{
${ }_{95}$ Convertendo para valores atuais, a partir da cotação do dólar americano em julho de 1973, que valia CR\$ 6,13, e hoje, setembro de 2016, que vale $R \$ 3,27$, o valor da construção da FAUS giraria em torno de $R \$ 1.359 .210,44$, ou seja, $R \$ 3.467,37$ por metro quadrado.

${ }^{96}$ Ver o artigo, Estrutura pré-moldada: novidade anunciada para o prédio da FAUS. Jornal A tribuna de Santos, 21 de julho de 1973. 


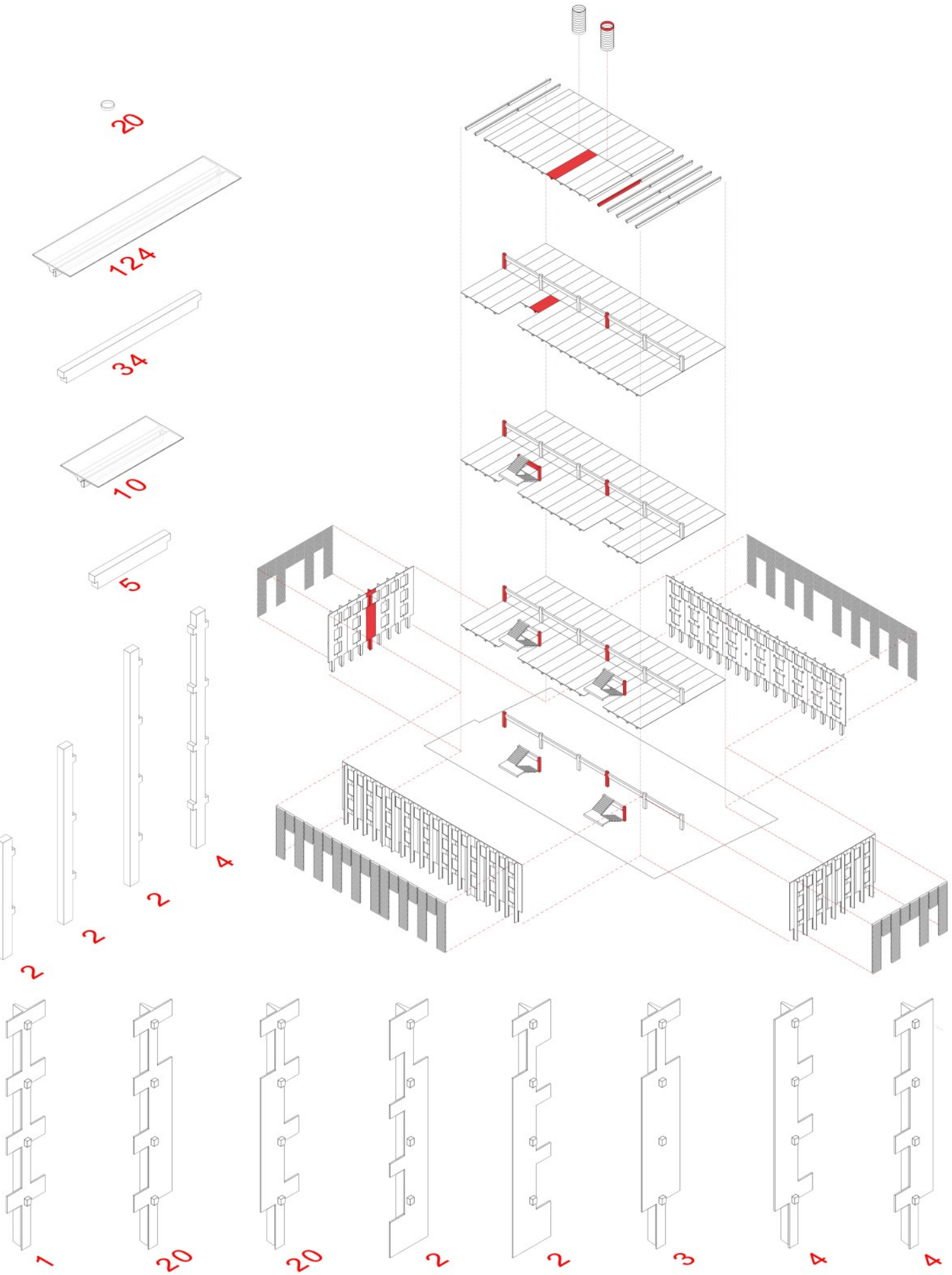

FIG. 50. Classificação dos elementos estruturais componíveis do Prédio da FAUS. Sistema estrutural totalmente pré-fabricado com vigamento protendido, as peças de fechamento do edifício são desenhadas na mesma modulação de 2,50 metros dos painéis das lajes, perfazendo um total de 259 peças. 
Todas as peças foram feitas em São Paulo na fábrica da Construtora Rodrigues Lima, algumas delas tinham aproximadamente 17 metros de comprimento e, devido às suas dimensões, desceram a Serra do Mar pela sinuosa Rodovia Padre Anchieta em caminhões especiais e em horários específicos, geralmente durante a madrugada, quando o tráfego era baixo tanto na estrada como na cidade de Santos.

Ao descarregar a primeira remessa de peças, foi constatado que era preciso iniciar a obra de trás para frente, pois o guindaste deveria operar dentro do lote. Dessa forma, o prédio foi montado integralmente (três pavimentos e cobertura) por trechos, sucessivamente, até chegar à frente do terreno, quando as últimas peças da fachada frontal foram instaladas. A Construtora Rodrigues Lima alterou toda a lógica de fabricação e de envio para atender essa estratégia, e a montagem foi concluída em pouco mais de um ano e meio. Devido às características do projeto, concluída a montagem o prédio estava praticamente pronto, restando apenas o acabamento.

Contudo, surgiram novos contratempos que implicaram na descontinuidade da obra. O mais grave foi a necessidade de se executar um enchimento de aproximadamente $15 \mathrm{~cm}$ em todos os pavimentos, para corrigir a contra flecha dos painéis de laje protendidos. Esse procedimento provocou um expressivo aumento na sobrecarga da estrutura, principalmente nas mísulas e consoles de encaixe das vigas e painéis de laje. Foi necessário consultar um especialista em pré-moldados de concreto armado e, dessa maneira, a engenheira Maria Aparecida de Azevedo Noronha foi contratada para realizar um extenso processo de esclerometria ${ }^{97}$ em toda a edificação, além de ensaios com concreto sem agregados finos para executar os enchimentos com a menor carga possível. Nesse sentido, a solução adotada foi a utilização de concreto leve com argila expandida para o contra piso, juntamente com a construção de reforços nas mísulas dos painéis verticais de fechamento. ${ }^{98}$

\footnotetext{
${ }^{97}$ Regulado pela NBR 7584, esse procedimento consiste em um ensaio não destrutivo, cujo objetivo é a verificação da dureza superficial do concreto, e mede o retorno de uma força no regime elástico após seu impacto com a superfície do concreto.

${ }^{98}$ Texto elaborado a partir do depoimento do professor e engenheiro responsável pela obra da FAUS, Sérgio Novita Fortis, coletado pelo autor em 22 de setembro de 2016. 

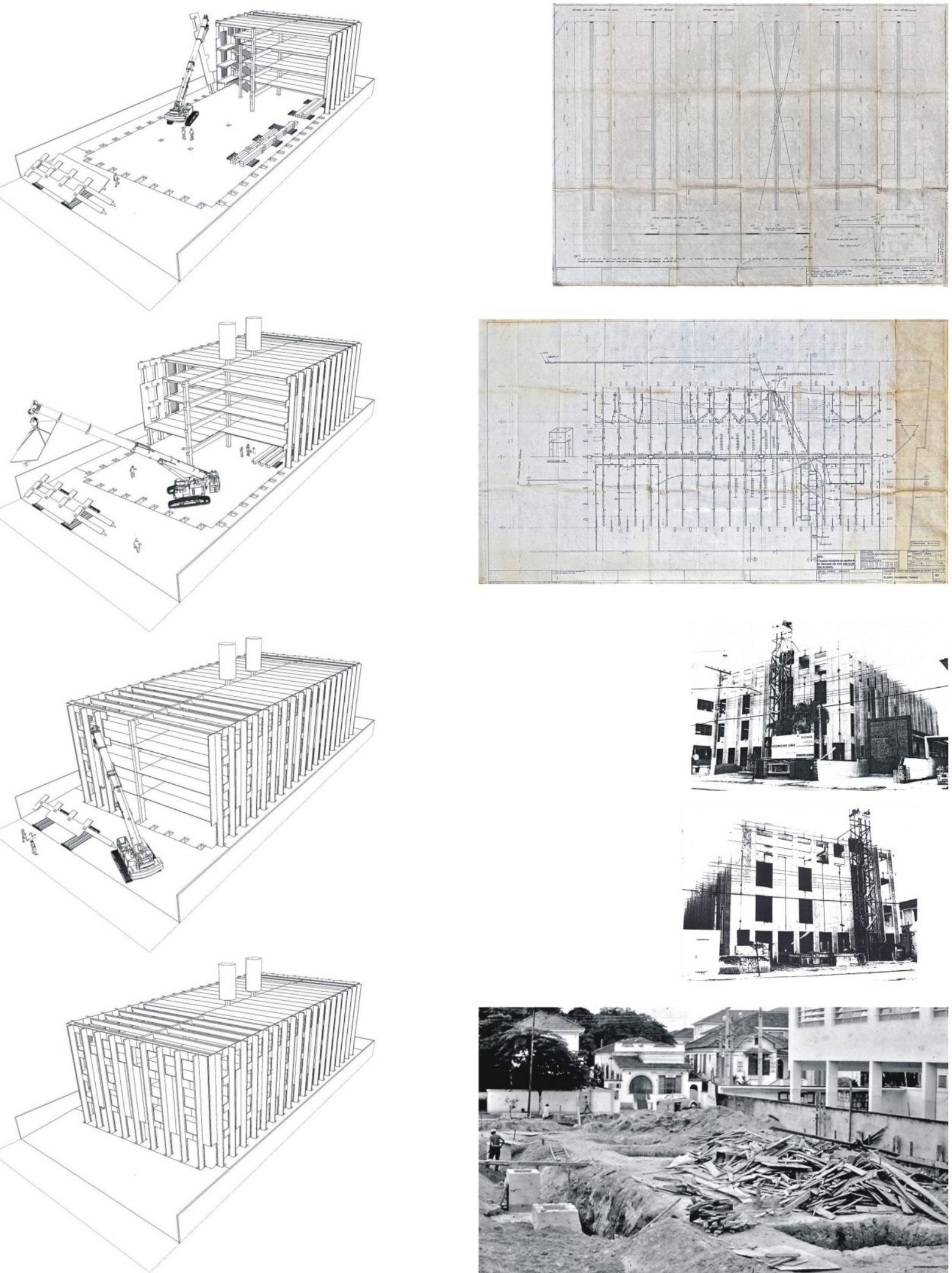

FIG. 51. À esquerda, diagrama do processo construtivo. À direita, de cima para baixo, projeto executivo estrutural dos painéis de fechamento e painéis de laje; projeto executivo das instalações elétricas do pavimento térreo; fase final da construção com as peças montadas e execução das fundações do prédio da FAUS. 
Resolvido o problema estrutural, os compartimentos do pavimento térreo e os compartimentos de apoio dos demais pavimentos foram construídos com blocos de concreto que permaneceram aparentes. As divisões das salas de aula e demais dependências administrativas foram feitas com painéis industrializados de madeira. Os banheiros e copas receberam revestimentos de mosaico de vidro coloridos, painéis melamínicos e divisórias em argamassa armada. Entretanto, o atraso na montagem da superestrutura do edifício configurou um problema mais complicado para os estudantes da primeira turma, que já haviam concluído o curso em 1974 e aguardavam com grande preocupação a conclusão da obra para reconhecimento do título conquistado. Esse fato obrigou a direção a obter a autorização da SVSL para ocupar o prédio ainda inacabado, sem que a caixilharia e os elementos de proteção solar estivessem completamente instalados. Finalmente, com a entrega do prédio, a FAUS foi autorizada a continuar em funcionamento através do Decreto de reconhecimento no $77.441 / 1976 .{ }^{99}$

O prédio era imenso, abrigava cinco turmas de 70 alunos, totalizando 350 estudantes e, nesse período, havia somente o curso de arquitetura. Configurava um espaço grande, amplo e até pouco aproveitado, pois ainda estava sendo apropriado. Apesar de ter iniciado suas atividades, ainda havia algumas coisas para definir, as salas estavam prontas, o atelier era um espaço único e generoso como é hoje. Na cobertura tínhamos um pergolado que, segundo o projeto original, era um espaço de lazer dos alunos de arquitetura. ${ }^{100}$

A presente leitura demonstra o caráter didático desse projeto que, juntamente com sua construção, envolveu professores e alunos na discussão, concepção e desenvolvimento das propostas, e teve como objetivo construir um edifício com caráter inovador na região. A materialidade apresentada em sua forma bruta, estrutura, vedações e instalações totalmente aparentes, com a aplicação de materiais industrializados e indo além de aspectos como ritmo, leveza e transparência desde o início, teve pretensões de ser um instrumento de apoio ao ensino. A austeridade alcançada através do rigor técnico com poucas operações de obra constituiu uma arquitetura capaz de reafirmar o propósito de que o desenvolvimento e a aplicação de novos conceitos e tecnologias configuram novas possibilidades para o desenvolvimento econômico e social do país, ou seja, uma contundente afirmação da linha escolhida após a crise de 1972: a linha de Vilanova Artigas.

\footnotetext{
${ }_{99}^{9}$ DECRETO № 77.441 - DE 14 DE ABRIL DE 1976 concede reconhecimento ao curso de Arquitetura e Urbanismo da Faculdade de Arquitetura e Urbanismo de Santos, com sede na cidade de Santos, Estado de São Paulo. UNIVERSIDADE CATÓLICA DE SANTOS. Projeto Pedagógico de Curso - Arquitetura e Urbanismo. Op.cit. p. 4.

${ }^{100}$ Entrevista com o professor Marco Antônio Lança, FAUS 1975-1979, para o estudante Gabriel Curti e transcrita pelo estudante João Guilherme Marques. Parte de uma série de entrevistas promovidas pelo Diretório Acadêmico Michail Lieders, com professores egressos da FAUS, entre maio e setembro de 2011, sobre o “Projeto de tombamento do Prédio da FAUS". DIRETÓRIO ACADÊMICO MICHAEL LIEDERS. Projeto de tombamento do Prédio da FAUS. Santos, 2011.
} 

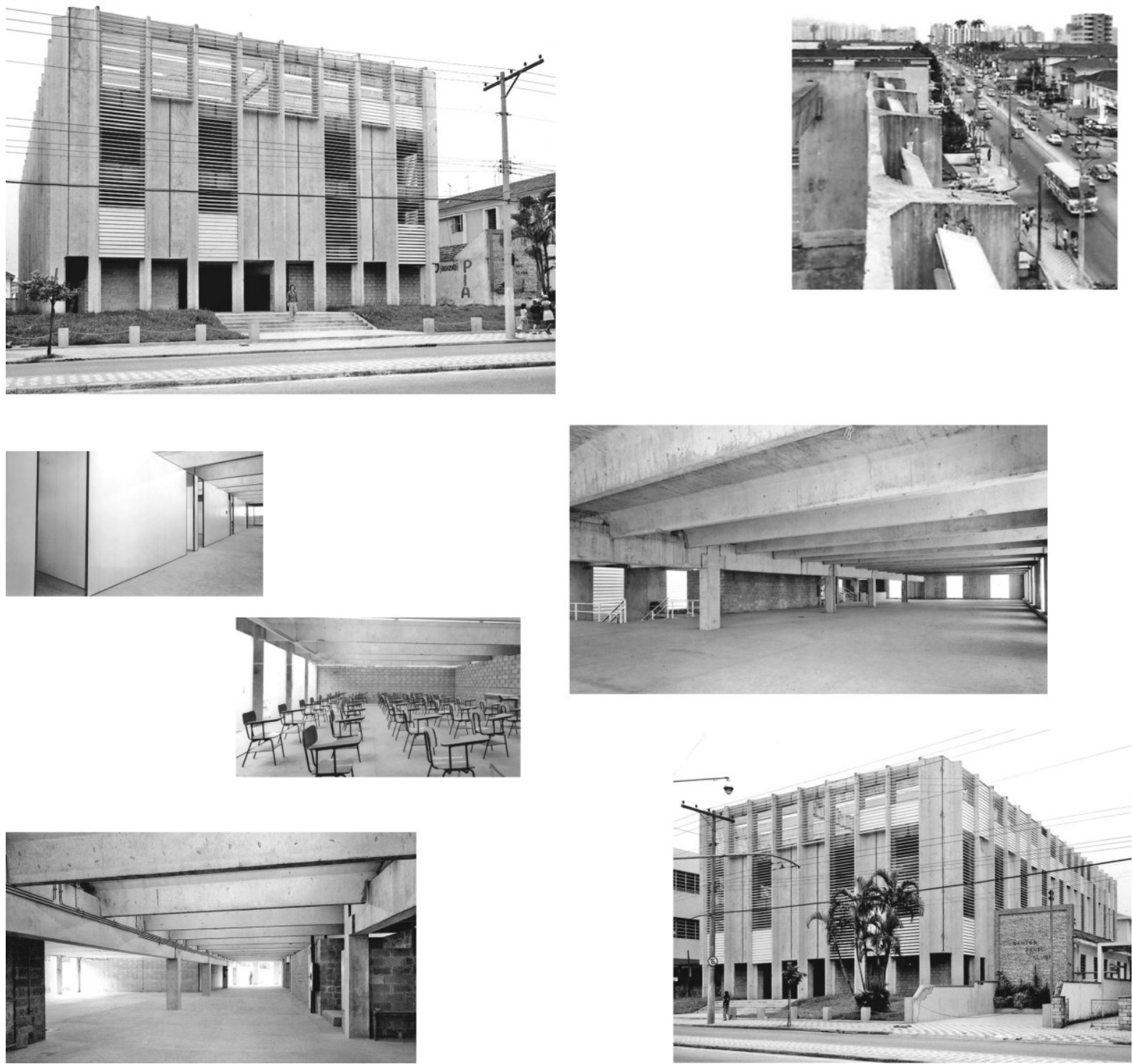

FIG. 52. Coluna da esquerda acima, prédio da FAUS inaugurado em 1976, nota-se a ausência de portas; abaixo sala de aula e circulação e vista interna do pavimento térreo, dos fundos para a frente. Coluna da direita acima, aspecto da Avenida Conselheiro Nébias no final da década de 1970, a partir do pergolado da FAUS; abaixo, vista interna do Atelier sem esquadrias e vista externa do prédio.

Apesar desse sistema não ter se mostrado tão econômico e rápido quanto o esperado, obrigando a mantenedora a entregar o edifício inacabado, a ausência dos fechamentos estabeleceu com a cidade virtuosas relações de continuidade espacial, um constante convite para o visitante e, ao mesmo tempo, uma constante afirmação para seus estudantes da importância do caráter público e coletivo na formação do arquiteto. Essa inesperada, porém, bem-vinda relação com a cidade somou-se aos espaços de convívio da escola. Nesse sentido, merece destaque o atelier, projetado como espaço de produção, e o pergolado da cobertura, projetado como lugar de contemplação. Para o professor Jon Maitrejean, "era uma escola de cidade, uma escola inserida na cidade." 101

${ }^{101}$ Além da ênfase urbana, Jon Maitrejean destaca a radicalidade do sistema construtivo do prédio da FAUS, que o inspirou a projetar sua casa, nos anos 1970 em São Paulo, utilizando materiais industrializados, inclusive o mesmo módulo e painéis divisórios desenvolvidos para a FAUS. Trecho da entrevista de Jon Maitrejean concedida ao autor em 01 de julho de 2016. 
Em resumo, tal fato, curiosamente, está relacionado ao inicial caráter itinerante da FAUS, mesmo que movido por questões operacionais e financeiras, e permitiu aos seus estudantes e professores o reconhecimento da cidade através do deslocamento das suas instalações pela malha urbana de Santos. Quando questionado acerca da falta de laboratórios nessas estruturas adaptadas para uma faculdade de arquitetura, Oswaldo Corrêa Gonçalves tinha um verdadeiro prazer em afirmar que: "a cidade é o laboratório da FAUS".

Os elementos necessários para que o ensino da arquitetura e do urbanismo fosse ministrado na Região da Baixada Santista estavam dados: corpo discente, corpo docente, pedagogia e espaço.

\begin{abstract}
O acerto da criação de uma Faculdade de Arquitetura e Urbanismo em Santos, polo de desenvolvimento da Baixada Santista, é comprovado pela procura cada vez maior da mocidade estudiosa, presente aos exames de vestibulares. Por outro lado, a solicitação e demanda, seja por parte da iniciativa privada, seja por parte do poder público, do concurso de nossos estudantes, para utilização de seu conhecimento, ainda em fase de formação, em prestação de serviços da sua futura especialidade, dizem do acerto daquela decisão. Hoje, a Faculdade de Arquitetura e Urbanismo de Santos já constitui um patrimônio, não só da cidade, mas da região e do estado. Como elemento ativo da cidade, está em condições não só de prestar serviços à sua comunidade, mas também reivindica o direito de emitir opinião sobre os seus destinos. ${ }^{102}$
\end{abstract}

Do ponto de vista político, os embates ideológicos entre distintos grupos de professores da FAU-USP, matizados na FAUS em seus anos iniciais, conferiram caráter próprio à escola e foram capazes de deixar marcas indeléveis em seus primeiros estudantes. Inclusive, alguns desses egressos tornaramse professores e atualmente lecionam na FAUS. Nesse sentido, pode-se dizer seguramente que ainda transmitem aquele espírito crítico às novas gerações. Em síntese, interessa saber em que medida a opção feita pelo projeto como instrumento de emancipação e sustentação política, sedimentada com a proposta para a elaboração do projeto para a construção de sua sede própria, "O prédio da FAUS", como síntese de sua pedagogia, influenciou, ou não, para a construção de sua identidade.

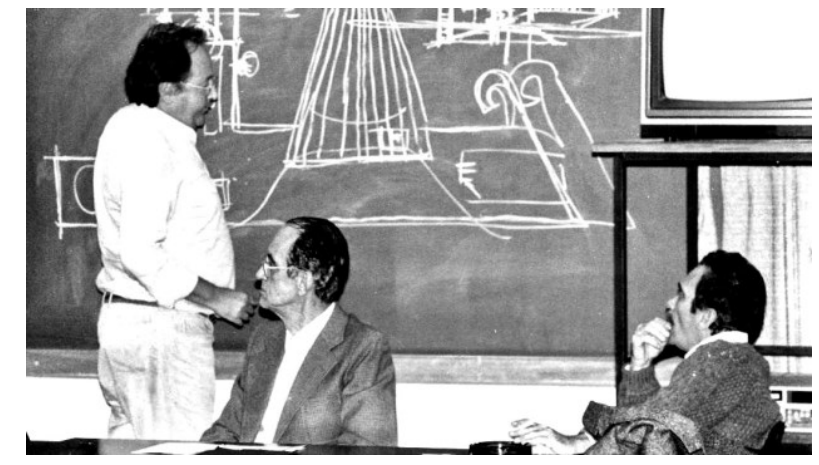

FIG. 53. Abrahão Sanovicz, Oswaldo Corrêa Gonçalves e Julio Katinsky.

${ }^{102}$ GONÇALVES, Oswaldo Corrêa. Oração do Paraninfo. FAUS, 1976. mimeo. 


\section{3 \\ CONTINUIDADE}

Princípio da ruptura a-significante: contra os cortes demasiados significantes que separam as estruturas, ou que atravessam uma estrutura [...] há ruptura no rizoma cada vez que linhas segmentares explodem numa linha de fuga, mas a linha de fuga faz parte do rizoma. Essas linhas não param de se remeter umas às outras. É por isso que não se pode contar com um dualismo ou dicotomia, nem mesmo sob a forma rudimentar do

bom e do mau. ${ }^{1}$

Ainda no contexto dos capítulos anteriores, importa ressaltar que a elaboração do projeto para da FAUS, sua fundação e seus primeiros anos de funcionamento ocorreram durante o conturbado período da ditadura militar, marcado principalmente pela perda de direitos e liberdade de expressão. Como forma de resistência, o viés político e ideológico ancorado nas teorias marxistas que permeavam os meios intelectuais, universidades e movimentos estudantis, ganhou força ao longo da década de 1970. Nesse sentido, pode-se dizer que o ensino da arquitetura no Brasil, grosso modo e dentre outros pontos, ao enfatizar o papel social do arquiteto, alinhava-se ao principal conceito defendido pelos VKhUTEMAS e, até certo ponto, pela Bauhaus: a natureza socialista e proletária da arquitetura do estilo internacional do início do século XX. Aqueles arquitetos, artistas, professores e

\footnotetext{
${ }^{1}$ DELEUZE, Gilles; GUATTARI, Félix. Mil platôs, capitalismo e esquizofrenia. Vol. 01. São Paulo: Editora 34, 1995. p.18.
} 
estudantes inauguraram uma nova forma de pensar arquitetura, uma forma de invenção utópica, coletiva e capaz de promover uma grande transformação do mundo através da elevação do espírito aos altos ideais artísticos, materializados e construídos através da técnica.

\begin{abstract}
Quando se fala em estilo internacional, qualquer comunista, como eu naquele tempo, logo sabia que o sentido da internacionalidade era de origem proletária, universal. Quer dizer, universal pelo conteúdo, nacional pela forma. Uma arquitetura internacional seria aquela que servisse ao total da humanidade e tivesse suas formas nacionais cobrindo a internacionalidade da intenção. Essa relação entre formas e conteúdo é tipicamente do pensamento dessa época e, particularmente, de Lênin. ${ }^{1}$
\end{abstract}

Isto posto, é possível dizer que a primeira crise institucional da FAUS, meticulosamente registrada pelos alunos, foi provocada justamente por questões políticas expondo as fraturas de natureza ideológica abertas no Fórum de 1968 na FAU-USP. A FAUS seguiu a linha de Vilanova Artigas do desenho como desejo e emancipação, princípio materializado com a construção de seu próprio edifício. Entretanto, a contínua falta de autonomia da escola não se limitou às relações administrativas e financeiras com a Sociedade Visconde de São Leopoldo, mantenedora das Faculdades Católicas de Santos, mas também com o governo militar. O período que se seguiu foi marcado pelas diversas tentativas de censura dentro da própria faculdade, resultante das relações entre professores e alunos que, sob o pretexto de ameaças subversivas, viviam um processo de desconfiança mútua, pois sabiam que seus movimentos eram acompanhados de perto pela inteligência do alto comando do exército. O professor Graeff melhor define essa condição "o docente, reprimido e ameaçado, recebe o tratamento que se dá ao peão relapso e de pouca confiança; e o estudante comparece no sítio como um tipo imaturo, irresponsável e mal-intencionado, presa fácil de maus pensamentos e de ideologias exóticas..." ${ }^{2}$

Em 1976, ano em que a FAUS inaugurou seu novo prédio, a Faculdade de Arquitetura e Urbanismo de São José dos Campos (FAU-SIC) foi fechada e, indo além das justificativas de ordem econômica apresentadas pela Mantenedora Fundação Valeparaibana de Ensino (FVE), a extinção da escola tinha motivações ideológicas e políticas e resultava de pressões internas e externas ao universo institucional. Esse fato provocou um novo movimento migratório de professores e a FAUS recebeu os arquitetos Ari Vicente Fernandes, Paulo de Mello Bastos e Jorge Caron ${ }^{3}$ que, enfraquecidos para se reorganizarem politicamente naquele momento, aceitaram as condições de trabalhar sob a linha de

\footnotetext{
${ }^{1}$ ARTIGAS, João Batista Vilanova. A função social do arquiteto. São Paulo: Nobel, 1989. p. 60. Segundo Segawa, a reconstituição do raciocínio de Vilanova Artigas, em diferentes períodos, demonstra "correlações que permitem compreender a coerência interna do pensamento desse arquiteto, fundamental na formulação de conceitos que embasaram a arquitetura paulista nos anos de 1960". SEGAWA, Hugo. Arquiteturas no Brasil 1900-1990. São Paulo: EDUSP, 2002. pp. 145-146.

2 GRAEFF, Edgar Albuquerque. Arte e técnica na formação do arquiteto. São Paulo: Nobel, 1995. p. 50.

${ }^{3} \mathrm{Na}$ FAUS desde 1975 e assim como o professor Paulo Bastos, o professor Jorge Caron também executava projetos e, em 1987, ao ingressar como professor-colaborador na Escola de Engenharia de São Carlos, afirmou: "a qualidade que me apontava para a indicação era a minha experiência como profissional "prancheteiro", o que, se por um lado me causava satisfação, por outro lado, deixava em segundo plano um trabalho de vinte e poucos anos em que tentei construir-me como educador". CARON, 1999, p. 15. Apud. RUGGIERO, Amanda Saba. Jorge Caron: uma trajetória. 2006. 183p. Dissertação (Mestrado em arquitetura e urbanismo) Escola de Engenharia de São Carlos, Universidade de São Paulo. São Paulo, 2006. pp. 78-79.
} 
Vilanova Artigas. Nesse ponto, interessa dizer que o legado deixado por Sérgio Ferro, Rodrigo Lefèvre, Francisco de Oliveira, Mayumi Watanabe e Sérgio Souza Lima, definitivamente, não foi algo para ser desconsiderado e, de certo modo, foi continuado, ainda que sutilmente, em um primeiro momento pelos seus ex-alunos da FAUS e, posteriormente, pelos professores refugiados da FAU-SJC.

A resistência à repressão e à imposição de pedagogias instrumentais do governo consolidou e afirmou a importância dos movimentos estudantis na luta pela elaboração coletiva e paritária de estruturas curriculares críticas, pautadas por princípios libertários para a melhor formação do arquiteto. Esses grupos formados dentro de escolas públicas e particulares, independente da atuação do governo, promoveram debates de alto nível com instituições governamentais a partir dos escritos de professores como Edgar Graeff, Ari Fernandes, Jorge Caron, dentre outros.

Mas, naquele momento, a tênue linha de paz não era forte o bastante para suportar o desgaste do contínuo processo de discussão entre grupos tão heterogêneos e, nesse sentido, no início de 1980, a FAUS viveu uma nova crise que, diferente da polarização do quadro docente e discente da escola em 1972, unificou professores e estudantes na luta contra as esferas de poder instituídas. Configurou uma nova oportunidade para se repensar qual era o perfil do arquiteto formado na FAUS, qual o papel da escola na cidade e na região e como estabelecer parâmetros paritários e democráticos nas decisões dos caminhos a serem tomados daquele momento em diante.

O processo de aperfeiçoamento do currículo do curso de arquitetura conduzido pelo MEC com a criação de novas disciplinas, laboratórios, centros de pesquisa e extensão, somado às questões específicas colocadas pelas crises de 1972 e 1982, debatidas pela comunidade da FAUS e da SVSL, orientaram as sucessivas reformas que o prédio da escola sofreu ao longo dos anos 1980 até os dias de hoje. Dessa maneira, tanto as exigências curriculares do governo como as imposições políticas e administrativas da mantenedora resultaram na criação de compartimentos específicos para o ensino em detrimento dos espaços coletivos de convívio e socialização docente e discente.

Apesar dos problemas oriundos das crises, ameaças e paralizações, desde sua inauguração em 1976 até o presente momento, o atelier da FAUS se converteu no principal lugar da ininterrupta busca pela síntese dos conhecimentos produzidos na escola. Constitui a força motriz de captação e processamento de subsídios sociais e urbanos, convertendo ideias em projetos, no seu sentido mais amplo, divulgando e devolvendo para a cidade a produção de estudantes e professores no campo da arquitetura e do urbanismo. 


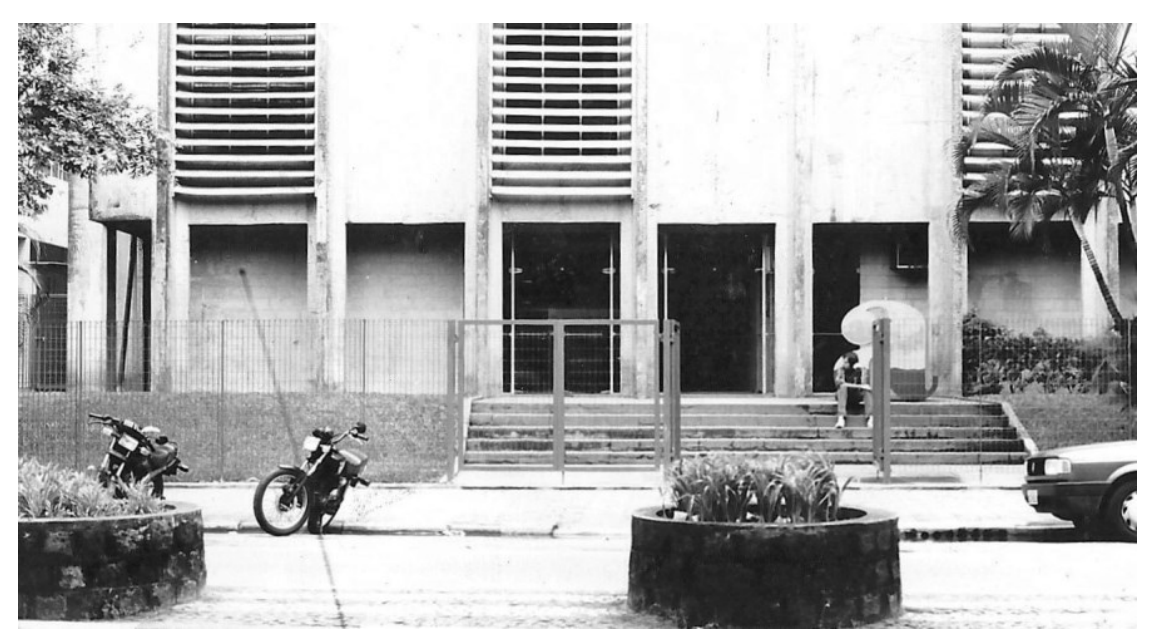


Resistência e afirmação

As prisões dos professores Sérgio Ferro e Rodrigo Lefèvre em 1970, e a posterior crise em 1972, inevitavelmente, posicionaram a FAUS como um núcleo de resistência ao governo ditatorial e a escola passou a ser monitorada pela inteligência do alto comando do exército. No início do ano de 1972, a Delegacia de Ordem Política e Social de Santos (DOPS-Santos) abriu dois prontuários, um para a FAUS, registrado como "Faculdade de Arquitetura e Urbanismo de Santos", prontuário no 1359, e outro para o seu diretório acadêmico, registrado como "Centro Acadêmico Lucio Costa", prontuário no 3679. Naturalmente, esses dois arquivos compilavam informações que expandia o universo da escola e, dessa maneira, a Sociedade Visconde de São Leopoldo e demais cursos relacionados ao campo das Ciências Sociais das Faculdades Católicas de Santos também eram monitorados. $^{1}$

Em 1973, Oswaldo Corrêa Gonçalves recebeu um aviso reservado do Ministro da Educação e Cultura, ${ }^{2}$ recomendando que encontros e reuniões de estudantes tais como congressos, conferências, simpósios, seminários, competições científicas, culturais ou desportivas, cursos especiais ou qualquer outro tipo de reunião deveria ter autorização da faculdade e toda a documentação deveria ser encaminhada com antecedência mínima de noventa dias "necessária à apreciação deste Ministério". Recomendava ainda que o evento deveria ser acompanhado pelo dirigente da entidade onde se realizou o encontro e que, "para estimativa dos benefícios advindos", deveria ser enviado um relatório circunstanciado para o Gabinete do Ministério de Estado até trinta dias após o seu encerramento.

Reconheço a delicadeza do assunto, dado que não pretendemos impor silêncio aos estudantes, mas é preciso notar que, à falta de motivação para movimento de massa, as esquerdas pretendem, através da ativação aparentemente irresponsável dos Diretórios Acadêmicos, chegar às reuniões de âmbito nacional onde, a par dos assuntos estritamente estudantis, se desenvolva a articulação de novas lideranças voltadas para a subversão. Natural é que essa manobra causa apreensões e vital é, para nós, que os propósitos esquerdistas sejam firmemente neutralizados. ${ }^{3}$

\footnotetext{
${ }^{1}$ DELEGACIA DE ORDEM POLÍTICA E SOCIAL DE SANTOS (DOPS-Santos). Centro Acadêmico Lucio Costa. Prontuário no 3679. 112p. Santos, 1972. Disponível em <http://www.arquivoestado.sp.gov.br/upload/Deops/Prontuarios/BR_SP_APESP_DEOPS_SAN_P003679_01.pdf.>. Acesso em: 05 ago. 2016. DELEGACIA DE ORDEM POLÍTICA E SOCIAL DE SANTOS (DOPS-Santos). Faculdade de Arquitetura e Urbanismo de Santos. Prontuário no 1359. 138p. Santos, 1972.Disponível em: <http://www.arquivoestado.sp.gov.br/upload/Deops/Prontuarios/BR_SP_APESP_DEOPS_SAN_P001359_01.pdf.>.Acesso em: 05 ago. 2016.

2 Trata-se do ofício no 3444 AEPC encaminhado pelo Diretor da Divisão de Segurança e Informações, com uma cópia do Aviso Reservado n 873/73 de 31 de julho de 1973, do Ministério da Educação e Cultura, em decorrência do aumento da intensidade de encontros e reuniões, sob os mais diversos pretextos, tanto em âmbito nacional, como regional e estadual, sem fiel cumprimento da Portaria no 25, de 17-JAN-68 e do Decreto no 69.053, de 11-AGO-71, assinado pelo ministro Jarbas Gonçalves Passarinho. Arquivo Biblioteca da FAUS.

${ }^{3}$ Elaborado pelo Ministro da Educação Jarbas Passarinho. Aviso reservado no 873/73 de 31 de julho de 1973 , do Ministério da Educação e Cultura. Arquivo Biblioteca da FAUS.
} 
Ao mesmo tempo em que o governo criava mecanismos para neutralizar os movimentos políticos e ideológicos estudantis dados como subversivos, no final do ano de 1973 foram criados dois órgãos com o objetivo de aprimorar o ensino da arquitetura e do urbanismo. O primeiro foi a Associação Brasileira de Escolas de Arquitetura ABEA, que teve como primeiro presidente o professor Nestor Goulart Reis Filho (na época diretor da FAU-USP), como vice-presidente o professor Aluízio José Rosa Monteiro (FAU-SJC) e a secretaria da associação foi assumida pela professora Marlene Yurgel (FAUUSP). ${ }^{4}$ Seus objetivos eram congregar as instituições de ensino de Arquitetura e Urbanismo para que desenvolvessem suas atividades educacionais e culturais de forma apolítica e independente, não tomando posições político-partidárias e discriminatórias quanto a ideologias, crenças religiosas ou origens raciais. Somente depois disso estava o aprimoramento e aperfeiçoamento dos métodos de ensino, qualificação docente, apoio à pesquisa e promoção do intercâmbio de experiências. ${ }^{5}$

O segundo órgão fundado foi a Comissão de Especialistas no Ensino de Arquitetura e Urbanismo (CEAU), pertencente ao Departamento de Assuntos Universitários (DAU) do Ministério da Educação e Cultura. Seu objetivo era a verificação das condições de funcionamento das escolas e colaborar com o MEC na fixação de diretrizes nesse campo. A CEAU era presidida pelo diretor do DAU-MEC e a comissão composta por um representante do Instituto dos Arquitetos do Brasil, por diretores ou representantes de quatro ou cinco escolas (sendo uma delas particular) e de um representante do Serviço Federal de Habitação e Urbanismo (SERFHAU). ${ }^{6}$

O acordo MEC-USAID se mostrava um eficiente e poderoso instrumento de privatização, em larga escala, do ensino superior brasileiro. Entretanto, como não previa políticas de qualificação e ampliação do corpo docente no país, em 1974, a maioria dos professores eram profissionais horistas, improvisados no novo ofício, com reduzida importância política e pedagógica o que revelava a baixíssima qualidade de ensino praticado nas novas escolas. ${ }^{7}$ Ao mesmo tempo, como fator agravante, o avanço tecnológico e a ampliação dos problemas urbanos e habitacionais brasileiros demonstravam que a formação do arquiteto e urbanista deveria ser aperfeiçoada. O primeiro boletim da ABEA destacou a necessidade de substituição do currículo mínimo de 1969 por um currículo novo e atualizado. Segundo Gutierrezabea, o objetivo era deter o processo de criação de novas faculdades de arquitetura e urbanismo e viabilizar políticas de avaliação das escolas em

\footnotetext{
${ }^{4}$ Fundada no dia 22 de novembro de 1973, na ocasião do 1 o Encontro de Diretores de Escolas de Arquitetura, a mesa diretora foi composta pelo reitor da UnB, Amadeu Cury; pelo vice-reitor, o capitão de mar e guerra José Carlos Azevedo; pelo diretor adjunto do Departamento de Assuntos Universitário (DAU) do Ministério da Educação e Cultura, Dr. Lynaldo Albuquerque e pelo professor Miguel Pereira, como presidente do Instituto de Arquitetos do Brasil e diretor do Instituto de Artes e Arquitetura (1969-1976) da UnB. O Encontro teve a participação de dezenove escolas de instituições de ensino superior, sendo oito públicas e onze privadas. GUTIERREZABEA, Ester Judite Bendjouya. "A Associação Brasileira de Ensino de Arquitetura e os seus primeiros tempos (1973-1985)". In ASSOCIAÇÃO BRASILEIRA DE ENSINO DE ARQUITETURA E URBANISMO. A construção de um novo olhar sobre o ensino de Arquitetura e Urbanismo no Brasil: Os 40 anos da ABEA. Brasília: ABEA, 2013. p. 24.

${ }^{5}$ GUTIERREZABEA, Ester Judite Bendjouya. Ibid. p. 25.

${ }^{6}$ Criado pela Portaria Ministerial no 699, em 18 de dezembro de 1973. GUTIERREZABEA, Ester Judite Bendjouya. Ibid. p. 26.

${ }^{7}$ GRAEFF, Edgar Albuquerque. Op. cit. p. 51. 
funcionamento. Nessa mesma direção, durante a primeira reunião da CEAU em janeiro de 1974, foi estabelecido um cronograma com um conjunto de recomendações que contava com a cooperação da ABEA para sua realização:

- Suspender a criação de novos cursos ou escolas de arquitetura no país, até que a Comissão reexaminasse os requisitos mínimos para tanto para sua realização;

- Elaboração de um diagnóstico da situação atual do ensino de arquitetura e urbanismo;

- Estudo dos currículos, atribuições e modelos de ensino;

- Definição de um sistema permanente de informação para renovação de orientação no campo educacional;

- Estudo do mercado de trabalho e estabelecimento de planos de expansão para pós-graduação, especialização e pesquisa. ${ }^{8}$

Em 1976, uma nova diretoria assumiu a ABEA, o professor Eduardo Corona (FAU-USP e FAU-UBC) assumiu a presidência, o professor Oswaldo Corrêa (diretor da FAUS) assumiu a vice-presidência e o professor Ruy Gama (FAU-USP) a secretaria. O I Encontro Regional de Escolas de Arquitetura, realizado na Pontifícia Universidade Católica de Campinas (PUC-CAMP), marcou o início de uma nova etapa no ciclo de reuniões e debates da ABEA: a substituição dos eventos nacionais por encontros regionais. Nesse encontro participaram sete escolas da região da grande São Paulo que trataram do ensino de Estruturas, Teoria e História da Arquitetura, Conforto Ambiental, Projeto do Edifício, Planejamento, Desenho Industrial, Comunicação Visual e Paisagismo. ${ }^{9}$
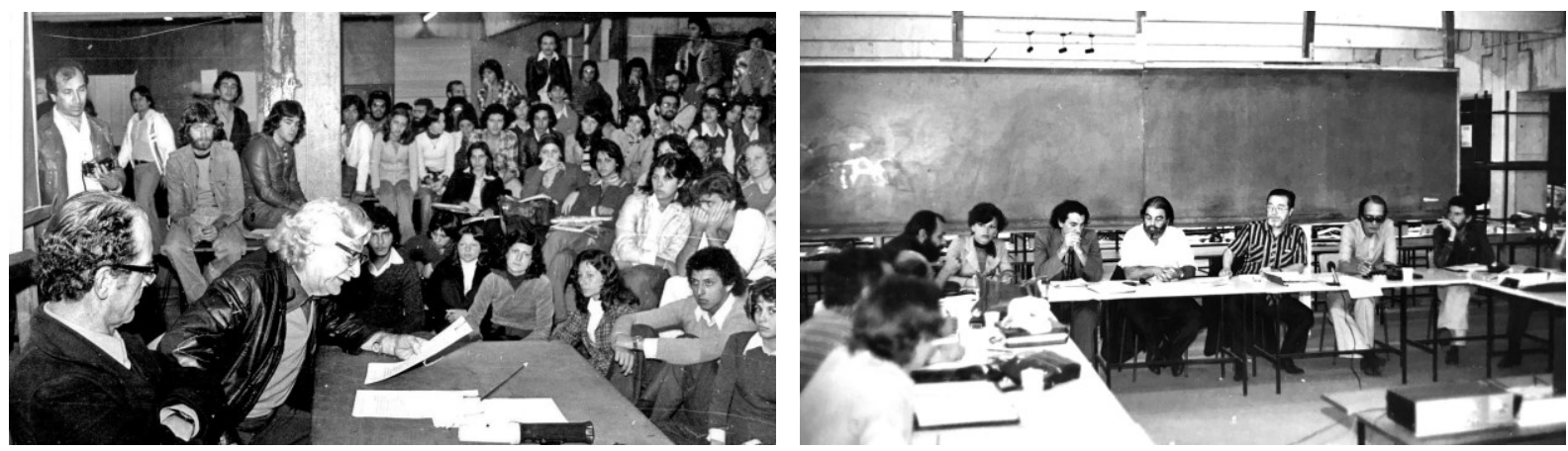

FIG. 54. Conferência de Roberto Burle Marx no atelier da FAUS em 27 de setembro de 1976 e reunião da ABEA, também no atelier da FAUS em dezembro do mesmo ano.

Entretanto, o movimento estudantil via esses órgãos como organismos burocráticos criados "de cima para baixo", orgânica e estatutariamente como parte de mais um mecanismo da política educacional do Estado. Os estudantes identificavam contradições nas propostas defendidas, tanto pela ABEA como pela CEAU, inerentes às instituições pouco democráticas, onde apenas seus dirigentes estavam envolvidos no processo de discussão e decisão para implantar gradativamente as diretrizes impostas pela Reforma Universitária. Ao desconsiderarem os aspectos ideológicos e políticos, fundamentais à

\footnotetext{
${ }^{8}$ GUTIERREZABEA, Ester Judite Bendjouya. Op. cit. pp. 26-27.

${ }^{9}$ Esse primeiro encontro ocorreu em maio de 1976. GUTIERREZABEA, Ester Judite Bendjouya. Ibid. p.28.
} 
construção coletiva de novos modelos de ensino, ignoravam os interesses dos estudantes e professores, pois segundo estes, ambas as instituições estavam focadas na instrumentação técnica dos cursos com o claro objetivo de atender às exigências do mercado de trabalho.

Em resposta ao convite da ABEA para participação do I Encontro Regional de Escolas de Arquitetura, realizado na PUC-CAMP, as representações estudantis das FAU's do estado de São Paulo encaminharam um comunicado dando ciência de que haviam realizado várias reuniões abertas de caráter consultivo e uma plenária no dia 25 de maio de 1976, na FAU-USP. Em síntese, deliberaram que não aceitariam uma estrutura que não permitia a ampla participação de todos os estudantes, professores e profissionais com direito a voz e voto em condições de igualdade e que os legítimos organismos de representação dos estudantes e professores eram, de um lado, os diretórios e centro acadêmicos e, de outro, as associações de professores, entidades livres e abertas. ${ }^{10}$

Assim não aceitamos quaisquer representações das escolas para Encontros como o de Campinas, convidando os participantes a se retirarem. Somente com base na livre organização dos estudantes, professores e profissionais de Arquitetura, com participação ampla em nível regional e nacional, será conduzida a luta pela melhoria de ensino, na formação profissional do arquiteto, subordinada às reais necessidades da maioria da população brasileira. ${ }^{11}$

Esse documento foi lido por um aluno na abertura do Encontro de Campinas seguindo-se a imediata retirada de todos os estudantes presentes ao auditório. Em seguida, os representantes das FAU's enviaram um comunicado para os diretórios e centros acadêmicos das faculdades de arquitetura, afirmando a necessidade de se retomar a livre organização, com participação ampla, para estruturação de bases efetivas na esfera regional e nacional. ${ }^{12}$ Foi elaborado um calendário com reuniões semanais, durante o mês de junho de 1976, para organizar um ciclo de debates que seria realizado em julho do mesmo ano na FAU-USP. Essas discussões tinham como objetivo definir o local, temas e organizar de maneira geral o Encontro Regional de São Paulo, seguido do Encontro Nacional de Estudantes de Arquitetura (ENEA), previsto para novembro de 1976.

\begin{tabular}{l|c|c}
\hline \multicolumn{2}{c}{ CALENDÁRIO DE REUNIÕES DAS FAU'S DO ESTADO DE SÃO PAULO - JUNHO 1976} \\
DATA & LOCAL & HORÁRIO \\
\hline QUINTA-FEIRA DIA 03/06/1976 & FAU-SANTOS & $14 \mathrm{hO0}$ HORAS \\
QUINTA-FEIRA DIA 10/06/1976 & FAU-SÃO JOSÉ DOS CAMPOS & $14 \mathrm{~h} 00$ HORAS \\
QUARTA-FEIRA DIA 16/06/1976 & FAU-BRÁS CUBAS (MOGI DAS CRUZES) & $9 \mathrm{h00} \mathrm{HORAS}$ \\
QUINTA-FEIRA DIA 23/06/1976 & FAU-FARIAS BRITO (GUARULHOS) & $9 \mathrm{h00} \mathrm{HORAS}$ \\
\hline
\end{tabular}

TAB. 08. Quadro elaborado pelo autor com base no comunicado das FAU's do Estado de São Paulo.

\footnotetext{
${ }^{10}$ Formulado pelas delegações de estudantes da FAU-Brás Cubas - Mogi das Cruzes; FAU-PUC - Campinas; FAU-FB Farias Brito - Guarulhos; FAU-MACK - São Paulo; FAU-UMC - Mogi das Cruzes; FAU-SJC - São José dos Campos; FAU-USP - São Paulo e FAU- Santos. FAU'S DO ESTADO DE SÃO PAULO; DELEGAÇÕES DE ESTUDANTES. Comunicado à diretoria da Associação Brasileira de Escolas de Arquitetura e aos participantes do encontro regional de Campinas. São Paulo, 25 mai. 1976. Arquivo Diretório Acadêmico Michail Lieders.

${ }^{11}$ FAU'S DO ESTADO DE SÃO PAULO; DELEGAÇÕES DE ESTUDANTES. Comunicado à diretoria da Associação Brasileira de Escolas de Arquitetura e aos participantes do encontro regional de Campinas. São Paulo, 25 mai. 1976. Arquivo Diretório Acadêmico Michail Lieders.

12 Ibid. 
Não por acaso, em 8 de maio de 1977 foi publicado, por um jornal da cidade de Santos, um documento elaborado pelos estudantes da FAUS que, insatisfeitos com os rumos das políticas repressivas e o futuro incerto da educação do país, estavam em assembleia permanente debatendo com professores sobre o tema: "Análise estrutural da FAUS e o sistema de ensino no País". Os alunos convidavam a sociedade a participar das atividades programadas na faculdade, como leitura de textos, palestras, apresentação e debate de filmes de curta metragem etc., através do manifesto intitulado Carta Aberta.

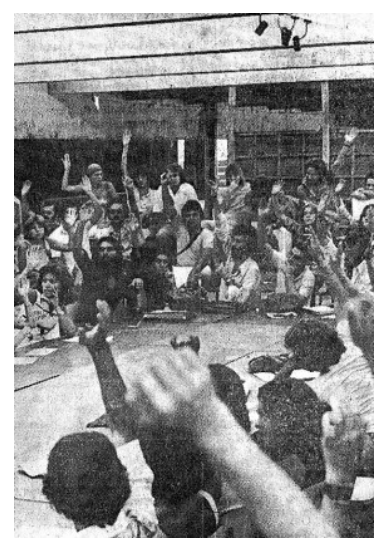

FIG.55. Alunos em assembleia permanente na FAUS.

Em defesa da liberdade democrática que a cada ser humano, indistintamente, deve ser respeitada em quaisquer circunstâncias. Os alunos da FAU de Santos decidiram, em reunião geral ocorrida no dia 05/05/77, manifestar nossa solidariedade às últimas tentativas de organização e manifestação para reivindicar nossos direitos e declarar repúdio a toda e qualquer atitude descabida de força e abuso de poder contra grupos que, positivamente, defendem o interesse comum através de processos democráticos. ${ }^{13}$

Vale lembrar que, naquele momento o Centro de Assessoramento, Pesquisa e Documentação de Arquitetura e Urbanismo da FAUS tinha como objetivos "propiciar a pesquisa e o aprimoramento didático profissional do quadro docente da FAUS" ${ }^{14}$ e oferecia um curso de aperfeiçoamento em pedagogia para arquitetos que desejavam ingressar no corpo docente da escola, sendo chamados de arquitetos-estagiários docentes. Desse modo, o movimento estudantil recebeu apoio irrestrito dos arquitetos-estagiários docentes que consideraram uma oportunidade aberta pelos alunos para um amplo debate a respeito dos processos de ensino da escola, um problema que se estendia ao conjunto da sociedade indo além dos alunos, professores e funcionários. Foram organizados grupos que debateram o tema proposto e, a partir de pesquisas, leituras e discussões, organizaram outros fóruns que deram início à constituição de um rico acervo sobre o ensino de arquitetura naqueles anos.

\footnotetext{
13 JORNAL A TRIBUNA DE SANTOS. Arquitetos estagiários dão apoio aos estudantes. Santos, 8 mai. 1977.

${ }^{14}$ Capítulo 1 - Objetivos; Artigo 3; Alínea A in UNIVERSIDADE CATÓLICA DE SANTOS. Regimento interno do Centro de Assessoramento, Pesquisa e Documentação de Arquitetura e Urbanismo da FAUS. 8p. Santos, 1972. p. 1.
} 

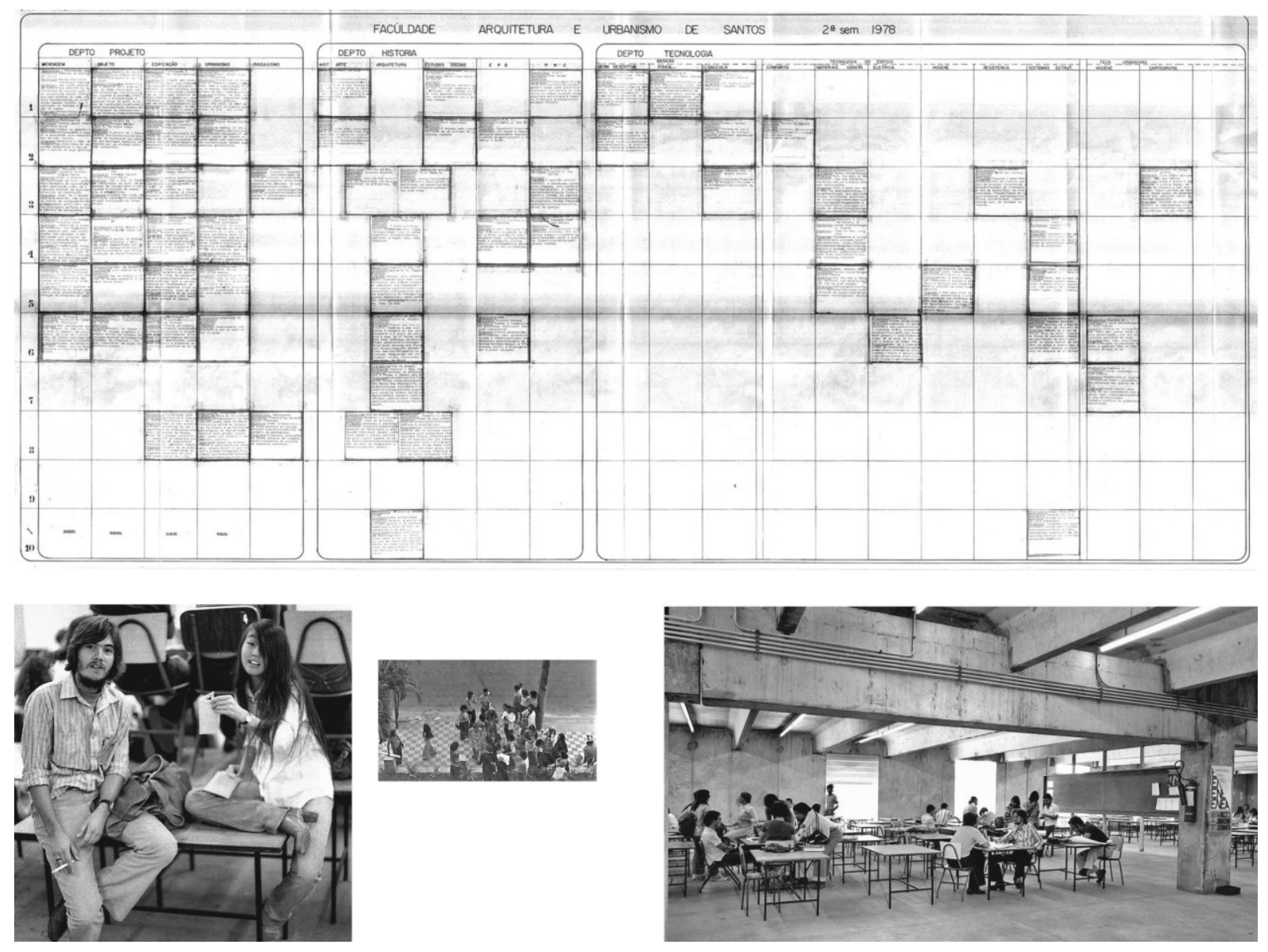

FIG. 56. Quadro para organização das ementas das disciplinas dos Departamentos de Projeto, História e Tecnologia, 1978. Abaixo, Tuca Reinés e Sonia Yamagata, foto de Sérgio Waissmann. Estudantes em frente ao prédio da FAUS, foto de Paulo Martins e Atelier da FAUS operando no final da década de 1970.

No primeiro semestre de 1979, em continuidade aos assuntos iniciados nos fóruns anteriores, estudantes e professores organizaram um ciclo de debates com o tema: "O Ensino de Arquitetura na FAUS". O evento ficou conhecido como Fórum de $1979 .{ }^{15}$ Reuniu o corpo docente e discente na discussão dos objetivos gerais e específicos da escola, na avaliação e reformulação curricular para, a curto prazo, garantir o melhor desenvolvimento do curso. Algumas comissões debateram, ao longo do segundo semestre de 1979, assuntos relacionados ao ensino na FAUS e no Brasil, assim como sobre o processo de constituição da escola. Essas comissões tinham participação paritária entre alunos, professores e funcionários. Como forma de apoio para as discussões foram propostos alguns temas que deveriam ser discutidos. 1. Regimento Interno; 2. Metodologia de Ensino; 3. Currículo Mínimo da Escola; 4. Perfil Profissional; 5. Ciência voltada à Arquitetura como agente de transformação Social e 6. Viabilizações Materiais-Instrumentais. Além disso foram coletados depoimentos dos professores e estudantes da escola sobre o que pensavam acerca da essência da profissão, do ensino e da realidade brasileira. Tudo deveria ser documentado e distribuído para

\footnotetext{
${ }^{15}$ Esses encontros ocorreram na semana do dia 04 ao dia 09 de junho de 1979, nas dependências da FAUS, as resoluções do fórum foram aprovadas em 09 de junho de 1979 pelo Presidente do Diretório Acadêmico Lucio Costa, o estudante Luiz Otávio Zamariolli, pela Secretária, a estudante Claudete Aparecida Júlio e pela Vice-Presidente, a estudante Kelli Arruda. DIRETÓRIO ACADÊMICO LUCIO COSTA. Resoluções do Fórum de Debates. Santos, 1979.
} 
todos os membros da FAUS, para que a discussão fosse constante. Em novembro de 1979, foram apresentadas as Considerações gerais sobre o ensino da FAUS. ${ }^{16}$

A introdução do documento reforçava as teses apresentadas e amplamente discutidas no IX Congresso Brasileiro de Arquitetos de $1976 .{ }^{17}$ Reafirmava a evidente privatização do ensino com a proliferação de escolas "isoladas", ou seja, desvinculadas de uma universidade. Situação estimulada pelo promissor mercado profissional que, de certa maneira, compensava o elevado investimento dos estudantes durante os cinco anos de curso. Reiterava o desconhecimento quase absoluto das mantenedoras a respeito do funcionamento dos cursos de arquitetura que, de maneira geral, contratavam uma equipe inicial de educadores, livres para ministrar as aulas, planejar o curso inteiro, projetar as instalações, infraestruturas e serviços necessários ao funcionamento da nova escola. Desse modo, a concepção dos modelos de escola de arquitetura e urbanismo vigentes na época havia se tornado uma espécie de metiê de alguns profissionais, mas que com as ações da ABEA e do CEAU surgiram as primeiras propostas de modelos gerais de ensino, com caráter regional e nacional. Isto posto, o documento constatava que o modelo de ensino estruturado em três departamentos da FAUS era deficiente e desiquilibrado. Apontava que mesmo dentro dos departamentos, a maioria das disciplinas eram ministradas de forma isolada sem integração vertical e horizontal. Foi verificada a ênfase dada ao Departamento de Projeto que dispunha da maior carga horária do curso, para cumprir o papel de "espinha dorsal da escola", ao passo que o Departamento de Tecnologia basicamente apoiava as atividades de projeto restringindo-se ao campo da tecnologia aplicada, sem desenvolvimento de pesquisas e sem autonomia didática, e o Departamento de Ciências Históricas, responsável pela sustentação teórica inerente ao curso, era uma contradição, pois representava uma separação equivocada entre a teoria e prática. Por se limitar ao simples fornecimento de um "verniza" cultural para distinguir o arquiteto de um técnico projetista, incapaz de elaborar memoriais, justificativas sociais e econômicas dos projetos executados.

Foi apresentado um quadro, extraído do regimento da FAUS, para demonstrar o desequilíbrio na distribuição da carga horária entre os três departamentos. O documento destacava que essa assimetria "tinha origem no modelo de ensino adotado a partir de 1972, quando a escola conseguiu superar uma crise de grandes proporções que a manteve praticamente paralisada por dois semestres

\footnotetext{
${ }^{16}$ DIRETÓRIO ACADÊMICO LUCIO COSTA. Considerações gerais sobre o ensino da FAUS: documento final do III fórum de debates. Santos, 1979.

${ }^{17}$ Assunto já abordado no capítulo anterior, mas vale maior destaque do ponto de vista ideológico: a dependência cultural do país se fortaleceu amparada pela propaganda do governo que celebrava o aumento expressivo de vagas nos cursos superiores. Por volta de 1965 aproximadamente 75 mil estudantes estavam matriculados em faculdades no Brasil, grande parte em instituições públicas e, em 1978, as matrículas alcançavam 1,4 milhão, um aumento de vinte vezes em pouco mais de dez anos, praticamente tudo na esfera privada. GRAEFF, Edgar Albuquerque. Arte e técnica na formação do arquiteto. Op. cit. p. 51.
} 
letivos consecutivos." ${ }^{18}$ E lembrava que a superação da crise se fez pela definição de uma linha "hegemônica" de atividade didática em "detrimento" das demais, priorizando as disciplinas de projeto. O relatório frisava a importância de se praticar o ensino voltado à pesquisa a partir da adoção, consciente e deliberada pelo coletivo da escola, de políticas educacionais que aceitassem a pesquisa como base do processo de formação dos arquitetos.

Isso representa antes de mais nada uma formação crítica e não puramente profissionalizante que se expressa na preocupação permanente de conhecer a realidade sobre a qual se pretende intervir, saber interpretar o significado da atuação profissional, seu compromisso de classe e com as classes da sociedade brasileira, refletindo-se no plano curricular interno em um maior entrosamento das disciplinas e em flexibilidade de conteúdos e permanente debate crítico e avaliação da produção escolar realizada. ${ }^{19}$

CARGA HORÁRIA DO CURRÍCULO PLENO DA FAUS 1979 - DISTRIBUIÇÃO SEMESTRAL EM HORAS/AULA

\begin{tabular}{|c|c|c|c|c|c|}
\hline SEMESTRE & DISCIPLINAS DE PROJETO & DISCIPLINAS DE TECNOLOGIA & DISCIPLINAS DE HISTÓRIA & DISCIPLINAS ISOLADAS & TOTAL \\
\hline 1 & 180 & 135 & 90 & 75 & 480 \\
\hline$\|$ & 180 & 135 & 90 & 105 & 510 \\
\hline III & 270 & 180 & 45 & 105 & 600 \\
\hline IV & 270 & 90 & 45 & 75 & 480 \\
\hline $\mathrm{V}$ & 270 & 135 & 45 & 30 & 480 \\
\hline $\mathrm{VI}$ & 270 & 180 & 45 & 30 & 525 \\
\hline VII & 240 & 180 & 90 & 30 & 540 \\
\hline VIII & 300 & 45 & 90 & 30 & 465 \\
\hline $\mathrm{IX}$ & 300 & - & 45 & 30 & 375 \\
\hline $\mathrm{x}$ & 150 & - & 45 & 30 & 225 \\
\hline TOTAIS DO CURSO & 2430 & 1080 & 630 & 540 & 4680 \\
\hline PERCENTUAIS & $51,9 \%$ & $23,1 \%$ & $13,5 \%$ & $11,5 \%$ & $100,0 \%$ \\
\hline
\end{tabular}

TAB. 09. O quadro síntese da carga horária por Departamento expressa, em números, a composição disciplinar do modelo da escola. Transcrição do anexo do regimento em vigor naquele momento na FAUS.

Por último, as Resoluções do Fórum de 1979 ressaltavam que a inexistência de professores contratados em regime de dedicação exclusiva inviabilizava outras atividades acadêmicas além das aulas regulares, e a falta de infraestrutura de apoio, ou base operacional mínima, constituíam obstáculos a serem transpostos para a realização de pesquisas na FAUS.

É impossível falar de qualidade de ensino sem tocar no aspecto da pesquisa e consequentemente, da produção do conhecimento. Aqui mais uma vez, deve ser feita a ressalva de que não é possível pensar em melhor qualidade de ensino como um compromisso particular ou específico de cada escola: a má qualidade de ensino, a despreocupação com o processo de aprendizagem, a inexistência de pesquisas e de produção de conhecimento, são características de todo o ensino superior brasileiro na atual conjuntura. Estamos diante de um círculo vicioso: se por um lado, uma escola sozinha, pelo seu esforço coletivo (alunos, professores e administração) não pode alterar toda uma conjuntura deficitária de ensino, é certo também que a transformação radical do quadro desanimador ora vigente não pode ser relegada como tarefa de instâncias "superiores" ou externas à escola. Nessas condições dois desvios devem ser evitados: o idealismo ou utopia de resolver tudo a partir do esforço interno, ou o imobilismo e pessimismo de nada fazer até que mude a conjuntura. A história recente das lutas democráticas em nosso país leva a crer que o momento é favorável a um trabalho de organização, crítica, proposição e reivindicação de melhorias nas condições mínimas para tal. E a FAUS apresenta essas condições mínimas. ${ }^{20}$

${ }^{18}$ DIRETÓRIO ACADÊMICO LUCIO COSTA. Considerações gerais sobre o ensino da FAUS: documento final do III fórum de debates. Santos, 1979.

19 Ibid.

${ }^{20} \mathrm{lbid}$. 
A ênfase com que os estudantes solicitavam a instalação de programas de pesquisa na escola leva a crer que o Centro de Assessoramento, Pesquisa e Documentação de Arquitetura e Urbanismo da FAUS, criado em 1972, era um organismo obsoleto no que se refere ao incentivo e operacionalização da pesquisa acadêmica.
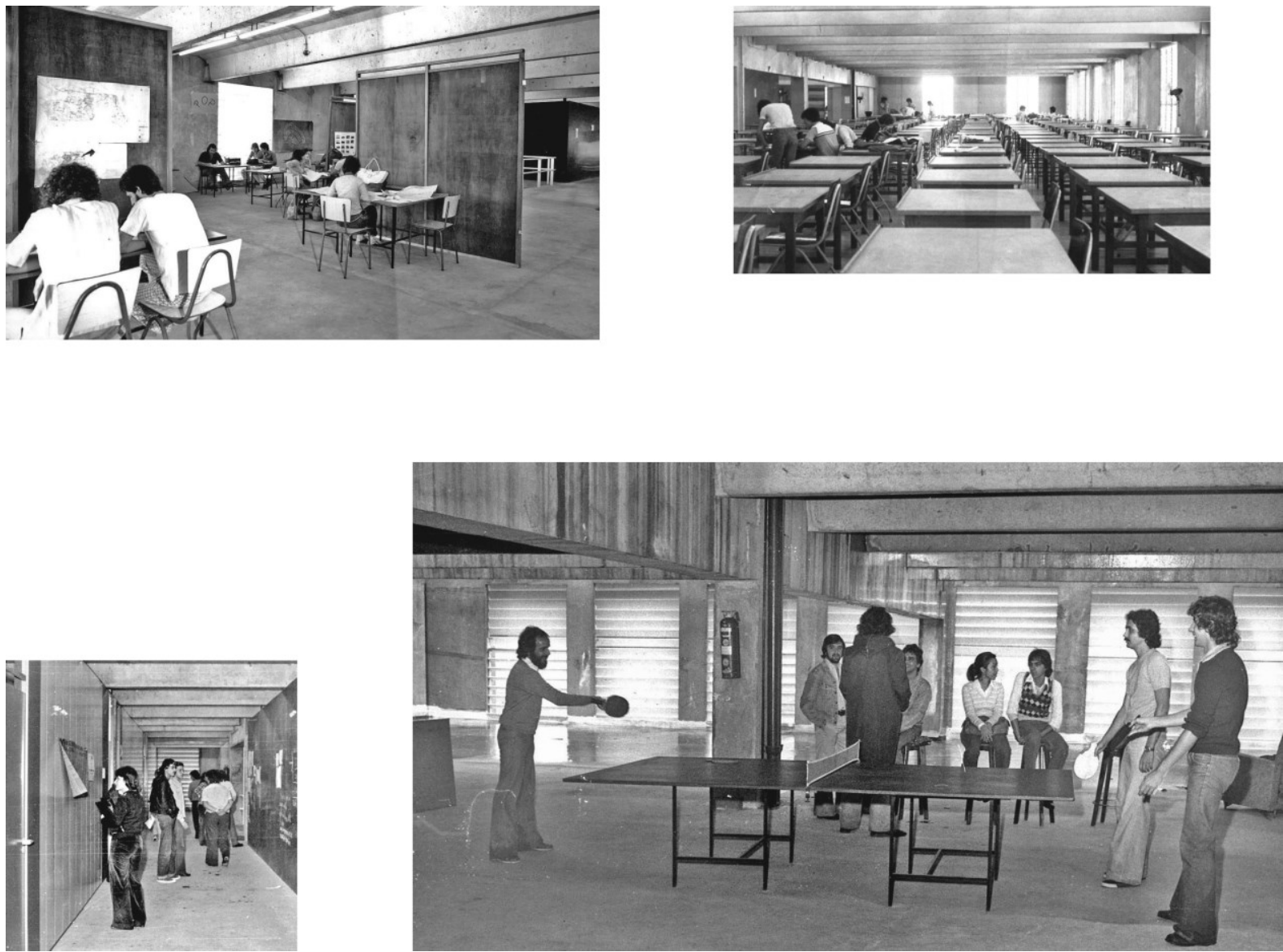

FIG. 57. Cotidiano da FAUS no final da década de 1970

Em 1980, a FAUS completava dez anos de atividades quando um dos arquitetos ligados a Vilanova Artigas, o professor Jon Maitrejean, ${ }^{21}$ assumiu a direção da escola. Por sua postura comprometida com o ensino, ele foi indicado para o cargo pela secretaria das Faculdades Católicas de Santos, em substituição ao Professor Oswaldo Corrêa Gonçalves, há sete anos no cargo. Sua relação com a SVSL era muito boa e se resumia na participação em reuniões com os demais diretores das Faculdades Católicas, sempre defendendo o conceito de liberdade responsável dos alunos da arquitetura.

\footnotetext{
${ }^{21}$ Jon Andoni Vergareche Maitrejean nasceu no País Basco, na cidade de Elbar, em 19 de janeiro de 1929, e chegou ao Brasil com doze anos de idade. Foi aluno da segunda turma da FAU-USP, 1949 - 1954, conviveu com importantes arquitetos e professores ligados ao movimento moderno de São Paulo, como Vilanova Artigas, Abelardo de Souza, Ernest Mange, Eduardo Corona, entre outros. Sobre a obra do professor Maitrejean ver RAMOS, F. G., BUZZAR, M. A., \& FUJIOKA, P. (2018). Introdução à Obra de Arq. Jon Maitrejean. Risco Revista De Pesquisa Em Arquitetura E Urbanismo (Online), 16(2), 113-133. Disponível em: <https://doi.org/10.11606/issn.1984-4506.v16i2p113133>. Acesso em: 16 dez. 2019.
} 
A FAUS era uma escola incrível, completamente aberta no meio da cidade, em sua condição urbana, diferente da cidade universitária que fechava às $17 \mathrm{~h}$ e que perdia o caráter vital, na FAUS isso não acontecia, era uma escola de cidade que funcionava $24 \mathrm{~h}$ por dia, permitia o encontro, as reuniões e discussões, acadêmicas ou políticas eram pretexto para o encontro e para a vivência coletiva, além disso, os professores costumavam jantar em um restaurante ao lado da escola chamado Lobby, onde ficavam até tarde com os alunos e demais professores em discussões que transcendiam o universo da arquitetura. ${ }^{22}$
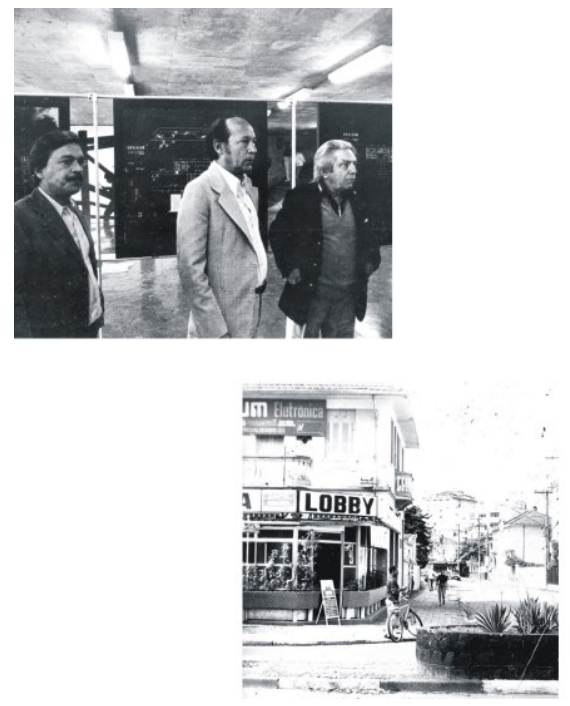

FIG. 58. Acima à esquerda, professor Jon Andoni Vergareche Maitrejean, antes de assumir a direção da FAUS, foi beneficiado pela anistia política implantada no país em 1979, sendo reintegrado, juntamente com os professores João Batista Vilanova Artigas e Paulo Mendes da Rocha ao quadro docente da FAU-USP. Abaixo, Restaurante Lobby, frequentado por alunos e professores da FAUS. Prédio da FAUS aberto para a cidade.

Jon Maitrejean havia acompanhado as discussões dos fóruns dos anos anteriores sobre o problema do ensino na FAUS tendo, portanto, consciência da posição do corpo docente quanto às recomendações da ABEA e CEAU. Sobre esse ponto, vale lembrar que esses órgãos haviam elaborado um documento, conhecido como "Carta de Ouro Preto" ${ }^{23}$, determinando que, para formar arquitetos com embasamento crítico e instrumental, era necessário definir com nitidez o perfil do egresso e elaborar as estratégias mais eficientes para atingir esse objetivo. A reforma do currículo mínimo era urgente e necessária, mas em si, não era capaz de garantir a qualidade do curso e, nesse sentido, a Carta de Ouro Preto sugeria, como um possível instrumento de aferição de qualidade, um permanente processo de autoavaliação do ensino ministrado pelas escolas.

Diante desse cenário, no final do primeiro semestre de 1980, provavelmente baseado na Carta de Ouro Preto, o chefe do Departamento de Projeto e vice-diretor da FAUS Noêmio Xavier ${ }^{24}$ aplicou um questionário ao grupo de professores da escola com o objetivo de "efetuar a avaliação de um aspecto do currículo da FAUS e compreender as diversas posturas dos educadores em relação ao

\footnotetext{
${ }^{22}$ MAITREJEAN, Jon V. Entrevista com Jon Vergareche Maitrejean. São Paulo: 01 jul. 2016. Entrevista a José Maria de Macedo Filho.

${ }^{23}$ Documento produzido em um encontro organizado pela ABEA, entre 7 e 9 de setembro de 1977, na cidade de Ouro Preto e publicada em 1978. GUTIERREZABEA, Ester Judite Bendjouya. A Associação Brasileira de Ensino de Arquitetura e os seus primeiros tempos (1973-1985). Op. cit. pp. 35-36.

${ }^{24}$ Arquiteto e urbanista formado na FAU-Mackenzie em 1964, com Especialização em Estrutura e Didática do Ensino Superior pelas Faculdades Metropolitanas Unidas (FMU) em 1979.
} 
currículo, da interpretação ideológica às suas relações com o meio social". ${ }^{25}$ Para a coleta e análise dos dados, estabeleceu uma metodologia de pesquisa centrada na organização e classificação de alguns princípios como: composição do currículo em áreas de estudo, integração disciplinar, relações do currículo com a comunidade, técnicas de aula e métodos de avaliação mais praticados, deficiências de formação dos alunos ingressantes, deficiências dos alunos em vias de se formar e principais deficiências nas instalações e infraestrutura disponíveis no prédio da FAUS.

Noêmio Xavier iniciou a análise dos dados comentando que a insatisfação dos professores em relação ao currículo vigente, grosso modo, giravam em torno de um necessário reordenamento sequencial e paralelo das disciplinas com o objetivo de incrementar a instrumentalização técnica e a formação cultural dos estudantes. Nesse sentido, foram sugeridas pelos docentes as seguintes alternativas: maior ênfase nas disciplinas de Tecnologia da Construção, Prática de Obra, Desenho Técnico e Pesquisa Prática; ampliação da carga horária das disciplinas de Ciências Históricas para melhorar a formação teórica e metodológica de pesquisa, corrigindo falhas tanto na formação básica dos alunos ingressantes, quanto na capacidade de formulação conceitual e visão crítica dos estudantes dos últimos semestres. Era quase unânime o desejo de integração horizontal e vertical das disciplinas, por meio de um programa intensivo de reuniões, apesar do reconhecimento da dificuldade de operacionalização devido ao regime de dedicação "horista".

Sua pesquisa revelou uma evidente preocupação dos docentes com o afastamento da FAUS tanto em relação aos problemas regionais, comunitários e socioambientais, quanto em relação aos estágios e práticas profissionais monitoradas. Esse fato foi atribuído à falta de clareza de objetivos específicos na organização do currículo da escola e ao desconhecimento da legislação e funcionamento dos ateliers profissionais.

Seguindo nessa direção, para determinação do enfoque dominante do currículo da FAUS, cada professor classificou em ordem de valor algumas afirmações, sendo cada uma delas uma clara e única postura a favor de uma determinada diretriz ideológica. Como forma de sustentação teórica e conceitual desse aspecto, Noêmio baseou-se nas elaborações de Elliot Eisner acerca do termo currículo e seus enfoques, demonstrando diferentes direcionamentos que um currículo poderia seguir, a saber: 1 . O racionalismo acadêmico; 2 . O processo cognitivo; 3 . A tecnologia do ensino; 4. A

\footnotetext{
${ }^{25}$ Questionário com dezesseis questões que foram respondidas na própria escola, algumas objetivas, de múltipla escolha e ouras dissertativas, aplicado nas duas últimas semanas de junho de 1980 pelo próprio professor Noêmio com o título: "Um exemplo de procedimento de avaliação: o enfoque do currículo da FAUS - Faculdade de Arquitetura e Urbanismo de Santos", respondido por trinta docentes de um total de 84. Ver a integra desta pesquisa em SILVEIRA FILHO, N.X. da. Avaliação do enfoque dominante de currículo na faculdade de arquitetura e urbanismo de Santos in Revista Educação e Avaliação, edição no 02. Jan. 1981. pp. 100-130.
} 
autorrealização; 5. A reconstrução social. Dessa maneira, as opções oferecidas no questionário estavam de acordo com essas cinco posturas. ${ }^{26}$

A grande ênfase dada pelos docentes ao enfoque voltado para a reconstrução social ficou claramente manifestada com o desejo de uma maior aproximação dos problemas que afligem a comunidade regional. Quanto a isso, surgiu uma contradição: a elevada pontuação para o enfoque do racionalismo acadêmico, cuja postura se caracteriza justamente pela indiferença quanto aos problemas imediatos do contexto social e ambiental. Refletindo em uma baixa pontuação no enfoque da autorrealização do estudante que, por sua vez, revela uma tendência para o magistocentrismo, ensino centrado no professor e não no aluno.

\begin{abstract}
Existem várias explicações alternativas para esse tipo de aparente incoerência: de um lado podemos estar diante de uma ambiguidade ideológica - típica da classe média brasileira - onde os valores declarados estão diferentemente posicionados em relação às práticas cotidianas; os valores verbalizados são fruto de posturas muito mais literárias do que concretas; por outro lado, pode ser que a manifestação do racionalismo acadêmico esteja por demais arraigada nas nossas estruturas de vida para que tenhamos a possibilidade de opinião totalmente isenta de sua influência. ${ }^{27}$
\end{abstract}

Foi constatada uma baixa pontuação ao enfoque da tecnologia do ensino, outra contradição, pois conflitava com as reivindicações por melhores equipamentos na escola e, segundo Noêmio, os poucos recursos tecnológicos disponíveis na escola eram subutilizados, portanto, seu incremento não era garantia de maior utilização.

\begin{abstract}
Os professores têm o hábito de pleitear instalações e equipamentos, mas não tem o hábito de utilizá-los intensamente. Por que isso ocorre? Esse problema decorre possivelmente do regime de dedicação "horista", que não remunera o tempo e preparação de materiais para a aula; o professor aspira a aulas mais instrumentalizadas e mais bem apoiadas do ponto de vista material, mas não dispõe do tempo necessário para isso. Outra possível explicação está na falta de preparação pedagógica do arquiteto [...] o arquitetoprofessor não foi treinado para a utilização plena de uma didática mais implementada e moderna. ${ }^{28}$
\end{abstract}

O professor Noêmio Xavier finalizou seus comentários recomendando um sistemático procedimento de avaliação das reais capacidades do aluno recém-chegado do ensino médio, bem como do estudante em vias de se formar, como forma de estimar o "efetivo resultado" do processo educacional da FAUS. Assim, pode-se dizer que as contradições ou inconsistências verificadas nessa enquete apenas confirmavam a falta de clareza ou até mesmo a inexistência de um projeto pedagógico consistente para a escola. Como visto no capítulo anterior, os instrumentos de ensino e avaliação de algumas disciplinas pautavam-se por princípios de autonomia intelectual a médio e longo prazo, enquanto outras seguiam metodologias focadas em resultados imediatos.

\footnotetext{
${ }^{26}$ Elliot Eisner foi educador da Universidade de Stanford, especialista em reforma curricular e pesquisa qualitativa. Noêmio utiliza suas formulações para amparar conceitualmente o seu questionário, neste sentido as cinco posturas citadas no texto fazem parte das formulações de Elliot Eisner. SILVEIRA FILHO, N.X da. Op. cit. p. 106.

${ }^{27}$ Ibid. pp. $125-126$

${ }^{28}$ Ibid. p. 126. (grifo nosso). 
QUADRO SÍNTESE DA AUTOAVALIAÇÃO DO CURRÍCULO DA FAUS

\begin{tabular}{|c|c|c|c|c|c|c|}
\hline \multicolumn{2}{|c|}{$\begin{array}{c}\text { O ATUAL CURRÍCULO DA FAUS PREPARA O } \\
\text { ALUNO PARA A VIDA PROFISSIONAL }\end{array}$} & \multicolumn{2}{|c|}{ SIM $\quad 38 \%$} & & NÃO & $61,3 \%$ \\
\hline \multirow{2}{*}{\multicolumn{2}{|c|}{$\begin{array}{c}\text { DISTRIBUIÇÃO DA CARGA HORÁRIA COM } 4.065 \\
\text { H/A POR SEQUÊNCIA }\end{array}$}} & \multicolumn{5}{|c|}{ RESPOSTAS OBTIDAS QUANTO À DISTRIBUIÇÃO DA CARGA HORÁRIA } \\
\hline & & DIMINUIR & AUMENTAR & & & TOTAL \\
\hline URBANISMO & $23 \%$ & 8 & 4 & & & 30 \\
\hline EDIFICAÇÃO & $23 \%$ & 7 & 5 & & & 30 \\
\hline MENSAGEM & $7 \%$ & 6 & 3 & & & 30 \\
\hline OBJETO & $7 \%$ & 6 & 3 & & & 30 \\
\hline CIÊNCIAS HISTÓRICAS & $15 \%$ & 0 & 12 & & & 30 \\
\hline \multicolumn{2}{|c|}{$\begin{array}{l}\text { O ATUAL PERFIL DO EGRESSO DA FAUS ATENDE } \\
\text { AS NECESSIDADES DA REGIÃO }\end{array}$} & $\begin{array}{c}\text { SIM } \\
5\end{array}$ & $\begin{array}{l}\text { NÃO } \\
21\end{array}$ & \multicolumn{2}{|c|}{ SEM RESPOSTA } & $\begin{array}{l}\text { TOTAL } \\
30\end{array}$ \\
\hline \multicolumn{2}{|c|}{$\begin{array}{c}\text { GRAU DE INTEGRAÇÃO HORIZONTAL E VERTICAL } \\
\text { ENTRE DISCIPLINAS }\end{array}$} & $\begin{array}{l}\text { ISOLADA } \\
5\end{array}$ & $\begin{array}{l}\text { INTEGRADA } \\
5\end{array}$ & \multicolumn{2}{|c|}{$\begin{array}{l}\text { PARCIALMENTE ISOLADA } \\
20\end{array}$} & $\begin{array}{l}\text { TOTAL } \\
30\end{array}$ \\
\hline \multicolumn{2}{|c|}{ PRÁTICAS DE AULA MAIS UTILIZADAS } & $\begin{array}{l}\text { AULA EXPOSITIVA } \\
27\end{array}$ & $\begin{array}{l}\text { PRÁTICA ATELIER } \\
22\end{array}$ & $\begin{array}{l}\text { SEMINÁRIO } \\
19\end{array}$ & $\begin{array}{c}\text { VISITAS } \\
12\end{array}$ & $\begin{array}{l}\text { OUTRAS } \\
5\end{array}$ \\
\hline \multicolumn{2}{|c|}{ RECURSOS DIDÁTICOS MAIS UTILIZADOS } & $\begin{array}{l}\text { AUDIOVISUAIS } \\
15\end{array}$ & $\begin{array}{l}\text { LABORATÓRIOS } \\
\qquad 5\end{array}$ & $\begin{array}{l}\text { BIBLIOTECA } \\
23\end{array}$ & $\begin{array}{l}\text { APOSTILAS } \\
13\end{array}$ & $\begin{array}{l}\text { OUTROS } \\
\qquad 5\end{array}$ \\
\hline \multicolumn{2}{|c|}{ MÉTODOS DE AVALIAÇÃO MAIS UTILIZADOS } & $\begin{array}{l}\text { TRABALHOS } \\
\text { PRÁTICOS } \\
28\end{array}$ & $\begin{array}{c}\text { EXAMES } \\
7\end{array}$ & $\begin{array}{c}\text { PROCESSUAL } \\
18\end{array}$ & $\begin{array}{l}\text { AVALIAÇÃO } \\
\text { INICIAL } \\
9\end{array}$ & $\begin{array}{l}\text { OUTRAS } \\
5\end{array}$ \\
\hline \multicolumn{2}{|c|}{ ENFOQUE DOMINANTE DE CURRÍCULO NA FAUS } & $\begin{array}{l}\text { RACIONALISMO } \\
\text { ACADÊMICO } \\
166 \text { PONTOS }\end{array}$ & $\begin{array}{c}\text { AUTO } \\
\text { REALIZAÇÃO } \\
112 \text { PONTOS }\end{array}$ & $\begin{array}{l}\text { PROCESSO } \\
\text { COGNITIVO } \\
146 \text { PONTOS }\end{array}$ & $\begin{array}{l}\text { TECNOLOGIA } \\
\text { DE ENSINO } \\
76 \text { PONTOS }\end{array}$ & $\begin{array}{l}\text { RECONSTRUÇÃO } \\
\text { SOCIAL } \\
216 \text { PONTOS }\end{array}$ \\
\hline \multicolumn{2}{|c|}{$\begin{array}{l}\text { PRINCIPAIS DEFICIÊNCIAS, INSUFICIÊNCIA OU } \\
\text { FALTA DE INFRAESTUTURA DA ESCOLA }\end{array}$} & $\begin{array}{c}\text { CONFORTO } \\
\text { ACÚSTICO } \\
15\end{array}$ & $\begin{array}{l}\text { LABORATÓRIOS E } \\
\text { AUDITÓRIO } \\
15\end{array}$ & $\begin{array}{c}\text { BIBLIOTECA } \\
\text { DEFICIENTE } \\
7\end{array}$ & $\begin{array}{c}\text { RECURSO } \\
\text { AUDIOVISUAL } \\
5\end{array}$ & $\begin{array}{l}\text { CENTRO DE } \\
\text { PUBLICAÇÕES } \\
3\end{array}$ \\
\hline \multicolumn{2}{|c|}{$\begin{array}{l}\text { PRINCIPAIS DEFICIÊNCIAS DOS ALUNOS } \\
\text { INGRESSANTES ORIUNDOS DO ENSINO MÉDIO }\end{array}$} & $\begin{array}{l}\text { CONHECIMENTO } \\
\text { GERAL/ARTÍSTICO } \\
12\end{array}$ & $\begin{array}{l}\text { AUTONOMIA } \\
\text { CRÍTICA } \\
10\end{array}$ & $\begin{array}{l}\text { FORMAÇÃO } \\
\text { POLÍTICA } \\
4\end{array}$ & $\begin{array}{l}\text { FORMAÇÃO } \\
\text { TÉCNICA } \\
4\end{array}$ & $\begin{array}{l}\text { TOTAL } \\
30\end{array}$ \\
\hline \multicolumn{2}{|c|}{$\begin{array}{l}\text { PRINCIPAIS DEFICIÊNCIAS OU FALTA DE } \\
\text { CONHECIMENTOS ESPECÍFICOS DOS ALUNOS } \\
\text { DOS ÚLTIMOS SEMESTRES }\end{array}$} & $\begin{array}{l}\text { FORMAÇÃO } \\
\text { TECNOLÓGICA } \\
5\end{array}$ & $\begin{array}{l}\text { CONHECIMENTO } \\
\text { DA PROFISSÃO } \\
5\end{array}$ & $\begin{array}{l}\text { MÉTODO DE } \\
\text { TRABALHO } \\
4\end{array}$ & $\begin{array}{l}\text { EXPRESSÃO } \\
\text { GRÁFICA } \\
4\end{array}$ & $\begin{array}{l}\text { CONTATO COM A } \\
\text { COMUNIDADE } \\
3\end{array}$ \\
\hline $\begin{array}{r}\text { ORGANIZAÇÃO DEPARTAMEI } \\
\text { DE REUNIÕES ADEQUADA A } \\
\text { CURSO }\end{array}$ & $\begin{array}{l}\text { AGENDA } \\
\text { OS DO }\end{array}$ & $\begin{array}{l}\text { SIM } \\
15\end{array}$ & NÃO & \multicolumn{2}{|c|}{ SEM RESPOSTA } & $\begin{array}{c}\text { TOTAL } \\
30\end{array}$ \\
\hline
\end{tabular}

TAB. 10. Quadro síntese da coleta de dados da pesquisa: Um exemplo de procedimento de avaliação: o enfoque do currículo da FAUS Faculdade de Arquitetura e Urbanismo de Santos. Elaborado pelo autor a partir da tabulação do professor Noêmio Xavier.

Nesse sentido, vale destacar que o diretor Jon Maitrejean estava alinhado ao conceito de liberdade responsável que permitiu, junto ao corpo docente da escola, a manifestação ideológica, política e pedagógica do corpo discente da FAUS na busca de uma melhor formação, colaborando dessa maneira com a discussão mais ampla sobre os rumos da profissão e seu ensino. Entretanto, a condição de liberdade de comportamento e expressão nem sempre era bem vista e, a partir de um determinado momento, o comportamento de alguns grupos passou a ser alvo de críticas da própria 
comunidade acadêmica e vizinhos da escola. Sob esse aspecto, a SVSL vinha recebendo constantes reclamações de estudantes, professores e vizinhos quanto ao barulho, festas durante a semana e com a entrada e saída de alunos, inclusive de pessoas estranhas à escola, vinte e quatro horas por dia. Como forma de minimizar esses problemas, a SVSL decidiu que o prédio da FAUS deveria ter acesso controlado e providenciou painéis e portas de vidro para serem instalados na entrada da escola. Jon Maitrejean rechaçou qualquer tipo de controle de acesso e, como condição de permanência no cargo, a escola deveria continuar aberta para a cidade.

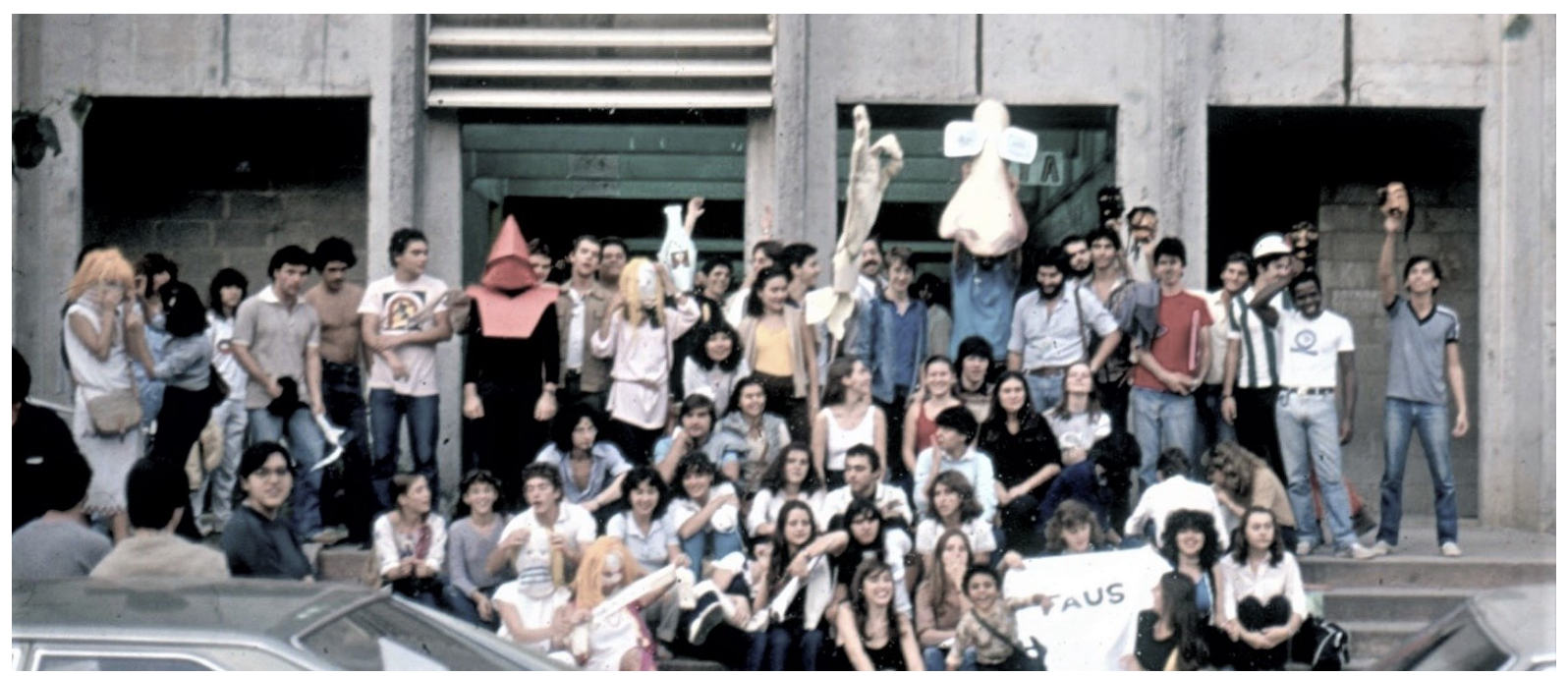

FIG. 59. Estudantes em frente ao prédio da FAUS depois da entrega de um trabalho da disciplina de Mensagem 2, em 1981.

No dia 05 de maio de 1981, apesar do esforço empreendido pela direção junto ao corpo discente para redução dos conflitos com a vizinhança, alguns estudantes promoveram uma festa organizada pelo Grupo Barra Lucífer, ${ }^{29}$ composto por alunos de diversos anos da escola e conhecido por suas posturas polêmicas e provocadoras. O caráter da festa escandalizou os vizinhos, a polícia militar foi acionada e ao iniciar o procedimento de invasão do prédio da FAUS foi contido pelo diretor geral da SVSL Padre Waldemar Martins. ${ }^{30}$ Por se tratar de um edifício particular, era necessária uma autorização judicial para acessá-lo, o diretor da mantenedora comprometeu-se em resolver a situação, entrou no edifício e convenceu os alunos a acabarem com a festa. ${ }^{31}$ A SVSL estabeleceu alguns procedimentos que deveriam ser seguidos, como a instalação das portas de vidro na entrada do prédio para controle de acesso e horário de funcionamento.

\footnotetext{
${ }^{29}$ Grupo integrante da chapa eleita com 262 votos para assumir o Diretório Acadêmico em 23 de maio de 1980. DELEGACIA DE ORDEM POLÍTICA E SOCIAL DE SANTOS (DOPS-Santos). Centro Acadêmico Lucio Costa. Prontuário no 3679. 112p. Santos, 1972. Op. cit.

${ }^{30}$ O Padre Waldemar Valle Martins (1926-2004) ingressou nas Faculdade Católicas de Santos em 1953 e liderou a criação da Universidade Católica de Santos, sendo o primeiro reitor entre 1986 e 1990. Coordenou o Curso de Mestrado em Educação da UNISANTOS de 2003 a 2004, ano do seu falecimento.

${ }^{31}$ Durante a madrugada, Jon Maitrejean recebeu uma ligação do Padre Waldemar solicitando sua presença na FAUS, mas, impossibilitado de descer para Santos naquele momento, instruiu o padre a resolver a situação. MAITREJEAN, Jon Vergareche. Entrevista com Jon Vergareche Maitrejean. São Paulo: 01 jul. 2016. Entrevista a José Maria de Macedo Filho.
} 

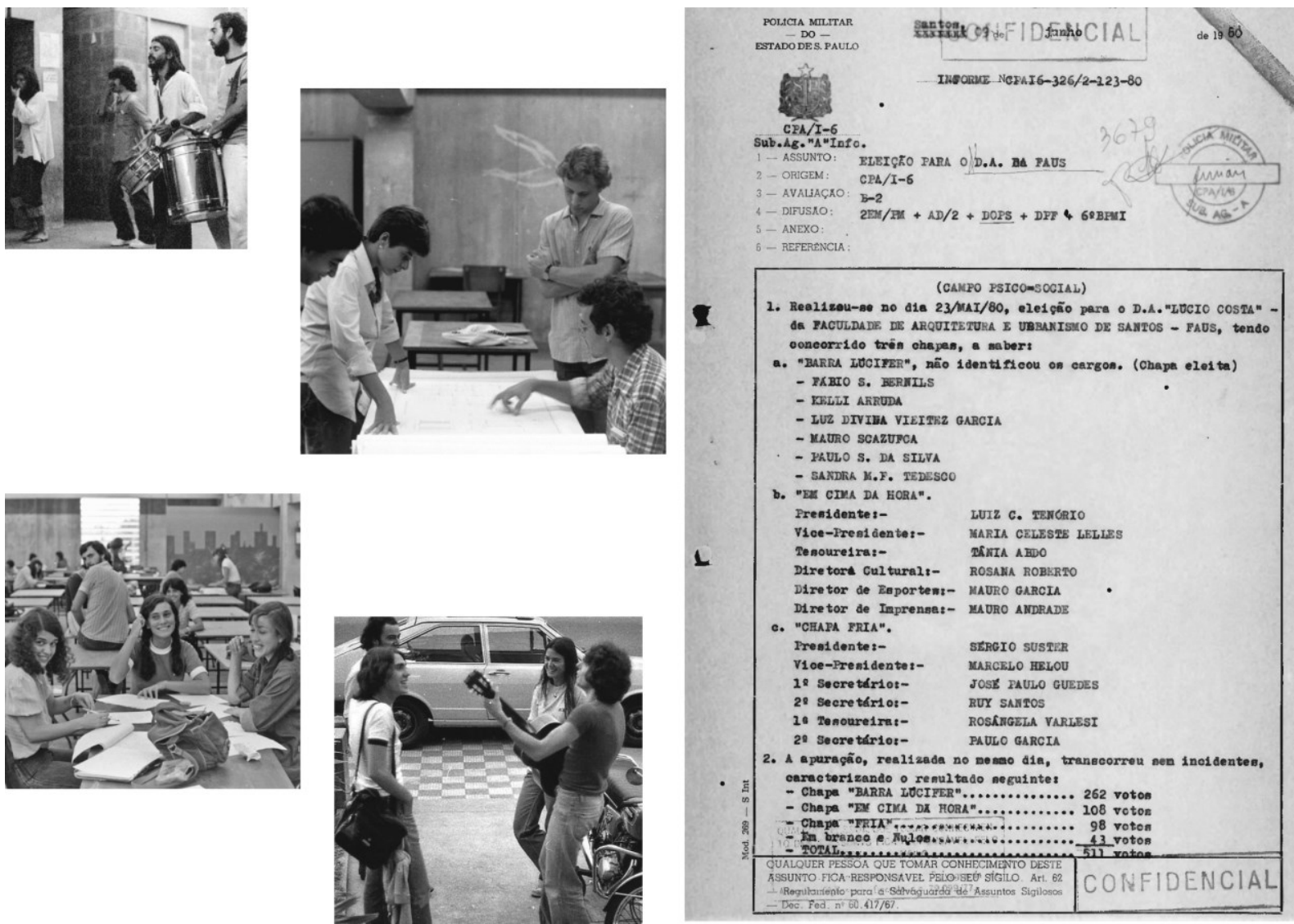

FIG. 60. À esquerda acima, alunos no pergolado da FAUS, foto Paulo Elias. Abaixo, estudantes no atelier e Tony Bellotto ao violão em frente ao prédio da FAUS, foto Sérgio Waissmann. À direita, documento confidencial da Policia Militar registrando o resultado das eleições para o Diretório Lucio Costa.

Devido à necessidade de uma viagem, Jon Maitrejean deixou temporariamente a direção da FAUS e, naturalmente, o vice-diretor Noêmio Xavier assumiu interinamente o cargo. Ao retornar, Maitrejean não o reconheceu, pois "havia se tornado uma figura intransigente e defensor das recomendações da reitoria, além de fechar a escola com a instalação das portas de vidro, passou a controlar a frequência, pontualidade e demais ações dos seus colegas professores." ${ }^{32}$ A FAUS havia perdido sua relação direta com a cidade.

No dia 31 de dezembro de 1981, devido ao término de seu mandato, Maitrejean entregou a diretoria da FAUS, e a SVSL conduziu Noêmio Xavier ao cargo de diretor interino da escola. ${ }^{33}$ Essa decisão se deu a despeito da existência de uma lista sêxtupla, votada no final do mesmo ano, na qual o professor Maitrejean tinha ampla maioria de votos para ser reconduzido à direção da escola. Nessa

\footnotetext{
32 MAITREJEAN, Jon Vergareche. Op. cit.

${ }^{33}$ Em 19 dezembro de 1981, o presidente SVSL Dom David Picão por meio de um ofício (of. D. 362/81) ao vice-diretor em exercício Noêmio Xavier com o seguinte conteúdo: "Tendo em vista que no dia 31 de dezembro p.f. vencerá o mandato do atual Sr. diretor, Prof. Arq. Jon Andoni Vergareche Maitrejean, e não tendo sido nomeado o professor que o substituirá no próximo biênio, solicitamos assuma V. Sa. como vice-diretor em exercício, a partir de 1 janeiro 1982, até a data da nomeação do futuro diretor". Esse ofício foi seguido da Portaria no 11/81 de 30 de dezembro de 1981, na qual o Presidente SVSL Dom David Picão nomeava como vice-diretor da FAUS o professor Noêmio Xavier da Silveira, com mandato de diretor interino por dois anos a partir de 10 janeiro de 1982. DIRETÓRIO ACADÊMICO LUCIO COSTA. Dossiê da Crise de 1982. Santos, 1982. Não p.
} 
lista não constava o nome do professor Noêmio Xavier, ${ }^{34}$ apesar desse fato, estava confiante na sua condição de especialista em Estrutura e Didática do Ensino Superior, legitimada com a recém publicação da sua pesquisa sobre o Currículo da FAUS em um importante periódico especializado em educação. ${ }^{35}$ Essa pesquisa, elaborada alguns meses antes, Ihe posicionava diante da SVSL como o professor melhor preparado para assumir a direção da escola naquele momento. Noêmio tinha, portanto, o respaldo para manter o rigor no controle dos procedimentos administrativos e disciplinares da FAUS.

Na primeira reunião do Conselho Departamental do ano de 1982, Noêmio justificou seu aceite para dirigir a FAUS afirmando que, em um primeiro momento, havia negado o convite da SVSL, pois acreditava no processo democrático praticado na escola para indicação de seus diretores. Entretanto, em uma reunião na sede da mantenedora the foi comunicado que, antes do mês de março, seria solicitado o descredenciamento do curso junto ao MEC, em função da detecção de uma nova crise na FAUS. Diante desse cenário e da impossibilidade de recondução do professor Maitrejean, ele aceitou o cargo com algumas condicionantes: 1. Alteração do regimento interno da FAUS; 2. Reformas no prédio da FAUS; 3. Contratação somente de professores de Santos. ${ }^{36}$

A formação de um quadro docente local, segundo o novo diretor, estava amparada no fato de que a FAUS já havia formado profissionais suficientes e capazes de lecionar na escola. Além disso, julgava "que todo problema crônico da Faculdade é decorrente de um corpo docente visitante, que não tem compromissos com a Escola. O mesmo fato ocorreu em São José dos Campos e a Escola foi fechada. ${ }^{37}$ Essas declarações provocaram protestos de alunos e professores e a crise detectada pela SVSL, em função dos fatos de ordem disciplinar, agora tomava proporções gigantescas do ponto de vista político, unindo corpo docente e discente contra a mantenedora e o diretor da escola. Estudantes e professores suspenderam as atividades acadêmicas e instalaram um fórum permanente para debates de natureza política, ideológica e pedagógica, matizados por questões de ordem econômica.

A gravidade dos fatos polarizou a comunidade acadêmica, posicionando de um lado a FAUS, que solicitava melhores condições de infraestrutura e maior qualidade de ensino, pautada nas resoluções dos fóruns anteriores que exigiam transparência e instrumentos democráticos paritários nas

\footnotetext{
${ }^{34}$ A SVSL não considerava possível, em hipótese alguma, a recondução de Maitrejean para a direção da escola devido à uma suposta manipulação dos resultados da eleição para constituição da lista sêxtupla. DIRETÓRIO ACADÊMICO LUCIO COSTA. Op. cit. Não p.

${ }^{35}$ C.f. SILVEIRA FILHO, N.X da. Op. cit. pp. 100-130.

${ }^{36}$ Ata da reunião do Conselho Departamental da FAUS realizada no dia 30/01/1982. DIRETÓRIO ACADÊMICO LUCIO COSTA. Dossiê da Crise de 1982. Santos, 1982.

${ }^{37}$ Fala do professor Noêmio Xavier registrada na Ata da reunião do Conselho Departamental da FAUS realizada no dia 30/01/1982. Além dos professores, os alunos também estranharam a menção de uma "nova crise" que acarretaria o descredenciamento do curso, devido ao não comprometimento dos professores de São Paulo. Nesse sentido, o Conselho Departamental pediu uma audiência ao Bispo e a diretoria da SVSL para esclarecer os "fatos estranhos". DIRETÓRIO ACADÊMICO LUCIO COSTA. Ibid. Não p. 
tomadas de decisões da faculdade. Do outro lado estava a SVSL, pressionada pelo monitoramento do regime militar devido aos recorrentes problemas disciplinares, com denúncias da ocorrência de "reuniões subversivas" e "festas barulhentas e degeneradas" dentro de um dos prédios das Faculdades Católicas de Santos. Além disso, estava diante de problemas de ordem econômica com as exigências dos docentes por melhores salários e condições de trabalho e infraestrutura, o que resultaria em grandes investimentos.

O estado de crise se estendeu por todo o primeiro semestre de 1982, tornou-se público e despertou o interesse da imprensa local que passou a registrar todos os acontecimentos. A SVSL via essa greve como um ato de indisciplina dos estudantes apoiado pelos professores e, no início de junho, foi publicada uma portaria que regulamentava o horário de funcionamento da FAUS. A escola passaria a ser fechada as $23 \mathrm{~h} 30$ e reabriria as $7 \mathrm{~h} 30$, durante o período de fechamento estavam proibidas quaisquer atividades curriculares ou extracurriculares. Ao mesmo tempo que a SVSL notificava o público que o vestibular de julho da FAUS seria suspenso em virtude da indisciplina reinante na escola, atribuída ao corpo discente e que, segundo o Padre Waldemar, a mantenedora vinha sendo muito tolerante com os graves fatos ocorridos e, diante das severas e reiteradas críticas da vizinhança, foi decidido que não era mais possível aceitar tal comportamento. Dessa maneira, a suspensão do segundo vestibular estava relacionada com a necessidade urgente da revisão do regimento interno e do currículo da faculdade. ${ }^{38} \mathrm{Em}$ resposta, a comunidade acadêmica criou a Comissão de Defesa da FAUS, composta por professores e alunos. Essa comissão, baseada nas declarações públicas do Padre Waldemar, afirmava que o movimento difamatório da FAUS poderia estar relacionado com a intenção da SVSL de fechar a escola em função da unificação regimental dos cursos, visando a criação de uma universidade. Esta hipótese, também pode ser verificada em um dos relatórios confidenciais do DOPS-Santos:

\begin{abstract}
Diante dos fatos, aparentemente, existe interesse da mantenedora em fechar a FAUS, [...] tal medida não foi tornada pública pela mantenedora, mas deixa clara essa intenção com a abertura do vestibular para o curso de Pedagogia [...] além desse fato, a mantenedora organizou uma comissão de professores para o estudo da unificação dos regimentos das seis faculdades mantidas pela SVSL. Os alunos da FAUS realizaram várias reuniões de repúdio ao cancelamento do vestibular da FAUS, no entanto, até a presente data, embora contando com o apoio do Centro dos Estudantes de Santos (CES), não conseguiu sensibilizar os dirigentes da mantenedora. ${ }^{39}$
\end{abstract}

Nesse sentido, a comissão passou a exigir esclarecimentos de todas as declarações e ações praticadas pelo diretor, desde questões administrativas e regimentais, horário de funcionamento restrito da escola, até sobre a reforma do prédio, cujo projeto não havia sido apresentado em nenhuma das reuniões até então realizadas. Entretanto, a falta de diálogo e resolução dos problemas

\footnotetext{
${ }^{38}$ Matéria publicada no dia 1 de junho de 1982 em diferentes jornais da cidade. O periódico Jornal Cidade de Santos publicou: Fim da Tolerância. FAUS cancela o 2ํ vestibular. DIRETÓRIO ACADÊMICO LUCIO COSTA. Op. cit. Não p.

39 DELEGACIA DE ORDEM POLÍTICA E SOCIAL DE SANTOS (DOPS-Santos). Faculdade de Arquitetura e Urbanismo de Santos. Op. cit.
} 
agravava a situação. Diante disso, a Comissão de Defesa da FAUS solicitou ajuda de diversas instituições como o IAB-SP, a Conferência Nacional dos Bispos do Brasil (CNBB), a Câmara de Vereadores de Santos, os sindicatos de arquitetos, professores, sociólogos, etc. Recebeu apoio de todas essas, além de uma série de outras instituições públicas e privadas de todo o país, por meio de correspondências, telegramas e visitas e a imprensa local passou a publicar quase que diariamente $o$ embate que a FAUS travava com a mantenedora e seus representantes. Esse material foi cuidadosamente organizado pelos estudantes e professores em um dossiê conhecido como "Livro Azul" ${ }^{\prime 0}$ e também pelo DOPS-Santos, que acompanhava silenciosamente os desdobramentos da crise, ao ponto de Oswaldo Corrêa fazer a seguinte ponderação: “É importante não tomar nenhuma atitude sem primeiro conversar com todos, alunos e professores. Senão nos desentenderemos, e a escola, é preciso que se diga, está muito visada. A FAUS, por outro lado não é só nossa: alunos, professores, administração e direção, mas também é da comunidade." ${ }^{41}$

Não obstante, ao longo dos noventa dias em que a escola ficou parada, estudantes e professores, paralelamente aos debates, assembleias e reuniões, organizaram algumas atividades de extensão com objetivo de avançar alguns pontos que vinham sendo discutidos desde os fóruns da década anterior. Dessa maneira, em maio de 1982, o professor Walter Maffei, baseado na experiência da formação do Laboratório de Habitação da Faculdade de Arquitetura e Urbanismo de Belas Artes de São Paulo, escreveu o primeiro documento concebendo um núcleo de pesquisas e projetos no campo da habitação para a FAUS. Com o objetivo de aproximar a teoria ensinada em sala de aula da prática da profissão, focou em um dos grandes problemas sociais da região: a questão habitacional.

Indo nessa direção, o Professor Mauricio Nogueira Lima, ex-integrante do Grupo Ruptura ${ }^{42}$ e com sólida carreira como artista do movimento concreto de São Paulo, reuniu-se com os estudantes para organizar uma exposição com os trabalhos produzidos na FAUS, merece destaque o painel geométrico feito no atelier da escola com a ajuda dos alunos. ${ }^{43}$ Organizaram uma semana cultural com exposições, trabalhos de extensão comunitária, oficinas, palestras e debates sobre o ensino de arquitetura. Abriram a FAUS para a cidade e, principalmente, para os seus vizinhos participarem dos eventos durante os dias 14 a 19 de junho de 1982.

\footnotetext{
40 DIRETÓRIO ACADÊMICO LUCIO COSTA. Dossiê da Crise de 1982. Op.cit. Não p.

${ }^{41}$ GONÇALVES, Oswaldo Corrêa. Entrevista com o Professor Arquiteto Oswaldo Corrêa Gonçalves. Santos, 21 nov. 1982 , entrevista a Edison Gloeden e Eugênio Lara. p. 8.

${ }^{42}$ Em dezembro de 1952, o Museu de Arte Moderna de São Paulo (MAM-SP) abriu a exposição que marcou o início da arte concreta no Brasil. Intitulada Ruptura, a mostra é concebida e organizada por um grupo de sete artistas de São Paulo: Anatol Wladyslaw, Leopoldo Haar, Lothar Charoux, Féjer, Geraldo de Barros, Luiz Sacilotto e Waldemar Cordeiro. Alguns anos mais tarde, o Grupo Ruptura, contando com outros adeptos como Hermelindo Fiaminghi, Judith Lauand e Maurício Nogueira Lima, com o apoio dos poetas concretos paulistas, organizam a 1a Exposição Nacional de Arte Concreta (1956/1957). Disponível em: <http://enciclopedia.itaucultural.org.br/grupo538325/grupo-ruptura>. Acesso em: 15 nov. 2019.

${ }^{43}$ Mauricio Nogueira Lima expôs suas pinturas geométricas na III, IV e VI Bienal de São Paulo e foi convidado por Max Bill a participar da mostra Konkrete Kunst, realizada em Zurique em 1960. Disponível em: <http://mauricionogueiralima.com.br/>. Acesso em: 15 nov. 2019. 

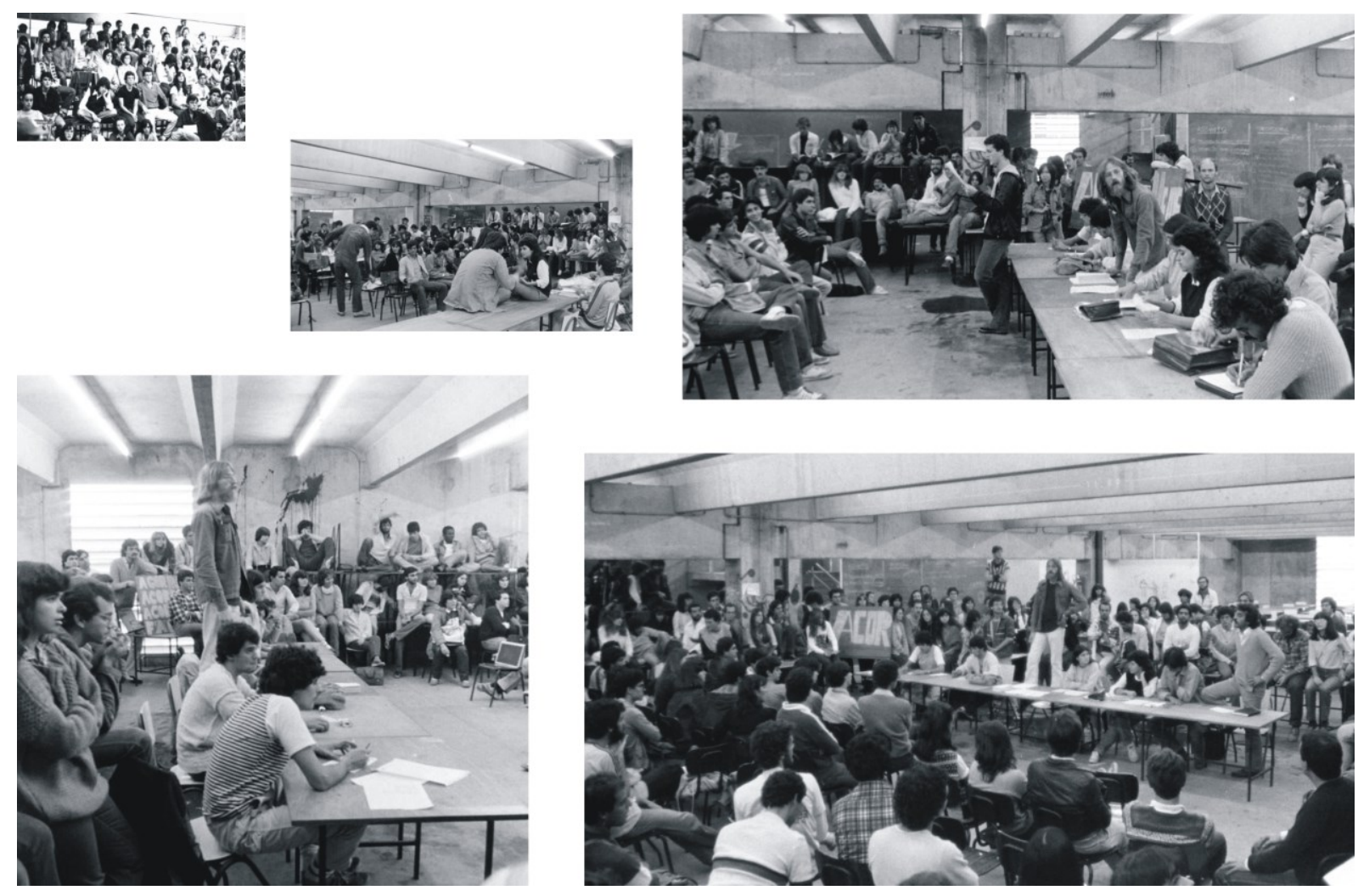

FIG. 61. Estudantes e professores em assembleia no atelier da FAUS, em pé na cadeira, Edison Gloeden que, junto a Eugênio Lara foram dois estudantes muito ativos em favor da FAUS durante a crise de 1982

Aproveitando a oportunidade da presença dos vizinhos, os alunos explicaram que o barulho produzido na escola, a despeito do excesso de alguns grupos, era muito em função da falta de eficiência térmica e acústica do prédio, até então inacabado, pois como podia ser visto naquele momento, os vãos ainda estavam abertos, sem caixilharia e sem vedação. Dessa forma, conseguiram o precioso apoio dos vizinhos na exigência por melhores condições de infraestrutura junto à mantenedora.

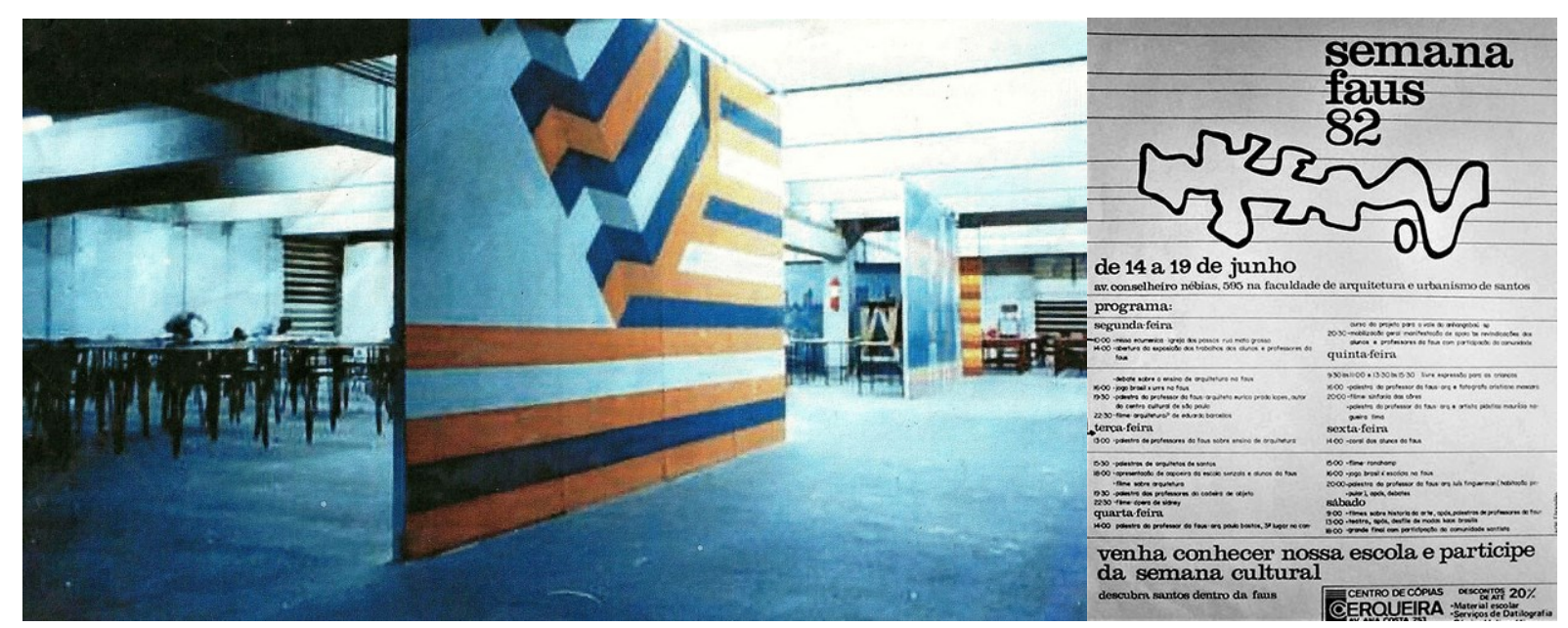

FIG. 62. Painel produzido pelo professor Mauricio Nogueira Lima no atelier da FAUS, com a ajuda dos estudantes. Cartaz com a programação da Semana da FAUS 82. 
Paralelamente a esse evento, a mantenedora criou uma comissão de inquérito para averiguar as denúncias de irregularidades na FAUS, coletou uma série de depoimentos de alunos, professores e funcionários. E, no final do mês de junho, antes mesmo de a comissão apresentar suas conclusões, o diretor Noêmio Xavier demitiu por justa causa a secretária da faculdade Vera Debs e mais dezessete professores oriundos de São Paulo, sem apresentar justificativas que sustentassem essa decisão. Aprofundando ainda mais a crise instaurada.

\begin{tabular}{l|l|c|c|c}
\hline \multicolumn{5}{|c}{ PROFESSORES DEMITIDOS NA CRISE DE 1982} \\
& \multicolumn{1}{|c}{ PROFESSOR } & DISCIPLINA / DEPARTAMENTO & ANO DE ADMISSÃO & TEMPO DE CONTRIBUIÇÃO \\
\hline 01 & ALFRED TALAAT & PROJETO & 1973 & 09 ANOS \\
02 & ANTONIO DOMINGOS BATTAGLIA & URBANISMO & 1978 & 04 ANOS \\
03 & ARI VICENTE FERNANDES & URBANISMO & 1976 & 06 ANOS \\
04 & CHRISTINA DE CASTRO MELLO & PROJETO & 1978 & 04 ANOS \\
05 & EDISON ELOY DE SOUZA & PROJETO & 1976 & 06 ANOS \\
06 & EURICO PRADO LOPES & PROJETO & 1980 & 02 ANOS \\
07 & EVELYN LEVY & TEORIA E HISTÓRIA & 1980 & 02 ANOS \\
08 & JAIR PEREIRA DOS SANTOS & TECNOLOGIA & 02 ANOS \\
09 & JON MAITREJEAN & PROJETO & 1980 & 04 ANOS \\
10 & JORGE OSVALDO CARON & PROJETO & 1978 & 07 ANOS \\
11 & LUIS FINGERMANN & URBANISMO & 1975 & 02 ANOS \\
12 & MARIA ARGENTINA BIBAS & PLÁSTICA & 1980 & 06 ANOS \\
13 & MAURÍCIO NOGUEIRA LIMA & PLÁSTICA & 1976 & 09 ANOS \\
14 & NELSON ACHCAR & TECNOLOGIA & 1973 & 08 ANOS \\
15 & ROBERTO FRANKLIN RONDINO & OBJETO & 1974 & 03 ANOS \\
16 & VOLF STEINBAUM & 1979 & 10 ANOS \\
17 & WALTER MAKHOHL & 1972 & 07 ANOS \\
\hline
\end{tabular}

TAB. 11. Quadro elaborado pelo autor.

A decisão surpreendeu a todos e a SVSL recebeu uma série de ofícios, telegramas e cartas de repúdio de diversas instituições da cidade, região e do Estado de São Paulo. A falta de diálogo e mediação fez com que alunos e professores procurassem a Câmara Municipal de Santos para interceder, mas não obteve sucesso. E mesmo com a intermediação do Cardeal de São Paulo, Dom Paulo Evaristo Arns, a mantenedora se mostrou irredutível na negativa de dialogar com alunos e professores ${ }^{44} \mathrm{O}$ corpo discente abriu um processo judicial contra a SVSL e passou a depositar o valor das mensalidades em juízo. Da mesma maneira, o corpo docente recorreu à justiça solicitando a readmissão dos dezessete professores e da secretária. Os Departamentos de Projeto, Tecnologia e Ciências Históricas se manifestaram a favor dos docentes demitidos, repudiaram o desrespeito ao regimento e a cada um dos professores da FAUS, informando ao diretor que não havia condições dignas e morais para o prosseguimento das atividades didáticas.

\footnotetext{
${ }^{44}$ Carta enviada pela comissão de Defesa da FAUS para a Associação Brasileira de Escolas Superiores Católicas (ABESC), em 13 de julho de 1982. DIRETÓRIO ACADÊMICO LUCIO COSTA. Dossiê da Crise de 1982. Santos, 1982. Não p. 
Em resposta, o diretor Noêmio enviou um ofício aos docentes justificando que todas as ações tomadas até então, por ele e pela mantenedora, estavam de acordo com o Regimento Interno, inclusive sua indicação para a diretoria da FAUS feita pela SVSL: "deve ficar claro, portanto, que qualquer reinvindicação ou proposta de eleições não tem amparo regimental e jamais teve origem nos órgãos dirigentes da FAUS e da SVSL." ${ }^{45}$ No mesmo documento ressaltou que o objetivo da FAUS não era somente o ensino da arquitetura e do urbanismo, "mas a formação integral do jovem, oferecendo-Ihe diretrizes de organização da vida e integração na comunidade, estruturando seu tempo dentro da faculdade de forma produtiva e sadia." ${ }^{46} \mathrm{O}$ ofício ainda tratava das providências quanto ao cancelamento do vestibular, licenças, contratações e apresentava um cronograma de aulas, aprovado pelo Conselho Departamental em reunião extraordinária, para recuperar os meses de paralização.

Para finalizar o documento e não deixar dúvidas quanto à legitimidade das decisões, destacou que o controle de frequência dos professores era feito de maneira tolerante, o que acarretou um hábito de atrasos crescentes com efetivo prejuízo do ensino, indo contra os objetivos de qualidade, portanto, "esses procedimentos foram coibidos por novas normas de registro de frequência [...] faz-se necessário, neste momento, um exame de consciência, por parte de todos, para a retomada da normalidade da vida acadêmica." ${ }^{47}$
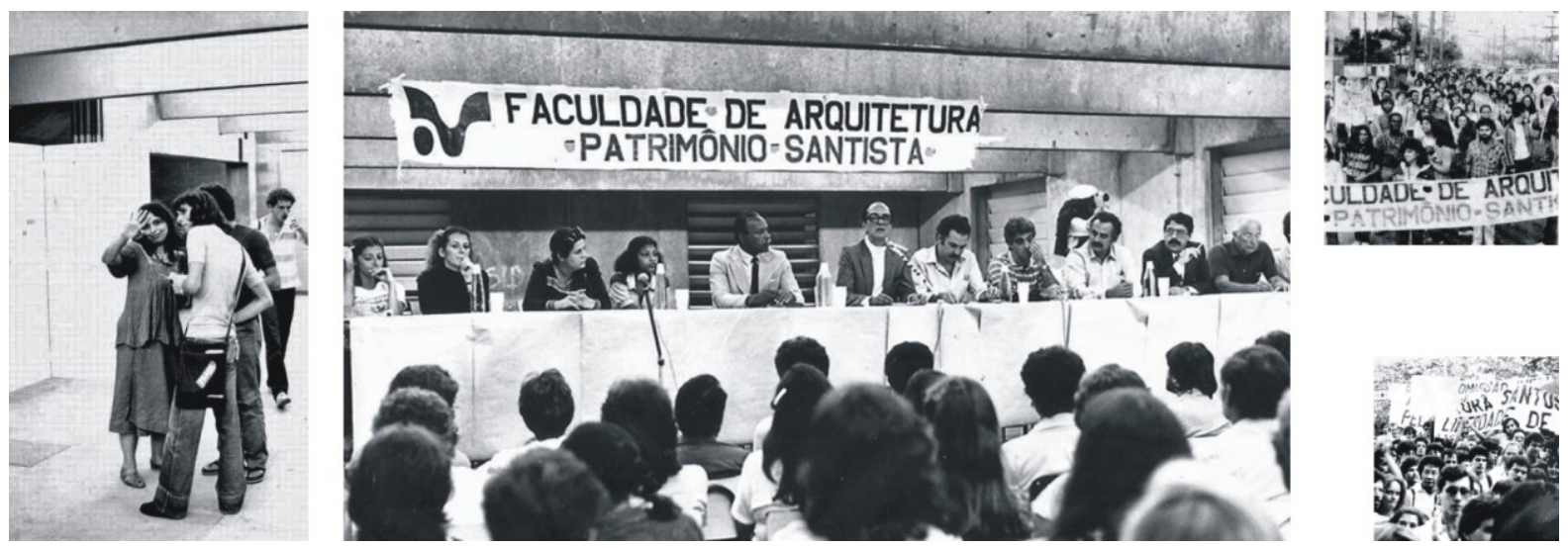

FIG. 63. À esquerda, Maria Argentina Bibas, uma das professoras demitidas, com estudantes. No centro, plenária de manifestação de apoio aos professores demitidos. À direita, passeatas pela readmissão dos professores e pela garantia de direitos e liberdade de expressão, 1982.

Quanto aos procedimentos disciplinares tomados em relação ao corpo discente, além do controle de horário de funcionamento do prédio, o diretor apresentou um novo formulário de solicitação de matrícula, dando ciência ao solicitante de quais eram os objetivos e normas a serem cumpridas. Todos os pedidos seriam avaliados por uma comissão e aqueles cujo histórico escolar não estivesse

\footnotetext{
${ }^{45}$ Oficio Diretor da FAUS enviado ao corpo docente da FAUS em 20 de julho de 1982. DIRETÓRIO ACADÊMICO LUCIO COSTA. Ibid. Não p.

${ }^{46}$ Ibid. Não p.

${ }^{47}$ Ibid. Não p.
} 
voltado para a busca da qualidade do ensino seriam convidados a se transferir para outra faculdade. ${ }^{48}$

Aproximadamente um mês após o envio do ofício aos docentes, Noêmio Xavier encaminhou aos pais, alunos e professores, um comunicado que detalhava ainda mais os problemas por ele identificados ao assumir o cargo. Grosso modo, as questões giravam em torno da mesma temática já apresentada: o ensino na FAUS não era somente profissionalizante, mas uma formação integral; que a qualidade do ensino dependia de um bom currículo, boas instalações e equipamentos, mas sobretudo das qualificações humanas, morais, profissionais e pedagógicas do corpo docente. Nesse ponto, reforçava a distorção na proporção de professores locais e professores de outras cidades, com poucas horas de dedicação agravadas por um currículo fracionado, resultando no baixo comprometimento com a instituição. ${ }^{49}$

O comunicado apresentava as medidas adotadas pela direção para resolver esses problemas, tais como: controle do horário de funcionamento do prédio, proibição dos professores realizarem aulas em suas casas ou escritórios em São Paulo (o que ocorria com frequência) e determinação de descontos salariais pelas horas-aula não cumpridas por faltas, atrasos e encerramentos antecipados. Apelava para os departamentos indicarem professores locais para atualização e regionalização do projeto pedagógico da FAUS, além de propor a reforma do prédio para atender às novas exigências curriculares. Na sua opinião, essas medidas ao serem anunciadas e postas em prática, constituíam a gênese da indisciplina generalizada, o que justificava as atitudes dos dirigentes da escola. ${ }^{50}$

Diante desse quadro, Jon Maitrejean, Edison Eloy e Telésforo Cristofani entraram em contato com Oswaldo Corrêa solicitando sua ajuda, pois na condição de fundador da escola ele tinha responsabilidade e força para resolver o problema. Dessa maneira, Oswaldo conversou com todos os envolvidos, a mantenedora afirmava que o problema era indisciplina, os estudantes e professores repudiavam as ações autoritárias do diretor agravadas com a demissão da secretária da escola e dos dezessete professores. Por último, ao conversar com Noêmio Xavier e ouvir seu relato, Oswaldo Ihe aconselhou a não pedir demissão. ${ }^{51}$

\footnotetext{
48 “As medidas adotadas pela direção da SVSL vão mais além chegando a uma verdadeira triagem com relação às rematrículas [...] os alunos terão sua vida escolar analisada por uma comissão de professores designados pela diretoria, conforme orientação da mantenedora. Os critérios dessa avaliação ainda não ficaram muito claros, mas naturalmente o aluno barrado enfrentará sérios problemas, mesmo que a escola lhe conceda a transferência o que por certo fará". Jornal Cidade de Santos: Fim da Tolerância. FAUS cancela o $2^{\circ}$ vestibular. DIRETÓRIO ACADÊMICO LUCIO COSTA. Dossiê da Crise de 1982. Santos, 1982. Não p.

${ }^{49}$ Trata-se de um relatório dos fatos ocorridos nos últimos meses na FAUS e das soluções tomadas pela SVSL e pela direção da escola. Era uma espécie de resposta ou justificativa aos pais dos estudantes que já haviam recebido um comunicado dos professores relatando os problemas a partir de outro ponto de vista. DIRETÓRIO ACADÊMICO LUCIO COSTA. Ibid. Não p.

50 DIRETÓRIO ACADÊMICO LUCIO COSTA. Ibid. Não $p$.

${ }^{51}$ Oswaldo não revela o que foi dito por Noêmio, mas afirmou: “Depois de toda essa conversa, vi que o pessoal estava exagerando na forma do diálogo. Em vez de se falar em alto nível, denegria-se a Mantenedora e certos indivíduos, e vice-versa, isso não lograria sucesso. Então, as intervenções que fiz foram: pode-se reclamar das coisas que não estão de acordo conosco, os outros também podem falar, mas em alto nível". GONÇALVES, Oswaldo Corrêa. Entrevista com o Professor Arquiteto Oswaldo Corrêa Gonçalves. Op. cit. p. 9.
} 
Apesar de ser especialista em pedagogia do ensino superior e acreditar que, para a melhor formação do arquiteto, deveria ser adotado um sistema didático-pedagógico sustentado por métodos científicos de verificação de qualidade a partir de resultados, Noêmio não foi capaz de estabelecer instrumentos de mediação, politicamente articulados, entre as instâncias da comunidade acadêmica, impondo sua visão atrelada aos interesses da mantenedora. Por outro lado, a aliança entre o corpo docente e discente apoiada por uma série de outras instituições ganhava força e, através de um documento com caráter reconciliatório dirigido a SVSL, buscava "o estabelecimento de bases sólidas e justas que atendam as partes envolvidas - mantenedora, docentes, discentes e funcionários possibilitando o correto desenvolvimento da vida acadêmica." ${ }^{52}$

Em meio a esse cenário em ebulição, o grupo Arte e Oficina ${ }^{53}$ construiu uma escultura em concreto armado com a forma da letra "a" minúscula. Com um metro e meio de altura e pesando setecentos quilos, foi projetada e moldada pelos estudantes utilizando argila expandida. A intenção do grupo estava alinhada com as outras ações de aproximar a FAUS da comunidade e vizinhos. Nesse sentido, a letra "a" que inicia o alfabeto e o nome do grupo, representava o desejo da escola em refundar suas relações com seu lugar, e era uma forma de marcar um novo ponto de contato entre a FAUS e a cidade.

Juntamente com um grupo de amigos, resolvemos fazer um "a" como protesto contra a demissão de vários professores. Tivemos a oportunidade de utilizar o depósito da construtora de um amigo do grupo para fazer a complexa caixaria, armadura de ferro a concretagem do "a". Foi um exercício interessante para quem não tinha prática de obra. Para obtermos a autorização de sua instalação na entrada do prédio da FAUS, junto à escada de acesso principal, foi dito para a mantenedora que se tratava de uma homenagem à escola, o que não deixava de ser verdade. Depois de concretado e curado, um caminhão o levou para ser chumbado no piso, tivemos o cuidado de o deixar "suspenso" no ar, solto do chão. Sutilezas que, com as sucessivas reformas do piso, já se perderam. Instalado, finalmente pintamos o "a" de vermelho! ${ }^{54}$

FIG. 64. O "a" da FAUS
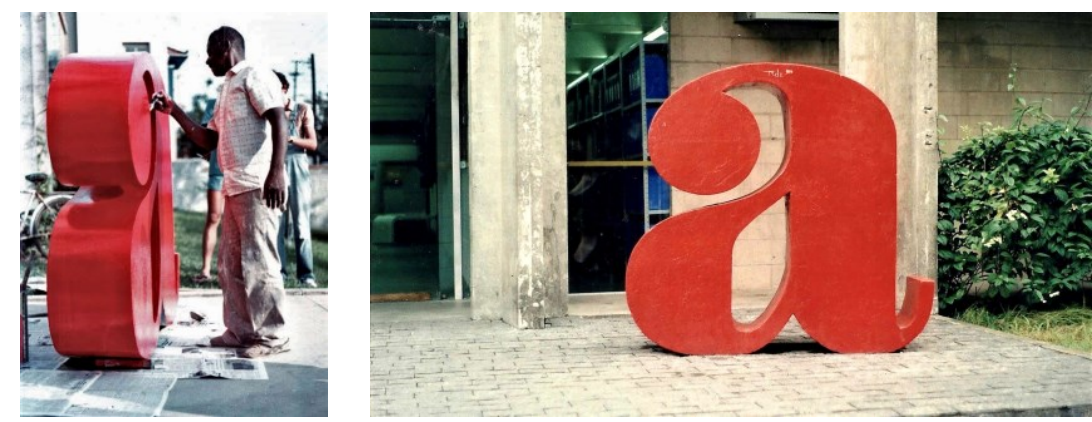

\footnotetext{
${ }^{52}$ Ver Quadro das medidas a serem adotadas para o encaminhamento da FAUS a normalidade. DIRETÓRIO ACADÊMICO LUCIO COSTA. Op. cit. Não $p$

${ }^{53}$ Grupo formado pelos estudantes do último ano da FAUS: Luisa Alegria, Cesar Costa, Jacques Moraes, Marcos Frugoli, Luís Acosta e Paulo Ferreira em matéria publicada no dia 11 de agosto de 1982 pelo Jornal a Tribuna de Santos: Um presente de 700 quilos. DIRETÓRIO ACADÊMICO LUCIO COSTA. Ibid. Não p.

${ }^{54}$ Depoimento da arquiteta Luisa Alegria, ex-integrante do grupo Arte e Oficina da FAUS, dado ao autor em 19 de julho de 2016.
} 
No final do mês de agosto, depois de oito meses de insucesso no cargo que ocuparia até dezembro de 1983, Noêmio Xavier da Silveira pediu demissão. ${ }^{55}$ Foi substituído por Oswaldo Corrêa Gonçalves, que novamente assumia a direção da FAUS para resolver um estado de crise. Entretanto, diferentemente da crise de 1972, a nova diretoria deveria acatar as condições da mantenedora: presença diária do diretor na escola; cumprimento estrito do regimento vigente, especialmente quanto ao regime disciplinar; manutenção das normas já baixadas como horário de funcionamento do prédio; controle de frequência e horários dos professores que deveriam ministrar suas aulas, exclusivamente, nas instalações da faculdade e, finalmente, respeitar a nova estrutura administrativa, com o secretário atual, o novo cargo de administrador e o serviço de segurança vigente. ${ }^{56}$

A indicação de Oswaldo para o cargo foi comemorada pela FAUS, o fundador da escola proferiu uma aula inaugural na qual apresentou as condições da SVSL reforçando que daquele momento em diante o regimento deveria ser integralmente seguido. Os professores demitidos foram reintegrados ao quadro docente da escola e as aulas recomeçaram imediatamente. ${ }^{57} \mathrm{~A}$ secretária Vera Debs foi a única que não foi readmitida, os estudantes em sua homenagem, rebatizaram o Diretório Acadêmico com o seu nome. Em novembro de 1982, na ocasião de uma entrevista para dois alunos da escola, Oswaldo Corrêa, ao ser indagado sobre a situação da FAUS pós-crise, fez a seguinte declaração:

\begin{abstract}
Acabamos de sair de um período de crise em que todo mundo ficou traumatizado. Portanto, no meu entender, estamos recuperando certas posições, assumindo novas posturas, aproveitando a experiência que a crise nos proporcionou. A minha maneira de proceder durante a crise, nada mais foi do que ficar alerta a todas as posições que se colocavam aqui, sem assumir nenhuma, ainda que tivesse a minha voltada para a da FAUS; uma das coisas que cheguei a declarar quando um professor disse que todos os professores iriam se demitir era que isso não era verdade. Demitem-se os oitenta, mas eu fico, porque o Noêmio passa, mas a FAUS fica, então eu não saio. Nesse momento de recuperação percebemos que é claro que os professores estão desacostumados a chegar no horário, os alunos também estão desacostumados porque o professor não chega. $\mathrm{Na}$ administração as coisas acontecem com facilidade, tudo se fala, tudo se diz e nada acontece. $^{58}$
\end{abstract}

Em resumo, pode-se dizer que, independente das motivações, a crise de 1982 foi uma oportunidade para a FAUS repensar suas relações com a SVSL e, principalmente, com a cidade. Naquele momento, qualquer sinal ou menção de apoio às posturas alinhadas com as esferas de poder, afeitas ao controle e imposição de procedimentos administrativos e pedagógicos, deveria ser rechaçado. Nesse

\footnotetext{
${ }^{55}$ Ver matéria publicada no Jornal a Tribuna de Santos do dia 29 de agosto de 1982. Diretor da FAUS põe o cargo à disposição. DIRETÓRIO ACADÊMICO LUCIO COSTA. Dossiê da Crise de 1982. Santos, 1982. Não p.

${ }^{56}$ Trechos do comunicado ao novo diretor da FAUS, com a seguinte introdução: "A Diretoria da Sociedade Visconde de São Leopoldo, em reunião realizada no dia 31 de agosto de 1982, presidida pelo Exmo. Sr. Bispo Diocesano de Santos, Dom David Picão, resolveu fixar as seguintes condições para o exercício do cargo de Diretor da Faculdade de Arquitetura e Urbanismo de Santos". DIRETÓRIO ACADÊMICO LUCIO COSTA. Ibid. Não p.

${ }^{57}$ Ver matéria publicada no Jornal a Tribuna de Santos do dia 02 de setembro de 1982. Novo Diretor da FAUS reintegra professores. DIRETÓRIO ACADÊMICO LUCIO COSTA. Ibid. Não $p$.

${ }^{58}$ Vale registrar que, em resposta à última pergunta da conversa, Oswaldo foi categórico ao afirmar qual foi o motivo principal da crise de 1982: GLOEDEN E LARA - "Só para finalizar, diga em poucas palavras, você atribui a crise da FAUS a esse problema de indisciplina, levantado pela Mantenedora? O que você vê como principal fator da crise da FAUS? OCG - No meu entender foi realmente indisciplina". GONÇALVES, Oswaldo Corrêa. Entrevista com o Professor Arquiteto Oswaldo Corrêa Gonçalves. Op. cit. p. 8.
} 
sentido, por descuido ou inabilidade política, a aspereza da direção e da mantenedora na ruptura dos canais de diálogo com a FAUS foi interpretada como uma postura contrária às reivindicações dos movimentos estudantis que mobilizavam escolas de arquitetura de todo o país.

A crise da Faculdade de Arquitetura teve também seu lado positivo. Não apenas no que se refere ao contraste com a inércia, tão característica da modorrenta Santos. Por esse aspecto, que já seria suficiente, tivemos verdadeira movimentação social, trazendo à tona as adormecidas forças vivas da Cidade. ${ }^{59}$

É oportuno lembrar que os professores da FAUS Jorge Caron, Geraldo Vespasiano Puntoni e Paulo de Mello Bastos, entre 1975 e 1979, estruturaram e instalaram o Curso de Arquitetura da Faculdade de Belas Artes de São Paulo (FEBASP) e, paralelamente às suas atividades na FAUS na ocasião da crise de 1982, o professor Jorge Caron coordenava o curso em São Paulo. Contudo, apenas dois anos mais tarde, em junho de 1984, entregou o cargo, provocando uma crise de grandes proporções com greve de estudantes e de docentes, demissão em massa de professores e, inclusive, transferência de alguns alunos. Para alguns, Caron já previa a crise e saiu da escola antes de o conflito ser deflagrado, para outros, o esgarçamento das negociações entre mantenedora e docentes, resultante dos constantes embates realizados ao longo de sua gestão, foi a razão principal de sua saída. ${ }^{60} \mathrm{Com}$ essa notável similaridade e quase simultaneidade de eventos críticos, arrisca-se dizer que a experiência vivida na crise da FAUS, conhecendo os reais motivos e interesses dos diversos agentes envolvidos, gerou subsídios para Caron não ver saída aos verdadeiros problemas e pressões, internas e externas, a que estavam submetidos coordenadores, professores, estudantes e mantenedora da FEBASP.

O processo de discussão sobre a qualidade de ensino nos cursos de arquitetura se estendeu e, em 1986, diante das transformações ocorridas no país com a "abertura democrática" e já no contexto da Universidade Católica de Santos, a FAUS realizou um Seminário de Avaliação do Ensino e, diferentemente do questionário de Noêmio Xavier, envolveu estudantes e professores ao longo de uma semana, dispondo inclusive de uma ficha intitulada "o que pensam os alunos de seus professores" ${ }^{61} \mathrm{Em}$ 1987, o Diretório Acadêmico organizou outro seminário de avaliação para debater as propostas apresentadas no ano anterior.

A resistência às imposições curriculares do governo militar vista na FAUS, estava apoiada no desejo por uma formação fundada sobre princípios democráticos e emancipadores, potencializados pela

\footnotetext{
${ }^{59}$ ASSOCIAÇÃO DOS DOCENTES DA SOCIEDADE VISCONDE DE SÃO LEOPOLDO. A Crise da FAUS e as lutas da Associação. Boletim informativo no 8. nov.1982. pp. 1-3.

60 "Caron foi um grande maestro, soube conduzir o curso, estimular e coordenar a viabilização dos projetos do corpo docente como um todo. Teve sabedoria para encontrar brechas num sistema corrompido e vislumbrar um espaço de atuação". RUGGIERO, Amanda Saba. Jorge Caron: uma trajetória. Op.cit. pp. 68-75.

${ }^{61}$ Ofício circular 636/86. UNIVERSIDADE CATÓLICA DE SANTOS. FAUS: Ofício Circular 636/86. 3.p. Santos: UNISANTOS, 1986. mimeo.
} 
confiança mútua entre seu corpo docente e discente. Ao longo da década de 1970, o movimento nacional contrário ao ensino instrumental refletia na escola e, logo depois da crise de 1982, transpôs as discussões políticas e pedagógicas do plano teórico para o campo concreto, ou seja, as transformações curriculares cobravam alterações na estrutura do edifício e, inexoravelmente, fundia pedagogia e espaço.

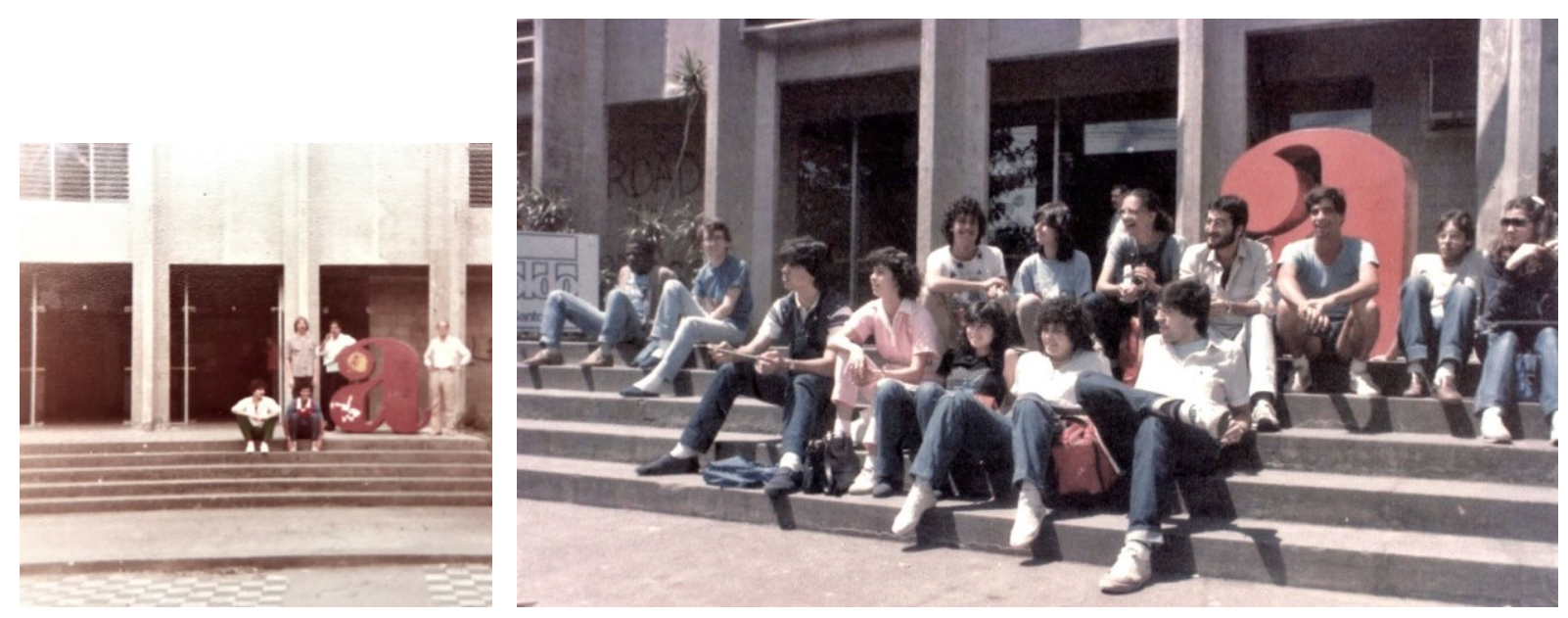

FIG. 65. Oswaldo Corrêa Gonçalves em frente ao Prédio da FAUS com seus estudantes. 


\title{
Fragmentação curricular e espacial
}

Conforme o exposto até aqui, é possível dizer que a formação do arquiteto no Brasil, de maneira geral, é marcada pela fragmentação dos conteúdos curriculares organizados em disciplinas estanques de diferentes campos do conhecimento. A reforma de 1962 na FAU-USP estabeleceu claramente três eixos principais na estruturação do curso de arquitetura: projeto, tecnologia e história, sendo o atelier de composição o lugar da síntese dos conhecimentos apreendidos pelo estudante. Entretanto, mesmo na FAU-USP, a partir do Fórum de 1968, esse modelo foi colocado em xeque, talvez mais por razões ideológicas do que pedagógicas e, desse modo, todo o debate sobre o ensino de arquitetura que se seguiu centrou esforço na criação e operacionalização de mecanismos pedagógicos de integração curricular.

Vale lembrar que a luta pela emancipação, afirmação e reforma do ensino de arquitetura no Brasil culminou com a substituição das cátedras pelos departamentos, cujo objetivo era integrar os conteúdos curriculares de projeto, tecnologia e história. Contudo, segundo Minoru Naruto, com a implantação da reforma universitária e o novo sistema de créditos, as matrículas, planos de ensino, avaliações, aprovações ou reprovações passaram a ser efetuadas por disciplinas, inclusive as optativas. Dessa maneira, segundo o professor Minoru Naruto, pode-se dizer que esse modelo potencializou o caráter político e ideológico do ensino.

\begin{abstract}
Essa nova organização do ensino dividiu e transferiu para as disciplinas o antigo poder acadêmico concentrado nas cátedras, por sinal abolidas pela mesma reforma. Como a nova legislação universalizou o acesso a esses novos nichos do poder, dispensando quaisquer ritos como aqueles que regiam os concursos para as cátedras, todos os professores passaram a deter os fragmentos desse poder assim que eram alocados nas disciplinas, independentemente de sua competência ou titulação acadêmicas. Por outro lado, como não havia restrições para a criação de novas disciplinas, a nova estrutura universitária trazia no seu cerne a possibilidade de multiplicação desses pequenos nichos de poder para delimitar e proteger os territórios do conhecimento, cada vez mais especializado. ${ }^{62}$
\end{abstract}

Tratando do objeto de estudo dessa tese, foi verificado que na FAUS a concepção e organização disciplinar de cada departamento apresentava visões específicas do seu campo de conhecimento com lógicas de funcionamento distintas sendo, portanto, fragmentárias em sua essência. 0 departamento de projeto, por exemplo, encarregado da aplicação prática e de síntese dos conhecimentos adquiridos nas demais áreas, encontrou tamanha dificuldade de integração departamental que as suas próprias disciplinas se tornaram estanques, quase independentes.

\footnotetext{
62 Naruto afirma que, dentro da estrutura universitária moderna, o poder conquistado pelas disciplinas as converteu de simples "unidades de ensino" em verdadeiras "unidades de poder". NARUTO, Minoro. Repensar a Formação do arquiteto. 2006. 129p. Tese (doutorado em arquitetura e urbanismo) - Faculdade de Arquitetura e Urbanismo da Universidade de São Paulo. São Paulo, 2006. pp. 92-93.
} 

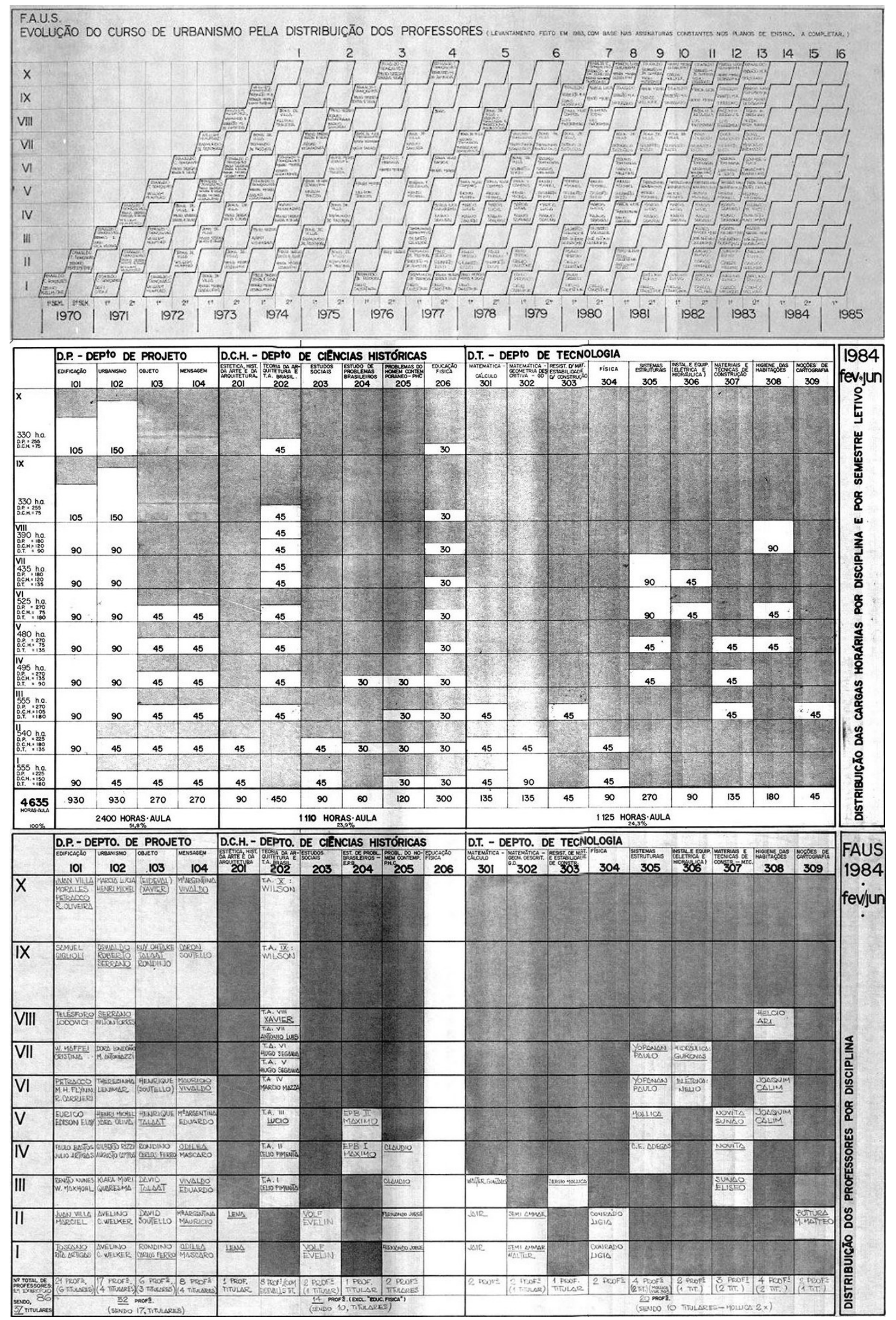

FIG. 66. No topo, diagrama de evolução do Curso de Urbanismo pela distribuição dos professores, elaborado pelo professor Henri Michel Lesbaupin em 1983. No centro, distribuição das cargas horárias por disciplinas e por semestre letivo em 1984. As 4.635 horas/aula estavam distribuídas nos três departamentos da escola da seguinte maneira: Departamento de Projeto, 2.400h/a (51,8\%), o Departamento de Ciências Históricas, 1.110 h/a (23,9\%) e o Departamento de Tecnologia com 1.125 h/a (24.3\%). Abaixo, distribuição dos professores por disciplinas nos Departamentos de Projeto História e Tecnologia em 1984. 
Com efeito, a prerrogativa da autonomia intelectual posicionava o estudante como o elemento encarregado de estabelecer as correlações entre os conteúdos trabalhados no curso. Não obstante, cada disciplina propunha um problema distinto, sobrecarregando o aluno com uma grande carga de trabalho, superpondo conteúdos e inviabilizando o aprofundamento das pesquisas, mas sobretudo pulverizando o conhecimento transmitido. Era evidente a incompatibilidade entre o desejo de integração do projeto e o caráter dispersivo dos conteúdos das disciplinas. ${ }^{63}$ Assim, muitas das alterações do edifício da FAUS estiveram atreladas às constantes exigências do MEC, tanto do ponto de vista curricular com a criação de novas disciplinas, quanto ao incremento tecnológico com a necessidade de instalação de novos laboratórios e infraestruturas específicas. Mas também são resultado das exigências de estudantes e professores, conquistadas junto à mantenedora, para a atualização e aprimoramento do ensino ministrado na escola.

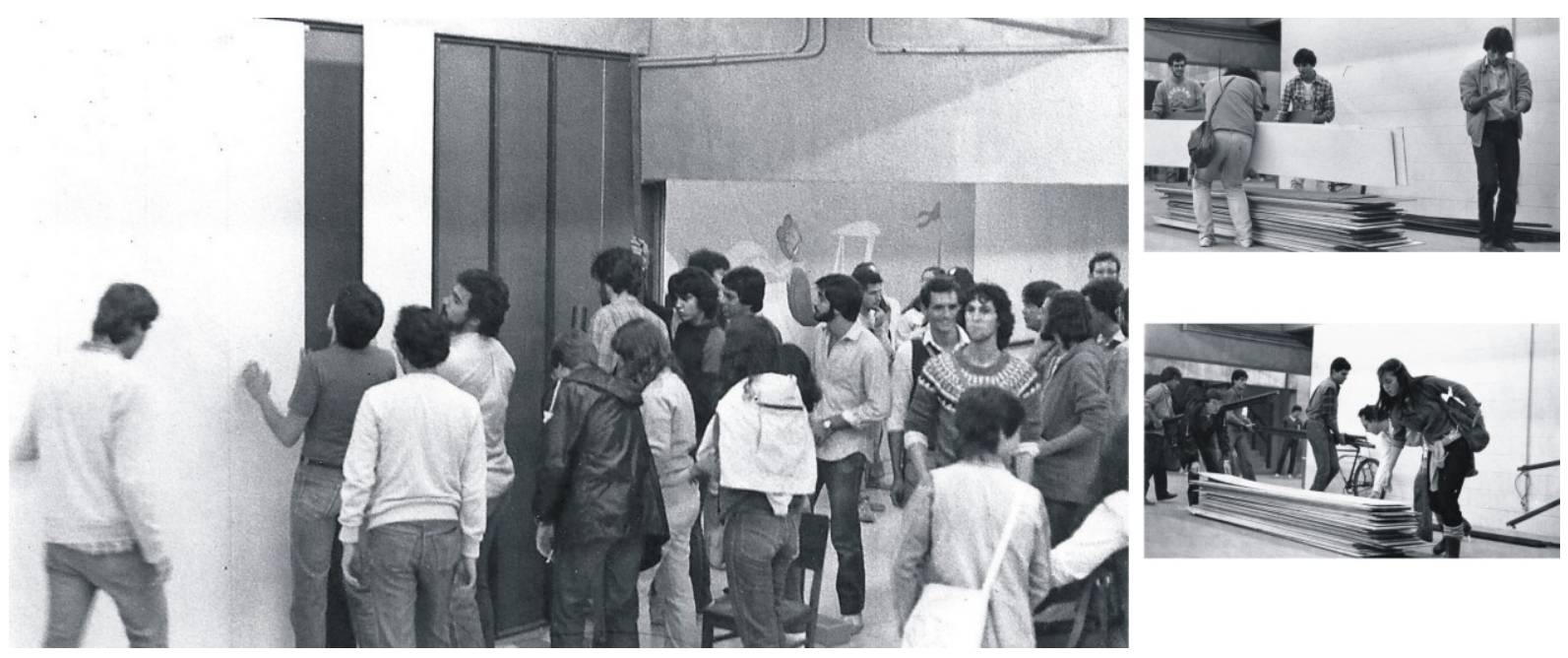

FIG. 67. Estudantes desmontando as divisórias que compartimentavam o atelier em cinco salas de aula em 1983. Os painéis e estrutura foram retirados cuidadosamente e devolvidos para a mantenedora intactos.

Indo nessa direção, a ideia de instalar uma instância de pesquisa e extensão no campo da habitação social semeada pelo professor Maffei em 1982 ganhou força e, em maio de 1983, foi realizada a primeira reunião preparatória para viabilizar a implantação do laboratório de habitação da FAUS, o HABITAFAUS. Promovida pelo Diretório Acadêmico e com a participação dos professores Juan Villá, Fábio Serrano e Walter Maffei, contou com aproximadamente 52 estudantes. Na ocasião foi criada uma comissão, formada por docentes e discentes para elaborar um projeto de extensão comunitária. Trata-se do Projeto Urbanístico da Vila Progresso, no qual os estudantes construíram um protótipo para a cobertura das habitações propostas no plano. Esse projeto foi premiado no concurso para estudantes da União Internacional de Arquitetos - UIA, assunto que será abordado adiante.

\footnotetext{
${ }^{63}$ Segundo Minoru Naruto, em síntese "a incompatibilidade do ensino de projeto com a estrutura disciplinar se dá em três níveis: o projeto se baseia na operação por síntese e a Disciplina, por análise; o projeto compõe conteúdos, a Disciplina decompõe conteúdos; o projeto tem um conteúdo aberto a constituir, a Disciplina conteúdo fechado, pré-estabelecido, instituído". NARUTO, Minoro. Repensar a Formação do arquiteto. 2006. Op. cit. pp. 92-120.
} 
Em fevereiro de 1984, a Sociedade Visconde São Leopoldo passou a apoiar o laboratório e cedeu a seus membros bolsa integral de estudos. No mesmo ano o HABITAFAUS organizou a primeira Semana de Habitação da FAUS, realizando palestras e debates sobre as problemáticas da habitação. ${ }^{64}$ O laboratório compartilhava seu espaço com um grupo de estudantes que passou a editar um periódico próprio da faculdade, o Jornal Revista ${ }^{65} \mathrm{O}$ editorial estava diretamente ligado às atividades do HABITAFAUS, com a divulgação de projetos e pesquisas de extensão, inclusive experiências de outras escolas. O Jornal Revista, com bom humor e desenhos extraordinários, registrou o cotidiano da escola no período pós crise, foram realizadas entrevistas, publicados artigos de professores, trabalhos e viagens em destaque, divulgação de eventos como as citadas Semanas da Habitação, além de relatos quanto aos problemas de infraestrutura e custos do curso.
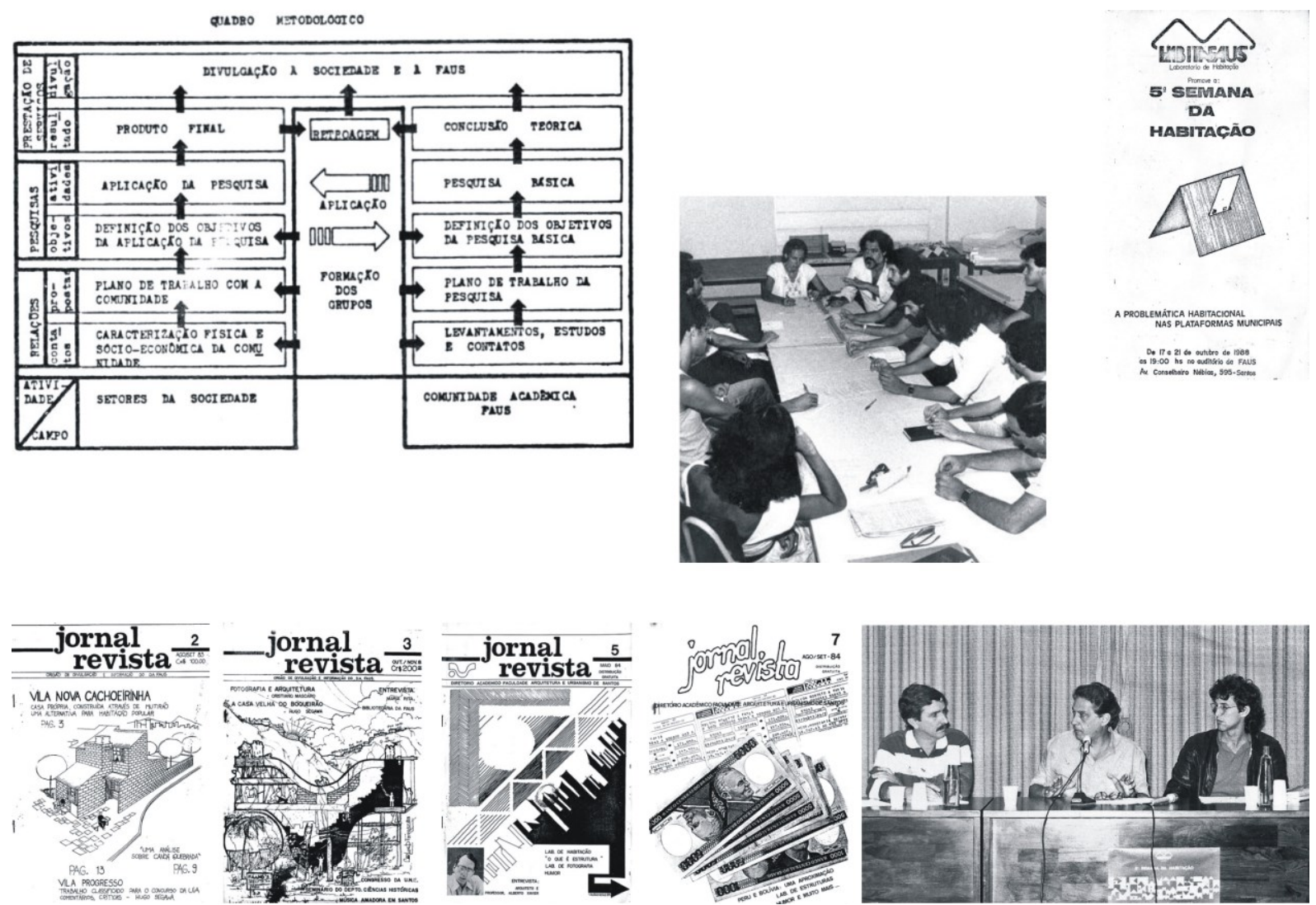

FIG. 68. Diagrama de funcionamento do Habitafaus. Reunião dos professores Juan Villa e Cristina de Castro Mello com alunos em 22 de fevereiro de 1984. Cartaz da 5a semana da Habitação promovida pelo HABITAFAUS. Capas do periódico Jornal Revista, com apenas sete edições e produzido por estudantes, entre 1983 e 1984. Conversas com estudantes, série de eventos promovidos pelo HABITAFAUS ao longo do ano de 2017. 3a Semana da Habitação - Habitação e Constituinte. Conferência organizada pelo HABITAFAUS, contou com a presença do sociólogo Fernando Henrique Cardoso, do Diretor da FAUS Fabio Serrano e o aluno Ney Caldatto, 1986.

\footnotetext{
${ }^{64}$ No dia 04 de agosto de 1984, através do ato 2/84, o Diretor Oswaldo Corrêa Gonçalves criou oficialmente o Laboratório de Habitação da FAUS, mas somente em 1988 o HABITAFAUS constituiu um Regimento Interno. UNIVERSIDADE CATÓLICA DE SANTOS. Regimento interno do Laboratório de Habitação - HABITAFAUS. 9p. Santos: UNISANTOS, 1988. mimeo.

${ }^{65} \mathrm{O}$ Editorial não está completo pela impossibilidade de acesso a todas as edições. Editores: Adhemar Dizioli e Rivaldo Serrão. Datilografia: Ana Pancini. Cartuns: Fabio Vital. Montagem: Rivaldo Serrão e Jarbas Oliveira. Colaboradores: Eugenio Lara, José Veranese, Eduardo Ferraz, Marcia Otoni, Milton Toshiro, Ney Caldatto, Maurício Azenha, Deladier Almeida, Luiz Paccillo. Professores colaboradores: Hugo Segawa, Cristiano Mascaro, Yopanan Rebello, Alberto Xavier, Antonio Carlos Sant'Anna, Oswaldo Corrêa Gonçalves e Edison Eloy.
} 
Atualmente, além do HABITAFAUS, a escola conta com os seguintes laboratórios: Observatório Sócio Espacial da Baixada Santista (OBSERVA-BS), Laboratório de Sustentabilidade (LABSUS), Laboratório de Artes Visuais (LAVUCS), Laboratório de Informática, Laboratório de Audiovisual, Laboratório de Modelos e Laboratório de Conforto Ambiental.

O vigente Projeto Pedagógico da FAUS, ao buscar responder à necessidade de superação da visão fragmentada nos processos de construção e socialização do conhecimento, propõe a recuperação do caráter de unidade e síntese, de totalidade e integração dos saberes, através da interdisciplinaridade de conteúdos horizontais como articuladores do processo de ensino e de aprendizagem:

\begin{abstract}
A interdisciplinaridade é evidenciada a partir de disciplinas de diferentes sequências e ocorre de forma horizontal, com disciplinas oferecidas nos mesmos semestres, como por exemplo no primeiro e segundo semestres, as disciplinas de Projeto do Objeto I e II com Projeto de Arquitetura I e II, Topografia I e II e Representação Gráfica I (desenho geométrico) e Representação Gráfica II (desenho técnico); Plástica I e II e Urbanismo I e II. No terceiro e quarto semestres, Teoria e História da Arquitetura e Urbanismo IV com Sistemas Estruturais IV; Projeto de Arquitetura III e IV e Urbanismo III e IV. No quinto e sexto semestres, Planejamento Urbano e Planejamento Urbano Regional com Paisagismo I e II e com Projeto do Mobiliário Urbano. No sétimo semestre, a disciplina de Estética II e Teoria e História da Arquitetura e Urbanismo V também possuem pontos de intersecção interdisciplinar. Nos últimos dois semestres, o Trabalho de Curso I possui interdisciplinaridade com Meios de Representação e Expressão e Partido Estrutural. ${ }^{66}$
\end{abstract}

Entretanto, essa interdisciplinaridade entendida apenas como pressuposto na organização curricular não é suficiente para superar a fragmentação. O próprio Projeto Pedagógico da FAUS reconhece que a integração curricular deve se produzir como atitude, como um modo de pensar. O princípio de integração interdisciplinar, ao ser compreendido como fundamento de sustentação teórica aplicado como ação na construção de metodológicas de ensino, fornece novo significado para o trabalho pedagógico em termos de currículo, de métodos, de conteúdos, de avaliação e, até mesmo no que diz respeito às formas de organização dos ambientes para a aprendizagem. ${ }^{67}$

Nesse sentido, no que diz respeito ao espaço edificado, a fragmentação curricular impôs a necessidade de ocupação e compartimentação de áreas livres para instalação das novas infraestruturas. Entre 1972 e 1973, o prédio da FAUS foi projetado para abrigar um curso de arquitetura e urbanismo segundo as diretrizes didáticas e pedagógicas daquele momento. Ao ser inaugurado em 1976, já estava desatualizado em relação às novas diretrizes propostas nos constantes debates e trocas de experiência entre as escolas, divulgadas em congressos, seminários, simpósios ou em reuniões nos órgãos de classe. Nesse sentido, o prédio da FAUS se apresenta como um importante registro da associação entre espaço e pedagogia. ${ }^{68}$

\footnotetext{
66 UNIVERSIDADE CATÓLICA DE SANTOS. Projeto Pedagógico de Curso - Arquitetura e Urbanismo. Op. cit. pp 29-30.

67 Ibid. p. 30.

${ }^{68}$ A partir do projeto original do prédio da FAUS, as reformas executadas foram sistematicamente comparadas com os projetos disponíveis Foram analisadas fotografias, memoriais descritivos, croquis, além da execução de levantamentos planialtimétricos in loco, possibilitando um mapeamento aproximado das principais alterações sofridas pelo edifício. Esse material foi apresentado para alguns dos professores
} 
Em 1984, a primeira grande reforma da FAUS foi marcada pelo fechamento do pergolado na cobertura da escola com a instalação de uma estrutura metálica. É possível dizer que essa ação foi mais efetiva do ponto de vista simbólico, pois era ali que ocorriam a maioria das festas dos estudantes, do que propriamente no ganho de espaço para outros programas.

No pavimento térreo a Secretaria e Administração foram transferidas para o fundo do prédio, apoiada com a construção de uma edícula para uso dos funcionários, dando lugar ao Diretório Acadêmico e a uma Mecanografia. Pode-se verificar uma pequena ampliação da Biblioteca e o Laboratório de Fotografia passou a ocupar todo o espaço da Maquetaria, que foi extinta. A circulação vertical do edifício foi incrementada com a instalação de um elevador.

No primeiro andar foi construído um Auditório no lugar das instalações da Faculdade de Serviço Social, a antiga Sala dos Professores deu lugar para o recém-inaugurado HABITAFAUS, a Diretoria mudou-se para o piso térreo abrindo espaço para um Laboratório de Recursos Audiovisuais e a Sala dos Professores foi ampliada, ganhando uma área residual para arquivo.

No segundo pavimento foram instaladas duas salas, e a circulação entre elas recebeu três painéis para exposição reduzindo a área do atelier quase pela metade. O fechamento do pergolado na cobertura, antes destinado ao convívio dos estudantes, supriu as necessidades do curso de Serviço Social com a criação de mais cinco salas de aula, secretaria e um pequeno laboratório de audiovisual. Os espaços abertos que garantiam a fluidez de circulação perimetral entre os núcleos de sanitários e demais usos foram ocupados com depósitos improvisados em todos os andares.
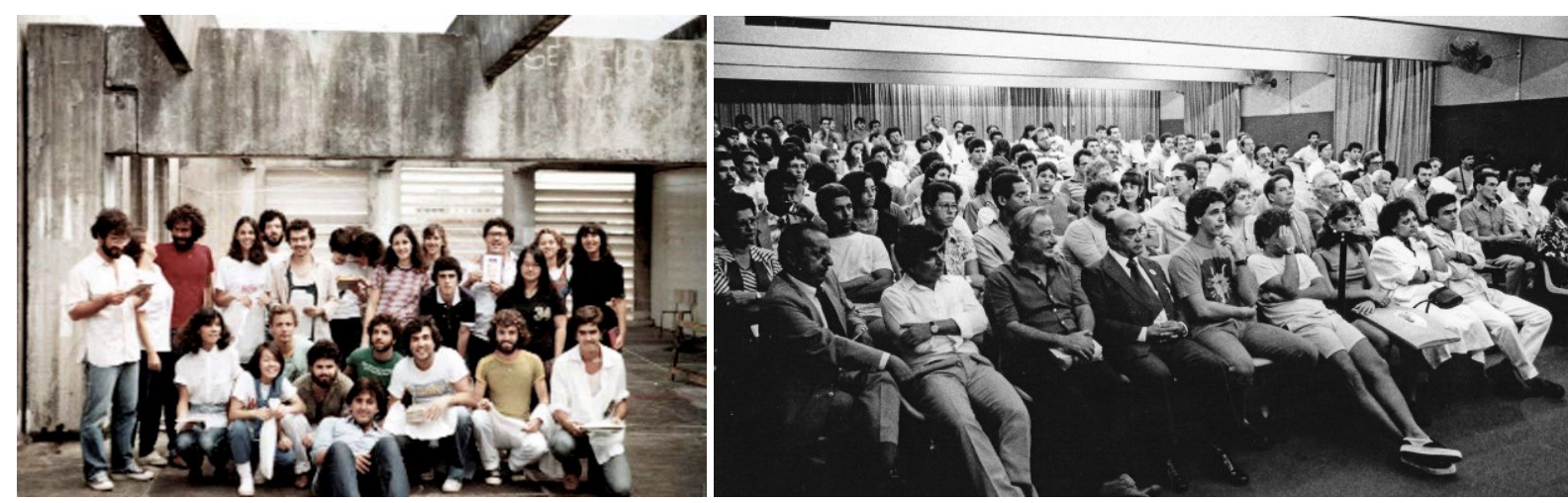

FIG. 69. Estudantes no pergolado antes de seu fechamento, ao lado, auditório para aproximadamente 200 pessoas na FAUS.

longevos da escola, para ex-alunos e funcionários antigos, a sobreposição de todos os comentários e levantamentos com as bases iniciais, resultou em desenhos e diagramas para montar a cronologia construtiva do prédio. 


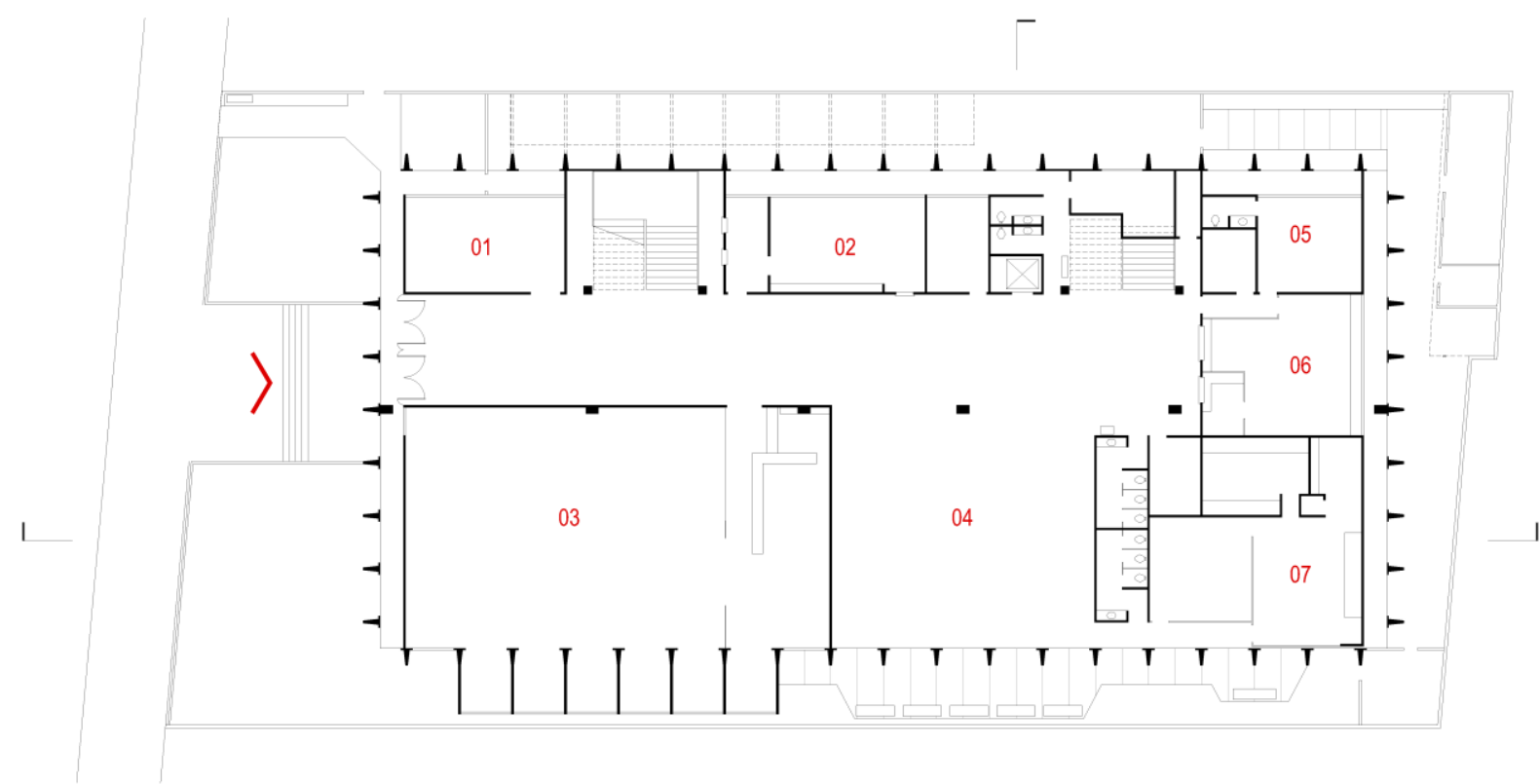

NIVEL + 0.90m. PLANTA DO PAVIMENTO TÉRREO

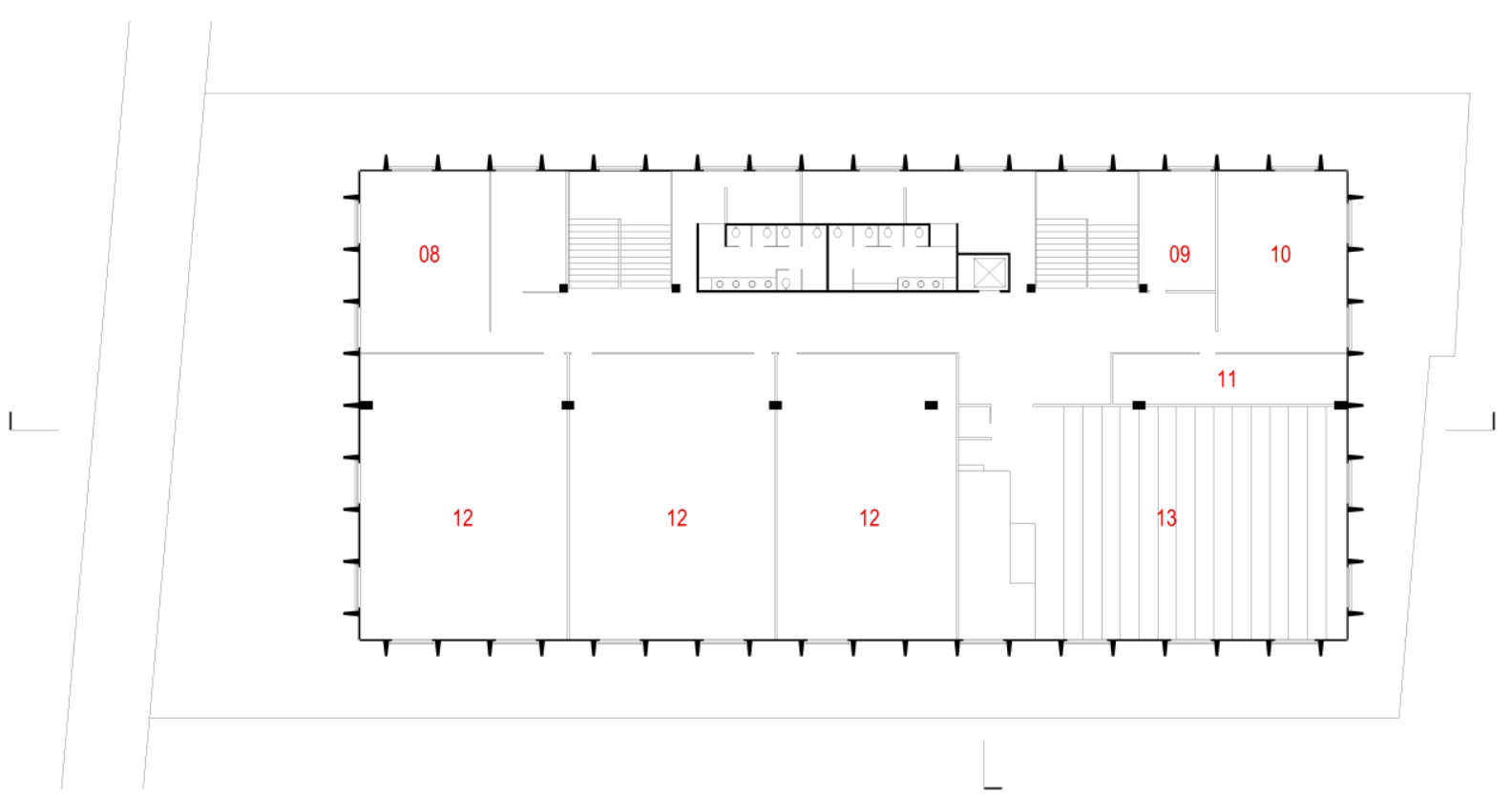

NIVEL + 4.90m. PLANTA DO $1^{\circ}$ PAVIMENTO

$\begin{array}{llll}0 & 1 & 5 & 10\end{array}$

01 DIRETÓRIO ACADÊMICO LUCIO COSTA 02 MECANOGRAFIA 03 BIBLIOTECA 04 EXPOSIÇÕES 05 DIRETORIA 06 SECRETARIA 07 LABORATÓRIO DE FOTOGRAFIA 08 HABITAFAUS 09 LABORATÓRIO DE AUDIOVISUAL 10 SALA DOS PROFESSORES 11 ARQUIVO 12 SALA DE AULA 13 AUDITÓRIO

FIG. 70. Reforma de 1984, desenho baseado nos documentos e registros disponíveis. 


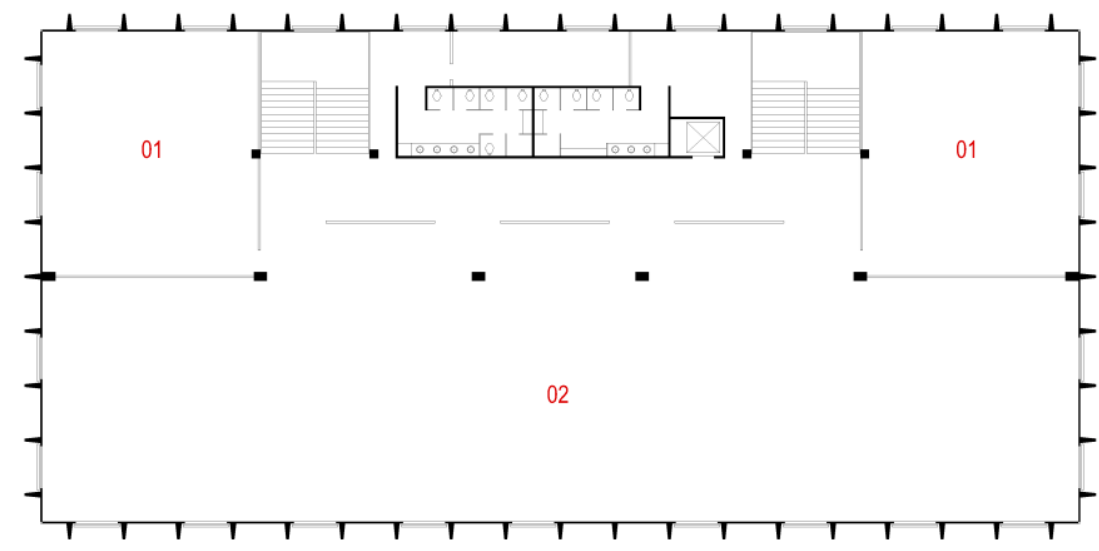

NIVEL $+8.90 \mathrm{~m}$. PLANTA DO $2^{\circ}$ PAVIMENTO

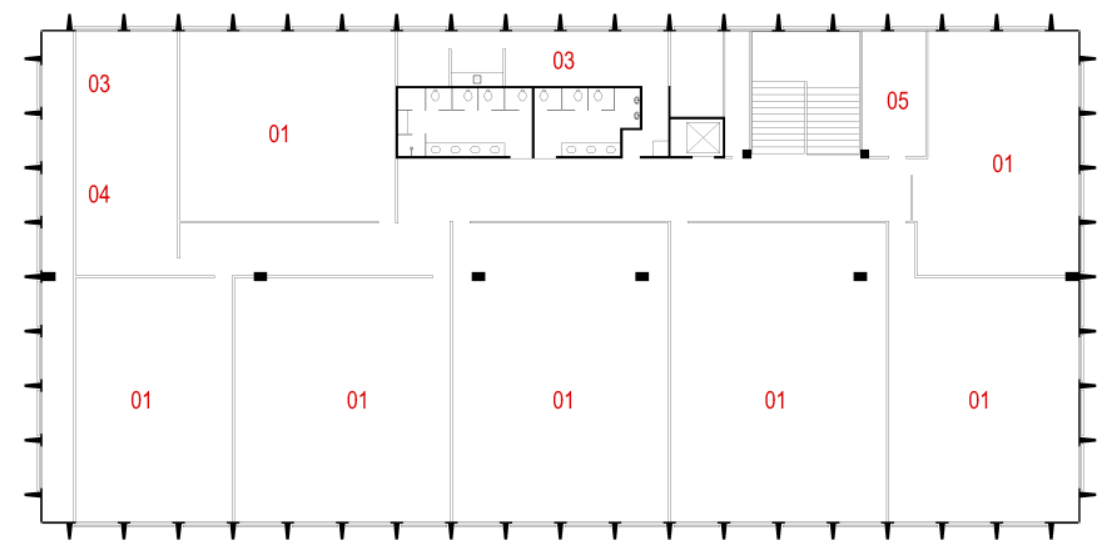

NIVEL +12.90m. PLANTA DO $3^{\circ}$ PAVIMENTO

$\begin{array}{llll}0 & 5 & 10 & 1\end{array}$

01 SALA DE AULA 02 ATELIER 03 DEPÓSITO 04 SECRETARIA DA FACULDADE DE SERVIÇO SOCIAL 05 LABORATÓRIO DE AUDIOVISUAL

FIG. 71. Reforma de 1984, desenho baseado nos documentos e registros disponíveis. 


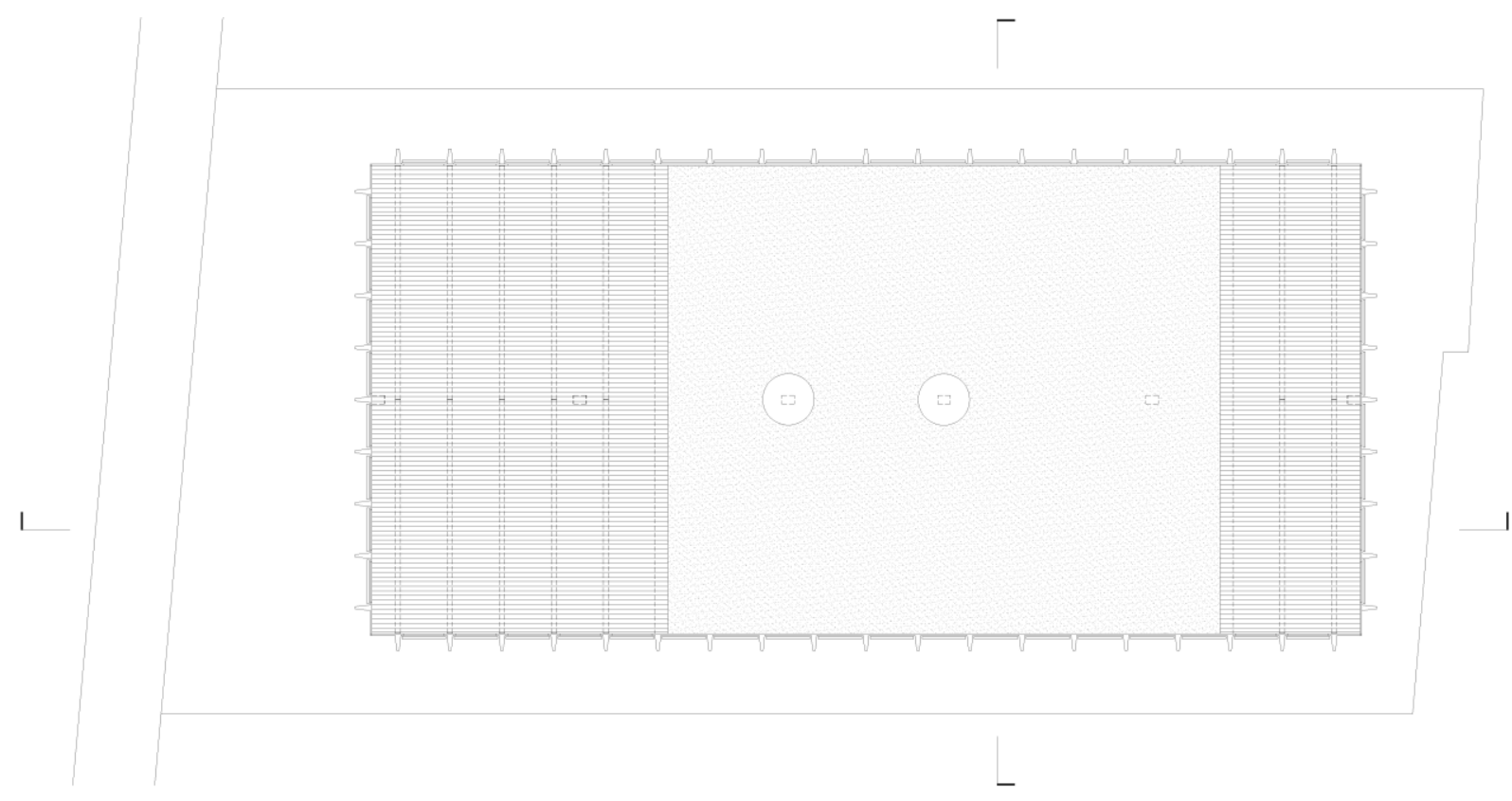

NIVEL +16.90m. PLANTA DA COBERTURA

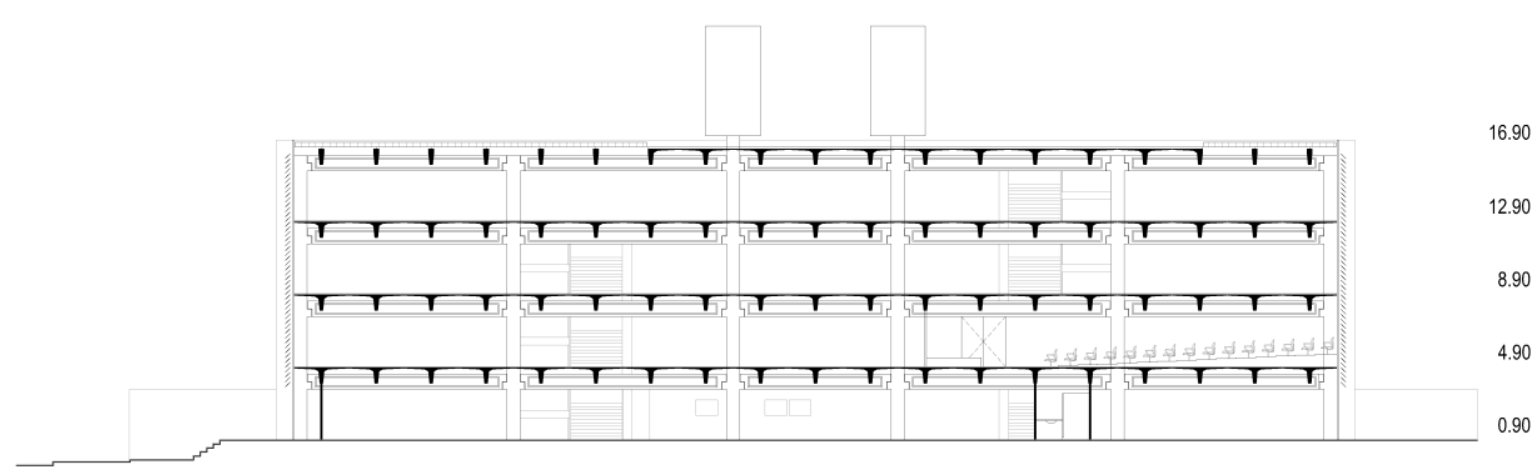

CORTE LONGITUDINAL

FIG.72. Reforma de 1984, desenho baseado nos documentos e registros disponíveis.

Entre 1984 e 1998, a necessidade de ampliação da biblioteca no pavimento térreo extinguiu a área de exposição e a mecanografia foi substituída por um laboratório de materiais e ensaios, pois a Faculdade de Serviço Social havia dado lugar à Faculdade de Engenharia Civil. O muro que separava a FAUS da Faculdade de Direito foi derrubado, constituindo uma primeira tentativa de estruturação de um campus universitário, a edícula no fundo do prédio foi ampliada incorporando usos de zeladoria e manutenção. Foi instalado um gradil metálico em todo o perímetro do complexo, junto ao passeio público, diminuindo ainda mais a mediação com a cidade. 
No primeiro andar foi implantado um Laboratório de Informática na sala que funcionava o HABITAFAUS que, desprestigiado e inativo naquele momento, foi transferido para um pequeno espaço ao lado. O segundo e o terceiro pavimentos não sofreram alterações físicas, apenas mudanças de uso. No segundo andar, o espaço atrás do núcleo de sanitários foi cedido para a Agremiação Esportiva Atlética FAUS, ao mesmo tempo que a Faculdade de Engenharia Civil substituiu a Faculdade de Serviço Social no terceiro piso, se beneficiando da infraestrutura instalada.

Em função da mudança do Estatuto da Universidade Católica de Santos e em atendimento às novas exigências e diretrizes curriculares do MEC, foi elaborado um novo Projeto Político Pedagógico para a FAUS, ao longo do ano 2000, atualizando e deixando mais claros seus objetivos, perfil desejado do egresso, novos conteúdos, carga horária etc. A implantação desse projeto pedagógico não alterava a estrutura física do edifício da escola. A SVSL reestruturou o Campus Boqueirão e, ao transferir o curso de engenharia civil para outro campus, facilitou a ocupação do terceiro pavimento do prédio da FAUS pela faculdade de direito. Com a justificativa de aumentar a segurança de professores e estudantes, a mantenedora unificou os acessos e implantou um sistema identificação e controle. Entretanto, essa intervenção provocou o deslocamento da entrada principal da FAUS da frente para a lateral do prédio, a escadaria de acesso, local de encontro e convívio de estudantes e professores, foi transformada em jardim rompendo definitivamente a relação direta com a Avenida Conselheiro Nébias. Essa alteração também provocou a demolição da sala do Diretório Acadêmico, transferido para fora do Campus ocupando uma casa alugada pela SVSL na Rua Dagoberto de Gasgon. ${ }^{69}$

Em atendimento à resolução no 6/2006 do MEC, que instituiu novas diretrizes curriculares nacionais para os cursos de arquitetura e urbanismo, o Projeto Político Pedagógico da FAUS sofreu sua primeira revisão. Grosso modo, essas revisões reforçaram o plano de 2000 e propuseram poucas alterações no currículo, como por exemplo, a supressão da disciplina de matemática, alterações nas nomenclaturas das disciplinas de desenho do objeto, sistemas estruturais, criação das disciplinas de paisagismo, ergonomia, ética profissional, etc. As alterações que implicaram em maiores intervenções nos espaços da escola estavam relacionadas à criação, ampliação, redução ou mesmo extinção de laboratórios. Desse modo, vale destacar a transferência do Laboratório de Materiais e Ensaios para o campus sede da universidade, Campus Dom Idílio José Soares, e a implantação do Laboratório de Modelos em seu local.

\footnotetext{
${ }^{69} \mathrm{O}$ Diretório Acadêmico da FAUS ficou fora do Campus Boqueirão por aproximadamente quatro anos antes de ser transferido para o espaço ocupado pela Agremiação Esportiva Atlética FAUS no andar do Atelier. Essas mudanças de endereço foram feitas sem a presença dos estudantes, tendo como consequência a perda significativa e irreparável de documentos e registros históricos dos diversos movimentos estudantis realizados desde a fundação da escola até aquele momento. 


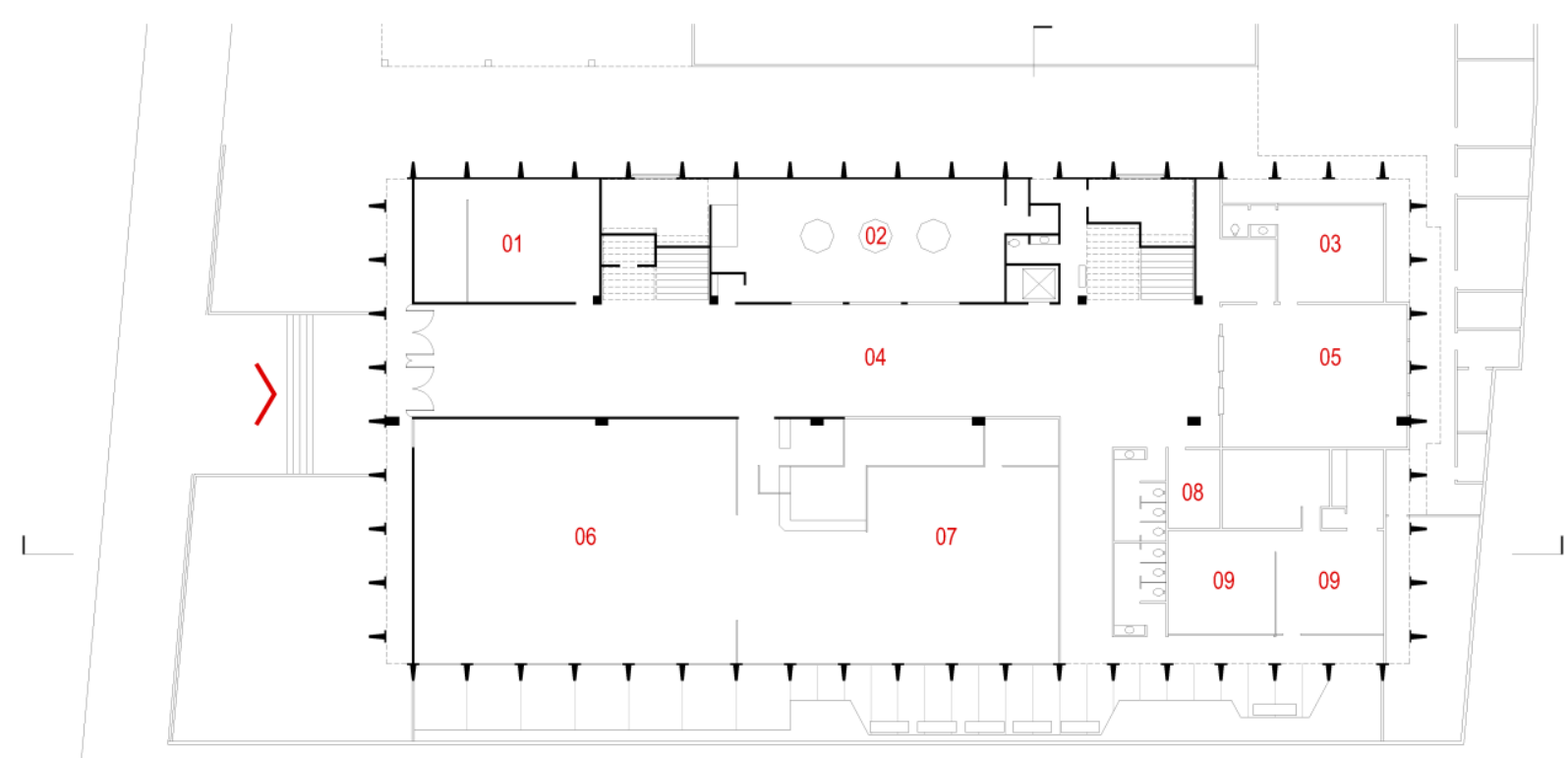

NIVEL + 0.90M. PLANTA DO PAVIMENTO TÉRREO

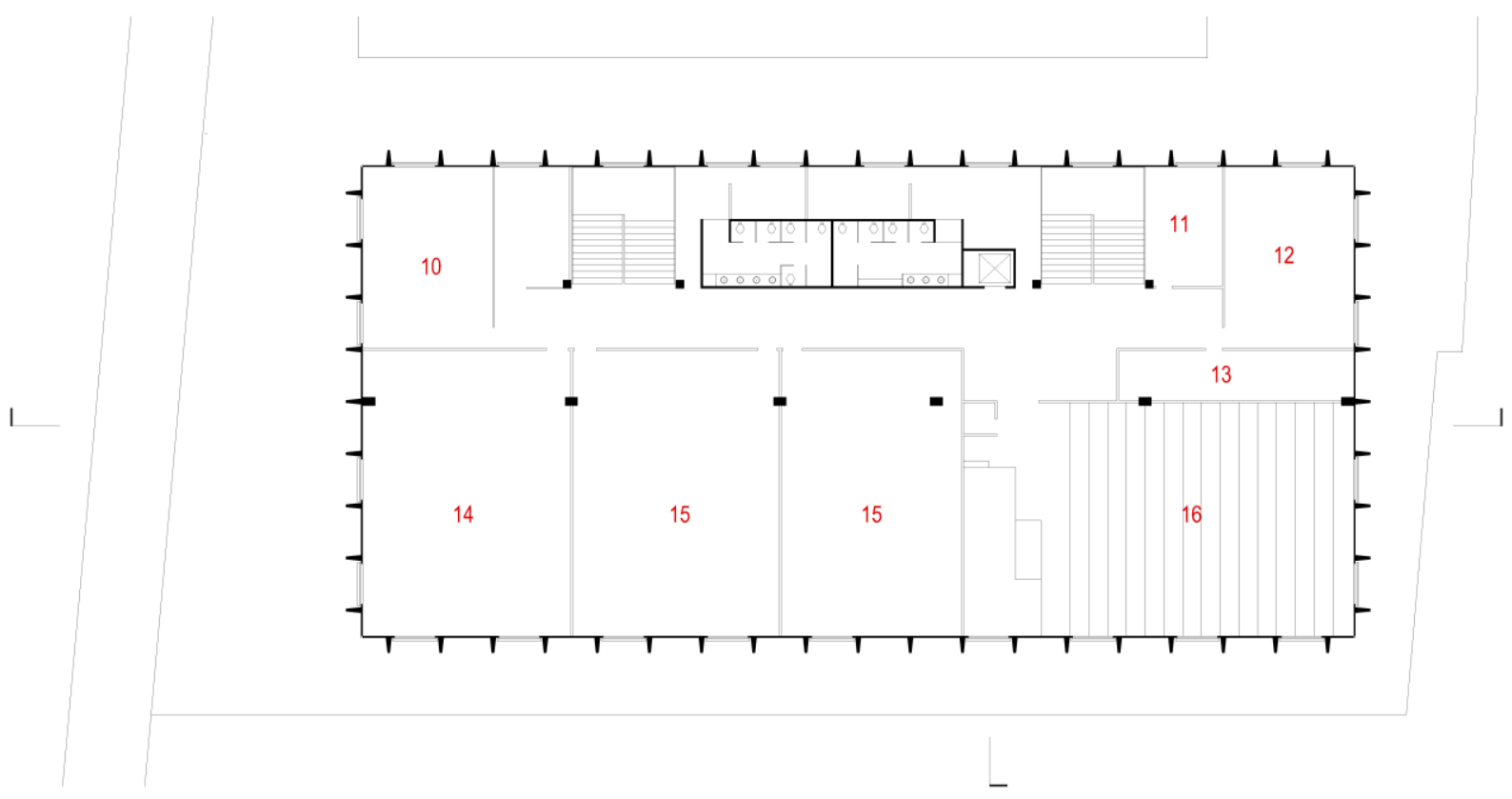

NIVEL + 4.90m. PLANTA DO $1^{\circ}$ PAVIMENTO

01 DIRETÓRIO ACADÊMICO MICHAIL LIDERS 02 LABORATÓRIO DE MATERIAIS E ENSAIOS 03 DIRETORIA 04 EXPOSIÇÃO 05 SECRETARIA 06 ACERVO DA BIBLIOTECA 07 ÁREA DE LEITURA 08 COPA 09 LABORATÓRIO E ESTÚDIO DE FOTOGRAFIA 10 LABORATÓRIO DE INFORMÁTICA 11 HABITAFAUS 12 LABORATÓRIO DE AUDIOVISUAL 13 SALA DOS PROFESSORES 14 ARQUIVO 15 SALA DE AULA 16 AUDITÓRIO

FIG. 73. Reforma de 1998, desenho baseado nos documentos e registros disponíveis. 


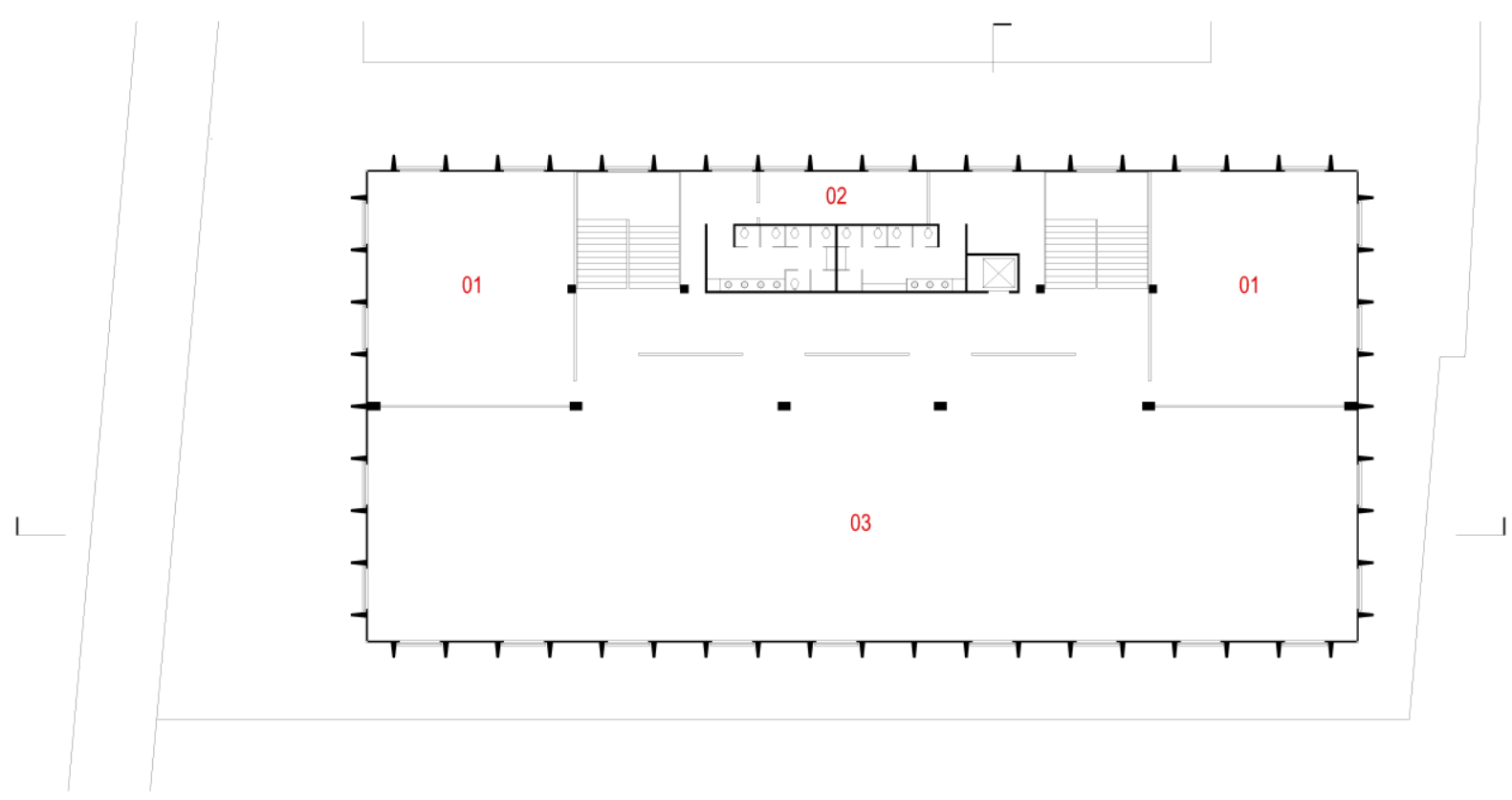

NIVEL $+8.90 \mathrm{~m}$. PLANTA DO $2^{\circ}$ PAVIMENTO

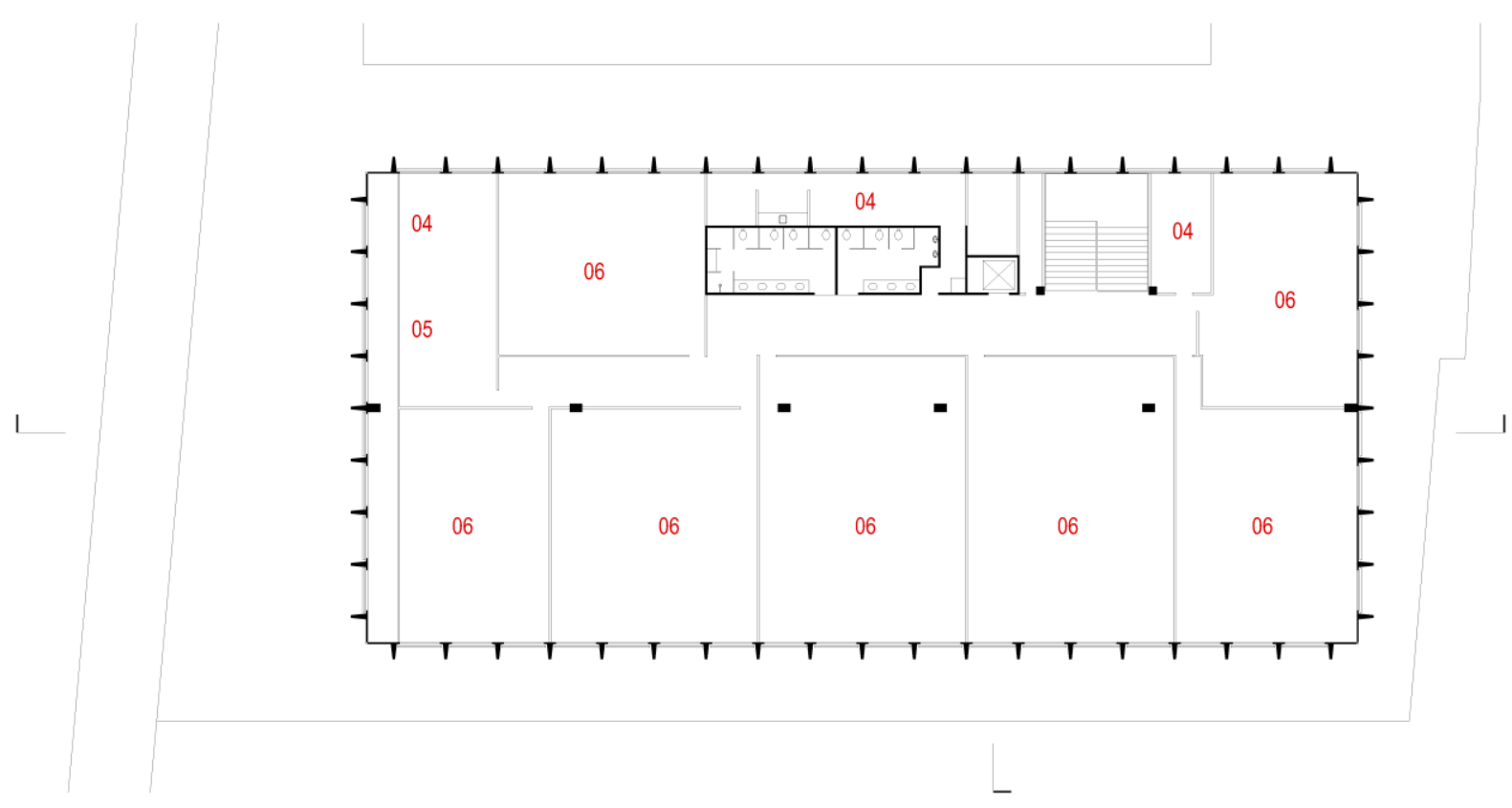

NIVEL +12.90m. PLANTA DO $3^{\circ}$ PAVIMENTO

$\begin{array}{llll}01 & 5 & 10 & 1\end{array}$

01 SALA DE AULA 02 ATLÉtICA FAUS 03 ATELIER 04 DEPósito 05 SECRETARIA DIREITO 06 SALA DE AULA

FIG. 74. Reforma de 1998, desenho baseado nos documentos e registros disponíveis. 


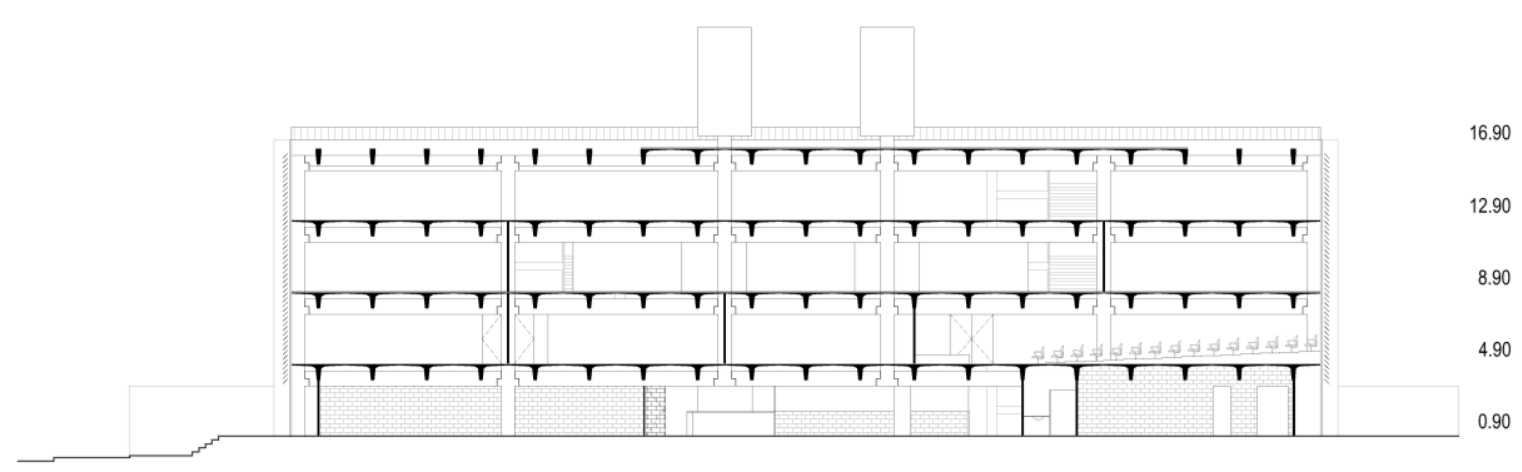

CORTE LONGITUDINAL

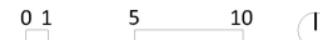

FIG. 75. Reforma de 1998, desenho baseado nos documentos e registros disponíveis.

Em 2016, na ocasião de uma nova revisão do projeto pedagógico do curso, foi feita outra reforma no pavimento térreo do edifício. A criação do Laboratório de Artes Visuais (LAVUCS) provocou a mudança do Laboratório de Modelos para o lugar da sala dos professores que, por sua vez foi reposicionada, junto com a secretaria e sala da coordenação, para o lugar do extinto Laboratório e Estúdio de Fotografia. O Laboratório de Conforto Ambiental passou a ocupar a antiga sala da coordenação. Apesar da instalação de novos equipamentos e infraestrutura, o novo Laboratório de Modelos da FAUS vem recebendo críticas dos alunos:

\footnotetext{
O recém-inaugurado Laboratório de Modelos não cumpre sua função. A mesa de corte não é apropriada para corte, pois depende de uma improvisada base de papel tipo Paraná ou Roller e pedaços de vidro retirados das janelas no momento da reforma do espaço. Seu uso é extremamente limitado, na medida que só é permitida a entrada com "roupa adequada" (calça, sapato fechado, blusa de manga). Vivemos no litoral e as temperaturas são elevadas, e o laboratório não possui climatização, como solução, sugerimos a disponibilização de uniformes, tipo macacão, para uso livre dos alunos quando não estiverem "adequadamente vestidos". Além de tudo isso, o espaço é insuficiente, na medida que o curso conta com mais de 300 alunos e o laboratório possui apenas 27 assentos. ${ }^{70}$
}

Por outro lado, a aceitação do corpo discente da FAUS quanto ao LAVUCS merece destaque, as atividades propostas por esse laboratório atraem extraordinariamente a atenção dos alunos, pois a atmosfera criada nesse lugar, devido à liberdade de expressão proposta, vai além dos seus objetivos: "o Laboratório de Artes Visuais é muito concorrido pelos alunos para realização de trabalhos de qualquer disciplina voltados ao uso de determinados materiais e experimentações." ${ }^{11}$

Nesse sentido, a despeito de problemas e virtudes, importa dizer que tanto o Laboratório de Modelos quanto o Laboratório de Artes Visuais, estão absolutamente deslocados do principal espaço de produção da escola: o atelier.

\footnotetext{
70 DIRETÓRIO ACADÊMICO MICHAEL LIEDERS. Ressurreição da FAUS. Santos, 2017. 


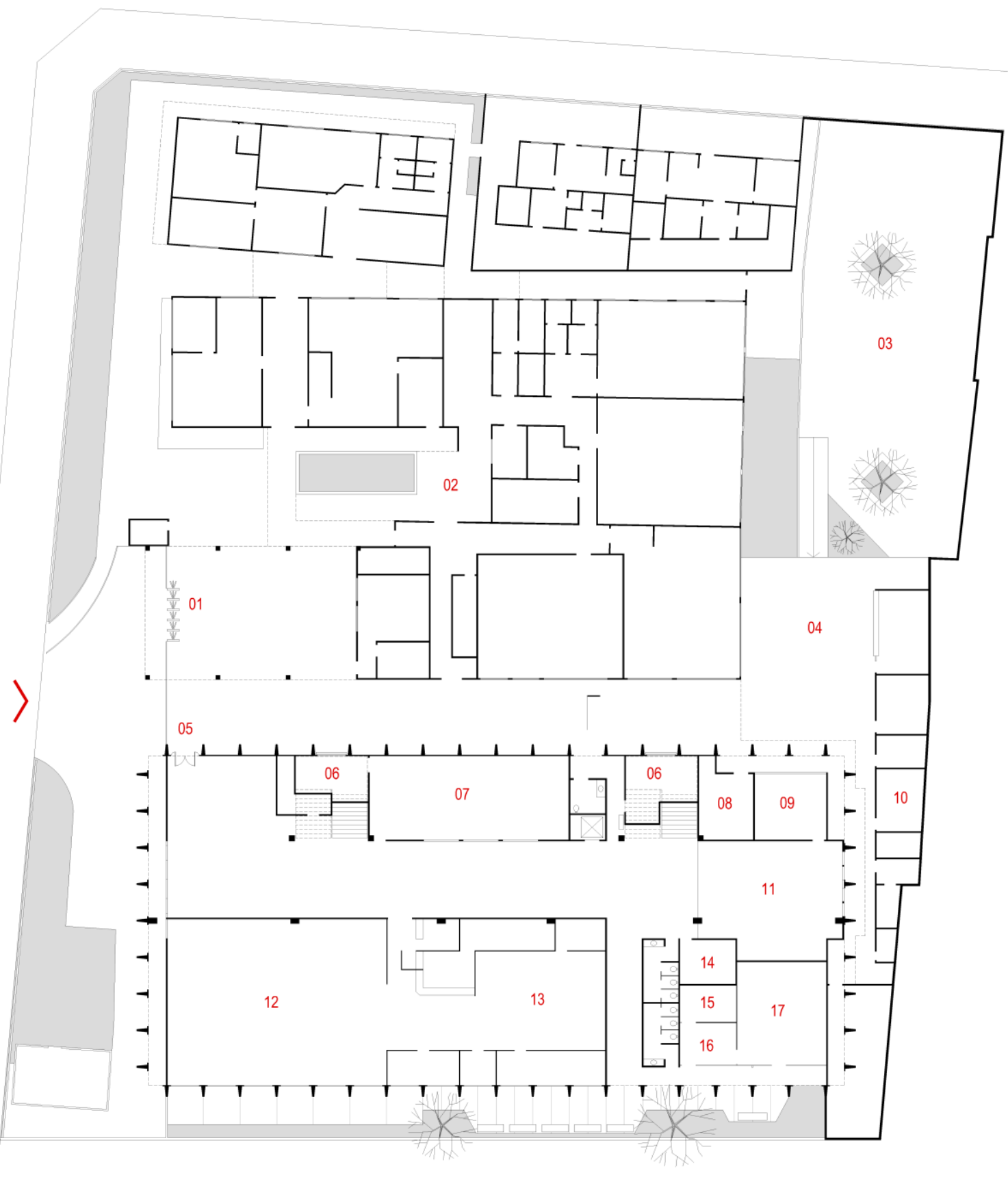

0.90m. PLANTA DO PAVIMENTO TÉRREO 


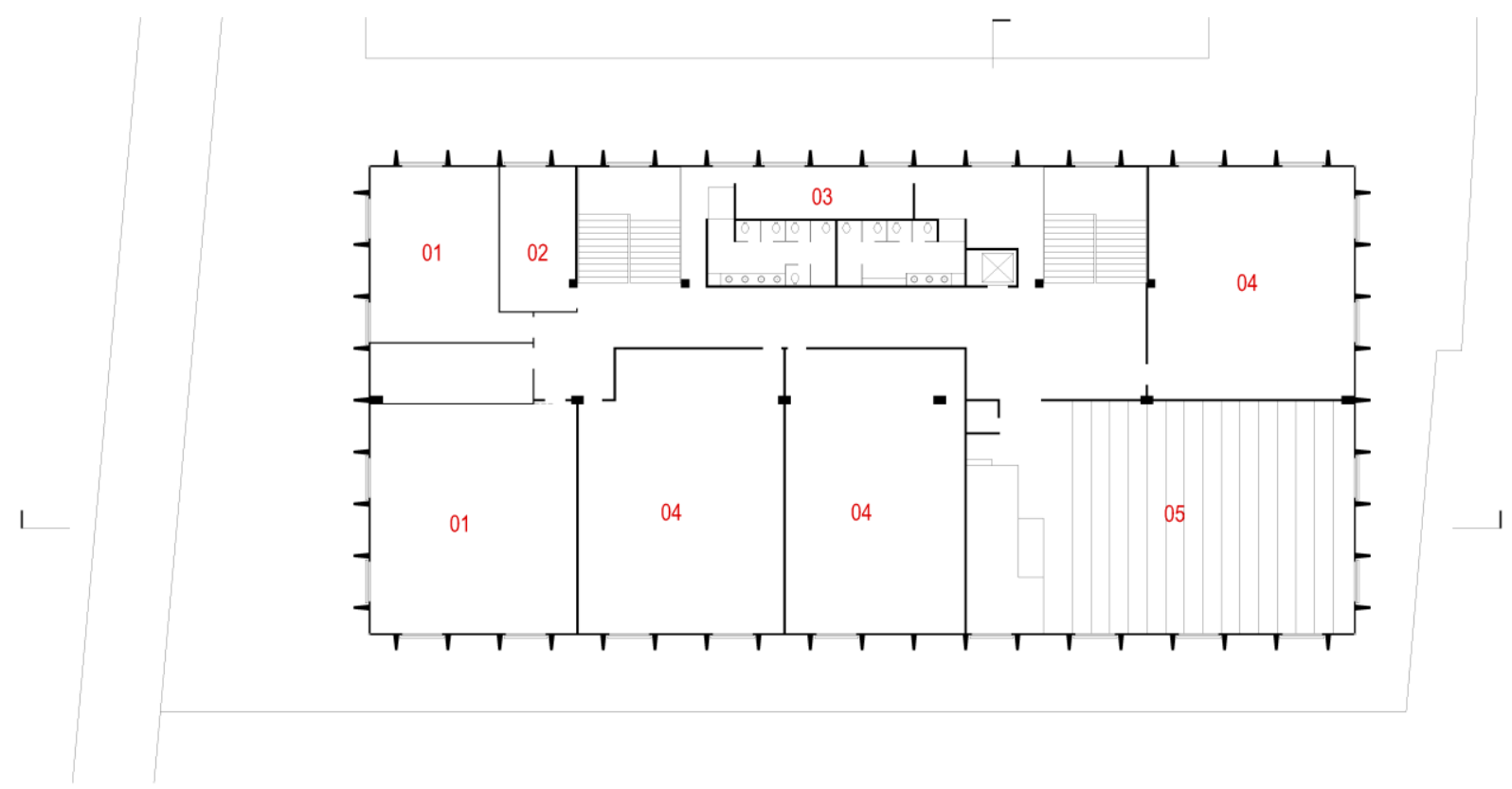

NIVEL + 4.90m. PLANTA DO $1^{\circ}$ PAVIMENTO

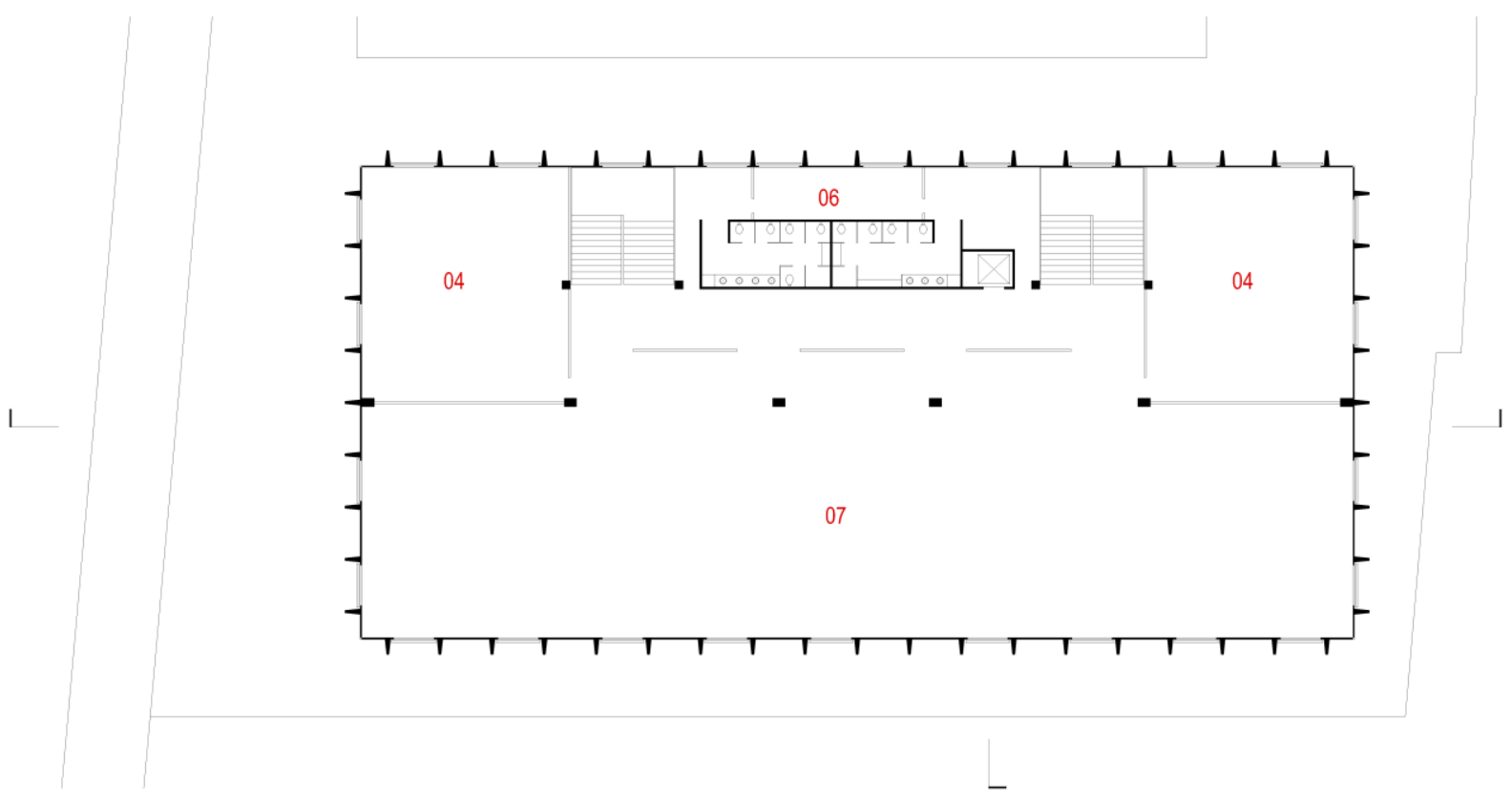

NIVEL + 8.90m. PLANTA DO $2^{\circ}$ PAVIMENTO. 


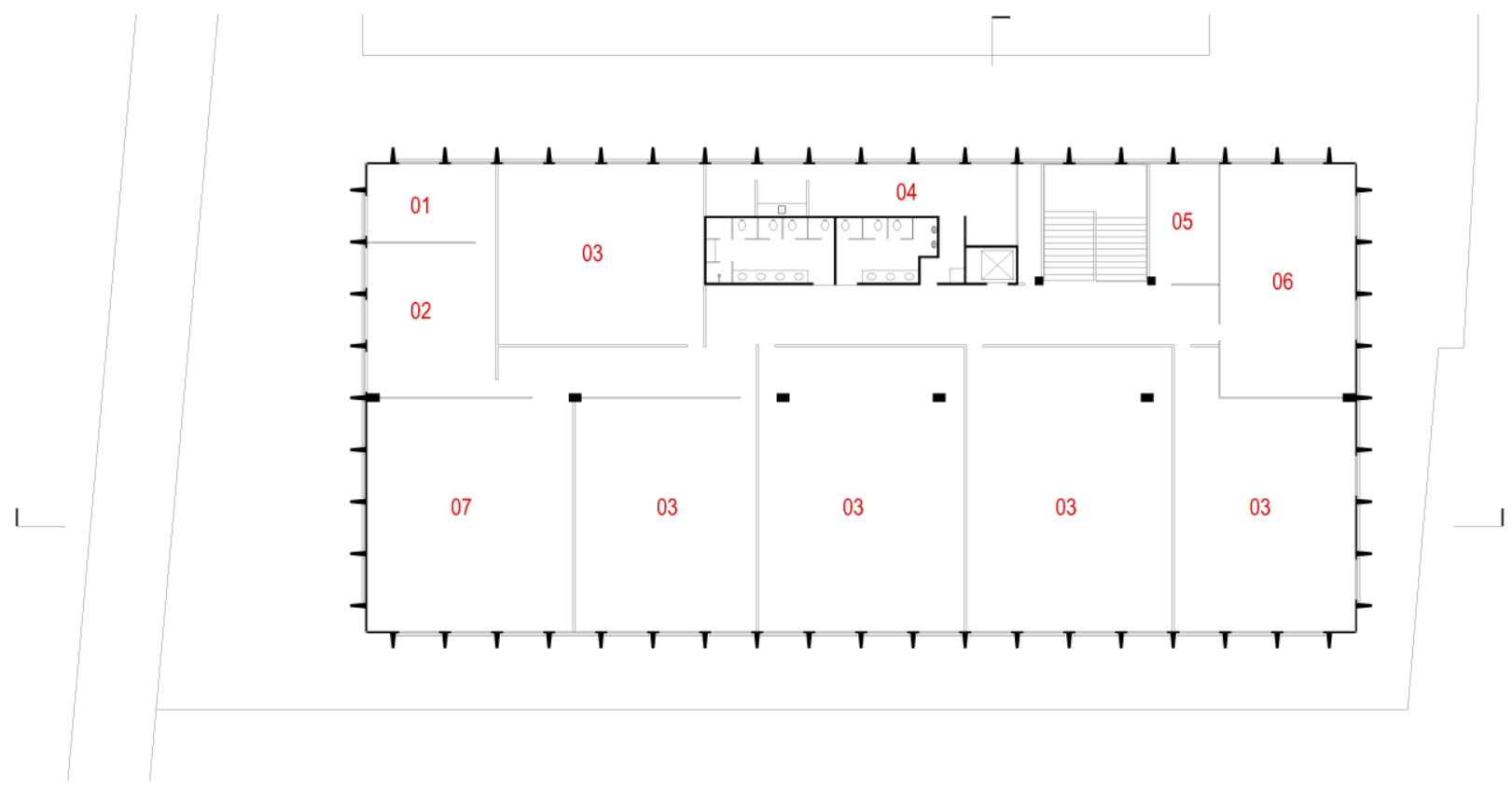

NIVEL + 12.90m. PLANTA DO $3^{\circ}$ PAVIMENTO

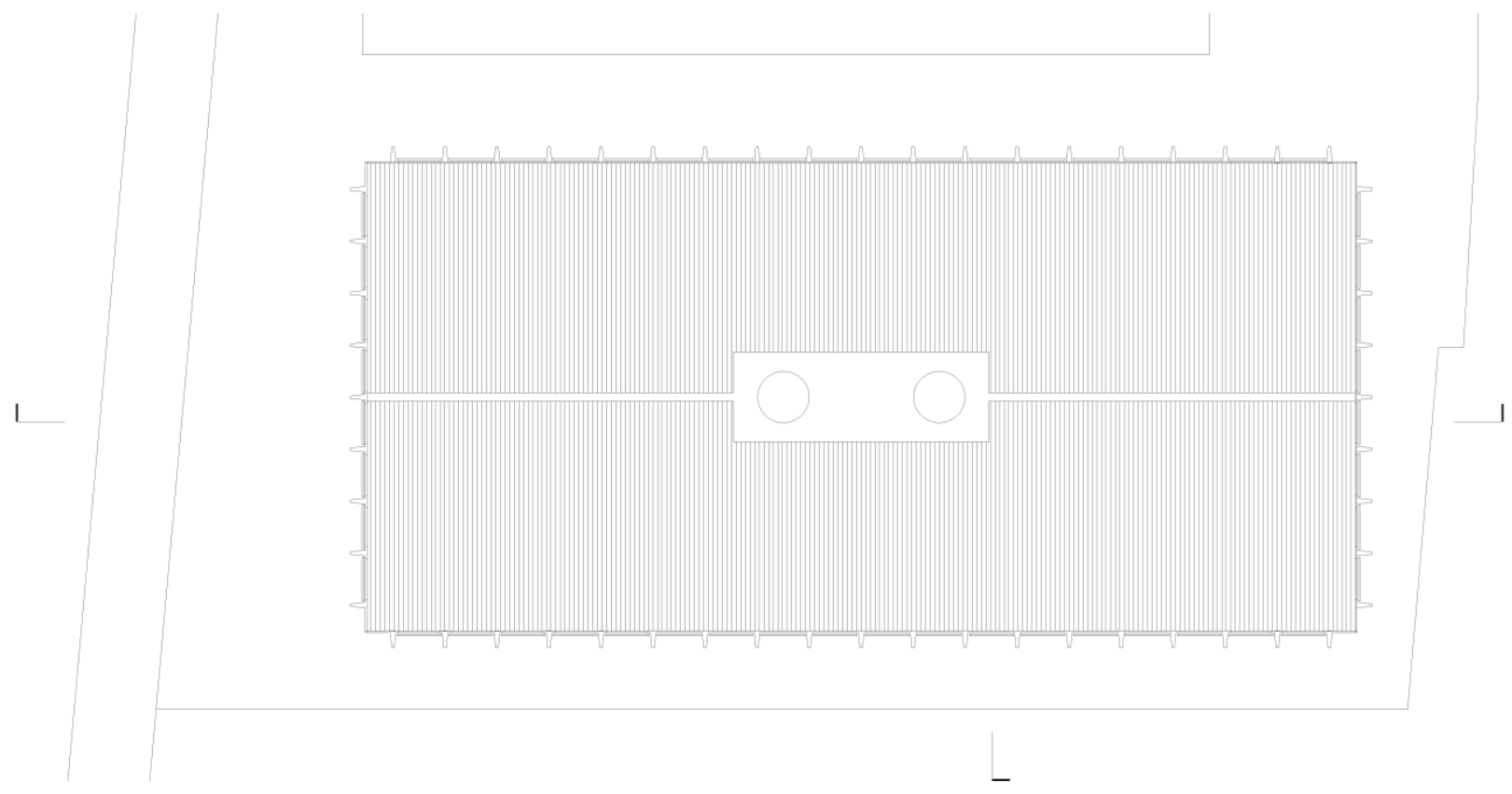

NIVEL + 16.90m. PLANTA DA COBERTURA

$015 \quad 10 \quad$ ।

01 ARQUIVO DA FAUS 02 CONTROLE DE ACERVO FAUS 03 SALA DE AULA 04 APOIO 05 LABORATÓRIO DE AUDIOVISUAL 06 SECRETARIA DA FACULDADE DE DIREITO 07 TRIBUNAL MODELO DA FACULDADE DE DIREITO

FIG. 78. Reforma de 2017, desenho baseado nos documentos e registros disponíveis. 


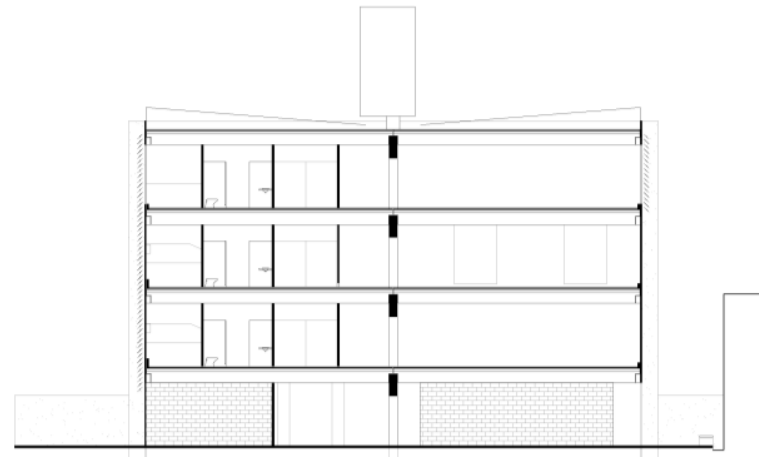

CORTE TRANSVERSAL

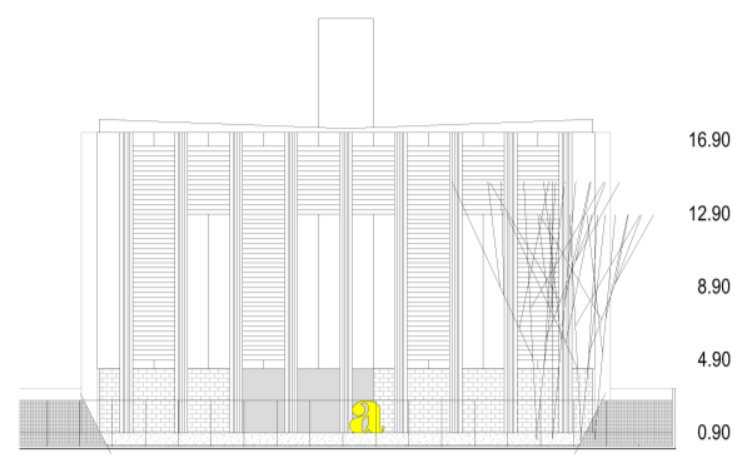

ELEVAÇÃO FRONTAL

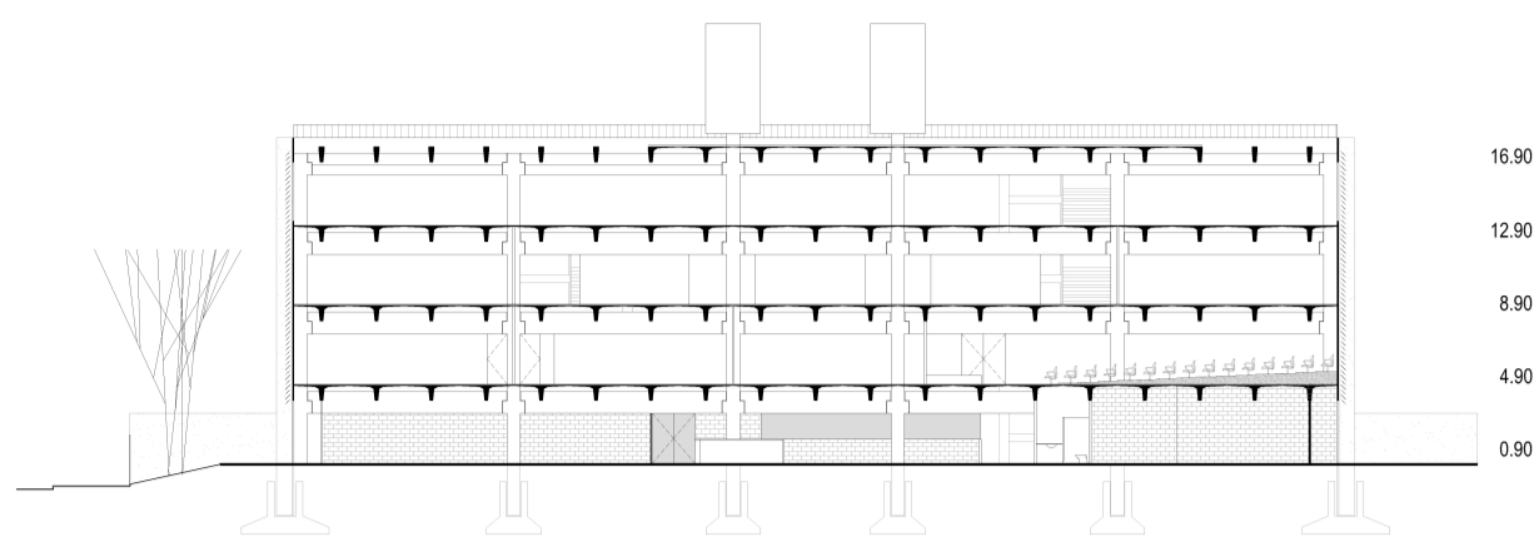

CORTE LONGITUDINAL

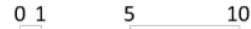

FIG. 79. Reforma de 2017, desenho baseado nos documentos e registros disponíveis.

Em um esforço de síntese foram elaborados desenhos que contém todas as alterações sofridas pelo prédio da FAUS organizadas cronologicamente. Essas peças gráficas configuram um importante instrumento de observação da capacidade de transformação dos espaços e suas relações com os processos de ensino da FAUS. 


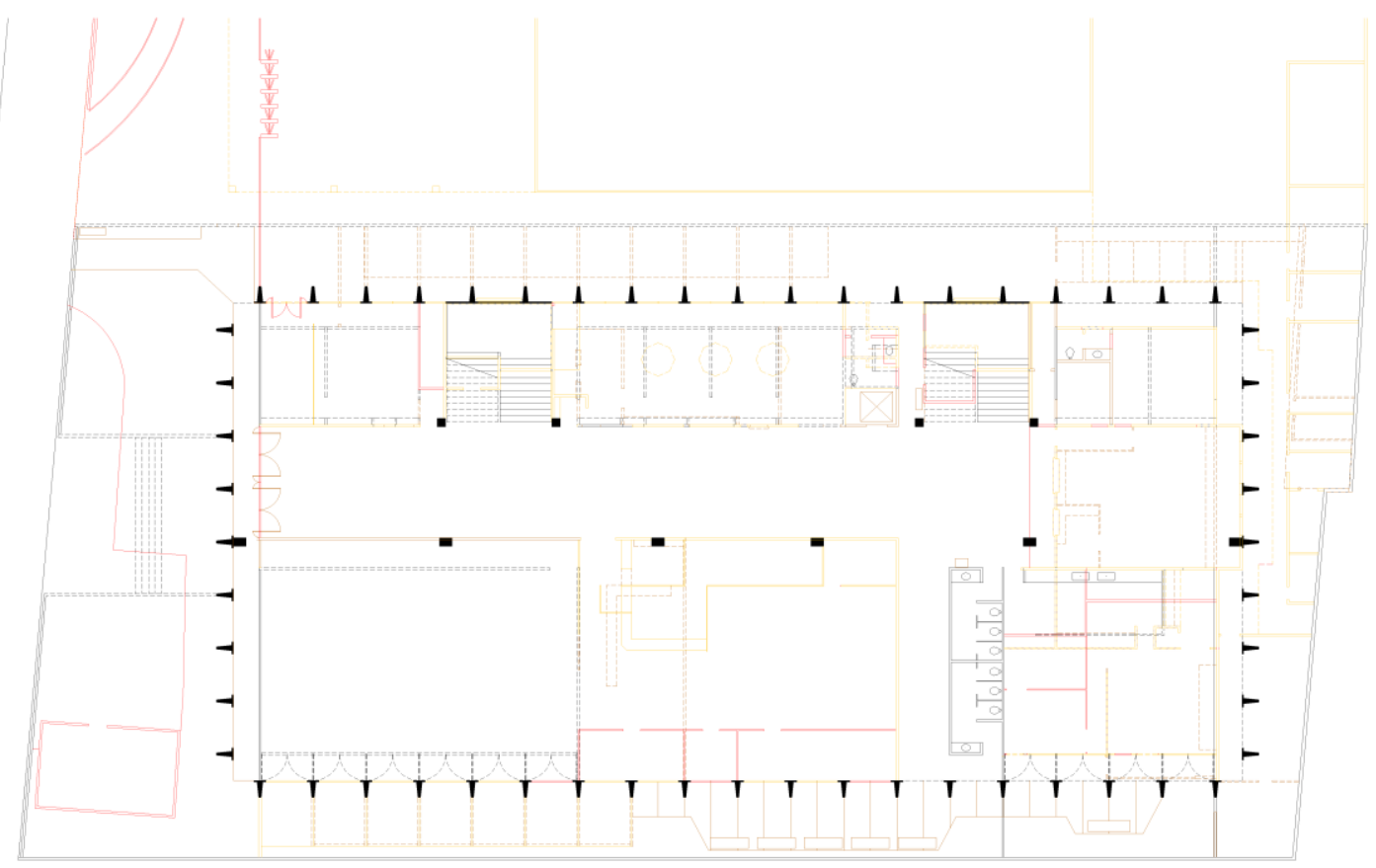

NIVEL + 0.90m. PLANTA DO PAVIMENTO TÉRREO

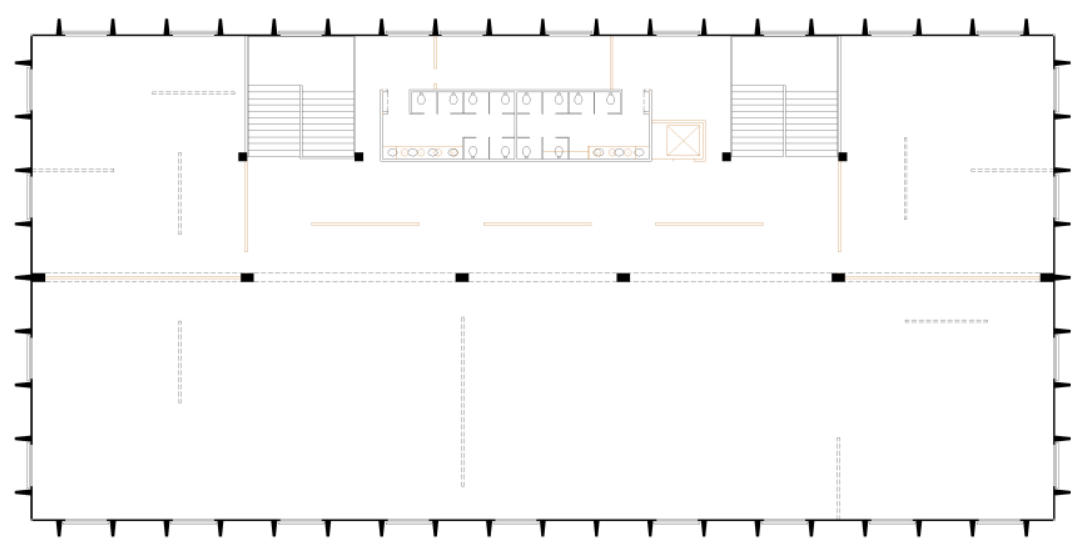

NIVEL + 4.90m. PLANTA DO $1^{\circ}$ PAVIMENTO 


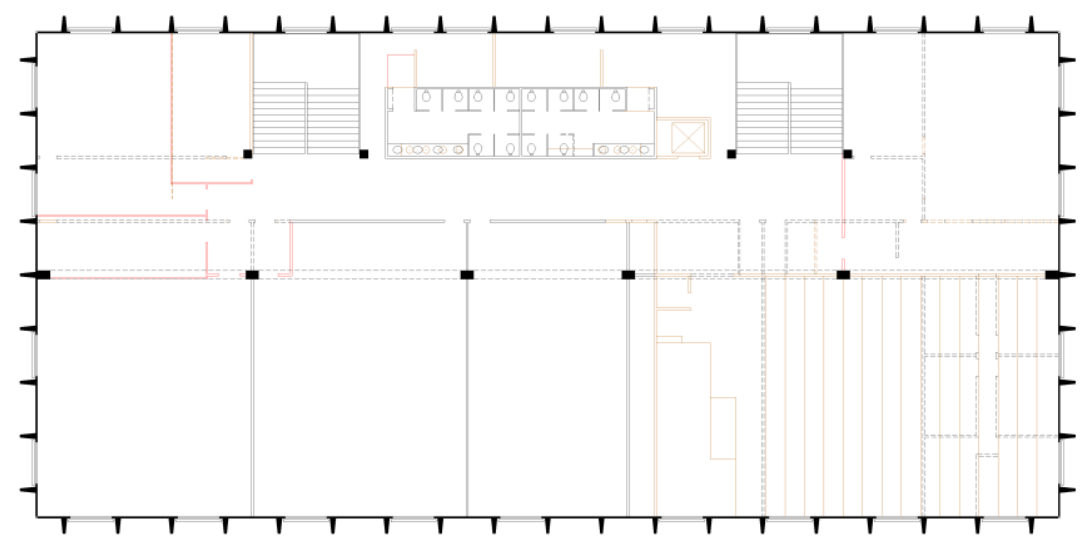

NIVEL $+8.90 \mathrm{~m}$. PLANTA DO $2^{\circ}$ PAVIMENTO

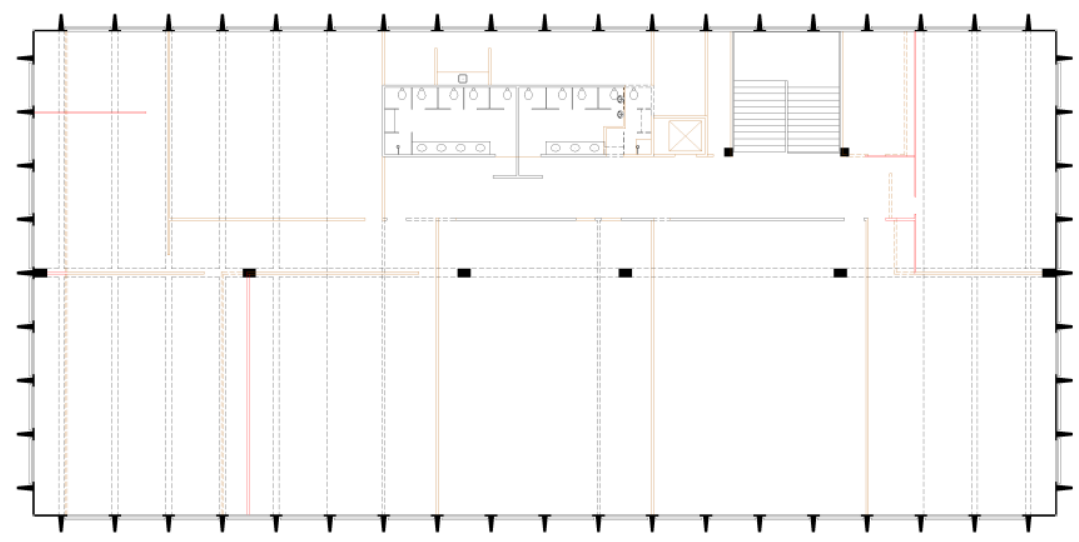

NIVEL + 12.90m. PLANTA DO $3^{\circ}$ PAVIMENTO

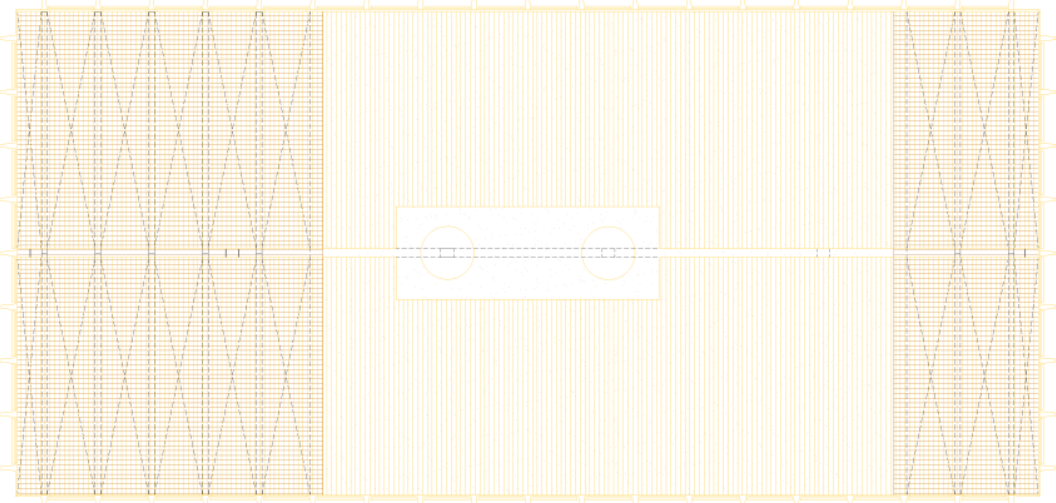

NIVEL + 16.90m. PLANTA DA COBERTURA

$\begin{array}{lll}01 & 5 & 10\end{array}$ 


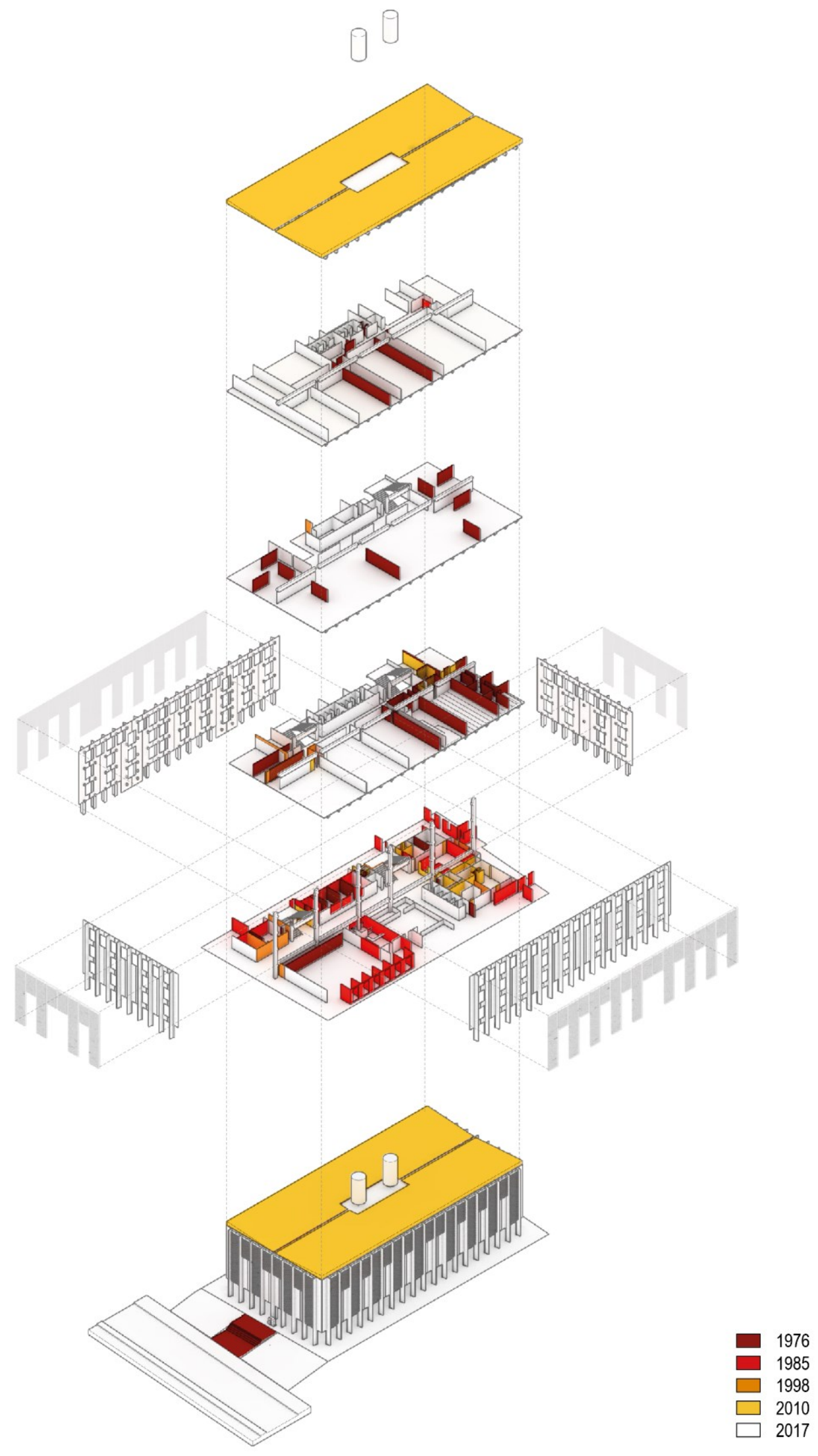

FIG. 82. Axonometria da cronologia construtiva, baseada nos documentos e registros das reformas de 1976, 1984,1998 e 2017. 
Como visto, ao longo de quase cinquenta anos a FAUS sofreu muitas transformações. No que se refere aos aspectos pedagógicos, o processo de pulverização disciplinar atrelado às constantes alterações das formas de produção e pesquisa auxiliadas pela tecnologia, que passaram a exigir espaços apropriados para sua realização, direcionaram a organização dos programas da escola a arranjos espaciais cada vez mais compartimentados, com evidente prejuízo das áreas livres de convívio e de exposições.

Além disso, do ponto de vista administrativo e no contexto da universidade, desde a sua inauguração o prédio admitiu o compartilhamento de suas áreas com outros cursos oferecidos pela Sociedade Visconde de São Leopoldo. Esses cursos ocupam o terceiro pavimento do edifício desde 1984, quando o pergolado foi coberto, para atender às demandas da universidade, contudo isso corresponde a uma perda de espaço para o curso de arquitetura de aproximadamente $20 \%$ da área da edificação.

Contudo, graças à flexibilidade prevista em seu projeto e à natureza do sistema construtivo utilizado, o prédio da FAUS foi capaz de se adaptar às novas demandas e garantir que as reformas impostas não descaracterizassem sua configuração principal. Com exceção das intervenções externas de fechamento e mudança da entrada principal do prédio que configuram operações mais delicadas para sua reversão, a grande maioria das alterações se restringiu a arranjos internos executados com divisórias industrializadas, isso demonstra certa facilidade de reconstituição de suas feições originais. Do ponto de vista político-pedagógico, o MEC continua com o processo de fragmentação curricular homogeneizante e instrumental, ampliando a proliferação de escolas e a burocratização do ensino. Esse processo tende a aniquilar a identidade das escolas e enrijecer os conteúdos de tal forma que o currículo e experiência do corpo docente, como organismo político e ideológico, não seja representativo.

\begin{tabular}{|l|r|r|}
\hline aula $13,6 \%$ & $\begin{array}{r}\text { coordenação } 0,2 \% \\
\text { secretaria } 0,3 \% \\
\text { habitafaus } 0,6 \%\end{array}$ \\
bombeiro $0,4 \%$
\end{tabular}

FIG. 83. Relações entre espaço e pedagogia no prédio da FAUS EM 2017. Elaborado a partir do diagrama de áreas do programa da FAU-USP elaborado pelo professor Antônio Carlos Barossi. 


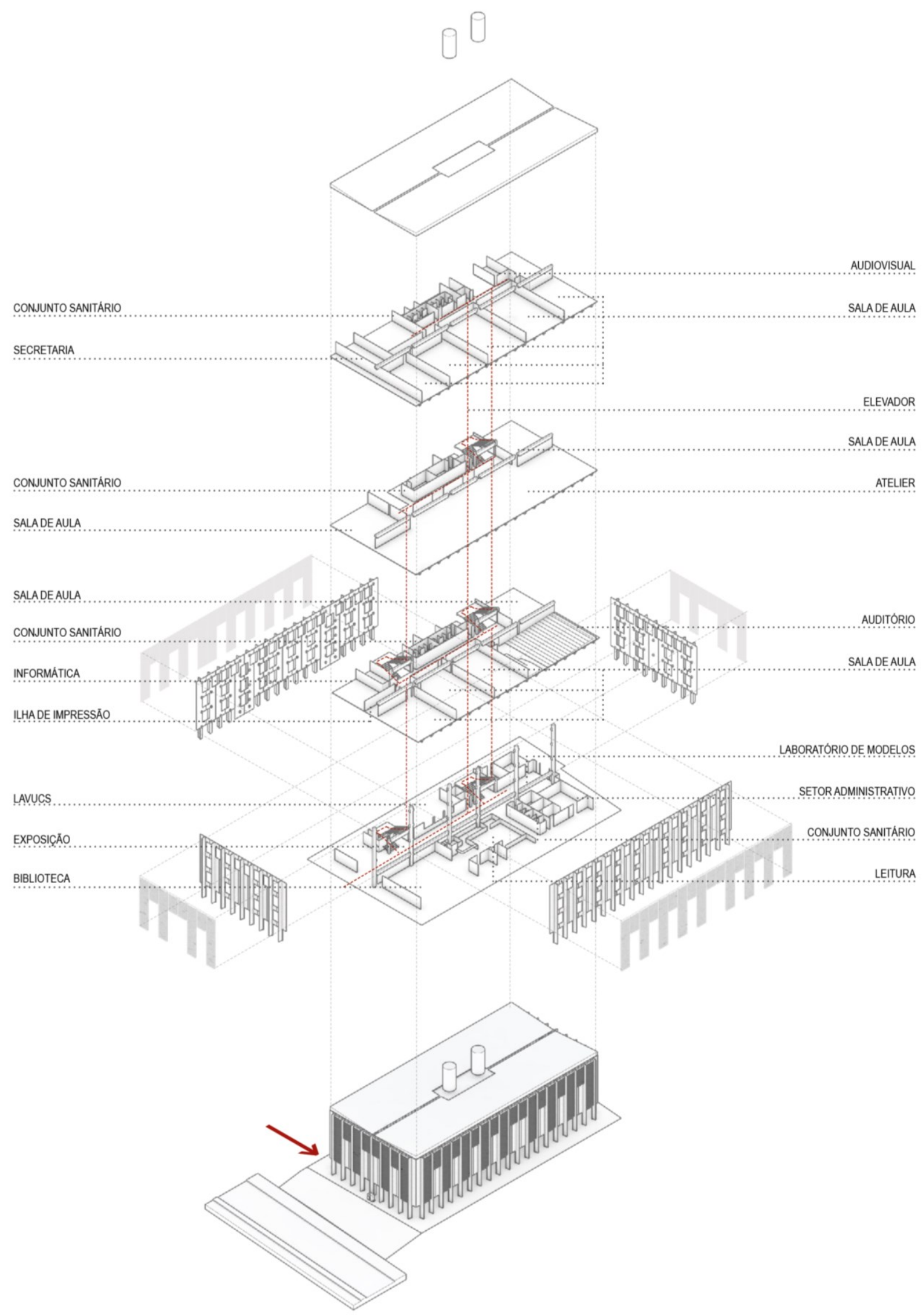

FIG. 84. Alteração da entrada, usos e circulação do Prédio da FAUS em 2017. 


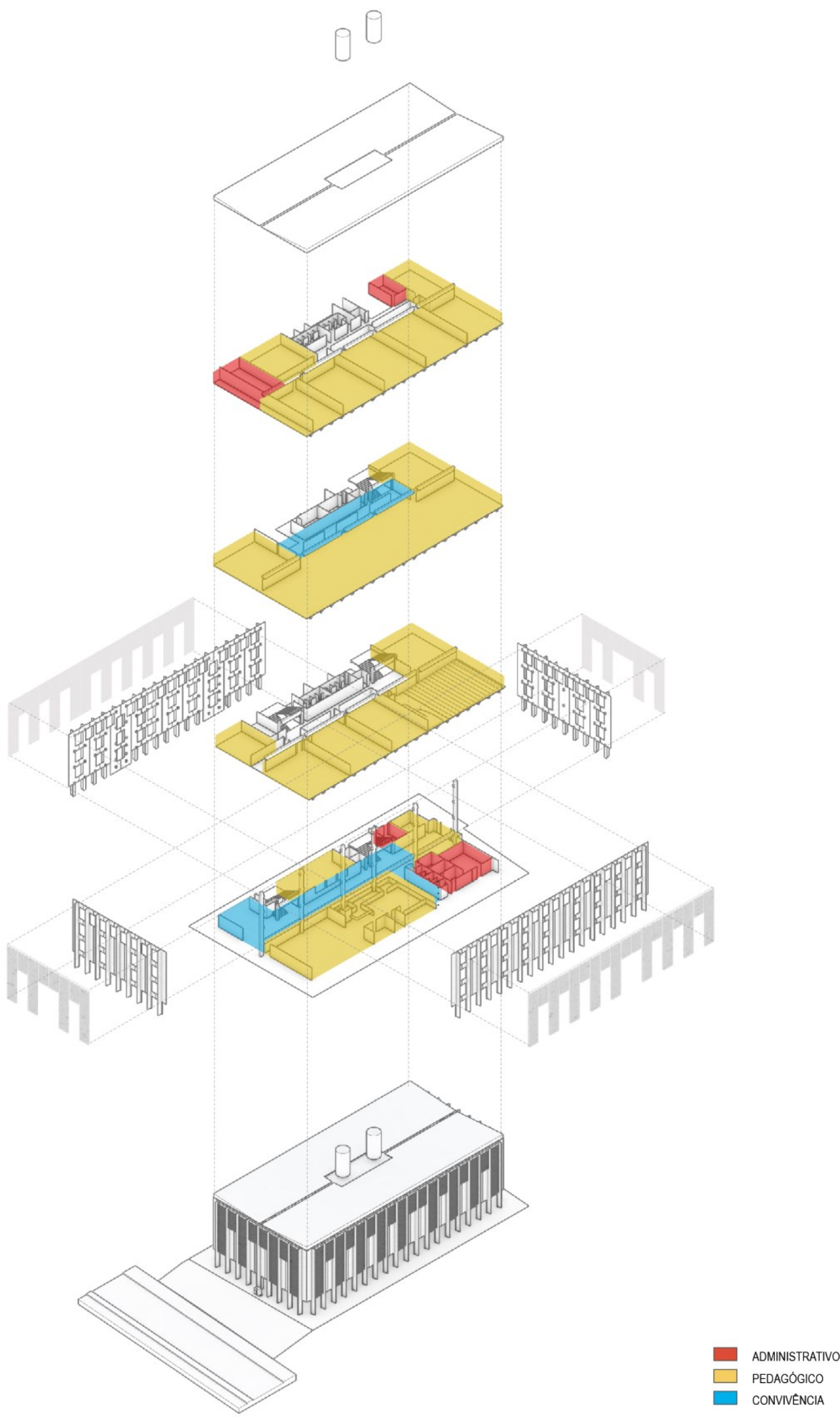



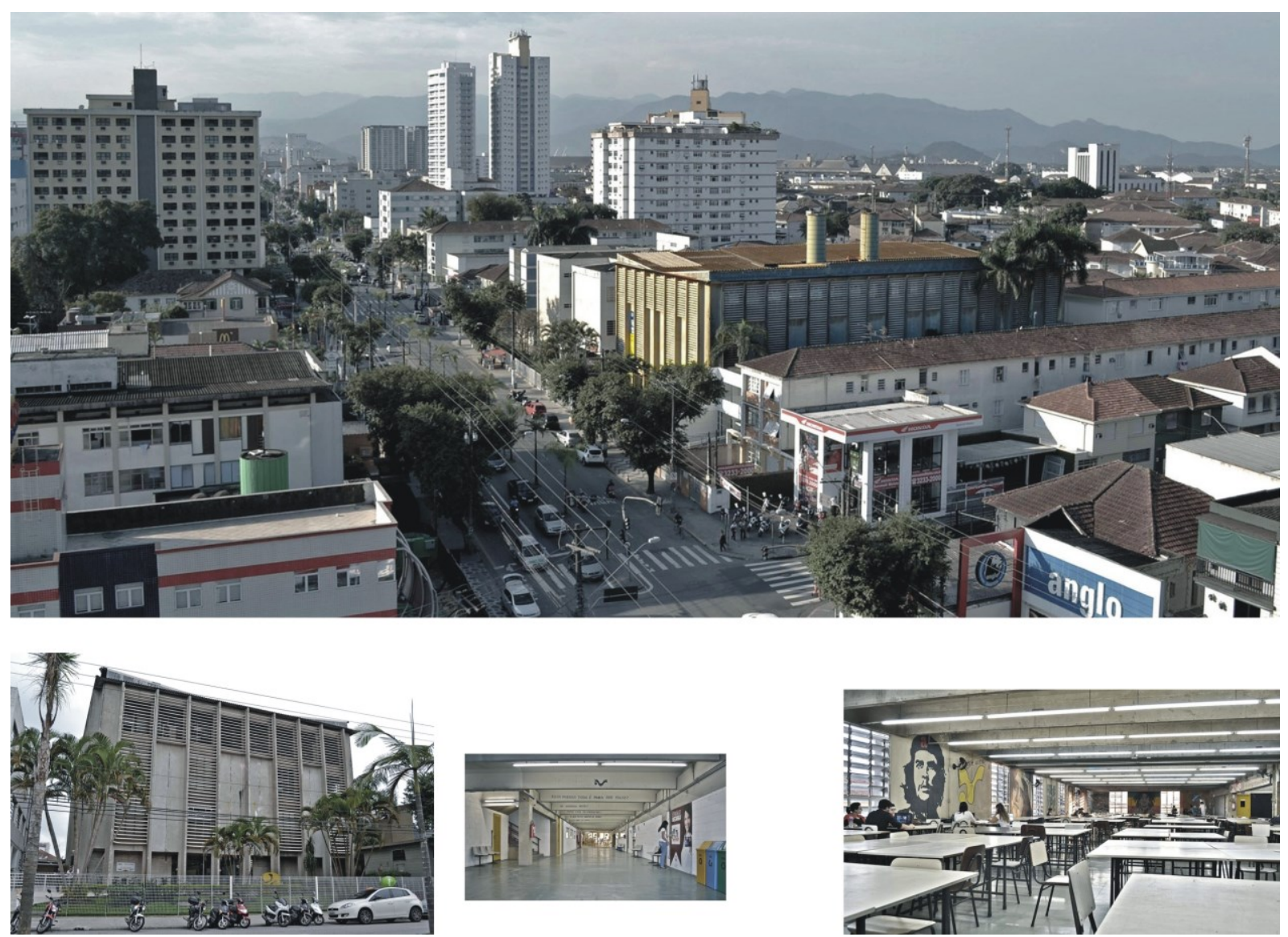

FIG. 86. Vista do prédio da FAUS no contexto urbano imediato e vista externa a partir da Avenida Conselheiro Nébias, pavimento térreo e atelier no segundo andar em 2017. 
Identificação comunitária

As Faculdades Católicas de Santos impulsionaram e ampliaram a ação da Sociedade Visconde de São Leopoldo, com a criação de novos cursos e faculdades entre as décadas de 1950 e 1980, dando sustentação ao "Projeto Universidade". Em 1974, foi fundada a editora universitária Leopoldianum, uma das instituições fundadoras da Associação Brasileira de Editoras Universitárias (ABEU), que prioriza publicações nas áreas de comunicação, artes, gestão, negócios, direito, meio ambiente, educação, saúde, ciências exatas, ciências humanas e administração. Nesse sentido, em 1983 a Sociedade Visconde de São Leopoldo aprovou a carta-consulta para a criação de uma universidade e, desse modo, em 28 de janeiro de 1986 o Conselho Federal de Educação reconheceu a Universidade Católica de Santos (UNISANTOS), oferecendo os cursos de Direto, Filosofia, Pedagogia, Ciências e Letras, Ciências Econômicas e Comerciais, Arquitetura e Urbanismo, Serviço Social, Jornalismo, Relações Públicas e Publicidade e Propaganda. O documento foi homologado em 6 de fevereiro do mesmo ano pelo Ministério da Educação, na figura do então ministro Marco Antônio Maciel, autorizando o funcionamento da primeira universidade da Baixada Santista. ${ }^{72}$

A partir de então, com a epígrafe Dilatentur Spatia Veritatis (ampliar o espaço da verdade), a UNISANTOS aumentou a oferta de cursos de acordo com as demandas regionais e com o estabelecimento de intercâmbios e convênios com instituições de ensino superior nacionais e internacionais. Desse modo, em 1985 foram criadas as Faculdades de Enfermagem e Obstetrícia, em 1989 foi instalada a Faculdade de Farmácia e Bioquímica, juntamente com a Faculdade de Engenharia Civil. Ao longo dos anos 1990, foi criado o Instituto de Pesquisas Científicas e Tecnológicas (IPECI), órgão responsável pelo incentivo e organização da pesquisa científica da universidade e instalada a Universidade Aberta para a Terceira Idade (UATI), a universidade desenvolveu e ofereceu cursos de pós-graduação lato sensu e, em 1999, instalou os mestrados stricto sensu em Direito e Educação. A criação do Programa Institucional de Bolsa de Iniciação à Docência (PIBID) tem o objetivo de qualificar seu corpo docente, integrando a universidade e as escolas no processo de formação do professor e, naturalmente, aproximando-se da comunidade local.

Em 2007, com o objetivo de alinhar a universidade às demandas regionais voltadas ao desenvolvimento sustentável, a UNISANTOS adotou quatro eixos de ação estratégicos: Energia, Meio Ambiente, Porto e Cidadania. Seguindo esse plano de ação, no mesmo ano instalou o mestrado

\footnotetext{
${ }^{72}$ Atos legais: Instituição de Educação Superior, confessional, multicampi, qualificada como Instituição Comunitária de Educação Superior (ICES) pela Portaria SERES no 384/2015. Regimento Geral aprovado pelo Conselho Universitário - CONSU em 2 de maio de 2009 . Cf. UNIVERSIDADE CATÓLICA DE SANTOS. Projeto Pedagógico de Curso - Arquitetura e Urbanismo. Op. cit. pp. 4-5.
} 
acadêmico em Saúde Coletiva e criou o curso de Engenharia de Produção, seguidos dos cursos de Engenharia Ambiental e Engenharia de Petróleo abertos em 2008. Os cursos de Relações Internacionais e Licenciatura em Música surgiram em 2010 e, entre 2011 e 2015, a universidade conquistou a aprovação de três novos cursos de Doutorado: Direito, Educação e Saúde. Ainda durante esse período, em 2013 foi criado o primeiro Curso de Engenharia Portuária do país e, finalmente, em 2014 o curso de Teologia iniciou suas atividades.

Para contribuir com o desenvolvimento socioeconômico e ambiental da região, o IPECl ampliou o número de grupos de pesquisa científica e tecnológica cadastrados no CNPq consolidando, no âmbito da universidade, a inerência entre ensino, pesquisa e extensão. Através de recursos próprios ou de agências de fomento, desenvolve projetos de pesquisa envolvendo estudantes da graduação e pósgraduação e oferece programas de extensão universitária de abrangência institucional, além de projetos e atividades de extensão mais específicos. Nesse sentido, em 2015, a UNISANTOS foi reconhecida como Instituição Comunitária de Ensino Superior (ICES),,$^{73}$ ou seja, passou a desfrutar do status de Universidade Pública não Estatal, o que confirma a sua contribuição para o desenvolvimento da comunidade local e regional. Atualmente, a Universidade Católica de Santos oferece, além dos cursos de especialização, 33 cursos de graduação presencial, três cursos de mestrado e três cursos de doutorado recomendados pela CAPES.

Diante desse contexto, as comemorações dos trinta anos de atividades da FAUS ocorreram durante uma greve geral de professores e estudantes que durou aproximadamente seis meses. No final de 1999, a reitoria da universidade, com o apoio do Conselho de Ensino Superior e, alinhada às novas diretrizes do MEC, alterou o regimento e a estrutura didática e pedagógica de todos os cursos, inclusive o da FAUS. Contudo, a decisão da reitoria em dissolver o curso vespertino, oferecido desde sua fundação, para criar um curso de arquitetura noturno, gerou uma série de protestos de professores e estudantes, que viram nessa ação somente interesses de ordem econômica com a redução da carga horária diária de 6 horas/aulas para 4 horas/aulas.

Essa constatação foi confirmada quando o vice-diretor da FAUS ${ }^{74}$ convocou o corpo docente para propor a redução da carga horária do curso afirmando que as novas diretrizes do MEC demonstravam que a carga horária do curso de arquitetura estava muito acima do mínimo exigido, sem qualquer justificativa quanto à qualidade do ensino oferecido pela instituição. $O$ colegiado de professores posicionou-se contra e recebeu apoio imediato do corpo discente, paralisaram todas as

\footnotetext{
${ }^{73}$ Além de instituição confessional, a Universidade Católica de Santos conquistou a condição de universidade pública não estatal, por não possuir finalidade lucrativa. Parte da receita é revertida em serviços para a comunidade. UNIVERSIDADE CATÓLICA DE SANTOS. Projeto Pedagógico de Curso - Arquitetura e Urbanismo. Op. cit. pp. 4-5.

${ }^{74}$ Oswaldo Corrêa Gonçalves era o diretor Emérito da FAUS, mas sua idade avançada o impossibilitava de exercer o cargo desde 1992 , dessa maneira todas as decisões eram tomadas por seus vice-diretores. 
atividades da escola em defesa da história e da garantia e melhoria da qualidade de ensino. Assim, foi instaurado um fórum de debates para repensar o currículo do curso, esse fato gerou uma insustentável pressão sobre o vice-diretor, provocando, no final do mês de março de 2000, mudanças tanto na reitoria quanto na FAUS. O professor Júlio Artigas assumiu a direção da escola e, como vice-diretora, a professora Cássia Magaldi. Dessa maneira, foi assegurado aos professores a manutenção da carga horária diária de seis horas aulas e a continuidade das práticas didáticas e pedagógicas vigentes até a elaboração de um novo Projeto Político e Pedagógico. Nesse sentido, tanto a direção quanto os chefes dos três departamentos da FAUS assumiram o compromisso de elaborar propostas para aumentar a qualidade do ensino praticado pela escola em conformidade com as alterações propostas no Estatuto da UNISANTOS aprovado em junho de 2000.

Para o encaminhamento desse processo de discussão, foi constituída uma Comissão Plena, formada pelo diretor, vice-diretora, chefe do Departamento de Tecnologia, chefe do Departamento de Teoria da Arquitetura, chefe do Departamento de Projeto, um professor representando o Departamento de Tecnologia e outro de Teoria da Arquitetura, seis professores representantes das "sequências" do Departamento de Projeto, bem como três alunos representantes estudantis. Também integrava essa Comissão Plena um representante do Núcleo de Apoio Pedagógico (NAP) da UNISANTOS, que forneceu as diretrizes metodológicas para a elaboração do Projeto Político Pedagógico da FAUS. A partir da constituição e convocação da Comissão Plena, foi el eita uma Comissão Executiva, presidida pelo Prof. Paulo de Mello Bastos, e integrada pelos professores Gino Caldatto Barbosa, Leila Regina Diêgoli, Paulo Von Poser, pela vice-diretora Cássia Regina Carvalho de Magaldi, além da estudante Paula Rodrigues Andrade. Nesse sentido, foram realizadas ao longo do ano de 2000 quinze reuniões das comissões plena e executiva, além das reuniões de grupos de trabalhos, que estudaram assuntos específicos. Importa destacar que, para a elaboração do Projeto Político e Pedagógico da FAUS, foi necessário maior aprofundamento acerca das seguintes questões: a participação do corpo docente e discente no processo de avaliação do ensino oferecido pela Faculdade de Arquitetura e Urbanismo; Informações sobre as estruturas didáticas e pedagógicas de diversas faculdades de arquitetura e urbanismo nacionais e internacionais; a história da Faculdade de Arquitetura e Urbanismo da UNISANTOS; diagnóstico da Faculdade de Arquitetura e Urbanismo elaborado pelos departamentos e pela representação estudantil; a organização de palestras com profissionais que detinham experiências na elaboração de diretrizes curriculares e planos pedagógicos de cursos de arquitetura e urbanismo. $^{75}$

\footnotetext{
${ }^{75}$ Essas etapas de trabalhos foram cumpridas e divulgadas através do documento Comissão Projeto Pedagógico FAUS 2000, relatório das atividades, agosto de 2000. UNIVERSIDADE CATÓLICA DE SANTOS. Projeto Político Pedagógico: Faculdade de Arquitetura e Urbanismo, relatório final das Atividades do Ano de 2000. Santos: UNISANTOS, 2000. não p. mimeo.
} 
PROJETO

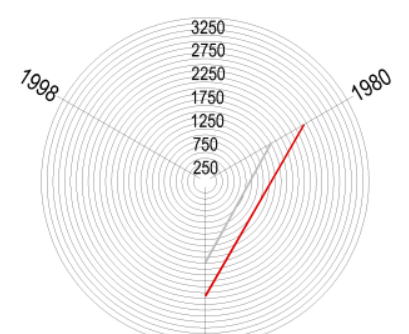

$\stackrel{œ}{\circ}$
TEORIA

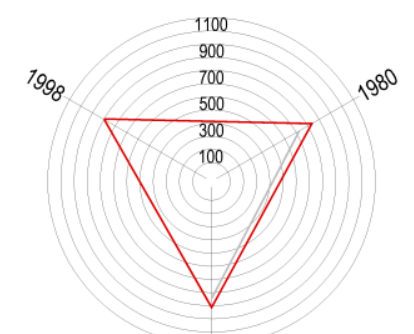

$\stackrel{\mathscr{8}}{\stackrel{9}{9}}$
TECNOLOGIA

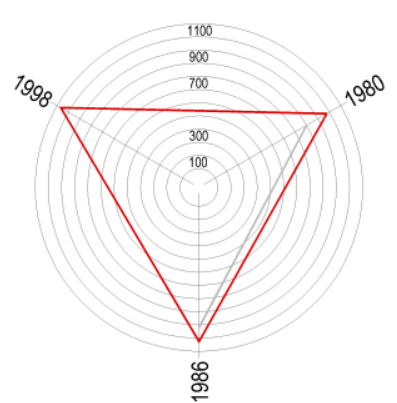

RECOMENDAÇÄO CEAU/ABEA _ FAUS

CARGA HORÁRIA CEAU/ABEA E FAUS CARGA HORÁRIA CEAU/ABEA E FAUS CARGA HORÁRIA CEAU/ABEA E FAUS

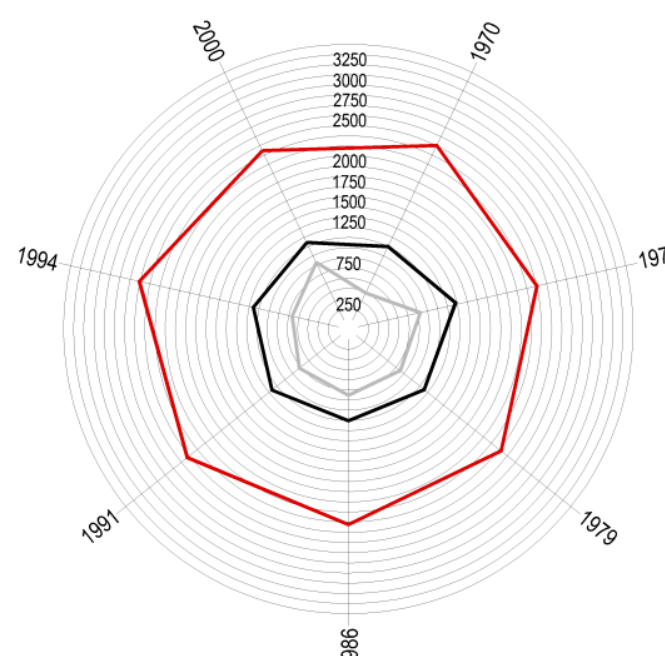

兽

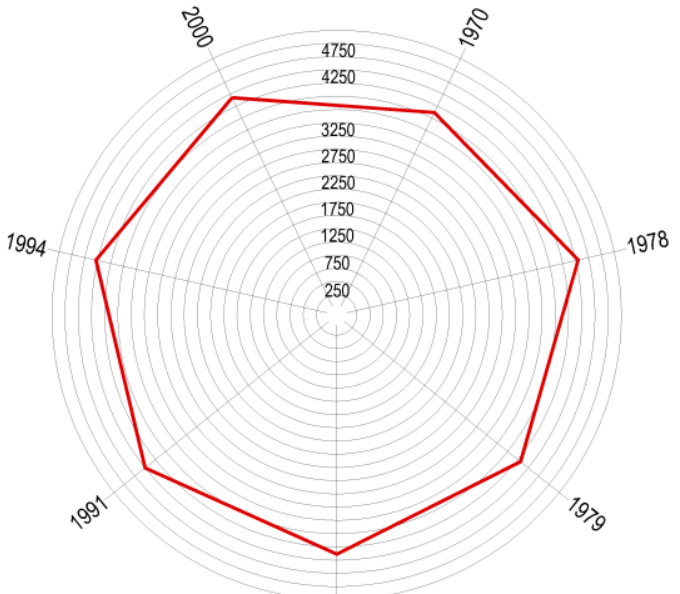

$\stackrel{\mathscr{8}}{9}$

— TEORIA TECNOLOGIA P PROJETO

CARGA HORÁRIA POR DEPARTAMENTO

CARGA HORÁRIA TOTAL DA FAUS

FIG. 87. Síntese da distribuição de horas apresentado pela comissão plena de desenvolvimento do Projeto Pedagógico da FAUS, 2000.

A partir do segundo semestre letivo de 2000 , todos os trabalhos e discussões voltaram-se para a formulação de propostas para o novo Projeto Político Pedagógico, o qual deveria atender ao disposto na legislação que rege o assunto, a exemplo a Lei de Diretrizes e Bases, da Portaria n. 1.770 de 21 de dezembro de 1994 do Ministério de Estado da Educação e do Desporto. Este fixava as diretrizes curriculares e o conteúdo mínimo do curso de graduação em Arquitetura e Urbanismo, bem como as 
diretrizes curriculares elaboradas pela Associação Brasileira de Escolas de Arquitetura (ABEA) as quais foram aprovadas pela Comissão de Especialistas em Arquitetura e Urbanismo (CEAU) - do Conselho Nacional de Educação do Ministério da Educação e do Desporto. Além disso, as propostas visavam contemplar as diretrizes estabelecidas no Estatuto da Universidade Católica de Santos, aprovado em 25 de julho de 2000, como também estavam atentas ao estabelecido na Congregação da Educação Católica, conforme a publicação A Escola Católica no Limiar do Terceiro Milênio. ${ }^{76}$
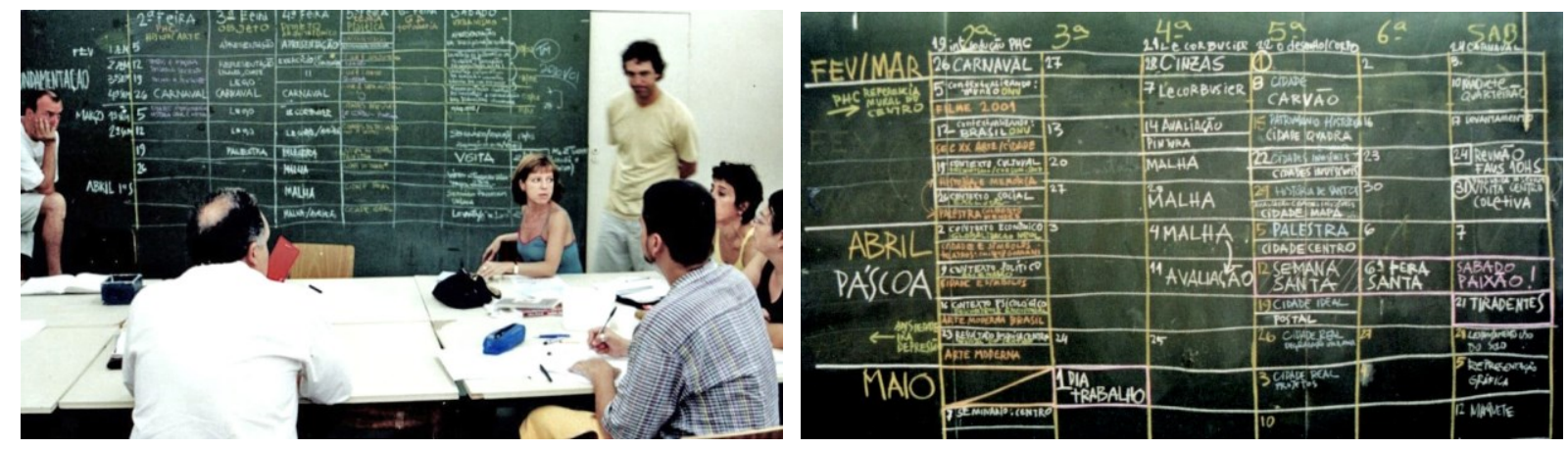

FIG. 88. Comissão Plena desenvolvendo o Projeto Pedagógico da FAUS, 2000.

Em síntese, as propostas aprovadas pelo colegiado de professores e alunos estavam relacionadas com as características, objetivos e diretrizes do curso, com a estrutura didática e pedagógica, com a estrutura departamental, com a necessidade de integração vertical e horizontal, além do estabelecimento de laboratórios e núcleo de estudos da cidade. O grupo avançava e conquistava mais espaço e confiança, nesse sentido, garantiu para o primeiro semestre de 2001 a carga horária diária de seis horas/aula, com a mesma grade praticada no ano de 2000, o que era imprescindível para viabilizar a implementação do novo projeto pedagógico.

Além disso, os professores das disciplinas oferecidas no primeiro semestre conseguiram estabelecer atividades didáticas que se complementavam e buscavam objetivos comuns na formação do arquiteto, resultando na desejada Integração Horizontal de Conteúdos Programáticos envolvendo as disciplinas de Plástica, Projeto de Arquitetura, Sistemas Estruturais, Desenho de Objeto, Teoria e História da Arquitetura, dentre outras. Entretanto os demais semestres do curso não alcançaram o mesmo padrão de integração. ${ }^{77}$

Continuaram as discussões sobre a reorganização da estrutura departamental, sobre a criação de laboratórios em conformidade com as diretrizes estabelecidas pelo MEC, bem como a criação de um

\footnotetext{
${ }^{76}$ CONGREGAÇÃO DA EDUCAÇÃO CATÓLICA. A escola católica no limiar do terceiro milênio. Roma: Vaticano, 1997. Disponível em: <http://www.vatican.va/roman_curia/congregations/ccatheduc/documents/rc_con_ccatheduc_doc_27041998_school2000_po.html> Acesso em: 24 out. 2019.

77 Sobre essa experiência de integração horizontal na FAUS, ver a tese da professora Vera Domschke. DOMSCHKE, Vera Lucia. O Ensino da arquitetura e a construção da modernidade. 331p. Tese (Doutorado em arquitetura e urbanismo) Faculdade de Arquitetura e Urbanismo da Universidade de São Paulo. São Paulo, 2007.
} 
núcleo de estudos da cidade como instância responsável pelo desenvolvimento de pesquisas e atividades de extensão. Como forma de ampliar o campo de discussão, paralelamente aos trabalhos em andamento, as comissões da FAUS estruturaram um ciclo de palestras com a participação de arquitetos especialistas em ensino da arquitetura e do urbanismo como o Prof.o Dr. Arquiteto Elvan Silva, da FAU-UFRGS e presidente do MEC/CEAU, o Prof.o Dr. Frank Svensson, da FAU-UnB, o Prof.o Minoro Naruto, da FAU-USP e o Prof. ㅇ Wilson Ribeiro dos Santos, da FAU-PUCCAMP. Desse modo, a Comissão Executiva do projeto pedagógico, através de um relatório de atividades elaborado juntamente com o corpo docente e o corpo discente da FAUS, apresentou um minucioso diagnóstico capaz de sustentar as propostas para a reformulação das práticas de ensino da FAUS. Datado de agosto de 2000, o relatório continha os seguintes documentos: síntese de diagnóstico e propostas apresentadas pelos departamentos e sequências da FAUS; síntese e conclusões das palestras proferidas; panorama dos cursos internacionais de arquitetura e urbanismo; quadro sintético sobre faculdades brasileiras de arquitetura e urbanismo e mudanças curriculares na FAUS. ${ }^{78}$

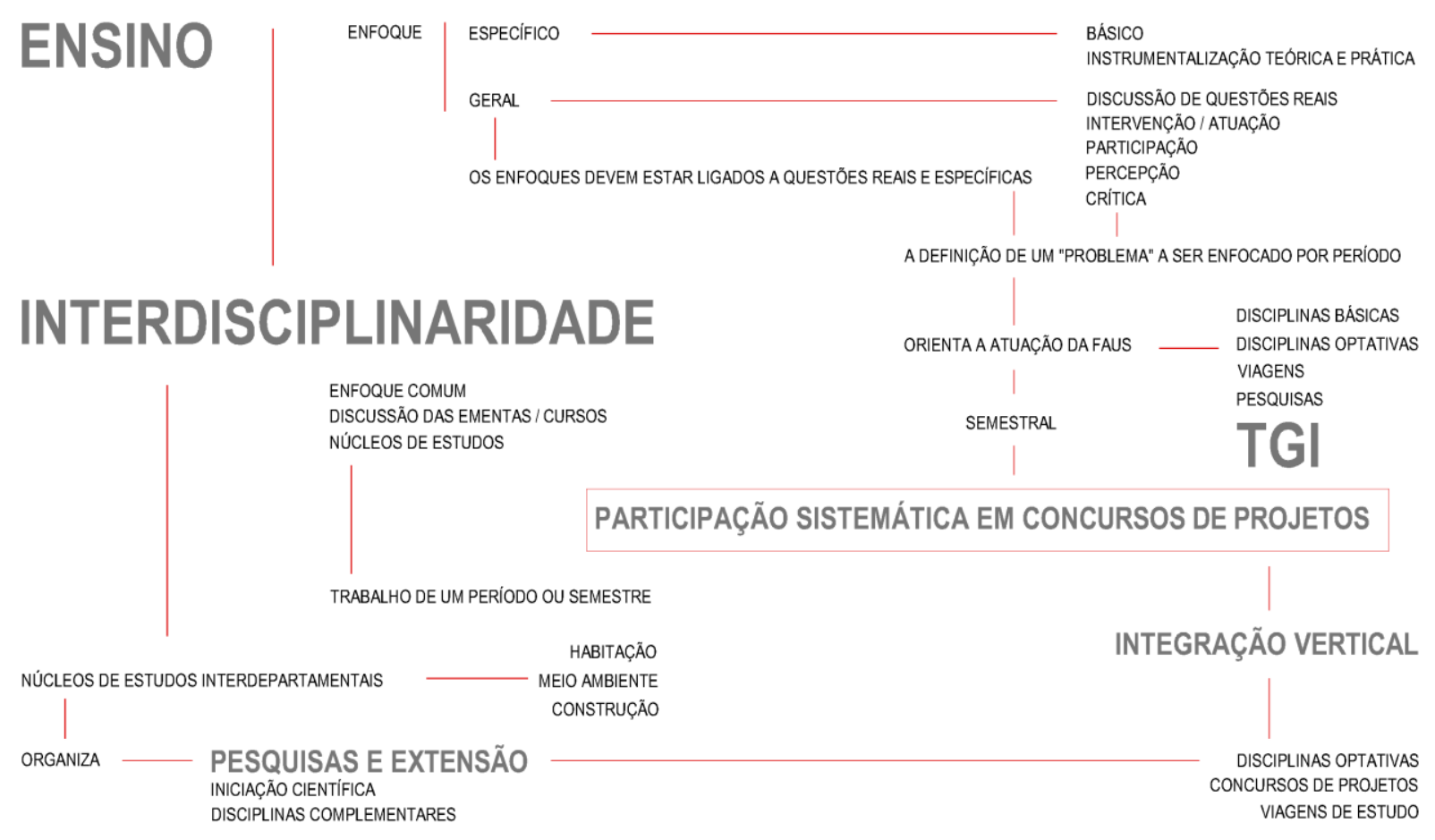

FIG. 89. Organização Conceitual do Projeto Pedagógico da FAUS, formulada pela Comissão Plena em 2000.

O dossiê final foi analisado e comentado pelo conjunto dos professores e alunos da FAUS, reunidos no dia 2 de setembro de 2000. Desde então, a escola vem concentrando esforços para o contínuo aprimoramento da formação de seus arquitetos, a partir das próprias experiências, mas também das

\footnotetext{
78 UNIVERSIDADE CATÓLICA DE SANTOS. Projeto Político Pedagógico: Faculdade de Arquitetura e Urbanismo, relatório final das Atividades do Ano de 2000. Op. cit. não $p$. 
ocorridas em outras instituições, principalmente no que se refere à qualidade e excelência do ensino, da pesquisa e da extensão.

Em 2004, a Universidade Católica de Santos centrou esforços para ampliar os seus programas de pesquisas e extensão, criando Centros de Ciências para o ensino e investigação, tanto na graduação quanto na pós-graduação. Devido a essa reestruturação institucional, a FAUS deixou de ser classificada como Faculdade de Arquitetura e Urbanismo de Santos e passou a ser denominada como Curso de Arquitetura e Urbanismo da Universidade Católica de Santos. Integrando o Centro de Ciências da Comunicação e Artes da Universidade, juntamente aos Cursos de Comunicação Social com as habilitações em Jornalismo, Publicidade e Propaganda e Relações Públicas, posteriormente em 2013, o Curso de Arquitetura e Urbanismo passou a integrar o Centro de Ciências Exatas, Arquitetura e Engenharia da UNISANTOS. ${ }^{79}$

Nesse ponto, é oportuno lembrar que a Faculdade de Engenharia da UNISANTOS foi criada em 1989, ou seja, dezenove anos depois da fundação da FAUS, e o Curso de Arquitetura e Urbanismo da UNISANTOS, ao integrar o Centro de Ciências Exatas, Arquitetura e Engenharia, constitui certa incoerência em relação ao histórico esforço empreendido em todo o país pela emancipação dos cursos de arquitetura em relação às escolas de engenharia. Entretanto, justifica-se teoricamente, pela correlação de núcleos de conhecimento estabelecendo o livre trânsito de professores nos cursos de arquitetura e engenharia, facilitando a montagem das suas grades curriculares, além de gerar economia de recursos para a universidade.

A alteração da condição de Faculdade para Curso, do ponto de vista político, configurou uma perda substancial de representatividade nas esferas de decisão da universidade, diminuindo ainda mais sua autonomia. Atualmente, segundo o estatuto da UNISANTOS, o reitor é indicado pela mantenedora SVSL, os diretores de centro são nomeados pelo reitor e os coordenadores de curso são escolhidos pelos diretores de centro, ou seja, o colegiado de curso não tem mais poder de decisão, não elege sequer o seu coordenador que, nessa estrutura, assume a posição de gerente a serviço do diretor de centro. Esse fato implica na criação de uma série de obstáculos institucionais que diminuem a flexibilidade curricular para novas experimentações do ano em curso, pois tudo deve estar previsto desde $o$ ano anterior.

Entretanto, é por demais sabido que o trabalho de mediação entre arte e técnica desempenhado pelos estudantes de arquitetura não configura algo previsível, "o contexto do design é a indeterminação do ser humano. $\mathrm{O}$ design nunca significou dar a alguém ou a algum grupo o que eles

79 UNIVERSIDADE CATÓLICA DE SANTOS. Projeto Pedagógico de Curso - Arquitetura e Urbanismo. Op. cit. p. 20. 
pediram, mas o que eles gostariam de ter pedido e, retrospectivamente, de fingir ter pedido." ${ }^{180}$ Desse modo, a dependência da aprovação de algo imprevisto por uma cadeia hierárquica mais complexa inevitavelmente implica em atrasos e perdas de oportunidades didáticas latentes. Vale destacar que não se tratam apenas de perdas relacionadas aos aspectos pedagógicos, mas também aos aspectos políticos e financeiros, pois, conforme descrito, a nova hierarquia dissolve a representatividade política dos colegiados de curso.

Ainda sobre a alteração de faculdade para curso, vale dizer que o reflexo simbolicamente mais danoso esteja relacionado à perda de identidade da escola, pois com o não reconhecimento por parte da universidade do termo "FAUS" em sua estrutura institucional, principalmente nos instrumentos de divulgação e propaganda, ainda que de forma involuntária, perde-se a oportunidade de reforçar a importância regional e nacional da escola construída ao longo de cinquenta anos. O termo "curso de arquitetura" posiciona a FAUS no mesmo plano dos novos "cursos de arquitetura" que têm surgido da noite para o dia na cidade de Santos e região. Ponto notável nesse debate é que o vigente plano pedagógico da FAUS destaca que o ensino superior vive um momento de tensão entre os aspectos relacionados à sua "identidade" e às exigências da sociedade contemporânea. ${ }^{81}$

Indo na mesma direção, no que se refere à comunicação e ao entendimento da especificidade da formação do arquiteto, desde a fundação da FAUS em 1970, seu corpo docente enfrenta dificuldades com a SVSL e a UNISANTOS, desencadeando sucessivos e desnecessários conflitos. Com efeito, apesar da crença de Oswaldo Corrêa Gonçalves no processo de reconhecimento da profissão pela sociedade brasileira manifestada em 1976, pode-se dizer que ainda não está claro qual é o papel e ou a função da profissão de arquiteto.

\begin{abstract}
A sociedade cada vez mais se conscientiza da contribuição que pode receber deste profissional - 0 arquiteto. Entretanto ainda depende muito de nós fazê-la conhecer a gama cada vez mais ampla de nossa faixa de atuação. $O$ arquiteto não é somente elemento capaz de propor soluções aos problemas da cidade, das casas e das coisas, mas um elemento pensante preparado para discutir a própria colocação do problema. E tem, como cidadão participante de uma comunidade e do processo de desenvolvimento do país, uma opinião valiosa para seu equacionamento. ${ }^{82}$
\end{abstract}

Em resumo, desde a proposta de 2000, pelo menos em tese, o Projeto Pedagógico da FAUS estrutura-se de modo a contribuir na formação de arquitetos com perfil humanista, generalista e

\footnotetext{
${ }^{80}$ COLOMINA Beatriz; WIGLEY, Mark. Are we human? Notes on an Archeology of design. Zurique: Lars Miller, 2016, pp. 102-103. Apud. WISNIK, Guilherme. Dentro do nevoeiro: arquitetura, arte e tecnologia contemporâneas. São Paulo: Ubu, 2018. pp. 45-46.

81 O Projeto Pedagógico da FAUS foi revisado pelo Núcleo Docente Estruturante (NDE), entre 2016 e 2018, pelos professores Dra. Ana Salvi (coordenadora), Dra. Cassia Magaldi, Dr. Cesar Perez, Dra. Clarissa Souza, DR. José Marques Carriço, Me. José Maria de Macedo Filho, Dra. Leila Regina Diêgoli, Dra. Marcia Aps e Dra. Maria Helena Barros Flynn. O NDE discute a estrutura do Projeto Pedagógico vigente, principalmente no que se refere ao perfil de formação desejado para os discentes. Os diagnósticos e debates realizados em cada área e o esforço para identificar e sintetizar posições comuns direciona os trabalhos para a formulação de propostas de reestruturação do conjunto do curso e não apenas de um ajuste ou melhoria de áreas ou disciplinas já existentes. Cf. UNIVERSIDADE CATÓLICA DE SANTOS. Projeto Pedagógico de Curso - Arquitetura e Urbanismo. Op. cit. pp. 52-53.

82 GONÇALVES, Oswaldo Corrêa. Oração do Paraninfo. FAUS, 1976. mimeo. 
crítico, no que diz respeito à compreensão da realidade atual e ao papel que o futuro profissional deve desempenhar no enfrentamento e solução dos problemas urbanos e territoriais que atingem a sociedade. ${ }^{83}$

O curso prepara os profissionais com sólida formação ética, notáveis no saber, habilitados ao eficiente desempenho de suas funções, com senso de responsabilidade social. A formação do arquiteto e urbanista na Universidade Católica de Santos, por ser generalista, evita o encaminhamento precoce de enquadramento profissional pragmático, imediatista e dominado pelas exigências individualistas e conjunturais do mercado imobiliário. ${ }^{84}$

Dessa maneira, se por um lado o perfil do egresso da FAUS necessita atender às demandas do universo profissional, por outro deve contribuir para que os processos de crítica e reflexão sobre os diversos conteúdos ministrados se convertam em conhecimento, de modo a preparar e ampliar a participação do arquiteto na vida coletiva, notadamente marcada pela multiplicidade, heterogeneidade, simultaneidade do mundo contemporâneo. Nesse sentido, para atingir os objetivos pedagógicos e construir o perfil profissional pretendido, o plano propõe duas vertentes de orientação ou premissas de formação:

1. Conjugar o ensino teórico com atividades práticas relevantes que contribuam para a consecução dos perfis, por meio dos estágios supervisionados, das atividades complementares e da reflexão transformada em ações; 2. Formar um cidadão participativo e capaz de compreender a realidade circundante e as demandas da sociedade, a fim de esforçar-se por colaborar na solução de seus problemas e contradições. ${ }^{85}$

Com clara referência ao pensamento de Paulo Freire, essas premissas organizam o currículo da FAUS de modo que os instrumentos didáticos propostos sejam direcionados para os exercícios críticos e autocríticos preparatórios para a vivência de situações diversificadas e significativas que, a partir de princípios de emancipação e autonomia, ${ }^{86}$ devem incentivar o corpo docente a promover o "afloramento das potencialidades e talentos trazidos como bagagem experiencial e intelectual dos discentes e tomar contato com a realidade tal qual ela se dá no mundo profissional." ${ }^{87}$ Vale lembrar que esses são os mesmos princípios defendidos pelos professores Sérgio Ferro, Rodrigo Lefèvre, Mayumi e Sergio Souza Lima, além do professor Francisco de Oliveira, nos primeiros anos de funcionamento da escola.

\footnotetext{
${ }^{83}$ De acordo com o segundo item do plano de transição para a formação de arquitetos de Walter Gropius, amplamente divulgado e recomendado, pode-se constatar sua influência nos documentos que regulamentam a profissão, não só no Brasil, mas no mundo inteiro até os dias de hoje. GROPIUS, Walter. Bauhaus: novarquitetura. 2ạ Edição. São Paulo: Perspectiva, 1974. pp. 93-96.

${ }^{84}$ De certo modo, pela especificidade deste trecho do PPC da FAUS, nota-se a ênfase dada ao projeto de arquitetura no perfil desejado do egresso. Cf. UNIVERSIDADE CATÓLICA DE SANTOS. Projeto Pedagógico de Curso - Arquitetura e Urbanismo. Op. cit. p. 24.

${ }^{85}$ Cf. Ibid. pp. 24-26.

${ }^{86}$ Ver FREIRE, Paulo. Pedagogia da autonomia: saberes necessários à prática educativa. 52a ed. Rio de Janeiro/São Paulo: Paz e Terra, 2015.

${ }^{87}$ Cf. UNIVERSIDADE CATÓLICA DE SANTOS. Projeto Pedagógico de Curso - Arquitetura e Urbanismo. Op. cit. pp. 12.
} 
Indo um pouco além do currículo mínimo exigido pelas diretrizes nacionais vigentes, ${ }^{88}$ o perfil do egresso da FAUS aprofunda os aspectos interdisciplinares do campo da arquitetura e urbanismo, ao abordar problemas significativos para a Região Metropolitana da Baixada Santista, como, por exemplo, as relações entre o porto e a cidade de Santos e seus conflitos socioespaciais em escala regional. Reconhece a importância da conservação e valorização do patrimônio construído, principalmente no que diz respeito aos centros antigos e monumentos tombados das primeiras ocupações portuguesas no Brasil. Toma partido da extraordinária condição geográfica, ambiental e paisagística como área de conhecimento privilegiado para levantamentos, pesquisas e projetos, constituindo um importante arcabouço de saberes úteis no âmbito local e regional.

Atualmente, a FAUS opera em regime presencial, distribuído em dois turnos de funcionamento, matutino e noturno. Está autorizada a oferecer sessenta vagas em cada um dos períodos. O ingresso continua sendo feito por processo seletivo organizado pela própria instituição, entretanto, sem o teste específico de Linguagem Arquitetônica (L.A.), extinto em 2004. Para obtenção do grau de Bacharel, o estudante deve integralizar o curso no mínimo em dez semestres, com a carga horária de 4.971 de horas aula que correspondem a 4.142 horas de sessenta minutos, sem cursar a disciplina optativa ou, no caso de o estudante cursar a optativa, a carga horária passa para 5.005 horas de aula correspondendo a 4.170 horas de sessenta minutos. O tempo máximo para a integralização é o dobro do prazo mínimo fixado no projeto pedagógico do curso. ${ }^{89}$

Sua matriz curricular está dividida em três núcleos estruturantes de conhecimentos propostos no seu plano pedagógico, a saber: Núcleo de Conhecimento de Fundamentação, Núcleo de Conhecimento Profissional e Núcleo de Conteúdo Transversal. Ao observar a distribuição da carga horária nesses núcleos, nota-se que o eixo profissionalizante, composto pelas disciplinas da Sequência de Projeto e Tecnologia, detém aproximadamente $\mathbf{6 8 , 0 5 \%}$ do total de horas do curso, seguido pelo núcleo de fundamentação, integrado pelas disciplinas de natureza artística e cultural, com apenas 15,05\% da carga horária total. O núcleo transversal é constituído basicamente pelas atividades complementares, pelo Estágio Curricular Supervisionado e pelo Trabalho de Curso e disciplinas optativas, somando juntos $16,90 \%$ da totalidade de horas do curso.

\footnotetext{
${ }^{88}$ Diretrizes Curriculares para Arquitetura e Urbanismo de 17 de junho de 2010; Resolução № 21 de 2012 e Resolução № 51 de 2013 do Conselho de Arquitetura e Urbanismo (CAU).

${ }^{89} \mathrm{O}$ Curso de Arquitetura e Urbanismo foi autorizado pelo Decreto no 66.568/1970, reconhecido pelo Decreto № 77.441/1976 e renovado o reconhecimento pela Portaria SERES/MEC no 286/2012. Conforme o disposto no art.1o da Resolução CONSU 06/2014, para os ingressantes a partir do ano de 2015. Cf. UNIVERSIDADE CATÓLICA DE SANTOS. Projeto Pedagógico de Curso - Arquitetura e Urbanismo. Op. cit. pp. 5-7. 


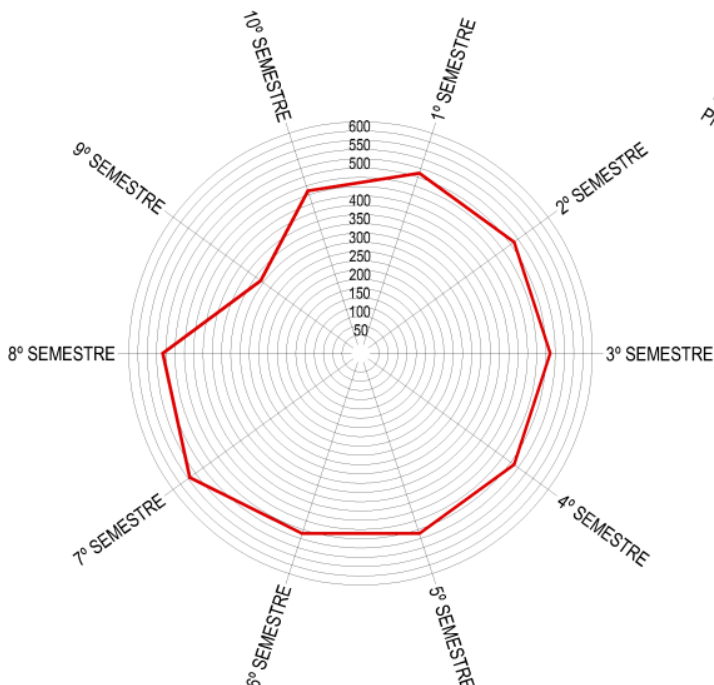

QUADRO SINTESE | HORASIAULA POR SEMESTRE
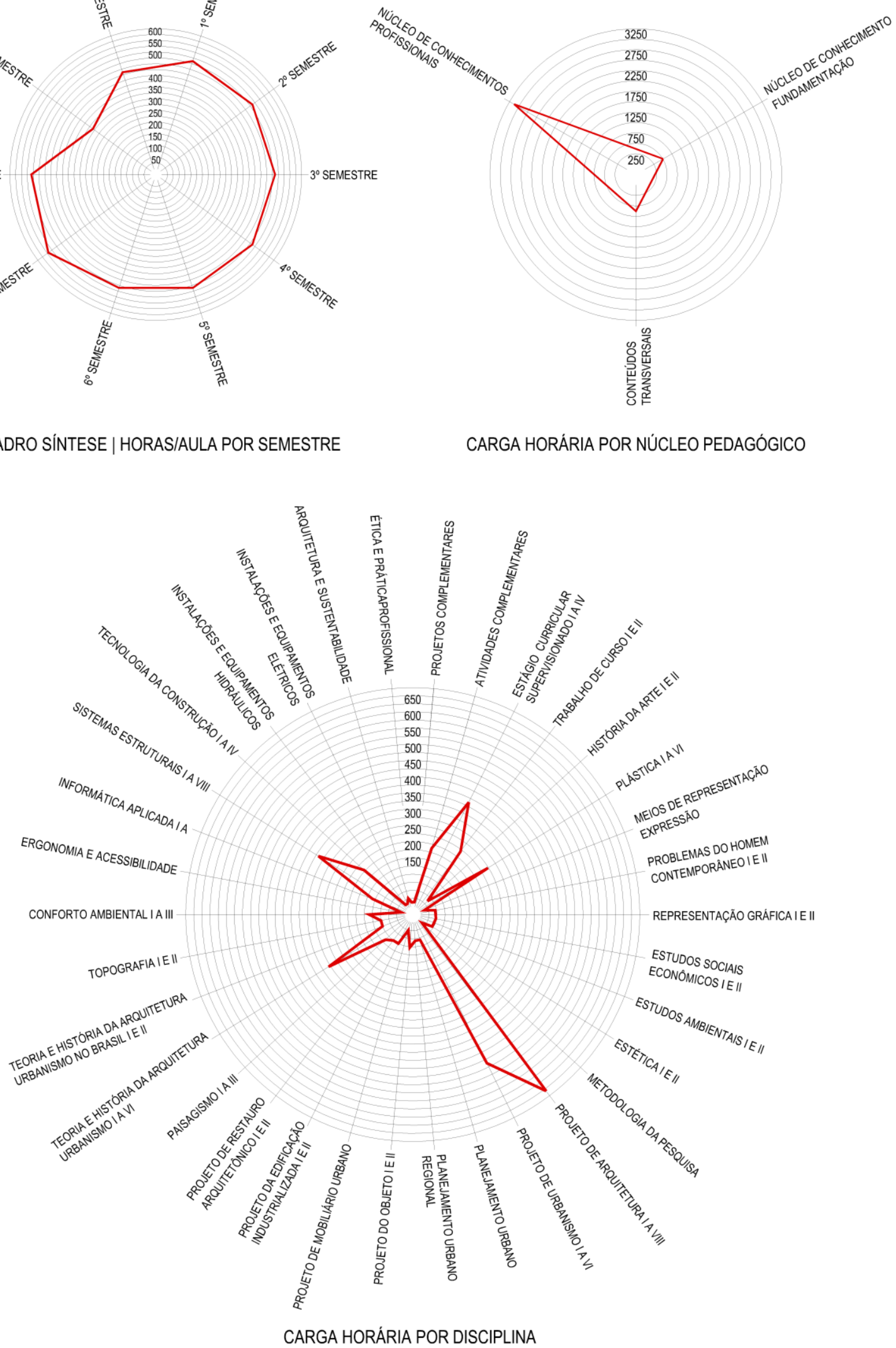

FIG. 90. Síntese da distribuição de horas do vigente Projeto Pedagógico de Curso da FAUS, 2017-2021. 


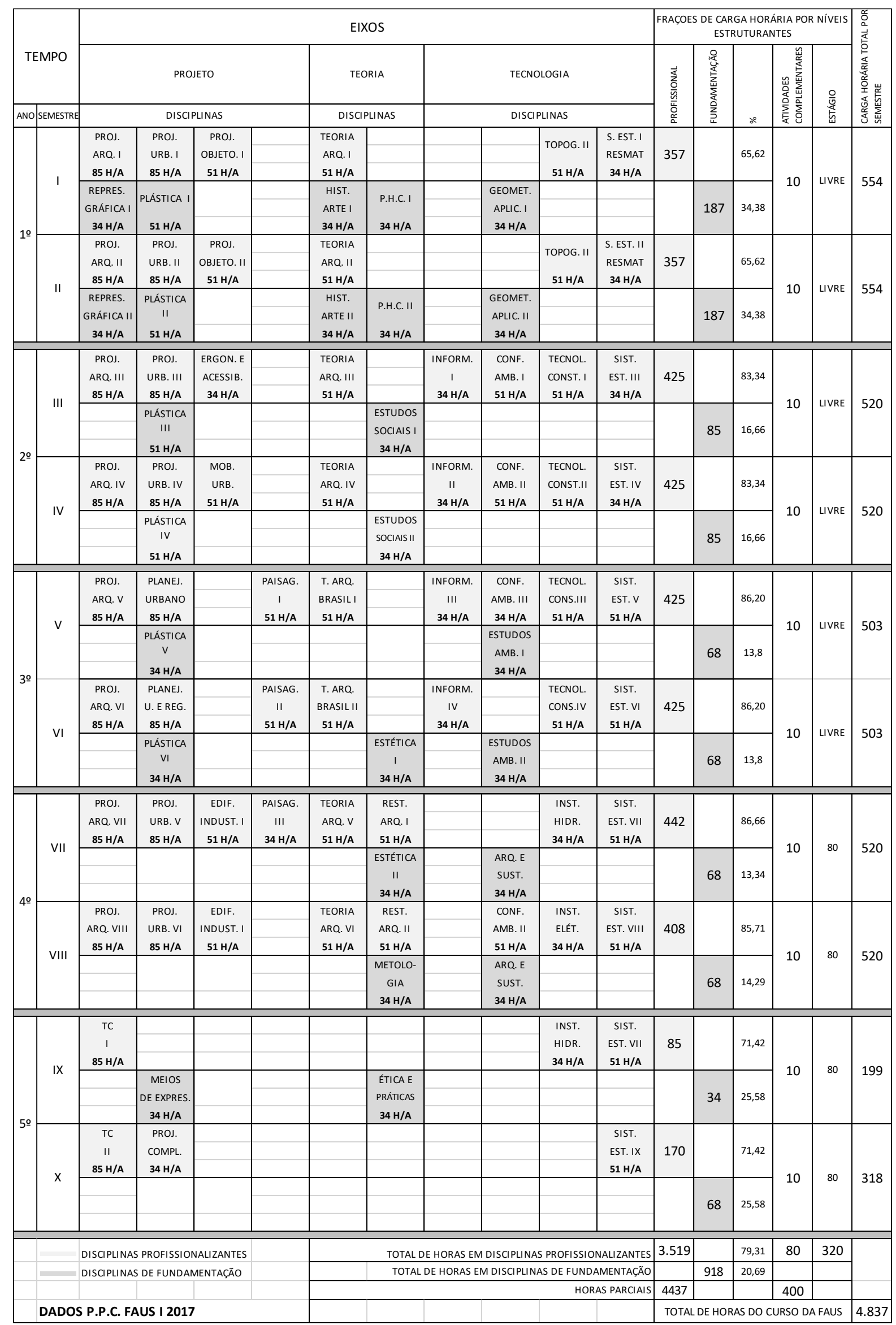

TAB. 12. Grade curricular e carga horária do atual Projeto Pedagógico de Curso da FAUS, 2017-2021. 
No que se refere às atividades transversais, a natureza profissionalizante do ensino de arquitetura na FAUS não impediu, desde seus anos iniciais, que estudantes e professores reivindicassem a implantação de programas de pesquisa na escola. Contudo dificuldades operacionais, econômicas e mesmo de compreensão sobre o assunto configuraram obstáculos e geraram atrasos na sua instalação. Com o reconhecimento da Universidade Católica de Santos em 1986, o cenário mudou e, junto com as crescentes exigências do MEC, ancoradas em novos sistemas de avaliação e pontuação institucionais, surgiram os primeiros grupos de pesquisa da universidade. Entretanto, no caso da FAUS, somente a partir de 2015 é que alguns docentes iniciaram a formação de grupos de estudos específicos nas áreas de urbanismo, plástica e projeto de arquitetura, disponibilizando para os estudantes linhas de pesquisa correlatas ao núcleo de conhecimento específico.

\section{GRUPOS DE PESQUISAS DA FAUS CERTIFICADOS NO DIRETÓRIO DO CNPQ}

\begin{tabular}{|c|c|c|c|}
\hline GRUPO & SEQUÊNCIA & FORMAÇÃO & LINHAS DE PESQUISA \\
\hline $\begin{array}{l}\text { DIREITO AMBIENTAL DAS CIDADES } \\
\text { (Integrado ao Programa de Pós- } \\
\text { Graduação em Direito Ambiental) }\end{array}$ & URBANISMO & 2015 & $\begin{array}{l}\text { DIREITO E POLÍTICA DA SUSTENTABILIDADE AMBIENTAL E } \\
\text { SOCIAL }\end{array}$ \\
\hline ENGENHARIA URBANA & URBANISMO & - & $\begin{array}{l}\text { 1) CONSTRUÇÃO CIVIL E URBANA } \\
\text { 2) INFRAESTRUTURA URBANA E SUSTENTABILIDADE }\end{array}$ \\
\hline $\begin{array}{l}\text { OBSERVATÓRIO SOCIOESPACIAL DA } \\
\text { BAIXADA SANTISTA }\end{array}$ & URBANISMO & 2015 & $\begin{array}{l}\text { 1) HABITAÇÃO E SUSTENTABILIDADE } \\
\text { 2) PROJETO E PLANEJAMENTO TERRITORIAL } \\
\text { 3) PLANEJAMENTO E PROJETO URBANO-REGIONAL }\end{array}$ \\
\hline $\begin{array}{l}\text { REGISTRO PLÁSTICO E AUDIOVISUAL E } \\
\text { REPRESENTAÇÕES EM ARQUITETURA E } \\
\text { URBANISMO }\end{array}$ & PLÁSTICA & 2015 & PAISAGEM E AMBIENTE: SUSTENTABILIDADE DO TERRITÓRIO \\
\hline SUPERESTÚDIO TRANSDISCIPLINAR & $\begin{array}{l}\text { PROJETO DE } \\
\text { ARQUITETURA }\end{array}$ & 2017 & $\begin{array}{l}\text { 1) ARQUITETURA E MANIFESTAÇÕES ARTÍSTICAS } \\
\text { 2) ARQUITETURA E PATRIMÔNIO } \\
\text { 3) ARQUITETURA E PENSAMENTO AMBIENTAL } \\
\text { 4) ARQUITETURA E PROCESSOS PEDAGÓGICOS } \\
\text { 5) ARQUITETURA E SUSTENTABILIDADE } \\
\text { 6) ARQUITETURA E TECNOLOGIA }\end{array}$ \\
\hline
\end{tabular}

TAB. 13. Elaboração do autor a partir da leitura do Projeto Pedagógico de Curso da FAUS.

Com efeito, o evidente atraso na formação desses grupos na FAUS não impediu que a pesquisa fosse produzida, ainda que de maneira independente, ou desvinculada dos órgãos governamentais reguladores, a exemplo das investigações e propostas elaboradas pelo HABITAFAUS desde 1984, constituídas por projetos de arquitetura e extensão comunitária. Nesse sentido, vale dizer que a organização e disseminação do conhecimento produzido pelos diversos pesquisadores constitui um elemento fundamental para o auxílio e desenvolvimento dos programas de ensino, pesquisa e extensão universitária. No âmbito da Universidade Católica de Santos, essa tarefa é feita por um conjunto de três bibliotecas integradas, cujo acervo documental é composto de aproximadamente 244.862 itens, distribuídos da seguinte forma: 


\begin{tabular}{|c|c|c|c|c|c|c|c|}
\hline \multirow{2}{*}{ BIBLIOTECA } & \multicolumn{2}{|c|}{ ACERVO DE LIVROS } & \multicolumn{2}{|c|}{ ACERVO DE PERIÓDICOS } & \multicolumn{2}{|c|}{ OUTROS DOCUMENTOS } & \multirow{2}{*}{$\begin{array}{c}\text { BASES DE DADOS } \\
\text { ACESSO AO PORTAL CAPES }\end{array}$} \\
\hline & TítUlos & EXEMPLARES & TítULOS & EXEMPLARES & TÍTULOS & EXEMPLARES & \\
\hline CAMPUS CENTRAL & 51.140 & 98.609 & 1.621 & 68.273 & 6.549 & 5.555 & 14 \\
\hline FAUS & 5.995 & 11.157 & 249 & 15.005 & 3.947 & 4.834 & \\
\hline DIREITO & 12.300 & 27.971 & 265 & 11.737 & 1.638 & 1.721 & \\
\hline TOTAL GERAL & 69.435 & 137.737 & 2.135 & 95.015 & 12.134 & 12.110 & 14 \\
\hline
\end{tabular}

TAB. 14. Acervo documental por biblioteca. Fonte: Departamento de Bibliotecas - dados estatísticos até 29 de março de 2016.

A biblioteca da FAUS é a mais relevante da Região Metropolitana da Baixada Santista, disponibiliza extensa bibliografia na área de arquitetura e urbanismo e suas ramificações - tecnologia, história, artes e sociologia - além de obras raras e periódicos encontrados somente na biblioteca da FAU-USP. Vale destacar que em seu acervo constam documentos, pesquisas e projetos relacionados às cidades da Baixada Santista, como, por exemplo, o projeto completo de drenagem e saneamento de efluentes da cidade de Santos elaborado pelo Engenheiro Sanitarista Francisco Saturnino de Brito no início do século XX, além de pesquisas e programas de extensão desenvolvidos dentro da própria Universidade.

Entretanto, não basta apenas organização e um conjunto de regras claras, é possível dizer que a formação acadêmica, a prática profissional e a experiência individual de cada professor, aliadas à capacidade de adaptação e participação do corpo discente nos processos de ensino, apresentam papel decisivo na elaboração das estratégias de educação, na formulação dos conteúdos didáticos e pedagógicos, que formam a estrutura dos cursos de arquitetura, conferindo identidade própria a cada um deles. Interessa lembrar que, indo nessa mesma direção, Walter Gropius destacava que:

\begin{abstract}
A escolha do professor adequado é decisiva para os resultados que um instituto de formação visa a obter. As características humanas são até mais decisivas do que o conhecimento técnico e o talento; pois do caráter do mestre depende o sucesso fecundo do trabalho em conjunto com a juventude. Quando se deseja ganhar para um instituto homens de capacidades artísticas extraordinárias, é preciso dar-lhes desde $o$ princípio tempo e espaço para que possam fomentar, nas mais amplas bases, seu desenvolvimento pessoal através do trabalho privado. O simples fato de que tais pessoas continuem a levar adiante seu próprio trabalho no instituto produz aquela atmosfera criativa em que jovens talentos podem desenvolver-se [...] $n a$ verdade, a arte não é um ramo da ciência que possa ser apreendida passo a passo em um livro. Só é possível intensificar o talento artístico inato quando a pessoa toda é influenciada pelo exemplo do mestre e por seu trabalho. ${ }^{90}$
\end{abstract}

Na esteira da proposta de Gropius, no que diz respeito à formação e origem dos professores da FAUS, o atual quadro docente da escola está mais diversificado do que nos anos iniciais, porém muito enxuto, contando com apenas 39 professores profissionais arquitetos, engenheiros, sociólogos, filósofos, geólogos, historiadores e matemáticos. 


\begin{tabular}{|c|c|c|c|c|}
\hline \multicolumn{5}{|c|}{ DOCENTES ATIVOS NA FAUS EM 2019} \\
\hline SEQ. & NOME & DISCIPLINA MINISTRADA & ADMISSÃO & FORMAÇÃO \\
\hline 1 & ANA ELENA SALVI & TEORIA E HISTÓRIA & 1994 & FAU-USP \\
\hline 2 & ÂNGELA MARIA FRIGÉRIO & ESTUDOS AMBIENTAIS & 1978 & GEOLOGIA - UNESP \\
\hline 3 & APOENA AMARAL E ALMEIDA & PROJETO DE ARQUITETURA & 2010 & FAU-USP \\
\hline 4 & CARLOS ANTUNES & PROJETO DE ARQUITETURA & 1992 & FAU-USP \\
\hline 5 & CASSIA REGINA MAGALDI & TEORIA E HISTÓRIA & 1987 & FAU-UFBA \\
\hline 6 & CESAR AGENOR FERNANDES DA SILVA & TEORIA E HISTÓRIA & 2010 & HISTÓRIA-UNESP \\
\hline 7 & CESAR AUGUSTO ALONSO CAPASSO & CONFORTO & 2006 & FAUS \\
\hline 8 & CESAR BARGO PEREZ & PLÁSTICA & 2014 & FAUS \\
\hline 9 & CHRISTIANE COSTA FERREIRA MACEDO & PLÁSTICA & 2008 & FAUS \\
\hline 10 & CLARISSA DUARTE DE CASTRO SOUZA & URBANISMO & 2011 & FAUS \\
\hline 11 & CLAUDIA MARIA BRAGA RIBEIRO & PLÁSTICA & 2013 & FAU-USP \\
\hline 12 & CLAUDIO SCHERER DA SILVA & TEORIA E HISTÓRIA & 2009 & FILOSOFIA-CLARENTIANO \\
\hline 13 & CLEBER FERRÃO CORREA & PAISAGISMO & 2001 & ENGENHARIA CIVIL -UNESP \\
\hline 14 & DEBORA BLANCO BASTOS DIAS & URBANISMO & 1991 & FAUS \\
\hline 15 & DENIS JOELSONS & PROJETO DE ARQUITETURA & 2018 & ESCOLA DA CIDADE \\
\hline 16 & FABIO EDUARDO SERRANO & TEORIA E HISTÓRIA & 1982 & FAU-USP \\
\hline 17 & GINO CALDATTO BARBOSA & TEORIA E HISTÓRIA & 1993 & FAUS \\
\hline 18 & JHONNES ALBERTO VAZ & TOPOGRAFIA & 2012 & ENGENHARIA CIVIL -UNITAU \\
\hline 19 & JOÃO CALLEJA ALCANIZ VALENTI & TECNOLOGIA - CÁLCULO & 1993 & MATEMÁTICA-UNISANTOS \\
\hline 20 & JOSE MARIA DE MACEDO FILHO & PROJETO DE ARQUITETURA & 2003 & FAUS \\
\hline 21 & JOSE MARQUES CARRIÇO & URBANISMO & 2010 & FAUS \\
\hline 22 & JUAN CABELLO ARRIBAS & PROJETO DE ARQUITETURA & 2016 & ETSAM-MADRID \\
\hline 23 & JUAREZ RAMOS DA SILVA & TECNOLOGIA DA CONSTRUÇÃO & 2014 & ENGENHARIA CIVIL-UNISANTA \\
\hline 24 & LEILA REGINA DIÊGOLI & TEORIA E HISTÓRIA & 1990 & FAU-UBC \\
\hline 25 & LENIMAR GONCALVES RIOS & URBANISMO & 1994 & FAUS \\
\hline 26 & MARCIA APS & TECNOLOGIA DA CONSTRUÇÃO & 2010 & ENGENHARIA CIVIL-USFCAR \\
\hline 27 & MARCOS ASSIS PIFFER & PLÁSTICA & 2006 & FAUS \\
\hline 28 & MARIA CRISTINA TUZZOLO VIDALLER & SISTEMAS ESTRUTURAIS & 2003 & ENGENHARIA CIVIL-MACKENZIE \\
\hline 29 & MARIA FERNANDA BRITTO NEVES & ESTUDOS AMBIENTAIS & 2007 & FAUS \\
\hline 30 & MIGUEL GUKOVAS & INSTALAÇÕES & 1976 & POLITÉCNICA-USP \\
\hline 31 & MONICA ANTÔNIA VIANA & URBANISMO & 1995 & FAU-PUCCAMP \\
\hline 32 & NEY CALDATTO BARBOSA & TEORIA E HISTÓRIA & 1997 & FAUS \\
\hline 33 & PAULO FERNANDO VON POSER & PLÁSTICA & 1986 & FAU-USP \\
\hline 34 & RAFAEL PAULO AMBRÓSIO & URBANISMO & 2015 & FAU-UNESP \\
\hline 35 & RICARDO AUGUSTO DE MELLO GRANATA & OBJETO & 2014 & FAU-FAAP \\
\hline 36 & RICARDO COSTA GALVANESE & TEORIA E HISTÓRIA & 1992 & FFCL-UNISANTOS \\
\hline 37 & SEBASTIAN FRIEDRICH BECK & PROJETO DE ARQUITETURA & 2018 & HOCH- KONSTANZ \\
\hline 38 & SERAFIM CARLOS DIAS POUZA & SISTEMAS ESTRUTURAIS & 1994 & FFCL-UNISANTOS \\
\hline 39 & RONALDO DE SOUZA BARCALA & SISTEMAS ESTRUTURAIS & 2013 & ENGENHARIA CIVIL-UNISANTA \\
\hline
\end{tabular}

TAB. 15. Quadro elaborado pelo autor a partir das informações fornecidas pelo Departamento de Recursos Humanos da Universidade Católica de Santos, atualizado em 20 de maio de 2019.

A relação de professores acima confirma, no mínimo, a emancipação política da FAUS em relação à FAU-USP e à FAU-Mackenzie. É notável que somente seis professores têm como instituição de formação a Universidade de São Paulo, e a Universidade Presbiteriana Mackenzie, apenas um docente, juntas não atingem $20 \%$ do quadro total dos professores. A Universidade Católica de Santos e a FAUS contam com quinze docentes egressos de seus cursos, detendo $40 \%$ do quadro, os dezesseis docentes restantes são oriundos de outras universidades, nacionais e internacionais. 


\section{A dimensão projetual do atelier}

Chega-se ao Atelier. Aqui vale arriscar algumas conexões entre ideias do universo da arquitetura com outro campo do conhecimento. Julgou-se pertinente examinar e fixar conceitos tratados na filosofia para o desenvolvimento da noção de que o projeto pode ser entendido, no seu sentido mais amplo, como pesquisa. Está claro que a problemática a seguir demanda um aprofundamento muito maior do que o proposto, trata-se de um assunto que oferece múltiplas e diferentes entradas e interpretações, constituindo um complexo sistema de ramificações que, ao modo do projeto, demanda escolhas e tomadas de decisões difíceis e arriscadas, mas também se apresenta como um instrumento de diálogo, oferecendo oportunidades para novas experimentações. Propor reflexões de natureza afirmativa para essas conexões e, ao mesmo tempo, deixar rastros capazes de orientar novos caminhos e significados longe de qualquer teoria exaustiva, só é possível através de um texto próximo a um ensaio, à interpretação se opõe a experimentação. ${ }^{92}$

FIG. 91. Expansão do conhecimento, forma de arborescência de Julien Pacotte.

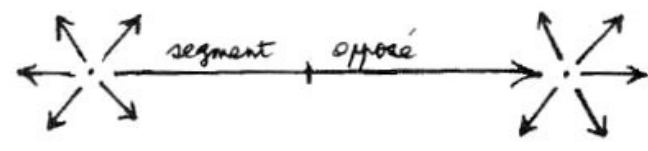

Isto posto, simplificando muito, a simultaneidade do modo de pensar e agir do arquiteto tem seduzido a filosofia desde a antiguidade até os dias de hoje. Não por acaso, inicia-se este ensaio pelas formulações de Jacques Derrida, pensador contemporâneo criador do desconstrutivismo no campo da filosofia, que posicionou suas formulações entre a matemática e a geometria investigando, a partir de princípios de decomposição, conceitos como intuição, construção e indecisão, elementos muito próximos do campo da arquitetura. ${ }^{93}$ Nesse sentido, Derrida tem como principal exemplo de conexão entre teoria e prática o architékton de Aristóteles, aquele que conhece a essência das coisas, um teórico que também pode ensinar aos incapazes de pensar por si mesmos e, ao fazê-lo, estabelece uma hierarquia política. No esforço para clarificar o que para ele é o pensamento arquitetônico, Derrida recorre ao seguinte princípio kantiano: a arquitetônica. Noção que se

\footnotetext{
91 Paulo Mendes da Rocha. Documentário Diretor: Joana Mendes da Rocha. Patricia Rubano Duração: 74 min Ano: 2017 Brasil UF: SP.

92 François Ewald sobre o livro Mil platôs. DELEUZE, Gilles. GUATTARI, Félix. Op. cit. p. 97.

93 Jacques Derrida (1930-2004) foi um filósofo franco-magrebino, autor da teoria da Desconstrução em filosofia, termo compreendido entre as concepções definidas como "intuicionismo" e "construcionismo" do campo da matemática e dos teoremas da indecidibilidade. A noção de desconstrução surgiu pela primeira vez na introdução à tradução de 1962 da obra Origem da Geometria, de Edmund Husserl (1961), o que lhe rendeu o prestigiado prêmio Jean Cavaillés (prêmio de epistemologia) com apenas 31 anos de idade. A desconstrução não significa destruição completa, mas sim desmontagem, decomposição dos elementos da escrita. A desconstrução serve nomeadamente para descobrir partes do texto que estão dissimuladas e que interditam certas condutas. Ver Willy Maley Disponível em: <http://www2.arts.gla.ac.uk/SESLL/EngLit/ugrad/hons/theory/Ten Ways.htm >. Acesso em: 23 nov. 2019.
} 
configura como uma arte de sistemas, adequada, portanto, à organização racional de todas as derivações do saber, podendo ser utilizada como referência retórica por uma linguagem que não conserva nenhum caráter arquitetônico e, seguindo essa lógica, toda linguagem pode sugerir uma espacialização, ${ }^{94}$ uma "disposição no espaço que não o domina, ou seja, só pode entendê-lo por aproximação feita através de um caminho que não tem de ser descoberto, mas criado. 0 caminho não é um método. O método é uma técnica, um procedimento para se obter o controle do caminho, para torná-lo viável." ${ }^{95}$

FIG. 92. Trabalho de Plástica de estudante da FAUS.

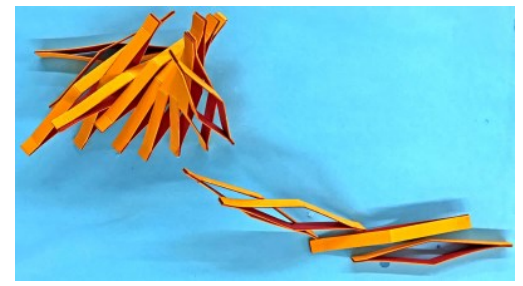

Derrida, ao utilizar o termo arquitetônica, inevitavelmente remete essa discussão ao século XVIII, época da primeira publicação da Crítica da Razão Pura de Immanuel Kant, filósofo alemão que reconheceu na produção de seu contemporâneo, o escocês David Hume, a luz que o despertou para o desenvolvimento de seu pensamento: o conceito metafísico da conexão de causa e efeito. A partir desse ponto e, ao contrário de Hume, que não conseguiu derrubar as contradições com que se deparou, Kant estabeleceu a fundamental distinção entre os elementos do conhecimento puro que devem ser entendidos a priori e os elementos do conhecimento fenomenológico que são entendidos a posteriori. Nesse sentido, para o conceito de a priori não conter contradições é preciso considerar os objetos como coisas em si, como objetos do conhecimento puro na esfera do incondicionado. ${ }^{96}$

Na elaboração da Arquitetônica da Razão Pura, Kant fundou a descrição mencionada por Derrida: "arquitetônica é a arte dos sistemas [...] a doutrina do científico em nosso conhecimento em geral, [...] pertencente necessariamente à doutrina do método, a ideia necessita de um esquema para sua realização" ${ }^{\prime 97}$, ou seja, tais sistemas não são projetados segundo as ideias, mas através de processos de aproximação, empiricamente, configurando uma unidade técnica, ordenando as partes determinadas a priori. Ao passo que aqueles sistemas que surgem em decorrência de uma ideia, no qual a razão force os fins a priori e não os espera empiricamente, funda uma unidade arquitetônica." ${ }^{98} \mathrm{~A}$ invenção desse conceito permitiu que Kant, de maneira científica, considerando o

\footnotetext{
${ }^{94}$ DERRIDA, Jacques. Escrever é um Modo de Morar. Revista Projeto, São Paulo, no 118, jan. / fev. de 1989. p. 115.

95 Ibid. p.115 e passim.

${ }^{96}$ KANT, Immanuel. Prolegômenos a toda metafísica futura que queira apresentar-se como ciência. Trad. Artur Morão. Lisboa: Edições 70, 1988.

${ }^{97}$ Ver mais sobre o assunto na segunda parte do livro Crítica da Razão Pura, denominada Doutrina transcendental do método, especificamente no terceiro capítulo intitulado Arquitetônica da Razão Pura. KANT, Immanuel. Crítica da razão pura. 4a ed. Rio de Janeiro: Vozes, 2015. pp. 600-601 e passim.

98 Ibid. pp. 600-601 e passim. 
conhecimento racional já demonstrado, pudesse contrapor as duas esferas do conhecimento humano em pé de igualdade: razão e intuição.

A partir da distinção entre objetos dos sentidos e objetos da razão, no campo do incondicionado, Kant teve instrumentos para questionar e derrubar formulações anteriores baseadas puramente em crenças e dogmatismos, e provou a natureza limitada da lógica e das ciências naturais (física) que dependiam somente do caráter racional revelado pelos seus experimentos e que, ao contrário da matemática, a metafísica pode usar critérios intuitivos verificados, meticulosamente, em todos os seus pormenores, para inventar conceitos. Talvez o aspecto mais importante desse modelo seja sua autonomia na construção dos procedimentos de investigação e, segundo o exemplo utilizado por Kant, essa autonomia pode ser compreendida através da observação do processo de construção do triângulo equilátero que dispensa sua demonstração, pois a partir de leis e princípios estabelecidos previamente pelo autor, o problema investigado se revela como mecanismo de sua própria resolução.

“O rigor escolástico aplicado na investigação desses problemas elimina os riscos de contradição, evitando as conclusões pautadas por opiniões subjetivas e qualquer fragilidade do plano terá de se trair inevitavelmente no uso" ${ }^{99}$ Esse método hipotético indutivo verificável de sistematização lógica e imaginativa, sem perder a ideia de completude, é capaz de produzir, com segurança, conhecimento científico.

Aquilo que denominamos ciência não pode surgir tecnicamente, devido à semelhança com o diverso ou ao uso contingente do conhecimento in concreto para todos os fortuitos fins externos, mas arquitetonicamente, devido à proximidade e à derivação de um único fim interno e supremo, que torna primeiramente possível o todo; e seu esquema tem de conter, conformemente à ideia, i.e., a priori, o esboço (monograma) e a divisão do todo em membros, bem como distingui-lo de todo o resto com segurança e segundo princípios. ${ }^{100}$

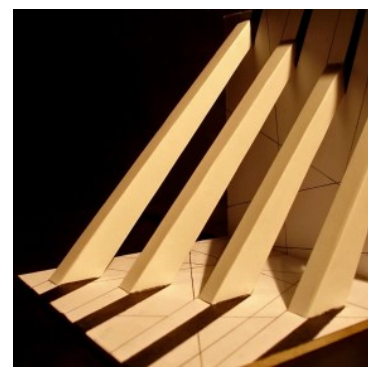

FIG. 93. Trabalho de Plástica de estudante da FAUS.

Nesse ponto interessa saber como esses princípios podem ser vistos a partir da ótica de pensadores alinhados ao campo da arquitetura, desse modo, vale destacar que, para o crítico italiano Giulio Carlo Argan, essa sistematização elaborada no campo da filosofia, ao tratar dos problemas da arquitetura, considera o espaço como lei geométrica e não como um fenômeno e, nesse sentido, "permanecerá

\footnotetext{
${ }^{99} \mathrm{O}$ exemplo do triângulo equilátero proposto por Tales foi utilizado por Kant ao se referir ao processo de investigação dos geômetras. KANT, Immanuel. Prolegômenos a toda metafísica futura que queira apresentar-se como ciência. Op. cit. passim.

100 KANT, Immanuel. Crítica da razão pura. Op. cit. p. 601.
} 
como uma mera hipótese ou postulado abstrato enquanto a atividade construtiva concreta, que é a arquitetura, não o determinar como forma." ${ }^{101}$ Seguindo o crítico italiano, isso explica, melhor do que o esquema de Kant, a ideia de síntese das artes, pois ao entender o espaço como fenômeno, essa síntese não se apresenta mais como "nivelamento e uniformidade de módulos, mas como identidade de processos inventivos ou criativos, já que toda invenção ou criação será sempre invenção ou criação de espaço" ${ }^{102}$ Isso não quer dizer que Argan invalide o princípio arquitetônica como um modelo científico de investigação do processo de se pensar a arquitetura, mas, ao deslocar o sistema Kantiano da superfície para o espaço, demonstra menos uma superação e mais uma evolução desse conceito. Talvez essa seja uma visão por demais ingênua e evidente, mas o que se pretende demonstrar é que, ao inserir a terceira dimensão nesse modelo, Argan amplia o horizonte para novas leituras no campo da arquitetura.

FIG. 94. Trabalho de Projeto de estudante da FAUS.

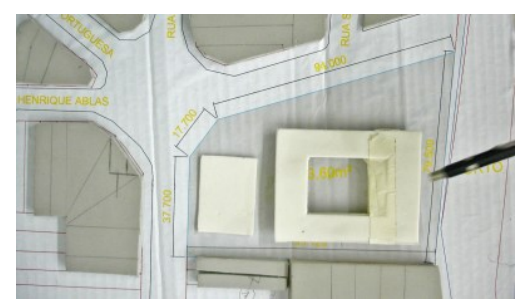

Ao se admitir que o espaço seja fenômeno, recorre-se mais uma vez a Derrida, que descreve a arquitetura como uma questão de lugar. Uma ação de ocupar um lugar no espaço, um desejo de estabelecer um lugar que antes não existia e que está de acordo com um projeto, um acontecimento técnico. O filósofo francês vai mais longe ao afirmar que a arquitetura, ao inventar um lugar habitável antes inexistente para alguém que já existia e necessitava dele, ou seja, alguém que já o determinava antes mesmo de sua invenção, insere a quarta dimensão ao sistema de Kant: o tempo. "Vista desta forma, a arquitetura não é uma questão de espaço, mas uma experiência do supremo, que não é superior, mas de certo modo mais antigo que o espaço, portanto, é uma espacialização do tempo." ${ }^{103}$ Em linhas gerais, pode-se dizer que Immanuel Kant, ao utilizar elementos do campo da arquitetura e da geometria para sustentar sua tese filosófica arquitetônica, como premissa seminal, demonstrou que o pensamento humano não poderia ser reduzido somente a uma atividade técnica, como um método ou apenas a um lampejo intuitivo, como uma crença. Deve ser entendido como a invenção de um caminho novo e original, percorrido através de processos que alternam entre o conhecimento científico e o conhecimento discursivo.

\footnotetext{
${ }^{101}$ Argan (1909-1992) chega a essas conclusões a partir da leitura da obra de Frank Lloyd Wright que, segundo sua visão, produz uma arquitetura que supera o geometrismo racionalista: "Wright compreendeu que espaço não é lei geométrica, mas fenômeno". ARGAN, Giulio Carlo. Projeto e destino. São Paulo: Editora Ática, 2004. p. 143.

102 Ibid. p. 143.

${ }^{103}$ DERRIDA, Jacques. Escrever é um Modo de Morar. Revista Projeto, São Paulo, no 118, jan. / fev. 1989. p. 116. 
Apesar do caráter panorâmico dessas conexões, o que se defende a seguir, no esforço de compreender a arquitetura como uma disciplina capaz de fundir arte e técnica com rigor científico, é que as noções de sistema, lugar, espaço e tempo, mesmo sendo elaboradas e reelaboradas por pensadores de diferentes campos do conhecimento, demonstram a dificuldade e imprecisão para definir, e principalmente esgotar, as riquezas da natureza aberta e, de certo modo, inacabada do fazer arquitetônico. Nesse sentido, apoiando-se na dimensão experimental da arquitetura, essas reflexões, ao serem encaradas como provocações, configuram um pretexto para novamente arriscarse, agora com uma proposição para a arquitetônica de Kant - matizada por Derrida e Argan - e, ao modo de um exercício de projeto, a seguinte representação.

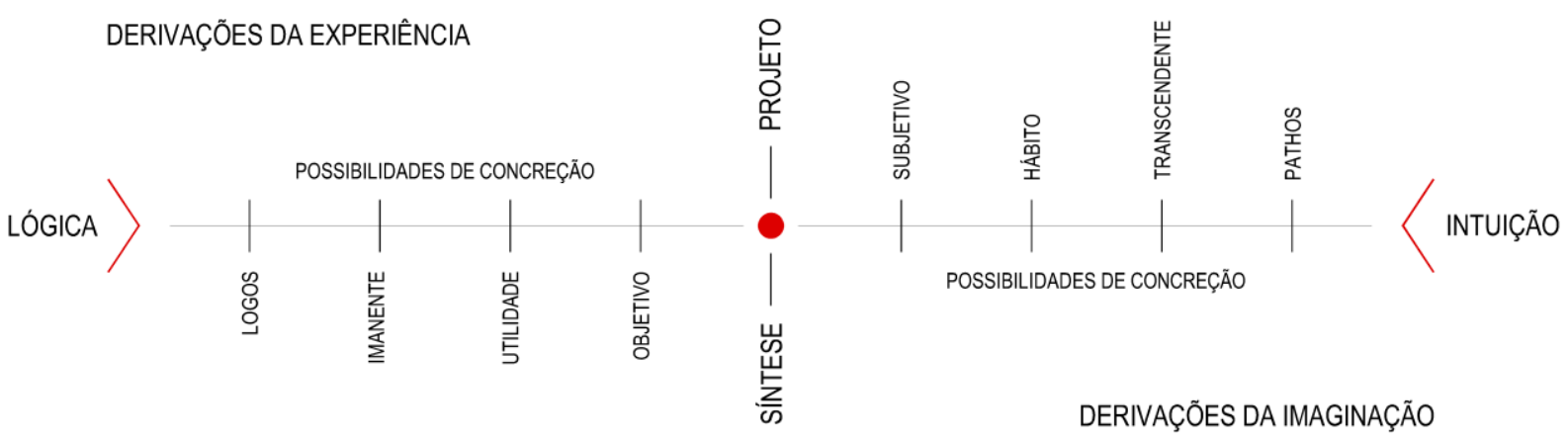

FIG. 95. Diagrama de aproximação do conceito de completude de Kant com o modo operativo do arquiteto que, ao investigar um problema utilizando o desenho, sintetiza e materializa sua pesquisa em um projeto.

Se por um lado o rizoma é expansão do conhecimento e o diagrama da arborescência proposto por Deleuze e Guattari representa pontos de fuga ou vetores que explodem em todas as direções, o modelo aqui proposto para o sistema kantiano constitui um sistema vetorial convergente. Uma estrutura na qual cada representação-aproximação configura uma possibilidade de concreção de uma determinada ideia, ao mesmo tempo em que revela um caminho viável e original. Sempre que esses vetores percorrerem caminhos equidistantes, o seu encontro se dará no centro, a síntese resultante é o projeto e o percurso, a pesquisa.

Nesse sentido e, recuperando o conteúdo apresentado no primeiro capítulo, acerca das experiências de ensino de arquitetura praticadas no início do século XX, Anna Bokov lembra que o curso dos VKhUTEMAS ofereceu uma das primeiras alternativas ao atelier acadêmico clássico e aos modelos de aprendizado do projeto de arquitetura. Ao passo que Anatole Kopp reforça que a Bauhaus estava no centro do movimento de contestação dos métodos de ensino da época e, desse modo, apoiava-se nas concepções pedagógicas baseadas no princípio do aprender fazendo de Maria Montessori, John Dewey, Ovide Decroly, dentre outros. ${ }^{104}$ Ambas estratégias de ensino posicionavam o estudante 
como agente da própria educação que, ao iniciar um trabalho pensando e trabalhando-o de maneira autônoma, não estava ciente do resultado final, pois a solução era parte da experiência de fazer.

Entretanto, referindo-se especificamente ao curso da Bauhaus, Sylvia Ficher, apesar de reconhecer o esforço em elaborar novas pedagogias para o ensino da arquitetura que nada tinham em comum com o academicismo praticado na época, afirma que a escola alemã não logrou êxito na ruptura com esse modelo, ainda que de seu ensino resultasse uma radical alteração na forma arquitetônica, "ou seja, ainda que a Bauhaus tenha se amparado na estética das vanguardas artísticas, a solução para a velha questão de como ensinar a projetar não se afastou muito da tradição beaux-arts de realizar projetos no papel. ${ }^{105}$

Com efeito, no curso soviético Espaço proposto por Nicolai Ladowsky, ao invés de copiar modelos existentes e reciclar soluções prontas, os alunos elaboravam suas próprias respostas tridimensionais a partir da articulação da forma abstrata resultante da sua deformação mecânica, ou seja, Ladovsky acreditava que era possível constituir a racionalidade arquitetônica condicionando e, até controlando, a percepção através da modelagem da forma no espaço. A síntese entre a técnica, baseada nos princípios tayloristas da administração científica, e a forma, baseada na psicologia perceptiva individual, era chamada por Ladovsky de Racionalismo Arquitetônico. ${ }^{106}$

Ao enfatizar o processo e não o resultado dos exercícios, essa estratégia permitia ao estudante experimentar novas maneiras de resolver problemas geométricos tridimensionais, destacando individualmente o seu potencial criativo e, ao mesmo tempo, evitando a padronização do próprio método. $\mathrm{O}$ objetivo era repensar a abordagem individual intuitiva, tipicamente praticada no projeto em termos objetivos, a fim de desenvolver uma ciência arquitetônica baseada no estudo da percepção e da experiência como forma de estabelecer uma nova sintaxe da forma plástica. Esse procedimento, metodológico psicanalítico, era subsidiado por quatro tipos de propriedades formais: geométrica, física, mecânica e lógica. Essas propriedades eram convertidas e atribuídas no processo de articulação da forma como espaço, volume, ritmo, estrutura, equilíbrio, massa e peso. ${ }^{107}$

\footnotetext{
${ }^{105}$ FICHER, Sylvia. Profissão de arquiteto e ensino de arquitetura: mitos e perspectivas. 8p. Faculdade de arquitetura e Urbanismo Universidade de Brasília: Julho 1994. p. 7. mimeo.

${ }^{106}$ Atendendo ao paradigma modernista de dar "um passo no desconhecido". Cf. primeiro capítulo, item Revolução no complexo arte técnica. BOKOV, Anna. Space: The Pedagogy of Nikolay Ladovsky. Walker Reader Magazine. Jun. 2017. Disponível em: https://walkerart.org/magazine/space-the-pedagogy-of-nikolay-ladovsky. Acesso em: 22 mar. 2019. passim.

${ }^{107}$ BOKOV, Anna. Ibid. 

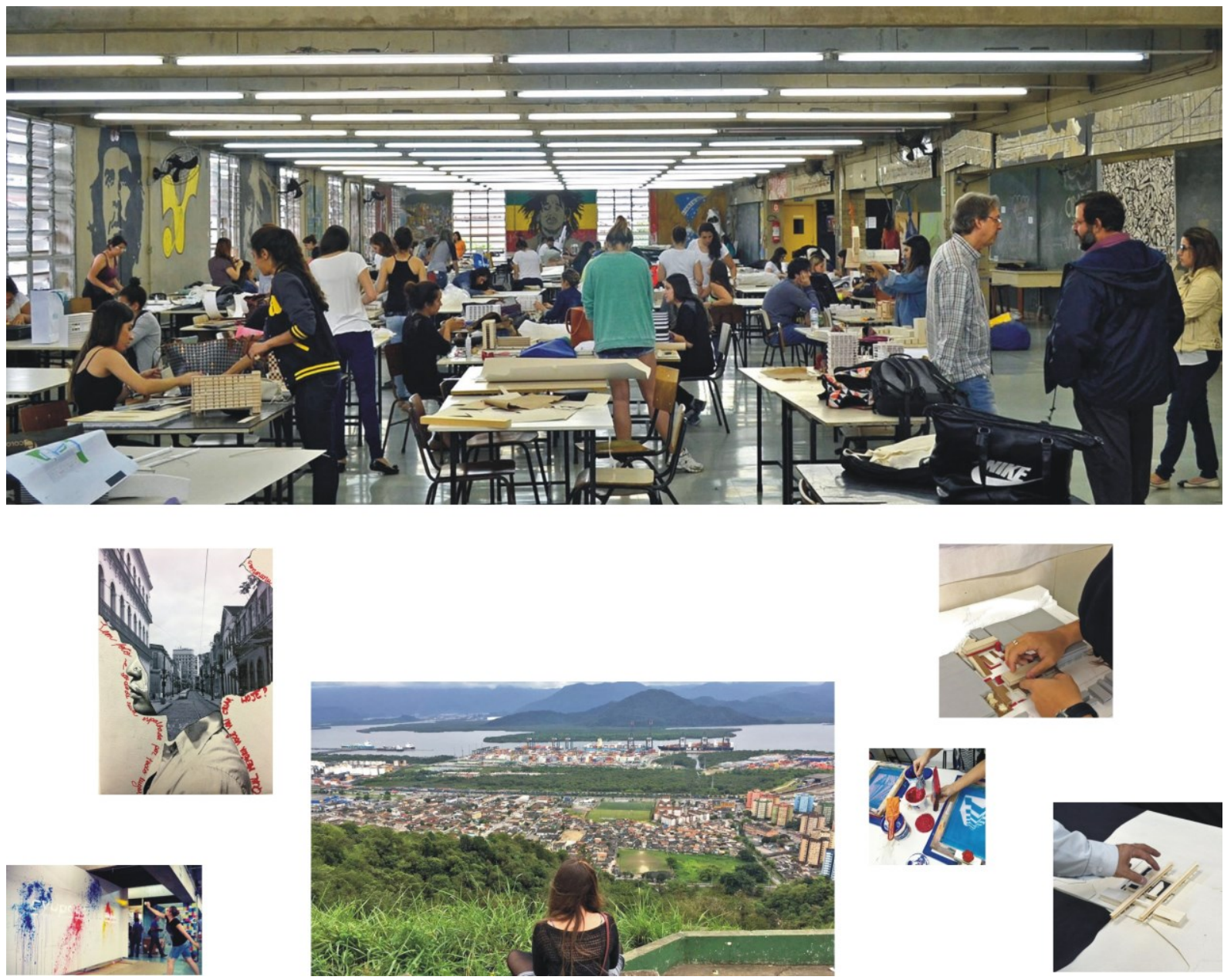

FIG. 96. Acima Atelier da FAUS, abaixo à esquerda, trabalhos de plástica, no centro, estudante desenhando a cidade e, à direita, modelos de projeto de arquitetura.

Inicialmente, os exercícios de articulação da forma abstrata consistiam na construção de modelos tridimensionais sem as restrições típicas da arquitetura como lugar, escala e função, a proposta era a de explorar outros elementos arquitetônicos. As tarefas, inicialmente livres de quaisquer requisitos, permitiram aos alunos explorarem por conta própria a forma em si, aos moldes das construções de laboratório dos construtivistas. Posteriormente, avançavam das preocupações puramente especulativas para aplicações pragmáticas e, uma vez que o exercício abstrato estava completo e formalmente identificável, era seguido por um exercício com programa, local e escala, trazendo a investigação do campo teórico para o campo da realidade. Desse modo, ao final dos dois anos do curso Espaço, o estudante havia adquirido repertório técnico e artístico suficiente para a execução dos exercícios abstratos e aplicados exigidos nos módulos mais avançados. ${ }^{108}$ É notável a relação dessas proposições com as da Reforma de 1962 na FAU-USP, influenciando a concepção das

\footnotetext{
${ }^{108}$ De acordo com o currículo dos VKhUTEMAS o aluno deveria estar habilitado para a articulação de uma superfície plana, articulação de volume, articulação de massa e peso e articulação de um espaço fechado. BOKOV, Anna. Space: The Pedagogy of Nikolay Ladovsky. Walker Reader Magazine. Op. cit.
} 
premissas do atelier paulista ${ }^{109}$ que, em síntese, pretendia ligar o ensino teórico e a prática de atelier à construção:

É através do ateliê que a faculdade realizará seus objetivos fundamentais. Sua contribuição na formação do arquiteto será no sentido de realizar o aprendizado e domínio dos meios de representação e expressão gráficas; iniciar o aluno, egresso dos cursos médios de caráter geral, no mundo dos valores plásticos e estéticos, desenvolvendo nele a experiência, a sensibilidade e a capacidade criadora, aliadas a uma necessária mentalidade de construtor; ser o lugar de estudo, de pesquisa e trabalho do planejamento do meio físico nas suas relações diretas com o homem, onde o aluno entrará em contato com os problemas vivos da Arquitetura e do Urbanismo, na forma mais próxima daquela em que os terá como profissional. ${ }^{110}$

Não muito diferente do curso Espaço de Ladowsky, os exercícios tinham caráter prático com a intensão de fixar a nova linguagem e a nova sintaxe que os estudantes começavam a conhecer. Os temas de composição, nos primeiros anos, restringiam-se a aspectos de organização espacial, possibilitando a verificação das implicações de ordem construtiva, instrumentalizando o aluno através de exercícios gráficos e plástico-construtivos de análise e de representação da forma e do espaço, para os problemas arquitetônicos mais complexos.

\begin{abstract}
Inaugura-se então um processo lento pelo qual entrará em contato progressivo com a Arquitetura e com o Urbanismo [...] se fosse possível classificar os problemas da Arquitetura por complexidades crescentes, como se faz com os problemas técnicos, seria lógico propor nos primeiros anos os mais simples e nos últimos os mais difíceis. Na verdade, mesmo quando a solução se revela através de um conjunto relativamente reduzido de formas, como por exemplo no caso da habitação, o problema arquitetônico se insere num contexto amplo que não deve ser sonegado ao aluno sob o pretexto didático de simplificação [...] daí decorre a necessidade de encarar Arquitetura e Urbanismo como um todo. Uma das falhas mais graves da estrutura de ensino que rejeitamos reside precisamente na sua dissociação, que subtrai a Arquitetura do seu contexto natural e imprescindível fora do qual ela não se explica e não pode ser compreendida. ${ }^{111}$
\end{abstract}

Com efeito, ainda persiste o dilema de que apesar do caráter racionalista dos métodos de problematização contínua, a prática projetual quando atrelada estritamente a categorias como intuição, inspiração, criação etc., entende-se que o projeto não pode ser ensinado, mas aprendido nos processos individuais de cada estudante. Ao mesmo tempo que apenas enfatizar processos de natureza funcionalista ou utilitária, em oposição ao conhecimento humanista, teórico e especulativo, acaba por constituir uma prática puramente técnica e instrumental, ou seja, contrária ao desenvolvimento da autonomia intelectual do estudante, nesse sentido, segundo Arcipreste:

\footnotetext{
${ }^{109}$ Ver item 5 "Várias manifestações a propósito do ensino da Arquitetura: A Experiência Estrangeira," no texto de Carlos Milan que, fato curioso, cita apenas as experiências sul-americanas destacando suas virtudes: "O ensino em ateliers, com a integração das cadeiras técnicas no desenvolvimento dos trabalhos de projeto através de uma assistência efetiva dos professores dessas cadeiras; o contato contínuo com a planificação ampla em todo o curso de forma a criar no futuro arquiteto uma mentalidade urbanística real; a formação técnica concentrada na fase inicial do curso, são todas diretrizes assentes e normas habituais e já quase tradicionais nas faculdades uruguaias e chilenas. Na Argentina, até há dois anos, a organização do ensino era semelhante à brasileira, na reforma então realizada foram adotadas diretrizes semelhantes às do Uruguai e Chile, os primeiros resultados são animadores". MILAN, C.B. O ateliê na formação do arquiteto. Relatório apresentado pelo professor Carlos Barjas Millan, Coordenador do Grupo de Estudos do Ateliê. São Paulo: Setor de publicações. Faculdade de Arquitetura e Urbanismo da Universidade de São Paulo. 1962, 46p. e passim.

${ }^{110}$ MILAN, C.B. Ibid. 46p. e passim.

${ }^{111}$ Ver item VI. O Ateliê, I. Objetivos, 2. Problemas de formação do arquiteto. MILAN, C.B. Ibid. 46p. e passim. 
O ensino de projeto deveria ser entendido como protótipo do ensino prático reflexivo, voltado para o desenvolvimento da criatividade, da habilidade na solução de problemas em situações desconhecidas e únicas. É preciso que o estudante de arquitetura experimente, exercite cada um dos componentes no contexto do aprender-fazendo, do seu próprio caminho de ação-reflexão-na-ação. [...] como sequência de etapas, em percursos de análise-síntese-análise, com variantes conforme o autor, no qual se deveria buscar a explicitação e objetivação dos dados de entrada - requisitos, demandas, condicionantes projetuais - para se alcançar a objetivação dos resultados, sempre se procurando mensurar e comparar parâmetros. Em geral, tais estudos também abordavam o ensino-aprendizagem do projeto como processo de solução contínua de problemas, reforçando que os princípios da metodologia da problematização relacionam-se à prática profissional do arquiteto e urbanista tanto quanto aos seus processos didático-pedagógicos. ${ }^{112}$

Não obstante, vale o alerta de Arcipreste de que apesar dos méritos alcançados por essa metodologia que tem fornecido aos estudantes ganhos significativos de conhecimento e articulação da prática da arquitetura em atelier, seus limites também precisam ser levantados e investigados, justamente devido "à excessiva sobrecarga colocada sobre os méritos e capacidades individuais do aluno - aspectos ligados às noções de dom e talento, que não podem ser formados, em detrimento de perspectivas pedagógicas mais alargadas." ${ }^{113}$ Para citar apenas um exemplo, um pouco mais atual, desse desejo de expandir o campo do ensino de arquitetura, vale lembrar dos exercícios pedagógicos de John Hejduk realizados na Irwin S. Chanin school of architecture of the Cooper Union, em Nova York nos anos 1970 que, para o experimento formal dos projetos, se apoiavam em plataformas não convencionais como partes inexploradas do corpo humano, a questão do feminismo, arquiteturas subterrâneas, saúde e, sobretudo, a literatura. Segundo Montaner, Hejduk contribuiu com a crítica radical na recuperação e expressão dos valores poéticos da arquitetura desenvolvendo um "método de projeto muito mais empírico, plástico, sensível e próximo às necessidades materiais e simbólicas das pessoas. ${ }^{114}$
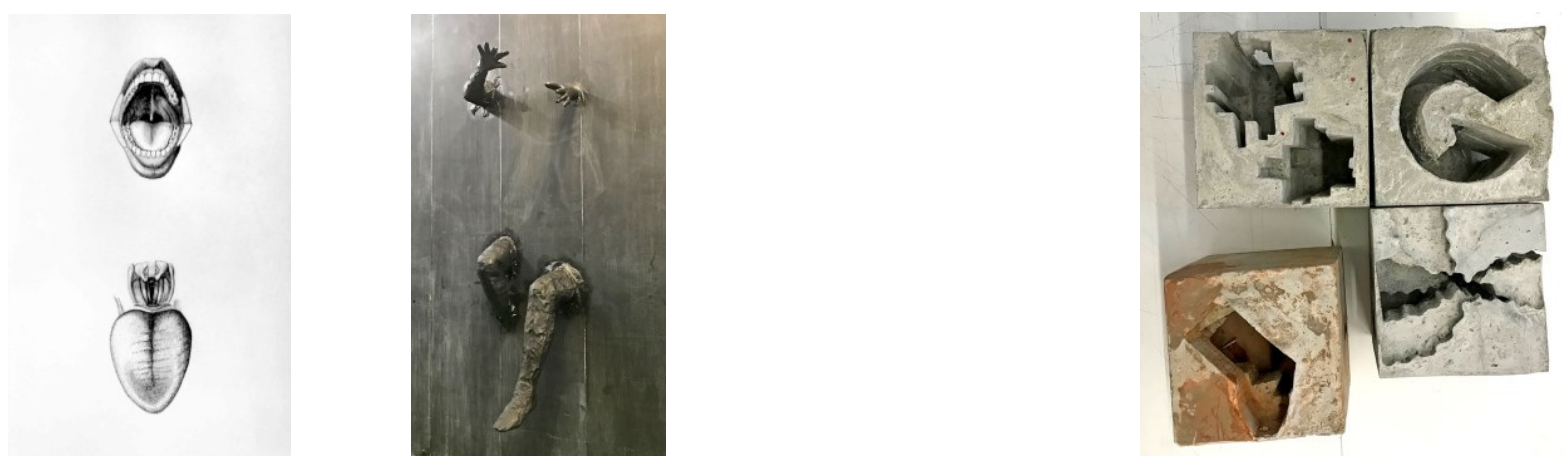

FIG. 97. Atelier John Hejduk, projeto de tese intitulado Instrumento musical: Larynx, elevação e corte. Atelier FAUS, no centro trabalho de Plástica VI: Angústia, ao lado trabalho de Projeto de Arquitetura II: Subtrações.

\footnotetext{
${ }^{112}$ ARCIPRESTE, C. M. Entre o discurso e o fazer arquitetônico: reflexões sobre o ensino de arquitetura e urbanismo e seus referenciais a partir do trabalho final de graduação. 2012. 287p. Tese (Doutorado em arquitetura e urbanismo) - Faculdade de Arquitetura e Urbanismo da Universidade de São Paulo. São Paulo, 2012. pp. 134-136. (grifo nosso).

113 Ibid. pp. 134-136.

${ }^{114}$ Sobre os exercícios praticados na Cooper Union, ver: HEJDUK, John (org.). Education of an architect: the Irwin S. Chanin school of architecture of the Cooper Union. New York, 1996. Sobre a crítica de Montaner quanto aos experimentos radicais de John Hejduk, ver "Teorias críticas e formas radicais" em MONTANER, Josep Maria. Sistemas arquitetônicos contemporâneos. Barcelona: Gustavo Gili, 2009. pp. 132-134. E o texto "A arquitetura do conceito e da forma", John Hejduk, em MONTANER, Josep Maria. Depois do movimento moderno: arquitetura da segunda metade do século XX. Barcelona: Gustavo Gili, 2001. p. 171.
} 
É evidente que o atelier não é o único local em que se processa a síntese do conhecimento técnicoartístico adquirido pelo estudante durante o curso, ainda que de maneira fragmentada pelas matrizes curriculares. No âmbito da FAUS, além do atelier principal localizado no segundo andar do prédio, as salas de aula que separam as classes são ateliers menores, e além dessas salas estão disponíveis os seguintes espaços: Laboratório de Modelos (maquetaria); Laboratório de Conforto Ambiental; Laboratório de Artes Visuais (LAVUCS); Laboratório de Informática; Laboratório de Habitação e Assentamentos Humanos (HABITAFAUS); Laboratório de Sustentabilidade (LABSUS) e o Laboratório de Práticas Construtivas (LPC), este último é o único espaço fora do prédio da escola, localizado no Campus Dom Idílio José Soares, sede da Universidade Católica de Santos.
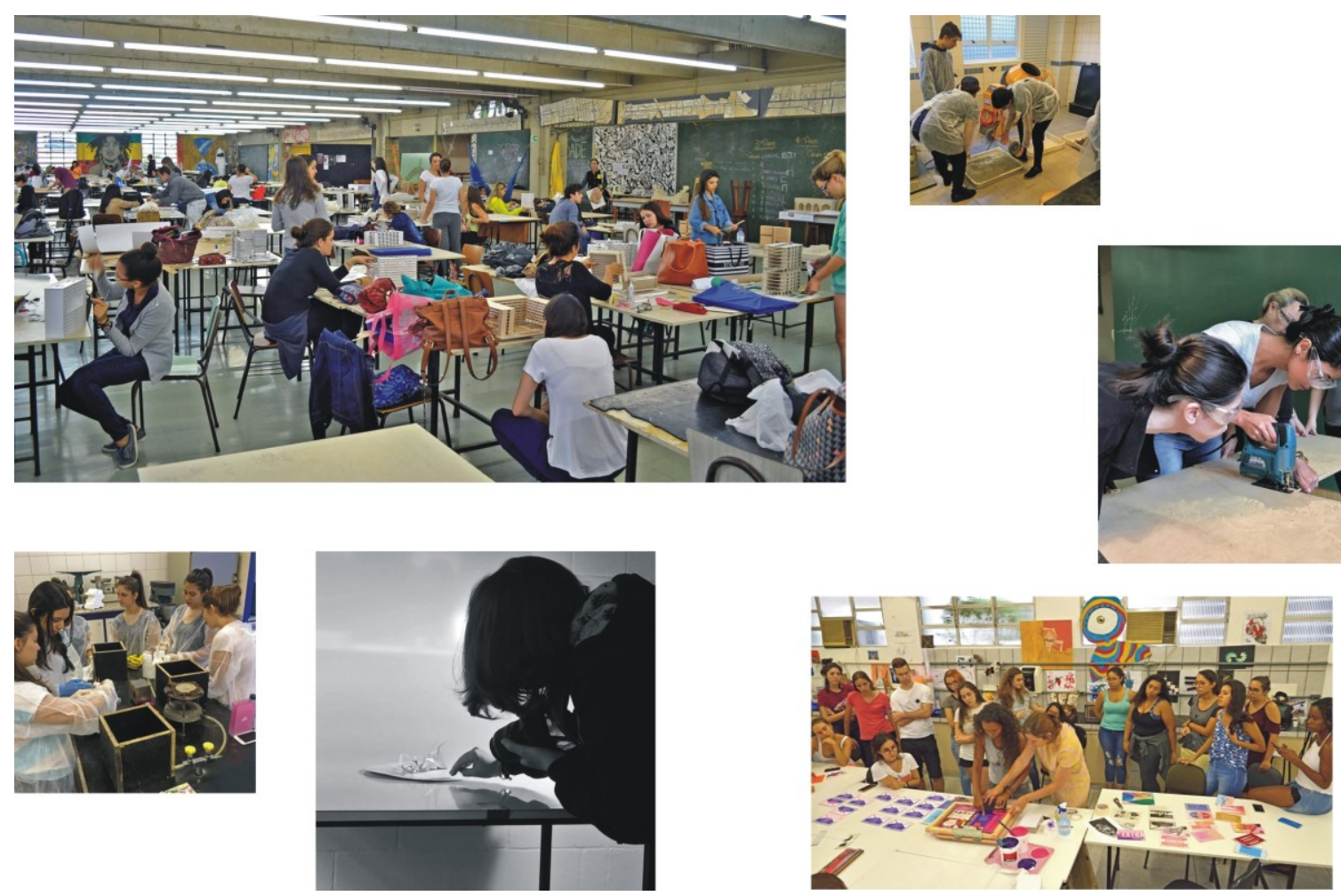

FIG. 98. Acima Atelier da FAUS, ao lado Laboratório de Práticas Construtivas (LPC), abaixo, maquetaria, Laboratório de Artes Visuais LAVUCS.

Entretanto, apesar de a maioria dos laboratórios estarem no mesmo prédio, estão implantados em pavimentos distintos. Um olhar um pouco mais desprevenido não constataria nenhum problema nessa situação, mas a partir de uma análise mais detida acerca dos processos de produção da escola, quatro espaços deveriam funcionar juntos e o mais próximo possível, como um único organismo: o Atelier principal, a Maquetaria, o Laboratório de Conforto Ambiental, o Laboratório de Artes Visuais e o Laboratório de Práticas Construtivas. O livre trânsito de estudantes de diferentes semestres por esses lugares com o objetivo de projetar, pesquisar e construir, já seria um grande passo no estabelecimento de instrumentos de integração vertical e horizontal de conteúdo, ou seja, o próprio 
arranjo espacial deveria ser usado como instrumento pedagógico. Nesse sentido, pode-se dizer que o edifício projetado há cinquenta anos possuía aspectos de natureza aberta, fluidez e generosas áreas de trabalho e convívio, ou seja, era mais acertado para a experimentação de novas pedagogias do que o atual labirinto, compartimentado e desconectado de qualquer visão de conjunto, uma contradição no mínimo curiosa para um curso que pretende formar agentes transformadores do espaço. Nos anos 1980, o professor Jorge Caron já havia alertado sobre o problema de separar a atividade do projeto da prática construtiva:

Desde o início de nossas recentes escolas de arquitetura o termo atelier tem sido empregado como lugar sítio, topos - onde se produzem os projetos. A origem, calcada no termo francês atelier, ficaria mais bem explicitada se procurássemos seu correspondente em espanhol, taller, ou em inglês, workshop. Esses termos denotam mais o conceito de oficina de projetos, que talvez, não tenha sido empregado para poder separar a atividade superior da projetação da prática aparentemente trabalhadora implícita na conotação da palavra oficina. Mas de qualquer forma, o termo francês atelier corresponde ao português oficina, significando o lugar onde se desenvolve um ofício e onde o trabalho comanda o produto final. Work in progress. ${ }^{115}$
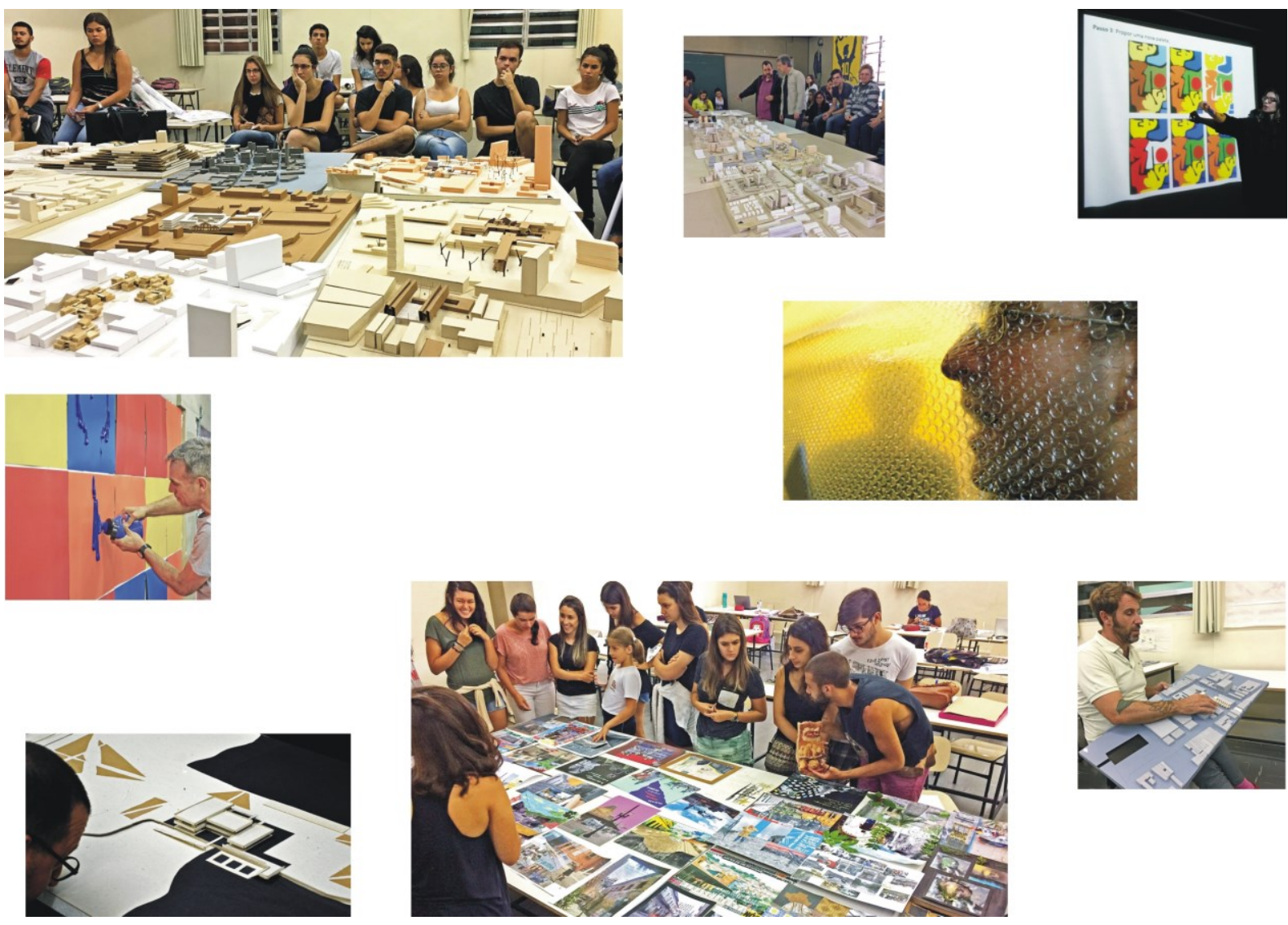

FIG. 99. Produção do Atelier da FAUS.

\footnotetext{
115 Para o professor Jorge Caron, o atelier é um processo de trabalho de projeto, mais do que um lugar em que se projeta. No atelier desenvolvem-se novas questões geradas pelo trabalho que se elabora, e "nesse espaço se manifestam os conhecimentos adquiridos extra escola, as experiências familiares e urbanas, sociais e poéticas". (CARON, 1990). Apud. RUGGIERO, Amanda Saba. Jorge Caron: uma trajetória. 2006. Op. cit. pp. 79-81.
} 

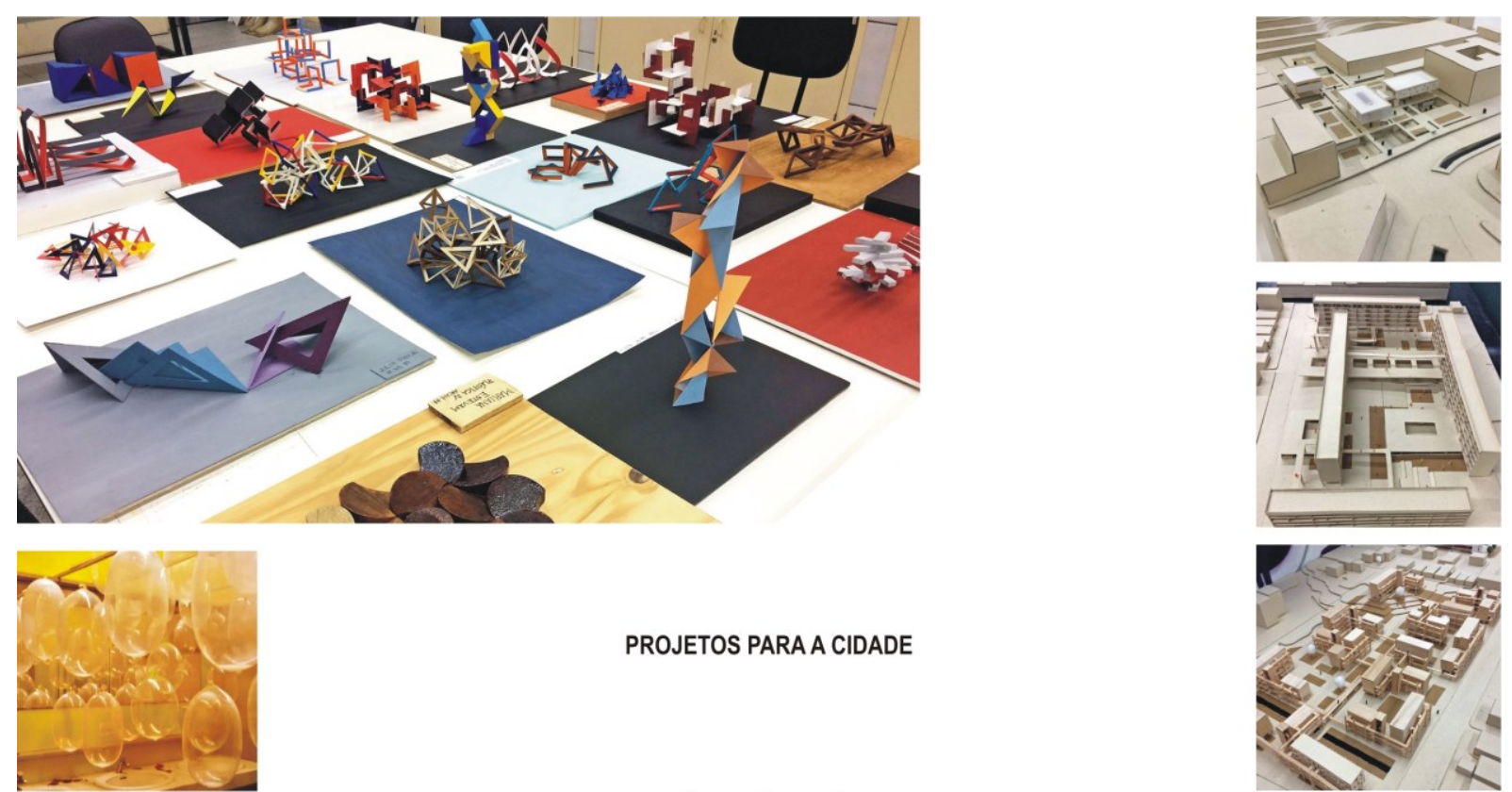

PROJETOS PARA A CIDADE
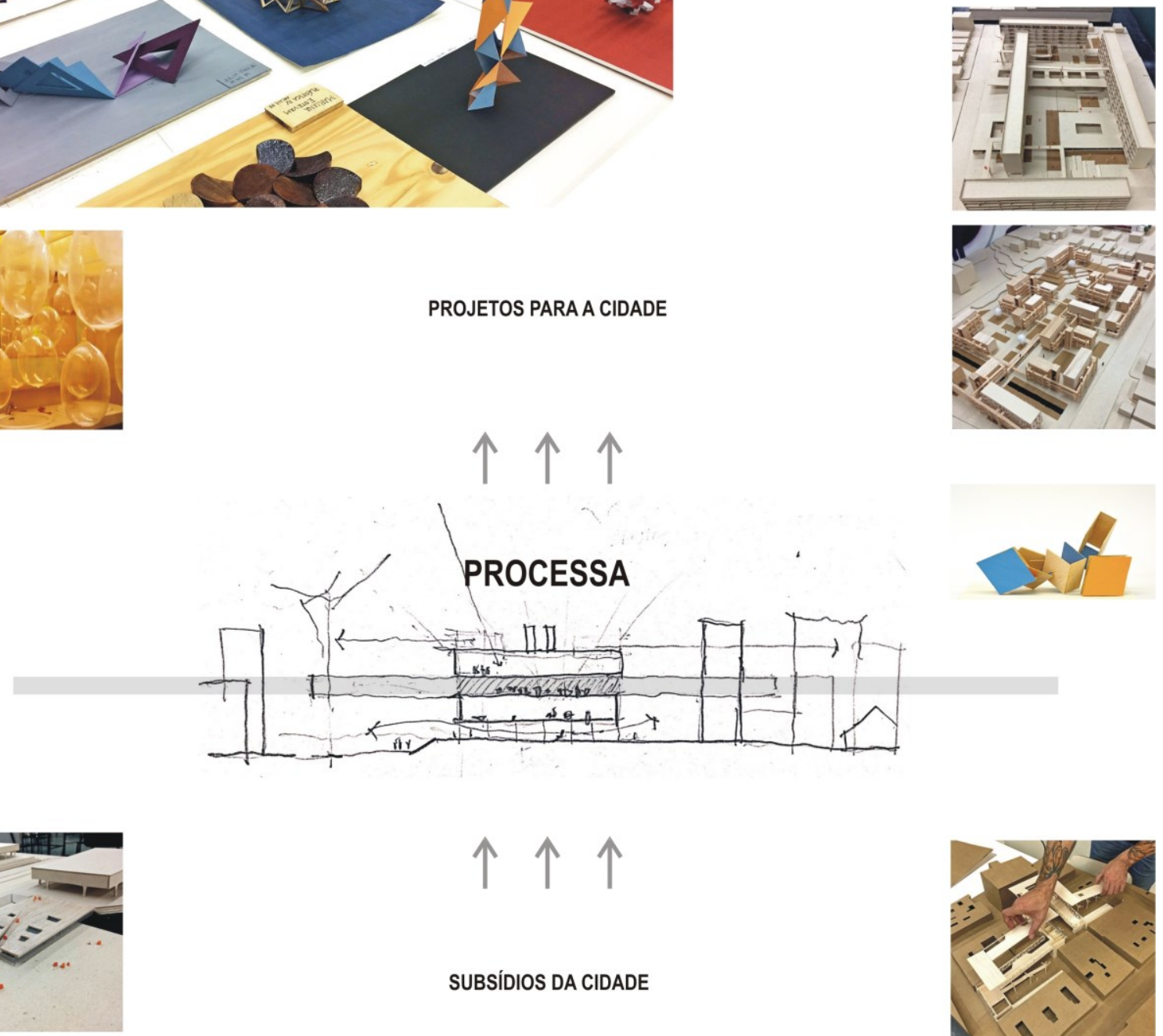

SUBSÍDIOS DA CIDADE
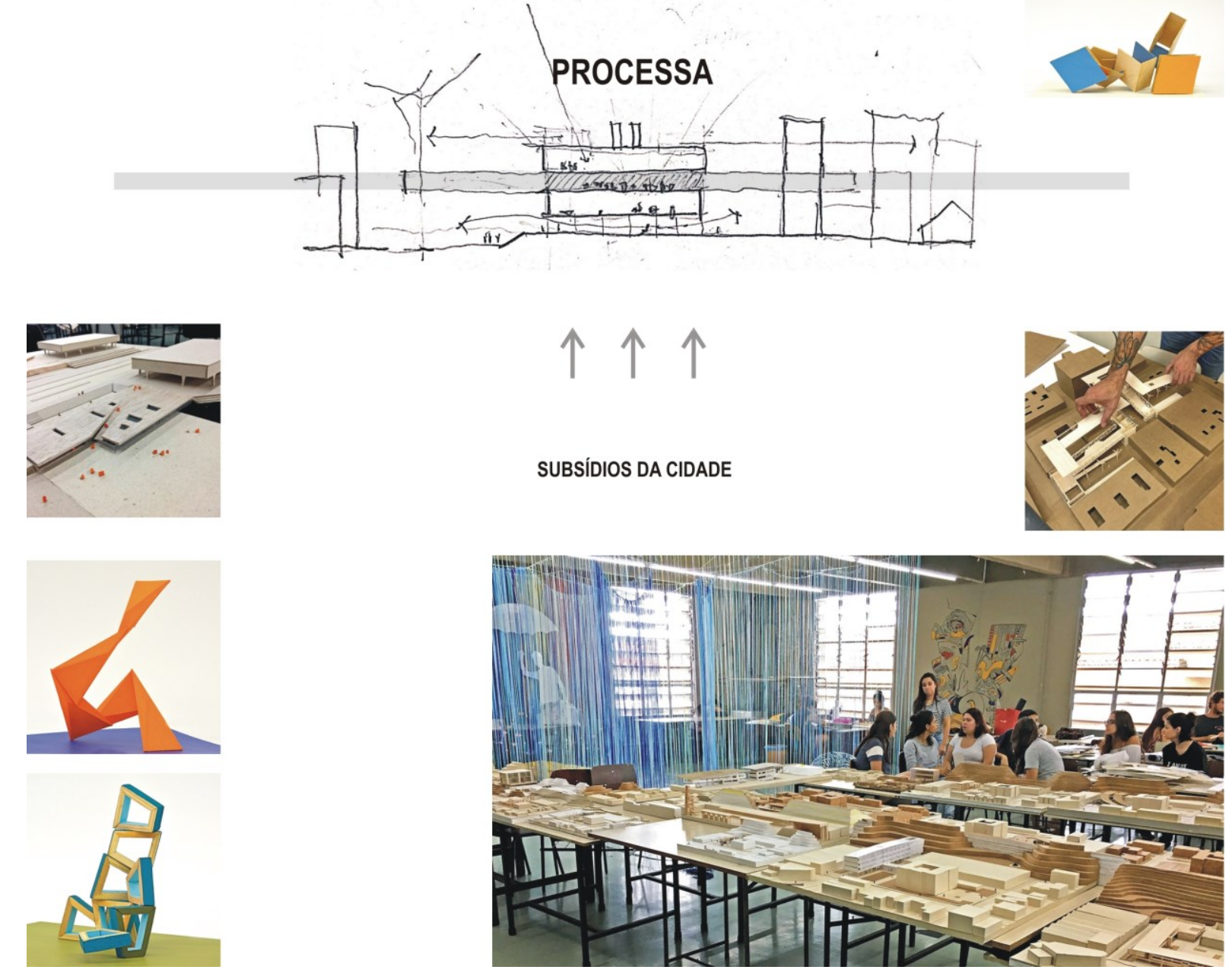

FIG. 100. Produção do Atelier da FAUS. 


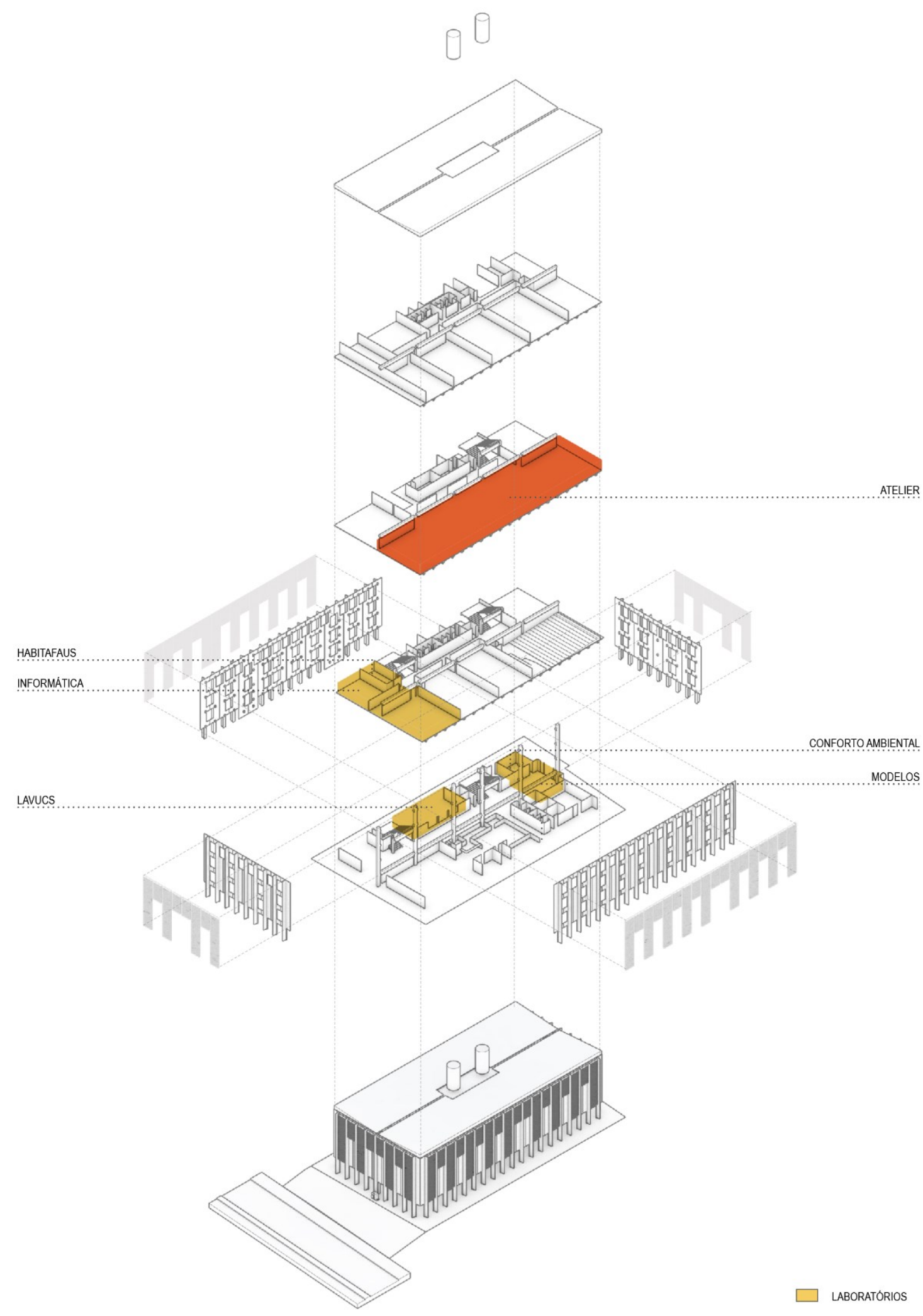

FIG. 101. Localização atual dos laboratórios da FAUS. 
Ao recorrer mais uma vez às impressões de Vilanova Artigas ao chegar nos Estados Unidos em 1946, a prática estabelecida no MIT de integração entre as atividades artísticas, de projeto e construção continua revelando o inexplicável atraso das faculdades de arquitetura no Brasil, no aprofundamento da crítica e experimentação radical na busca por pedagogias mais abertas e atualizadas.

\begin{abstract}
As nossas escolas superiores não têm vitalidade, não se transformam nunca; não são autônomas, dependem da politicagem e muito. Já aqui, uma organização universitária pode mudar sua rota da noite para o dia, é só despedir meia dúzia de professores e contratar novos que no mês seguinte a escola exibe os mais tentadores programas, os nomes publicados no catálogo do ano passado não representam nada hoje. Quando eu vi o catálogo em Nova York, por ocasião da chegada, estremeci, lá a revolução estava se processando. A sala de desenho a mão livre e aquarela estava sendo arrasada, e o termo é esse mesmo: arrasada. Eles acabaram de contratar um rapaz de Chicago, que por sinal é o melhor e quase o único bom elemento no MIT. E não se perde tempo, nem precisa de aquarela. A sala se transformou num laboratório fotográfico (não é bem isso, mas é o melhor termo que eu encontro em português para definir o laboratório) onde se começa agora a estudar cor, "visual design", composição com elementos abstratos e uma porção de outras coisas. É quase um laboratório de pesquisa sobre cor, forma e espaço. ${ }^{116}$
\end{abstract}

Nesse ponto é preciso destacar que a disciplina de plástica, no contexto da FAUS, assumiu um papel absolutamente fundamental para qualquer tentativa de experimentação e integração entre arte e arquitetura. Com laboratório próprio, o LAVUCS, seus docentes organizaram um curso autônomo que desenvolve pesquisas nas áreas relacionadas ao fazer artístico que, ao mesmo tempo, oferece um consistente ponto de apoio conceitual para investigações na área do projeto de arquitetura. Com foco na cidade, o curso está dividido em seis semestres, os primeiros quatro buscam construir o olhar dos estudantes, através do desenho de observação, cor, tempo e espaço, conceito de abstração e exercícios de construção tridimensional. Ao término dos primeiros dois anos do curso, o estudante está habilitado para elaborar críticas propositivas utilizando a cidade como plataforma de trabalho e pesquisa.

\begin{tabular}{|c|c|c|c|c|c|}
\hline & plástica & & linhas de pesquisa & técnicas abordadas & produto final \\
\hline \multirow{6}{*}{$\begin{array}{l}\mathbf{1} \\
\frac{\mathbf{0}}{\boldsymbol{0}} \\
\frac{\boldsymbol{0}}{0}\end{array}$} & 1 & \multirow{4}{*}{ 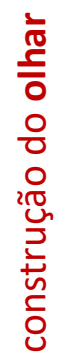 } & desenho de observação & $\begin{array}{l}\text { desenho com lápis, nanquim e } \\
\text { carvão sobre papel }\end{array}$ & sketchbook \\
\hline & II & & cor/tempo e espaço & $\begin{array}{l}\text { lápis de cor, giz pastel, aquarela, } \\
\text { marcadores, colagem }\end{array}$ & projeto mural 2D \\
\hline & III & & abstração & fotografia, estêncil e serigrafia & pintura com estêncil \\
\hline & IV & & tridimensionalidade & modelagem, fotografia & modelo 3D \\
\hline & V & \multirow{2}{*}{ 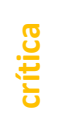 } & análise urbana & \multirow{2}{*}{ tudo! } & livro objeto \\
\hline & $\mathrm{VI}$ & & arte urbana & & projeto de intervenção urbana \\
\hline
\end{tabular}

FIG. 102. Quadro desenvolvido pelos professores da Sequência de Plástica em 2017.

${ }^{116}$ Carta de Vilanova Artigas a Oswaldo Corrêa Gonçalves, escrita em resposta ao amigo em 27 de dezembro de 1946, na cidade de Nova York. Arquivo Biblioteca da FAUS. 
Para finalizar este capítulo, no que se refere aos aspectos políticos e ideológicos, a FAUS enfrentou três grandes crises, em 1972, 1982 e em 2000, e foi capaz de superar todas elas conquistando e reconquistando a confiança de alunos, professores, funcionários e mantenedora. Indo além, a FAUS adquiriu espaço e reconhecimento junto à comunidade ao contribuir com pesquisas e projetos no campo da arquitetura e do urbanismo para a cidade de Santos e para as demais cidades da Baixada Santista. O papel dos estudantes desse período na busca por melhores condições de ensino e liberdade de expressão deve ser destacado, pois aliados aos professores e através de suas reivindicações, a instituição reconheceu a importância dos núcleos de pesquisa e, após a instalação do Centro de Assessoramento, Pesquisa e Documentação de Arquitetura e Urbanismo da FAUS de 1972 e do HABITAFAUS em 1984, seguiram as propostas para o Centro de Pesquisa e Extensão da Faculdade de Arquitetura e Urbanismo de Santos (CEMPEX/FAUS) e do Núcleo de Pesquisa e Documentação Arquitetônica e Ambiental da Baixada Santista, este último idealizado pelo professor Euler Sandeville.

Inexoravelmente, os problemas de ordem política em uma escola se refletem diretamente nas estratégias e metodologias de ensino e, consequentemente, nos lugares em que se processam. Ao longo dos últimos cinquenta anos o processo de fragmentação das matrizes curriculares proposto pelo Ministério da Educação e Cultura com o estabelecimento de currículos mínimos, atrelados a uma visão empresarial das universidades a partir das políticas educacionais desde 1968, vem reduzindo a capacidade de articulação política e pedagógica dos quadros docentes e discentes com consequente perda de identidade dos cursos e formação de novas escolas com perfil genérico.

No caso da FAUS, essa fragmentação curricular em atendimento às novas demandas e o estabelecimento de pequenas instâncias de poder materializadas no controle disciplinar resultaram em uma demasiada compartimentação dos espaços abertos da escola com claro prejuízo e perda de oportunidades de experimentação de outras pedagogias para a educação do arquiteto. Por outro lado, a formação do seu próprio quadro docente demonstra o amadurecimento político e pedagógico da escola conquistado ao longo do tempo através das diversas alianças firmadas entre arquitetos, instituições e, principalmente, com os estudantes.

É possível dizer que a opção feita em seus anos iniciais pelo projeto como forma de emancipação é potencializada pela tese do professor Minoru Naruto de que, antes de tudo, é possível reconhecer o "ensino de arquitetura como ensino de projeto". ${ }^{117}$ Projeto - aqui considerado como a principal atividade do arquiteto - entendido como a síntese da investigação e análise de uma determinada ideia, cuja construção-materialização contém, implicitamente, o conhecimento adquirido no decurso de sua invenção. Essa complexa forma de trabalho demonstra que arquitetura se aprende fazendo,

${ }^{117}$ NARUTO, Minoro. Op. cit. pp. 89.90. (grifo nosso). 
uma operação que compreende algo através do próprio exercício deste algo, ${ }^{118}$ e requer abordagens específicas a fim de determinar instrumentos didáticos que auxiliem o seu ensino.

Nesse sentido, pode-se dizer que o atelier da FAUS tem funcionando como um legítimo condensador e processador de dados da cidade conhecimento que recebe continuamente, processa todas as informações e as devolve na forma de pesquisas, planos e projetos de intervenção nas diversas escalas possíveis, desde a superfície do papel, do objeto, do edifício, da cidade e do território.

Logo, tanto no âmbito da prática profissional quanto no âmbito da investigação acadêmica, a Arquitetônica resulta de ações coletivas que, segundo Margotto, "movidas pelo desejo e governadas por conceitos subjetivos", são materializadas através de sucessivas representações e que, ao transitarem entre valores éticos, estéticos e artísticos, permitem que uma ideia alcance maior definição, transforma o que antes era opaco em transparente, concretiza algo que estava no pensamento em algo que possa ser copiado na realidade. Em outras palavras, inventa algo que antes não existia e o comunica através de uma linguagem específica, a arquitetônica que, em última análise, deseja apresentar-se como linguagem poética. ${ }^{119}$
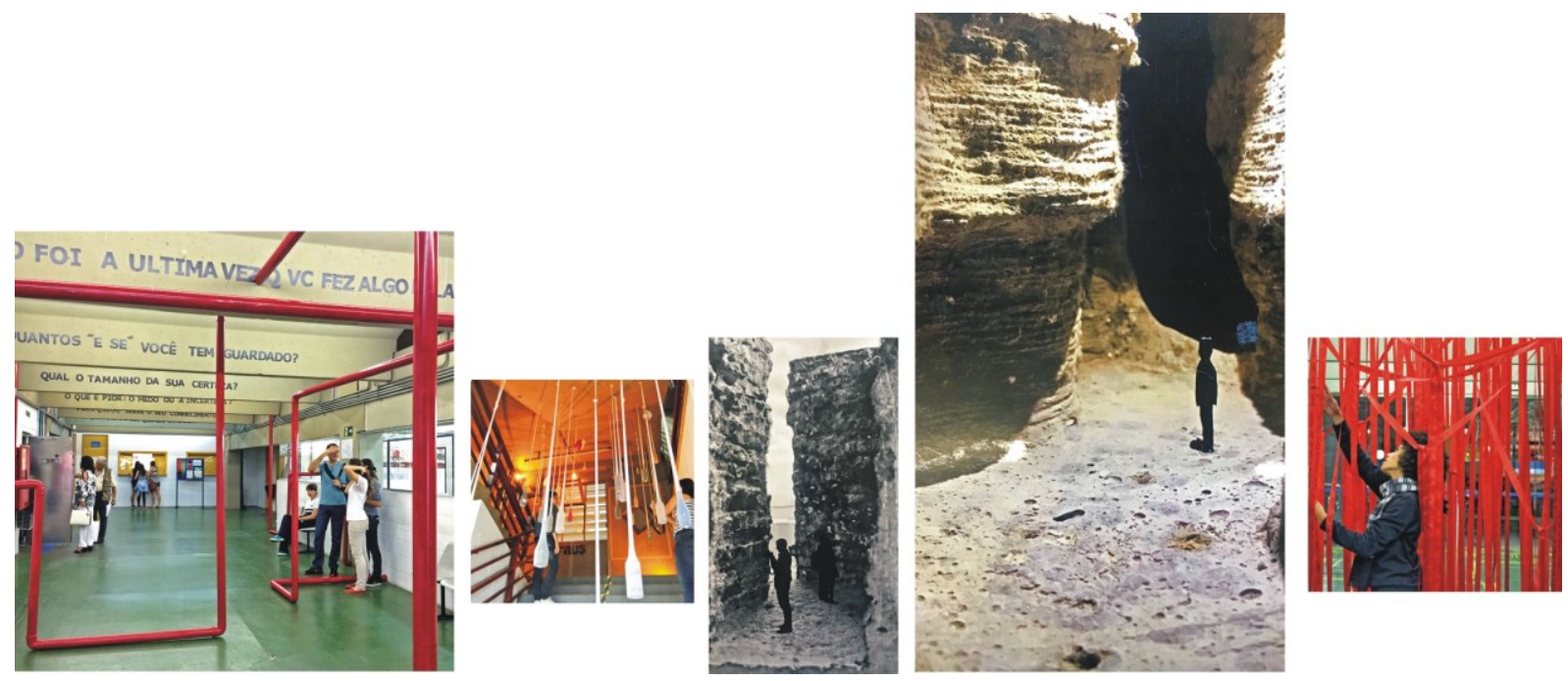

FIG. 103. Atelier FAUS, trabalhos de plástica VI, ao lado trabalho projeto de arquitetura II: Subtrações.

\footnotetext{
${ }^{118}$ Alfonso Corona Martinez, através de sua experiência didática em Buenos Aires, buscou sistematizar o ato de projetar para, a partir de uma análise minuciosa desde a concepção, do processo de elaboração e materialização de um determinado objeto, criar subsídios estruturantes para novas metodologias de ensino do projeto. Segundo o professor, a prática do projeto é a máquina de sua própria resolução e compreensão. Nesse sentido "o decisivo, então, não é possuir conhecimentos, mas sim exercitá-los e exibi-los implicitamente nos resultados. Supõe-se que o exercício desenho realizado está respaldado pelos conhecimentos sobre a arquitetura e sobre o desenhar, mas não de forma explicita". MARTINEZ, Alfonso C. Ensaio sobre projeto. Brasília: Editora UNB, 2000. p. 55.

${ }^{119}$ Austeridade, Generosidade, Liberdade, Público e Espacialidade configuram lições da arquitetura que, para o professor Luciano Margotto, são apreendidas como poética. MARGOTTO, Luciano. Lições da arquitetura: leituras a partir de poéticas. 246 p. Tese (Doutorado em arquitetura e urbanismo) - Faculdade de Arquitetura e Urbanismo da Universidade de São Paulo. São Paulo, 2016.
} 
Princípios de cartografia e decalcomania, um rizoma não pode ser justificado por nenhum modelo estrutural ou gerativo. Ele é estranho a qualquer ideia de eixo genético ou de estrutura profunda [...] que são, antes de tudo, princípios de decalque, reprodutíveis ao infinito [...] diferente é o rizoma, mapa e não decalque. [...] O mapa não reproduz um inconsciente fechado sobre ele mesmo, ele o constrói. ${ }^{1}$

O caráter empírico e propositivo deste capítulo impõe que se recorra a um gênero textual próximo ao de um ensaio, cuja natureza oferece maior liberdade para a observação e experimentação, tanto do pensamento como do projeto.

A revisão das pedagogias da Bauhaus e dos VKhUTEMAS configurou um importante ponto de apoio para delinear o período que antecedeu a fundação da FAUS, além de influenciarem na constituição, autonomia e consolidação da profissão de arquiteto e urbanista no Brasil, orientou as reformas do ensino sistematizadas pela FAU-USP que posicionou o projeto como cerne das atividades do arquiteto e o atelier como condensador das atividades da escola. A partir dessas ações, a FAU-USP forjou novos vetores, seguimentos e ramificações, expandindo e alinhando o ensino da arquitetura em São Paulo às discussões nacionais e internacionais daquele momento.

\footnotetext{
${ }^{1}$ DELEUZE, Gilles; GUATTARI, Félix. Mil platôs, capitalismo e esquizofrenia. Vol. 01. São Paulo: Editora 34, 1995. pp.21-22. (grifo nosso).
} 
Assim sendo, o projeto para a Faculdade de Arquitetura e Urbanismo de Santos, resultou das alianças políticas, ideológicas e pedagógicas firmadas pelo arquiteto Oswaldo Corrêa Gonçalves, sobretudo com docentes da FAU-USP e que, partir de sua fundação em 1970, revelou a Baixada Santista como um importante laboratório de investigação para seus estudantes além de um fértil campo de atuação para os arquitetos por ela formados.

Com efeito, a cidade de Santos, por abrigar o maior porto da América Latina, confere à Região Metropolitana da Baixada Santista papel estratégico na economia nacional, estadual e internacional, firmando-se como município sede da região. Tendo isso em vista, interessa saber, ainda que panoramicamente, qual a relevância da FAUS para as cidades da Baixada no âmbito acadêmico e profissional. Acredita-se que, ao investigar as prováveis contribuições da escola, surjam vestígios, elementos e subsídios que auxiliem na identificação de suas deficiências, virtudes e vocações, tornando possível contribuir na orientação do Projeto FAUS para a produção da arquitetura e do urbanismo contemporâneos. 
No início da FAUS o que se podia fazer com a cidade era descobri-la, foi um processo de reconhecimento da cidade, para os professores inclusive, ninguém sabia o que era Santos, então fomos estudar, investigar o que isso podia influenciar no curso. Nesse sentido, com a preocupação de entender a cidade, qualquer exercício de projeto e de urbanismo era feito levando em consideração a cidade de Santos e região. Portanto, acredito que a cidade tem essa possibilidade de moldar o perfil da escola, acho que com o tempo começa a ocorrer isso, no momento que começa a formar mais gente. ${ }^{1}$

O professor Orpheu Zamboni, reconhecendo a riqueza geográfica e urbana da cidade de Santos como elemento facilitador para se pensar a arquitetura, afirmou que, nos primeiros anos de atividade da FAUS, o modo de ler a cidade era o modo da FAU-USP, ou seja, "fazer a leitura da cidade, partir da cidade para entender as coisas e vice-versa, pois ao se montar uma escola, são estabelecidas estratégias de ensino a partir das experiências adquiridas, da história, das relações, não começa isso do zero, muito pelo contrário." ${ }^{2}$ Nesse sentido, verificar a contribuição de uma escola de arquitetura para a sociedade não constitui tarefa fácil, pois como visto até aqui, todo o processo de formação do arquiteto está exposto a uma série de variáveis que, além de extrapolar o próprio campo de conhecimento, na maioria das vezes, não podem ser descritas com precisão.

Isto posto, como uma nova entrada para investigação do processo de formação da identidade da FAUS e sua contribuição para o campo profissional e acadêmico, recorre-se mais uma vez ao vigente Projeto Pedagógico de Curso da escola, que posiciona a Região Metropolitana da Baixada Santista como principal objeto de extensão da Universidade Católica de Santos. Conforme o exposto no segundo capítulo, ${ }^{3}$ trata-se de uma das regiões mais antigas do Brasil, desenvolveu-se em sintonia com os principais ciclos econômicos do país, desde a virada do século XIX para o século XX com a economia agroexportadora impulsionada pela produção cafeeira. Posteriormente, na segunda metade do século XX, o avanço da industrialização potencializou a economia urbano-industrial, tendo como desdobramento o crescimento e a expansão das cidades de Santos e região.

Recentemente, um novo ciclo de desenvolvimento econômico teve início, baseado na especulação dos possíveis investimentos para a exploração da reserva de petróleo e de gás natural encontrada em águas profundas na Bacia de Santos. No âmbito industrial, esse fenômeno iniciou um processo de expansão do Porto de Santos, movido pela privatização e concessão de terminais de transbordo de carga e áreas para as operações retroportuárias, visando atrair mais investimentos com aumento da competitividade e a redução dos custos logísticos. Atualmente, o complexo portuário de Santos

\footnotetext{
${ }^{1}$ ZAMBONI, Orpheu. Entrevista com Orpheu Zamboni. São Paulo, 06 jun. 2016. Entrevista a José Maria de Macedo Filho.

2 Ibid.

${ }^{3}$ Cf. capitulo 2 Dobra, item 2.1. Alianças estruturantes: a fundação da FAUS.
} 
responde por quase um terço do comércio exterior do país, o que lhe garante, dentre os 34 portos marítimos nacionais, o título de principal porto concentrador e distribuidor do Brasil.

Nesse sentido, é seguro dizer que as ligações com o planalto têm papel determinante no desenvolvimento do estado de São Paulo e, segundo o professor Pedro Sales, esses ciclos de desenvolvimento estiveram associados aos vários estágios de implantação de infraestruturas de mobilidade portuária, ferroviária e rodoviária para escoar a produção agrícola e industrial do interior e estabelecer rotas comerciais com o mundo, além de atender à crescente demanda do tráfego turístico demandado pela crescente facilidade de acesso ao mar. ${ }^{4}$ Nesse aspecto, a indústria do turismo na Região Metropolitana da Baixada Santista atende, fundamentalmente, à demanda da Grande São Paulo e do interior do estado, fortalecendo a economia regional juntamente com o setor de serviços, comércio e mercado imobiliário.
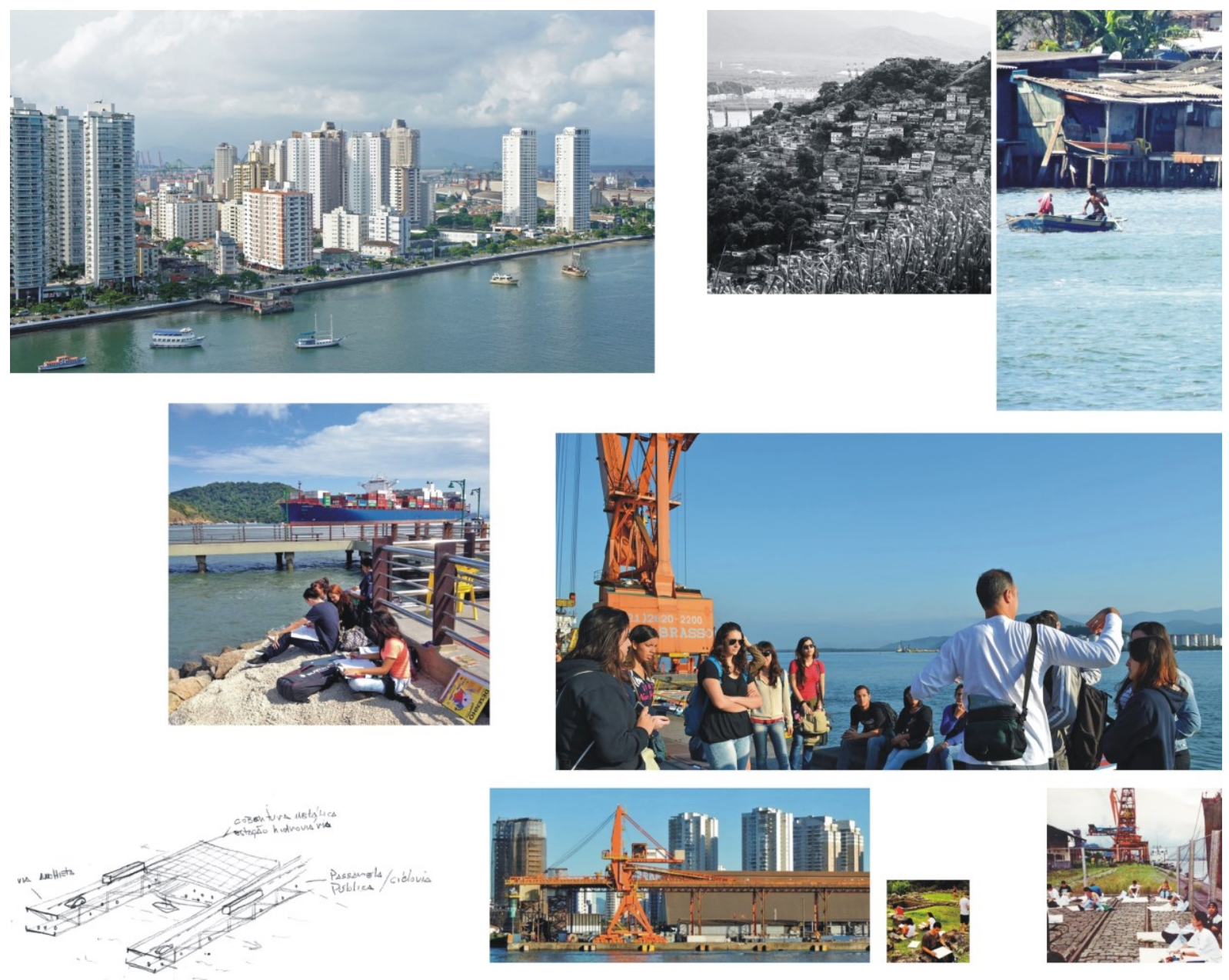

FIG. 104. Percorrer e reconhecer a cidade.

\footnotetext{
${ }^{4}$ RIVABEN DE SALES, Pedro M. Santos: a relação entre o porto e a cidade e sua (re)valorização no território macrometropolitano de São Paulo. 1999. 285p. Tese (Doutorado em arquitetura e urbanismo) - Faculdade de Arquitetura e Urbanismo da Universidade de São Paulo. São Paulo, 1999. p. 81.
} 
Com efeito, no contexto do Plano de Ação da Macrometrópole (PAM), o Governo do Estado propôs a elaboração de um Plano Metropolitano de Desenvolvimento Estratégico da Baixada Santista (PMDEBS), concluído em 2014, que foi apresentado aos municípios da região pela Agência Metropolitana da Baixada Santista (AGEM). ${ }^{5}$ O plano tem como objetivos, além da integração do planejamento metropolitano com visão de totalidade, consolidar o desenvolvimento urbano e fomentar o desenvolvimento econômico potencializando quatro eixos estruturantes: mobilidade urbana, saneamento, habitação e desenvolvimento econômico.

No que diz respeito à escala da cidade, o histórico mecanismo de especulação imobiliária teve como reflexo o acirramento do processo de valorização territorial, materializado na verticalização das áreas junto à orla da praia das principais cidades litorâneas da região e no fenômeno de segregação social do espaço urbano. ${ }^{6}$ As populações de baixa renda, diante da extrema valorização dos terrenos e imóveis junto ao mar, passaram a ocupar progressivamente regiões mais afastadas e periféricas, geralmente junto aos núcleos originais de suas cidades, centros comerciais e industriais obsoletos ou em áreas de mananciais e reservas ambientais.
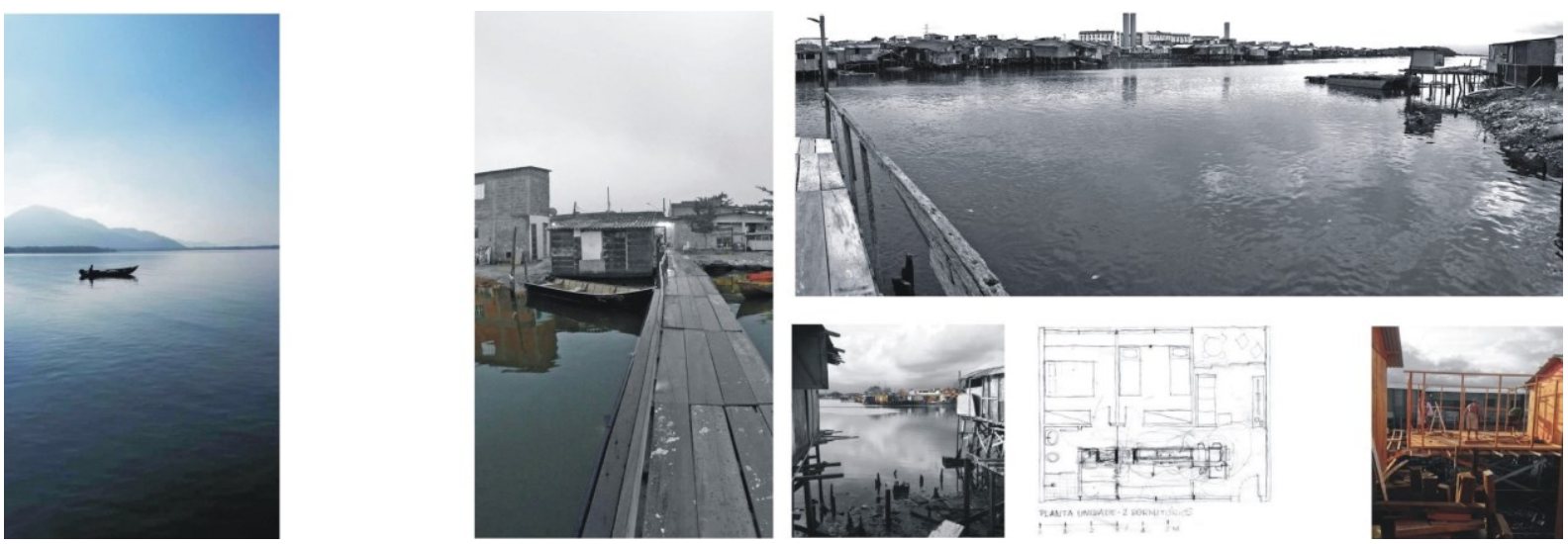

FIG. 105. Dique da Vila Gilda, 2017/2018.

Santos tem um papel ainda mais relevante nesse sistema que, por deter maior poder econômico devido às atividades portuárias, industriais, da construção civil e do turismo, foi capaz de gerar maior quantidade de postos de trabalho, transformando-se em um polo atrativo de investimento e, ao

\footnotetext{
${ }^{5}$ É o mais recente plano entregue pela Agência Metropolitana da Baixada Santista, em maio de 2014. Desenvolvido por uma consultoria especializada e realizado com recursos da Secretaria de Desenvolvimento Econômico, Ciência, Tecnologia e Inovação do governo do Estado de São Paulo, o estudo ordena o crescimento da Baixada Santista para os próximos dezesseis anos (2030) nos eixos de Mobilidade e Acessos, Habitação, Saneamento e Desenvolvimento Econômico. O Plano Metropolitano de Desenvolvimento Estratégico da Baixada Santista (PMDE-BS) consolida políticas municipais, estaduais e federais de desenvolvimento de longo prazo para Bertioga, Cubatão, Guarujá, Itanhaém, Mongaguá, Peruíbe, Praia Grande, Santos e São Vicente. Ver AGÊNCIA METROPOLITANA DA BAIXADA SANTISTA AGEM. Plano Metropolitano de Desenvolvimento Estratégico da Baixada Santista (PMDE-BS) 2014-2030. Santos: Geo Brasilis, 2014. p. 14.

${ }^{6}$ Em sua pesquisa baseada no pensamento de Flavio Villaça e outros teóricos do planejamento urbano e regional, Carriço demonstra como os processos de ocupação das cidades da Baixada Santista, ao longo do século XX, foram fortemente pautados pela ação da especulação imobiliária com a criação de monopólios e reservas de áreas valorizadas para as classes mais abastadas. CARRIÇO, José Marques. Legislação urbanística e segregação espacial nos municípios centrais da região metropolitana da Baixada Santista. Dissertação (mestrado em arquitetura e urbanismo) - Faculdade de Arquitetura e Urbanismo da Universidade de São Paulo. São Paulo, 2002. pp. 57-58.
} 
mesmo tempo, relegando as demais cidades da região à categoria de cidades dormitórios, com atividade econômica voltada praticamente para o turismo local. Em decorrência disso, alguns municípios da RMBS investiram na reformulação de suas legislações de uso e ocupação do solo e seus planos diretores, com atenção especial para os conflitos sócio espaciais, propondo instrumentos reguladores que visam o desenvolvimento econômico consciente dos problemas relacionados à conservação ambiental e à sustentabilidade. ${ }^{7}$

\begin{abstract}
[...] a ocupação do litoral paulista e, especificamente, da Baixada Santista, também se associa à implementação e ao desenvolvimento de atividades industriais, portuárias e logísticas, com impactos no crescimento urbano e no aumento da demanda de água, energia, habitação, saneamento e serviços públicos. Tais impactos tendem a se acentuar ao longo das próximas décadas, em face das novas configurações produtivas que emergem da descoberta e exploração da camada do pré-sal e da expansão e modernização do Porto de Santos. Em outros termos, se por um lado o desenvolvimento de forças produtivas alavancou o desenvolvimento econômico na zona costeira, por outro implicou em impactos sociais e ambientais significativos nessa região. Nesse sentido, a Baixada Santista representa um grande desafio à gestão ambiental do Estado de São Paulo, que tem no Plano Estadual de Gerenciamento Costeiro (PEGC) um importante instrumento de gestão desse território. ${ }^{8}$
\end{abstract}

Nesse ponto, vale lembrar que a década de 1980 expôs de maneira contundente a problemática ambiental da Região da Baixada Santista através da degradação dos ecossistemas de manguezais e da mata atlântica, provocada pelo parque industrial da cidade de Cubatão devido aos impressionantes índices de poluição, comprometendo mananciais subterrâneos, aquíferos e a qualidade do ar. A cidade ficou conhecida mundialmente como "Vale da Morte", entretanto, a extensão desses danos não se resumiu à área do município, mas atingiu diretamente outras cidades como São Vicente, Santos e Guarujá. Em decorrência, foram criadas legislações ambientais específicas e programas de controle da poluição industrial, por meio da Companhia Ambiental do Estado de São Paulo (CETESB).

Atualmente a RMBS é a terceira maior região do estado em termos populacionais, com mais de um 1,7 milhão de habitantes. Santos é a décima maior cidade do estado de São Paulo, com população estimada de 433.311 habitantes ${ }^{9}$ chegou a ostentar o quinto lugar no ranking de qualidade de vida dos municípios brasileiros, conforme Índice de Desenvolvimento Humano (IDH) aferido pela Organização das Nações Unidas (ONU) com base nos níveis de expectativa de vida, educação e PIB per capita. ${ }^{10}$ Além disso, dados da Fundação Sistema Nacional de Análise de Dados (Fundação Seade)

\footnotetext{
${ }^{7}$ UNIVERSIDADE CATÓLICA DE SANTOS. Projeto Pedagógico de Curso - Arquitetura e Urbanismo. pp. 7-15 e passim. Disponível em: <http://www.unisantos.br/wp-content/uploads/2016/12/PPC_Arq-e-Urb_2017-a-2021-9-de-dezembro.pdf>. Acesso em: 14 jul. 2019.

${ }^{8}$ SÃO PAULO (Estado). Secretaria do Meio Ambiente. ZEE Baixada Santista [recurso eletrônico]: zoneamento ecológico-econômico - setor costeiro da Baixada Santista / Secretaria do Meio Ambiente do Estado de São Paulo, Coordenadoria de Planejamento Ambiental. São Paulo: SMA, 2013. (Organização Luiz Roberto Numa de Oliveira). Apud. UNIVERSIDADE CATÓLICA DE SANTOS. Projeto Pedagógico de Curso Arquitetura e Urbanismo. Ibid. p. 10.

${ }^{9}$ Instituto Brasileiro de Geografia e Estatística IBGE. Diretoria de Pesquisas - DPE - Coordenação de População e Indicadores Sociais - COPIS. Disponível em: <http://www.cidades.ibge.gov.br/xtras/perfil.php?lang=\&codmun=354850>. Acesso em: 12 set. 2019.

${ }^{10}$ Existe uma certa distorção na composição e leitura desses índices, pois os municípios vizinhos da cidade de Santos cumprem o papel de periferia, são cidades dormitório, dependentes e que detêm as populações menos assistidas, concentrando os menores índices de IDH. 
apontam que Santos está entre as vinte cidades mais ricas do país. Em síntese, pode-se afirmar que os ciclos de desenvolvimento mais recentes confirmam que a função portuária e a relação entre o homem e o mar, além de marco da identidade regional, são os principais responsáveis pela geração de empregos e renda estabelecendo as condições para um contínuo processo de desenvolvimento econômico. Essas considerações são relevantes, pois sinalizam que todo estudo sobre o desenvolvimento regional deve reconhecer as condições socioambientais e urbanas dos municípios e da região que, por sua vez, são diretamente afetadas pela dinâmica do complexo portuário. Em outras palavras, as relações entre os processos urbanos que envolvem os nove municípios da Região Metropolitana da Baixada Santista ultrapassam os interesses das cidades e, portanto, devem ser tratados de forma integrada.

Isto posto, retornando ao universo acadêmico e no âmbito deste trabalho, o instrumento didático que apresenta condições mais favoráveis para críticas, reflexões e proposições para problemas dessa natureza é o Trabalho de Curso (TC). ${ }^{11}$ Vilanova Artigas, ao destacar o valor do projeto de final de carreira na formação do arquiteto, juntamente com sua capacidade de contribuir, por extensão, com a cidade através de propostas e pesquisas no campo da arquitetura e do urbanismo, revela que suas convicções estavam condensadas no pensamento de Oswaldo Corrêa Gonçalves, quando este afirmava que "o laboratório da FAUS era a cidade".

\begin{abstract}
O aluno do quinto ano da FAU hoje, a partir do projeto de 1962, faz uma tese sobre qualquer assunto que foi ensinado dentro da Faculdade de Arquitetura. E sai educado para ser um homem capaz de defender seu projeto, seja o edifício, a paisagem ou a história de um bairro, por exemplo. Estuda as casas remanescentes, a sociedade que retalhou aquele bairro; quais as intenções plásticas que existiam; como cresceu; quais as avenidas que passavam por ali e como elas deformaram ou consolidaram o bairro. Com essas teses, esses estudos peculiares vão fornecendo à cidade de São Paulo o diagnóstico das cicatrizes, os ferimentos, as modificações e o uso do espaço pela sociedade capitalista que nós conhecemos. ${ }^{12}$
\end{abstract}

Amparado nessa constatação, arrisca-se dizer que uma verificação, ainda que panorâmica do conjunto dos Trabalhos de Curso desenvolvidos pelos alunos da FAUS, pode ajudar na verificação da coerência dos objetivos descritos no Projeto Pedagógico de Curso da escola, especificamente, no que diz respeito ao perfil do arquiteto por ela formado, e a sua contribuição para as cidades da Região Metropolitana da Baixada Santista. Atualmente na FAUS, não muito diferente de outras instituições, e atendendo às diretrizes do Ministério da Educação e Cultura (MEC) e à legislação do Conselho de

\footnotetext{
11 Toda vez que o trabalho de final de curso de graduação em arquitetura e urbanismo for citado, independente da data, contexto ou instituição, com o objetivo de facilitar o entendimento do que se propõe argumentar, será adotado o termo atual para este componente curricular: Trabalho de Curso (TC), ou seja, TC é o mesmo que Trabalho de Graduação Interdisciplinar (TGI), Trabalho Final de Graduação (TFG) e Trabalho de Conclusão de Curso (TCC).

12 Testemunho de Vilanova Artigas realizado no Rio Grande do Sul, em 1981. "Nesta parte ele resume o significado do trabalho final de graduação no contexto da formação ampla e humanista pensada na Reforma de 1962. Fala sobre a questão do vestibular, da escolha dos estudantes a partir da capacidade de expressar o mundo por meio do desenho". FORTI, Marco Artigas. FAUUSP - 50 anos da Reforma de 1962. Disponível em <http://www.dearquiteturas.com>. Acesso em: 11 nov. 2015. Sobre a origem do TGI ver MALACRIDA, Sergio Augusto. Trabalho de Graduação Interdisciplinar (TGI): origens e problematização da proposta implantada em 1971 na Faculdade de Arquitetura e Urbanismo da Universidade de São Paulo (FAU/USP). 2005. 166 f. Dissertação (Mestrado em Fundamentos da Educação) - Centro de Educação em Ciências Humanas, Universidade Federal de São Carlos, São Carlos, 2005.
} 
Arquitetos e Urbanistas (CAU), o aluno desenvolve o Trabalho de Curso individualmente ao longo de um ano, dividido em dois semestres e orientado por um professor pertencente ao corpo docente da escola. Representa o momento no qual o estudante identifica, problematiza e propõe intervenções na cidade, devendo ser entendido como experimento de integração disciplinar e síntese do conhecimento teórico e prático apreendido ao longo do curso.

Com temática de livre escolha no âmbito geral das questões tratadas pelo campo da arquitetura e urbanismo, o Trabalho de Curso é uma importante ferramenta para ampliar o domínio específico sobre um determinado tema e desenvolver o espírito investigativo do futuro arquiteto, configurando uma oportunidade para demonstrar sua capacidade de produção e sistematização de conhecimentos por meio de projetos e críticas. Em síntese, o atual Projeto Pedagógico de Curso da FAUS expressa que esse trabalho seja coerente entre objetivos, metodologia, teoria e prática, com redação que demonstre clareza e precisão conduzido como um processo rigoroso, quanto à disciplina intelectual, sem ser desestimulador. ${ }^{13}$
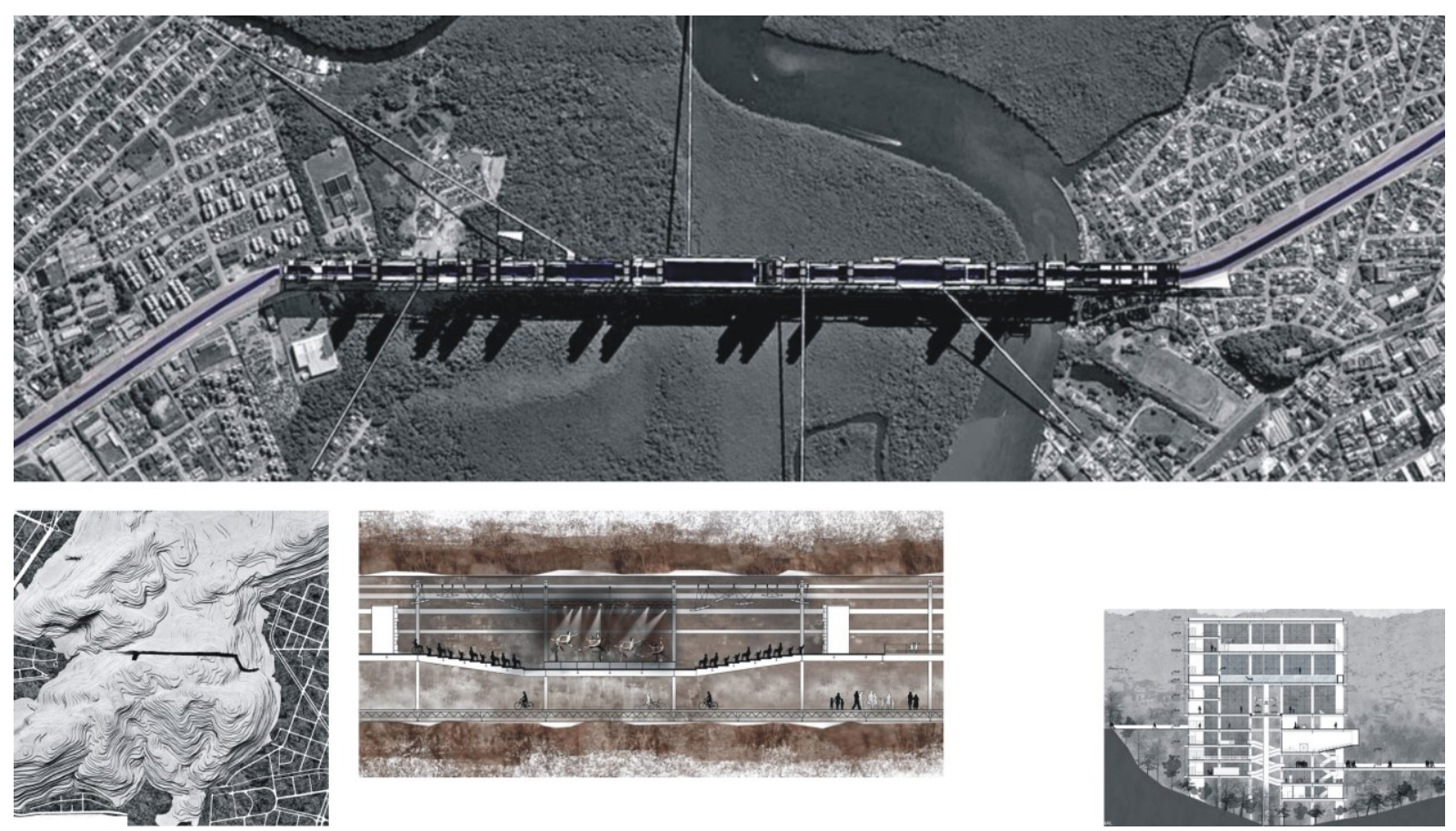

FIG. 106. Eixo fluvial - Mongaguá. Autor Thiago Zati, 2017. Travessia - Ilha de São Vicente. Autora Taynah Spinola, 2014. Entre cidades Morros de Santos. Autor Manoel Ricardo, 2018.

Pois bem, para verificação dos interesses de estudantes e professores no contexto dos trabalhos finais de curso ao longo de quase cinquenta anos de produção da escola, foi elaborado um quadro com uma amostragem dos projetos ordenados por década, permitindo uma observação sistematizada de dados relativos à escolha do lugar, escala, eixos disciplinares, programas e temas.

\footnotetext{
${ }^{13}$ Ver regimento do Trabalho de Curso da FAUS em UNIVERSIDADE CATÓLICA DE SANTOS. Projeto Pedagógico de Curso - Arquitetura e Urbanismo. Op. cit. pp. 145-146.
} 
Esta pesquisa foi feita a partir da leitura do livro de registros dos Trabalhos de Curso da FAUS, feitos à mão de 1974 até $1993,{ }^{14}$ e dessa data até 2017 foi utilizada a plataforma digital Pergamum, ${ }^{15}$ responsável pela catalogação de todos os itens disponíveis nas bibliotecas da Universidade Católica de Santos.

A organização metodológica segue apenas critérios de natureza quantitativa, ou seja, a classificação dos dados relativos a: lugar, eixo disciplinar e tema foi feita de acordo com sua frequência de aparição nos documentos pesquisados. Da mesma maneira, os programas com pouquíssima ocorrência, como por exemplo, cemitérios, crematórios, igrejas, capelas, presídios, manicômios, paços municipais, pontes, carros, barcos, submarino e estações espaciais, foram agrupados na coluna: outros assuntos. Os dados relativos à escala foram eleitos deliberadamente devido ao amplo leque de possibilidades temáticas e formas de atuação do arquiteto, e são representados no quadro pelos conceitos Superfície, Objeto, Edifício, Cidade e Território. Esses conceitos compreendem as escalas, desde a folha de papel com trabalhos teóricos, comunicação visual, design gráfico, objetos como utensílios domésticos, mobiliário, edifícios, cidades até intervenções de aporte metropolitano e regional.

Conforme mencionado, as estratégias de ensino da arquitetura dependem de variáveis que, em linhas gerais, não apresentam contornos claros e precisos, com efeito, o quadro de amostragem resultante permite diversos modos de leitura e frentes de investigação. Nesse sentido, a eleição de temas para o trabalho final pode estar relacionada a muitos fatores, como por exemplo, o estudo de problemas vistos em qualquer etapa ou disciplina da grade curricular, amadurecidos ao longo do percurso acadêmico do estudante; pode ocorrer a partir do desejo individual de aprofundamento de algum assunto apresentado e pouco desenvolvido no curso; na continuidade de trabalhos de iniciação científica, pode tratar-se de investigações bibliográficas acerca da história da arquitetura, pela mídia especializada impressa e digital. Não se descartando, portanto, os riscos de que esses trabalhos sejam influenciados por arquiteturas excepcionais, reproduzindo padrões formais universalizantes. ${ }^{16}$

Julgou-se que a leitura mais apropriada ao tempo disponível para sua elaboração é aquela que parte do cruzamento entre informações históricas, econômicas, políticas e sociais ocorridas nos últimos cinquenta anos. Acredita-se que o resultado desse amálgama possa gerar subsídios indicadores do quanto os distintos ciclos de desenvolvimento do país e da região influenciaram na formação dos

\footnotetext{
14 Trata-se do documento: TGI - Relação Nominal e Temática - FAU/Santos: 1974 a 1993. 91p. mimeo.

${ }^{15}$ Disponível em: <http://biblioteca.unisantos.br/pergamum/biblioteca/index.php?resolution2=1024_1\&tipo_pesquisa=>.

${ }^{16}$ Para uma análise mais detida sobre esses aspectos dos Trabalhos de Curso, ver o texto "Condições de excelência arquitetônica e urbanística" in ARCIPRESTE, C. M. Entre o discurso e o fazer arquitetônico: reflexões sobre o ensino de arquitetura e urbanismo e seus referenciais a partir do trabalho final de graduação. Op. cit. pp. 227-238.
} 
arquitetos da FAUS. Seguindo por esse caminho, a definição temática do trabalho final de curso de um estudante em vias de se formar, além do interesse individual de cada um, expressa que o fator contextual pode refletir quais foram, quais são e quiçá quais poderiam ser, as formas de atuação profissional no campo da arquitetura e do urbanismo.

\section{AMOSTRAGEM DOS TRABALHOS DE CURSO DA FAUS}

\begin{tabular}{|c|c|c|c|c|c|c|c|c|c|c|c|c|c|c|c|c|c|c|}
\hline \multirow[b]{2}{*}{ 志 } & \multirow[b]{2}{*}{ 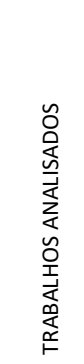 } & \multicolumn{6}{|c|}{ LUGAR } & \multicolumn{5}{|c|}{ ESCALA } & \multicolumn{6}{|c|}{ EIXO DISCIPLINAR } \\
\hline & & 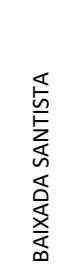 & 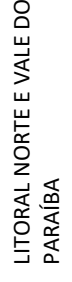 & 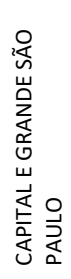 & 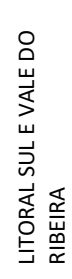 & 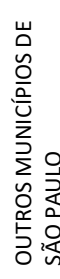 & 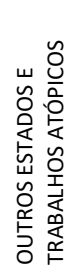 & 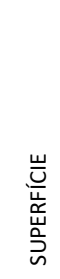 & $\begin{array}{l}\text { 을 } \\
\text { 。๊ }\end{array}$ & $\frac{\frac{O}{U}}{\frac{\underline{u}}{u}}$ & $\begin{array}{l}\text { 岩 } \\
\text { Oิ }\end{array}$ & 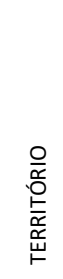 & 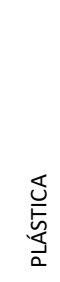 & $\begin{array}{l}\text { 음 } \\
\text { 잉 }\end{array}$ & 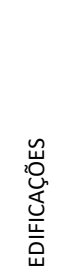 & 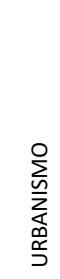 & 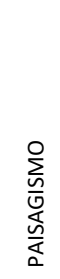 & 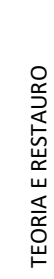 \\
\hline \multirow{2}{*}{1970} & 298 & 123 & 32 & 48 & 13 & 22 & 60 & 23 & 9 & 119 & 103 & 44 & 8 & 9 & 119 & 103 & 41 & 18 \\
\hline & $\%$ & 41.3 & 10.7 & 16.1 & 4.4 & 7.4 & 20.1 & 7.7 & 3 & 39.9 & 34.6 & 14.8 & 2.6 & 3 & 39.9 & 34.6 & 13.7 & 6.1 \\
\hline \multirow{2}{*}{1980} & 362 & 185 & 13 & 58 & 9 & 30 & 57 & 39 & 22 & 172 & 109 & 20 & 35 & 22 & 152 & 76 & 40 & 37 \\
\hline & $\%$ & 51.1 & 3.6 & 16.1 & 2.5 & 8.3 & 15.6 & 10.8 & 6.1 & 47.5 & 30.1 & 5.5 & 9.7 & 6.1 & 42 & 21 & 11 & 10.2 \\
\hline \multirow{2}{*}{1990} & 306 & 223 & 10 & 41 & 7 & 21 & 4 & 29 & 9 & 170 & 75 & 23 & 23 & 9 & 154 & 63 & 30 & 32 \\
\hline & $\%$ & 72.9 & 3.3 & 13.4 & 2.3 & 6.7 & 1.3 & 9.5 & 2.9 & 55.5 & 24.5 & 7.5 & 7.5 & 2.9 & 50.3 & 20.6 & 9.8 & 10.5 \\
\hline \multirow{2}{*}{2000} & 202 & 170 & 3 & 10 & 2 & 4 & 3 & 14 & 3 & 91 & 84 & 10 & 12 & 3 & 72 & 53 & 32 & 30 \\
\hline & $\%$ & 84.1 & 1.5 & 4.9 & 1 & 2 & 1.5 & 6.9 & 1.5 & 45 & 41.6 & 4.9 & 5.9 & 1.5 & 23.8 & 26.2 & 15.8 & 14.9 \\
\hline 2010 & 258 & 225 & 2 & 3 & 1 & 1 & 4 & 5 & 4 & 166 & 79 & 4 & 3 & 4 & 153 & 51 & 29 & 18 \\
\hline 2017 & $\%$ & 87.2 & 0.8 & 1.2 & 0.4 & 0.4 & 1.5 & 1.9 & 1.5 & 64.3 & 30.6 & 1.5 & 1.2 & 1.5 & 59.3 & 19.8 & 11.2 & 7 \\
\hline \multirow{2}{*}{ TOTAL } & 1.064 & 926 & 60 & 160 & 32 & 78 & 128 & 110 & 47 & 718 & 450 & 101 & 81 & 47 & 650 & 346 & 172 & 135 \\
\hline & $\%$ & 87.0 & 5.6 & 15.0 & 3.0 & 7.3 & 12.0 & 10.3 & 4.4 & 67.4 & 42.3 & 9.5 & 7.6 & 4.4 & 61.1 & 32.5 & 16.2 & 12.7 \\
\hline \multirow[b]{2}{*}{ 亳 } & \multirow[b]{2}{*}{ 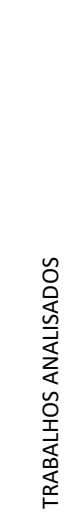 } & \multicolumn{17}{|c|}{ PROGRAMAS - ASSUNTOS - TEMAS } \\
\hline & & 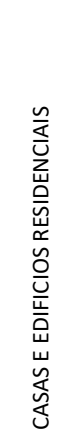 & 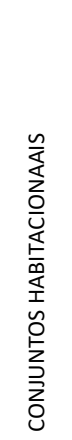 & 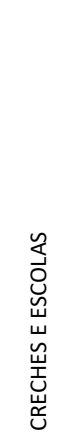 & 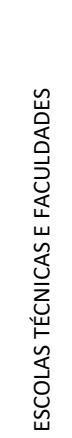 & 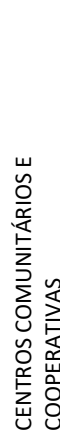 & 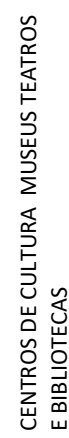 & 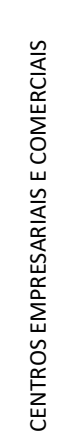 & 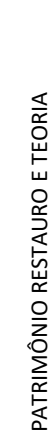 & 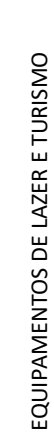 & 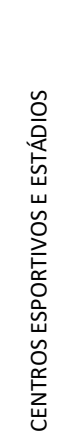 & 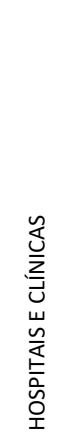 & 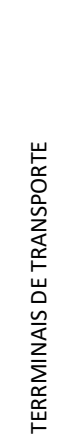 & 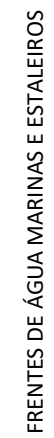 & 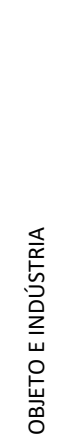 & 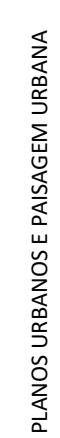 & 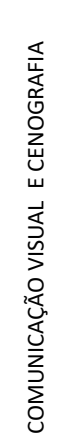 & 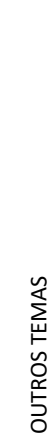 \\
\hline \multirow{2}{*}{1970} & 298 & 6 & 17 & 13 & 1 & 12 & 16 & 0 & 28 & 18 & 0 & 19 & 17 & 6 & 9 & 86 & 26 & 24 \\
\hline & $\%$ & 2 & 5.7 & 4.4 & 0.3 & 4 & 5.4 & 0 & 9.4 & 6 & 0 & 6.4 & 5.7 & 2 & 3 & 28.9 & 8.7 & 9.3 \\
\hline \multirow{2}{*}{1980} & 362 & 9 & 43 & 29 & 3 & 12 & 20 & 5 & 40 & 25 & 7 & 9 & 29 & 18 & 15 & 58 & 35 & 5 \\
\hline & $\%$ & 2.5 & 11.9 & 8 & 0.8 & 3.3 & 5.5 & 1.2 & 11 & 6.9 & 1.9 & 2.5 & 8 & 5 & 4.1 & 16 & 9.7 & 1.2 \\
\hline \multirow{2}{*}{1990} & 306 & 12 & 20 & 15 & 6 & 12 & 29 & 14 & 30 & 36 & 6 & 17 & 20 & 14 & 10 & 32 & 23 & 10 \\
\hline & $\%$ & 3.9 & 6.5 & 4.9 & 2 & 3.9 & 9.5 & 4.6 & 9.8 & 11.8 & 2 & 5.5 & 6.5 & 4.6 & 3.3 & 10.5 & 7.5 & 3.3 \\
\hline \multirow{2}{*}{2000} & 202 & 2 & 10 & 5 & 8 & 6 & 21 & 2 & 25 & 23 & 8 & 4 & 14 & 28 & 9 & 24 & 10 & 3 \\
\hline & $\%$ & 1 & 9.9 & 2.5 & 4 & 3 & 10.4 & 1 & 12.4 & 11.4 & 4 & 2 & 6.9 & 13.9 & 4.4 & 11.9 & 9.9 & 1.5 \\
\hline 2010 & 258 & 10 & 19 & 5 & 14 & 21 & 49 & 4 & 14 & 16 & 9 & 9 & 18 & 19 & 3 & 29 & 2 & 5 \\
\hline 2017 & $\%$ & 3.9 & 7.4 & 1.9 & 5.4 & 8.1 & 19 & 1.5 & 5.4 & 6.2 & 3.5 & 3.5 & 8.9 & 7.4 & 1.2 & 11.2 & 0.8 & 1.9 \\
\hline \multirow{2}{*}{ TOTAL } & 1.064 & 39 & 109 & 67 & 32 & 63 & 135 & 25 & 137 & 118 & 30 & 58 & 98 & 85 & 43 & 229 & 96 & 47 \\
\hline & $\%$ & 3.7 & 10.2 & 6.3 & 3 & 5.9 & 12.7 & 2.3 & 12.9 & 11.1 & 2.8 & 5.4 & 9.2 & 8 & 4 & 21.5 & 9 & 4.4 \\
\hline
\end{tabular}

TAB. 16. Quadro de amostragem dos Trabalhos de Curso da FAUS. 
Observando o quadro, pode-se dizer que a questão regional esteve presente na maior parte das pesquisas e projetos produzidos na escola em um crescente, desde os anos iniciais até os dias de hoje. Nem mesmo a presença majoritária de estudantes da capital e interior, verificada na década de 1970, foi capaz de mudar esse cenário. A escolha do projeto como instrumento de emancipação social e política na formação dos arquitetos de Santos, feita em 1972, pode ser constatada com a grande ênfase dada às ações projetuais na escala do edifício, seguida pelo planejamento, requalificação e desenvolvimento na escala da cidade e da paisagem.

A curva de variação de interesses sobre determinados programas também merece destaque, nota-se uma crescente preferência por temas relacionados à cultura, turismo e lazer associados às frentes de água, em detrimento de programas de menor envergadura, como creches, escolas infantis, trabalhos na escala do objeto, comunicação visual e cenografia. ${ }^{17} \mathrm{Na}$ mesma direção, é provável que a constante ocorrência de programas relacionados a terminais de transporte de passageiros e cargas esteja atrelada à tese do professor Pedro Sales que associa o desenvolvimento da Baixada com a implantação de infraestruturas de mobilidade portuária, ferroviária e rodoviária de cargas e tráfego turístico.

A visão desenvolvimentista das décadas de 1960 e 1970 pode ser verificada nos primeiros Trabalhos de Curso da FAUS, com pesquisas relacionadas ao planejamento, infraestrutura e indústria na escala do território. A partir de meados dos anos 1980, a abordagem territorial passou a ser feita a partir de planos e projetos de intervenção em assentamentos urbanos informais, na requalificação urbana de áreas centrais e em frentes de água subutilizadas ou obsoletas em processo de degradação. Nesse contexto, é possível verificar um crescente interesse por trabalhos de conservação e intervenção em patrimônio arquitetônico e urbano. Por último, nota-se que o caráter comunitário da Universidade Católica de Santos tem refletido, recentemente, nas decisões dos estudantes em desenvolverem projetos com temas relacionados a centros e cooperativas para comunidades em geral, sendo coerente com os objetivos do projeto institucional da universidade.

Quanto aos seus experimentos metodológicos, operacionais e avaliativos, interessa recuperar algumas experiências praticadas desde os anos 1970 até os anos 2000. Merece destaque a atuação do professor Jorge Caron, que registrou sua experiência na FAUS como professor titular do Departamento de Projeto, coordenador dos Cursos de Extensão Universitária em $1978,{ }^{18}$ e sobretudo como orientador de Trabalhos de Curso, trabalhando por dez anos nesse componente curricular,

\footnotetext{
${ }^{17}$ Os trabalhos relacionados aos eixos disciplinares de plástica e objeto foram prejudicados com a revisão do projeto pedagógico de 2006 , assunto que será abordado adiante.

${ }^{18}$ Conforme mencionado no capítulo anterior, um desses cursos de extensão tinha como objetivo o aprimoramento didático profissional do quadro docente da FAUS, visava o aperfeiçoamento em pedagogia para arquitetos que desejavam ingressar no corpo docente da escola. UNIVERSIDADE CATÓLICA DE SANTOS. Regimento interno do Centro de Assessoramento, Pesquisa e Documentação de Arquitetura e Urbanismo da FAUS. 8p. Santos, 1972.
} 
entre 1978 até 1988, quando deixou a escola. Utilizou essa instância do curso para propor alternativas aos modelos vigentes, iniciando uma discussão muito crítica e atual sobre a metodologia de orientação, os trabalhos em si e seus processos de avaliação. ${ }^{19}$

Há onze anos sou professor na FAUS. Há dez, no TGI. Há nove que me insurgi contra ele, e nessa época não conhecia todas as implicações dessa instituição nacional de "coroamento" dos cursos de arquitetura. Como desmontar, nesta escola, tal prática, se provava uma luta contra moinhos, propus e empreguei diversas metodologias que tentavam aportar certa vida a esse organismo espúrio. Não se trata de descrevê-las aqui, basta saber que, de fato, esses métodos didáticos foram se erodindo pela própria rigidez do sistema FAUS (subsistema pacífico do sistema MEC). ${ }^{20}$

O grande manancial de áreas e reservas naturais protegidas e a importância de ecossistemas litorâneos induziu uma primeira experiência coletiva para desenvolvimento do Trabalho de Curso. Em 1979, diante da dimensão do problema verificado, dez trabalhos abordaram a Serra do Mar como tema único de estudos. Dessa maneira, o grupo de alunos e orientadores envolvidos elaboraram um importante dossiê que, através da coleta de dados, diagnósticos e mapeamentos, foi capaz de reunir documentos dispersos e estruturar diretrizes de preservação para determinadas áreas que ainda não estavam protegidas. Do mesmo modo, em 1980, um grupo de dezoito alunos elegeu como tema os canais de Santos projetados por Saturnino de Brito, coletando dados, diagnosticando as diversas situações de implantação e suas relações entre a água e a cidade.

Nesse sentido, as orientações do professor Caron eram pautadas por discussões coletivas que tratavam de assuntos transversais para a ampliação da cultural geral dos alunos, assim, no primeiro semestre, ele propunha aos estudantes a elaboração de um plano de pesquisa capaz de sustentar o desdobramento das propostas ao longo do segundo semestre. "Durante o semestre $X$, a partir de uma avaliação das propostas reformuladas, seria realizada uma orientação sólida, sobre os trabalhos individuais em clima de discussão conjunta." ${ }^{21}$ Entretanto, esse procedimento de caráter aberto e coletivo encontrava resistência por parte dos estudantes que, conforme o trabalho ganhava complexidade e especificidade, solicitavam mais orientações individualizadas. Segundo o próprio Caron, "muitas vezes esse método foi entendido como [des]orientação." 22

Quanto a isso, interessa destacar que por sua própria estrutura organizacional, o Trabalho de Curso tende a enfatizar trabalhos excepcionais, contrapondo-se a perspectivas pedagógicas expandidas, demonstrando que "a noção do arquiteto-criador reforça e é reforçada por bases meritocráticas e

\footnotetext{
${ }^{19}$ A experiência adquirida na FAUS e a sua visão crítica sobre o Trabalho de Curso repercutiu no curso de Arquitetura e Urbanismo da Escola de Engenharia de São Carlos da Universidade de São Paulo (EESC-USP). Sobre a experiência do professor Jorge Caron na FAUS, na FEBASP e no curso da EESC-USP, ver RUGGIERO, Amanda Saba. Jorge Caron: uma trajetória. 2006. 183p. Dissertação (Mestrado em arquitetura e urbanismo) Escola de Engenharia de São Carlos, Universidade de São Paulo. São Paulo, 2006. pp. 65-76.

${ }^{20}$ CARON, Jorge. FAU-Santos: TGI. Santos: Diretório Acadêmico Michael Lieders, 1986. mimeo. (sic).

${ }^{21}$ Ibid. (sic).

22 Ibid. (sic). 
individualistas que ainda permeiam a formação do arquiteto e urbanista". ${ }^{23}$ Considerando esse alerta de Arcipreste, no contexto do Trabalho de Curso, independentemente de as referências estarem centradas em projetos e obras de arquitetura moderna brasileira ou da arquitetura contemporânea internacional, deve-se estar atento para que os trabalhos não reproduzam automaticamente, sem crítica e/ou reflexão, os padrões hegemônicos amplamente divulgados.

Com efeito, Jorge Caron atribuía ao estudante, ao orientador e à própria instituição a responsabilidade pela dificuldade no entendimento da importância do trabalho coletivo de crítica na construção dos trabalhos individuais. Dos estudantes exigia rigor na pesquisa e clareza na proposta, dos professores solicitava mais questionamento e reflexão sobre o significado da arquitetura. Caron também criticou duramente a forma de avaliação do Trabalho de Curso na FAUS, pois segundo ele, o processo de um ano de elaboração do trabalho, gerava (e ainda gera) uma grande e desnecessária carga emocional devido à expectativa de se produzir uma proposta grandiosa e eloquente criada pela escola, orientador, colegas e pelo próprio estudante.

\footnotetext{
Suponhamos que essa avaliação dure sete horas. Para sete trabalhos. Em uma hora cada estudante reduzirá a dez minutos sua trajetória de um ano, para dar outro tanto a cada um dos avaliadores para dizer a que veio e o que entendeu desse trabalho de um ano. Nessa hora, com uma avaliação completada, ele se torna um profissional e o trabalho vai para as prateleiras de aço da biblioteca. Pronto. Se esse sistema não é perverso, não sei o que é. Se eu fosse estudante, não conseguiria aceitá-lo. ${ }^{24}$
}

Da mesma forma que Jorge Caron, o professor Paulo de Mello Bastos também trazia consigo a experiência das atividades de ensino vivenciadas na FAU-SJC, e era defensor da instalação de um Trabalho de Curso Vertical, ou seja, um trabalho integrado por alunos de diversos semestres da escola e liderados pelo estudante matriculado no último ano. Segundo Paulo Bastos, essa estrutura oferecia oportunidades de aprendizado para todo o grupo, independentemente do nível de conhecimento de cada membro da equipe, ou seja, estudantes ingressantes, intermediários ou veteranos, naturalmente, aprenderiam uns com os outros na elaboração de uma determinada proposta, ao passo que o autor principal do trabalho exerceria a função de coordenador do projeto. Na ocasião da estruturação do Projeto pedagógico da FAUS no ano 2000, o professor Paulo Bastos chegou a desenhar um modelo pedagógico para viabilizar essa proposta, contudo, devido a dificuldades de operacionalização ou falta de interesse acadêmico, esse sistema nunca foi sequer testado.

\footnotetext{
${ }^{23}$ ARCIPRESTE, C. M. Op. cit. p. 226.

${ }^{24}$ Ibid. p. 226.
} 

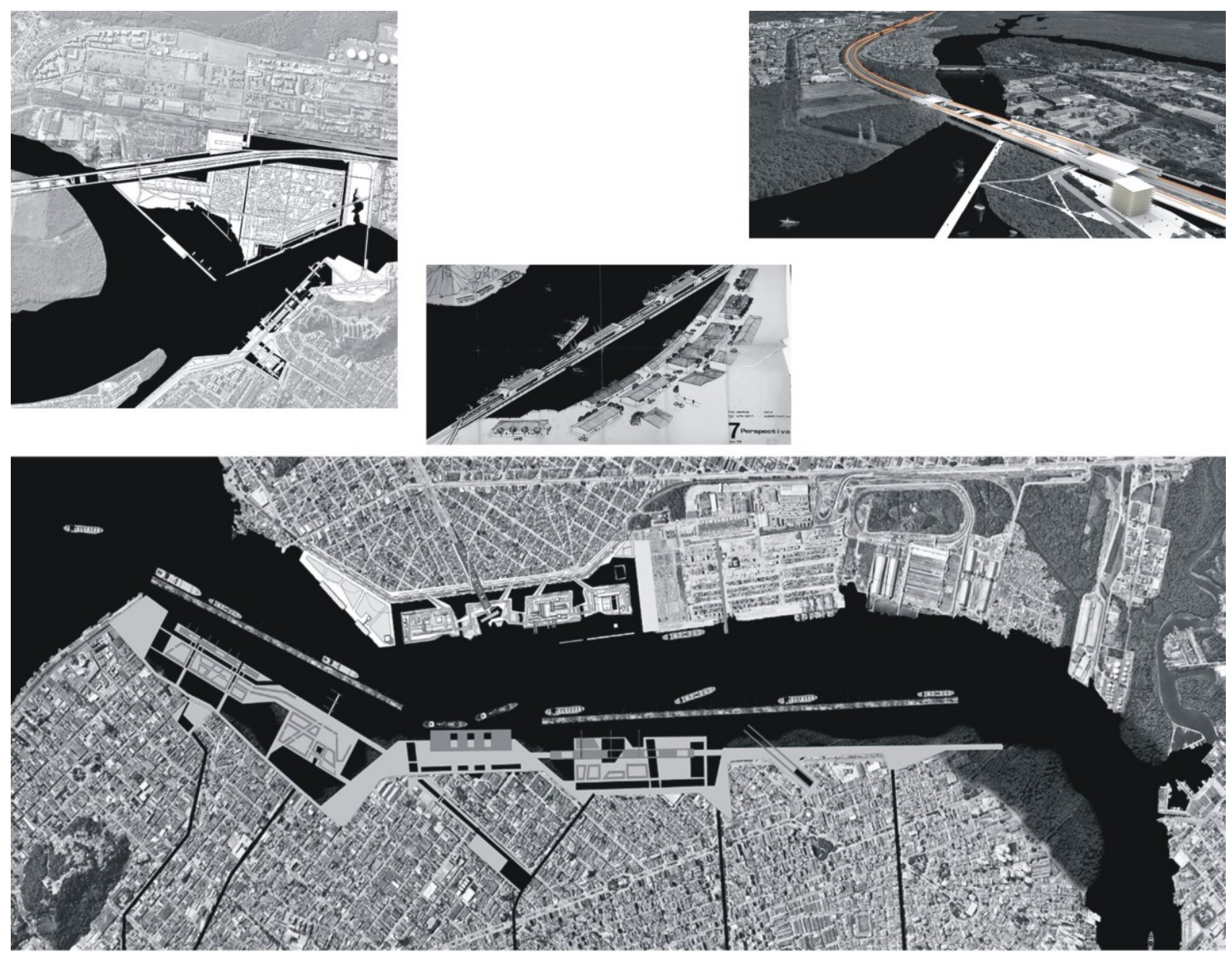

FIG. 107. Terminal metropolitano - Santos. Autor Gabriel Pestana, 2016. Acervo Biblioteca da FAUS. Cais substitutivo do Valongo - Porto de Santos. Autor Tânia Macedo, 1978. Eixo fluvial - Mongaguá. Autor Thiago Zati, 2017.

Na década de 1990, três professores do Trabalho de Curso representantes das disciplinas de teoria da arquitetura, restauro do patrimônio e projeto de urbanismo propuseram, de maneira autônoma ao regimento e com a anuência dos estudantes, um sistema de rodízio de orientação entre si. Esse procedimento consistia em uma operação muito simples e era registrado pelos próprios professores, ou seja, grosso modo, os estudantes tinham orientações a cada semana com um professor diferente, de maneira que o orientador principal se reunia com o seu grupo de origem duas vezes ao mês, intercalando os encontros com os outros dois professores. Essa proposta possuía algumas virtudes como, por exemplo, oferecer ao estudante uma perspectiva mais abrangente e integrada dos conteúdos relacionados ao seu trabalho, resultando em um valioso processo de discussão mediado pelo o próprio aluno. Entretanto, essa virtude, ao mesmo tempo que ampliava o campo de ação, gerava conflitos para os alunos pouco preparados para processar e tomar decisões próprias, devido ao caráter heterogêneo das opiniões de cada professor.

Vale dizer que essas tentativas e experimentos se deram em um cenário desfavorável, pois o Trabalho de Curso da FAUS era considerado uma disciplina e, como tal, sua natureza rígida não 
oferecia possibilidades para ajustes substanciais em sua estrutura e, mesmo dispondo de um professor coordenador, ementas, planos de aulas e cronogramas, dificilmente eram debatidos ou questionados. Era constituído por um grupo fechado de orientadores, representantes de cada uma das sequências do curso, cujo ingresso, ao modo de uma pequena cátedra, era feito por indicação da sequência, mas somente quando surgisse uma vaga. Esses docentes escolhiam os trabalhos que iriam orientar de acordo com os temas apresentados pelos estudantes, visando, em muitos casos, seu histórico ao longo do curso.

A partir da revisão do Projeto Pedagógico em 2006, independentemente do tema ou eixo disciplinar, os Trabalhos de Curso da FAUS, obrigatoriamente, devem apresentar como produto final, além do material teórico, um projeto de edificação ou um projeto urbano. Por um lado, essa alteração interrompeu a produção de trabalhos demasiado fora do campo da arquitetura e aquém do que se esperava como resultado de um ano de atividades, por outro lado, extinguiu a liberdade dos estudantes na proposição de planos autônomos em campos correlatos aos da arquitetura e do urbanismo, um virtuoso processo exaltado pelo professor Caron:

\footnotetext{
Se o trabalho reflete a escola só pode refletir um sistema atomizado e estratificado. Um locus onde "arquitetura" é um vocábulo frequente e dificilmente um questionamento, já que a escola não se questiona a si: vocábulo vazio no plano do significado. Por outro lado, como a escola não oferece alternativas periféricas organizadas que possam acrescentar experiência à trajetória dos estudantes, estes procuram estabelecer planos autônomos para exercício real de sua força jovem e de sua fome de saber. Aí entram a música, a fotografia, o bailado e sei lá que outras atividades..$^{25}$
}

As orientações ocorriam nas segundas-feiras no horário da aula, concentrando todas as atividades no atelier da escola. Grosso modo, esse formato funcionou desde a fundação da FAUS até o ano de 2018 , quando o Trabalho de Curso se tornou um componente curricular. Desse modo, ao perder o status de disciplina, tornou-se um organismo mais aberto e flexível, de maneira que qualquer professor arquiteto integrante do quadro docente da escola pode orientar o estudante que o eleger. Talvez esse modelo seja aquele que o professor Jorge Caron desejava, pois, além do caráter experimental, acabou com o problema de o aluno ser orientado por alguém que não tem afinidade profissional ou pessoal, simplesmente devido ao fato das "vagas" com os "melhores" professores terem se esgotado, ou seja, não existe mais o problema ironizado por Caron de que o docente para estar no grupo do TC "deve ser o bom, já que orienta estudantes no mais alto degrau da carreira escolar. Depois dele, serão profissionais, com seu aval."26

\footnotetext{
${ }^{25}$ CARON, Jorge. FAU-Santos: TGI. Santos: Diretório Acadêmico Michael Lieders, 1986. mimeo. (sic).

${ }^{26}$ Ibid. (sic).
} 

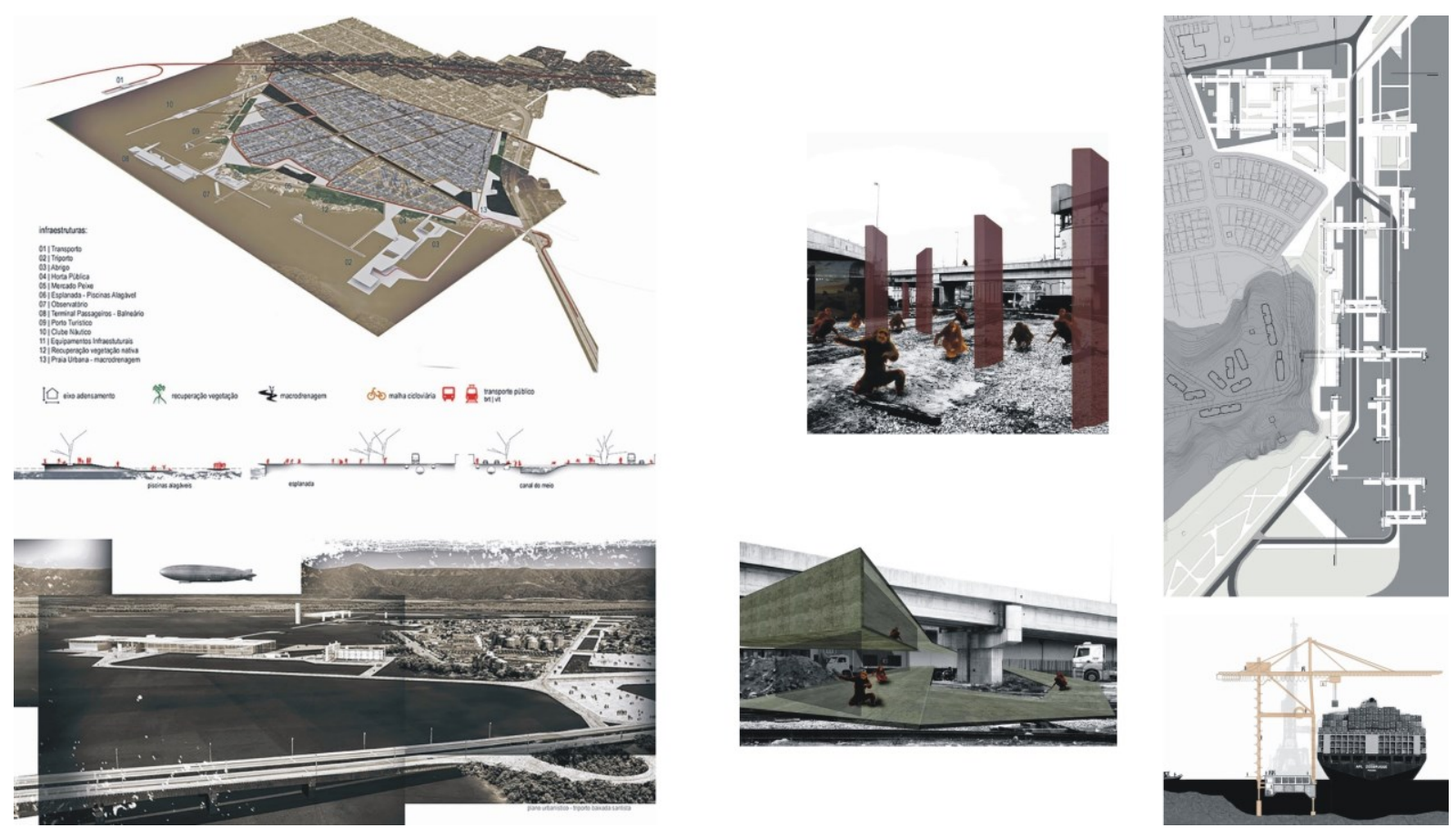

FIG. 108. Logística reversa - São Vicente. Autor Ricardson Ricardo, 2017. Vago - Porto de Santos. Autor Rodrigo Carvalho, 2010. Caminhos do Dique - Santos. Autora Izabela Volpi, 2016. Eixo fluvial - Mongaguá. Autor Thiago Zati, 2017.

Entretanto, esse mesmo caráter flexível provocou um assombroso esvaziamento do atelier, pois cada estudante ou grupo de estudantes tem horários e locais distintos de orientação, agendados de acordo com a disponibilidade do professor. Essa pulverização e desencontro é agravada pela falta de um coordenador pedagógico específico para o Trabalho de Curso de arquitetura, ${ }^{27}$ dificultando 0 acompanhamento e o estabelecimento de critérios de avaliação para os diversos temas desenvolvidos na escola, dando continuidade a outro problema histórico: a falta de isonomia na avaliação, que depende do rigor do professor orientador e da banca de avaliação indicada em conjunto com seus estudantes. Contudo, apesar dos problemas apontados, pode-se dizer que existe um esforço em curso para alterar esse quadro, principalmente no que se refere à ampliação do campo cultural do aluno. Através da experimentação de novas relações entre ensino e aprendizagem no âmbito do Trabalho de Curso, vêm sendo postas em prática ações coletivas durante as orientações, com seminários, temas unificados, pesquisa e produção de bases em grupo, dentre outras.

Em resumo, estudantes e professores da FAUS, ao longo dos últimos cinquenta anos, construíram um notável banco de dados sobre diversas frentes de atuação do arquiteto e urbanista a partir da pesquisa, experimento, crítica e intervenção nas cidades da Baixada. Indo além da problemática urbana dos núcleos de ocupação planejados, os Trabalhos de Curso da escola tratam das questões

\footnotetext{
${ }^{27}$ Ao ser considerado um componente curricular, o TC da FAUS passou a seguir o mesmo formato padronizado para todos os cursos da Universidade. O registro de orientações é feito através de um sistema digital, tornando possível um único docente ser o coordenador de todos os Trabalhos de Curso da universidade, independentemente de suas especificidades. Atualmente esse coordenador é um profissional do campo da Engenharia Elétrica.
} 
relacionadas à ocupação formal e informal em áreas periféricas ou continentais, áreas de morros, orlas de mar, manguezais, rios e estuários. No caso específico das cidades de Santos, Cubatão e Guarujá, esses conflitos são somados ao complexo processo de ocupação de áreas portuárias e suas relações com a cidade, além da implantação e conexão com os parques industriais da região, e com o sistema macrometropolitano da cidade de São Paulo.

A FAUS, ao abordar problemas significativos da Região Metropolitana da Baixada Santista, com maior ênfase no Trabalho de Curso, apresenta-se como referência no ensino da arquitetura e do urbanismo em termos regionais. Assim sendo, arrisca-se dizer que as características do território (lugar) e da escola (espaço) exercem influência na formação dos estudantes tendo, portanto, relevância na elaboração dos objetivos do seu projeto pedagógico, na constituição dos instrumentos didáticos, currículos e programas de extensão, dentre outras estratégias e experimentos de ensino.
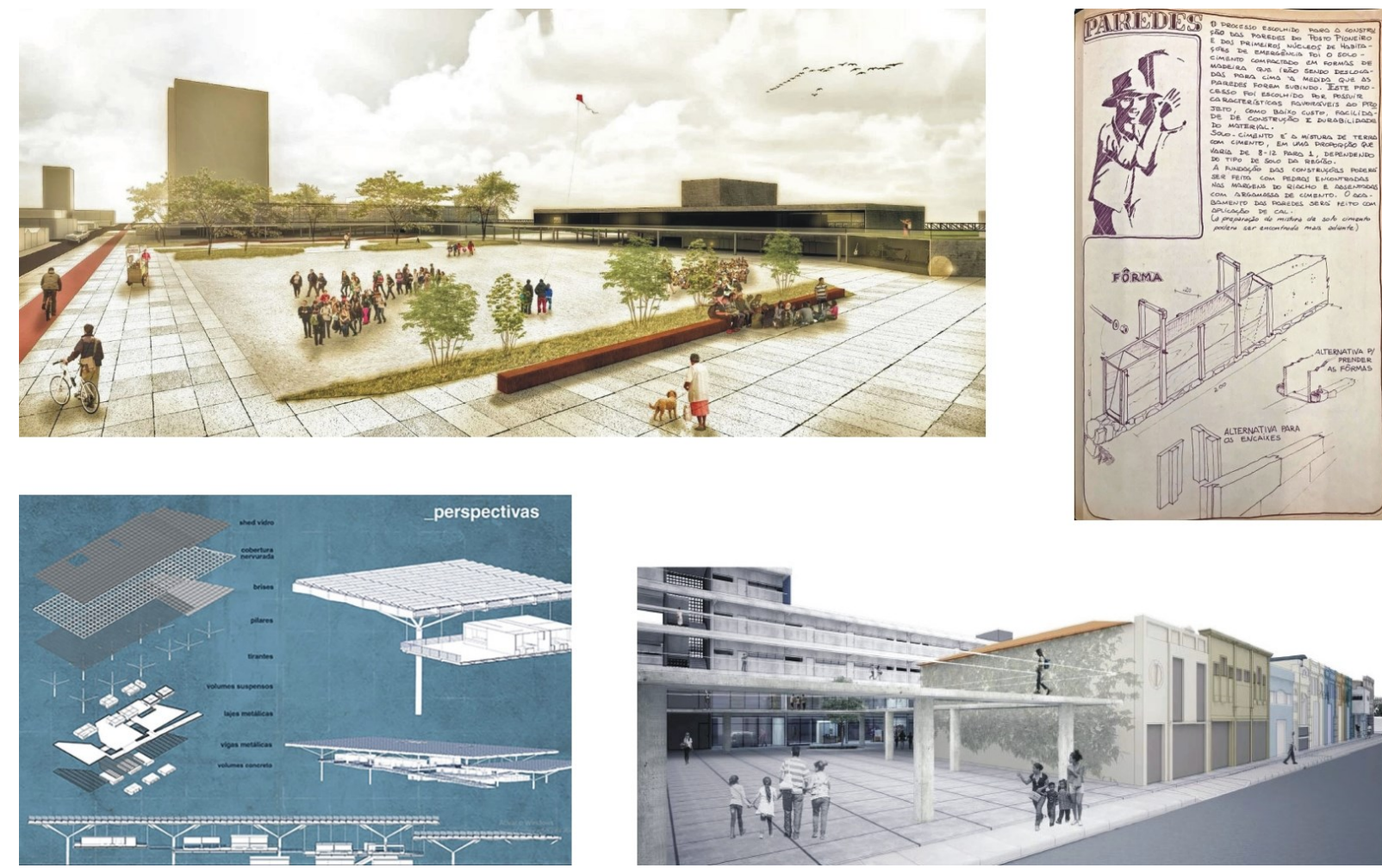

FIG. 109. Centro cultural - Praia Grande. Autora Marjory Tunisi, 2015. Vila sustentável - Itanhaém. Autor Mario Persona, 1978. Sistema hidroviário metropolitano - Guarujá - Santos. Autor Andrei Krichinak, 2018. Cortiços do Paquetá - Santos. Autora Priscila Araújo, 2017. 


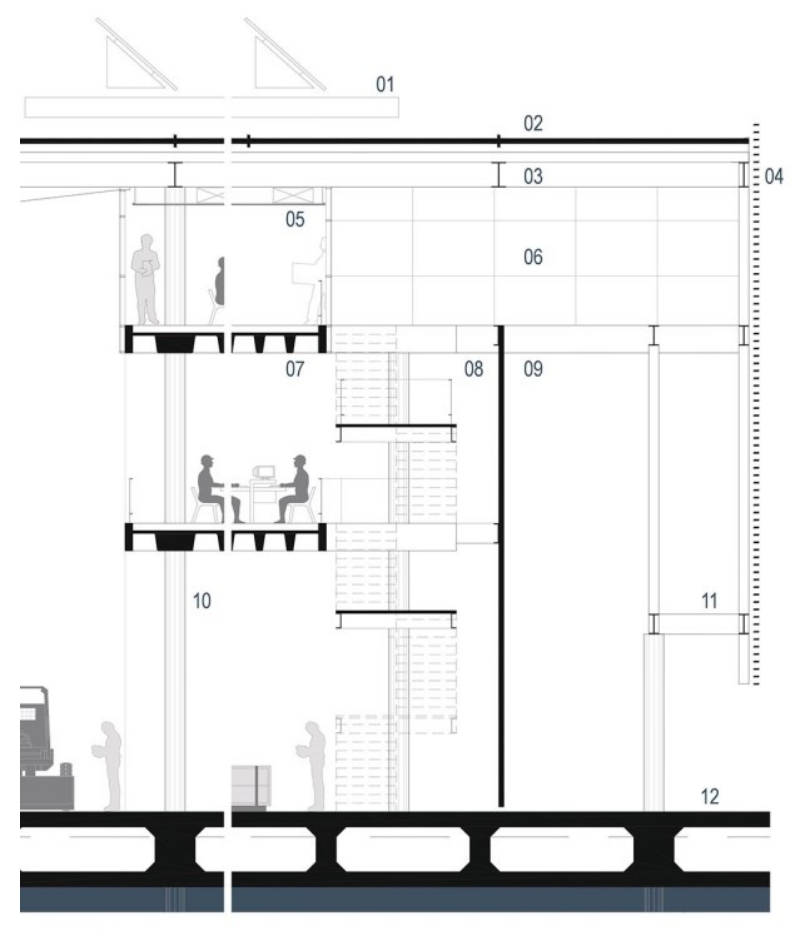

detalhe
esc: $1: 75$

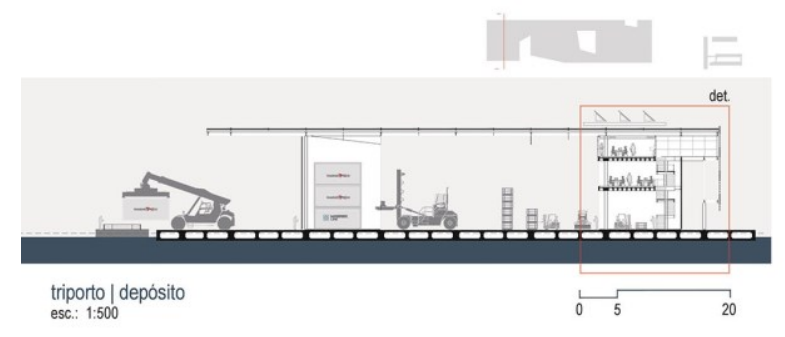

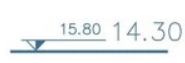
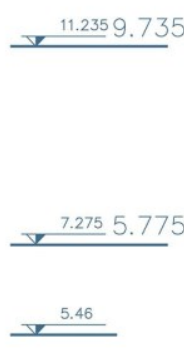

$\begin{array}{r}1.50 \quad 0.00 \\ \hline\end{array}$
01 | equipamentos sistema de captaçăo de energia solar
condensadoras | sistema de climatizaçăo vif

02 | cobertura metálica trapezoidal

termo acústica
captaçâo de água para aproveitamento

03 | estrutura metálica vigamento de perfis laminados

04 | brise metálico

conjunto de painèis em chapa metálica

05 | forro acústico mineral passagem instalaạ̄oes técnicas e dutos

06 | vidro laminado incolor colados sobre perfis de aluminio

07 | laje nervurada

08 | escadas

barra chata de aço galvanizado
guarda-corpo | perfis tubular

09 | telha metálica trapezoidal
termo acustica

10 | pilar circular

11 | passadiço metálico

grelha metálica elétrofundida

12 | piso

juntas de dilatą̧ăo | aç̄os do mar

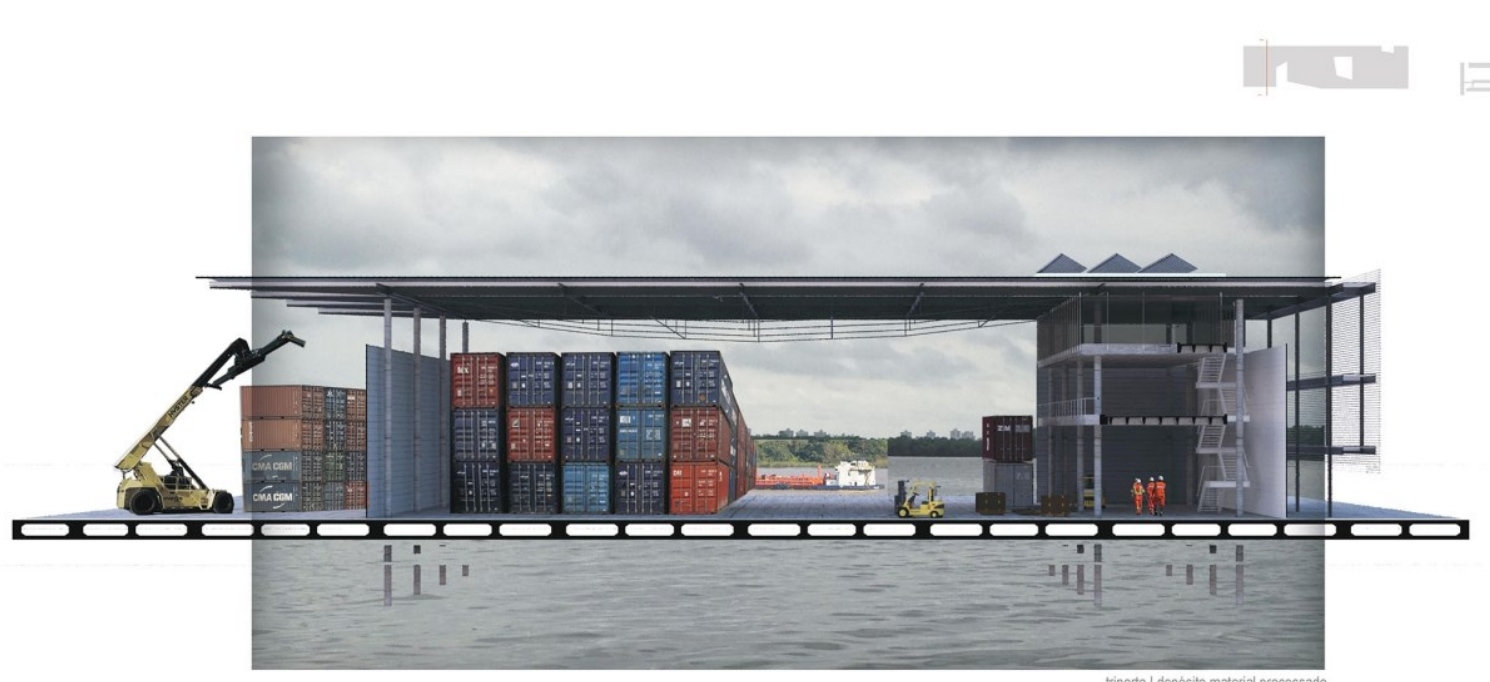

tiporto | depósitio material processado 
Legitimidade e distinção

Dois adjetivos. Legítimo do latim legitĭmu - "conforme às leis"; e Distinto do latim distīnctu - "partido, dividido, separado". Adjetivos que, ao expressarem valores como justiça, verdade, clareza, nitidez e respeito, apresentam-se como instrumentos auxiliares no reconhecimento ou aferição da natureza ou identidade da FAUS. Seguindo esse ponto de vista e sem qualquer pretensão de abrir uma discussão ética e qualitativa sobre o assunto, acredita-se que a participação dos estudantes da FAUS em concursos públicos, considerados a priori democráticos e legítimos, juntamente às alianças políticas e ideológicas firmadas para sua constituição e funcionamento, contribuíram e continuam contribuindo para aprimorar e desenvolver suas propostas de ensino.

Nesse contexto, interessa dizer que os concursos são entendidos como exercícios coletivos, nos quais os estudantes envolvidos têm a oportunidade de demonstrar posicionamento crítico e coerência no entendimento e interpretação de um problema qualquer no campo da arquitetura e do urbanismo, independentemente da escala de intervenção. Como resposta ou síntese desse processo, é apresentada uma proposição teórica e/ou projetual, claramente descrita em toda sua especificidade, comunicando ideias e proposta, geralmente apresentadas ou, melhor dizendo, representadas através da linguagem gráfica e textual.

Em linhas gerais, é possível afirmar que essa instância de produção, por constituir um exercício pautado pelo princípio da igualdade de oportunidade, têm contribuído para o aperfeiçoamento pedagógico e profissional da arquitetura. Os concursos muitas vezes incentivam o debate sobre assuntos extracurriculares, fora do horário das aulas e, por não constituírem uma obrigação ou uma tarefa, sua produção é dirigida pela motivação, pela vontade de estudantes e docentes. Desse modo, a experiência acadêmica e profissional dos professores, juntamente com o engajamento e energia dos estudantes, resulta em uma situação ideal para o aprendizado da arquitetura e do urbanismo. 0 professor Hugo Segawa, na ocasião de um concurso interno na FAUS para escolha do representante da escola em um concurso de estudantes, escreveu:

Acredito que uma instituição superior de ensino (com pretensões de universidade) deva necessariamente trilhar o questionamento da prática corrente da atividade arquitetônica, conduzir-se pela produção do conhecimento que objetive superar o usual marasmo que permeia o cotidiano do nosso mercado profissional. ${ }^{28}$

${ }^{28}$ Texto do professor de Teoria da Arquitetura no Brasil, Hugo Segawa: Vila Progresso in DIRETÓRIO ACADÊMICO VERA DEBS. Jornal revista: Edição no 2, ago. / set. 1983.p. 17. 
Com efeito, apesar de produzidos no plano da hipótese, grosso modo, os concursos para estudantes seguem a mesma lógica dos certames profissionais, cujos editais são pautados pela identificação de problemas reais relacionados ao edifício, lugar ou região em estudo. Ao modo de uma atividade complementar ou de extensão, esse exercício ao levar em conta a realidade submete o trabalho a fatores socioculturais, econômicos, geográficos, dentre outros, contribuindo para aprofundar o conhecimento teórico e a prática de projeto dos estudantes em um cenário próximo ao profissional.

A primeira experiência em concursos na FAUS surgiu em meio às discussões do Fórum de 1978. A escola foi contemplada com o primeiro lugar no Prêmio do Banco Nacional de Habitação (BNH), que tinha como tema: Habitação de Interesse Social. O grupo integrado pelos estudantes Paulo Salles, Márcia Davis, João Meyer, Márcia Pavan, Lélio Kolhy e Walter Antunes venceu o concurso com o trabalho Projeto de urbanização da Vila Progresso em Santos. No ano seguinte, em 1979, o estudante João Meyer conquistou o primeiro lugar na mesma premiação organizada pelo Banco Nacional de Habitação (BNH), com o tema: Habitação de Interesse Social. João Meyer apresentou o trabalho Localização Habitacional de Interesse Social na Baixada Santista, correspondente ao Trabalho de Curso apresentado na FAUS. ${ }^{29}$

Ainda sob o rescaldo da crise de 1982, o ano de 1983 foi muito profícuo para a FAUS, pois três grupos de estudantes, ao se destacarem na X Conferência Latino Americana de Escolas e Faculdades de Arquitetura - X CLEFA, ${ }^{30}$ demonstraram que a escola estava fortalecida politicamente com a superação da crise e melhor estruturada no que se refere ao seu ensino. Em um texto intitulado "A propósito dos concursos para estudantes na FAUS", o professor Hugo Segawa, na condição de membro da comissão julgadora para eleger os trabalhos que representariam a FAUS naquele concurso, fez as seguintes observações:

\begin{abstract}
Escrevi esses comentários sobre trabalhos apresentados para concurso interno da FAUS para projetos em preparação aos certames da UIA e X CLEFA [...] Fazendo uma observação genérica sobre o evento, diria que nenhum trabalho me satisfez. Faltou, basicamente, criatividade: criatividade para solucionar situações complexas, um desafio que, obviamente, não se resolve apenas com ideias boas, mas que concede espaço para divagações de toda ordem, principalmente as criativas. [...] Os termos do concurso constituíram apenas pretextos para trabalho que envolveria estreita colaboração com a população. Nenhuma equipe desenvolveu um paciente trabalho de aferição, o que, não é segredo para ninguém, não se realiza em poucos meses. Foi uma aproximação "oportunística" em função da temática solicitada. Isso é mau. ${ }^{31}$
\end{abstract}

\footnotetext{
${ }^{29}$ Esse trabalho propunha, de maneira inédita, a construção de um sistema de metrô de superfície, ou Veículo Leve sobre Trilhos (VLT) sobre a linha férrea da antiga empresa Sorocabana, depois conhecida como Ferrovia Paulista S/A (FEPASA). Circulando a llha de São Vicente, esse ferro anel associado à construção de moradias populares interligava a cidade de Santos ao bairro vicentino do Samaritá, conhecido por abrigar um importante modal de transbordo, manobras e conexões ferroviárias da região. Depois de mais de 37 anos desse projeto, a Empresa Metropolitana de Transportes Urbanos (EMTU) está implantando o sistema de VLT, proposto em 1979, pelo hoje Dr. João Meyer, professor da FAU-USP.

${ }^{30}$ UDUAL; FAUUSP. X Conferência Latino Americana de Escolas e Faculdades de Arquitetura (X CLEFA): Assentamentos Humanos e Adequação Regional. São Paulo: UDUAL/FAUUSP, 1983.

${ }^{31}$ Hugo Segawa: A propósito dos concursos para estudantes na FAUS in DIRETÓRIO ACADÊMICO VERA DEBS. Jornal revista: Edição no 2, ago./set. 1983.p. 16. 
Apesar da aspereza da crítica, o professor Segawa deixava claro que a participação de estudantes em concursos deveria ser levada com rigor e disciplina por tratar de problemas reais e no âmbito da atividade profissional:

\begin{abstract}
A falta de solidez das propostas apresentadas em pranchas decorre [...] da falta de maturação das possíveis respostas da problematização inicial em combinação com a dificuldade de se estabelecer relacionamentos sinceros com a população da Vila em tão pouco tempo. Aliás, questão que paira sobre todas as experiências relacionadas com assentamentos habitacionais de grupos sociais de mínimo poder aquisitivo. Assim como essa equipe não chegou ainda a uma resposta, poucos, mesmo formados e experientes profissionais, terão uma, ao problema. Mesmo porque a alternativa é passível de discussão. [...] Agora aguardo apenas um trabalho que corresponda a uma leitura própria da área de atuação, não uma intervenção que, enquanto solução arquitetônica e urbanística, paira sobre as favelas brasileiras. ${ }^{32}$
\end{abstract}
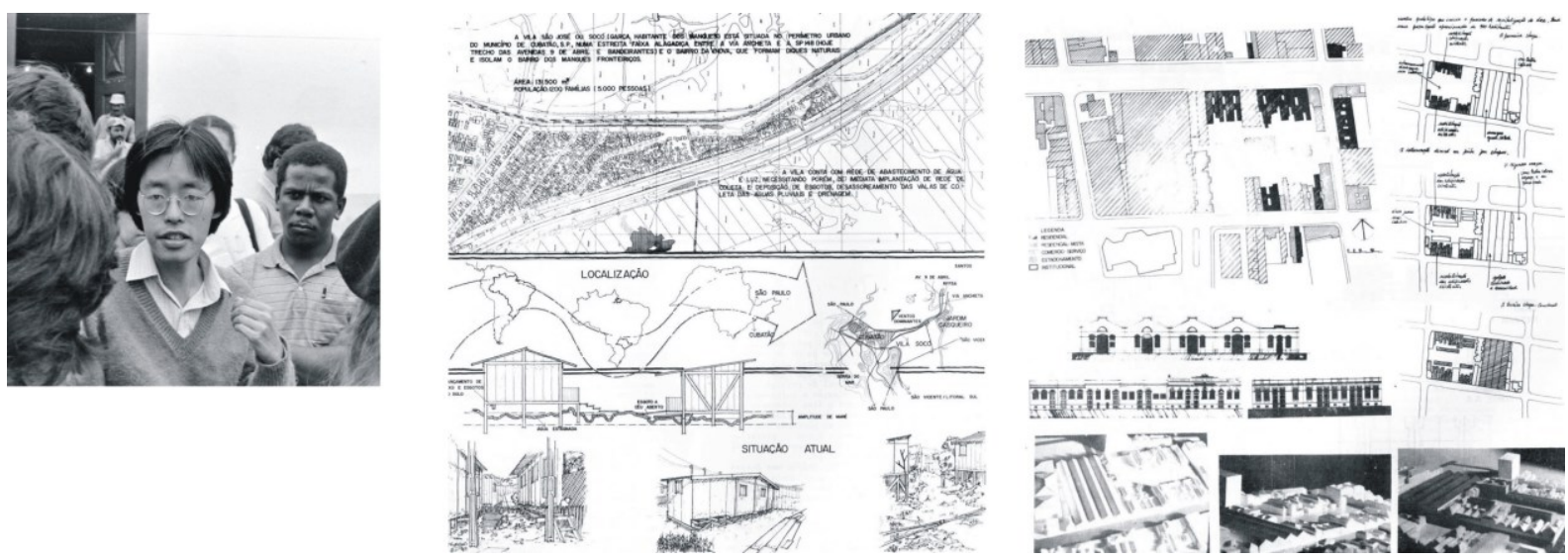

FIG. 111. Professor Hugo Segawa, em aula externa com os estudantes da FAUS. Concurso X CLEFA 1983. Projeto para remanejamento do assentamento humano de Vila São José. Autores: Albino Soares; Antonio Sérgio Galego; Denise Farina; Jarbas Oliveira Junior; José Oliveira Pinto; Marcia Velin; Mauro Garcia; Nilton Faria; Orlando Silva Filho; Renata Leite; Wagner Ortega. Habitação: revitalização do centro de Santos. Autores: Maruem Hatem; Nanci Cardoso; Sandy Junior; Sérgio Suster.

Indo nessa direção, uma das mais importantes premiações nacionais para estudantes de arquitetura é o Concurso Opera Prima, iniciado em 1988. Ao reconhecer e premiar o Trabalho de Curso como síntese das práticas pedagógicas de uma determinada escola, o Opera Prima tangencia o universo da profissão como um importante marco de início da vida profissional do estudante e, de certo modo, tem feito parte do rito de formação do arquiteto e urbanista no Brasil, colocando em competição trabalhos de escolas de todo o país, que encaminham anualmente seus melhores representantes. ${ }^{33}$

\footnotetext{
${ }^{32}$ Crítica do professor Hugo Segawa sobre o projeto escolhido para representar a FAUS no Concurso UIA/UNESCO, 1983. Título do trabalho: Vila Progresso - proposta de atuação. Autores: Ana Gabos; Eugênio Lara; Edison Gloeden; Julio Lacerda; Paulo Lara; Beni Skitneysky; Elisabete Galeão; Eduardo Ferraz; José Varanezze e Ricardo Caseiro. DIRETÓRIO ACADÊMICO VERA DEBS. Jornal revista: Edição no 2, ago. / set. 1983. pp. 13-17.

${ }^{33}$ Sobre o concurso Opera Prima ver ARCIPRESTE, C. M. Entre o discurso e o fazer arquitetônico: reflexões sobre o ensino de arquitetura e urbanismo e seus referenciais a partir do trabalho final de graduação Op. cit. p. 238.
} 

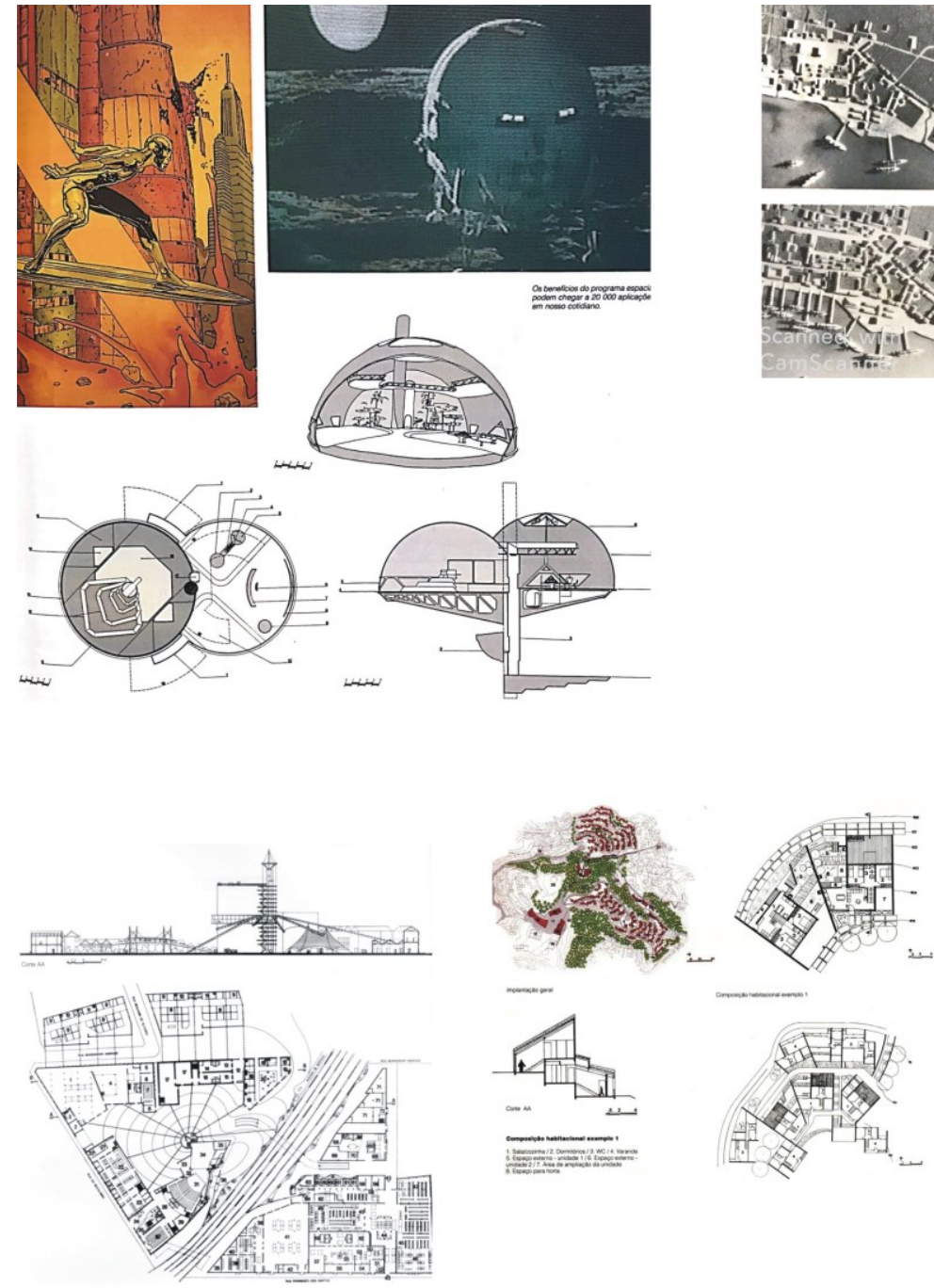

TRANSPOR
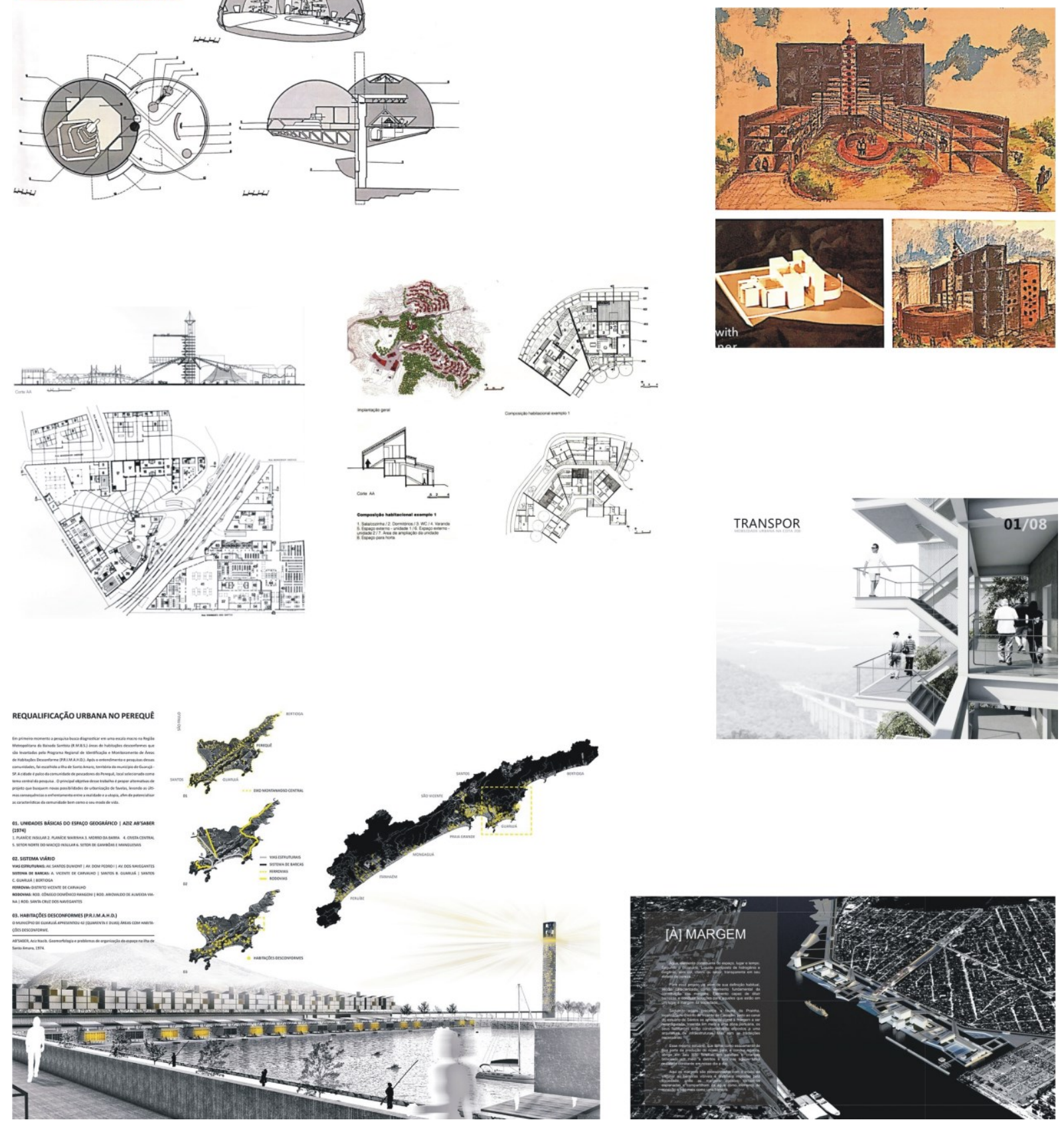

FIG. 112. 10 Opera Prima 1989. Estação experimental para o cultivo de algas. Autor: Ricardo Zanoli. 20 Opera Prima 1990. Revitalização do Valongo. Autor: Athea Paladino. 3o Opera Prima 1991. Um espaço para o Teatro. Autor: Flávia Neves Dantas. 6o Opera Prima 1994. Revitalização do Moinho Matarazzo. Autor: Fábio Luiz Arminio. 7o OPERA PRIMA 1995. Uma nova paisagem para os morros. Autor: Sidney Piochi Bernardini. 24ํ Opera Prima 2013. Requalificação do Perequê. Autor: Dhiego Magalhães Torrano e Transpor: mobilidade na Cota 200. Autor: Pedro Ribeiro. 26 Opera Prima 2016. [À] Margem. Autor: Fiama Evangelista da Costa. 
Vale destacar que suas regras diferem dos demais concursos para estudantes por centrar o debate nos Trabalhos de Curso pré-selecionados pela própria instituição de ensino, ou seja, o escopo para participação não depende de programa, lugar, técnica construtiva, escala, dentre outros termos presentes nos demais editais, o que, de certo modo, configura uma amostragem de natureza aberta e autônoma. Nesse sentido, apesar da liberdade de escolha dos representantes, a participação de cada escola é proporcional ao número de alunos por ela formados a cada ano. Na FAUS, por exemplo, a seleção é feita a partir da indicação dos Trabalhos de Curso pelos orientadores e, posteriormente, referendada por uma comissão constituída por professores da própria instituição e eventualmente por convidados externos.

Apesar de não constituir uma representação extensiva da produção da escola, os trabalhos selecionados para participarem da competição geralmente apresentam pesquisas e reflexões conceituais mais aprofundadas, além de maior desenvolvimento técnico. Feitas essas considerações, interessa dizer que desde 1989 a FAUS tem participado do concurso Opera Prima recebendo prêmios e menções honrosas. Na ocasião da revisão do projeto pedagógico da FAUS no ano 2000, dentre os objetivos da comissão plena de revisão, a participação sistemática em concursos de arquitetura foi enfaticamente destacada como um instrumento importante de desenvolvimento do estudante. ${ }^{34}$ Apesar desse desejo, a instituição não implementou nenhum programa específico de incentivo para alunos e professores participarem de concursos de projetos estudantis.

A despeito desse fato, em 2017 uma nova geração de estudantes começou a participar de concursos promovidos por portais de arquitetura na internet, desse modo conquistaram uma série de premiações com amplo destaque nas mídias digitais. Somente no ano de 2017 estudantes da FAUS foram vencedores do Concurso Projetar.org., do Prêmio V.B.O do concurso IDEAS FORWARD, arquitetura Biomimética. Em 2018 essa mesma geração se destacou em mais duas premiações, ambas no Concurso Projetar.org., na edição 24 e na edição 27. No final do mesmo ano, o portal de arquitetura na internet Archdaily promoveu uma competição intitulada: Os melhores trabalhos de conclusão de curso de 2018. Nessa edição, a FAUS recebeu duas menções em um universo de 466 propostas de todo o Brasil, além de cidades como Lisboa e Luanda. Vale destacar que, apesar de tratar do Trabalho de Curso como o Opera Prima, os critérios de julgamento e seleção dos trinta trabalhos publicados seguiram uma lógica distinta:

Mais que simplesmente resolver um projeto de modo satisfatório, entendemos que um TCC -- por condensar os esforços do estudante em um momento de passagem da academia para a vida profissional -deve levantar questões e incitar a discussão acerca do tema proposto. ${ }^{35}$

\footnotetext{
${ }^{34}$ Cf. Cap.3, Continuidade, Identificação Comunitária, diagrama Organização Conceitual do Projeto Pedagógico da FAUS.

${ }^{35}$ Editorial do portal Archdaily. Disponível em: https://www.archdaily.com.br/br/907142/os-melhores-trabalhos-de-conclusao-de-cursode-2018. Acesso em: 14 mar. 2019.
} 

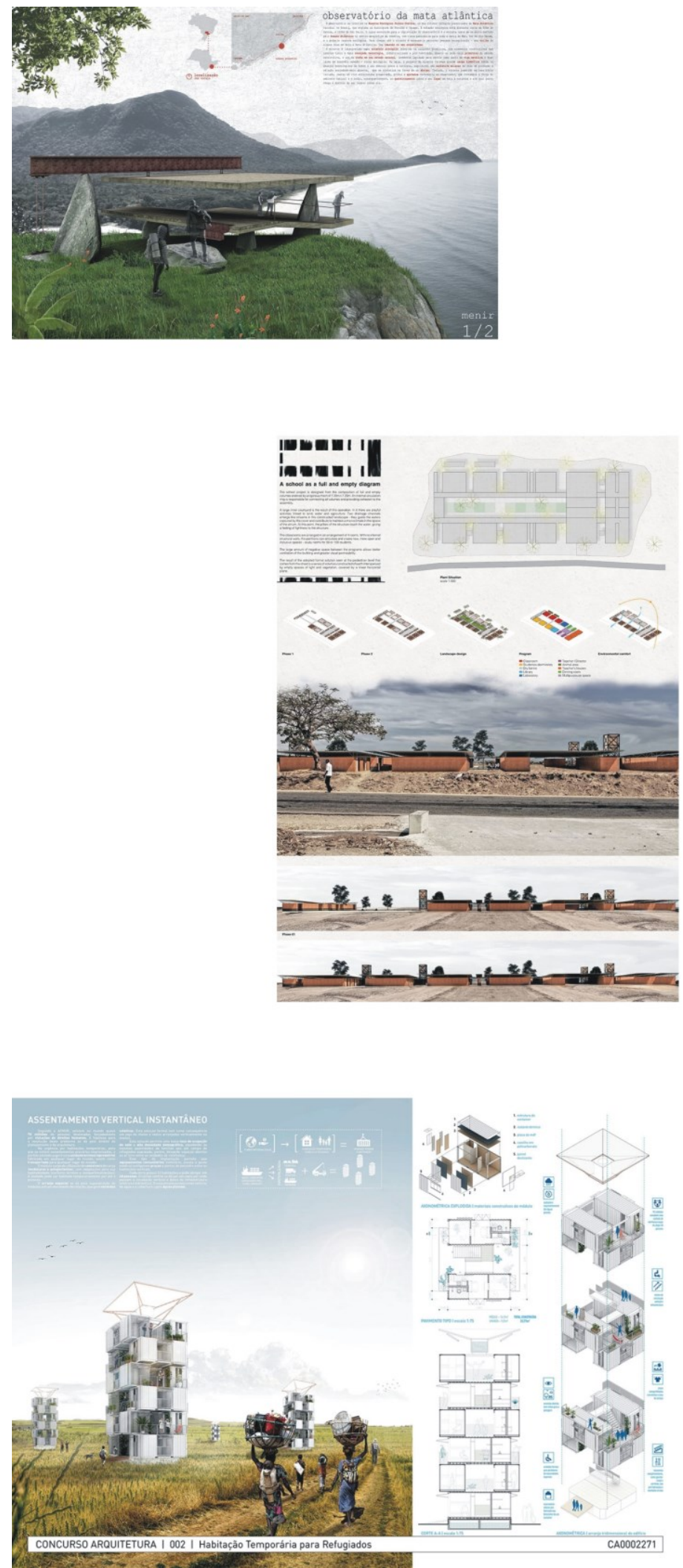
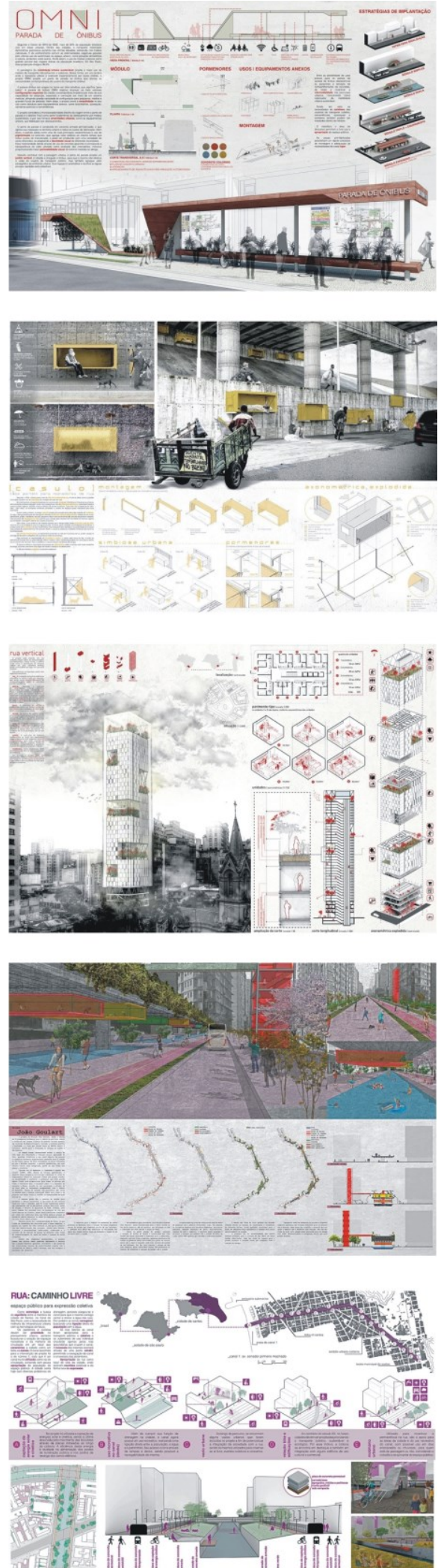

FIG. 113. Acima à esquerda, 2ㅇ. Prêmio VBO, 2017 - Observatório da Natureza. Autores: Matheus Pardal e Vitor Candido. Abaixo, Concurso Archstorming, 2019 - Africa School. Autores Matheus Pardal, Igor Coimbra, Ricardson Ricardo. Concurso C.A. 2019 - Habitação temporária para refugiados. Autor: Matheus Pardal. À direita de cima para baixo: 22을 Concurso Projetar .org. 2017 - Parada de ônibus. Autores: Matheus Pardal e Igor Coimbra. 24을 Concurso Projetar .org. 2018 - Casa Portátil. Autores: Caroline Tavares, Igor Coimbra e Matheus Pardal. 28ㅇ Concurso Projetar .org. 2018 - Habitação social no Largo do Paissandú. Autor: Matheus Pardal. 31을 Concurso Projetar .org. 2019 Imagine Parque Minhocão. Autores: Graziela Botelho e Victor Duarte. 32 Concurso Projetar .org. 2019 - Rua do Futuro. Autores: Stefanie Camargo, Cinthya Yukari, Gabriela Silva, Nadia Marques, Nájla Pires. 
Em 2019, a continuidade na participação em concursos estudantis rendeu mais quatro premiações para a escola nas seguintes competições: Concurso C.A.; Archstorming; Projetar.org., edição 31 e Projetar.org., edição 32.

Paralelamente a esses certames, e retornando ao universo das competições entre Trabalhos de Curso, destaca-se o Concurso Archiprix International ${ }^{36}$, premiação bienal que envolve aproximadamente 1700 faculdades de arquitetura do mundo inteiro promovendo uma ampla divulgação dos trabalhos. Cada faculdade pode indicar somente um representante e, da mesma maneira que o Opera Prima, após seleção interna o trabalho é enviado para a organização do concurso. Na edição de 2013 em Moscou, Rússia, a FAUS foi representada pelo estudante Dhiego Torrano. Em 2015, na cidade de Madri, Espanha, o projeto da estudante Milena Santos foi o selecionado. Em 2017, a premiação ocorreu em Ahmedabad, Índia, e a estudante Fiama Costa foi a representante da FAUS. Em busca da primeira premiação entre os melhores trabalhos de conclusão de curso de todo o mundo, a FAUS depositou sua confiança no estudante Ricardson Ricardo que concorreu na edição de 2019 na cidade de Santiago, no Chile.

Para uma observação sistematizada quanto à natureza dos concursos dos quais a FAUS participou e vem participando, foi elaborado um quadro com um resumo das premiações da escola, ordenadas por ano, instituição promotora, temática, escala e autores. ${ }^{37} \mathrm{Da}$ mesma maneira que o quadro desenvolvido para a verificação dos Trabalhos de Curso, a organização metodológica das premiações segue critérios quantitativos, ou seja, não foram consideradas informações relativas à classificação e tipo de prêmio recebido. Nesse ponto, interessa dizer que, devido ao caráter extracurricular dessas atividades, julgou-se mais interessante observar dados que possibilitem identificar indícios ou critérios de escolha dos estudantes para a participação em um determinado concurso, como por exemplo temas e escalas de intervenção.

\footnotetext{
${ }^{36} \mathrm{Na}$ primavera dos anos pares 1700 universidades registradas recebem um convite para participar da competição. Apenas os projetos de graduação concluídos nos últimos dois anos são selecionados pela instituição que, após seleção interna, envia para o concurso o que julga ser o seu melhor projeto de graduação. O Archiprix International publica todos os projetos submetidos em seu site em um livro, em exposições e filmes. Essa abrangente divulgação dos trabalhos de graduação oferece um notável panorama contemporâneo do ensino e da produção das escolas de arquitetura no mundo. Archiprix International, Museumpark, Rotterdam, The Netherlands. Disponível em <https://www.archiprix.org/> Acesso em: 19 jun. 2019. (tradução nossa).

${ }^{37}$ A pesquisa e coleta dos dados sobre as premiações da FAUS foi feita a partir da leitura de bibliografia específica sobre concursos para estudantes, teses e dissertações, leitura dos editais dos concursos disponíveis em periódicos e plataformas digitais e entrevistas com alunos, ex-alunos e professores da Faculdade de Arquitetura e Urbanismo da Universidade Católica de Santos. O caráter disperso do material sobre o assunto pode resultar na ausência de alguma premiação da escola no quadro aqui elaborado.
} 


\section{PREMIAÇÕES DA FAUS EM CONCURSOS PÚBLICOS PARA ESTUDANTES}

\begin{tabular}{|c|c|c|c|c|}
\hline ANO & PRÊMIO & TEMÁTICA & ESCALA & ESTUDANTES \\
\hline 1978 & $\mathrm{COHAB}$ & HABITAÇÃO & CIDADE & $\begin{array}{c}\text { PAULO SALLES, MARCIA DAVIS, JOÃO MEYER, MÁRCIA PAVAN, LÉLIO } \\
\text { KOLHY, WALTER ANTUNES }\end{array}$ \\
\hline 1979 & $\mathrm{COHAB}$ & HABITAÇÃO & TERRITÓRIO & JOÃO FERNANDO MEYER \\
\hline 1983 & X CLEFA & HABITAÇÃO & TERRITÓRIO & $\begin{array}{c}\text { JOSÉ CARRIÇO, MARIA BITTENCOURT, MARCELO MOROZETTI, NEWMA } \\
\text { BITTENCOURT }\end{array}$ \\
\hline 1983 & X CLEFA & HABITAÇÃO & TERRITÓRIO & $\begin{array}{c}\text { ALBINO SOARES, ANTÔNIO GALEGO, DENISE FARINA, JARBAS OLIVEIRA, } \\
\text { JOSÉ OLIVEIRA, MARCIA AVELIN, MAURO GARCIA, NILTON FARIA, } \\
\text { ORLANDO SILVA, RENATA LEITE, WAGNER ORTEGA }\end{array}$ \\
\hline 1983 & X CLEFA & HABITAÇÃO & CIDADE & MARUEM HATEM, NANCY CARDOSO, SANDY JUNIOR, SERGIO SUSTER \\
\hline 1984 & $\mathrm{BNH}$ & HABITAÇÃO & CIDADE & $\begin{array}{l}\text { ANTONIO FIORINI, CARLO DESIANO, JOSÉ MAIA, MARCELO COUTO, } \\
\text { NELSON TSUTOMUOTA, NIVALDO NOZOIE, OLEGÁRIO VASCONCELOS }\end{array}$ \\
\hline 1989 & OPERA PRIMA & RESTAURAÇÃO & EDIFÍCIO & INEZ DOS SANTOS GOSSI \\
\hline 1989 & OPERA PRIMA & ECOLOGIA & EDIFÍCIO & RICARDO ZANOLI \\
\hline 1989 & OPERA PRIMA & TECNOLOGIA & EDIFÍCIO & SILVIO CURADO COELHO \\
\hline 1990 & OPERA PRIMA & INFRAESTRUTURA & TERRITÓRIO & ATHÉA PALLADINO \\
\hline 1991 & OPERA PRIMA & CULTURA & EDIFÍCIO & FLÁVIA NEVES DANTAS \\
\hline 1994 & OPERA PRIMA & RESTAURAÇÃO & EDIFÍCIO & FÁBIO ARMÍNIO \\
\hline 1995 & OPERA PRIMA & HABITAÇÃO & CIDADE & SIDNEY BERNARDINI \\
\hline 1998 & OPERA PRIMA & HABITAÇÃO & CIDADE & FERNANDA MENEGHELO \\
\hline 2002 & PRÊMIO CAIXA & HABITAÇÃO & CIDADE & ADÃO RIBEIRO JÚNIOR \\
\hline 2003 & PRÊMIO ALCOA & MOBILIÁRIO & OBJETO & DOUGLAS COSTA E LUCIANA REIS \\
\hline 2003 & 5a BIENAL SP & CULTURA & CIDADE & ADÃO RIBEIRO, CAROLINE SILVA, JULIANA AZEVEDO, MARCUS BARGA. \\
\hline 2003 & OPERA PRIMA & CULTURA & CIDADE & ADÃO RIBEIRO JÚNIOR \\
\hline 2011 & OPERA PRIMA & CULTURA & EDIFÍCIO & CARLOS JACQUET \\
\hline 2013 & OPERA PRIMA & HABITAÇÃO & CIDADE & DHIEGO TORRANO \\
\hline 2013 & OPERA PRIMA & MOBILIDADE & TERRITÓRIO & PEDRO RIBEIRO \\
\hline 2016 & OPERA PRIMA & INFRAESTRUTURA & TERRITÓRIO & FIAMA EVANGELISTA \\
\hline 2017 & PRÊMIO V.B.O. & ECOLOGIA & EDIFÍCIO & MATHEUS PARDAL, VICTOR DUARTE \\
\hline 2017 & PROJETAR.ORG - 22 & MOBILIÁRIO URBANO & OBJETO & MATHEUS PARDAL, IGOR COIMBRA \\
\hline 2017 & IDEAS FORWARD & HABITAÇÃO & CIDADE & MATHEUS PARDAL, IGOR COIMBRA, THIAGO ZATI, CAROLINA FRANÇA. \\
\hline 2018 & PROJETAR.ORG - 24 & HABITAÇÃO & OBJETO & MATHEUS PARDAL, IGOR COIMBRA, CAROLINE TAVARES \\
\hline 2018 & PROJETAR.ORG - 27 & HABITAÇÃO & EDIFÍCIO & MATHEUS PARDAL \\
\hline 2018 & ARCHIDAILY & INFRAESTRUTURA & TERRITÓRIO & MATHEUS PARDAL \\
\hline 2018 & ARCHIDAILY & CULTURA & EDIFÍCIO & AGNES LÚCIA DA SILVA SANTOS \\
\hline 2019 & CONCURSO C.A. & HABITAÇÃO & TERRITÓRIO & MATHEUS PARDAL \\
\hline 2019 & ARCHSTORMING & EDUCAÇÃO & CIDADE & MATHEUS PARDAL, IGOR COIMBRA, RICARDSON RICARDO, \\
\hline 2019 & PROJETAR.ORG - 31 & PARQUE & CIDADE & GRAZIELA BOTELHO E VICTOR DUARTE \\
\hline 2019 & PROJETAR.ORG - 32 & MOBILIÁRIO URBANO & CIDADE & $\begin{array}{c}\text { STEFANIE CAMARGO, CINTHYA YUKARI, GABRIELA SILVA, NADIA } \\
\text { MARQUES, NÁJLA PIRES }\end{array}$ \\
\hline 2020 & OPERA PRIMA & INFRAESTRUTURA & TERRITÓRIO & MATHEUS PARDAL \\
\hline 2020 & OPERA PRIMA & INFRAESTRUTURA & TERRITÓRIO & MANOEL RICARDO \\
\hline
\end{tabular}

RESUMO

\begin{tabular}{c|c|c|c|c|c|c|c|c}
\hline \multirow{2}{*}{ TEMA } & HABITAÇÃO & $\begin{array}{c}15 \\
45.5 \%\end{array}$ & EDUCAÇÃO E CULTURA & $\begin{array}{c}8 \\
24.4 \%\end{array}$ & INFRAESTRUTURA & $\begin{array}{c}7 \\
21.2 \%\end{array}$ & $\begin{array}{c}3 \\
\text { MEIO AMBIENTE }\end{array}$ & \begin{tabular}{c}
$9.1 \%$ \\
\hline \multirow{2}{*}{ ESCALA }
\end{tabular} \\
\hline
\end{tabular}

TAB. 17. Quadro com o resumo das premiações da FAUS em concursos públicos para estudantes. 
Excetuando-se as premiações relacionadas ao Opera Prima, a variação temática dos concursos, no âmbito desse recorte, é baixa. Assim, nota-se maior predominância de trabalhos relacionados à problemática habitacional, que inclusive extrapola a dimensão do edifício se estendendo para a escala da cidade e do território. Nota-se que o tema Habitação ocorre com maior frequência nos anos 1970 e 1980, quando este era um assunto muito discutido nos meios acadêmicos e profissionais. Os temas Educação e Cultura figuram logo em seguida, atrelados a escala do edifício e maior ocorrência no contexto das competições entre trabalhos finais de graduação. Os projetos que tratam das questões de Infraestrutura ${ }^{38}$ merecem destaque por discutir problemas no âmbito urbano e territorial, também ocorrem com mais frequência nos certames para trabalhos finais de graduação. Infraestrutura poderia estar ligada aos temas relacionados ao Meio Ambiente, assunto que vem ganhando espaço, mas que surge discretamente nesse recorte. Resumidamente, pode-se dizer que habitação, cidade e edifício estiveram no centro das discussões dos grupos de alunos da FAUS ao participarem de concursos públicos para estudantes.

Em síntese, apesar de o caráter minoritário e excepcional das circunstâncias de produção e premiação de um trabalho em um concurso não refletir necessariamente o conjunto da produção de uma escola, esses eventos têm contribuído cada vez mais para a "percepção de questões arquitetônicas consideradas relevantes - tanto as percebidas como muito comuns às diversas regiões brasileiras quanto aquelas específicas de cada uma" ${ }^{39}$ Indo além, a partir de uma visão otimista, um trabalho consagrado por um certame público incentiva outros alunos a participarem desses eventos, dessa maneira, pode-se dizer que a vontade e a autonomia de estudantes e professores são responsáveis pelo reconhecimento em nível nacional da produção da FAUS, posicionando a escola como um dos agentes na construção do conhecimento no campo da arquitetura e urbanismo.
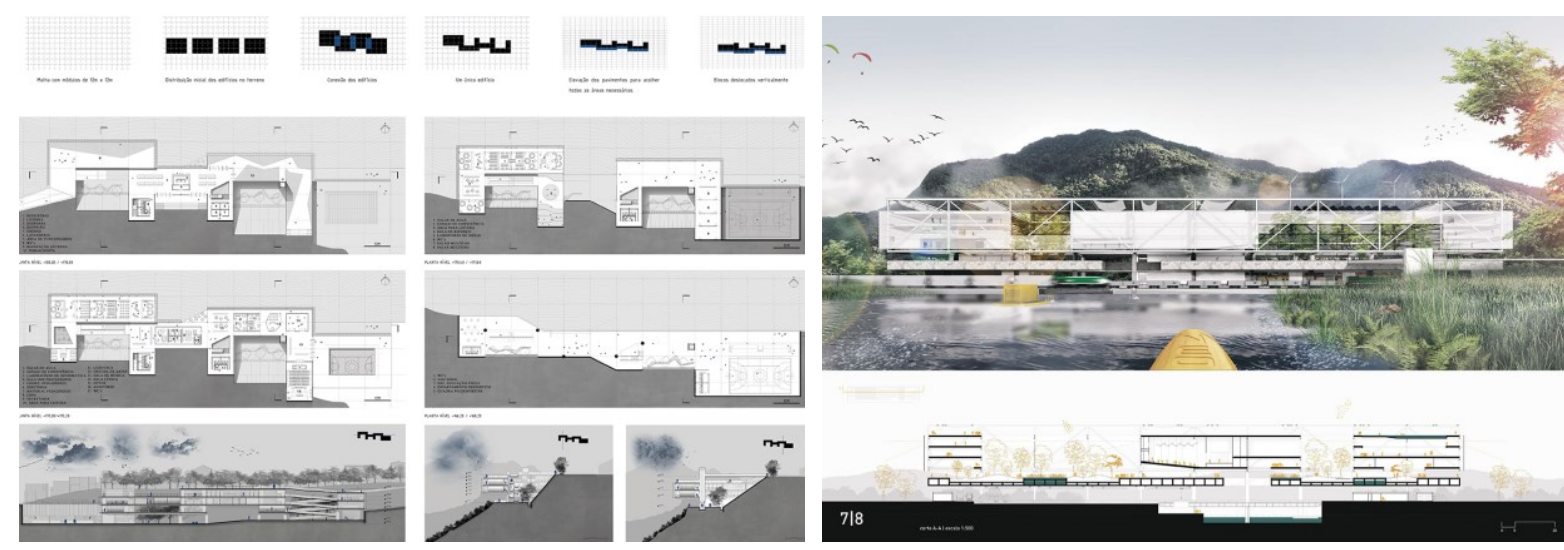

FIG. 114. Concurso Archdaily Melhores TCs de 2018 - De perto e de dentro. Autor Agnes Lucia e Metabolismo Caiçara. Autor: Matheus Pardal.

\footnotetext{
${ }^{38}$ No resumo dos dados, os temas tecnologia e mobilidade foram considerados, para efeito de cálculo, no contexto da Infraestrutura.

${ }^{39}$ ARCIPRESTE, C. M. Op. cit. pp. 238-239.
} 


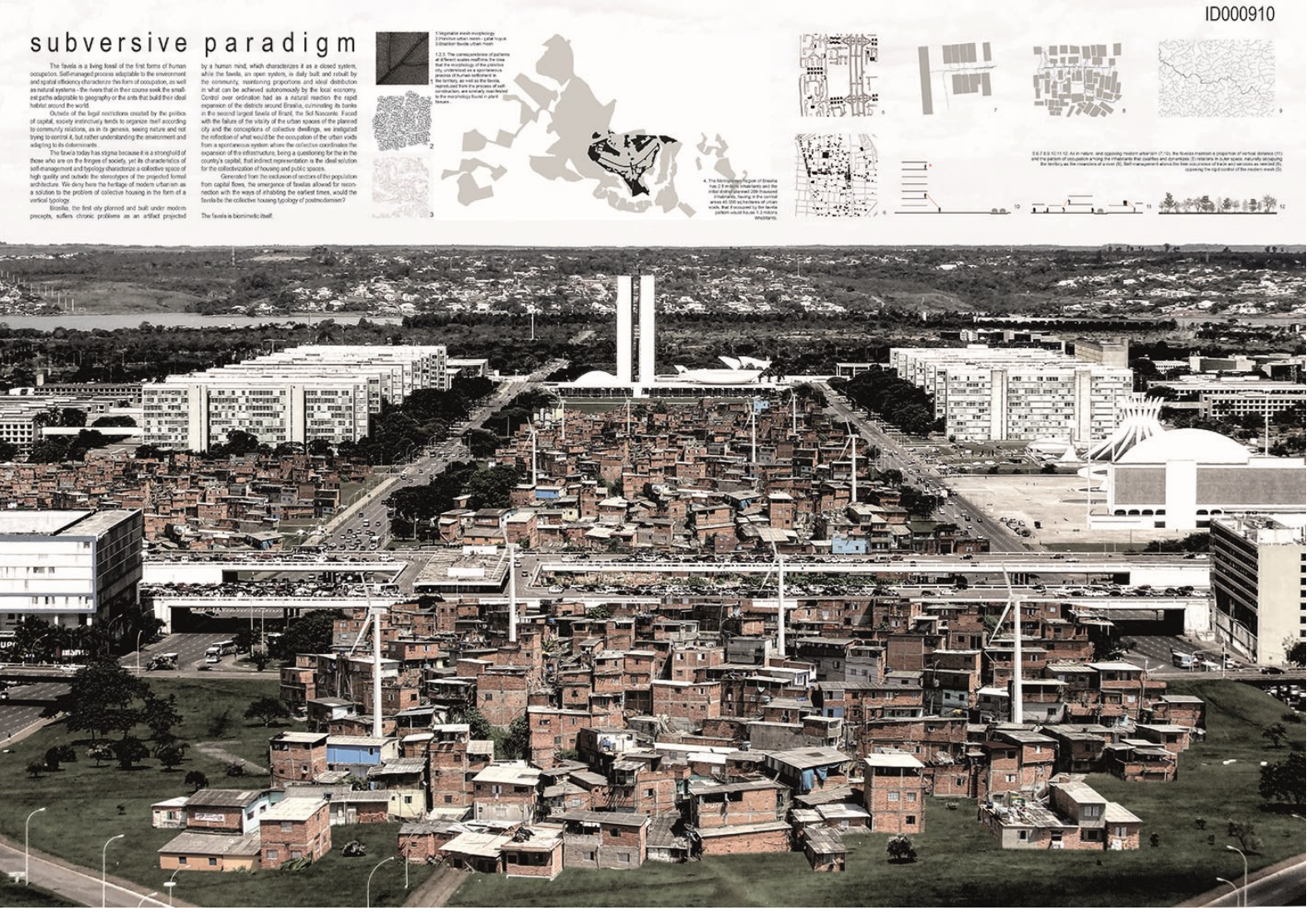

FIG. 115. Biomimetic $24 h$ competition. Autores. Igor Augusto Almeida, Matheus Pardal, Thiago Zati e Carolina Pereira. 


\title{
Devolução caiçara
}

\begin{abstract}
Na medida em que estamos trabalhando e que nossas pranchetas estão ocupadas, cada traço que fazemos significa trabalho para bastante gente. São os materiais que se usa, é a mão de obra empregada, o transporte necessário, a indústria ativada, coisas assim. Nosso trabalho é de ponta. Quando desenhamos dois traços, isso ativa toda uma população. É necessária a consciência do desdobramento dos mesmos. É um dos aspectos do nosso trabalho. ${ }^{40}$
\end{abstract}

Conhecer ou reconhecer o caráter do corpo docente de uma escola possibilita um melhor entendimento da dimensão pedagógica aplicada no decurso de suas atividades de ensino, pesquisa e extensão. Nessa mesma direção, conhecer ou reconhecer o caráter do corpo discente e, mais especificamente, o perfil do seu egresso, oferece a oportunidade de observar a dimensão extensiva do curso para a sociedade e sua relevância para a produção profissional e acadêmica em termos locais, regionais e mesmo nacionais. Em 47 anos de atividades a FAUS formou um total de 2.835 arquitetos, através de 64 turmas, sendo 1.637 mulheres e 1.198 homens e, ao afirmar que o Projeto Pedagógico e Institucional de uma escola é a sua identidade e que o perfil do egresso é o seu objetivo, interessa verificar sua estrutura curricular e estratégias pedagógicas utilizadas para consecução desses propósitos.

Para tanto, além da pesquisa bibliográfica e documental nas bibliotecas e arquivos da Universidade Católica de Santos, foi desenvolvido um questionário com o objetivo de mapear o maior número possível de arquitetos egressos da FAUS. Em linhas gerais, saber quem são, se atuam na área, quais eram suas cidades de origem no momento da matrícula na escola e, posteriormente, quais as cidades em que trabalham ou foram trabalhar. Averiguar se atuam em agências públicas ou privadas, quais são as ênfases de atuação profissional e se continuaram no meio acadêmico, em cursos de pósgraduação ou lecionando, dentre outros aspectos.

Para elucidar o recorte proposto: reconhecer um determinado grupo de arquitetos através de sua identificação e área de atuação, do ponto de vista metodológico, devido ao seu caráter objetivo e rápido, o questionário foi estruturado na forma de uma enquete. ${ }^{41}$ Nesse sentido, foram estabelecidas quatro áreas de interesse: identificação; atuação profissional; especialização e atuação acadêmica, organizados em um formulário digital. ${ }^{42}$ Quanto ao processo de coleta dos dados, para

\footnotetext{
${ }^{40}$ SANOVICZ, Abrahão. A pesquisa na área de projeto. Apud. SILVA, Helena A. Ayoub. Abrahão Sanovics: o projeto como pesquisa. 2004 610p. Tese (Doutorado em arquitetura e urbanismo) - Faculdade de Arquitetura e Urbanismo da Universidade de São Paulo. São Paulo, 2004. pp. 94-97.

${ }^{41}$ A descrição da metodologia utilizada nessa enquete, encontra-se disponível no Apêndice deste trabalho. BERNSTEIN, Any; ROITMAN, Riva. O que você precisa saber para realizar uma enquete. In Revista Educação Pública, Edição no 07. mar. 2016. Disponível em: <http://educacaopublica.cederj.edu.br/revista/artigos/o-que-voce-precisa-saber-para-realizar-uma-enquete>. Acesso em: 22 nov. 2017.

${ }^{42}$ Foi utilizado um sistema digital disponibilizado gratuitamente pela empresa Google Inc. Formuladas as questões, o aplicativo gerou um link que pôde ser postado em redes sociais e grupos específicos de ex-alunos da FAUS na internet. O formulário ficou disponível na internet do dia 09 de fevereiro de 2017 até o dia 09 de maio 2017. Disponível em: <https://www.google.com/intl/pt-BR/forms/about/>. Acesso em: 12 dez. 2016.
} 
evitar distorções com a seleção de uma determinada população, o formulário foi disponibilizado em comunidades de ex-alunos da FAUS existentes em redes sociais na internet. Desse modo, a decisão de responder a enquete foi espontânea, não direcionada.

Seguindo esses parâmetros, foram obtidas 248 respostas, o que corresponde a aproximadamente $10 \%$ do universo possível de entrevistados. Os nomes dos arquitetos foram tabulados e, para evitar o comprometimento dos resultados, a lista gerada foi comparada com os livros para lavratura dos termos de colação de grau da FAUS. Após essa ação, foram consideradas válidas 232 respostas dos 248 totais, pois 16 nomes não foram encontrados nos livros de registro da escola. Todas as informações foram organizadas em planilhas e fichas e, após o seu processamento, foram gerados gráficos e mapas para sua leitura.

Pois bem, dos arquitetos que responderam à enquete cerca de $87 \%$ atuam na área de arquitetura e urbanismo, os demais ou estão aposentados ou nunca atuaram no campo. No que se refere ao ano de conclusão do curso, a maior parte das respostas obtidas são de alunos formados nos anos 1980, 2000 e 2010. Os estudantes pioneiros, formados na década de 1970, aparecem em seguida a esse grupo, talvez devido à sua baixa presença nas redes sociais da internet, mas por outro lado e curiosamente, os formandos da década de 1990 foram os que menos demonstraram interesse no assunto investigado. Esse fato pode indicar, além do caráter proativo de determinadas gerações, um maior e permanente envolvimento político e afetivo com a escola, pois a maior participação foi justamente dos estudantes que viveram ou sofreram influência das crises ocorridas na FAUS em 1972, em 1982 e em 2000.

FIG. 116. Gate, Tuca Reinés, FAUS 1982. 

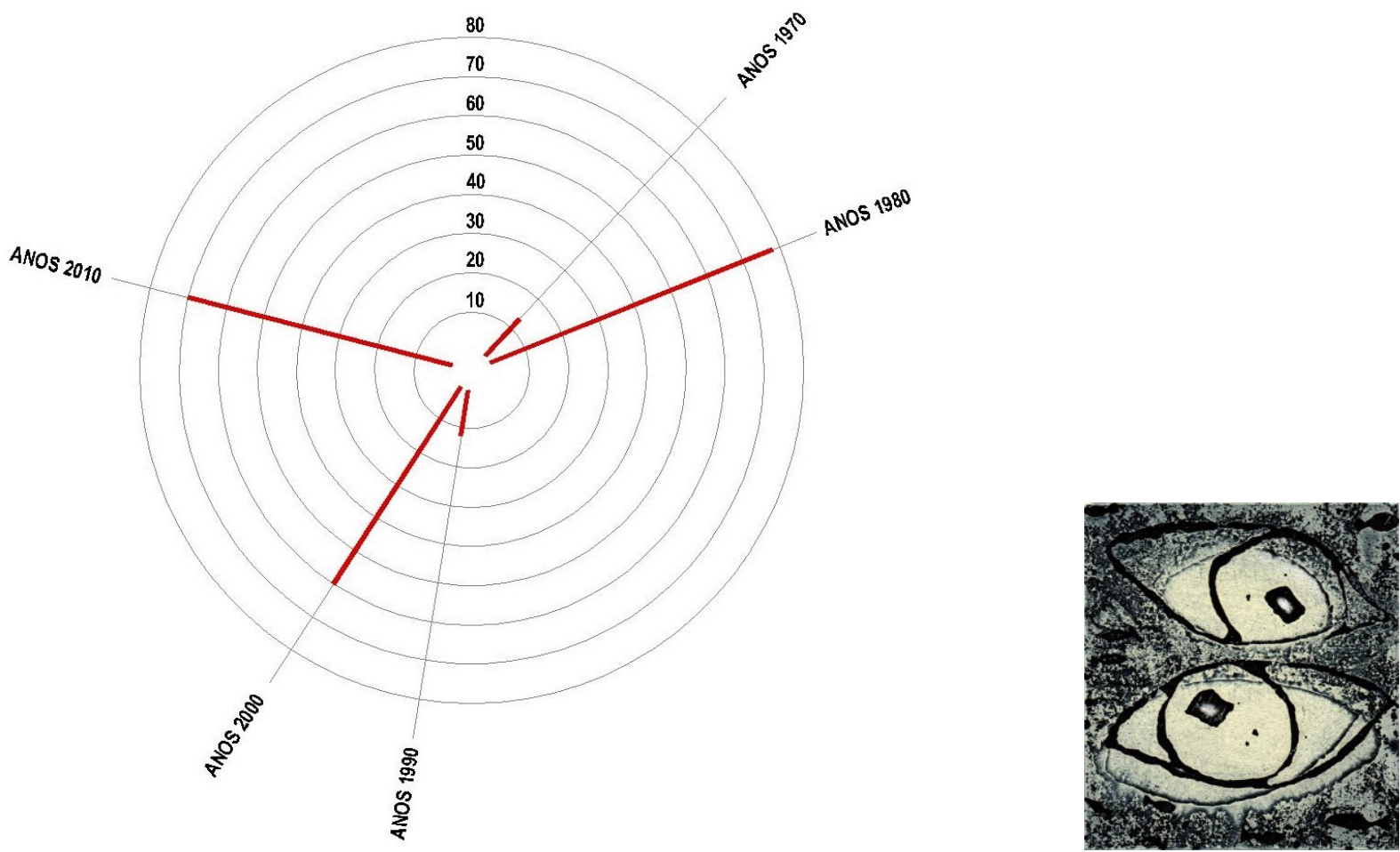

FIG. 117. Ano de formatura. Olhos que viram peixes II 1998, Sheila Goloborotko, FAUS 1981.

Foi constatado que apenas nos primeiros anos de atividade a escola atraiu mais estudantes da capital e interior do estado de São Paulo do que da própria região da baixada. Essa tendência foi diminuindo na medida em que outros cursos de arquitetura foram sendo oferecidos nas outras regiões, ao mesmo tempo em que os quadros profissionais na Região Metropolitana da Baixada Santista eram ampliados. Ao cruzar esse mapa com o gráfico de respostas por ano de formatura, nota-se que esse resultado sofre maior influência dos anos 2000 e 2010, seguidos dos anos 1970 e 1980, aferindo certo equilíbrio de respostas em relação ao período de atividade da FAUS, o que confirma as observações feitas pelos estudantes e professores mais antigos da escola.

A arquitetura, por ser uma atividade intimamente ligada a fatores econômicos, acaba submetendo esses dados a uma oscilação entre investimentos públicos e investimentos privados. Uma análise mais detida, ao serem cruzados com o recorte temporal, pode situar a relevância da escola para o setor público e para setor privado de acordo com o contexto socioeconômico do país. Tendo isso em vista, foi observado que a iniciativa privada concentra a maior parcela de atuação desses arquitetos, empregados ou com escritórios próprios, com $75 \%$ das respostas. A esfera pública aparece logo em seguida, com uma frequência $18,5 \%$ de representantes, e observa-se uma pequena parte de arquitetos que atuam em ambos os setores, com 6,5\%. 


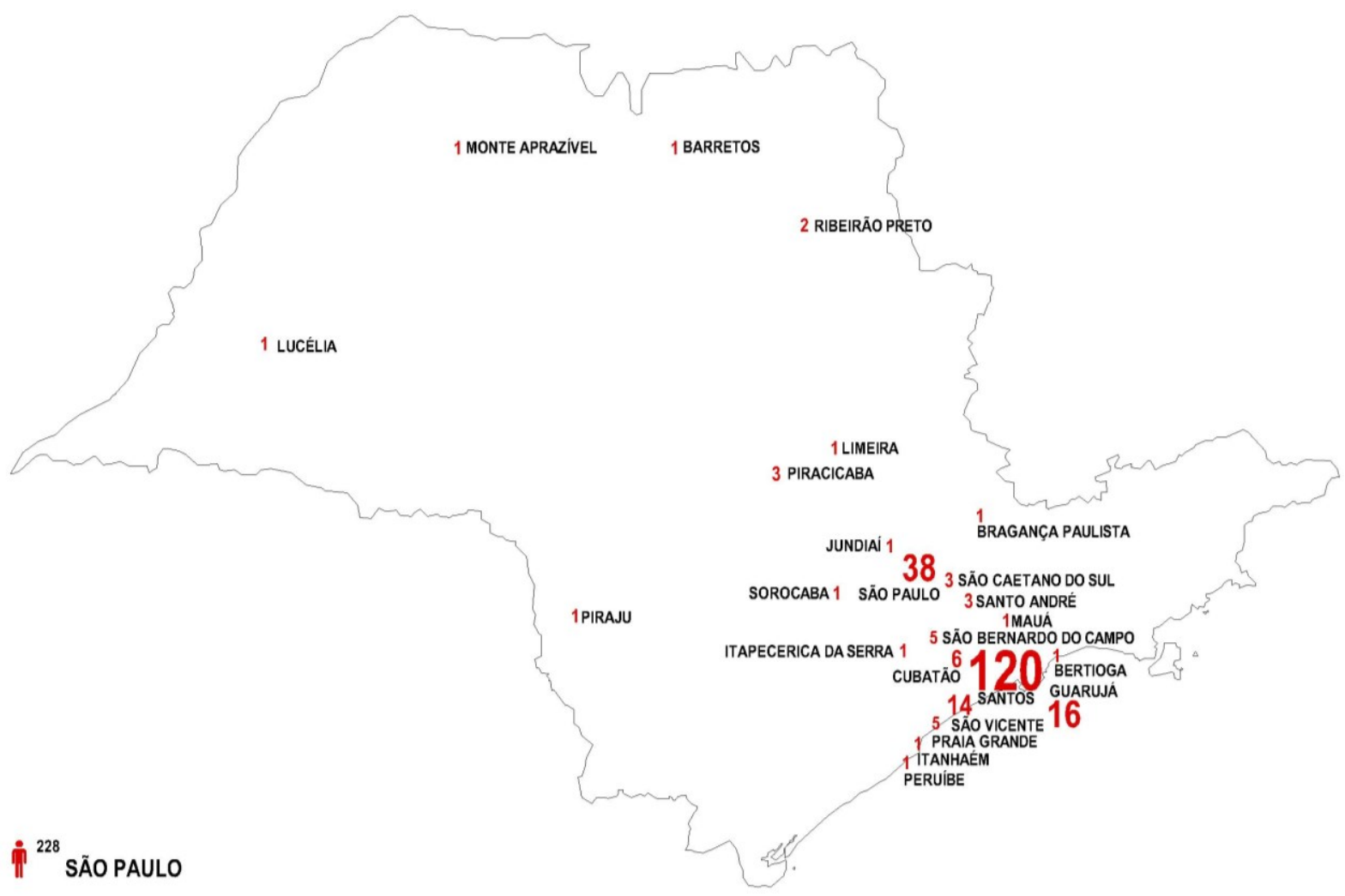

FIG. 118. Cidades de origem dos estudantes no estado de São Paulo ao entrarem na FAUS.
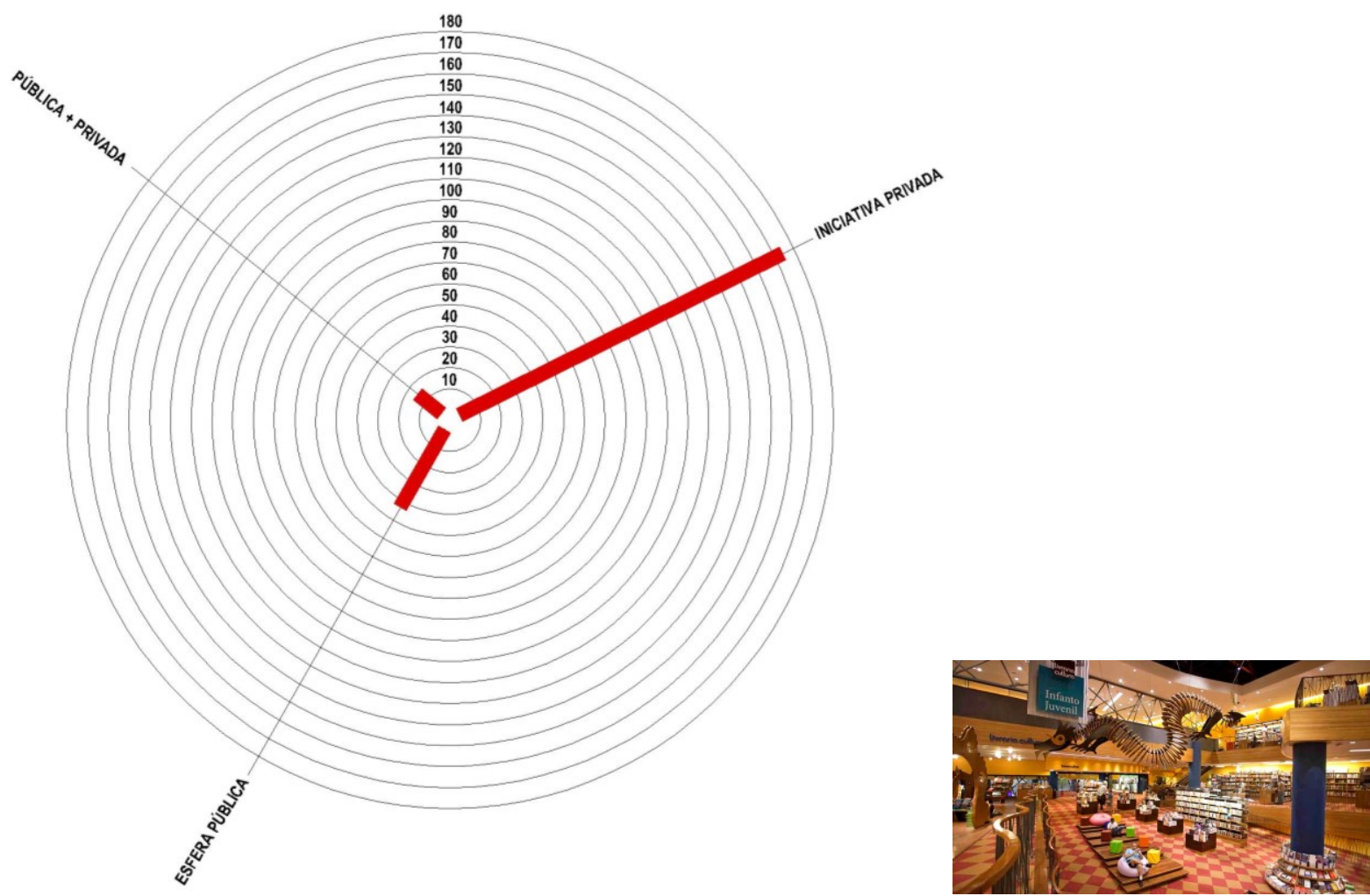

FIG. 119. Área de atuação como arquiteto. Livraria Cultura Conjunto Nacional, São Paulo, 2007. Arquiteto Fernando Brandão, FAUS 1983. 
A última imagem que levamos do Brasil é a de uma bonita livraria, uma catedral de livros, moderna, eficaz, bela. É a Livraria Cultura, está no Conjunto Nacional. É uma livraria para comprar livros, claro, mas também para desfrutar do espectáculo impressionante de tantos títulos organizados de uma forma tão atractiva, como se não fosse um armazém, como se de uma obra de arte se tratasse. A Livraria Cultura é uma obra de arte. $^{43}$

No que se refere aos objetivos desta pesquisa, julgou-se desnecessário subdividir as esferas públicas e privadas em categorias ou setores de atuação, como, por exemplo, setor administrativo, financeiro, educacional, dentre outros. Por outro lado, foi verificado que muitas vezes o arquiteto tem mais de uma frente de atuação profissional, e conhecer a sua ênfase pareceu mais interessante e oportuno. Nesse sentido, para não dissolver a noção de relevo da atuação prioritária do entrevistado, foi estabelecido como critério de leitura dos dados um limite de três áreas de atuação selecionadas por ordem de aparição: 1. Ênfase única, quando a resposta contempla apenas uma área de atuação; 2. Ênfase dupla, quando a resposta contempla duas áreas de atuação e 3. Ênfase tripla, quando a resposta contempla três áreas de atuação.

Assim sendo, das 232 respostas obtidas, 54\% dos entrevistados apontaram como ênfase única de atuação sendo que, desse universo, projeto de edificações representa $64 \%$ da principal atividade desse grupo, seguido de projeto de interiores com $17 \%$ e projeto de urbanismo com $12 \%$. As demais áreas ficaram abaixo de $4 \%$. Merece destaque paisagismo que não obteve nenhuma resposta. A ênfase em duas áreas obteve $25 \%$ das 232 respostas, sendo que projeto de edificação e projeto de interiores tiveram $45 \%$ das respostas, seguidas de projeto de edificações e projeto de urbanismo com $28 \%$ e projeto de interiores e projeto do objeto com $11 \%$. As demais giram em torno de $5 \%$ das respostas. Por último, foi verificado que a ênfase de atuação em até três áreas obteve $14 \%$ das 232 respostas, sendo que a maior frequência de respostas destaca projeto de edificação, projeto de interior e projeto de objeto com $22 \%$ das respostas, seguida pela ênfase tripla em projeto de interiores, projeto do objeto e projeto gráfico com 19\% de representatividade e projeto de edificação, projeto de urbanismo e projeto de interiores, juntamente com projeto de edificações, projeto de interior e projeto de paisagismo, com $12 \%$ cada.
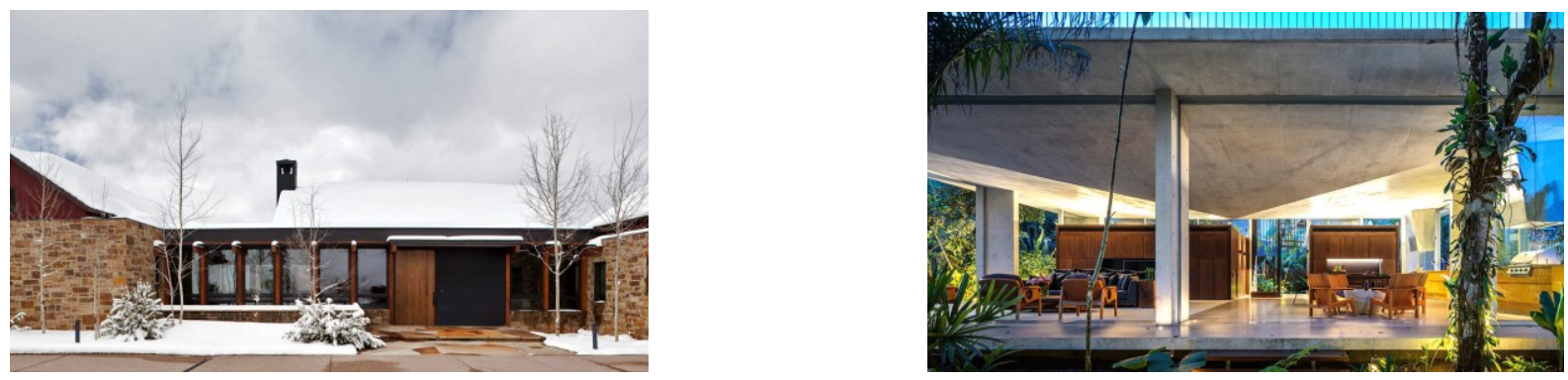

FIG. 120. Casa no Colorado, USA, 2006 e Casa Itamambuca, São Sebastião, 2016. Guilherme Mattos, FAUS 1987.

\footnotetext{
${ }^{43}$ Texto de José Saramago sobre a Livraria Cultura, publicado em 30 de novembro de 2008, pela Fundação José Saramago. Disponível em <https://caderno.josesaramago.org/14359.html> Acesso em: 09 jan. 2020. (sic).
} 


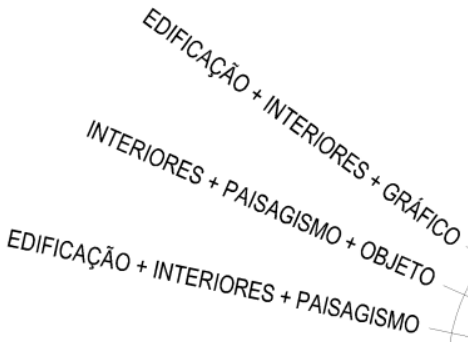

EDIFICAÇÃO + GRÁFICO + OBJETO

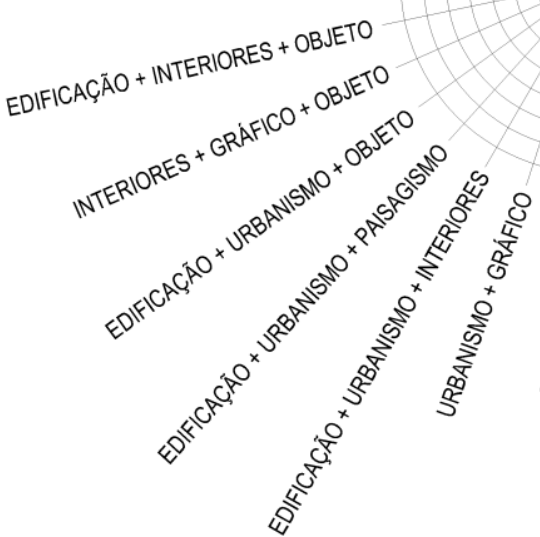

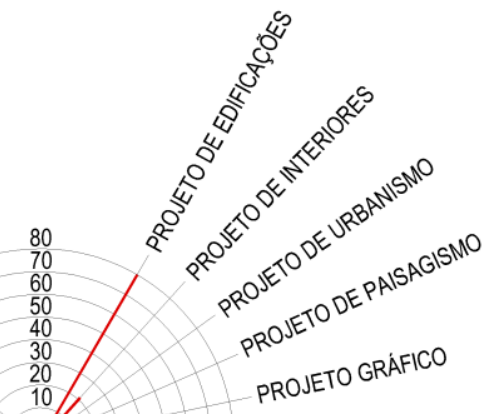

PROJETO DO OBJETO

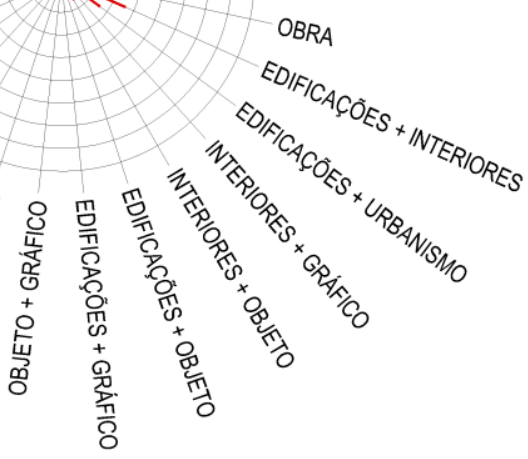

FIG. 121. Ênfase de atuação como arquiteto.

A formação de quadros profissionais para atuação local, regional ou nacional, além de associada a fatores políticos, econômicos e sociais, em linhas legais, encontra-se descrita nos objetivos do projeto pedagógico e do enfoque dominante do curso da FAUS. Questionar em qual cidade ou cidades o egresso trabalha ou trabalhou constituiu um bom instrumento para examinar a abrangência da escola nesse aspecto. Assim sendo, muitos participantes indicaram mais de uma cidade ou estado como lugar de atuação profissional do arquiteto da FAUS e, para a melhor leitura dos dados, foram produzidos três mapas nas escalas: estadual, nacional e internacional.

O mapa do estado de São Paulo revela que, apesar de a FAUS estar localizada em Santos, a cidade de São Paulo, isoladamente, é a que mais oferece ou ofereceu oportunidades de trabalho para seus arquitetos. No entanto, é possível verificar que, quando somadas, as cidades da Baixada Santista concentram maior número de respostas e representam, juntas, um importante campo de atuação para os arquitetos formados no litoral. Nesse cenário, as cidades do ABC Paulista ${ }^{44}$ se revelam como importantes mercados de trabalho, talvez pela localização geográfica, por estarem entre a cidade de Santos e a cidade de São Paulo, configuram um eixo perpendicular de atuação. As cidades com uma ou duas menções podem representar períodos específicos de atuação profissional tanto na esfera pública quanto na esfera privada, nesse sentido, é possível citar atividades relacionadas com o ensino,

\footnotetext{
${ }^{44}$ Região formada inicialmente pelas cidades de Santo André, São Bernardo, São Caetano (ABC original), Mauá, Ribeirão Pires, Rio Grande da Serra e Diadema. 
política (prefeituras e agências públicas) e mercado privado, tais casos também podem ser verificados no mapa do Brasil e no mapa do Mundo a seguir.

Ao cruzar os mapas das cidades de atuação com os mapas de origem dos estudantes da FAUS, devese considerar que muitos estudantes vieram da capital e do interior ou de outros estados para estudar em Santos e que, depois de formados, voltaram para essas cidades para trabalharem. É evidente que, para a obtenção de dados mais precisos, faz-se necessária a elaboração de uma pesquisa mais rigorosa do ponto de vista metodológico, com entrevistas direcionadas e específicas, mas para os objetivos já descritos desta enquete, as informações disponíveis já são relevantes.

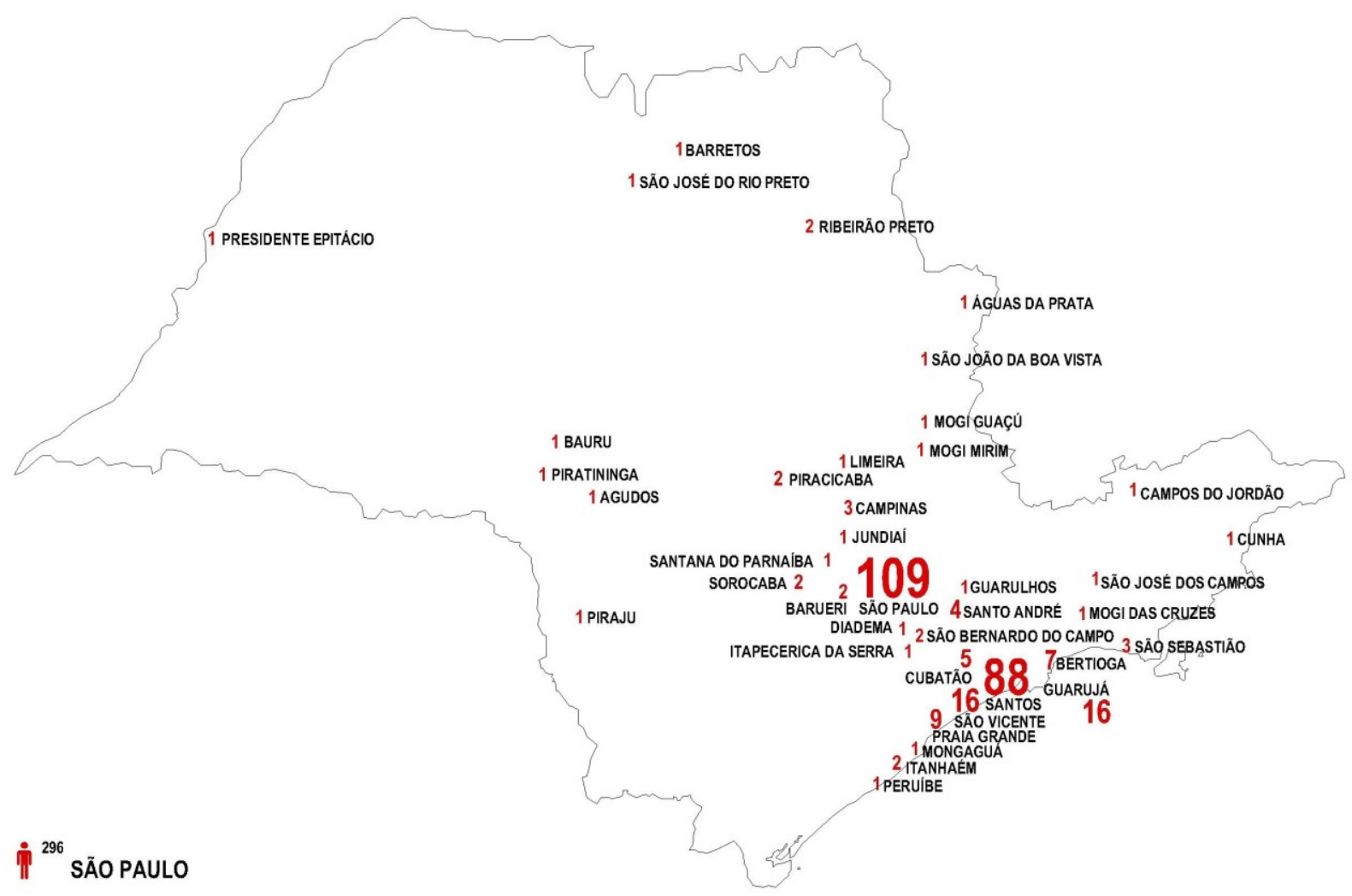

FIG. 122. Cidade em que trabalha ou trabalhou no estado de São Paulo. 

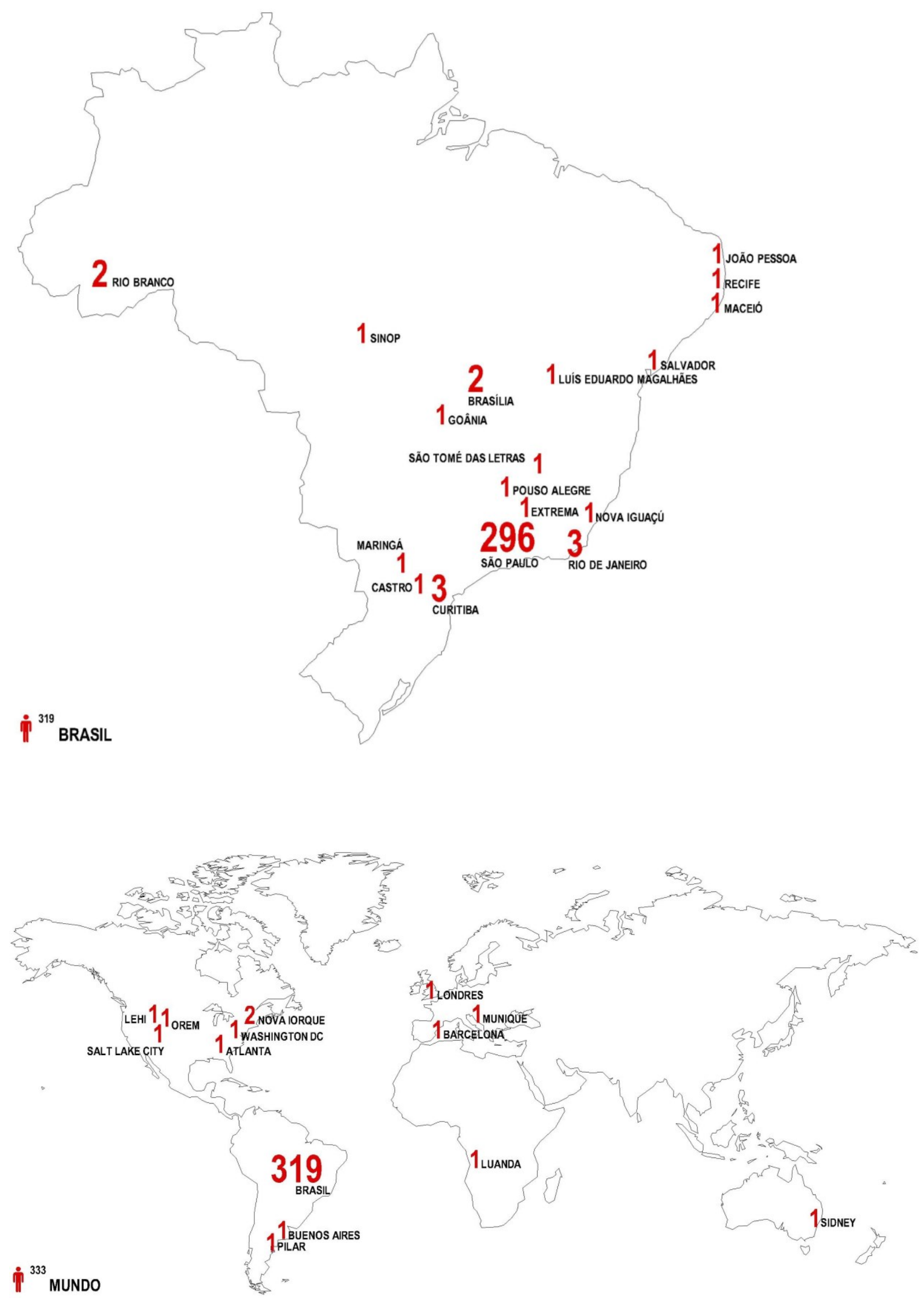

FIG. 123. Cidade em que trabalha ou trabalhou no Brasil e no Mundo. 
Importa saber em que medida a FAUS, ao formar profissionais arquitetos, contribui para o aperfeiçoamento e desenvolvimento profissional de seus egressos, no sentido da especialização profissional e da continuidade e aprofundamento acadêmico do campo da arquitetura e urbanismo, formando arquitetos-professores ou professores-pesquisadores.
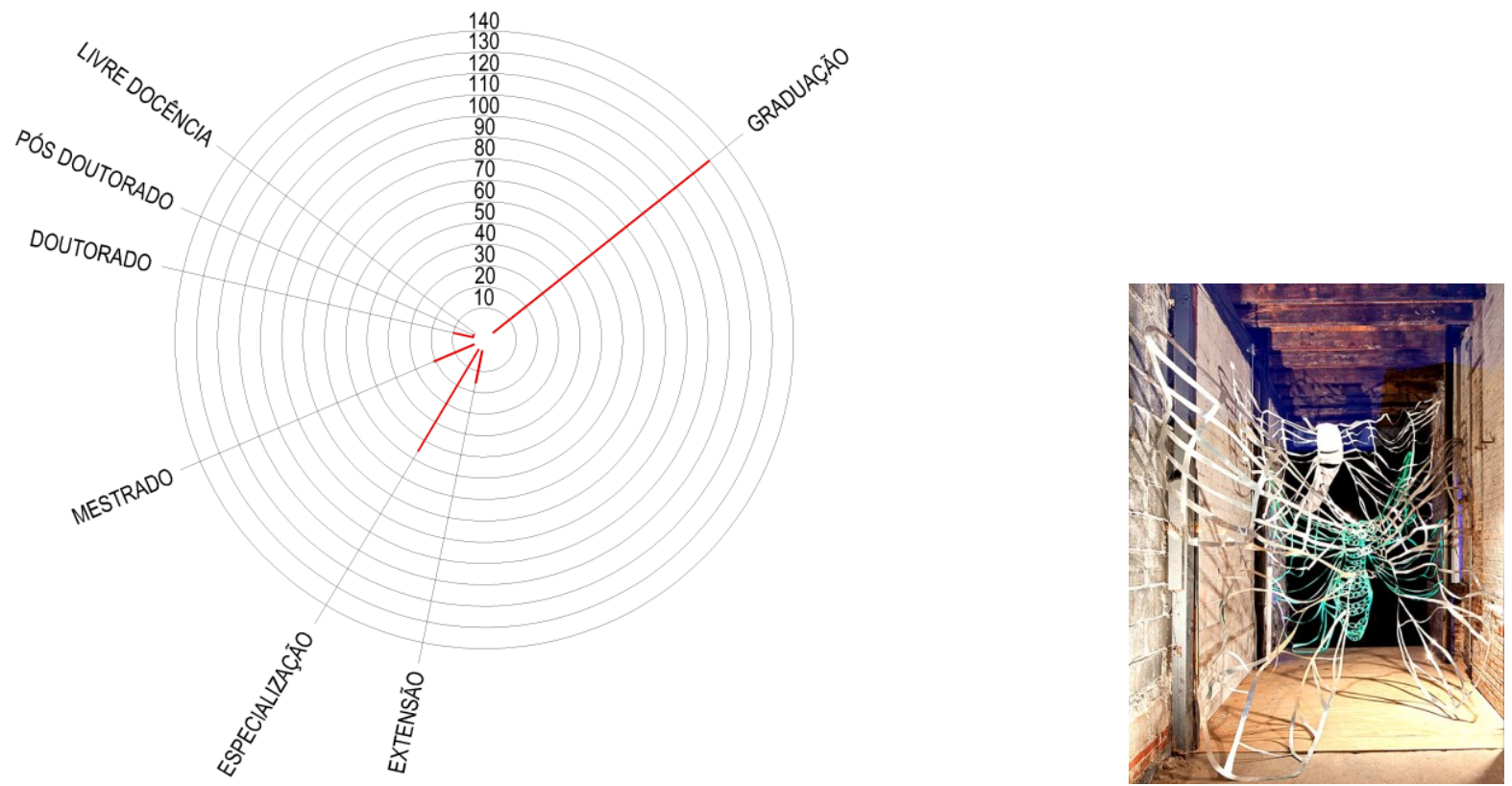

FIG. 124. Formação e especialização acadêmica. Life is hard silk is soft, aluminum paper linoleum, 2011. Sheila Goloborotko, FAUS 1981.

O gráfico acima demonstra que $56 \%$ dos arquitetos concluíram apenas a graduação e atuam ou atuaram como profissionais arquitetos podendo ser, eventualmente, professores de nível médio. A segunda opção, apontada com $24 \%$ das 232 respostas, diz respeito ao incremento da formação a partir de cursos de extensão e especialização profissional, em algumas instituições privadas, autorizam arquitetos nessa condição a lecionarem em nível superior. Os arquitetos com mestrado stricto-sensu, teoricamente habilitados para lecionar em qualquer instituição de ensino superior privada, correspondem a $9 \%$ das 232 respostas obtidas. Observa-se que $4,5 \%$ possuem doutorado stricto-sensu, o que os habilitaria para lecionar em escolas privadas e em instituições públicas, estaduais e federais. Finalmente, foi constatado que apenas $0,40 \%$, o que corresponde a uma das 232 respostas válidas, possui pós-doutorado. Conhecer as Instituições eleitas para o aperfeiçoamento e desenvolvimento desse grupo ajuda na construção identitária do egresso da escola. Nesse sentido, das 35 instituições mencionadas pelos entrevistados, a Universidade de São Paulo deteve 24 menções, seguida pela Universidade Católica de Santos com 19 menções e pela Universidade Santa Cecília com 11 menções. Como pode ser visto no gráfico, ainda que de forma esporádica, outras instituições nacionais e internacionais foram mencionadas. 


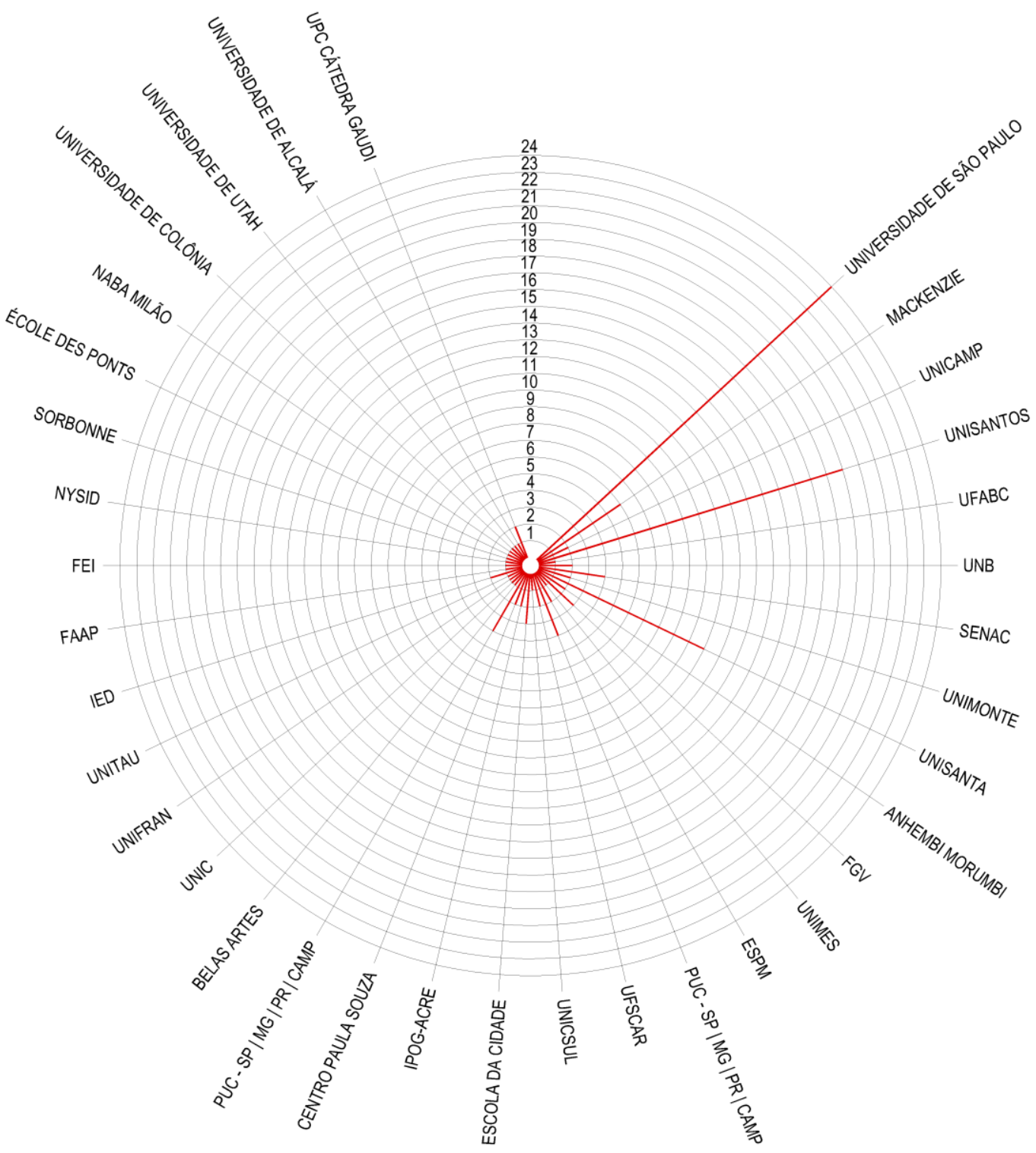

FIG. 125. Instituições de ensino de pós-graduação.

As relações entre ensino e profissão são um pouco mais imbricadas no pensamento do professor Antônio Carlos Barossi. Sua tese demonstra que a atividade de ensinar pode ser pensada como uma ação profissional do arquiteto, cuja construção da arquitetura do ensino resulta de um projeto. Segundo Barossi, essa fusão entre ensino e atividade profissional promove uma ruptura nas conhecidas relações docente-discente ao constatar a vivência universitária do estudante como atuação:

Uma ruptura que considero fundamental na formação do aluno na escola: entre a vivência didática do ensino médio, onde ele é objeto do ensino, e a universidade, na qual ele passa a ser sujeito, onde seu percurso na escola desde o primeiro dia já constrói de fato sua carreira profissional. ${ }^{45}$

${ }^{45}$ BAROSSI, Antônio Carlos. Ensino de Projeto na FAUUSP: Faculdade de Arquitetura e Urbanismo da Universidade de São Paulo. Tese (Doutorado) FAU-USP. São Paulo, 2005. p. 8. 
A afirmação de Barossi reforça a importância do estudante no processo de formação do ambiente acadêmico e, indo além, afirma que a escola já é o lugar da prática profissional. Pode-se dizer, muito simplificadamente, que a experiência de cada professor aliada à capacidade de participação de cada estudante nos processos de ensino-aprendizagem constitui o cerne pedagógico de um curso de arquitetura, conferindo-Ihe identidade própria. Desse modo, para Barossi, a pedagogia ideal está em cada estudante.

Se para Barossi o início da atividade acadêmica do estudante de arquitetura já é o início de sua carreira profissional, qual o ponto de inflexão que transforma o arquiteto em professor? Qual a diferença entre fazer e ensinar arquitetura? É evidente que respostas para questões dessa natureza não são imediatas e precisam de grande esforço metodológico para serem delineadas, o que excede o objetivo deste trabalho. Entretanto, para tornar o raciocínio mais simples e objetivo na leitura dos dados aqui apresentados, pode-se considerar, mesmo que de forma burocrática e legalista, que a especialização acadêmica configura um dos principais meios de capacitar arquitetos para exercerem a atividade docente.

Tendo em vista que a pesquisa acadêmica, para contribuir com o ensino e aperfeiçoamento da profissão, dentre outros fatores econômicos e sociais, pode depender do interesse pessoal e de um projeto institucional. Assim sendo, foi constatado que esse é um ponto a ser refletido pela FAUS, pois do universo de 232 entrevistados, apenas 63 responderam que lecionam ou lecionaram, o que corresponde a $27 \%$ do total. Desses $27 \%$ de arquitetos-professores, 38 respostas apontam a graduação como campo de atuação, 31 respostas o ensino técnico e somente 9 a pós-graduação como atividade docente.

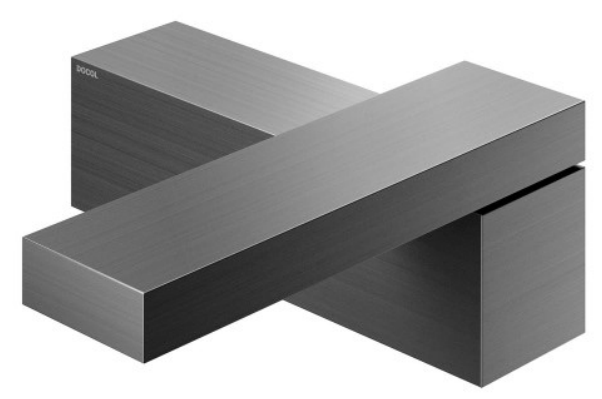




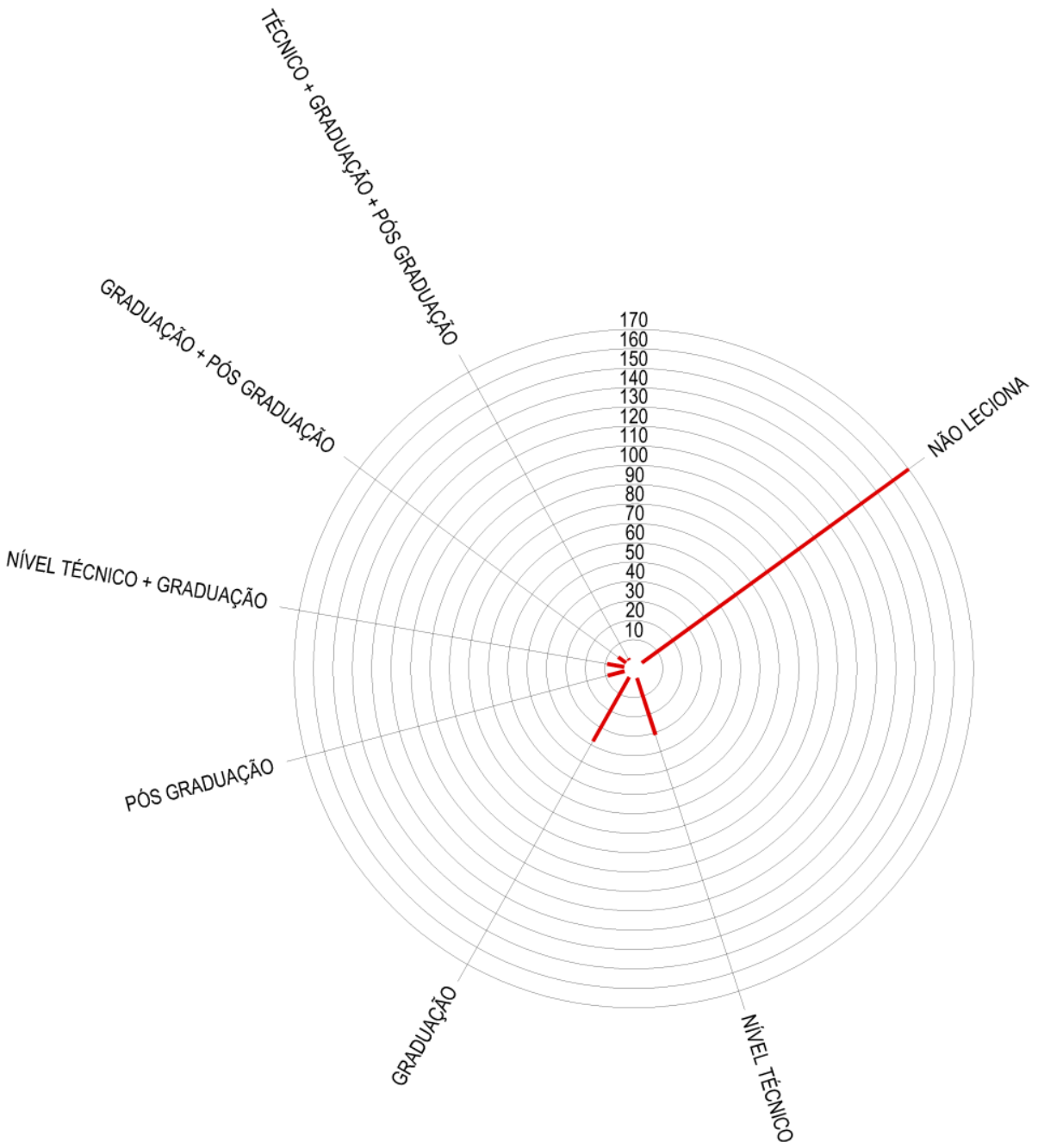

FIG. 127. Categorias de atuação docente.

Ainda quanto a essa questão, assim como na ênfase de atuação profissional, verificou-se que, em alguns casos, o arquiteto-professor tem mais de uma frente de atuação docente, lecionando tanto em nível técnico, nível superior de graduação e pós-graduação. Indo nessa direção, foram computadas nove ocorrências para ensino na graduação e ensino técnico, cinco ocorrências para ensino de graduação e pós-graduação e uma para as três atividades de ensino técnico, graduação e pós-graduação. Os níveis de atuação docente estão relacionados com os níveis de formação do egresso e a relevância da escola na comunidade científica.

FIG. 128. Map-Il inked drypoint on acetate, 2006. Sheila Goloborotko, FAUS 1981.

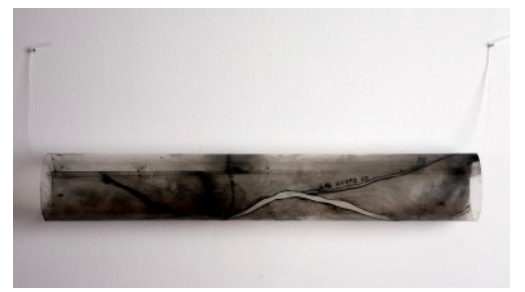




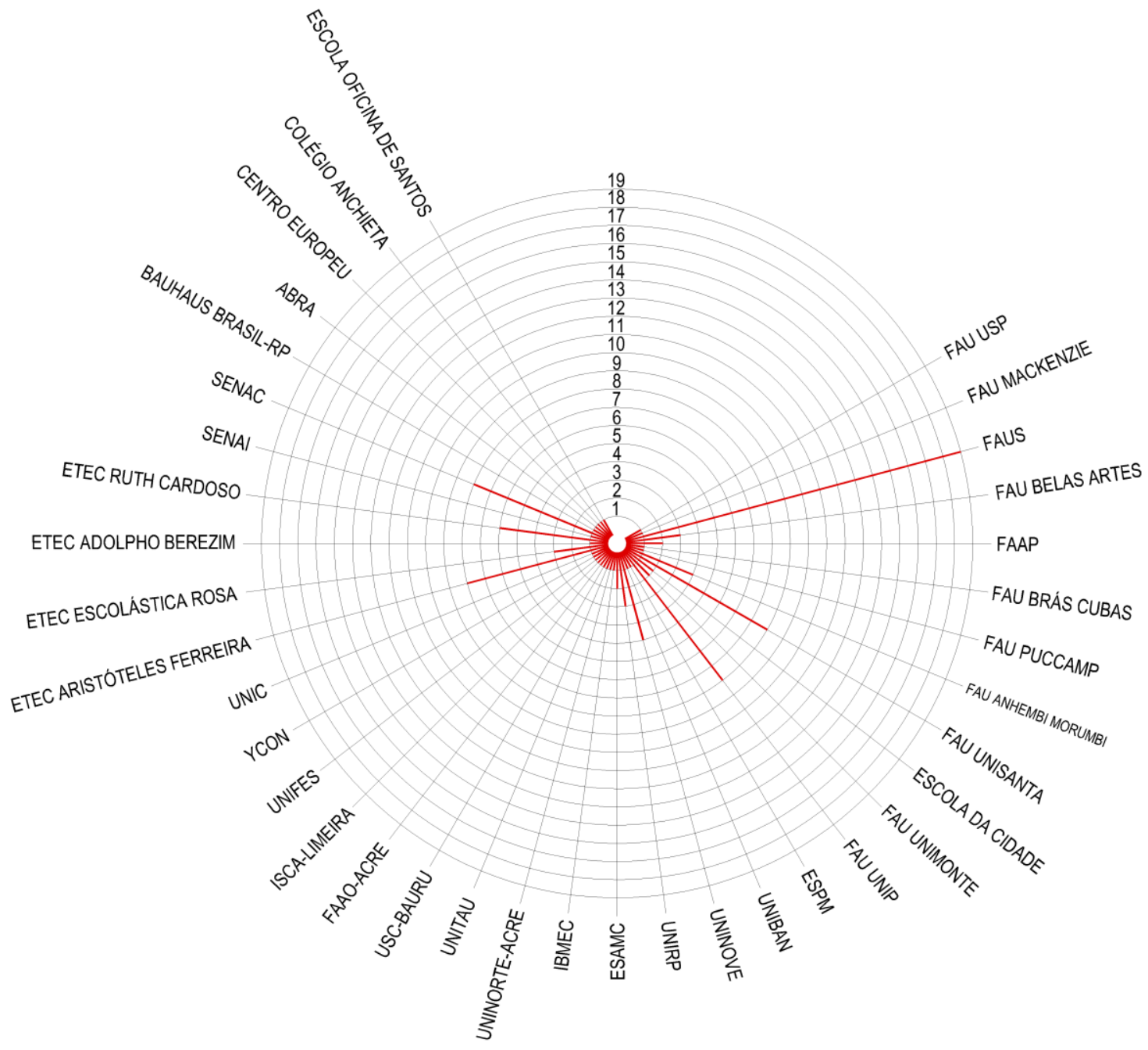

FIG. 129. Instituições de atuação acadêmica.

Foi constatado que, no âmbito do ensino médio as Escolas Técnicas Estaduais (ETECs) Aristóteles Ferreira e Escolástica Rosa, localizadas em Santos, juntamente com a Escola Técnica Estadual (ETEC) Ruth Cardoso, localizada em São Vicente, somam 17 menções, seguidas pelo Serviço Nacional de Aprendizagem Comercial (SENAC) com 8 menções, as demais escolas obtiveram 1 menção.

No que diz respeito às instituições de ensino superior, a FAUS recebeu 19 menções, a Universidade Santa Cecília (UNISANTA) e Universidade Paulista (UNIP) 9 menções cada uma, a Universidade Nove de Julho (UNINOVE) 5 menções, seguida pela Universidade Anhembi Morumbi com 4 indicações, as demais instituições receberam menos de 3 menções. Vale destacar que a Universidade de São Paulo e a Universidade Mackenzie, base de formação da FAUS, receberam apenas uma menção cada.

Em resumo, a iniciativa privada, no contexto da enquete, revelou-se como a principal área de atuação dos arquitetos da FAUS, representada por escritórios próprios, pequenas empresas de construção, funcionários de grandes empresas construtoras ou funcionários de escritórios de arquitetura. Foi constatada a ênfase de atuação em projeto de edificações e, desse modo, como o 
caráter de profissional liberal permite certo nomadismo, a fixação em determinado local pode ser temporária, pois depende do contexto do projeto em elaboração, sendo possível estar em duas ou três cidades praticamente ao mesmo tempo, dentro ou fora do país.

A esfera de atuação pública, apesar de menos representativa do que a iniciativa privada, tem importante papel na formação dos profissionais responsáveis pelo planejamento e gerenciamento de cidades. Vale lembrar mais uma vez que um dos objetivos de Oswaldo Corrêa Gonçalves ao fundar a FAUS era gerar quadros profissionais para a prefeitura de Santos e para a empresa pública Progresso e Desenvolvimento de Santos (PRODESAN).

A pesquisa inicial dos problemas da baixada foi muito importante, os ex-alunos santistas que saíram da faculdade, a maior parte deles acabou entrando para órgãos públicos, para trabalhar na prefeitura em Bertioga, Praia Grande etc., isso é uma grande influência na história da cidade e da região. ${ }^{46}$

Indo nessa direção, a partir do processamento e leitura das informações obtidas com o questionário e como forma de ampliar o horizonte deste trabalho, foi feita uma pesquisa sobre a presença dos arquitetos da FAUS nas prefeituras da Região Metropolitana da Baixada Santista. É evidente que a escolha do universo da RMBS tem como objetivo verificar a questão central desta pesquisa ao investigar a relevância da FAUS na região, e a atuação específica nas prefeituras demonstra o interesse público e urbano dos egressos.

Para tanto, foram analisadas as folhas de pagamento das cidades de Santos, São Vicente, Guarujá, Bertioga, Cubatão, Praia Grande, Mongaguá, Itanhaém e Peruíbe. Nessa análise foi considerado, majoritariamente, o cargo de arquiteto, seguido dos cargos de diretoria de Gestão e Planejamento Urbano, Habitação, Obras, Infraestrutura Urbana e por último o cargo de Fiscal de Obras. Após a contagem dos efetivos, os dados foram cruzados com os livros para lavratura dos termos de colação de grau da FAUS, em seguida foi montado um quadro síntese comparativo entre o total de arquitetos com os arquitetos da FAUS de cada município.
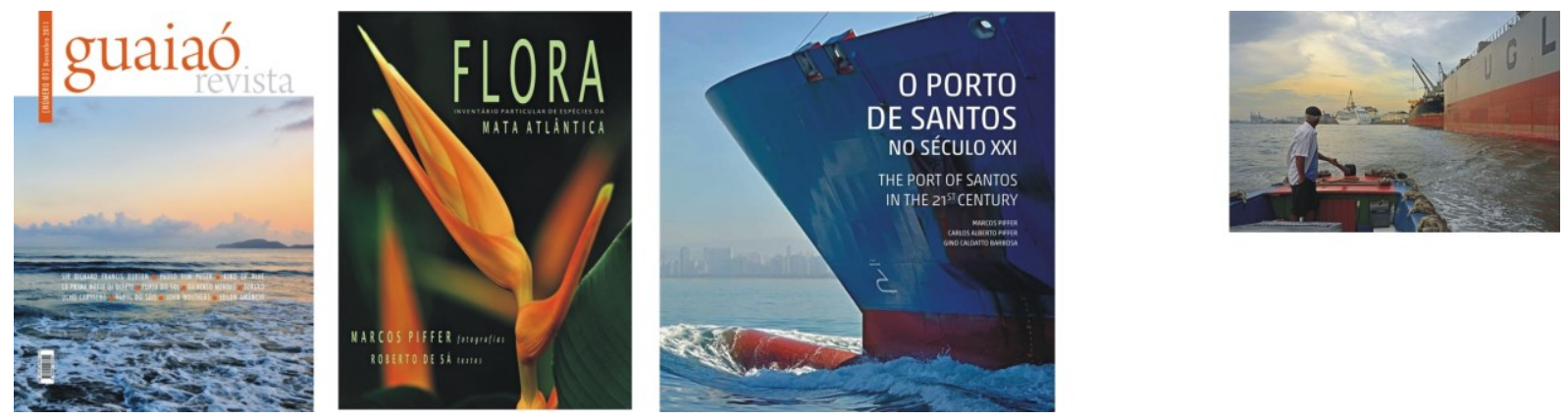

FIG. 130. Revista, livros e fotografia de Marcos Piffer, FAUS 1986.

${ }^{46}$ ZAMBONI, Orpheu. Entrevista com Orpheu Zamboni. São Paulo, 06 jun. 2016. Entrevista a José Maria de Macedo Filho. 


\section{ARQUITETOS DA FAUS NAS PREFEITURAS DA RMBS}

\begin{tabular}{c|c|c} 
MUNICÍPIO & QUADRO DE ARQUITETOS & ARQUITETOS DA FAUS \\
\hline SANTOS & 60 & 43 \\
PRODESAN & 6 & 4 \\
SÃO VICENTE & 10 & 7 \\
GUARUJÁ & 11 & 9 \\
BERTIOGA & 2 & - \\
CUBATÃo & 5 & 2 \\
PRAIA GRANDE & 13 & 4 \\
MONGAGUÁ & NÃO DISPONÍVEL & NÃO DISPONÍVEL \\
ITANHAÉM & 2 & - \\
PERUÍBE & 2 & 2 \\
\hline
\end{tabular}

TAB. 18. Atuação dos arquitetos da FAUS no setor público regional. ${ }^{47}$

Pareceu justo que no quadro síntese a cidade de Santos figurasse junto à PRODESAN, a partir da necessidade percebida por Oswaldo Corrêa de formação de profissionais arquitetos para atuação local. Isto posto, observando o quadro síntese é possível verificar que, dos 111 arquitetos das prefeituras da Região Metropolitana da Baixada Santista, 71 são formados pela FAUS, ou seja, aproximadamente $64 \%$ do universo pesquisado. A cidade de Santos ostenta o maior quadro de arquitetos da região metropolitana, junto à PRODESAN, conta com 66 profissionais, sendo que desses, 47 são formados na FAUS, cerca de $71 \%$ de todo o efetivo.

Expandindo ainda mais o horizonte do questionário, agora do ponto de vista da atuação docente dos arquitetos da FAUS, já que as respostas demonstraram uma tendência maior para a atuação na Região da Baixada Santista, foi necessária uma investigação um pouco mais detalhada junto às instituições que também oferecem o Curso de Arquitetura e Urbanismo em Santos. Ao observar os quadros docentes dessas instituições, constatou-se que os quatro coordenadores de curso e a maioria de seus docentes arquitetos são formados na FAUS, ${ }^{48}$ juntos, somam 83 docentes arquitetos, desses docentes, 51 são formados na FAUS, ou seja, aproximadamente $61 \%$ dos professores arquitetos em atividade na Região.

\section{DOCENTES DAS FACULDADES DE ARQUITETURA DA CIDADE DE SANTOS}

\begin{tabular}{c|c|c|c|c|c} 
INSTITUIÇÃO & FUNDAÇÃO & COORDENADOR & FORMAÇÃO & DOCENTES ARQUITETOS & ARQUITETOS DA FAUS \\
\hline FAUS & 1970 & ARQ. FERNANDA BRITO & FAUS & 30 & 16 \\
FAU-UNISANTA & 1996 & ARQ. NELSON LIMA & FAUS & 22 & 17 \\
FAU-UNIP & 2010 & ARQ. MAURICIO AZENHA & FAUS & 16 & 11 \\
FAU-UNIMONTE & 2012 & ARQ. RICARDO ANDALAFT & FAUS & 11 & 4
\end{tabular}

TAB. 19

47 Dados obtidos no portal da transparência dos municípios estudados que atendem a LEI COMPLEMENTAR NNo 131 , DE 27 DE MAIO DE 2009, disponível em www.santos.sp.gov.br; www.saovicente.sp.gov.br; www.guaruja.sp.gov.br; www.bertioga.sp.gov.br; www.cubatao.sp.gov.br; www.praiagrande.sp.gov.br; www.mongagua.sp.gov.br; www.itanhaem.sp.gov.br e www.peruibe.sp.gov.br. Acessados ao longo do mês de novembro de 2017 e referente à folha de pagamento do ano vigente.

48 Informações obtidas pelo autor no final do ano letivo de 2017, através de entrevistas com os coordenadores de curso das quatro instituições mencionadas. 
O curso de arquitetura da Universidade Santa Cecília, além de contratar professores, usou o modelo pedagógico da FAUS como referência na estruturação do seu próprio projeto pedagógico, constituindo assim, a primeira e legítima ramificação da FAUS no contexto regional. Entretanto, os cursos de arquitetura da Universidade Monte Serrat (UNIMONTE), pertencente à São Judas Universidades, ${ }^{49}$ e o da Universidade Paulista (UNIP), apesar de contar com muitos docentes da FAUS, seus projetos pedagógicos seguem o mesmo padrão para todos os cursos desses grupos empresariais, independentemente do contexto social, lugar, região e território.

\footnotetext{
Junto com o Chico Petracco fizemos outra escola, uma outra experiência: A Anhembi Morumbi. Essa escola começou com todos os professores de Projeto de Santos, toda a turma que deu aulas em Santos, fui o primeiro contratado, depois a Maria Helena Flynn, enfim, era um grupo de Santos que o Chico, por ter dado aula lá, tinha confiança, mas o conceito para montar essa escola era muito calcado no Mackenzie, pois o Chico é um mackenzista histórico..$^{50}$
}

Em 1989, no relatório de entrega do cargo de diretor, dentre uma série de conquistas, o professor Fabio Serrano destacou a importância da escola para o ensino e produção da arquitetura e do urbanismo na Região da Baixada Santista, "a FAUS parece ter completado o ciclo do projeto que a originou e que tinha o objetivo de formar quadros técnicos que dessem suporte para a implantação do processo de planejamento de Santos, instituído com o Plano Diretor Físico de 1968." ${ }^{11}$

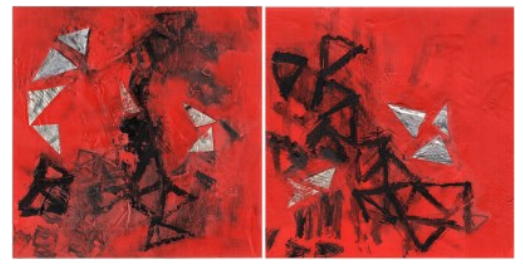

FIG. 131. If-the-storm-was-red1 2014. Sheila Goloborotko, FAUS 1981.

\footnotetext{
${ }^{49}$ SANTA CECÍLIA - Resolução Consun no 15/96 publicada em 26/09/96 Portaria no 1.394/10 publicada em 13/09/10 renovada pela Portaria no 1.099/15 publicada em 30/12/15. Carga horária 3.624 horas. 120 vagas. Período: manhã e noite. UNIP SANTOS - Renovação de Reconhecimento Portaria n. 766 de 21/07/2017 publicada em 24/07/2017. Carga horária 4.083 horas. 120 vagas. Período: manhã e noite. UNIMONTE - Ato de Regulamentação: Resolução CEPE no 08/2012, de 14/03/2012. Carga horária 4.520 horas. 120 vagas. Período: manhã e noite. A UNIMONTE pertencente grupo das Universidades São Judas Tadeu, desde abril de 2018.

${ }^{50}$ ZAMBONI, Orpheu. Entrevista com Orpheu Zamboni. Op. cit.

${ }^{51}$ SERRANO, Fabio Eduardo. Relatório da Diretoria 1986-1989. 4p. Santos, 1989. mimeo. 
Projeto FAUS: Dilatentur spatia veritatis

A epígrafe da Universidade Católica de Santos: Dilatentur Spatia Veritatis, ao ser considerada uma provocação, constitui um pretexto para construir algo que, ao modo de um projeto, possa ser aberto, com múltiplas entradas para reflexões sobre o que poderia ser "ampliar o espaço da verdade" no campo pedagógico da arquitetura e do urbanismo. Nesse sentido, o caráter empírico e ensaístico deste capítulo oferece a possibilidade de que, ao compartilhar experimentos didáticos e metodológicos realizados na FAUS, com sucesso ou não, algum aspecto possa contribuir com outras investigações e práticas de ensino futuras.

Pois bem, conforme o exposto até aqui, pode-se dizer resumidamente que as estratégias ou métodos da prática do projeto são dirigidos por processos de crítica reflexiva para obtenção, através do fazer em atelier, da síntese de conhecimento que, grosso modo, é pautada por noções como partido arquitetônico e composição. Também foi constatado que, ao longo do tempo, esse modelo praticamente não se alterou e, mesmo com o amplo leque de atribuições, o projeto se mantém como principal atividade do arquiteto, tanto na prática profissional quanto no ensino e, simplificando muito, pode-se dizer que sua essência ainda está submetida aos universais vitruvianos utilitas, firmitas e venustas. Atualizando esse debate, Arcipreste afirma que:

\footnotetext{
O quadro deste início de século XXI retrata um lugar do arquiteto ainda marcado por aspectos conceituais e metodológicos que indicam a continuidade de posturas e pensamentos que marcaram a arquitetura moderna em seus momentos de afirmação e consolidação no século XX. Posturas e pensamentos nos quais circulam valores atrelados às imposições dos poderes socioeconômicos contemporâneos, gerando produtos universais e totalizantes. ${ }^{52}$
}

No que diz respeito ao recorte temporal desta pesquisa, a constatação de que os modos de atuação e ensino de arquitetura pouco evoluíram desde as inovações propostas pelos VKhUTEMAS e pela Bauhaus, e oferece outro ponto de reflexão, dessa vez a partir do viés da sociologia da profissão. Garry Stevens, em um esforço para revelar os valores e mecanismos da profissão do arquiteto, afirma que o caráter heterogêneo do campo de atuação profissional repercute diretamente sobre aspectos fundamentais do ensino e da pesquisa em arquitetura e urbanismo. ${ }^{53}$ Com efeito, Stevens, grosso modo, classifica o campo da arquitetura e urbanismo em dois subcampos de atuação profissional.

O primeiro subcampo é descrito como de produção de vanguarda, de natureza simbólica e produção restrita, importando o "prestígio ou o status intelectual, no qual os arquitetos competem para ser

\footnotetext{
${ }^{52}$ ARCIPRESTE, C. M. Op. cit. p. 110.

${ }^{53}$ STEVENS, Garry. O círculo privilegiado: fundamentos sociais da distinção arquitetônica. Brasília: UnB, 2003. pp. 194-200 e passim.
} 
reconhecidos como grandes criadores ou pensadores." ${ }^{54}$ Esse subcampo está intimamente ligado aos meios acadêmicos, por contribuírem na construção de valores, disseminação de ideias, posturas e, portanto, na validação de nomes e obras alinhadas com a produção de vanguarda: "eles sabem que, sem o sistema educacional para conservar sua memória, cairiam no esquecimento." ${ }^{55}$

O segundo subcampo é representado pela produção de mercado e de massa, cujo poder profissional relaciona-se prioritariamente ao sucesso material e econômico. Essa produção cotidiana reproduz mais do que propõe novas formas devido às restrições econômicas em obras voltadas para maior aceitação de público. No mercado de trabalho as dimensões artísticas não deixam de ser consideradas, mas são pautadas por outros mecanismos que em geral estão muito distantes das realizações de vanguarda. Para facilitar o entendimento dos conceitos das oposições estruturadas entre os subcampos da produção arquitetônica, Stevens propõe a seguinte subdivisão:

\begin{tabular}{r|l} 
SUBCAMPO SIMBÓLICO OU DE PRODUÇÃO RESTRITA & SUBCAMPO TEMPORAL OU DE PRODUÇÃO DE MASSA \\
OBJETOS ÚNICOS & MERCADO DE MASSA, PRODUÇÃO EM LARGA ESCALA \\
PROJETISTAS DE RENOME & PROJETISTAS ANÔNIMOS \\
CLIENTES RICOS & CLIENTES COM RECURSOS MÉDIOS \\
CRITÉRIOS ESTÉTICOS E SIMBÓLICOS & CRITÉRIOS ECONÔMICOS E FUNCIONAIS \\
PARA SATISFAZER DEMANDAS SIMBÓLICAS DE CONSUMIDORES & PRODUÇÃO PARA SATISFAZER DEMANDAS ECONÔMICAS DE \\
NO INTERIOR DO CAMPO & CONSUMIDORES EXTERNOS AO CAMPO \\
OBJETIFICAÇÃO NÃO SOCIAL & FUNÇÕES SOCIAIS EXPLÍCITAS
\end{tabular}

TAB. 20. Campos de atuação profissional segundo Garry Stevens.

As considerações do professor Gabriel Bolaffi, de certo modo, vão na mesma esteira dos conceitos de Garry Stevens, em seu texto "Arquitetura do poder e o poder da arquitetura", escrito em 1984, que afirmava que a crise do ensino de arquitetura estava relacionada ao fato da prática profissional do arquiteto depender do poder:

[...] desde que o "boom democratizante" dos anos 1950 facilitou o acesso às carreiras universitárias, discute-se "a crise do ensino da arquitetura", a qual está claro, não é outra coisa senão a crise da própria prática profissional [...] Nesse contexto, o verdadeiro drama das escolas, tal como ela continua a ser concebida, resulta de sua inequívoca dependência do poder. Trata-se infelizmente de uma dependência que os mecanismos predominantes no mercado de trabalho obrigam a transformar-se numa vocação para o poder. O caráter esquizoide da grande maioria das escolas resulta da reintrodução sub-reptícia dessa vocação no ensino. A verdadeira crise no ensino de arquitetura decorre, portanto, da ambiguidade dos objetivos transmitidos aos estudantes. O discurso é liberal, e frequentemente esquerdista, mas os valores estéticos, as opções tecnológicas e os objetivos práticos que se ensina a perseguir correspondem invariavelmente às necessidades do poder, nas várias formas que elas assumem na edificação contemporânea. ${ }^{56}$

\footnotetext{
${ }^{54}$ STEVENS, Garry. Op. cit. p. 107.

${ }^{55}$ Ibid. p. 246.

${ }^{56} \mathrm{O}$ ex-professor da FAUS Gabriel Bolaffi foi sociólogo e professor da FAU-USP. Este texto foi originalmente publicado em Novos Estudos Cebrap, São Paulo no. 9, pp. 47-55, julho de 1984. in BOLAFFI, Gabriel. Arquitetura do poder e o poder da arquitetura. Revista Projeto, no 81, nov. 1985. pp. 144-145. 
A despeito da aspereza, tais considerações remetem esse debate aos dilemas e condições de trabalho da maioria dos arquitetos que, por um lado, percebem a produção de uma arquitetura de exceção e excepcionalidade artística amplamente divulgada e, por outro lado, tem como perspectiva viável de atuação profissional, uma arquitetura cotidiana que atende às demandas comerciais e utilitárias do mercado de trabalho, marcada por um lento processo de evolução. Essa dualidade operativa, além de expor conflitos conceituais internos do campo, de certo modo também se reproduz dentro da escola refletindo, inevitavelmente, na forma como a sociedade enxerga a profissão. Segundo Arcipreste, o ciclo formação - qualificação - prática profissional se retroalimenta timidamente, pois "as escolas estão contribuindo pouco para a construção de outros lugares do arquiteto no mercado ou para o resgate de lugares que já foram seus em tempos passados." ${ }^{57}$

Nessa direção, Sylvia Ficher afirma que desde a Academia Royale de Architecture, criada por Colbert em 1671, o ensino da arquitetura está pautado pela concepção do projeto como obra monumental e de exceção, "qualquer que seja o programa, através de exercícios levados às últimas consequências dos limites literais do papel." ${ }^{58}$ Nesse ponto, interessa destacar que a produção do projeto em arquitetura e urbanismo tem como inerente aspecto metodológico o princípio da referência, ou seja, grosso modo, sua elaboração é acompanhada da pesquisa e observação de aspectos de outras obras, análogas ou não. O problema reside quando no ensino é desconsiderado o contexto no qual foi produzida a obra tomada como referência, por estudantes e professores, nos exercícios de projeto que, ao ser analisada superficialmente resulta, na grande maioria dos casos, na reprodução acrítica de projetos e obras aclamados pela mídia especializada como forma de propagar determinados princípios e valores do campo profissional.

Retornando ao objeto de estudo desta pesquisa, em 2016, a coordenação da FAUS na metade de sua gestão foi substituída devido a problemas no encaminhamento da revisão do Projeto Pedagógico da escola para o período de 2017 a 2021. Assim, ao assumir o cargo e com a justificativa de atender às diretrizes do Ministério da Educação e Cultura (MEC), a nova coordenação iniciou um confuso processo de revisão do projeto pedagógico da FAUS, pautado pelo modelo de competição entre empresas de educação, que tratam o ensino como produto, e centrou esforço na busca de melhores resultados nas avaliações do MEC. ${ }^{59}$

\footnotetext{
57 ARCIPRESTE, C. M. Op. cit. p. 268.

${ }^{58}$ FICHER, Sylvia. Profissão de arquiteto e ensino de arquitetura: mitos e perspectivas. 8p. Faculdade de arquitetura e Urbanismo Universidade de Brasília: jul. 1994. p. 7. mimeo.

${ }^{59}$ Para essas empresas, a preocupação não é educar, mas treinar seus alunos com provas simuladas visando o Exame Nacional de Desempenho dos Estudantes (ENADE). Os bons resultados dessas empresas no ENADE vão diretamente para seus departamentos de publicidade e propaganda para aumentar sua clientela. Paula Bezerra aponta que a possibilidade de investir em universidades e cursos privados tornou o mercado educacional um meio muito atraente e lucrativo para grupos nacionais e internacionais que, desde então, seguem constantemente envolvidos em grandes e milionárias negociações, como a fusão dos gigantes da educação. BEZERRA, Paula. 10 grupos de educação que movimentam as aquisições do setor. Disponível em:< https://exame.abril.com.br/negocios/10-grupos-deeducacao-que-movimentam-as-aquisicoes-do-setor/>. Acesso em: 05 out. 2016.
} 
Paralelamente a esse processo, e em contraponto à essa visão tecnicista e instrumental, a Sequência de Projeto de Arquitetura entendeu que o seu curso deveria retomar as discussões até então produzidas na FAUS de como propiciar ao estudante formas de adquirir conhecimento crítico para solucionar problemas, sem depender quase que totalmente da competência do professor e do que este indica como resposta. Uma das alternativas era considerar, efetivamente, o projeto como pesquisa:

O profissional que dentro da escola obtém, através de técnicas de ensino usuais, apenas a capacidade de aprender a copiar modelos, vai ser rapidamente superado pelo deus computador. O profissional que não vai ser superado pelo deus computador é o profissional da pesquisa. A pesquisa em arquitetura é também uma virtuosidade muito rica no campo profissional. Em todas as profissões o ensino está se organizando para formar profissionais capazes de pesquisar, mais do que repetir receitas para tratamentos que já estão nas bulas dos remédios que os laboratórios oferecem. ${ }^{60}$

O conceito de autonomia pedagógica esteve presente na FAUS desde sua fundação em 1970 e, como visto anteriormente, era defendido pelos Departamentos de Tecnologia e História e pelos docentes ligados ao professor Sergio Ferro. A aceitação desse modelo por muitos estudantes da primeira turma da escola pode ser vista nas alianças estabelecidas entre alunos e professores na crise de 1972. Vale lembrar que esses alunos foram muito ativos no processo de formação da escola e, posteriormente, os principais difusores desses fundamentos garantindo, de certo modo, a continuidade desse processo que, em maior ou menor intensidade, também contribuiu para a formação da identidade da FAUS.

Com efeito, indo na esteira do professor Francisco de Oliveira, Jorge Caron, além das experimentações no âmbito do Trabalho de Curso, propunha práticas de projeto distintas daquelas em que o atelier era entendido como "um locus que se ensinava a fazer uma arquitetura, pelo método de exercícios dominados pela disciplina de projeto, cujas certezas eram inquestionáveis." ${ }^{61} \mathrm{O}$ que para ele não deixava de ser uma contradição, pois segundo o professor, naqueles anos as certezas já estavam se diluindo e inaugurando um mundo permeado de incertezas, cujos valores só poderiam ser negados por discursos totalitários e, como alternativa, propunha que o projeto deveria ser praticado como pesquisa:

Não há um modelo para ensinar, mas um universo a investigar. Nosso atelier seria o atelier da incerteza científica, da investigação. Do reconhecimento e da procura. Da visão contemporânea, referenciada ao hoje. Não mais o atelier do modelo certo, da boa arquitetura, expressão que deixava à margem toda aquela que não participasse de seu elenco de certezas. ${ }^{62}$

\footnotetext{
${ }^{60}$ Fala do professor Francisco de Oliveira na quarta plenária da FAUS em 18 de setembro de 1971, em meio as discussões que anteciparam a crise de 1972. UNIVERSIDADE CATÓLICA DE SANTOS. Registro de "atas plenárias". Santos, 1970. pp. 15-16. (grifo nosso).

${ }^{61}$ Esse discurso é coerente com as posições tomadas pelos professores alinhados ao Grupo Arquitetura Nova, CARON, Jorge. (199-). Reflexões sobre o atelier na EESC-USP. (S.I.: s.n.), Apud. RUGGIERO, Amanda Saba. Jorge Caron: uma trajetória. Op.cit. pp. 82-83.

${ }^{62}$ CARON, Jorge. (199-). Reflexões sobre o atelier na EESC-USP. (S.I.: s.n.), Apud. RUGGIERO, Amanda Saba. Jorge Caron: uma trajetória. Op.cit. pp. 82-83. (grifo nosso). 
Essa proposta apoiava-se na convicção de desvincular o aprendizado da dependência quase total do docente, propondo que o ensino devesse ter caráter emancipatório. Com efeito, pode-se dizer que a autonomia intelectual do estudante desejável diz respeito à sua habilidade de aprendizagem, do progresso em seu próprio ritmo, de permitir reforçar o aprendizado por experiências diversas, adquirir conhecimento em horários e locais flexíveis, além do uso da tecnologia e meios diversos. Para tanto, faz-se necessário entender que a competência do professor em sala de aula não é a de transferir conhecimento, mas de propor "problemas" e dar subsídios à sua resolução, no caso específico das disciplinas projetuais, o próprio processo de elaboração do projeto deve ser entendido como pesquisa. ${ }^{63}$

No campo profissional do arquiteto, como parte da afinidade metodológica, deveria se pensar em critérios mais flexíveis para que no fim do curso o aluno formado pela escola possa optar por uma carreira de projetista, tida como nós conhecemos, ou optar por uma carreira de pesquisador. Um campo que realmente está se abrindo e parece realmente que há possibilidades para a formação de arquitetos, como em qualquer outra profissão. ${ }^{64}$

Indo na mesma direção das considerações do professor Francisco de Oliveira, em 2017, como plano de desenvolvimento da Sequência de Projeto de Arquitetura, foi criado o grupo de pesquisa Superestúdio Transdisciplinar, com as seguintes linhas de investigação: 1. Arquitetura e manifestações artísticas; 2. Arquitetura e patrimônio; 3. Arquitetura e pensamento ambiental; 4. Arquitetura e processos pedagógicos; 5 . Arquitetura e sustentabilidade; 6 . Arquitetura e tecnologia. Além das linhas de pesquisas, e como forma de ampliação do campo cultural dos alunos, ao modo de um fanzine, foi idealizada a revista Canal, cujo conteúdo transcende o universo arquitetônico propondo relações com diversas formas de artes, como o teatro, cinema, literatura, fotografia. Atualmente, o HABITAFAUS é o local das reuniões do Superestúdio.
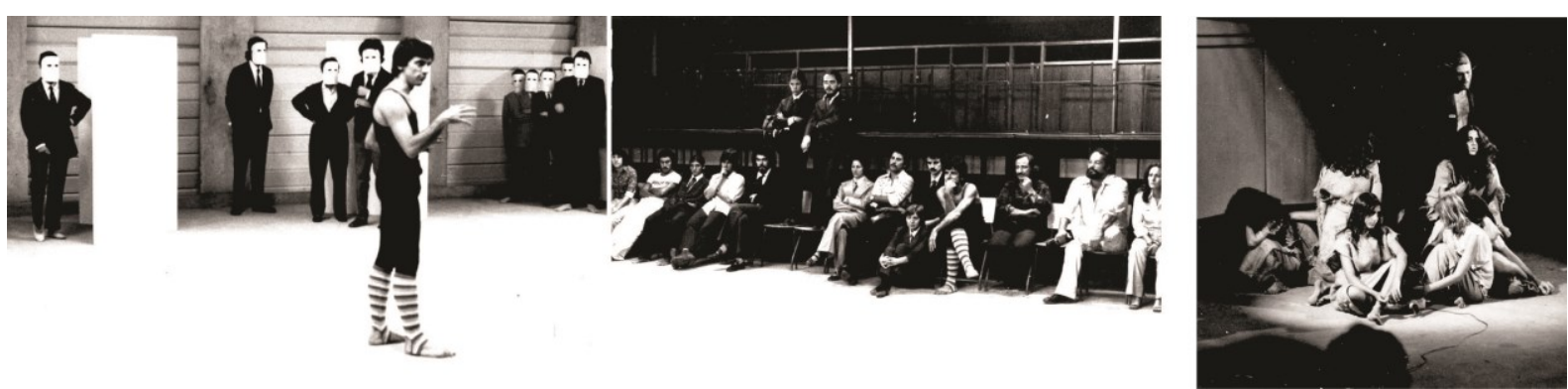

FIG. 132. Ensaio II para o primeiro Show FAUS em 1977, professor Henri Michel Lesbaupin com meias listradas, na plateia os professores Carlos Ferro, Semi Ammar e Gilberto Salvador junto aos alunos todos de paletó e gravata. Abaixo, espetáculo no segundo Show FAUS, 1978. Segundo o professor Fabio Serrano as apresentações teatrais ocorriam no pergolado do prédio.

\footnotetext{
${ }^{63}$ Sobre processos de autonomia ver os seguintes títulos: RANCIÈRE, Jacques. O mestre ignorante: cinco lições sobre a emancipação intelectual. 3.ed. Belo Horizonte: Autêntica Editora, 2011. FREIRE, Paulo. Pedagogia da autonomia: saberes necessários à prática educativa. 52a edição. Rio de Janeiro/São Paulo: Paz e Terra, 2015. GRAEFF, Edgar Albuquerque. Arte e técnica na formação do arquiteto. São Paulo: Nobel, 1995. MARTINEZ, Alfonso c. ensaio sobre projeto. Brasília: Editora UnB, 2000.

${ }^{64}$ Fala do professor Francisco de Oliveira na quarta plenária da FAUS em 18 de setembro de 1971, em meio as discussões que anteciparam a crise de 1972. UNIVERSIDADE CATÓLICA DE SANTOS. Registro de “atas plenárias". Op. cit. pp. 15-16.
} 
O atelier constitui o espaço de desenvolvimento dos trabalhos, o local que concentra a maioria das atividades da escola promovendo maior contato e troca de experiências entre os estudantes dos diversos semestres. O Atelier deve ligar o ensino teórico, artístico e técnico à prática da construção, desde as oficinas experimentais, como o Laboratório de Artes Visuais (LAVUCS) e o Laboratório de Maquetes, até a participação efetiva nos canteiros de construção, desenvolvendo o raciocínio construtivo tridimensional do estudante. ${ }^{65}$ Nesse caso, o Laboratório de Informática deve ter como ênfase o ensino e treinamento em programas de representação gráfica digital.

[...] o ensino no atelier não pode ser feito tornando-se o "fazer o projeto" como simples aplicação de conhecimentos e conceitos elaborados ou assumidos anteriormente. Cada vez mais precisamos tomar o "fazer um projeto" como parte do desenvolvimento do conhecimento, como instrumento desse desenvolvimento. ${ }^{66}$

Interessa dizer que um dos pontos de inflexão desse plano de reestruturação da Sequência de Projeto de Arquitetura foi a constatação da dificuldade enfrentada por alguns estudantes no desenvolvimento individual do Trabalho de Curso. Grosso modo, tratava-se de uma recorrente insuficiência técnica e crítica, tanto na leitura e investigação do lugar, quanto na concepção, produção e representação do projeto, independentemente da escala, programa ou técnica construtiva adotada. Parte desse problema poderia estar relacionado aos exercícios de projeto que, do sexto ao oitavo semestre, eram elaborados na sua totalidade em grupos formados por três, quatro ou cinco alunos. Sabe-se que, diante da demasiada carga de trabalho no final dos semestres, os estudantes estrategicamente se dividem e criam frentes de produção para atender todas as disciplinas, ou seja, alguns fazem os trabalhos de urbanismo e outros os de projeto. É evidente que esse fato não prejudica apenas a Sequência de Projeto, mas todas as demais disciplinas do curso.

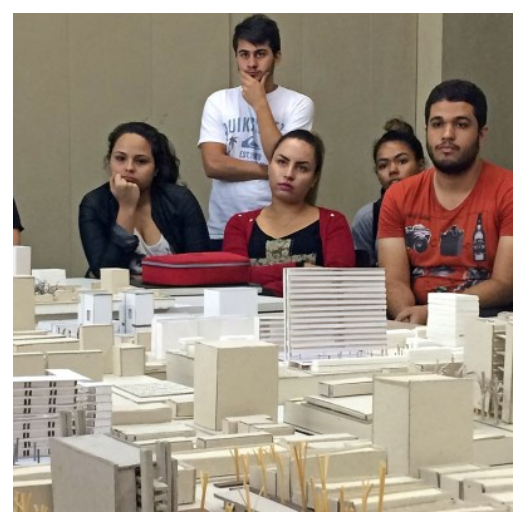

\footnotetext{
${ }^{65}$ Ver o fundamento educacional geral do Plano de Formação de Arquitetos em: GROPIUS, Walter. Bauhaus: novarquitetura. 2a Edição. São Paulo: Perspectiva, 1974. pp. 79-96.

${ }^{66}$ Citação de Rodrigo Lefèvre feita pelo professor Jorge Caron para embasar sua concepção do que deve ser um atelier de projeto em uma escola de arquitetura. O atelier deve ter o caráter de uma disciplina teórico-prática absolutamente multidisciplinar. Não deve se assemelhar a um simulacro de escritórios de projeto. Sendo uma escola, lugar de aprender e pensar arquitetura: o atelier é sua síntese. Lugar de pensar, elaborar e produzir o projeto. RUGGIERO, Amanda Saba. Jorge Caron: uma trajetória. Op. cit. p. 81.
} 
Sabendo que esse problema, longe de ser uma novidade, constitui um entrave histórico em praticamente todas as escolas de arquitetura e não deixa espaço para ingenuidades, qualquer pretensão em propor soluções para a desfragmentação curricular em arquitetura oferece muitos riscos. Assim sendo, interessa mais continuar a exposição e a investigação acerca dos problemas relacionados à integração e interdisciplinaridade de conteúdo e, nesse sentido, retoma-se o discurso do professor Francisco de Oliveira que, apesar de proferido há quase cinquenta anos, continua sendo um problema atual:

Integração é uma palavra mágica pela qual reúne coisas muito divergentes, e que na prática, na reunião de grupos de trabalho e centros de estudos vão aparecer no primeiro momento. O que estou propondo é suprimir a palavra integração, pois isto é uma mistificação [...] o que existe, tanto do ponto de vista do corpo docente como discente, são virtuosidades completamente divergentes. É provável que isso não seja simétrico, ou seja, que esses grupamentos por afinidades metodológicas não terminem criando um problema específico. Na verdade, cria-se um profissional capaz de chegar aos diversos campos de aplicação profissional. ${ }^{67}$

Isto posto, parecia importante desenhar um sistema para ao menos organizar o encadeamento dos assuntos do curso da Sequência de Projeto de Arquitetura, desde o primeiro até o oitavo semestre, de modo que fossem apresentadas metodologias de pesquisa e produção de projeto em um crescente de ações, de tal forma que o estudante pudesse aprender a processar a síntese do conhecimento, através da prática do próprio projeto. Isso incentivou a reflexão do grupo de professores da Sequência, ${ }^{68}$ que trouxe à tona a tríade Projeto, Tecnologia e História, proposta por Vilanova Artigas para a FAU-USP em 1962, não por acaso, pois essa mesma estrutura havia organizado a Sugestão para a FAUS em 1969. Como visto no primeiro capítulo, o documento de 1969 propunha os seguintes universais para iniciar a escola: Comunicação - linguagem do espaço; Desenho industrial - objeto no espaço; Edifício - construção, espaço; Urbanismo - paisagem e espaço. ${ }^{69}$ Esses conceitos foram decantados e reelaborados pela professora Maria Helena Flynn em um texto produzido na ocasião do falecimento de Vilanova Artigas que, examinando o tripé projeto, história e tecnologia, propôs como sistematização do campo operacional do projeto, os seguintes universais: superfície, ${ }^{70}$ objeto, edifício, cidade e território, enriquecendo o material até então pesquisado.

\footnotetext{
${ }^{67}$ Fala do professor Francisco de Oliveira na quarta plenária da FAUS em 18 de setembro de 1971, em meio as discussões que anteciparam a crise de 1972. UNIVERSIDADE CATÓLICA DE SANTOS. Registro de "atas plenárias". Op.cit. pp. 15-16. (grifo nosso).

${ }^{68}$ A primeira fase deste projeto foi elaborada ao longo do segundo semestre de 2016 , as reuniões do grupo de professores ocorreram na FAUS, às quartas-feiras à tarde, envolvendo os seguintes docentes: Apoena Amaral, Carlos Antunes, Fernando Cabral, Gino Caldatto, José Claudio Paneque, José Maria Macedo, Juan Cabello Arribas, Maria Helena Flynn, Moracy Amaral e Ney Caldatto. A segunda fase de desenvolvimento e aplicação conta com os seguintes docentes: Apoena Amaral, Denis Ferri, Denis Joelsons, Fabio Onuki, José Maria Macedo, Juan Cabello Arribas, Marcos Piffer e Sebastian Beck.

${ }^{69}$ Cf. capitulo 1 Entrada, itens 1.3. Contribuição paulistana e 1.4. Uma escola necessária.

${ }^{70}$ Segundo a professora Maria Helena Flynn, o conceito Superfície está relacionado aos trabalhos que tratam do plano bidimensional, como por exemplo, trabalhos de comunicação visual, textos críticos/teóricos, desenhos e pinturas sobre superfícies planas etc.
} 
Indo além, a pesquisa revelou que princípios similares orientaram a organização e encadeamento dos cursos do Departamento de Projeto da FAU-USP até 1997, esse mesmo sistema, embora um pouco mais simplificado, foi instalado na FAUS em 1987 pelo professor Edgar Dente, vigorando até 2016, ou seja, sem atualização por mais de trinta anos. É oportuno dizer que, paralelamente aos trabalhos da Sequência de Projeto, o Núcleo Docente Estruturante (NDE) fazia a revisão e atualização do Projeto Pedagógico da FAUS, e havia constatado que, além de desatualizada, a estrutura do curso de projeto vigente apresentava dissonâncias com o perfil do egresso a ser implantado em 2017.

\begin{tabular}{|c|c|c|}
\hline & PROGRAMA / CONTEUDOS & PLANO DE ENSINO \\
\hline \multirow[t]{4}{*}{ P1-130 } & Entender / Representar o espaço edificado & Desenhos e modelos \\
\hline & Fisico / Material / Real / Construido & Abstratos e reais \\
\hline & & Capacitar totalmente na "representação" \\
\hline & & Saber ver ESPACCO \\
\hline \multirow[t]{4}{*}{ P2-132 } & Entender / Representar o espaço edificado & Desenhar projeto para maquete \\
\hline & Cultural / Urbano / Estetico / Formal & Maquete "histórica" \\
\hline & & Ampliar a cultura arquitetonica \\
\hline & & Saber ver AROUTTETURA \\
\hline \multirow[t]{4}{*}{ P3-134 } & Organizar e conceber o espaço edificado & Mostrar que o edificio é feito com componentes, \\
\hline & Componentes / Construção / Modulação & sistemas, estrutura, geometria etc. \\
\hline & & Desenvolver capacidade analitica. \\
\hline & & Saber ANALISAR \\
\hline \multirow[t]{4}{*}{ P4-136 } & Organizar e conceber o espaço edificado & Mostrar que estes sistemas interagem, \\
\hline & Normas / Padrões / Pré-requisitos & Impor limites e parametros / Areas \& Funções \\
\hline & & Desenvolver capacidade de sintese. \\
\hline & & Saber SINTETIZAR \\
\hline \multirow[t]{4}{*}{ P5-138 } & Exequibilidade / Diversidade & Trabalhar com programas reais \\
\hline & Circunstancia $->$ Programa $->$ Projeto & Enfatizar metodo de trabalho. Explorar, resolver \\
\hline & & Desenvolver metodo de trabalho no aluno \\
\hline & & Saber DISCUTIR \\
\hline \multirow[t]{4}{*}{ P6-140 } & Exequibilidade / Determinação & Trabalhar com situações na qual a solução ar- \\
\hline & Conceito $\rightarrow$ Ideia $\rightarrow>$ Partido & quitetonica não ê evidente ou dada de antemão. \\
\hline & & Desenvolver o conceito de "partido" \\
\hline & & Saber INFERIR \\
\hline \multirow[t]{4}{*}{ P7-142 } & Viabilidade & Cobrar uma solução viavel. Exigir cumprimento de \\
\hline & Urbano / Economico / Social & condicionantes: areas, quantidades, coerencia. \\
\hline & & Desenvolver a urbanidade. \\
\hline & & Saber RESOLVER \\
\hline \multirow[t]{7}{*}{ P8-144 } & Viabilidade & Propor utopias \\
\hline & Humano / Cultural / Etico & Desenvolver a noção de responsabilidade \\
\hline & & social do arquiteto. \\
\hline & & Saber SONHAR \\
\hline & & \\
\hline & & TEMATICA \\
\hline & & EXEMPLO: HABITAÇÃO \\
\hline
\end{tabular}

FIG. 134. Estrutura do Departamento de Projeto que vigorou até 1997 na FAU-USP.

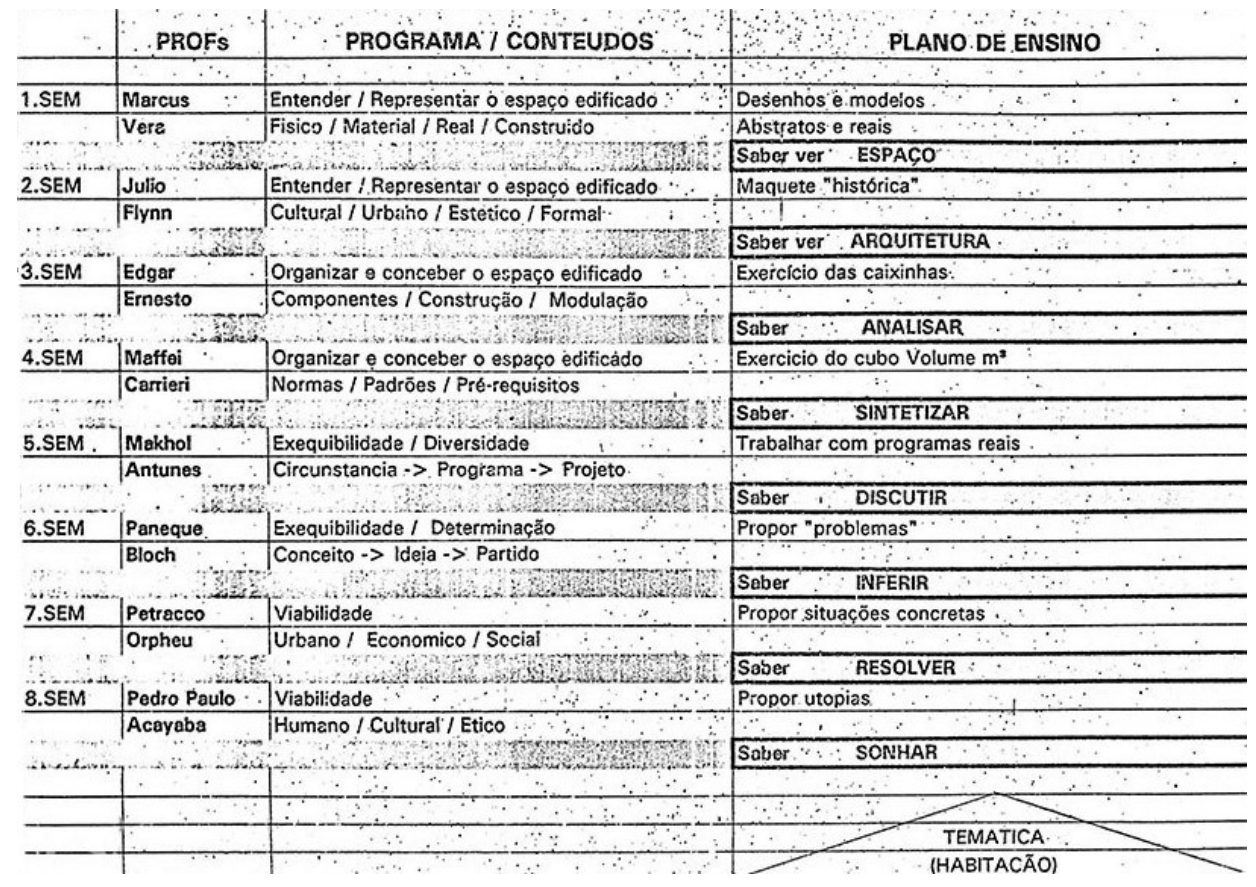

FIG. 135. Estrutura do Departamento de Projeto da FAUS que vigorou de 1987 até 2016. 
Diante disso, as reuniões do grupo foram pautadas pela busca de universais que melhor representassem o perfil desejado para a escola, reforçando e valorizando a identidade do curso como um todo. Desse modo, foram propostos os seguintes universais: Lugar, Conceito, Linguagem, Espaço e Construção.

Contribuir para uma formação de caráter humanista, generalista e crítico quanto à compreensão da realidade atual e ao papel que o futuro profissional deve desempenhar no enfrentamento e na solução dos graves problemas urbanos e territoriais que atingem nossa sociedade [...] Nessa perspectiva, o perfil do egresso envolve uma formação em que estão presentes não só os aspectos interdisciplinares do universo da arquitetura e urbanismo, mas também a abordagem de problemas significativos para a Região Metropolitana da Baixada Santista. Destacam-se a relação porto-cidade e seus conflitos espaciais. ${ }^{71}$

Para cada semestre foi determinada uma ação, um objetivo e uma ênfase, apresentados em uma escala crescente de complexidade, de modo que os temas dos exercícios sejam pretextos para discutir as estratégias e conteúdos fundamentais da disciplina de projeto de arquitetura. Os conceitos Superfície, Objeto, Edifício, Cidade e Território foram considerados referenciais de escala, obedecendo a seguinte ordem de grandeza: pequeno, médio, grande e muito grande. Isso se mostrou pertinente para auxiliar a organização e seriação dos temas a serem problematizados nos cursos de projeto, não obedecendo à mesma ordem crescente, mas implementados de acordo com os universais do projeto pedagógico da sequência.

\begin{tabular}{|c|c|c|c|c|}
\hline \multicolumn{4}{|c|}{ ESTRUTURA UNIVERSAL } & \multirow{3}{*}{$\begin{array}{c}\text { ESTRUTURA TEMÁTICA } \\
\text { SUPERFÍCIE | OBJETO | EDIFÍCIO | CIDADE | TERRITÓRIO } \\
\text { PROGRAMAS }\end{array}$} \\
\hline \multicolumn{4}{|c|}{ LUGAR | CONCEITO | LINGUAGEM | ESPAÇO | CONSTRUÇÃO } & \\
\hline SEM & AÇÃo & OBJETIVO & ÊNFASE & \\
\hline 10 & APROXIMAR & $\begin{array}{l}\text { CONHECER OPERAÇÕES DE } \\
\text { PROJETO }\end{array}$ & ESPAÇO E ATMOSFERA & $\begin{array}{l}\text { INVESTIGAÇÕES GRAMATICAIS DE APROXIMAÇÃO E LEITURA DO } \\
\text { CORPO E ESPAÇO }\end{array}$ \\
\hline 20 & CRITICAR & $\begin{array}{l}\text { APLICAR OPERAÇÕES DE } \\
\text { PROJETO }\end{array}$ & LUGAR E PROGRAMA & DISPOSITIVOS DE CIRCULAÇÃO E ESPAÇOS HABITÁVEIS \\
\hline 30 & MODULAR & DESENVOLVER O PROGRAMA & $\begin{array}{l}\text { RACIOCÍNIO } \\
\text { CONSTRUTIVO }\end{array}$ & EQUIPAMENTOS EDUCACIONAIS E CULTURAIS \\
\hline 40 & VIABILIZAR & RELACIONAR COM A CIDADE & PÚBLICO E PRIVADO & HABITAÇÃO DE ALTA DENSIDADE \\
\hline 50 & MEDIAR & PROPOR O PROGRAMA & CONCEITO E LUGAR & EQUIPAMENTOS PARA O DESENVOLVIMENTO SOCIAL \\
\hline 60 & CONSOLIDAR & INTERVIR NO TERRITÓRIO & RELAÇÃO TERRA-ÁGUA & INFRAESTRUTURA METROPOLITANA, PORTUÁRIA E INDUSTRIAL \\
\hline 70 & ESPECIFICAR & COMPATIBILIZAR DISCIPLINAS & DESENHO E EXECUÇÃO & $\begin{array}{l}\text { PROGRAMAS DE ALTA COMPLEXIDADE PROGRAMÁTICA E } \\
\text { CONSTRUTIVA }\end{array}$ \\
\hline 80 & SINTETIZAR & COEXISTIR NA CIDADE & $\begin{array}{l}\text { PREEXISTÊNCIA E } \\
\text { MEMÓRIA }\end{array}$ & INTERVENÇÕES EM PATRIMÔNIO ARQUITETÔNICO RECONHECIDO \\
\hline
\end{tabular}

TAB. 21. Quadro síntese da reestruturação pedagógica da Sequência de Projeto de Arquitetura de 2017.

\footnotetext{
${ }^{71}$ UNIVERSIDADE CATÓLICA DE SANTOS. Projeto Pedagógico de Curso - Arquitetura e Urbanismo. Op. cit. pp.23-24. (grifo nosso).
} 
Definidos os eixos estruturantes e programáticos de cada ano, as ementas das disciplinas, do primeiro ao oitavo semestre foram revisadas para que seus conteúdos fossem relacionados aos universais propostos e orientadas pela bibliografia única da sequência, elaborada conjuntamente pelo grupo de professores de projeto, evitando repetições ou incoerências na relação teoria e prática. Apesar de parecer contraditório, devido à carga excessiva de trabalho imposta aos alunos dos cursos de arquitetura, a sequência julgou necessário que os exercícios de projeto fossem elaborados individualmente, pois foi constatado que todos os estudantes deveriam conhecer e experimentar, na teoria e na prática, toda a cadeia de decisão e produção da atividade de projeto. Contudo, em etapas específicas do trabalho, é desejável que sejam organizados grupos de pesquisa para proposição coletiva de objetivos, análise de planos e projetos. Além disso, como forma de otimizar o processo de aprendizado, minimizando a sobreposição e acúmulo de tarefas, deve ser feito um esforço para integração entre as demais disciplinas do curso.

Para cada um dos semestres, foram propostos exercícios de projeto relacionados a temas ou questões arquitetônicas específicas e resultantes do cruzamento dos elementos da estrutura universal com os elementos da estrutura temática. O plano de ensino foi organizado em aulas teóricas-expositivas e aulas práticas com o desenvolvimento das atividades individuais de desenho e projeto no atelier. Para auxiliar na formação de repertório do estudante, estabeleceu-se como prática a apresentação de projetos e obras edificadas, análogas ou não ao assunto em curso, com projeção de imagens seguidas de comentários críticos acerca das características conceituais, metodológicas e construtivas dos projetos, além do contexto e biografia dos autores.

No que se refere à operacionalização desse sistema, com o desenvolvimento individual dos trabalhos, e devido à relação de um professor para cada vinte e cinco alunos, as turmas foram divididas em equipes para viabilizar as orientações. Dispondo geralmente de dois professores, os grupos de estudantes seguem um rodízio trocando de orientador a cada semana. A validade desse procedimento é permitir que os professores acompanhem a evolução de todos os alunos, assim como todos os estudantes tenham a oportunidade de receber críticas a partir de pontos de vista distintos, procedimento ideal para que este formule suas respostas a partir do contraditório. Assim, as orientações são coletivas.

Organizados em uma grande mesa, cada estudante apresenta o estado de avanço do seu projeto. Terminada a exposição dos trabalhos do grupo tem início um debate, mediado pelo orientador, com críticas e comentários entre o aluno autor do trabalho em análise e os demais estudantes do grupo. Assim, as aulas práticas e expositivas são fundamentadas na dinâmica de discussão de projetos em grupo, de forma que envolva o estudante na apresentação e crítica-reflexiva conjunta dos projetos expostos. 
FIG. 136. Orientação de Projeto FAUS.
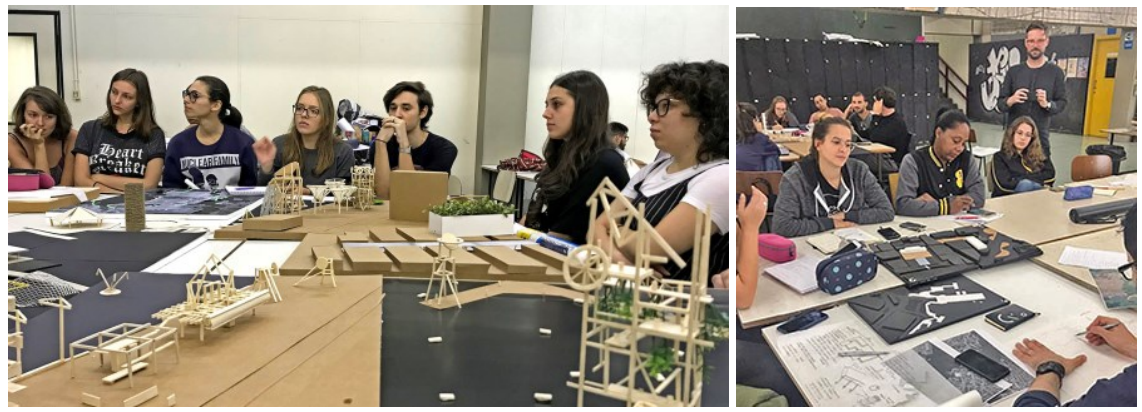

O processo contínuo de produção do trabalho e a participação ativa do estudante constituem a essência da avaliação da sequência de projeto da escola. Foi estabelecido um sistema de entregas intermediárias quinzenais que, ao modo de seminários de orientação e crítica, funcionam como registro do processo de desenvolvimento individual de cada estudante. Os trabalhos expostos são comentados coletivamente e os produtos mínimos de cada entrega, quando somados no final do processo, constituem a totalidade do projeto. Os conteúdos, objetivos, ênfases e produtos de cada entrega são registrados nos planos de ensino e cronogramas de curso entregues aos estudantes no início de cada semestre, não descartando ajustes, feitos com a participação dos alunos.

De maneira geral, e não muito diferente dos procedimentos de avaliação de projeto de outras instituições, como por exemplo da FAU-USP, os itens avaliados nas entregas dos exercícios de projeto de arquitetura na FAUS, em linhas gerais, seguem os seguintes critérios e encadeamento de entrega: 1. Conceituação do projeto: leitura do sítio, definição do programa e implantação; 2. Organização funcional: distribuição do programa, fluxos e circulação; 3. Organização espacial: volumetria e relações espaciais; 4. Raciocínio construtivo: conceito e resolução estrutural e materialidade; 5. Apresentação: comunicação, expressão, linguagem e clareza.

FIG. 137. Avaliação de Projeto na FAUS

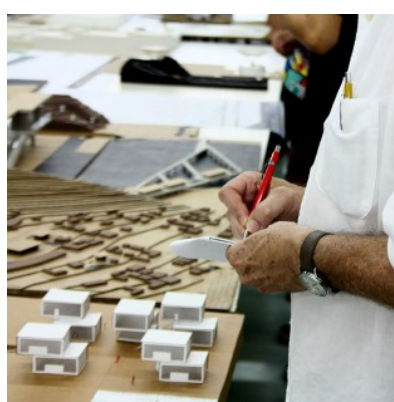

A entrega final, no âmbito de cada curso, é realizada através da exposição de pranchas com o registro gráfico do projeto e de modelos tridimensionais produzidos ao longo do semestre, explicitando o processo de desenvolvimento individual e do conjunto da classe, todo material exposto é comentado coletivamente. No segundo semestre, a avaliação final deve contar com pelo menos um professor do ano subsequente com o objetivo de preparar as estratégias de ensino de acordo com as características das novas turmas. Ao término de cada ano letivo, além das avaliações 
por classe, foi proposta uma última avaliação nomeada pela sequência como Visão de Conjunto Final, trata-se de uma exposição com todos os projetos elaborados pela escola, padronizada com pranchas e maquetes e distribuída nas dependências da FAUS, permitindo o reconhecimento integral da produção da Sequência de Projeto de Arquitetura.

Indo nessa mesma direção, no início de cada ano letivo, a aula inaugural da Sequência destina-se à apresentação da metodologia aplicada e produção do curso no ano anterior, trata-se de uma aula expositiva conjunta do grupo de professores de projeto para toda a faculdade. Nessa ocasião, são apontados objetivos e procedimentos didáticos preparando os alunos para as novas etapas e, ao mesmo tempo, procedendo uma rápida, mas oportuna revisão do que já foi aprendido. Essa preleção é chamada de Visão de Conjunto Inicial.
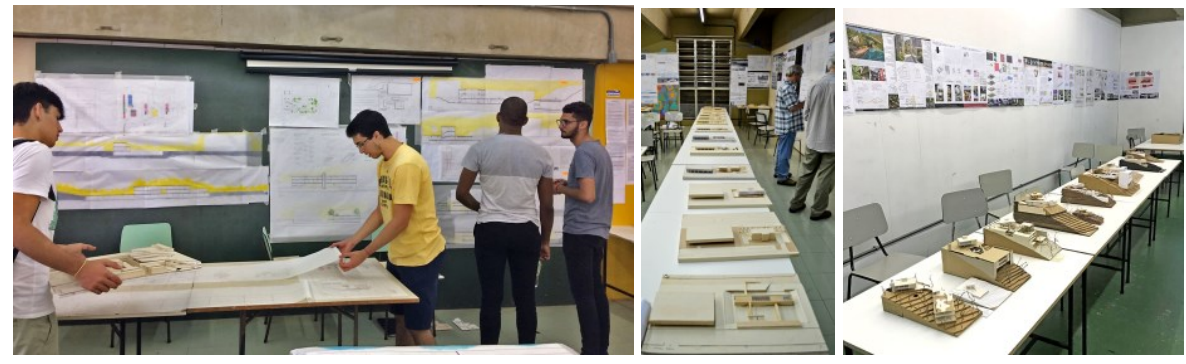

Avaliação de Projeto. FIG. 138.

De maneira semelhante a essa reestruturação da Sequência de Projeto, em 1983 o professor Henri Michel Lesbaupin havia organizado um quadro com os planos de ensino de urbanismo em um esforço para ajustar o conteúdo das disciplinas da sequência para, a partir disso, propor a horizontalização com outras sequências. Passados oito anos, Lesbaupin apresentou o mesmo quadro em 1991, no contexto de um trabalho por ele nomeado: Um Projeto para a FAU-UNISANTOS:

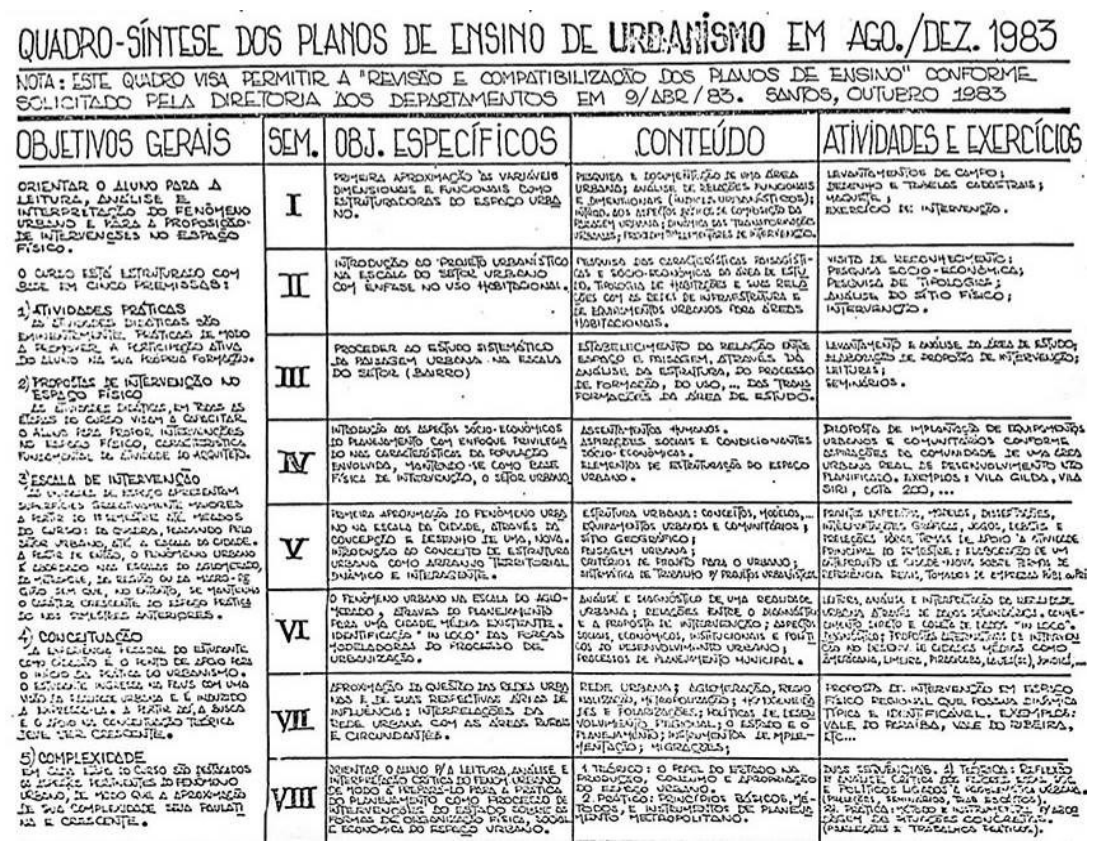

FIG. 139. Planos de ensino da Sequência de Urbanismo em 1983. 
Mesmo diante da grande dificuldade de integração disciplinar, o grupo de projeto propôs um ajuste horizontal com as disciplinas de plástica, objeto, urbanismo e tecnologia, de modo a contribuir para que o estudante processe a síntese entre os conteúdos oferecidos no semestre, aliviando a carga de trabalho, ainda que somente no que se refere à pesquisa.

\section{EMENTAS DAS DISCIPLINAS DAS SEQUÊNCIAS DE PROJETO E TECNOLOGIA}

\begin{tabular}{|c|c|c|c|c|c|}
\hline SEM. & PLÁSTICA & OBJETO & PROJETO & URBANISMO & TECNOLOGIA \\
\hline 10 & $\begin{array}{l}\text { Desenho de observação da } \\
\text { figura humana e da paisagem } \\
\text { urbana a partir da percepção, } \\
\text { pesquisa e desenvolvimento } \\
\text { de conhecimento das } \\
\text { relações do aluno e a relação } \\
\text { de seu corpo com o espaço } \\
\text { em que vive. }\end{array}$ & $\begin{array}{l}\text { Percepção, } \\
\text { representação, projeto } \\
\text { e conceituação de } \\
\text { objetos e de sistemas } \\
\text { de objetos. }\end{array}$ & $\begin{array}{l}\text { Fundamentos de projeto, } \\
\text { percepção do espaço e } \\
\text { atmosferas. Aproximação e } \\
\text { leitura do corpo e espaço no } \\
\text { reconhecimento das } \\
\text { relações volumétricas dos } \\
\text { elementos }\end{array}$ & $\begin{array}{l}\text { Introdução às técnicas de } \\
\text { leitura do espaço urbano e } \\
\text { representação de seus } \\
\text { elementos constituintes, } \\
\text { assim como à análise } \\
\text { problematizada das relações } \\
\text { entre a morfologia e a } \\
\text { qualidade da vida urbana. }\end{array}$ & $\begin{array}{l}\text { Propriedades geométricas de } \\
\text { áreas planas, estudo dos } \\
\text { vetores e dos principais } \\
\text { esforços que atuam em uma } \\
\text { estrutura isostática bi apoiada } \\
\text { bem como suas reações de } \\
\text { apoio. }\end{array}$ \\
\hline 20 & $\begin{array}{l}\text { Conceito de tempo, espaço e } \\
\text { paisagem através do estudo } \\
\text { de pontos referenciais da } \\
\text { cidade. Intensificação do } \\
\text { olhar, desenho de } \\
\text { observação como pesquisa. } \\
\text { Teoria da cor e experimento } \\
\text { de materiais de desenho. }\end{array}$ & $\begin{array}{l}\text { Projeto e aplicação de } \\
\text { objetos e sistemas às } \\
\text { diversas escalas do } \\
\text { ambiente construído, } \\
\text { noções de ergonomia, } \\
\text { espacialidade e } \\
\text { resistência dos } \\
\text { materiais. }\end{array}$ & $\begin{array}{l}\text { Introdução aos processos de } \\
\text { projeto através da sua } \\
\text { análise sistemática, } \\
\text { considerando o lugar e } \\
\text { programas de necessidades } \\
\text { para proposta de partido } \\
\text { arquitetônico. }\end{array}$ & $\begin{array}{l}\text { Introdução às técnicas de } \\
\text { levantamentos, análise e } \\
\text { diagnóstico de uma cidade, } \\
\text { sua interação com o sítio em } \\
\text { que se localiza e com a } \\
\text { sociedade que nela vive. }\end{array}$ & $\begin{array}{l}\text { Estudo do comportamento dos } \\
\text { esforços que atuam sobre os } \\
\text { diversos elementos que } \\
\text { constituem uma estrutura. } \\
\text { Principais tensões de relevância } \\
\text { nas estruturas hipostáticas e a } \\
\text { evolução da Resistência dos } \\
\text { Materiais. }\end{array}$ \\
\hline 30 & $\begin{array}{l}\text { Experimentação construtiva } \\
\text { e compositiva em materiais e } \\
\text { meios diversos (desenho, } \\
\text { pintura, fotografia, serigrafia) } \\
\text { a partir do conceito de } \\
\text { abstração, para apropriação } \\
\text { no processo do projeto de } \\
\text { arquitetura. }\end{array}$ & - & $\begin{array}{l}\text { Conhecimento de } \\
\text { metodologia de projeto e } \\
\text { emprego de elementos } \\
\text { construtivos que compõem } \\
\text { o espaço arquitetônico e } \\
\text { suas relações com o meio } \\
\text { ambiente urbano. }\end{array}$ & $\begin{array}{l}\text { Análise de setor urbano. } \\
\text { Elaboração de projeto } \\
\text { urbano. Definição de uso e } \\
\text { ocupação do solo, } \\
\text { hierarquização do sistema } \\
\text { viário, tipologias } \\
\text { habitacionais, infraestrutura } \\
\text { e modelos de organização } \\
\text { espacial. }\end{array}$ & $\begin{array}{l}\text { Sistemas estruturais } \\
\text { convencionais em concreto } \\
\text { armado moldados in loco. } \\
\text { Relação entre partido } \\
\text { arquitetônico e partido } \\
\text { estrutural. Composição de } \\
\text { cargas e pré-dimensionamento } \\
\text { de elementos, noções de } \\
\text { durabilidade, nomenclatura, } \\
\text { formas e armação. }\end{array}$ \\
\hline 40 & $\begin{array}{l}\text { Experimentação construtiva } \\
\text { espacial, com ênfase na } \\
\text { concepção de objetos } \\
\text { tridimensionais, a partir do } \\
\text { conceito de abstração, para } \\
\text { apropriação no processo do } \\
\text { projeto de arquitetura. }\end{array}$ & - & $\begin{array}{l}\text { Conhecimento de } \\
\text { metodologia de projeto e } \\
\text { dispositivos de mediação do } \\
\text { espaço arquitetônico do } \\
\text { edif́cio com o meio } \\
\text { ambiente urbano. }\end{array}$ & $\begin{array}{l}\text { Métodos e técnicas de análise } \\
\text { do projeto urbano, centrado } \\
\text { na eficiência e relação custo- } \\
\text { benefício, para atender } \\
\text { condicionantes de qualidade } \\
\text { paisagística e ambiental dos } \\
\text { espaços produzidos. }\end{array}$ & $\begin{array}{l}\text { Sistemas estruturais } \\
\text { complexos, suas interações } \\
\text { com a arquitetura. Conceito de } \\
\text { concreto protendido e pré- } \\
\text { dimensionamento e } \\
\text { detalhamento de peças e pré- } \\
\text { moldados de concreto. }\end{array}$ \\
\hline 50 & $\begin{array}{l}\text { Desenvolvimento de } \\
\text { linguagem gráfica relacionada } \\
\text { à paisagem urbana, através } \\
\text { da investigação de meios } \\
\text { diversos, incentivando a } \\
\text { formação do pensamento e } \\
\text { análise crítica a respeito das } \\
\text { questões da cidade. }\end{array}$ & - & $\begin{array}{l}\text { Investigação e proposição de } \\
\text { programas arquitetônicos } \\
\text { complexos enfatizando sua } \\
\text { inserção na cidade a partir } \\
\text { de processos críticos e } \\
\text { criativos. }\end{array}$ & $\begin{array}{l}\text { Planejamento: estudo da } \\
\text { estruturação sócio espacial e } \\
\text { dinâmica urbana na escala do } \\
\text { município, identificando } \\
\text { problemas e potencialidades } \\
\text { no contexto regional para } \\
\text { elaboração de Plano Diretor } \\
\text { Municipal Sustentável. } \\
\end{array}$ & $\begin{array}{l}\text { Origem e tipos de solos, } \\
\text { partículas e ensaios. Índices } \\
\text { físicos, estrutura, plasticidades, } \\
\text { consistência. Reconhecimento e } \\
\text { investigação do subsolo para } \\
\text { conceituação das fundações } \\
\text { diretas e profundas e recalques. }\end{array}$ \\
\hline 60 & $\begin{array}{l}\text { Projetos de intervenção } \\
\text { artística no ambiente urbano, } \\
\text { a partir de uma leitura } \\
\text { espacial e poética das } \\
\text { questões da cidade. }\end{array}$ & - & $\begin{array}{l}\text { Metodologia de projeto para } \\
\text { elaboração de partidos } \\
\text { arquitetônicos complexos } \\
\text { com inserção em } \\
\text { ecossistemas que } \\
\text { reconhecem a cidade como } \\
\text { infraestrutura, a partir da } \\
\text { relação terra-água. }\end{array}$ & $\begin{array}{l}\text { Planejamento: análise e } \\
\text { crítica do processo de } \\
\text { produção do espaço urbano- } \\
\text { regional, identificando } \\
\text { dinâmicas sociais para } \\
\text { elaboração de Plano Diretor } \\
\text { Regional sustentável. }\end{array}$ & $\begin{array}{l}\text { A madeira na construção. } \\
\text { Propriedades físicas e } \\
\text { mecânicas: ligações, peças } \\
\text { tracionadas e comprimidas, } \\
\text { treliças planas, vigas maciças e } \\
\text { laminadas, interface entre } \\
\text { madeira, alvenaria e concreto. }\end{array}$ \\
\hline 70 & - & $\begin{array}{l}\text { Projeto de mobiliário e } \\
\text { equipamentos } \\
\text { públicos, a partir de } \\
\text { sistemas de objetos } \\
\text { aplicados à escala do } \\
\text { espaço urbano. }\end{array}$ & $\begin{array}{l}\text { Concepção do espaço com } \\
\text { programas relacionados à } \\
\text { diversidade da realidade } \\
\text { urbana tendo em vista uma } \\
\text { pré-existência arquitetônica } \\
\text { relevante. }\end{array}$ & $\begin{array}{l}\text { Produção e análise de dados, } \\
\text { diagnósticos urbanísticos, } \\
\text { baseados na legislação } \\
\text { vigente. Projetos de } \\
\text { requalificação de áreas } \\
\text { centrais próximas ao porto. }\end{array}$ & $\begin{array}{l}\text { O aço na construção. Aspectos } \\
\text { físicos e mecânicos: ligações, } \\
\text { peças tracionadas e } \\
\text { comprimidas, vigas, treliças } \\
\text { planas e espaciais e interface } \\
\text { entre aço e concreto. }\end{array}$ \\
\hline 80 & - & $\begin{array}{l}\text { Coordenação modular } \\
\text { e os processos de } \\
\text { produção industrial no } \\
\text { projeto da edificação. }\end{array}$ & $\begin{array}{l}\text { Concepção do espaço no } \\
\text { contexto físico e social, } \\
\text { discutindo questões que } \\
\text { viabilizem o projeto no } \\
\text { contexto do território da } \\
\text { cidade, com proposição de } \\
\text { desenho urbano. }\end{array}$ & $\begin{array}{l}\text { Projetos urbanos em áreas } \\
\text { consolidadas de cidades } \\
\text { portuárias. Uso e ocupação, } \\
\text { mobilidade, patrimônio } \\
\text { histórico, questões } \\
\text { socioambientais e quanto à } \\
\text { legislação em vigor }\end{array}$ & - \\
\hline 9 은 & $\begin{array}{l}\text { Projeto Gráfico para } \\
\text { desenvolvimento de material } \\
\text { de apresentação de projeto } \\
\text { de arquitetura e urbanismo. }\end{array}$ & $\begin{array}{l}\text { pesquisa e prática de } \\
\text { processos construtivos } \\
\text { industrializados } \\
\text { aplicados a diferentes } \\
\text { programas. }\end{array}$ & - & 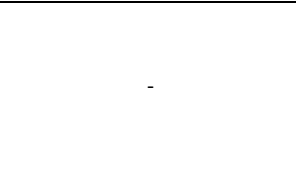 & $\begin{array}{l}\text { Sistemas estruturais no âmbito } \\
\text { do Trabalho de Curso: obras } \\
\text { urbanas, passarelas, viadutos, } \\
\text { túneis e contenções. Revisão de } \\
\text { conteúdo e assessoria aos } \\
\text { projetos do Trabalho de Curso. }\end{array}$ \\
\hline
\end{tabular}


Ao se observar o quadro de ementas das disciplinas de projeto e tecnologia, é possível notar alguns pontos ou termos que apresentam tentativas de horizontalização de conteúdo. Entretanto, a integração ou interdisciplinaridade dificilmente ocorre somente em função da organização horizontal dos conteúdos programáticos na grade horária. A integração depende da escolha de determinadas áreas de estudo coincidentes nas diversas disciplinas, das temáticas dos programas projetuais serem complementares, cujo resultado propicia avaliações conjuntas do mesmo projeto ou trabalho prático sob a ótica de cada disciplina envolvida, garantindo que o discente tenha uma visão menos fragmentada do conhecimento. ${ }^{72}$

Tendo em vista essas experiências, e ainda no contexto da reestruturação da Sequência de Projeto de Arquitetura da FAUS em 2017, foi proposta a retomada de uma atividade, implementada na escola pelo professor Edgar Dente, em 2002 e 2003, intitulada: Trabalho de Graduação Inicial (TGI). Naquela época, tratava-se de um trabalho individual no âmbito da Sequência de Projeto, com duração de duas aulas e envolvendo a totalidade dos estudantes da FAUS. O tema do exercício era apresentado na primeira aula e, de maneira autônoma sem orientação formal, os alunos apresentavam suas hipóteses de projeto na segunda aula do curso. Era organizada uma grande exposição que ocupava todo o prédio da FAUS, com aproximadamente 400 trabalhos, apresentados somente através de desenhos, em pranchas previamente padronizadas. $\mathrm{O}$ objetivo desse exercício, além de configurar um estímulo para o corpo docente e discente na retomada das atividades acadêmicas, era propiciar uma rápida verificação das habilidades individuais dos estudantes de modo a orientar a organização dos cursos da sequência para o ano letivo que se iniciava.

Curiosamente, o Trabalho de Graduação Inicial nasceu como uma provocação ao termo fixado pelo MEC: Trabalho Final de Graduação (TFG) em substituição ao termo Trabalho de Graduação Interdisciplinar (TGI) de Vila Nova Artigas. A despeito do sofisma relacionado aos acrônimos, naquele momento, o Trabalho de Graduação Inicial se mostrou como uma promissora ferramenta pedagógica, capaz de mobilizar a comunidade da FAUS na discussão de problemas regionais a partir de programas fora da estrutura dos cursos regulares da Sequência de Projeto. Nesse sentido, em 2002 a escola apresentou propostas para a ligação seca entre a cidade de Santos e a cidade do Guarujá, feita até os dias atuais por meio de balsas e barcas. Em 2003, o tema abordado foi a reestruturação do Estádio Urbano Caldeira, pertencente ao Santos Futebol Clube, visando uma melhor relação urbanística com o bairro da Vila Belmiro. Nas duas ocasiões, a avaliação dos trabalhos

\footnotetext{
72 Sobre integração e interdisciplinaridade o Projeto Pedagógico da FAUS recomenda os seguintes trabalhos: FAZENDA, Ivani C. Integração e interdisciplinaridade no ensino brasileiro: efetividade ou ideologia. São Paulo: Loyola, 1979; JAPIASSU, H. Interdisciplinaridade e patologia do saber. Rio de Janeiro: Imago, 1976; GADOTTI, M. Pedagogia da Práxis. São Paulo: Cortez, 2004; POMBO, O. Interdisciplinaridade. Ambições e limites. Lisboa: Relógio d'Água, 2004; MORIN, E. Educação e complexidade: Os sete saberes e outros ensaios. 3. Ed. São Paulo: Editora Cortez, 2005. UNIVERSIDADE CATÓLICA DE SANTOS. Projeto Pedagógico de Curso - Arquitetura e Urbanismo. Op. cit. pp $29-31$. 
foi feita por todos docentes da sequência, independente da seriação curricular, entretanto sem a participação dos estudantes.

Em 2017, o TGI foi apresentado com uma nova estrutura, o tempo de duração foi estendido de duas para quatro semanas e o desenvolvimento do trabalho passou a ser feito em grupos formados por alunos de semestres distintos, ou seja, o TGI passou a constituir um exercício de integração vertical. Pode-se dizer, grosso modo, que além de contrapor a extinção do desenvolvimento coletivo dos projetos no âmbito dos cursos regulares, essa alteração ampliou o horizonte de investigação dos alunos e reposicionou o atelier da FAUS como centro de pesquisa, processamento e difusão de conhecimento, desde a prática integrada de projeto.

Programado para ocorrer nas quatro primeiras semanas de aula de cada semestre letivo, o trabalho configura um exercício único e abrangente para todas sequências disciplinares do curso da FAUS. Os trabalhos são orientados por todos os professores de forma coletiva, tem como objetivo integrar verticalmente os semestres do curso para que os estudantes reconheçam a escola com um todo, além de propor uma reflexão crítica acerca dos problemas e urgências das cidades no âmbito regional, nacional e, até mesmo, internacional. Nesse ponto, interessa dizer que os laboratórios de pesquisa da FAUS configuram organismos fomentadores de assuntos a serem problematizados no TGI, podendo inclusive apontar para as oportunidades na seleção de áreas e programas de interesse, tanto para o desenvolvimento dos exercícios dos cursos de projeto como para a escolha dos assuntos e as áreas do Trabalho de Curso.

No que diz respeito à sua operacionalização, imediatamente após a apresentação do tema é iniciado um processo de imersão e pesquisa coletiva com todos os alunos da escola, seguido de duas semanas de orientações e produção simultânea do material final. O corpo discente é dividido em equipes de trabalho, cada uma deve conter pelo menos um estudante de cada semestre, do primeiro ao oitavo, formando grupos de quatro a seis membros. Ao modo da proposta de Carlos Millan para o Atelier da FAU-USP, ${ }^{73}$ contudo, indo um pouco além, o caráter vertical do TGI da FAUS, ao propor exercícios práticos de síntese de conhecimentos, permite que os alunos dos semestres mais avançados auxiliem os estudantes dos primeiros semestres a fixarem a linguagem e construção de conhecimento específicos do campo da arquitetura e urbanismo que começam a conhecer.

O processo culmina com uma exposição geral dos trabalhos no atelier da escola, seguida de uma reflexão coletiva entre professores, estudantes e convidados externos acerca dos assuntos tratados, processos, dificuldades, virtudes, dentre outros. Os critérios ou parâmetros de avaliação consistem na verificação do desenvolvimento dos projetos e de que forma ocorreu a integração vertical entre

\footnotetext{
${ }^{73}$ Ver MILAN, C.B. O ateliê na formação do arquiteto. São Paulo: Setor de publicações. Faculdade de Arquitetura e Urbanismo da Universidade de São Paulo. 1962, 46p.
} 
os alunos. Sobre os conteúdos ou resultados, são analisados os seguintes aspectos: pesquisa, projeto, relevância social, contribuição cultural e poética das propostas para o local estudado, enfatizando o desenho da cidade, desenho da paisagem e o desenho do edifício que, independentemente do tamanho, tem como referência seminal a pessoa. A temática aplicada revela a evolução e ampliação sistêmica da autonomia dos estudantes.

TGI 1. Ponte de ligação entre Santos e Guarujá - 2002.

TGI 2. Reestruturação do Estádio da Vila Belmiro - 2003

TGI 3. Terminal de Passageiros na Ponta da Praia em Santos - 2017.
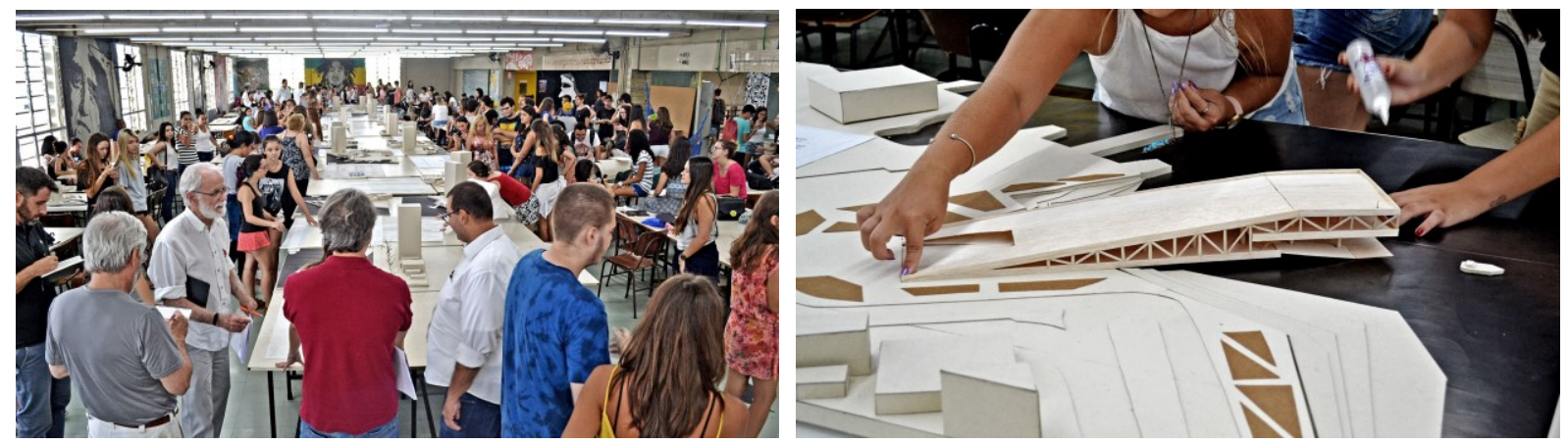

FIG. 140. Entrega e avaliação do TGI em março de 2017. A primeira edição do novo formato do TGI ocorreu no início do ano letivo de 2017, as novas diretrizes despertaram grande interesse nos estudantes, mobilizando radicalmente a escola na organização dos grupos e na produção dos trabalhos durante três semanas, entretanto do ponto de vista metodológico diferiu pouco em relação as disciplinas regulares de projeto, pois foram dados parâmetros claros e bem definidos quanto ao tema, lugar e programa. Ainda assim as propostas extrapolaram a discussão do edifício e estenderam o campo de intervenção para a cidade, centrando o debate para questões de mobilidade e redesenho da paisagem.

TGI 4. Anexo do Teatro Municipal de Santos - 2017.
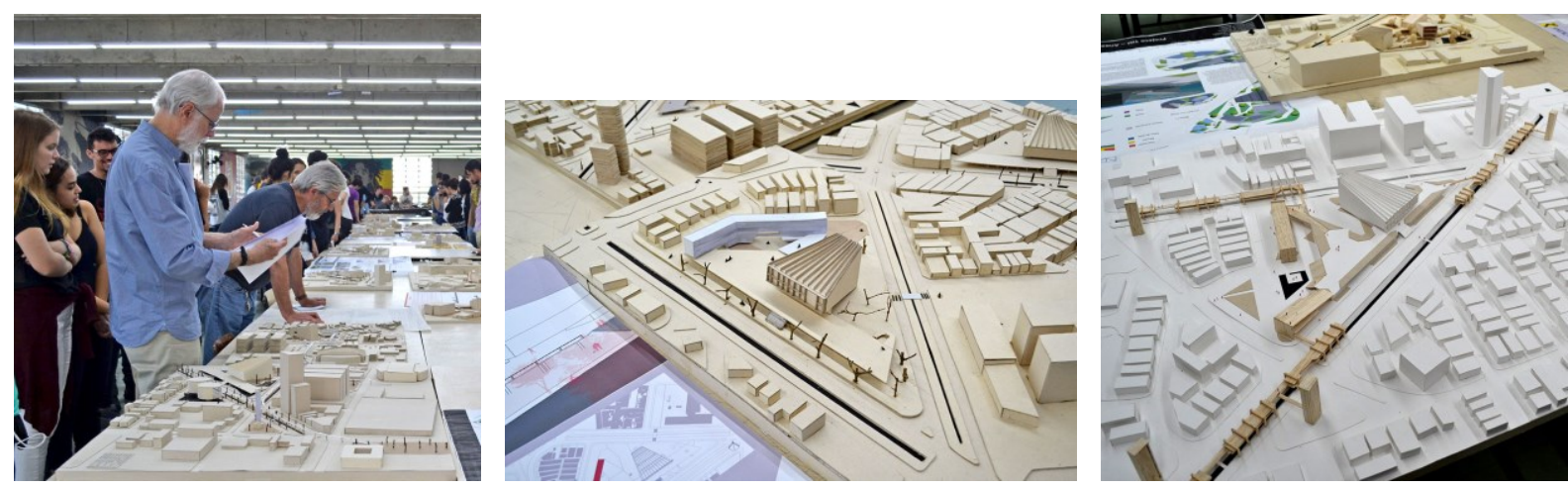

FIG. 141. Entrega e avaliação do TGI em setembro de 2017. A segunda edição do TGl ocorreu no início do segundo semestre de 2017, envolvendo a Sequência de Plástica e propondo maior autonomia para os estudantes. As diretrizes estabeleciam que as equipes deveriam propor um anexo para o Teatro Municipal de Santos, cujo programa deveria estar de acordo com as necessidades do equipamento verificadas in loco. A mobilização dos estudantes foi imediata, logo após a apresentação do exercício, algumas equipes saíram para conhecer o lugar. A produção dos trabalhos durou três semanas, e o resultado foi uma grande diversidade de propostas que expandiram não só os limites do anexo, mas avançaram sobre a cidade redesenhando o entorno e propondo relações com os equipamentos vizinhos. As propostas amparadas em levantamentos físicos, históricos e entrevistas com artistas, arquitetos do CONDEPASA ${ }^{74}$ e administradores do local apresentaram grande consistência.

\footnotetext{
${ }^{74}$ Conselho de Defesa do Patrimônio Cultural de Santos, além do CONDEPASA, a especulação imobiliária quer enfraquecer a atuação do Programa Alegra Centro, criado em 2003 para promover a recuperação do patrimônio arquitetônico santista e proporcionar a melhoria da paisagem urbana, a iniciativa teve o objetivo alcançado por meio de vários incentivos fiscais a companhias que se instalaram nessa região da cidade. Disponível em: <https://www.santos.sp.gov.br/?q=projeto/alegra-centro>. Acesso em: 22 set. 2019.
} 
TGI 5. Centro histórico de Santos: Projeto General Câmara - 2018.
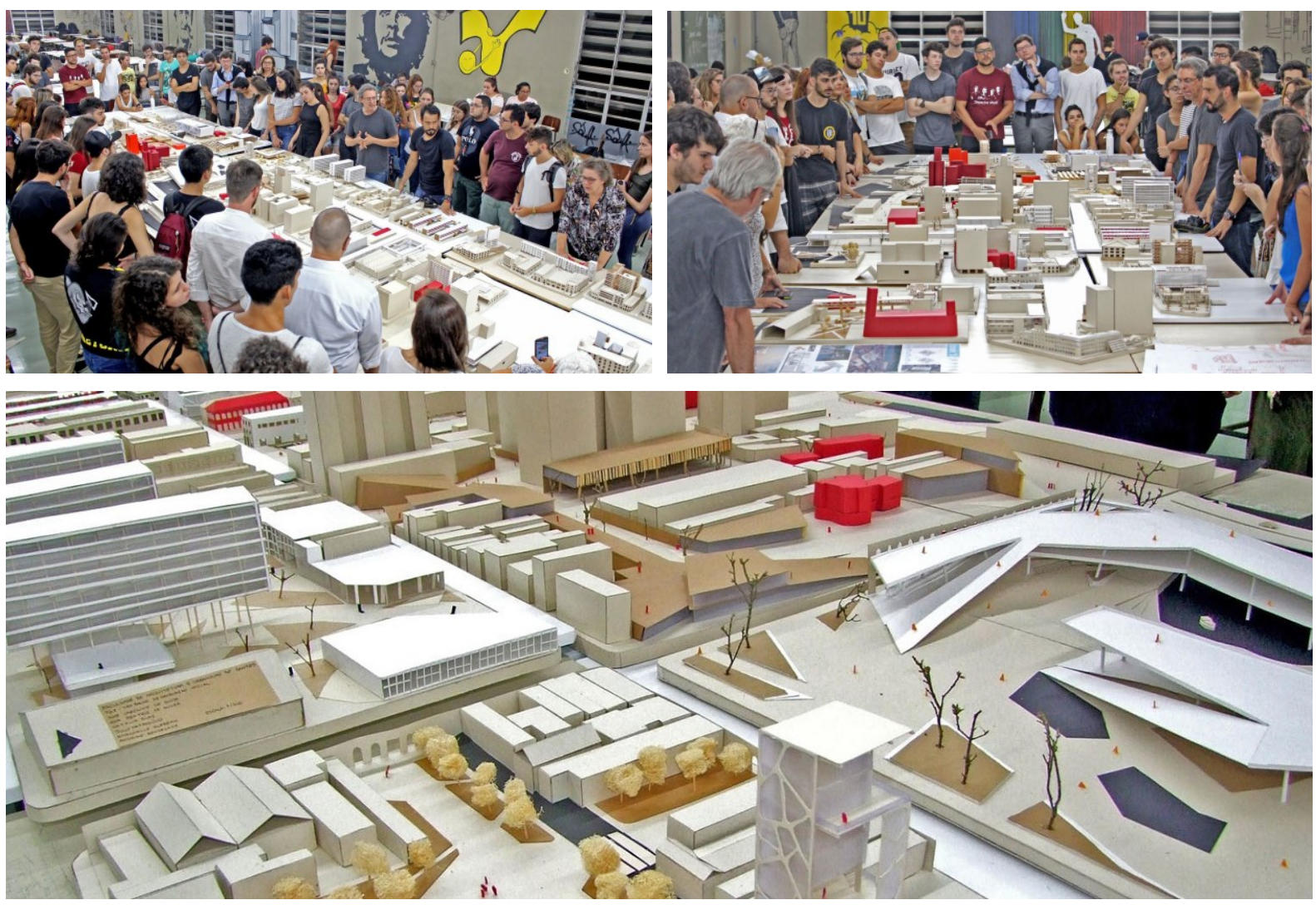

FIG. 142. Entrega e avaliação do TGI em março de 2018. Diante do movimento para flexibilização da legislação de proteção do patrimônio arquitetônico e urbano do centro de Santos, o TGI do primeiro semestre de 2018 propôs que a FAUS oferecesse uma resposta contundente com possibilidades de intervir e transformar o centro da cidade, respeitando sua história e pré-existências. As equipes mapearam quarenta quadras do centro histórico, tendo como eixo a Rua General Câmara, as propostas ofereceram vasto repertório de possibilidades de projetos e programas de renovação, desde a criação de bulevares, melhora nas relações com a água do canal do estuário, com o terminal hidroviário de passageiros e com o futuro trecho do VLT, foram verticalizados e adensados setores específicos, até a ocupação de vazios nos interiores das quadras e edificações abandonadas. Essa edição envolveu as sequências de Urbanismo, Teoria e História e Plástica.

TGI 6. Anexo Museológico da Pinacoteca Benedito Calixto em Santos - 2018.
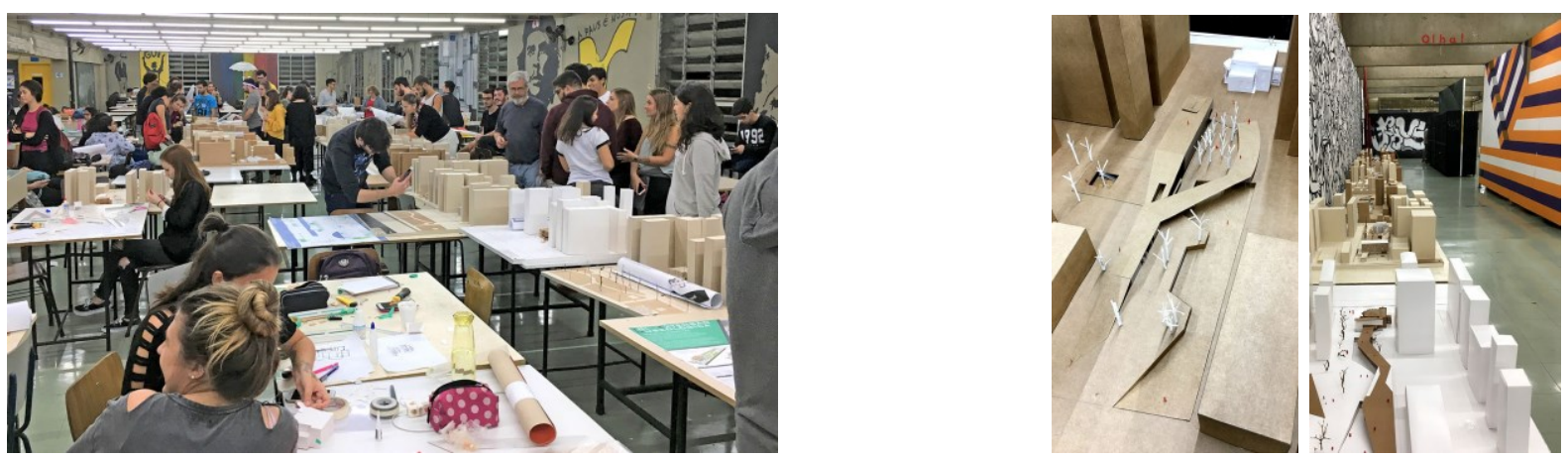

FIG. 143. Entrega e avaliação do TGI em setembro de 2018. Constatada a ineficiência estrutural da Pinacoteca de Santos para receber maior variação de exposições e, examinando o projeto para o Museu de Arte Moderna de Santos, elaborada pelo arquiteto Paulo Mendes da Rocha em 2010, foi proposto como tema para o TGI do segundo semestre de 2018 a construção de um Anexo Museológico para a Pinacoteca. Deveria ser considerado como patrimônio, o casarão, o bosque e o jardim envoltório. $O$ resultado desse trabalho revelou o amadurecimento e aprofundamento dos estudantes nas questões relacionadas às técnicas de restauração e intervenção em obras de interesse cultural, direcionando as propostas para ações mais delicadas e precisas nas conexões com o velho casarão e com a manutenção e ampliação do bosque, muitos trabalhos, além do anexo, propunham passagens para pedestres ligando a Avenida Bartolomeu de Gusmão (avenida da praia) à Avenida Epitácio Pessoa. Essa edição envolveu as sequências de Urbanismo, Teoria e História e Plástica. 
TGI 7. Projeto Toro Muerto Peru - 2019.
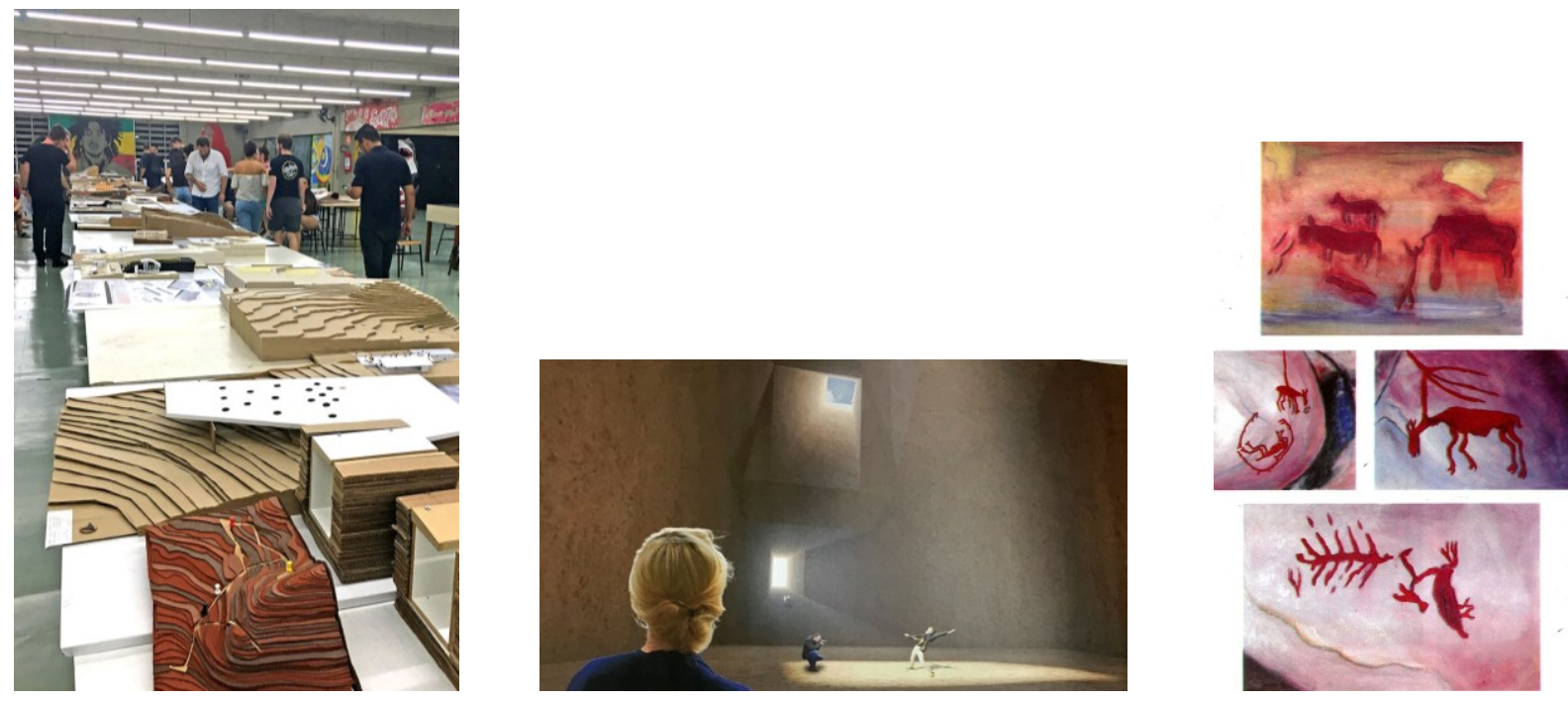

FIG. 144. Entrega e avaliação do TGI em março de 2019. A primeira experiência internacional do TGI da FAUS foi um projeto para potencialização do Vale de Majes em Arequipa no Peru. O lugar foi apresentado pelo Professor arquiteto Jimmy Efrén Liendo da Universidad Nacional de San Agustín de Arequipa, no primeiro semestre de 2019. O trabalho consistiu em propor intervenções que fomentassem o desenvolvimento do Vale de Majes, cuja comunidade rural local sofre com a escassez de água e com a falta de equipamentos básicos. A sustentabilidade desses programas poderia estar atrelada ao incremento da visitação do sítio arqueológico de petróglifos pré-colombianos, com a construção de infraestrutura de apoio para arqueólogos, cientistas, estudantes e demais visitantes. Depois de três semanas de produção, foram apresentados projetos desde construção de escolas, postos de saúde e vias de acesso na parte baixa do vale junto à comunidade, até sistemas de transposição vertical e apoio junto ao sítio arqueológico no trecho elevado dos Andes. Também foram apresentados alguns projetos para construção de artefatos de captação de águas do subsolo e da própria atmosfera, utilizando técnicas locais. A avaliação e debate final contou com a participação do Professor Jimmy Liendo que, posteriormente levou os resultados produzidos pela FAUS para apresentá-los na Universidad Nacional de San Agustín de Arequipa. Essa edição envolveu as sequências de Urbanismo, Teoria e História e Plástica.

TGI 8. Território Líquido: entre a pedra e a água - 2019.
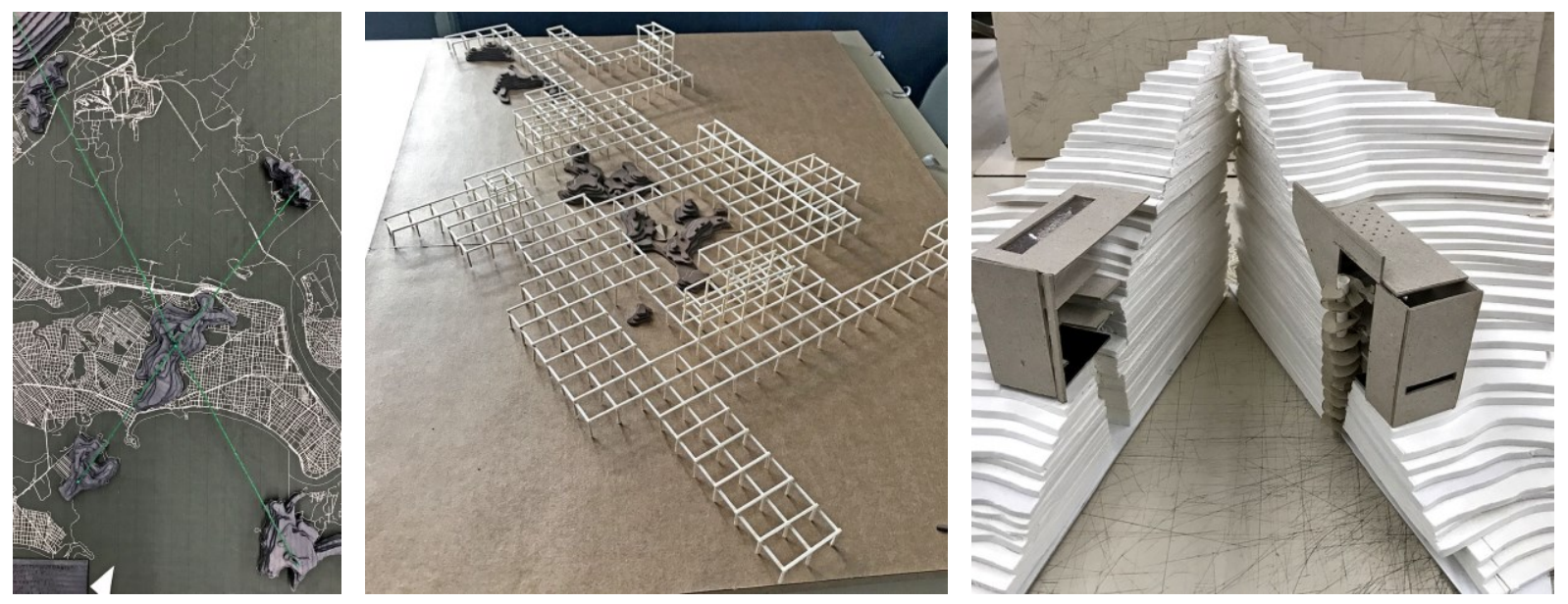

FIG. 145. Entrega e avaliação do TGI em setembro de 2019. No segundo semestre de 2019, o TGI propôs a experimentação projetual no limiar entre arte e técnica, para tanto, o professor convidado Ciro Miguel da ETH de Zurich na Suíça, apresentou uma aula referencial tratando das relações projetuais no complexo arte-arquitetura. Não foi proposto nenhum programa, apenas o lugar e seu potencial de intervenção, a total liberdade propositiva se revelou como uma barreira a ser transposta pelos estudantes, a síntese poderia ser feita a partir de qualquer motivação, além do universo arquitetônico, desde uma imagem, uma música ou um poema. Nessa edição foi solicitado que os estudantes filmassem o processo de produção dos trabalhos e apresentassem junto com desenhos, modelos, colagens, um vídeo com dois minutos de duração. Foram apresentadas propostas que não romperam com o universo meramente racional-construtivo da arquitetura, mas muitos trabalhos superaram a barreira da timidez e apresentaram propostas utópicas e distópicas, essencialmente, inventivas e sobretudo provocativas. Essa edição envolveu as sequências de Urbanismo, Teoria e História e Plástica. 
Ao observar a produção dos trabalhos, nota-se que a natureza aberta do TGI, ao permitir múltiplas entradas, o mantém em constante processo de evolução. Por se tratar de uma atividade prática no complexo arte-técnica desde a perspectiva do projeto, qualquer ajuste sempre será resultado da experimentação, da crítica e do fazer coletivo, envolvendo docentes e discentes na generosa troca de conhecimentos. O TGI deve ser entendido como pretexto para ampliar o campo cultural dos estudantes da FAUS, além disso, em virtude da sua natureza breve, quase efêmera, necessita de um profícuo processo de imersão, pois projeto e pesquisa ocorrem de maneira simultânea. Arrisca-se dizer que funciona como um escritório de projetos participando de um concurso de arquitetura, ou seja, a equipe deve operar com rigor e disciplina para atender os curtos prazos de entrega, ao mesmo tempo em que o projeto precisa apresentar as melhores respostas para o problema proposto.

Apesar de o conceito de integração vertical não ser novidade, pois como visto, surge na Reforma de 1962 na FAU-USP e chegou a ser implementado na FAU-SJC entre 1970 e 1976. Atualmente, esse procedimento pedagógico ocorre como disciplina regular na Escola da Cidade Arquitetura e Urbanismo, conhecido como Estúdio Vertical $(\mathrm{EV}),{ }^{75}$ tem duração semestral e opera em função de um eixo temático. O maior tempo oferecido no $\mathrm{EV}$, em relação ao TGI, permite que os estudantes possam refletir por mais tempo as questões conceituais e o processo de produção dos trabalhos se assemelham ao cotidiano de um escritório de arquitetura, aprofundando questões e detalhando os projetos. Os resultados são extremamente relevantes e a evolução dos estudantes, principalmente dos primeiros níveis é substancial e visível ao avançarem de um semestre para o outro. Entretanto, o caráter extensivo do EV pode provocar, em alguns casos, certa dispersão e arrefecimento do processo de produção dos trabalhos.

Finalmente, o TGI da FAUS não deve ser considerado um organismo autossuficiente. Seu pleno potencial será alcançado somente com a colaboração direta e harmônica das outras sequências da FAUS. Além das disciplinas da Sequência de Projeto, é imprescindível a participação das disciplinas da Sequência de Tecnologia que, aos moldes do proposto por Artigas na FAU-USP em 1962, "poderão ser chamadas ao atelier para ministrar cursos auxiliares e participar da crítica. A convivência entre matérias técnicas e o atelier melhora e surgem novos pontos de encontro cada vez em nível mais elevado." ${ }^{76}$ Assim como as disciplinas da Sequência de Teoria e História da Arquitetura e do

\footnotetext{
75 O Estúdio Vertical (EV) representa um momento de integração acadêmica entre alunos e professores de diferentes disciplinas em um trabalho coletivo, organizados em grupos para o desenvolvimento de projetos ou de partes de um projeto, ligados à um Eixo Temático. Ao modo de um escritório de projetos, desenvolvem seu trabalho ao longo de um ano. Em sua composição cada grupo conta com um ou dois alunos de cada ano do curso, garantindo a integração ampla com a troca de experiências entre todo o corpo discente nas atividades programadas da Escola da Cidade. Ver mais sobre o EV em: < http://www.escoladacidade.org/>.

${ }^{76}$ Trecho de uma curta abordagem de Artigas a respeito dos ateliers intitulada: "Sobre os ateliers e as disciplinas técnicas", segundo Forti, feito "com a preocupação visível de acalmar os ânimos dos professores das disciplinas técnicas e, ao mesmo tempo, de caracterizar a ideia de "departamento" - em oposição à estrutura de cátedras". FORTI, Marco Artigas. FAUUSP - 50 anos da Reforma de 1962. Op. cit.
} 
Urbanismo, sendo desejável ainda a participação de outros componentes curriculares, como, por exemplo, o Trabalho de Curso.

Além disso, importa dizer que o TGI tem potencial de extensão comunitária e, desse modo, pode expandir suas atividades para todos os campos de conhecimento da universidade, ou seja, todo docente pode ser convidado a participar dos trabalhos de acordo com os assuntos abordados. Sendo assim, o TGI deve ser dirigido pelo coletivo dos professores da FAUS, que participarão da organização dos programas, metodologias, critérios de avaliação e calendários. Aqui, vale lembrar as concepções do professor Caron partidário do atelier vertical como elemento de integração disciplinar.

\begin{abstract}
Para isso ocorrer, na prática, o atelier é coordenado por um conselho para que haja integração de fato. 0 coordenador de Atelier é a instância mais próxima de provisão e intercostura do Atelier. O conselho se reúne nas questões mais básicas e amplas: temática, organização interna, avaliação, alterações. 0 coordenador organiza a continuidade, os entre choques da prática quotidiana. A figura do nosso coordenador de ano passa a ser substituída pela do coordenador de atelier. ${ }^{77}$
\end{abstract}

A partir da experiência do TGI, torna-se desejável para o primeiro semestre do Trabalho de Curso, a implementação de análises de macro áreas comuns a todos os temas, possibilitando pesquisas coletivas, debates sobre os principais temas, reflexão crítica sobre a seleção e construção dos programas, produção coletiva de bases, desenhos e maquetes. No segundo semestre, o desenvolvimento e finalização do trabalho deve enfatizar a produção individual. Assim, faz-se necessário o estabelecimento de critérios comuns de avaliação dos Trabalhos de Curso, com o objetivo de garantir os princípios de isonomia na fase final de formação dos arquitetos.

Da mesma forma, as viagens de estudo, com programação semestral oferecidas a todos os estudantes, também configuram oportunidades de investigação e problematização de assuntos a serem desenvolvidos no TGI. Os resultados podem ser ofertados para as comunidades visitadas e estudadas como contribuição de valor científico, social e cultural. Os destinos poderiam ser determinados conforme orientação do HABITAFAUS.

\begin{abstract}
Ao arquiteto, em particular, o reconhecimento dos espaços constitui necessidade vital para seu trabalho. Quando dizemos espaço, devemos, ao menos, caracterizá-lo melhor [...] o espaço para o arquiteto não se configura apenas por questões de metragem [...] tampouco por fachadas decorativas ou interiores bem mobiliados, como poderia imaginar um cidadão desconhecedor das atribuições desse profissional. 0 arquiteto trabalha com as medidas do homem - em todas suas dimensões: sociais, psicológicas, políticas, econômicas, culturais, materiais, ergonométricas. $\mathrm{O}$ espaço trabalhado pelo arquiteto é aquele permeado pela presença do homem. Não é de se estranhar, portanto, que os arquitetos recebam grandes lições em suas viagens através do contato com diferentes maneiras de pensar, agir, viver, frente a contingências diversas, caracterizando diferentes culturas, acentua em nós o que realmente é peculiar a nossa maneira de ser. ${ }^{78}$
\end{abstract}

\footnotetext{
77 CARON, Jorge. (199-). Reflexões sobre o atelier na EESC-USP. Op. cit. p. 81.

${ }^{78}$ Hugo Segawa, sobre a viagem dos estudantes Álvaro da Silva e Rubens Mano in DIRETÓRIO ACADÊMICO VERA DEBS. Jornal revista: Edição no 7, ago. / set. 1984.p. 15. 
Pois bem, a reestruturação da Sequência de Projeto de Arquitetura e a implantação do novo formato do Trabalho de Graduação Inicial (TGI) na FAUS demonstraram a falta de espaço e má disposição dos laboratórios para as necessidades do curso. Conforme visto no capítulo anterior, a fragmentação curricular ao longo dos anos resultou na compartimentação dos espaços da escola. Entretanto, apesar de parecer um problema de fácil identificação, a Universidade ainda encontra dificuldade no entendimento da melhor organização funcional e espacial para a produção de conhecimento no campo da arquitetura e do urbanismo. Nesse sentido, arrisca-se dizer que o problema que necessita maior atenção esteja relacionado aos lugares de processamento e produção, pois segundo o vigente Projeto Pedagógico da escola apresenta uma clara contradição na relação pedagogia-espaço:

Os Laboratórios específicos da FAUS estão locados próximos uns aos outros de forma a propiciar seu uso de forma racional e interligada. São espaços projetados especificamente para abrigar os principais equipamentos necessários para o bom desempenho das atividades, aulas práticas e experimentações. Atualmente ocupam o andar térreo do edifício do Curso de Arquitetura e Urbanismo contíguos à Biblioteca. Para sua utilização é necessário realizar o agendamento de acordo com os procedimentos institucionais. Futuramente atenderão também ao Curso de Mestrado Profissional em Arquitetura e Urbanismo. ${ }^{79}$

Como visto, os laboratórios de atividades "práticas e experimentais" estão absolutamente desconectados do Atelier, quando na verdade deveriam ser pensados como extensão dele, entendidos como locais de produção que também processam a síntese dos conteúdos, produz conhecimento a partir das operações de projeto, em sentido amplo, operações entendidas, antes de tudo, como pesquisa. Além disso, foram identificadas deficiências quanto à falta de um laboratório de tecnologia da construção aplicada ao ensino, à inexistência de áreas adequadas de exposição e convívio, falta de espaços específicos para os grupos de pesquisa, cursos de pós-graduação, LatoSensu e Stricto-Sensu.

O Laboratório de Práticas Construtivas (LPC) oferece a possibilidade de extensão das aulas teóricas e práticas de projeto, no que se refere à experimentação construtiva e ao contato direto com elementos da construção civil. Nesse sentido, o objetivo principal desse espaço é a busca por novas tecnologias, materiais e sistemas construtivos através da interação entre concepção-projeto e sua produção-efetivação na prática, em um espaço apropriado para esse fim.

No que se refere à interação multidisciplinar e à criação de novos cenários o LPC, ao oferecer e receber informações técnicas e ensaios práticos de outros ambientes laboratoriais, pode contribuir com o sistema de laboratórios da universidade, como os Laboratórios de Geologia, Solos, Conforto Ambiental, Hidráulica e Sistemas Construtivos, além dos espaços de produção e pesquisa da FAUS, como o Atelier, a Maquetaria, o LAVUCS e o HABITAFAUS.

\footnotetext{
${ }^{79}$ UNIVERSIDADE CATÓLICA DE SANTOS. Projeto Pedagógico de Curso - Arquitetura e Urbanismo. Op. cit. p.105. (grifo nosso).
} 
Levando em conta que a flexibilidade espacial resultante do sistema construtivo do edifício permite que todas as descaracterizações sejam revertidas, a começar pela reconstrução do acesso original da FAUS e pela retomada do terceiro pavimento para redistribuição dos programas. Desse modo, o pavimento térreo poderia concentrar as atividades de exposição, convívio, estudos, administração e sala de professores, junto ao HABITAFAUS e ao OBSERVA-BS. Ao propor uma entrada lateral e independente pela Rua Dagoberto de Gasgon, além de dar uso para o espaço desocupado no fundo do complexo, facilitaria o acesso para as operações de carga e descarga de materiais, sem prejuízo das demais atividades do Campus, viabilizando a implantação do Laboratório de Práticas Construtivas $(\mathrm{LPC}) .{ }^{80}$

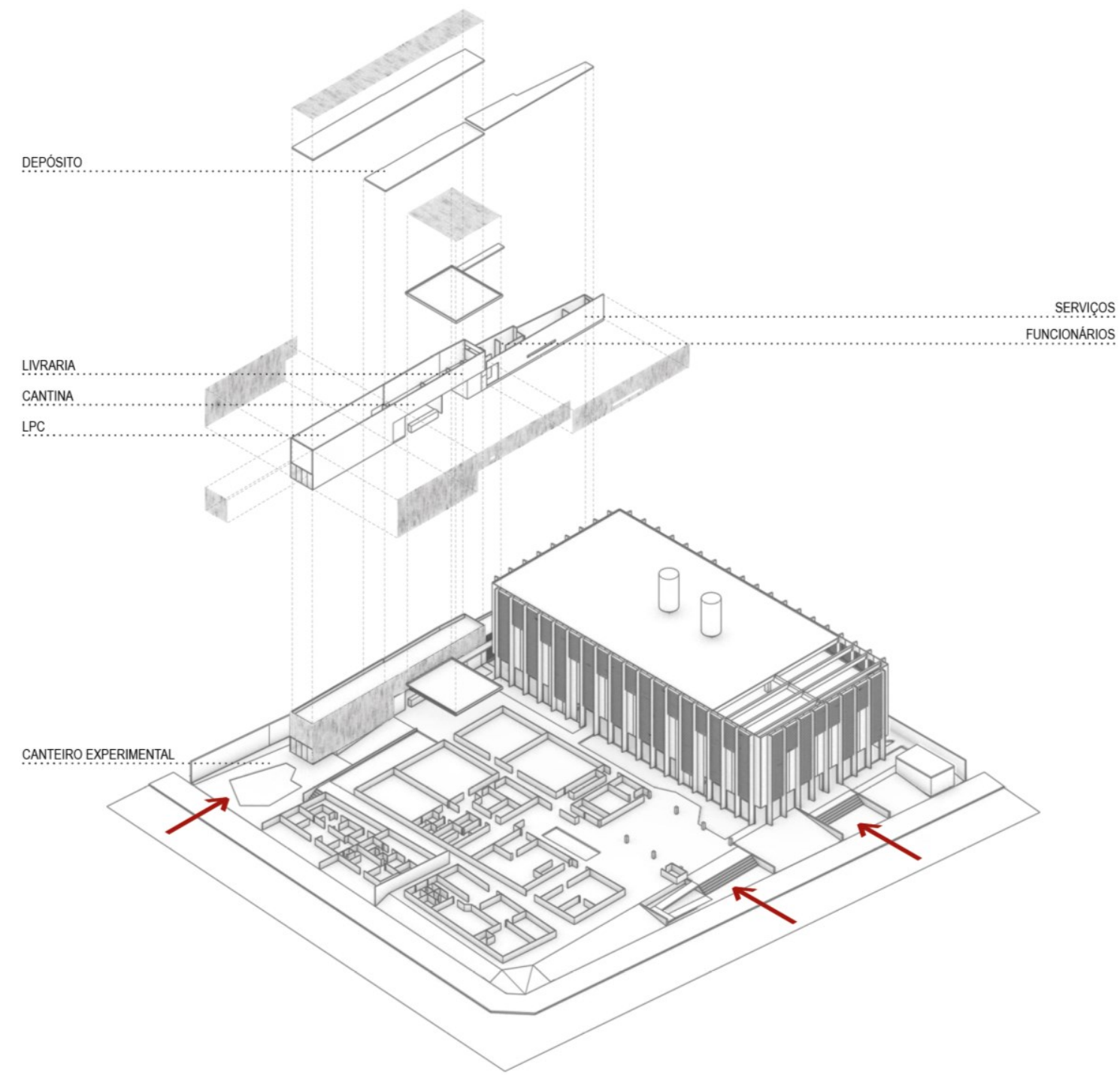

FIG. 146. Axonometria com a localização do Laboratório de Práticas Construtivas no Campus Boqueirão.

\footnotetext{
${ }^{80}$ Em outubro de 2013, a pedido da Reitoria da UNISANTOS, foi elaborado e apresentado um documento intitulado: Análise para a Implantação do Laboratório de Práticas Construtivas (LPC), desenvolvido pelos professores Gustavo Maia Rodrigues e José Maria de Macedo Filho. Esse documento tomou como referência uma proposta para a instalação de um canteiro de obras modelo dentro da Universidade, feita em 2010 pelos professores da FAUS Cássia Regina Carvalho de Magaldi, Leila Regina Diêgoli, José Marques Carriço e Roberto Hage Chain.
} 
Para tanto, a estrutura de apoio existente no fundo da FAUS deveria ser totalmente revista com a construção de espaços adequados para as atividades existentes e para os trabalhos a serem realizados no $\mathrm{LPC}$.

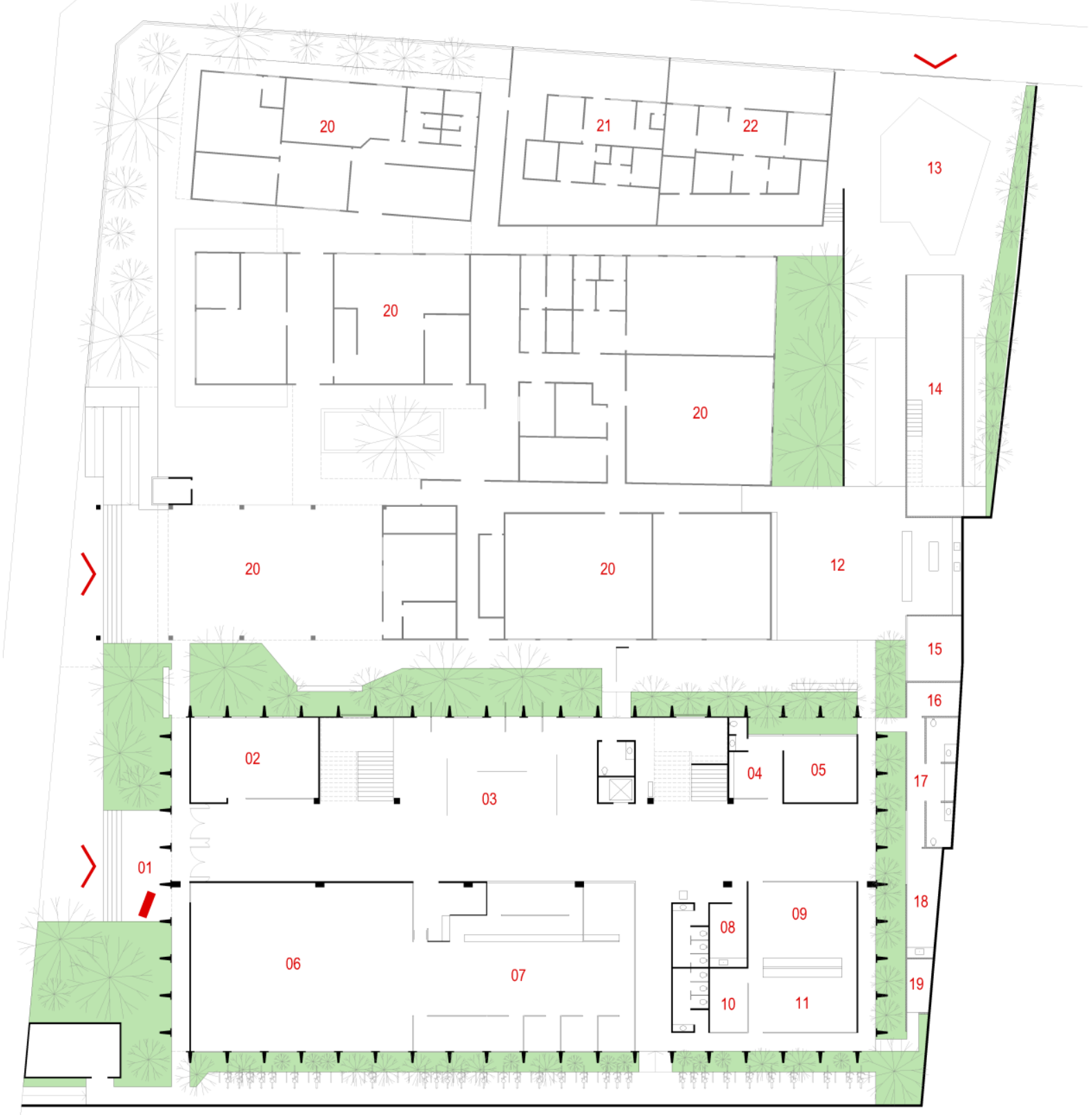

01 ENTRADA DA FAUS 02 DIRETÓRIO ACADÊMICO 03 EXPOSIÇÕES 04 SECRETARIA 05 DIRETORIA 06 BIBLIOTECA 07 LEITURA 08 COPA 09 SALA DOS PROFESSORES 10 REUNIÕES 11 OBSERVA-BS E SUPERESTUDIO 12 CANTINA 13 CANTEIRO EXPERIMENTAL 14 LPC 15 COPIADORA | PAPELARIA 16 ZELADOR 17 FUNCIONÁRIOS 18 REFEITÓRIO 19 SERVIÇO 20 FACULDADE DE DIREITO 21 SERVIÇO PSICOLOGIA 22 SERVIÇO APOIO SOCIAL 


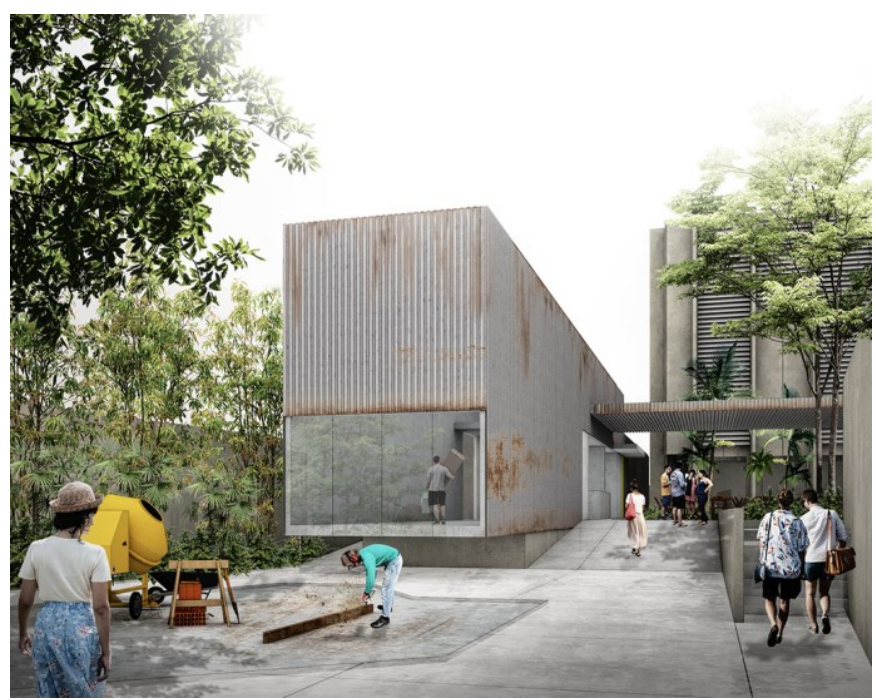

FIG. 148. Vista do Laboratório de Práticas Construtivas a partir da entrada na Rua Dagoberto de Gasgon no Campus Boqueirão.

O primeiro pavimento do prédio da FAUS permaneceria praticamente sem alterações, talvez uma possível ampliação do Laboratório de Audiovisual. No segundo pavimento, junto ao Atelier, estariam concentradas as atividades do Laboratório de Artes Visuais, Laboratório de Fotografia, Maquetaria e Laboratório de Conforto. Na circulação entre os painéis seriam instaladas estantes para guarda de trabalhos em andamento e, atrás do núcleo de sanitários, armários individuais para os estudantes.

O terceiro pavimento seria destinado às atividades da pós-graduação, curso de especialização e programa de mestrado. Merece destaque a recuperação da área de convívio com o pergolado, ainda que somente a área frontal do projeto original constitui uma importante ação simbólica, de contemplação da cidade a partir do prédio da FAUS e devolvendo a sofisticada transparência da fachada de quem olha a escola a partir da cidade.

O pergolado era um espaço livre de manifestação. O bem maior era a liberdade de escolha e essa era a nossa batalha na época, por eleições diretas e livres. Pensando em pergolado eu me lembro das festas, dos shows exclusivos e intimistas do Jorge Mautner e do Toni Bellotto, no início do grupo que se tornaria os Titãs! Lembro-me das festas do Diretório Acadêmico, lembro-me da nossa união, dos violões, do tridente com os sutiãs ardendo, éramos nós crescendo e nos unindo, construindo novos laços maduros de companheirismo, de consciência de grupo, de classe. Aquilo era política, sim, viver é um ato político! 0 pergolado era um espaço democrático. ${ }^{81}$

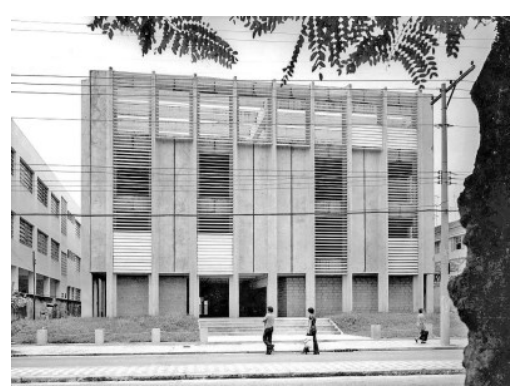

FIG. 149. Prédio da FAUS recém-inaugurado.

\footnotetext{
${ }^{81}$ Depoimento da arquiteta Luisa Alegria, ex-integrante do grupo Arte e Oficina da FAUS, dado ao autor em 19 de julho de 2016.
} 


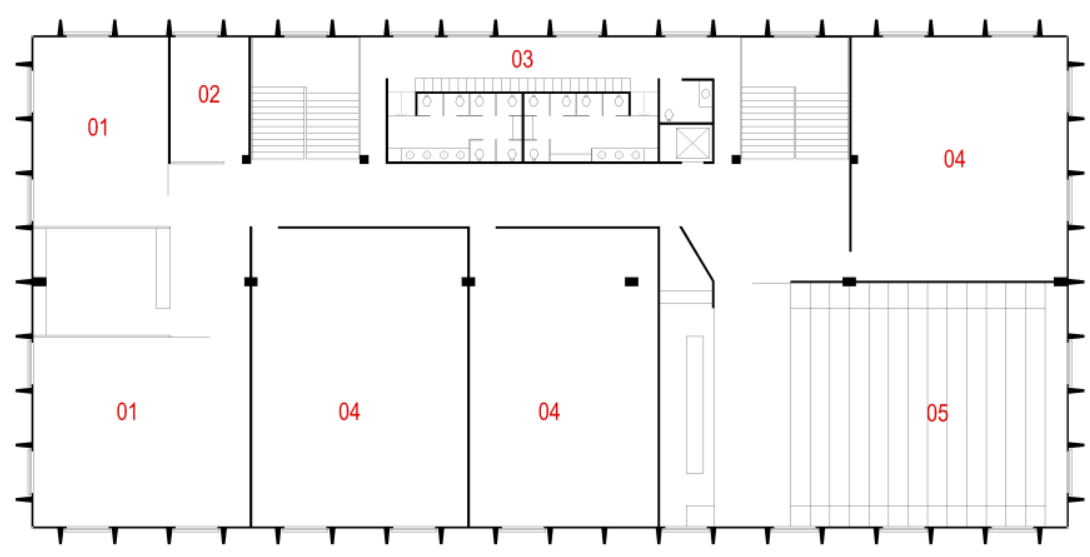

NIVEL $+4.90 \mathrm{~m}$. PLANTA DO $1^{\circ}$ PAVIMENTO

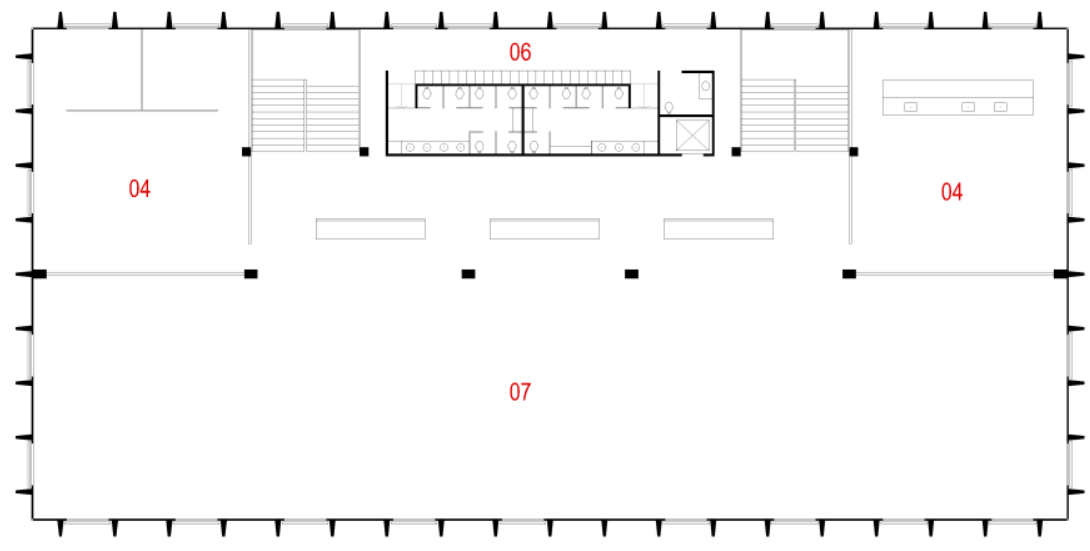

NIVELL $+8.90 \mathrm{~m}$. PLANTA DO $2^{\circ}$ PAVIMENTO

$01 \quad 5 \quad 10$

01 INFORMÁTICA 02 HABITAFAUS 03 DEPÓSITO 04 SALA DE AULA 05 AUDITÓRIO 06 ATLÉTICA 07 ATELIER 


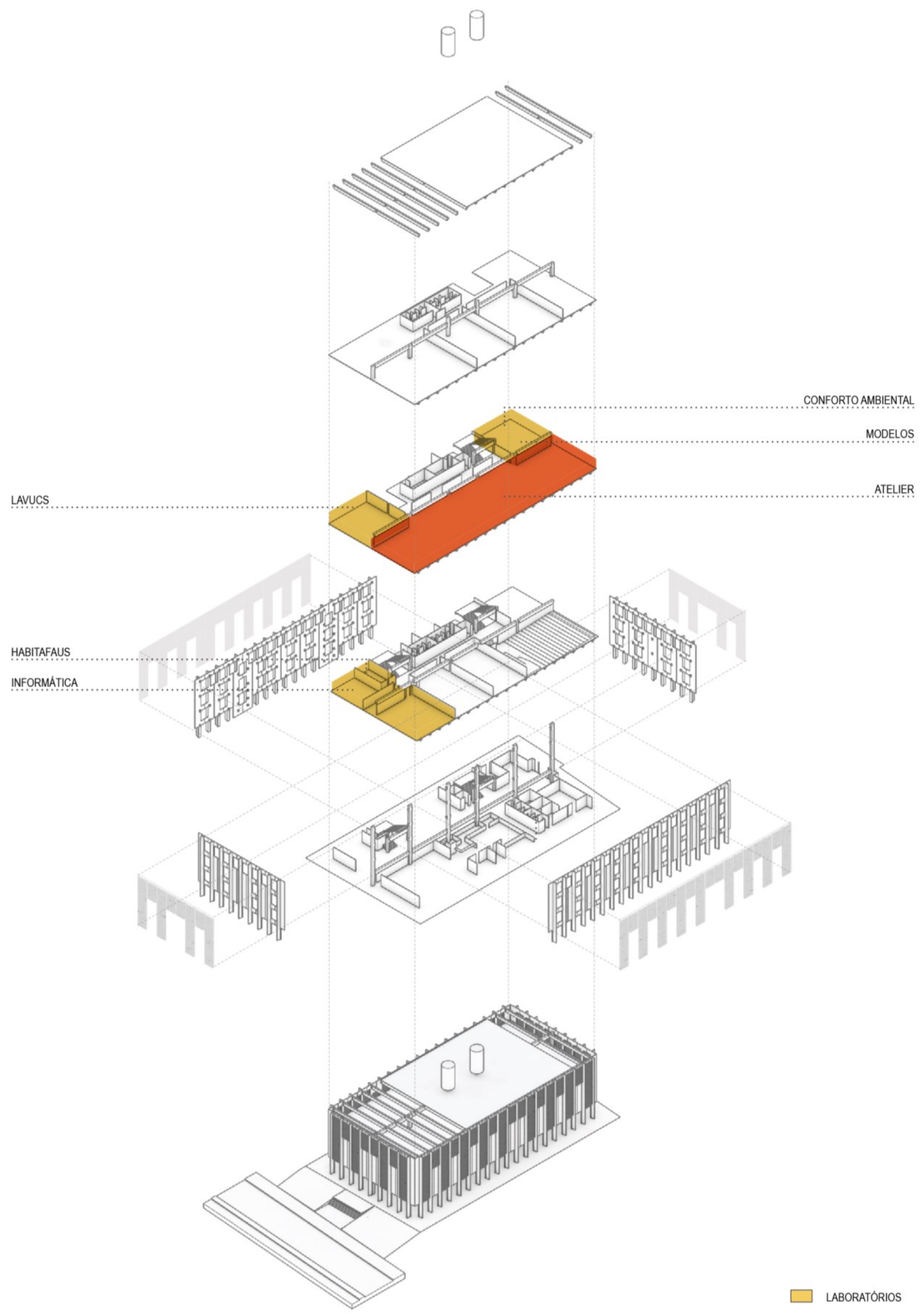

FIG. 151. Diagrama com a proposta de concentração dos laboratórios de produção junto ao Atelier. 


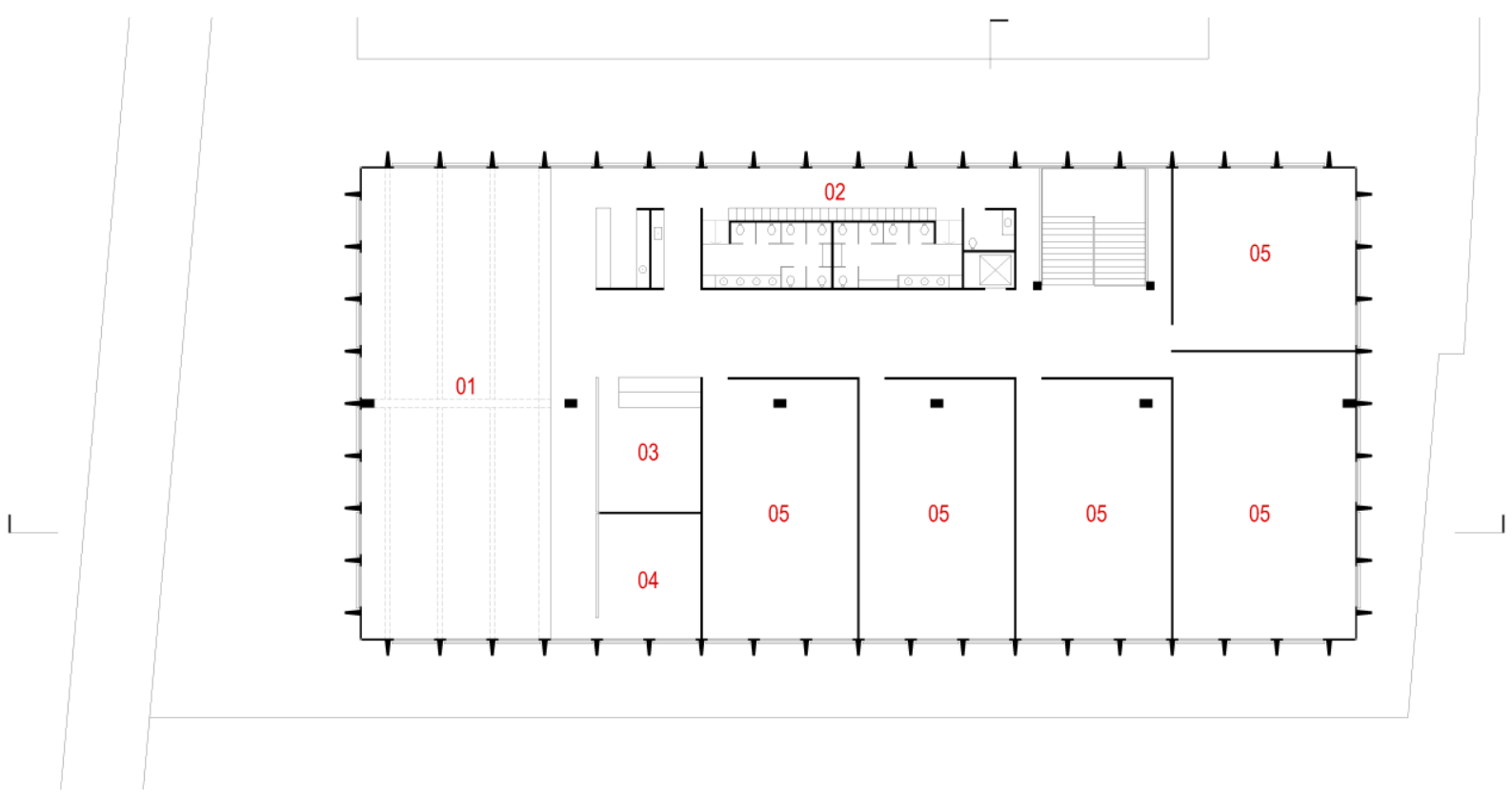

NIVEL $+12.90 \mathrm{~m}$. PLANTA DO $3^{\circ}$ PAVIMENTO

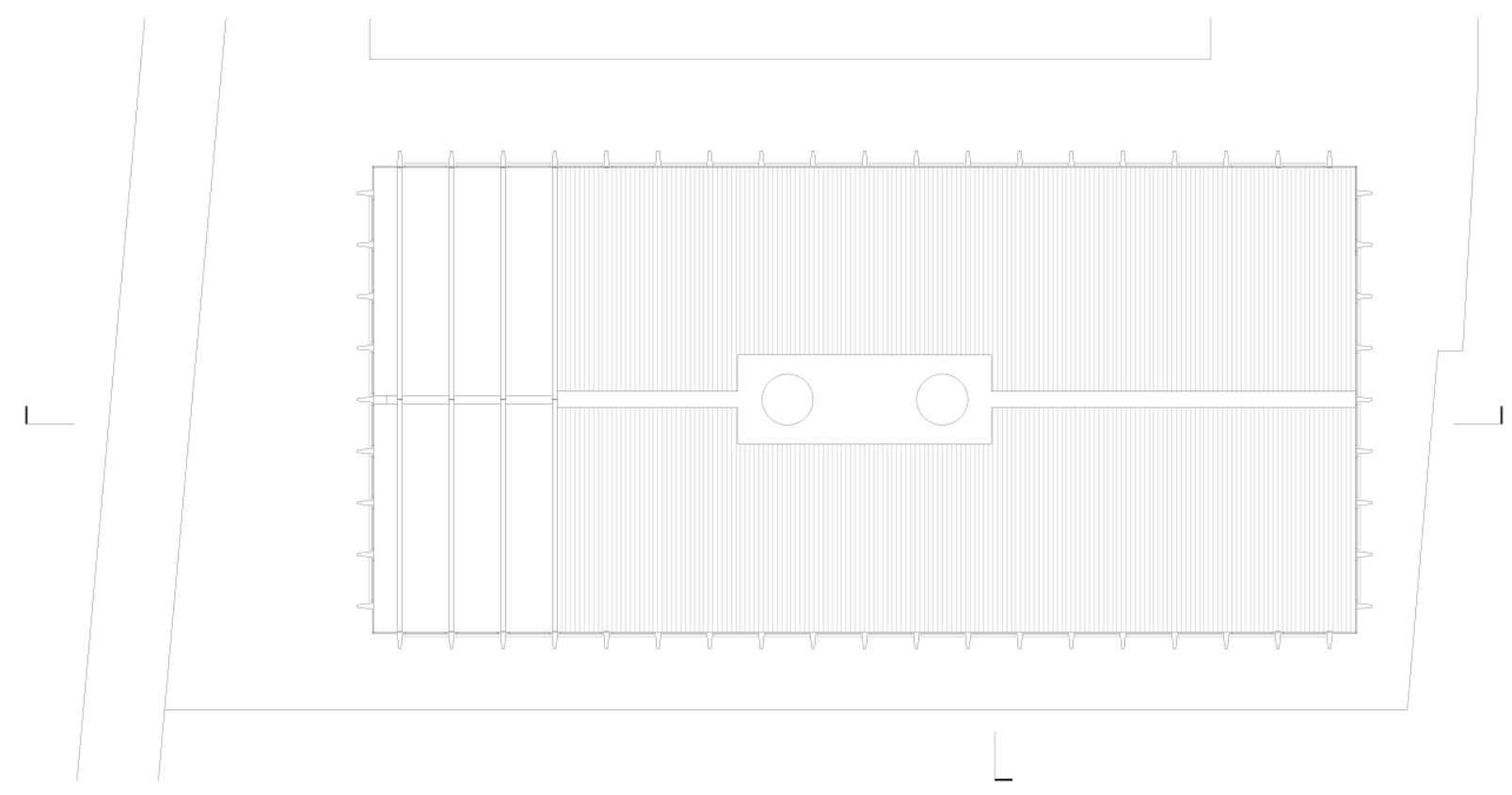

NIVEL + 16.90m. PLANTA DA COBERTURA

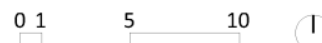

01 PERGOLADO 02 ARMÁRIOS 03 SECRETARIA DE PÓS-GRADUAÇÃO 04 ATLÉTICA 05 SALA DE AULA 

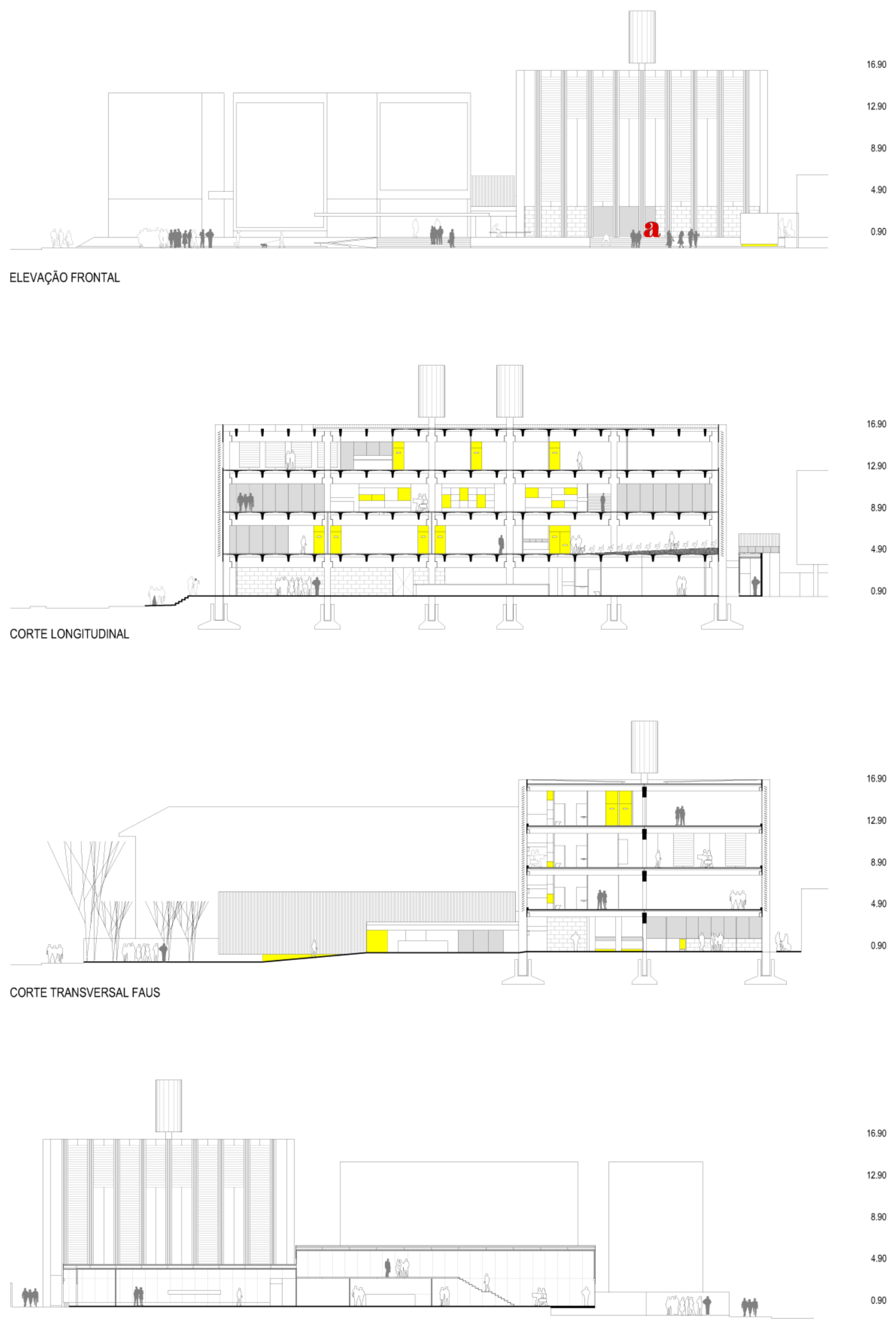


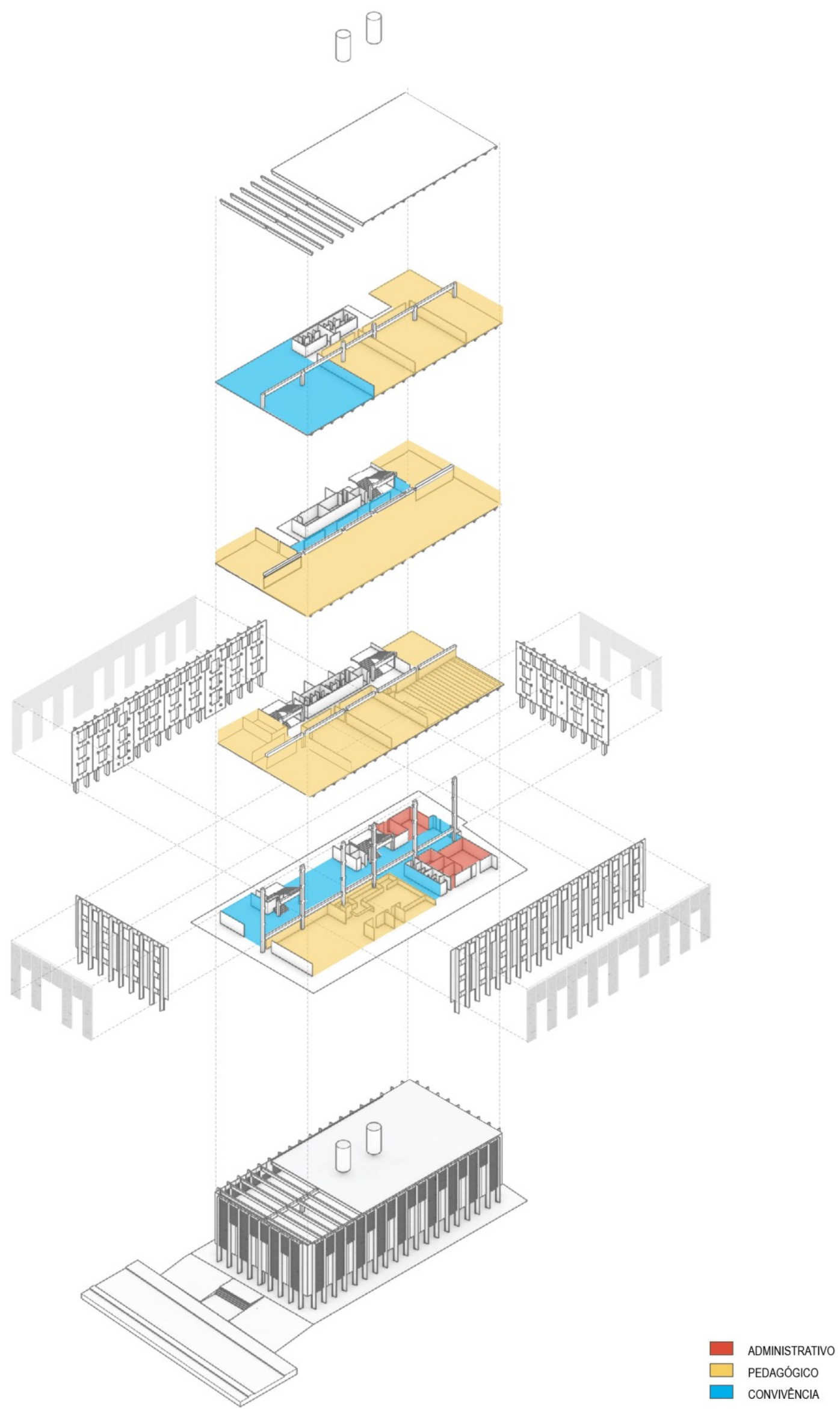

FIG. 154. Diagrama com a proposta das novas relações entre programas e distribuição espacial da FAUS. 
Em síntese, a observação e leitura dos dados apresentados neste capítulo indicam que a Faculdade de Arquitetura e Urbanismo de Santos, ao considerar as cidades da Região Metropolitana da Baixada Santista como centro de suas ações, contribuiu e vem contribuindo no seu planejamento, ordenamento e construção. Em um primeiro momento, isso confirma o objetivo inicial e pragmático de formar quadros técnicos de arquitetos para atuarem na Baixada, tanto na esfera pública quanto na iniciativa privada. Interessa dizer que a ênfase de atuação na área de projeto de edificação demonstra um claro reflexo da decisão de Oswaldo Corrêa em centrar os objetivos da escola no projeto. Por outro lado, arrisca-se dizer que o caráter profissionalizante dessa decisão atrelado aos iniciais limites institucionais resultou em um atraso significativo na formação de pesquisadores e, consequentemente, na formação de docentes.

Contudo, apesar dessa deficiência, a FAUS, a partir da própria experiência e consolidação da sua estrutura política e pedagógica, influenciou outras instituições no processo de ramificação do ensino na Baixada através da atuação dos professores por ela formados. Indo além do contexto local e regional, a participação e conquista de diversos prêmios e menções em concursos para estudantes ao longo de sua história, ainda que de forma pontual e esporádica, revela a capacidade de superação de estudantes e docentes que, ao participarem desses eventos de maneira autônoma, sem apoio institucional, vêm projetando a FAUS no cenário estadual e nacional.

No que se refere às ações experimentais da Sequência de Projeto da FAUS, o Trabalho de Graduação Inicial (TGI), por se tratar de uma atividade recente, é muito difícil dimensionar o seu valor pedagógico, entretanto, essa experiência apresenta-se como uma alternativa, ainda que paliativa ou panorâmica, de antecipação de questões multidisciplinares vistas somente no decorrer do Trabalho de Curso. Indo além, devido à sua organização vertical, auxilia na integração de todo corpo discente da escola, inclusive, dos alunos ingressantes. Esses alunos, ao chegarem do ensino médio, iniciam sua experiência no universo da arquitetura e do urbanismo, em um ambiente marcado pela necessidade de agenciar as virtuosidades divergentes ${ }^{82}$ do grupo na tomada de toda e qualquer decisão. Isso é bom.

Quanto ao projeto apresentado para a FAUS, trata-se de uma tentativa de síntese entre teoria e prática, um esforço desde a perspectiva do estudante de arquitetura que, diante da dimensão de uma investigação como essa, rende-se ao desejo de associar, articular e fundir conceitos através da materialização de ideias na forma de projeto. Acredita-se que cada estágio concluído de um determinado processo de pesquisa representa o fechamento de um ciclo e revela o contexto em que foi elaborado. Desse modo, reivindica-se que o trabalho aqui apresentado seja visto como um

\footnotetext{
82 Parafraseando Francisco de Oliveira. UNIVERSIDADE CATÓLICA DE SANTOS. Registro de "atas plenárias". Op. cit. pp. 15-16. 
processo de busca que permanece aberto, representando apenas mais uma instância de formação do arquiteto.

Para encerrar este capítulo, talvez como forma de agradecimento, recorre-se uma última vez às palavras do professor fundador da FAUS, Julio Katinsky:

Portanto, a meu ver, existe uma situação concreta: a contribuição da FAUS foi fundamental para o desenvolvimento cultural da cidade de Santos e região. Ela é uma presença concreta na cidade, tem formado muitos arquitetos que, inclusive vêm aqui, na pós-graduação da FAU, para completar sua formação, mas, em breve, pelo menos o mestrado poderá ser feito na FAUS. O que será bom, pois criará uma nova condição, que é da pesquisa institucionalizada que, não pode ser feita em outro lugar, mas também não devemos imaginar que a universidade possa substituir a atividade prática social do arquiteto, não existe essa possibilidade. ${ }^{83}$

\footnotetext{
83 KATINSKY, Julio Roberto. Entrevista com Julio Roberto Katinsky. São Paulo: 23 mai. 2016. Entrevista a José Maria de Macedo Filho.
} 


\title{
CONSIDERAÇÕES FINAIS
}

\author{
Ao modo de saída
}

A difusão do ideário da arquitetura modernista internacional do início do século XX influenciou o processo de emancipação e consolidação da profissão do arquiteto no Brasil e conduziu a FAU-USP na reforma do ensino da arquitetura e urbanismo, posicionando o projeto e o atelier no centro do curso nos anos 1960. Nessas bases, as alianças firmadas para a prática didática e profissional da arquitetura, em especial no Estado de São Paulo, geraram o lastro de sustentação ideológico, político e pedagógico que orientou a expansão do ensino de arquitetura nos anos 1970.

A constituição da Faculdade de Arquitetura e Urbanismo de Santos - FAUS - resultou do empenho do arquiteto Oswaldo Corrêa Gonçalves que, imbuído dos conceitos propostos na FAU-USP e dirigido pelo princípio da confiança, foi capaz de agenciar a montagem de um quadro docente heterogêneo, portanto virtuoso, no qual teve o privilégio de contar com importantes nomes da cultura brasileira. Esse grupo de arquitetos e urbanistas, artistas, sociólogos e engenheiros, além de colaborarem para a formação da identidade da escola, sempre entenderam a cidade como principal campo de pesquisa e objeto de intervenção para os seus estudantes. 
A FAUS logo depois da sua fundação em 1970, centrada na linha do projeto como instrumento de emancipação e sustentação política, projetou e construiu sua sede própria como síntese da sua pedagogia, a consolidação dessa estrutura permitiu que a escola alcançasse seu objetivo inicial de formar quadros técnicos de arquitetos para atuação na região da Baixada Santista. Seu atelier constitui o cerne da produção e articulação política da escola, funciona como um condensador que processa os dados recebidos continuamente da cidade e os devolve na forma de pesquisas, planos e projetos de intervenção em distintas escalas, desde a superfície do papel até o desenho do objeto, do edifício, da cidade e do território. Desse modo, pode-se dizer que a FAUS tem contribuído significativamente para o desenvolvimento do panorama cultural de Santos e, além disso, através da atuação dos seus professores na instalação, coordenação e docência nas novas instituições, tem exercido forte influência no processo de ramificação do ensino de arquitetura e urbanismo na cidade. Essas considerações resultam da problemática inicialmente identificada e da verificação das hipóteses norteadoras dessa pesquisa, confirmadas no desdobramento da investigação. Evidenciam a importância da valorização da identidade no todo para revisar princípios, ideias e desejos, fortalecendo o conjunto de escolas na busca de novos meios de comunicação dos processos de produção da arquitetura, um fazer que opera entre elementos intuitivos e analíticos, entre o geral e o particular, e tem o contexto territorial, histórico e cultural da cidade como principal campo de ação do arquiteto.

A observação de material inédito demonstrou que os embates ideológicos entre distintos grupos de professores da FAU-USP, matizados na FAUS em seus anos iniciais, contaram com a essencial ajuda do corpo discente que, aliado ao corpo docente no desfavorável contexto da ditadura militar, demonstrou autonomia, maturidade e posicionamento político na busca por melhores condições de ensino e liberdade de expressão junto à instituição. Participou na tomada das decisões da escola, registrou as discussões políticas e pedagógicas em dossiês que permitem verificar, a partir da perspectiva do aluno, que os períodos de crises foram convertidos em oportunidades de mudanças e motivação para a FAUS continuar suas atividades.

Os dados coletados revelaram a efetiva contribuição e relevância da FAUS para o ensino da arquitetura e do urbanismo, para o planejamento urbano, projetos e construções, tanto no setor público quanto na iniciativa privada, das cidades integrantes da Região Metropolitana da Baixada Santista - RMBS. A formação do seu próprio quadro docente demonstra o amadurecimento político e pedagógico da escola conquistado ao longo do tempo e através das diversas alianças firmadas entre arquitetos, instituições e, principalmente, com os estudantes. Expuseram que a ênfase de atuação dos arquitetos da FAUS é na área de projeto de edificação, vista no perfil do seu egresso até os dias de hoje. Contudo, explicitaram um atraso significativo na formação de pesquisadores e, 
consequentemente, na formação de docentes. Assim, ainda que a Universidade Católica de Santos (UNISANTOS) incentive e apoie ações nessa direção, a FAUS depende das decisões institucionais quanto aos aspectos políticos, financeiros e administrativos que, quando somados ao atraso na produção científica, expõem o dilema de como propor autonomia sem ter autonomia.

Esse ponto levantado permite contextualizar a escola no atual cenário do ensino de arquitetura e urbanismo no Brasil. Segundo o "Anuário de Arquitetura e Urbanismo de 2019", editado e publicado pelo Conselho de Arquitetura e Urbanismo do Brasil (CAU/BR), somente em 2018, os 729 cursos de arquitetura existentes no país foram responsáveis pela formação de cerca de 12 mil arquitetos e urbanistas. Pode-se dizer que hoje é uma profissão dominada por mulheres jovens, com menos de 40 anos, e que a maioria dos profissionais está concentrada da Região Sudeste, sendo um terço deles, apenas em São Paulo. ${ }^{1}$

Esses números remetem à tarefa pedagógica de Nicolai Ladovsky ao lecionar para centenas de estudantes nos VKhUTEMAS. O alto número de alunos norteava a elaboração das estratégias de ensino, mas apesar do seu esforço para contemplar a diversidade discente, o inerente caráter instrumental das metodologias voltadas para as massas convertia a formação em treinamento. Nesse sentido, a forma que o atual mercado de educação brasileiro encontrou para ampliar esses números e aumentar seu capital se apoia na tecnologia para tornar possível que o ensino de massa seja feito à distância, em uma modalidade conhecida como "EaD"- Ensino à Distância.

Além do uso da tecnologia, são utilizadas algumas estratégias empresariais para tornar essa modalidade de ensino ainda mais eficiente, ou seja, algumas Instituições de Ensino Superior contratam docentes por três meses para formularem cartilhas, manuais detalhados e gravarem vídeo-aulas, garantindo que seu conteúdo possa ser aplicado por qualquer professor. As avaliações devem ser feitas, prioritariamente, a partir de questões alternativas, o que autoriza que o acompanhamento dos alunos seja feito por um tutor. No caso de alguma avaliação propor questões dissertativas, o docente deixa de ser caracterizado como tutor, entretanto, alterar seu contrato de trabalho para a categoria de professor significa mais custos para a empresa. Ao término da produção dos manuais e vídeos, os docentes assinam um documento de cessão dos seus direitos autorais para que a IES possa utilizar o material por setenta anos. Em seguida são demitidos.

Em setembro de 2019, na ocasião de uma audiência sobre o EaD na Assembleia Legislativa de São Paulo (ALESP), foram apresentados alguns grupos empresariais de educação constituídos por

\footnotetext{
${ }^{1}$ Na última década, o número de escolas de arquitetura no Brasil mais que triplicou. Em 2011, havia pouco mais de 200 cursos e, em 2019 o sistema e-MEC do Ministério da Educação (MEC) tinha 729 escolas de arquitetura e urbanismo em atividade, sendo destas 32 na modalidade de Ensino à distância (EAD). Entre as 697 escolas presenciais registradas no MEC, 65 eram públicas e 664 particulares. CONSELHO DE ARQUITETURA E URBANISMO DO BRASIL. Anuário de Arquitetura e Urbanismo 2019. 116p. Brasília: CAU/BR, 2019. p. 8. Disponível em: < https://caubr.gov.br/wp-content/uploads/2019/06/ANU\%C3\%81RIO-FINAL-WEB.pdf >. Acesso em: 05 fev. 2020.
} 
conglomerados de IES. Para que se tenha uma ideia, apenas um desses grupos detém o controle de doze Instituições de Ensino Superior e os números revelados reforçam a noção do ensino como produto e o processo contínuo de desvalorização do professor. Nesse sentido, por exemplo, a IES B tem uma relação de seiscentos alunos por tutor, e a IES A conta com 274 mil estudantes matriculados em cursos oferecidos integralmente à distância, dispondo de 300 docentes, em uma relação de 913 alunos por professor. ${ }^{2}$

No que se refere ao campo da arquitetura e do urbanismo, apesar de o Conselho de Arquitetura e Urbanismo (CAU) em decisão recente ter deliberado não registrar egressos de cursos com mais de $20 \%$ de aulas na modalidade EaD, esse cenário continua agravado pelo sistema de avalição das Instituições de Ensino Superior proposto pelo Ministério da Educação e Cultura (MEC), no caso o Exame Nacional de Desempenho de Estudantes (ENADE). ${ }^{3}$ Em linhas gerais, consiste de provas pautadas por assuntos pontuais e de caráter genérico, permeadas de armadilhas que, para a educação do estudante de arquitetura, são irrelevantes, no entanto, e no pior sentido, contribuem para acirrar a competição entre as escolas, através da publicação anual de listas, ou melhor dizendo, rankings com os melhores cursos de arquitetura do país.

Ainda sobre esse ponto, a ABEA propôs a incorporação do Trabalho de Curso (TC) no Exame Nacional de Desempenho de Estudantes (ENADE), "como mais um instrumento para medição da qualidade e desempenho dos cursos, confrontando-o com o universo de cursos no país." ${ }^{4}$ Segundo a ABEA, permite-se a partir do Trabalho de Curso conhecer critérios internos de avaliação em cada curso, temas mais frequentes, nível de abrangência de cada trabalho, metodologias desenvolvidas, práticas pedagógicas adotadas, capacidade de resolução de problemas em arquitetura e urbanismo, dentre outros critérios. Mesmo que involuntariamente, grosso modo, ao utilizar os termos medição e desempenho, a ABEA, ao mesmo tempo em que aceita a continuidade da competição entre escolas, oferece o risco de tornar o Trabalho de Curso alvo das empresas de educação que, como visto, dirigidas por interesses econômicos, provavelmente excluiriam a autonomia do estudante na identificação de problemas, escolha de temas e desenvolvimento do trabalho.

\footnotetext{
${ }^{2} \mathrm{~A}$ audiência debateu a precarização do ensino EaD no Brasil. Resultou de uma denúncia feita ao Ministério Público por um ex-professor e sociólogo que trabalhava na IES A, que chegou a ministrar aulas de história da arte na modalidade EaD. O ex-reitor da Universidade Federal do Rio de Janeiro, Roberto Leher, explicou que, quando uma empresa educacional é negociada na bolsa, sua cotação é medida diariamente com base na expectativa de lucro. Um exemplo foi a reestruturação da IES C em 2017, com a demissão de 2 mil trabalhadores, que fez seus papéis valorizarem $8 \%$ em um único dia. Por isso, ele vê a crise do FIES de 2015 como a grande impulsionadora do EaD, já que passou a ser nova promessa de lucro certo. O presidente da Federação dos Professores (FEPESP) remeteu a origem do problema à má gestão do FIES, que garantiu às faculdades "receita certa e cliente cativo". O novo mercado atraiu grandes grupos econômicos, que viram no EaD uma forma de ampliar a lucratividade. O FIES dispõe de 31 bilhões de reais de orçamento anual enquanto as Universidades Federais têm 6 bilhões. Disponível em <https://www.al.sp.gov.br/noticia/?09/09/2019/audiencia-debate-precarizacao-do-ensino-ead> Acesso em: 22 jan. 2020.

${ }^{3}$ Antigo "Provão", foi aplicado pela primeira vez na área de arquitetura e urbanismo em junho de 2002. Na ocasião, a FAUS boicotou a avaliação com o não comparecimento de seus estudantes.

${ }^{4}$ ASSOCIAÇÃO BRASILEIRA DE ESCOLAS DE ARQUITETURA - ABEA. Disponível em: < http://www.abea.org.br/?page_id=16 > não p. Acesso em: 22 jan. 2020. (grifo nosso).
} 
Diante disso, e não eximindo a responsabilidade da classe de arquitetos por tal distorção, torna-se difícil vislumbrar uma alternativa para o processo de massificação, pois os interesses financeiros são o grande objetivo, e não a excelência da formação do estudante. Indo além, preocupadas em conquistar melhor posição no ranking do MEC seguem todas suas resoluções e exigências sem criticá-las, mas do modo que melhor lhes convém. Assim sendo, por um lado não aceitam professores sem titulação e trocam profissionais experientes por recém-formados titulados, por outro lado, descartam ou não aceitam docentes com alta titulação por serem mais caros. Soma-se a essa desastrosa conjuntura a má formação dos estudantes advindos do ensino médio que encontram grande dificuldade para entender o que significa a pesquisa e autonomia intelectual no âmbito da universidade, mais bem explicado pelo professor Maitrejean:

Os alunos atualmente não entendem o que eu digo, não vejo seus olhos brilharem, querem respostas pragmáticas para seus problemas imediatos de desenho, infelizmente as escolas estão formando cadistas, desenhistas de projeto de prefeitura, sou um professor que não tem mais alunos. ${ }^{5}$

A postura dessas empresas de educação é clara. Interessadas em captar cada vez mais alunos, formatam/adaptam cursos instrumentais apostilados para massas apáticas, com planos de ensino pré-determinados que, ao serem aplicados seguindo um roteiro, não oferecem margem para ajustes ou alterações. As regras dos órgãos reguladores da política educacional brasileira incentivam o capital privado a testar os limites da relação custo-benefício na educação, basta observar o processo de fragmentação das matrizes curriculares e o estabelecimento de currículos mínimos, implantados e divulgados pelo governo em cartilhas, manuais prontos e, do mesmo modo que o tutor, as Instituições de Ensino Superior apenas seguem o roteiro. Interesses alinhados, constata-se a perniciosa redução da capacidade de articulação política dos quadros docentes e discentes na formulação das estratégias de ensino, além da consequente perda de identidade dos cursos, por meio da formação de novas escolas com perfil genérico. O acordo MEC-USAID, firmado há cinquenta anos, atinge seu ápice. Assim, tal cenário apresenta mais questões do que respostas para os problemas da atual conjuntura do ensino superior brasileiro.

No que se refere ao ensino de arquitetura, a pesquisa indicou que problemas identificados cinquenta anos atrás pouco evoluíram ou sequer foram resolvidos até os dias de hoje e, indo além, alguns se referem a dilemas propostos pela Bauhaus e pelos VKhUTEMAS há cem anos, no início do século XX. Desse modo, para formar a grande quantidade de estudantes com diferentes características culturais, socioeconômicas, níveis de formação, localidades, dentre outras variáveis, um dos pontos que definitivamente devem ser intensificados é o incentivo ao debate contínuo, através de investimentos

\footnotetext{
${ }^{5}$ MAITREJEAN, Jon Vergareche. Entrevista com Jon Vergareche Maitrejean. São Paulo: 01 jul. 2016. Entrevista a José Maria de Macedo Filho.
} 
maciços para a identificação e experimentação de alternativas no ensino de arquitetura no Brasil, considerando as Diretrizes Curriculares Nacionais e a desleal disputa por alunos.

É por demais sabido que a pesquisa científica configura uma das ferramentas contra a instrumentalização da educação, nesse sentido, desde 2003, ainda contrária à modalidade de ensino à distância, a Universidade Católica de Santos UNISANTOS oferece um curso de especialização latosensu em Restauro do Patrimônio Arquitetônico e Urbanístico, montado pelos professores da sequência de Teoria e História da Arquitetura e do Urbanismo da FAUS. Apesar da ênfase técnica e profissionalizante de um de curso de especialização, a heterogeneidade do corpo discente, por receber candidatos formados em distintos campos de conhecimento, diferentes instituições e localidades, naturalmente quando juntos, compartilham experiências sociais e culturais que enriquecem a formação de todo o grupo. Indo nessa direção, em um esforço conjunto entre docentes e a universidade, o programa de mestrado profissional stricto-sensu em arquitetura e urbanismo foi instalado em 2019 com o curso Arquitetura e Cidade, e tem início previsto para o primeiro semestre de 2020.

A pesquisa ressaltou que a ação projetual do arquiteto trata de um procedimento aberto que, ao admitir entradas múltiplas e simultâneas, ao modo do rizoma de Deleuze e Guattari, configura um processo de natureza aberta e inacabada, que se aprende fazendo, aplicando, experimentando e construindo. Valendo-se da tese de Barossi de que a pedagogia é o estudante, arrisca-se dizer que o ensino de arquitetura poderia se apoiar em procedimentos didáticos compatíveis com sua natureza, ou seja, aberta, múltipla e simultânea, por vezes inacabada, e que também se aprende fazendo. Desse modo, o sujeito do estudo torna-se o principal agente e especialista na definição do objeto de investigação, simultaneamente como sujeitos de testes e provedores de dados.

Tendo isso em vista, apesar de remeter aos centenários conceitos da Bauhaus, a sexagenária ressalva de Vilanova Artigas continua válida ao entender que "a formação técnica deve introduzir métodos de verificação das propostas que a sensibilidade artística determina e concorrer para a sistematização da experiência." ${ }^{6}$ No que se refere à FAUS, importa dizer, ou mesmo alertar, que a constatação da ênfase dada ao Núcleo de Conhecimentos Profissionalizantes em detrimento do Núcleo de Conhecimentos de Fundamentação no currículo da graduação pode refletir em um ensino demasiado técnico e instrumental. Além de contradizer os objetivos do seu Projeto Pedagógico, que propõe uma educação pautada por princípios de autonomia intelectual e produção de conhecimento cultural e generalista, estruturas como esta dificilmente formam pensamento crítico-reflexivo e de síntese de

\footnotetext{
${ }^{6}$ Abordagem de Artigas a respeito dos ateliers, com a preocupação visível de acalmar os ânimos dos professores das disciplinas técnicas e, ao mesmo tempo, de caracterizar a ideia de "departamento" - em oposição à estrutura de cátedras - que foi um dos pontos importantes da Reforma de 1962. FORTI, Marco Artigas. FAUUSP - 50 anos da Reforma de 1962. Disponível em <http://www.dearquiteturas.com>. Acesso em: 11 nov. 2015.
} 
expressão, necessários para incentivar a pesquisa, qualificar a atividade profissional e contribuir para o desenvolvimento do campo de conhecimento.

A dimensão projetual do atelier da FAUS demonstrou ser necessário, portanto, incrementar as disciplinas que ampliem o repertório cultural do estudante na direção de uma maior autonomia intelectual, com o objetivo de formar arquitetos que pensem e não apenas executem. Assim, é desejável o aumento da carga horária de disciplinas que investigam, de maneira propositiva, as relações entre arte e arquitetura como a disciplina de Plástica, por exemplo, entendida como uma dimensão intrínseca e inseparável do projeto arquitetônico, além da ampliação e valorização de disciplinas que tratam das questões do universo da sociologia. $O$ equilíbrio dos conteúdos culturais e profissionalizantes pode contribuir na formação de arquitetos com visão crítica, social e política, evitando assim a atual proliferação de massas apáticas e instrumentalizadas de profissionais incapazes de perceber o quanto é abrangente o pensamento arquitetônico.

Quanto ao espaço, a pesquisa indicou que a fragmentação curricular resultou em uma demasiada compartimentação dos lugares abertos da FAUS, com claro prejuízo e perda de oportunidades de experimentação didática para a educação do arquiteto. Esse fato sinaliza a necessidade de reversão dessas alterações com a recuperação dos espaços de convívio, a reestruturação do arranjo programático e a instalação de novas estruturas junto ao prédio, para atender as demandas contemporâneas do ensino e da produção da arquitetura. Essa leitura reforça a noção de que os problemas de ordem política em uma escola refletem diretamente nas estratégias e metodologias de ensino e, consequentemente, nos lugares em que se processam. Todos esses são importantes elementos para a constatação da dimensão política e pedagógica dos espaços de produção, convívio e interação de uma escola.

Nesse sentido, apesar de ser muito difícil dimensionar o valor pedagógico do Trabalho de Graduação Inicial (TGI), por se tratar de uma atividade recente iniciada em 2017, arrisca-se dizer que essa experiência de projeto ao apresentar a dimensão do trabalho vertical convocando a íntegra do corpo discente da escola para a execução de uma atividade única no mesmo espaço, no caso o Atelier, derrubou paredes e a FAUS se reconheceu como um todo, não como turmas isoladas em salas de aula organizadas em séries. Assim, nesse mesmo ano, diante dos problemas na ocasião da revisão do Projeto Pedagógico da escola, com prejuízo direto aos estudantes, o atelier na FAUS se converteu de forma imediata, e até inesperada, em um poderoso instrumento de organização e articulação política.

A nova geração da FAUS percebeu sua força através de uma ação de projeto coletiva e vertical e no final do ano de 2017, a primeira evidência dessa afirmação pôde ser vista em um manifesto 
intitulado "Ressurreição da FAUS", elaborado pelo Diretório Acadêmico Michail Lieders, em resposta à falta de diálogo e às confusas ações da coordenação do curso da época. Esse documento foi destinado à Reitoria e à Chancelaria da Mantenedora da Universidade Católica de Santos.

Em linhas gerais, tratava do cerceamento de expressão artística devido à supressão das intervenções da disciplina de Plástica no Campus Boqueirão e dentro da FAUS; mau funcionamento dos laboratórios; falta de espaço para armazenamento de materiais; reclamações e reivindicações ignoradas reiteradamente pela coordenação; ${ }^{7}$ eleições diretas para o coordenador do curso; contratação de novos professores acompanhada pelos docentes das sequências contratantes, pois “os professores são a base estruturante do curso, responsáveis pelo sistema pedagógico dentro e fora de sala de aula, e dessa forma necessitam de mais autonomia e voz ativa." ${ }^{8}$ Além desse documento, foram organizadas outras formas de protesto como, por exemplo, a colocação de pranchetas do atelier com maquetes em andamento no passeio público e no canteiro central da Avenida Conselheiro Nébias, seguida de uma passeata da FAUS até o Campus Dom Idílio, sede da Universidade Católica de Santos, reivindicando essas e outras melhorias.

Todas essas ações resultaram em uma profícua reunião entre reitor, pró-reitores, diretor de centro, coordenador e alunos. No início do ano letivo de 2018, a instituição já havia atendido parte das solicitações em reconhecimento à postura crítica e politizada dos seus estudantes, antes de tudo uma confirmação do êxito da própria Universidade que tem como objetivo, além da formação profissional e instrumental de seus egressos, uma educação pautada pela autonomia intelectual e pela visão humanista e generalista do mundo. Atualmente, a revisão em curso do Projeto Pedagógico da FAUS para o período de 2021 a 2025, apoia-se conceitualmente na reestruturação da Sequência de Projeto de Arquitetura e posiciona o Trabalho de Graduação Inicial (TGI) no mesmo plano do Trabalho de Curso (TC) e, por recomendação direta da Reitoria da Universidade, deve ser considerado um componente curricular.

Em resumo, a epígrafe Dilatentur Spatia Veritatis conduziu as reflexões dessa investigação sobre a natureza das possíveis expansões do campo pedagógico da arquitetura e do urbanismo. Indicou que, ao se propor ampliações de qualquer natureza no campo do conhecimento, corre-se o risco da dispersão, assim, quando se percebe um incontido alargamento, faz-se necessária uma reunião ou reagrupamento, caso contrário a dispersão estará dada. Tal necessidade não é uma contradição, pois o retorno que se propõe é o contínuo revisar da própria condição humana; ao mesmo tempo que o

\footnotetext{
${ }^{7}$ Ver também a carta anterior enviada à Reitoria da universidade em agosto de 2017. DIRETÓRIO ACADÊMICO MICHAEL LIEDERS. AbaixoAssinado: solicitação de solução de problemas e mais diálogo. Santos, 2017. Disponível em <https://www.abaixoassinado.org/abaixoassinados/37119>. Acesso em: 20 dez. 2017.

${ }^{8}$ Síntese do documento elaborado em 18 de dezembro de 2017, disponível no arquivo do Diretório Acadêmico da FAUS. DIRETÓRIO ACADÊMICO MICHAEL LIEDERS. Ressurreição da FAUS. Santos, 2017. 
homem amplia o espaço, ele o mapeia e o reagrupa. Reconhecer a identidade de um indivíduo no todo permite uma generosa continuidade da ampliação do campo do conhecimento. Procedendo ajustes e revisões, monta-se um mapa das virtuosidades divergentes, como proposto pelo professor Francisco de Oliveira na FAUS. Nesse sentido, valendo-se uma última vez de Deleuze e Guattari:

\begin{abstract}
O mapa é aberto, é conectável em todas as suas dimensões, desmontável, reversível, suscetível de receber modificações constantemente. Ele pode ser rasgado, revertido, adaptar-se a montagens de qualquer natureza, ser preparado por um indivíduo, um grupo, uma formação social [...] construí-lo como uma ação política ou como uma meditação. Uma das características mais importantes do rizoma talvez seja a de ter sempre múltiplas entradas. ${ }^{9}$
\end{abstract}

Assim, a metodologia de investigação centrada no estudante, professor, pedagogia e espaço contribuiu na elucidação da problemática inicialmente proposta que, de fato, é oferecer insumos que possam ser cruzados com os de outras instituições, situando a relevante contribuição da Faculdade de Arquitetura e Urbanismo de Santos no campo ampliado do ensino de arquitetura em São Paulo, a partir do material gerado com a observação dos desdobramentos das alianças firmadas nos processos de concepção, instalação, consolidação e evolução da escola.

Finalmente, a tese de Oswaldo Corrêa Gonçalves de que "a cidade é o laboratório da FAUS", além de comprovada teve seu significado expandido: a falta de recursos, que impôs a inauguração do seu prédio inacabado, sem portas e janelas, converteu-se na acidental, contudo poética, relação explícita com a cidade, uma moldando e construindo a outra. Desse modo, pode-se dizer que a FAUS está na cidade assim como a cidade está na FAUS. Quem faz essa aliança é o estudante.

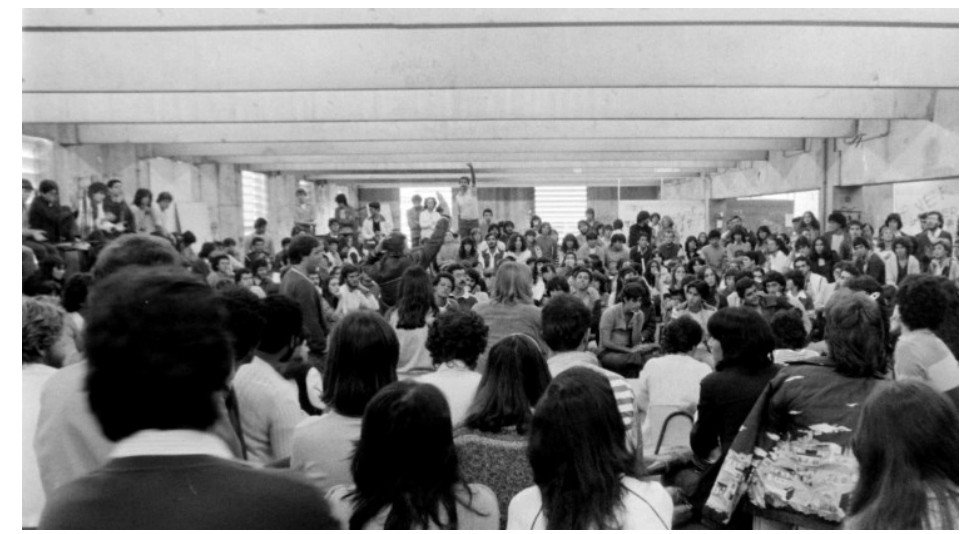

FIG. 155. Estudantes e professores no atelier da FAUS em 1982.

\footnotetext{
${ }^{9}$ DELEUZE, Gilles. GUATTARI, Félix. Mil platôs, capitalismo e esquizofrenia. Vol. 01. São Paulo: Editora 34, 1995. pp.21-22.
} 


\section{REFERÊNCIAS BIBLIOGRÁFICAS}

ABASCAL, Eunice H.S.; ABRUNHOSA Eduardo C.; ALVIM, Angélica T. B. (orgs.). Arquitetura FAU-Mackenzie 100 anos: pioneirismo e atualidade. São Paulo: Editora Mackenzie, 2017.

ACAYABA, Marlene M. Residências em São Paulo: 1947-1975. São Paulo: Projeto, 1986.

AFONSO, Cintia Maria. A paisagem da Baixada Santista: urbanização, transformação e conservação. São Paulo: Fapesp/Edusp, 2006.

ALBUQUERQUE, Roberto Portugal. Caderno dos riscos originais: o projeto do edifício da FAUUSP na cidade universitária. São Paulo: FAUUSP, 1998.

ALQUERES, Elvira de Almeida. Sistema integrado de pré-fabricação e autoconstrução de móveis: racionalização de um princípio construtivo espontâneo. São Paulo: INOCOOP, 1974.

ANDRADE, Oswald. Do pau-brasil à antropofagia e às utopias. Rio de Janeiro: Civilização Brasileira, 1978.

ARGAN, Giulio Carlo. Projeto e destino. São Paulo: Ática, 2004.

ARANTES, Pedro Fiori. Arquitetura Nova: Sérgio Ferro, Flávio Império e Rodrigo Lefèvre, de Artigas aos mutirões. 2eed. São Paulo: Editora 34, 2011.

ARTIGAS, João Batista Vilanova. A função social do arquiteto. São Paulo: Nobel, 1989.

ARTIGAS, João Batista Vilanova. Caminhos da Arquitetura. São Paulo: Cosac Naify, 2004.

ARTIGAS, Rosa (org.). Paulo Mendes da Rocha. São Paulo: Cosac Naify, 2000.

ARTIGAS, Rosa (org.). Paulo Mendes da Rocha: projetos 1999-2006. São Paulo: Cosac Naify, 2007.

ARTIGAS, Rosa (org.). Vilanova Artigas. São Paulo: Terceiro Nome, 2015.

ASSOCIAÇÃO BRASILEIRA DE ENSINO DE ARQUITETURA E URBANISMO. A construção de um novo olhar sobre o ensino de Arquitetura e Urbanismo no Brasil: Os 40 anos da ABEA. Brasília: ABEA, 2013.

BANHAM, Reyner. Teoria e projeto na primeira era da máquina. São Paulo: Perspectiva, 1975.

BARBOSA, Gino Caldatto; FRANCO, Ruy E. Debs (orgs.). Oswaldo Corrêa Gonçalves, arquiteto cidadão. Santos: Edição do Autor, 2019.

BAROSSI, Antônio Carlos. O edifício da FAU-USP de Vilanova Artigas. São Paulo, Editora da Cidade, 2017.

BARDI, Lina Bo. Contribuição propedêutica ao ensino da teoria da arquitetura. São Paulo: Instituto Lina Bo Bardi, 2002.

BRITO, Mônica Silveira (org.). 100 anos de ensino de arquitetura e Urbanismo em São Paulo. São Paulo: LPG FAUUSP, 1996.

BRUNA, Paulo J. V. Arquitetura, industrialização e desenvolvimento. 2a ed. São Paulo: Perspectiva, 2002.

BRUAND, Yves. Arquitetura Contemporânea no Brasil. 3a ed. São Paulo: Perspectiva, 1997.

COSTA, Lucio. Registro de uma vivência. São Paulo: Edições Sesc São Paulo/Editora 34, 2018.

CURTIS, William J. R. Arquitetura moderna desde 1900. 3a ed. Porto Alegre: Bookman, 2008.

DAL Co, Francesco (org.). El arquitecto em la lucha de clases y otros escritos, Hannes Meyer. Barcelona: Gustavo Gili, 1972. 
DAHER, Luiz Carlos. Flavio de Carvalho: arquitetura e expressionismo. São Paulo: Projeto Editores Associados, 1982.

DE FEO, Vittorio. URSS: architettura, 1917-1936. Roma: Editori Riuniti, 1963.

DELEUZE, Gilles; GUATTARI, Félix. Mil platôs, capitalismo e esquizofrenia. Vol. 01. São Paulo: Editora 34, 1995. DROST, Magdalena Kate. Bauhaus, 1919-1933. Berlim: Bauhaus-Archiv, 2006.

FERRO, Sérgio. A história da arquitetura vista do canteiro: três aulas de Sérgio Ferro. São Paulo: GFAU, 2010.

FERRO, Sérgio. O canteiro e o desenho. São Paulo: Projeto Editores Associados, 1979.

FERRO, Sérgio. Arquitetura e trabalho livre. São Paulo: Cosac Naify, 2006.

FICHER, Sylvia. Os arquitetos da Poli: ensino e profissão em São Paulo. São Paulo: Edusp, 2005.

FOSTER, Hal. O complexo arte-arquitetura. São Paulo: Cosac Naify, 2015.

FRAMPTON, Kenneth. História crítica da arquitetura moderna. São Paulo: Martins Fontes, 1997.

FREIRE, Paulo. Pedagogia da autonomia: saberes necessários à prática educativa. 52a ed. Rio de Janeiro/São Paulo: Paz e Terra, 2015.

FRIGERIO, Angela Maria Gonçalves; OLIVEIRA, Yza Fava de. Santos: a geografia através dos mapas. Santos: A3 Editora, 1991.

GFAU. Corredor das Humanas, a poesia poderia ter sido e que não foi. São Paulo: Grêmio da Faculdade de Arquitetura e Urbanismo FAU, 2009.

GOODWIN, Philip. Brazil Builds: Architecture New and Old 1652- 1942. Nova York: The Museum of Modern Art, 1943.

GRAEFF, Edgar Albuquerque. Arte e técnica na formação do arquiteto. São Paulo: Nobel, 1995.

GROPIUS, Walter. Bauhaus: novarquitetura. 2ª ed. São Paulo: Perspectiva, 1974.

HEJDUK, John (org.). Education of an architect: the Irwin S. Chanin school of architecture of the Cooper Union. Nova York, 1996.

INSTITUTO LINA BO E P. M. BARDI. Vilanova Artigas, Coleção Arquitetos Brasileiros. São Paulo: Instituto Lina Bo e P.M. Bardi e Fundação Vilanova Artigas, 1997.

KAMITA, João Masao. Vilanova Artigas. São Paulo: Cosac Naify, 2000.

KANDINSKY, Wassily. Curso da Bauhaus. São Paulo: Martins Fontes, 2003.

KANT, Immanuel. Crítica da razão pura. 4ae ed. Rio de Janeiro: Vozes, 2015.

KANT, Immanuel. Prolegômenos a toda metafísica futura que queira apresentar-se como ciência. Trad. Artur Morão. Lisboa: Edições 70, 1988.

KEESE, Jefferson Lafaiette (org.). Anistia na FAUUSP: a reintegração dos professores cassados pelo Al-5. São Paulo: GFAU, 1998.

KOPP, Anatole. Quando o moderno não era um estilo e sim uma causa. São Paulo: Nobel, 1990.

KOWALTOWSKY, Doris C.C.K.; MOREIRA, Daniel C.; PETRECHE, João R.D.; FABRICIO, Márcio M. (orgs.). O processo de projeto em arquitetura: da teoria à tecnologia. São Paulo: Oficina de textos, 2011.

KOURY, Ana Paula (org.). Arquitetura moderna brasileira: uma crise em desenvolvimento: textos de Rodrigo Lefèvre (1963-1981). São Paulo: Edusp/Fapesp, 2019.

KOURY, Ana Paula. Grupo Arquitetura Nova: Flávio Império, Rodrigo Lefèvre, Sérgio Ferro. São Paulo: Romano Guerra, Edusp, 2003.

KRUPSKAYA, Nadezhda Konstantinovna. A construção da Pedagogia Socialista. São Paulo: Expressão Popular, 2017.

LANNA, Ana L. Duarte. Uma cidade na transição. Santos: 1870-1913. São Paulo-Santos: Hucitec, Prefeitura Municipal de Santos, 1996.

LARA, Fernando; MARQUES, Sonia. Quid novi? Dilemas do ensino de arquitetura no século 21. Austin: nhamericapress, 2015. 
LEMOS, Carlos A. Cerqueira. A arquitetura brasileira. São Paulo: Melhoramentos e Universidade de São Paulo, 1979.

LIMA, Sérgio de Souza (org.). Mayumi Watanabe de Souza Lima: arquitetura e educação. São Paulo: Studio Nobel, 1995.

LIRA, José. Warchavchik: fraturas da vanguarda. São Paulo: Cosac Naify, 2011.

LISSITZKY, El. Rússia: a reconstrução da arquitetura na União Soviética. São Paulo: Estação Liberdade, 2019.

MAGALHÃES, Mario. Marighella - o guerrilheiro que incendiou o mundo. São Paulo: Companhia das Letras, 2012.

MARTINEZ, Alfonso C. Ensaio sobre projeto. Brasília: Editora UnB, 2000.

MILHEIRO, Ana Vaz; NOBRE, Ana Luiza; WISNIK, Guilherme. Coletivo-arquitetura paulista Contemporânea. São Paulo: Cosac Naify, 2006.

MIZOGUCHI, Ivan. A formação do arquiteto. Porto Alegre: Corag/CAU-RS, 2016.

MOHOLY-NAGY, László. Do material à arquitetura. Barcelona: Gustavo Gili, 2005.

MONEO, Rafael. Inquietação teórica e estratégia projetual na obra de oito arquitetos contemporâneos. São Paulo: Cosac Naify, 2008.

MONTANER, Josep Maria; MUXI, Zaida. Arquitetura e política: ensaios para mundos alternativos. Barcelona: Gustavo Gili, 2014.

MONTANER, Josep Maria. A modernidade superada: arquitetura, arte e pensamento do século XX. Barcelona: Editorial Gustavo Gili, 2001.

MONTANER, Josep Maria. Arquitetura e crítica. Barcelona: Gustavo Gili, 2007.

MONTANER, Josep Maria. Sistemas arquitetônicos contemporâneos. Barcelona: Gustavo Gili, 2009.

MONTANER, Josep Maria. Depois do movimento moderno: arquitetura da segunda metade do século XX. Barcelona: Gustavo Gili, 2001.

MONTEIRO, Ana M. R. G. (org.). A construção de um novo olhar sobre o ensino de arquitetura e urbanismo no Brasil: os 40 anos da Associação Brasileira de Ensino de Arquitetura e Urbanismo. Brasília: ABEA, 2013.

MORAES, Mario Sergio. 50 anos construindo a democracia: do golpe de 64 à comissão da verdade. São Paulo: Vlado Editora, 2014.

MOTA, Carlos Guilherme; LOPEZ, Adriana. História do Brasil, uma interpretação. 4ạ ed. São Paulo: Editora 34, 2015.

MUNFORD, Eric Paul. The CIAM discourse on urbanism, 1928-1960. Massachusetts: The MIT Press, 2000.

NESBITT, Kate (org.). Uma nova agenda para a arquitetura: antologia teórica (1965-1995). São Paulo: Cosac Naify, 2006.

NOBRE, Ana Luiza (org.). Lucio Costa. Rio de Janeiro: Beco do Azougue, 2010.

OLIVEIRA, Francisco. Crítica à razão dualista, o ornitorrinco. São Paulo: Boitempo, 2013.

PELBART, Peter Pál. Rizoma temporal. São Paulo: Editora da Cidade, 2017.

PEREIRA, Miguel Alves. Arquitetura e os caminhos de sua explicação. São Paulo: Projeto Editores, 1984.

PEREIRA, Miguel Alves (org.). Sobre arquitetura brasileira e ensino na virada do século. Vol. I. e Vol. II. São Paulo: FAUUSP, 2008.

PERNISA Jr., Carlos (org.). Vertov: o homem e sua câmera. Rio de Janeiro: Mauad X, 2009.

PERRONE, Rafael Antonio Cunha; VARGAS, Heliana Comin (orgs.). Fundamentos de projeto: arquitetura e urbanismo. São Paulo: Edusp, 2016.

PETRONE, Pasquale. Aldeamentos paulistas. São Paulo: Edusp, 1995.

PORTAS, Nuno. Arquitetura(s): história e crítica, ensino e profissão. Porto: FAUP, 2005.

PORTAS, Nuno. Arquitetura(s): teoria e desenho, investigação e projecto. Porto: FAUP, 2005.

PRADO Jr., Caio. História econômica do Brasil. São Paulo: Brasiliense, 2008. 
RANCIÈRE, Jacques. O mestre ignorante: cinco lições sobre a emancipação intelectual. 3 a ed. Belo Horizonte: Autêntica, 2011.

REED, John. Dez dias que abalaram o mundo. São Paulo: Penguin Classics/Companhia das Letras, 2010.

REIS, Daniel Aarão. Ditadura e democracia no Brasil: do golpe de 1964 à constituição de 1988. Rio de Janeiro: Zahar, 2014.

RIBEIRO, Darcy. A universidade necessária. 3ạ ed. Rio de Janeiro: Paz e Terra, 1978.

RICKEY, George. Construtivismo: origens e evolução. São Paulo: Cosac Naify, 2002.

ROCHA, Paulo Mendes da. Maquetes de papel. São Paulo: Cosac\&Naify, 2007.

SABESP. O saneamento na Baixada Santista e seu legado cultural. São Paulo, 1995.

SANOVICZ, Abrahão; KATINSKY, Julio Roberto. Desenho industrial e programação visual para escolas de arquitetura. Brasília: ABEA/ MEC, 1977.

SANTOS, Milton. A natureza do espaço: Técnica e Tempo, Razão e Emoção. São Paulo: Edusp, 2009.

SEGAWA, Hugo. Arquiteturas no Brasil. 1900-1990. 3a ed. São Paulo: Edusp, 2010.

SEGRE, Roberto. Ministério da educação e saúde: ícone urbano da modernidade brasileira (1935-1945). São Paulo: Romano Guerra, 2013.

SEVERINO, Antonio Joaquim. Metodologia do trabalho Científico. 24ạ ed. São Paulo: Cortez, 2016.

STEVENS, Garry. O círculo privilegiado: fundamentos sociais da distinção arquitetônica. Brasília: UnB, 2003.

SUBIRATS, Eduardo. A flor e o cristal: ensaios sobre arte e arquitetura modernas - em torno da utopia urbana de Hugh Ferris. São Paulo: Nobel, 1988.

SYKES, A. Krista (org.). O campo ampliado da arquitetura: antologia teórica (1993-2009). São Paulo: Cosac Naify, 2013.

TAFURI, Manfredo. Projecto e utopia. Lisboa: Editorial Presença, 1985.

TASSINARI, Alberto. O espaço moderno. São Paulo: Cosac Naify, 2001.

TAVARES, André. Uma anatomia do livro de arquitectura. Porto: Dafne Editora/CCA, 2016.

VILLAÇA, Flavio. Espaço intra-urbano no Brasil. São Paulo: Nobel, 1998.

VIRILIO, Paul. O espaço crítico e as perspectivas do tempo real. São Paulo: Editora 34, 2005.

XAVIER, Alberto. Depoimento de uma geração: arquitetura moderna brasileira. São Paulo: Cosac Naify, 2003.

XAVIER, Alberto; LEMOS, Carlos; CORONA, Eduardo. Arquitetura moderna paulistana. São Paulo: Pini, 1983.

WAISMAN, Marina. O interior da História: historiografia arquitetônica para uso de latino-americanos. São Paulo: Perspectiva, 2013.

WICK, Rainer. Pedagogia da Bauhaus. São Paulo: Martins Fontes, 1989.

WISNIK, Guilherme. Dentro do nevoeiro: arquitetura, arte e tecnologia contemporâneas. São Paulo: Ubu, 2018.

WISNIK, Guilherme et al. Fórum, o percurso do ensino na FAU. Revista Caramelo, no 6, jun. 1993.

WISNIK, Guilherme. Lucio Costa. São Paulo: Cosac Naify, 2001.

WöLFFLIN, Heinrich. Conceitos fundamentais da história da arte. São Paulo: Martins Fontes, 2006.

ZEIN, Ruth Verde. O lugar da crítica: ensaios oportunos de arquitetura. Porto Alegre: Hitter dos Reis/Pro Editores, 2003.

2

Teses e dissertações

ANDRADE, Wilma T. F. O discurso do progresso: a evolução urbana de Santos. 1870 -1930. Tese (Doutorado) Faculdade de Filosofia, Letras e Ciências Humanas, Universidade de São Paulo. São Paulo, 1989. 
ARAPIRACA, José Oliveira. A USAID e a educação brasileira: um estudo a partir de uma abordagem crítica do capital humano. 1979. 273p. (Dissertação de mestrado em educação) - Instituto de Estudos Avançados em Educação, Fundação Getúlio Vargas. Rio de Janeiro, 1979.

ARAÚJO, Fanny Schroeder de Freitas. Telésforo Cristófani (1929-2002): contribuições à arquitetura paulista. 2009. 121p. Dissertação (Mestrado em Arquitetura e Urbanismo) - Faculdade de Arquitetura e Urbanismo da Universidade Presbiteriana Mackenzie. São Paulo, 2009.

ARCIPRESTE, C. M. Entre o discurso e o fazer arquitetônico: reflexões sobre o ensino de arquitetura e urbanismo e seus referenciais a partir do trabalho final de graduação. 2012. 287p. Tese (Doutorado em arquitetura e urbanismo) - Faculdade de Arquitetura e Urbanismo da Universidade de São Paulo. São Paulo, 2012.

BAROSSI, Antônio Carlos. Ensino de Projeto na FAUUSP: Faculdade de arquitetura e urbanismo da Universidade de São Paulo. 2005. 462p. Tese (Doutorado em arquitetura e urbanismo) - Faculdade de Arquitetura e Urbanismo da Universidade de São Paulo. São Paulo, 2005.

BRONSZTEIN, Maressa. A experiência construtiva na obra de Arnaldo Martino: treze projetos residenciais. 2013. 293p. Dissertação (Mestrado em Arquitetura e do Urbanismo) - Faculdade de Arquitetura e Urbanismo da Universidade de São Paulo. São Paulo, 2013.

BUITONI, Cássia Schroeder. Mayumi Watanabe Souza Lima: a construção do espaço para a educação. 2009. 226p. Dissertação (Mestrado em arquitetura e urbanismo) - Faculdade de Arquitetura e Urbanismo da Universidade de São Paulo. São Paulo, 2009.

BUZZAR, Miguel Antônio. Rodrigo Lefèvre e a ideia de vanguarda. Tese (Doutorado em arquitetura e urbanismo) - Faculdade de Arquitetura e Urbanismo da Universidade de São Paulo. São Paulo, 2001.

CARRIÇO, José Marques. Legislação urbanística e segregação espacial nos municípios centrais da região metropolitana da Baixada Santista. Dissertação (mestrado em arquitetura e urbanismo) - Faculdade de Arquitetura e Urbanismo da Universidade de São Paulo. São Paulo, 2002.

CHIARELLI, Silvia Raquel. Telésforo Cristófani: construção e composição. 2013. Dissertação (Mestrado em Arquitetura e Urbanismo) - Faculdade de Arquitetura e Urbanismo da Universidade Presbiteriana Mackenzie. São Paulo, 2013.

CONTIER, Felipe de Araújo. O Edifício da Faculdade de Arquitetura e Urbanismo na cidade universitária: projeto e construção da escola de Vilanova Artigas. 2015. 441p. Tese (Doutorado em arquitetura e urbanismo) Instituto de Arquitetura e Urbanismo da Universidade de São Paulo. São Carlos, 2015.

COSTA, Angélica Irene Da. Sérgio Ferro: Didática e formação. 2008. 183p. Dissertação (mestrado em arquitetura e urbanismo) Escola de Engenharia de São Carlos da Universidade de São Paulo. São Carlos, 2008.

COSTA, Juliana Braga. História, arte e arquitetura: Flávio Motta e o ensino como ofício. 2017. 362p. (Doutorado em arquitetura e urbanismo) - Faculdade de Arquitetura e Urbanismo da Universidade de São Paulo. São Paulo, 2017.

COSTA, Juliana Braga. Ver não é só ver: dois estudos a partir de Flávio Motta. 2010. 250p. (mestrado em arquitetura e urbanismo) - Faculdade de Arquitetura e Urbanismo da Universidade de São Paulo. São Paulo, 2010.

DEDECCA, Paula Gorenstein. Sociabilidade, crítica e posição: o meio arquitetônico, as revistas especializadas e o debate do moderno em São Paulo (1945-1965). 2012. 403p. Dissertação (Mestrado em arquitetura e urbanismo) - Faculdade de Arquitetura e Urbanismo da Universidade de São Paulo, São Paulo. 2012.

DOMSCHKE, Vera Lucia. O Ensino da arquitetura e a construção da modernidade. 331p. Tese (Doutorado em arquitetura e urbanismo) Faculdade de Arquitetura e Urbanismo da Universidade de São Paulo. São Paulo, 2007.

FORTIS, Sergio Novita. A formação do arquiteto na Faculdade de Arquitetura e Urbanismo da Unisantos Universidade Católica de Santos: trajetória, organização curricular e condições de funcionamento no período de 1970 a 2003. Dissertação (Mestrado em Educação) - Universidade Católica de Santos. Santos, 2004.

GAIO, Daniel Machado. A concepção de modernização na política de cooperação técnica entre o MEC e a USAID. 2008. 162p. Dissertação (Mestrado em educação) - Universidade de Brasília. Brasília, 2008. 
GUIMARÃES, Humberto Pio. Rodrigo Brotero Lefèvre: a construção da utopia. 2006. 206p. Dissertação (Mestrado em arquitetura e urbanismo) Escola de Engenharia de São Carlos, Universidade de São Paulo. São Paulo, 2006.

JUNQUEIRA, Luiz Eduardo Vasconcellos. Os anexos da FAU-USP: do ateliê da Vila Penteado ao concurso de 1989. 2016. 451p. Dissertação (Mestrado em arquitetura e urbanismo) - Faculdade de Arquitetura e Urbanismo da Universidade de São Paulo. São Paulo, 2016.

LEITE, Maria Amélia Devitte F. D'Azevedo. A aprendizagem tecnológica do arquiteto. 2005. Tese (Doutorado em Arquitetura e Urbanismo) - Faculdade de Arquitetura e Urbanismo, Universidade de São Paulo, São Paulo, 2006.

MACEDO. Christiane Costa Ferreira. Teatro Municipal de Santos: (re)apropriação do espaço moderno. 2008. 212p. Dissertação (Mestrado em arquitetura e urbanismo) - Faculdade de Arquitetura e Urbanismo da Universidade de São Paulo. São Paulo, 2008.

MACEDO FILHO, José Maria de. Santos, zona de fronteira: mutações do Largo Marquês de Monte Alegre. 2008. 230p. Dissertação (Mestrado em arquitetura e urbanismo) - Faculdade de Arquitetura e Urbanismo da Universidade de São Paulo. São Paulo, 2008.

MALACRIDA, Sergio Augusto. Trabalho de Graduação Interdisciplinar (TGI): origens e problematização da proposta implantada em 1971 na Faculdade de Arquitetura e Urbanismo da Universidade de São Paulo (FAU/USP). 2005. 166f. Dissertação (Mestrado em Fundamentos da Educação) - Centro de Educação em Ciências Humanas, Universidade Federal de São Carlos, São Carlos, 2005.

MANTELLATTO, Edmir. A obra de Ruy Ohtake: uma contribuição para a compreensão do processo do desenho da arquitetura contemporânea. 2012. 262p. Dissertação (Mestrado em arquitetura e urbanismo) - Faculdade de Arquitetura e Urbanismo da Universidade de São Paulo. São Paulo, 2012.

MARGOTTO, Luciano. Lições da arquitetura: leituras a partir de poéticas. 246 p. Tese (Doutorado em arquitetura e urbanismo) - Faculdade de Arquitetura e Urbanismo da Universidade de São Paulo. São Paulo, 2016.

MIGUEL, Jair Diniz. Arte, ensino, utopia e revolução: os ateliês artísticos Vkhutemas/Vkhutein (Rússia/URSS, 1920-1930). 2006. 404p. Tese (doutorado) - Faculdade de Filosofia, Letras e Ciências Humanas, Departamento de História, Programa de Pós-Graduação em História Social da Universidade de São Paulo. São Paulo, 2006.

MONTEIRO, A.M.R. de G. O ensino de arquitetura e urbanismo no Brasil: a expansão dos cursos no Estado de São Paulo no período de 1995 a 2005. 2007. 293p. Tese (doutorado em arquitetura e urbanismo) - Faculdade de Engenharia Civil, Arquitetura e Urbanismo da Universidade Estadual de Campinas. Campinas, 2007.

NARUTO, Minoro. Repensar a formação do arquiteto. 2006. 129p. Tese (doutorado em arquitetura e urbanismo) - Faculdade de Arquitetura e Urbanismo da Universidade de São Paulo. São Paulo, 2006.

NOVO, Leonardo Faggion. Entre arte e técnica: arquiteturas políticas na legitimação da profissão no Brasil [1920-1930]. 2018. 179p. Dissertação (Mestrado em Arquitetura) - Instituto de Filosofia e Ciências Humanas da Universidade Estadual de Campinas. Campinas, 2018.

OLIVEIRA, Elaine Rodrigues. A contribuição de Oswaldo Corrêa Gonçalves para a arquitetura moderna brasileira. 1999. 171p. Dissertação (Mestrado em Arquitetura) - Departamento de Arquitetura e Urbanismo da Escola de Engenharia de São Carlos, Universidade de São Paulo. São Carlos, 1999.

OLIVEIRA JÚNIOR, Jorge Antônio de. Edifício-sede do DNIT: o monumento de Rodrigo Lefèvre fora do eixo. 2017. 156p. Dissertação (Mestrado em arquitetura e urbanismo) - Universidade de Brasília. Brasília, 2017.

PRONSATO, Sylvia A. Dobry. Para quem e com quem: ensino de arquitetura e urbanismo. 2008. 321p. Tese (Doutorado em arquitetura e urbanismo) Faculdade de Arquitetura e Urbanismo da Universidade de São Paulo. São Paulo, 2008.

RIVABEN DE SALES, Pedro M. Santos: a relação entre o porto e a cidade e sua (re)valorização no território macrometropolitano de São Paulo. 1999. 285p. Tese (Doutorado em arquitetura e urbanismo) - Faculdade de Arquitetura e Urbanismo da Universidade de São Paulo. São Paulo, 1999.

ROCHA, Beatriz Araújo. O concurso para formandos de arquitetura e urbanismo Opera Prima: 1989-2011. 2016. 211p. Dissertação (Mestrado em Arquitetura) - Faculdade de Engenharia Civil, Arquitetura e Urbanismo da Universidade Estadual de Campinas. Campinas, 2016. 
RUGGIERO, Amanda Saba. Jorge Caron: uma trajetória. 2006. 183p. Dissertação (Mestrado em arquitetura e urbanismo) - Escola de Engenharia de São Carlos, Universidade de São Paulo. São Paulo, 2006.

SANTOS, Luciene Ribeiro. Os professores de projeto da FAU-USP (1948-2018): esboços para a construção de um centro de memória. 2018. 262p. Dissertação (Mestrado em arquitetura e urbanismo) - Faculdade de Arquitetura e Urbanismo da Universidade de São Paulo, 2018.

SEABRA, Odette C. de Lima. A muralha que cerca o Mar - uma modalidade de uso do solo urbano. Dissertação (Mestrado) - Faculdade de Filosofia, Letras e Ciências Humanas da Universidade de São Paulo. São Paulo, 1979.

SILVA, Helena A. Ayoub. Abrahão Sanovicz: o projeto como pesquisa. 2004. 610p. Tese (Doutorado em arquitetura e urbanismo) - Faculdade de Arquitetura e Urbanismo da Universidade de São Paulo. São Paulo, 2004.

SODRÉ, João Clark de Abreu: Roteiros americanos: as viagens de Mindlin e Artigas pelos Estados Unidos, 19431947. 2016. 256p. Tese (Doutorado em arquitetura e urbanismo) - Faculdade de Arquitetura e Urbanismo da Universidade de São Paulo. São Paulo, 2016.

TEIXEIRA. Kátia A. Ensino de projeto: integração de conteúdos. 2005. 237p. Tese (Doutorado em arquitetura e urbanismo) - Faculdade de Arquitetura e Urbanismo da Universidade de São Paulo. São Paulo, 2005.

3

Artigos e periódicos

AGÊNCIA METROPOLITANA DA BAIXADA SANTISTA - AGEM. Plano Metropolitano de Desenvolvimento Estratégico da Baixada Santista (PMDE-BS) 2014-2030. Santos: Geo Brasilis, 2014.

ASSOCIAÇÃO DOS DOCENTES DA SOCIEDADE VISCONDE DE SÃO LEOPOLDO. A Crise da FAUS e as lutas da Associação. Boletim informativo no 8, nov. 1982.

BAUHAUS-ARCHIV. Fotodateien und Dokumentation. Disponível em <https://www.bauhaus.de/de/fotoservice/> Acesso em: 21 mar. 2019.

BERNADINI, Sidney Piochi. Os Planos da cidade: As políticas de intervenção urbana em Santos - de Estevan Fuertes a Saturnino de Brito (1892-1910). 2007. São Carlos: RIMA/Fapesp, 2006.

BERNSTEIN, Any; ROITMAN, Riva. O que você precisa saber para realizar uma enquete. Revista Educação Pública, no 07. Mar. 2016. Disponível em <http://educacaopublica.cederj.edu.br/revista/artigos> Acesso em: 22 nov. 2017.

BOKOV, Anna. Experiment, interrupted. Jun. 2017. Yale Literary and Arts magazine. Volume VI: Failure. Palimpsest, 2014. Disponível em <http://yale.academia.edu/AnyaBokov> Acesso em: 28 mar. 2019.

BOKOV, Anna. Institutionalizing the Avant-Garde: Vkhutemas 1920-1930. Walker Reader Magazine. Jun. 2017. Disponível em <https://walkerart.org/magazine/institutionalizing-the-avant-garde-vkhutemas-1920-1930> Acesso em: 22 mar. 2019.

BOKOV, Anna. Rhythm and Other Elements: Analysis and Composition in Soviet Avant-Garde Architecture. New Haven: Actar Publisher/ Yale School of Architecture, 2016.

BOKOV, Anna. Soviet workers' clubs: lessons from the social condensers. The journal of architecture, volume 22 , issue 3. Publicado online: 08 mai. 2017. Disponível em <https://www.tandfonline.com/doi/full/10.1080/13602365.2017.1314316> Acesso em: 28 mar. 2019.

BOKOV, Anna. Space: The Pedagogy of Nikolay Ladovsky. Walker Reader Magazine. Jun. 2017. Disponível em <https://walkerart.org/magazine/space-the-pedagogy-of-nikolay-ladovsky> Acesso em: 22 mar. 2019.

BOKOV, Anna. VKhUTEMAS Training. Fair Enough, Venice Biennale, Nov 2014. Disponível em <http://yale.academia.edu/AnyaBokov> Acesso em: 28 mar. 2019.

BOLAFI, Gabriel. A arquitetura do poder e o poder da arquitetura. Revista Projeto, no 81, nov. 1985.

CAMARGO, Mônica Junqueira. 50 anos de FAU/Mackenzie. Revista Projeto, no 212, set. 1997.

COMISSÃO DA VERDADE DA UNIVERSIDADE DE SÃO PAULO. Depoimento de Sérgio Ferro. Disponível em <http://sites.usp.br/comissaodaverdade/informacoes-disponiveis/depoimentos/faculdade-de-arquitetura-eurbanismo/professores/>. Acesso em: 04 jul. 2016. 
CORONA, Eduardo. Considerações sobre o vestibular. Revista Acrópole, no 369, set. 1970.

DERRIDA, Jacques. Escrever é um Modo de Morar. Revista Projeto, São Paulo, no 118, jan. / fev. 1989.

FACULDADE DE ARQUITETURA E URBANISMO - USP. Anais do Seminário Ensino Arquitetura e Urbanismo. São Paulo: FAUUSP, 2007.

FERNANDES, Ari Vicente et al. Prática - Investigação. In Anais do IX congresso Brasileiro de Arquitetos. São Paulo: IAB, 1976.

FERNANDES, Ari Vicente. Resistência estudantil ao acordo MECUSAID. Disponível em: <http://www.sasp.arq.br/single-post/2016/05/11/Ari-Fernandes-lembra-resist\%C3\%AAncia-estudantil-aoacord-MECUSAID>. Acesso em: 02 jan. 2018.

FICHER, Sylvia. Profissão de arquiteto e ensino de arquitetura: mitos e perspectivas. 8p. Faculdade de Arquitetura e Urbanismo - Universidade de Brasília: Julho, 1994. mimeo.

FORTI, Marco Artigas. FAUUSP - 50 anos da Reforma de 1962. Disponível em <http://www.dearquiteturas.com>. Acesso em: 11 nov. 2015.

FRACALOSSI, Igor. Clássicos da Arquitetura: Pavilhão do Brasil em Osaka / Paulo Mendes da Rocha e equipe. 2014. ArchDaily Brasil. Disponível em: <https://www.archdaily.com.br/br/624060/ classicos-da-arquiteturapavilhao-do-brasil-em-osaka-paulo-mendes-da-rocha-e-equipe>. Acesso em: 26 nov. 2018.

GATI, Catharine. Oswaldão: construindo a profissão. Documento Oswaldo Corrêa Gonçalves. Revista AU, São Paulo, no 59, abr. 1995.

GIGLIOLI, Ubyrajara. Cinquentenário da FAUUSP. Revista Projeto, São Paulo, no 228, jan. / fev. 1999.

GONÇALVES, Oswaldo Corrêa. In: ENCICLOPÉDIA Itaú Cultural de Arte e Cultura Brasileiras. São Paulo: Itaú Cultural, 2019. Verbete da Enciclopédia. ISBN: 978-85-7979-060-7 Disponível em:

<http://enciclopedia.itaucultural.org.br/pessoa345742/oswaldo-correa-goncalves> Acesso em: 10 jul. 2019.

GONÇALVES, Oswaldo Corrêa. O Plano Diretor Físico de Santos. Revista Acrópole, São Paulo, no 374, jun. 1970.

GONÇALVES, O. C.; BALLARIO, P. B.; FERREIRA, J. W. L. O Plano de Desenvolvimento da Nova Cintra. Revista Acrópole, São Paulo, no 374, jun. de 1970.

CONGREGAÇÃO DA EDUCAÇÃO CATÓLICA. A escola católica no limiar do terceiro milênio. Roma: CEC/Vaticano, 1997. Disponível em

<http://www.vatican.va/roman_curia/congregations/ccatheduc/documents/rc_con_ccatheduc_doc_27041998 _school2000_po.html> Acesso em: 24 out. 2019.

JORNAL A TRIBUNA DE SANTOS. Arquitetos estagiários dão apoio aos estudantes. Santos, 8 mai. 1977.

KATINSKY, Julio Roberto. Um militante fiel da arquitetura - evocação. Instituto dos Arquitetos do Brasil Departamento de São Paulo - Boletim informativo. São Paulo, nº 51, p. 8-9, jul. /ago. /set. 2005.

MOTTA, Flávio. Textos informes. São Paulo: FAUUSP, 1973.

OLIVEIRA, Francisco. O Vício da virtude: autoconstrução e acumulação capitalista no Brasil. Revista Novos Estudos. CEBRAP. São Paulo, n‥ 74, mar. 2006.

PASTORE, F.; VILLAVECCHIA. L. Rodoviária de Santos. Revista Acrópole, São Paulo, no 374, jun. 1970.

PASTORE, F.; VILLAVECCHIA. L. Edifício Sede da Prodesan. Revista Acrópole, São Paulo, no 374, jun. 1970.

PASTORE, F.; VILLAVECCHIA. L.; YAMAGUCHI, K.; CHAHIM, R. Plano turístico das praias de Santos. Revista Acrópole, São Paulo, no 374, jun. 1970.

PERELMUTTER, Benno. Um militante fiel da arquitetura - atuação. Instituto dos Arquitetos do Brasil Departamento de São Paulo - Boletim informativo. São Paulo, nº 51, p. 8-9, jul/ago/set. 2005.

RAMOS, F. G., BUZZAR, M. A., \& FUJIOKA, P. (2018). Introdução à Obra de Arq. Jon Maitrejean. Risco Revista De Pesquisa Em Arquitetura E Urbanismo (Online), 16(2), 113-133. Disponível em <https://doi.org/10.11606/issn.1984-4506.v16i2p113-133>. Acesso em: 16 dez. 2019.

RIOS, Lenimar G.; LEAL, Lucio; MINCHERIAN, Margarida. Formação do arquiteto: uma crítica possível e necessária. In Anais do IX congresso Brasileiro de Arquitetos. São Paulo: IAB, 1976. 
SANTOS, Rafael Mendes. A produção arquitetônica dos professores pioneiros da Faculdade de Arquitetura e Urbanismo de Santos. 2019. 114p. Relatório final de atividades de pesquisa. Instituto de Pesquisas Científicas e Tecnológicas - IPECI. Universidade Católica de Santos, Santos, 2019.

SERAPIÃO, Fernando. Vilanova Artigas e a FAUUSP. Coleção Monolito no 27. São Paulo: Monolito, 2015.

SILVEIRA FILHO, N.X. Avaliação do enfoque dominante de currículo na faculdade de arquitetura e urbanismo de Santos. Revista Educação e Avaliação, no 02. jan. 1981.

UDUAL; FAUUSP. X Conferência Latino Americana de Escolas e Faculdades de Arquitetura (X CLEFA): Assentamentos Humanos e Adequação Regional. São Paulo: UDUAL/FAUUSP, 1983.

WISSENBACH, Vicente (org.). Siegbert Zanettini. Cadernos Brasileiros de Arquitetura, no 8. São Paulo: Projeto, s/d.

4

Documentos

ARTIGAS, João Batista Vilanova. Carta de Vilanova Artigas a Oswaldo Corrêa Gonçalves. Nova York, 27 dez. 1946. Arquivo Bibliografia da FAUS.

CARON, Jorge. FAU-Santos: TGI. Santos: Diretório Acadêmico Michael Lieders, mimeo, 1986.

CONSELHODE ARQUITETURA E URBANISMO DO BRASIL. Anuário de Arquitetura e Urbanismo 2019. 116p. Brasília: CAU/BR, 2019. Disponível em: < https://caubr.gov.br/wp-content/uploads/2019/06/ANU\%C3\%81RIOFINAL-WEB.pdf >. Acesso em: 05 fev. 2020.

DELEGACIA DE ORDEM POLÍTICA E SOCIAL DE SANTOS (DOPS-Santos). Centro Acadêmico Lucio Costa. Prontuário no 3679. 112p. Santos, 1972. Disponível em

<http://www.arquivoestado.sp.gov.br/upload/Deops/Prontuarios/BR_SP_APESP_DEOPS_SAN_P003679_01.p df.>. Acesso em: 05 ago. 2016.

DELEGACIA DE ORDEM POLÍTICA E SOCIAL DE SANTOS (DOPS-Santos). Faculdade de Arquitetura e Urbanismo de Santos. Prontuário no 1359. 138p. Santos, 1972. Disponível em

<http://www.arquivoestado.sp.gov.br/upload/Deops/Prontuarios/BR_SP_APESP_DEOPS_SAN_P001359_01.p df.>. Acesso em: 05 ago. 2016.

DIRETÓRIO ACADÊMICO LUCIO COSTA. Considerações gerais sobre o ensino da FAUS: documento final III Fórum de Debates. Santos, 1979.

DIRETÓRIO ACADÊMICO LUCIO COSTA. Dossiê da Crise de 1972. 107p. Santos, 1972.

DIRETÓRIO ACADÊMICO LUCIO COSTA. Dossiê da Crise de 1982. não paginado. Santos, 1982.

DIRETÓRIO ACADÊMICO LUCIO COSTA. Resoluções do Fórum de Debates. Santos, 1979.

DIRETÓRIO ACADÊMICO VERA DEBS. Jornal revista: Edição no 2, ago. / set. 1983. Edição no 3, out. / nov. 1983. Edição no 5, maio 1984. Edição no 6, jun. 1984 e Edição no7, ago. / set. 1984.

DIRETÓRIO ACADÊMICO MICHAEL LIEDERS. Abaixo-Assinado: Solicitação de solução de problemas e mais diálogo. Santos, 2017. Disponível em <https://www.abaixoassinado.org/abaixoassinados/37119>. Acesso em: 20 dez. 2018.

DIRETÓRIO ACADÊMICO MICHAEL LIEDERS. Dossiê da Crise de 2000. Santos, 2000.

DIRETÓRIO ACADÊMICO MICHAEL LIEDERS. Projeto de tombamento do Prédio da FAUS. Santos, 2011.

DIRETÓRIO ACADÊMICO MICHAEL LIEDERS. Ressurreição da FAUS. Santos, 2017. mimeo.

DENTE, Edgar Gonçalves. Estudo Crítico e Proposta para a Estrutura Curricular da FAU-USP. Edição do Autor. não paginado. São Paulo, FAU-USP. 1987.

FAU'S DO ESTADO DE SÃO PAULO; DELEGAÇÕES DE ESTUDANTES. Comunicado à diretoria da Associação Brasileira de Escolas de Arquitetura e aos participantes do encontro regional de Campinas. São Paulo, 25 maio 1976.

FAU'S DO ESTADO DE SÃO PAULO; DELEGAÇÕES DE ESTUDANTES. Comunicado aos estudantes, diretórios e centros acadêmicos das faculdades de arquiteturas. São Paulo, 28 maio 1976. 
GONÇALVES, Oswaldo Corrêa. Oração do Paraninfo. FAUS, 1976. mimeo.

MILLAN, C.B. $O$ ateliê na formação do arquiteto. Relatório apresentado pelo professor Carlos Barjas Millan, Coordenador do Grupo de Estudos do Ateliê. São Paulo: Setor de publicações. Faculdade de Arquitetura e Urbanismo da Universidade de São Paulo. 1962, 46p.

PREFEITURA DE BERTIOGA. Portal da Transparência. Disponível em:

<http://transparencia.bertioga.sp.gov.br:8080/dadosweb/loginWeb.jsp?execobj=XXPW20200> Acesso em: 22 nov. 2017.

PREFEITURA DE CUBATÃO. Portal da Transparência. Disponível em:

<http://sistema.cubatao.sp.gov.br/?cod=49> Acesso em: 22 nov. 2017.

PREFEITURA DE GUARUJÁ. Portal da Transparência. Disponível em:

<http://guaruja.prodataweb.inf.br:4555/sig/app.html\#/transparencia/transparencia-folha-pagamento/>

Acesso em: 22 nov. 2017.

PREFEITURA DE ITANHAÉM. Portal da Transparência. Disponível em:

<http://www2.itanhaem.sp.gov.br/portaltransparencia/recursos-humanos/> Acesso em: 23 nov. 2017.

PREFEITURA DE MONGAGUÁ. Portal da Transparência. Disponível em:

<http://201.63.230.98:5656/transparencia/> Acesso em: 23 nov. 2017.

PREFEITURA DE PERUÍBE. Portal da Transparência. Disponível em:

<http://www.peruibe3.sp.gov.br/transparencia-publica-municipal-2/> Acesso em: 23 nov. 2017.

PREFEITURA DE PRAIA GRANDE. Portal da Transparência. Disponível em:

<http://leideacesso.etransparencia.com.br/praiagrande.prefeitura.sp/Portal/desktop.html?410> Acesso em:

21 nov. 2017.

PREFEITURA DE SANTOS. Portal da Transparência. Disponível em:

$<$ http://folha.santos.sp.gov.br/QvAJAXZfc/opendoc.htm?document=TRANSPARENCIA\%20-

\%20SERVIDORES.qvw\&anonymous=true\&sheet=FOLHA> Acesso em: 21 nov. 2017.

PREFEITURA DE SÃO VICENTE. Portal da Transparência. Disponível em:

$<$ http://201.28.194.11/pmsaovicente/websis/portal_transparencia/financeiro/contas_publicas/index.php?cons ulta=.../lei_acesso/lai_remuneracoes $>$. Acesso em: 21 nov. 2017.

SOCIEDADE VISCONDE DE SÃO LEOPOLDO. Memorial no 85-72, 1972. 4p. Faculdades de Católicas de Santos. Santos, 1972.

SERRANO, Fabio Eduardo. Relatório da Diretoria 1986-1989. 4p. Santos, 1989. mimeo.

UNIVERSIDADE CATÓLICA DE SANTOS. Espólio de Oswaldo Corrêa Gonçalves. Biblioteca da FAUS. Santos, 2002. UNIVERSIDADE CATÓLICA DE SANTOS. Livro 1 para lavratura dos termos de colação de grau da FAUS. Santos, 1976.

UNIVERSIDADE CATÓLICA DE SANTOS. Livro 2 para lavratura dos termos de colação de grau da FAUS. Santos, 1976.

UNIVERSIDADE CATÓLICA DE SANTOS. Livro de registro de funcionários da FAUS de 1970, 1971 e 1972. Santos, 1970.

UNIVERSIDADE CATÓLICA DE SANTOS. Livro de registro de funcionários da FAUS de 1972, 1973, 1974, 1975 e 1976. Santos, 1972.

UNIVERSIDADE CATÓLICA DE SANTOS. Marco Referencial. Disponível em <http://www.unisantos.br/portal/universidade/institucional/marco-referencial/>. Acesso em: 14 out. 2018.

UNIVERSIDADE CATÓLICA DE SANTOS. FAUS: Ofício Circular 636/86. 3p. Santos: UNISANTOS, 1986. mimeo.

UNIVERSIDADE CATÓLICA DE SANTOS. Plano de Desenvolvimento Institucional. Disponível em <http://www.unisantos.br/wp-content/uploads/2015/01/pdi_unisantos.pdf>. Acesso em: 14 out. 2018.

UNIVERSIDADE CATÓLICA DE SANTOS. Projeto Pedagógico Institucional. Disponível em

$<$ http://www.unisantos.br/wp-content/uploads/2015/01/ppi_unisantos.pdf>. Acesso em: 14 out. 2018. 
UNIVERSIDADE CATÓLICA DE SANTOS. Projeto Pedagógico de Curso - Arquitetura e Urbanismo. Disponível em $<$ http://www.unisantos.br/wp-content/uploads/2016/12/PPC_Arq-e-Urb_2017-a-2021-9-de-dezembro.pdf>. Acesso em: 14 jul. 2019.

UNIVERSIDADE CATÓLICA DE SANTOS. Projeto Político Pedagógico: Faculdade de Arquitetura e Urbanismo, relatório final das Atividades do Ano de 2000. Santos: UNISANTOS, 2000. mimeo.

UNIVERSIDADE CATÓLICA DE SANTOS. Regimento interno do Centro de Assessoramento, Pesquisa e Documentação de Arquitetura e Urbanismo da FAUS. 8p. Santos, 1972.

UNIVERSIDADE CATÓLICA DE SANTOS. Regimento interno do Laboratório de Habitafaus - HABITAFAUS. 9p. Santos: UNISANTOS, 1988. mimeo.

UNIVERSIDADE CATÓLICA DE SANTOS. Registro de "atas plenárias". Santos, 1970.

UNIVERSIDADE CATÓLICA DE SANTOS. Relatório do ano letivo de 1970. Santos, 1970.

UNIVERSIDADE CATÓLICA DE SANTOS. Relatório do ano letivo de 1971. Santos, 1971.

UNIVERSIDADE CATÓLICA DE SANTOS. Relatório do ano letivo de 1972. Santos, 1972.

UNIVERSIDADE CATÓLICA DE SANTOS. TGI: Relação nominal e temática, FAUS 1974 a 1993. 91p. mimeo.

\section{5}

Entrevistas

DENTE, Edgar Gonçalves. Entrevista com Edgar Gonçalves Dente. São Vicente, 06 jun. 2016. Entrevista a José Maria de Macedo Filho.

FORTIS, Sergio Novita. Entrevista com Sergio Novita Fortis. Santos, 22 set. 2016. Entrevista a José Maria de Macedo Filho.

GONÇALVES, Oswaldo Corrêa. Entrevista com o Professor Arquiteto Oswaldo Corrêa Gonçalves. Santos, 21 nov. 1982, entrevista a Edison Gloeden e Eugênio Lara.

KATINSKY, Julio Roberto. Entrevista com Julio Roberto Katinsky. São Paulo, 23 maio 2016. Entrevista a José Maria de Macedo Filho.

MAITREJEAN, Jon Vergareche. Entrevista com Jon Vergareche Maitrejean. São Paulo, 01 jul. 2016. Entrevista a José Maria de Macedo Filho.

SOUZA, Edison Eloy. Entrevista com Edison Eloy de Souza. Santos, 13 jul. 2016. Entrevista a José Maria de Macedo Filho.

ZAMBONI, Orpheu. Entrevista com Orpheu Zamboni. São Paulo, 06 jun. 2016. Entrevista a José Maria de Macedo Filho.

\section{6}

Catálogos de exposição

KOMAROVA, L. K. Die Archilektur-Fakultät der WCHUTEMAS und des W.CHUTEIN 1920 -1930. Weimar: Wissenschaftliche Zeitschrift / Hochschule für Architektur und Bauwesen, 1979.

KREIS, Barbara. WChUTEMAS - ein russisches Labor der Moderne: Architekturentwürfe 1920 - 1930. Berlim: Martin-Gropius-Bau, dez. 2014 / abr. 2015. Catálogo de exposição.

LIMA, Celso; JALLAGEAS, Neide. Vkhutemas, o futuro em construção: 1918-2018. São Paulo: SESC Pompéia, jun set 2018. Catálogo de exposição.

TSCHEPKUNOWA, Irina. WChUTEMAS - ein russisches Labor der Moderne: Architekturentwürfe 1920 - 1930. Berlim: Martin-Gropius-Bau, dez. 2014 / abr. 2015. Catálogo de exposição. 


\section{Créditos das imagens}

1. Lênin, Krupskaya e Estudantes dos VKhUTEMAS, p. 26

Disponivel em: < https://leninism.su/fotogalereya/1919/v-i-lenin-8-59.html\#joomimg >. Acesso em: 26 jul. 2019.

2. Organização pedagógica dos VKhUTEMAS, p. 27

Desenvolvido por Anna Bokov para a exposição VKhUTEMAS Training. Fair Enough, Venice Biennale, nov. 2014.

3. Bauhaus e VKhUTEMAS, p. 30

À esquerda: BOKOV Anna. VKhUTEMAS Training. Fair Enough, Venice Biennale, nov. 2014.

À direita: Acervo Bauhaus-Archiv Berlin. Disponivel em: < https://www.bauhaus.de >. Acesso em: 07 mar. 2019.

4. Bauhaus e VKhUTEMAS, p. 34

Esquerda, no topo e ao centro: WChUTEMAS - ein russisches Labor der Moderne: Architekturentwürfe 1920 - 1930. pp. 233 - 234

Esquerda, abaixo: BOKOV, Anna. Disponivel em: < http://yale.academia.edu/AnyaBokov >. Acesso em: 28 mar. 2019.

Direita: Acervo Bauhaus-Archiv Berlin. Disponivel em: < https://www.bauhaus.de >. Acesso em: 07 mar. 2019.

5. Estudante dos VKhUTEMAS, p. 40

BOKOV Anna. VKhUTEMAS Training. Fair Enough, Venice Biennale, Nov. 2014.

6. Crachá de Oswaldo Corrêa, p. 43

Arquivo Biblioteca da FAUS.

7. Homenagem ao professor Luiz de Anhaia Mello, p. 47 Arquivo Biblioteca da FAUS

8. Discurso de Walter Gropius, p. 48

Arquivo Biblioteca da FAUS.

9. Vilanova Artigas e o grupo de arquitetos, p. 49

KAMITA, João Masao. Vilanova Artigas. São Paulo: Cosac Naify, 2000. p. 123.

10. Atelier FAU-USP, p. 53

Organograma do atelier da FAU-USP proposto em 1957: MILLAN, C.B. O ateliê na formação do arquiteto. São Paulo: FAU-USP. 1962. Flavio Motta na FAU-USP. COSTA, Juliana Braga. História, arte e arquitetura: Flávio Motta e o ensino como ofício. 2017. FAU-USP, 2017. p. 187. Atelier da Vila Penteado. JUNQUEIRA, L. E. V. Os anexos da FAU-USP: do ateliê da Vila Penteado ao concurso de 1989. FAU-USP, 2016. p. 86.

11. Proposta de Rodrigo Lefèvre para o curso de projeto da FAU-USP, p. 60 DENTE, Edgar G. Estudo Crítico e Proposta para a Estrutura Curricular da FAU-USP. Edição do Autor. São Paulo, FAU-USP. 1987.

12. Ateliers da FAU-USP na Cidade Universitária, p. 61 Foto de José Moscardi. BAROSSI, Antônio Carlos. O edifício da FAU-USP de Vilanova Artigas. São Paulo, Editora da Cidade, 2017. p. 49.

13. Estudante no atelier da FAU-Maranhão, p. 62 Arquivo Edgar Dente.

14. Oswaldo Corrêa, Eduardo Corona e Walter Gropius em 1954, p. 63 Arquivo Biblioteca da FAUS.

15. Oswaldo Corrêa, Eduardo Kneese de Mello, Vilanova Artigas, Rino Levi e outros e sede do IAB/SP, p. 65 Arquivo Biblioteca da FAUS.

16. Projetos de Oswaldo Corrêa, p. 66 Arquivo Biblioteca da FAUS

17. Sugestão para a Faculdade de Santos, p. 68 Arquivo Biblioteca da FAUS.

18. Organização pedagógica da FAUS, Bauhaus e VkhUTEMAS, p. 70 Gráfico da FAUS: elaborado pelo autor. Gráfico da Bauhaus: WICK, Rainer. Pedagogia da Bauhaus. São Paulo: Martins Fontes, 1989. p.88. Gráfico VKhUTEMAS: BOKOV Anna. VKhUTEMAS Training. Fair Enough, Venice Biennale, Nov 2014.

19. Distribuição de cursos por cidades em 1974, p. 77 Fonte: CEAU. Condições \& diretrizes. Brasília: MEC, SESU, 1974.

20. Dados sobre as cidades da RMBS, p. 80

Agência Metropolitana da Baixada Santista e FRIGERIO, A. M. G.; OLIVEIRA, Y. F. Santos: a geografia através dos mapas. Santos: A3 Editora, 1991.

21. Projeto de saneamento para Santos, p. 82

Imagem do projeto: ANDRADE, W. T. F. O discurso do progresso: a evolução urbana de Santos. 1870 -1930. FFLCH-USP, 1989. p. 175 Fotos: Arquivo Público do Estado de São Paulo; tratamento das imagens: Dhiego Torrano.

22. Alguns exemplares da arquitetura moderna na região da Baixada Santista nos anos 1970, p. 84 Elaborado pelo autor. Fotos: Revista Acrópole e www.novomilenio.inf.br.

23. Plano Diretor de 1968 para Santos, p. 87

O plano diretor físico de Santos. Revista Acrópole, São Paulo, no 374, junho de 1970. p. 15. Demais imagens: Revista Acrópole, São Paulo, № 374, jun. 1970, pp. 15, 34-38.

24. Distribuição dos professores fundadores na grade curricular inicial da FAUS, p. 93 Dados: Relatório do ano letivo de 1970. Fotografias: Departamento de Recursos Humanos da Universidade Católica de Santos.

25. Quadro síntese dos professores da FAUS, p. 96 Elaborado pelo autor. 
26. Contextualização da produção dos professores da FAUS, p. 98 Pesquisa Rafael Mendes. Diagrama reelaborado pelo autor, redesenho Matheus Pardal.

27. Produção dos professores da FAUS, p. 99 Pesquisa Rafael Mendes. Diagrama reelaborado pelo autor, redesenho Matheus Pardal.

28. Produção dos professores da FAUS, p. 100 Pesquisa Rafael Mendes. Diagrama reelaborado pelo autor, redesenho Matheus Pardal.

29. Produção dos professores da FAUS, p. 101 Pesquisa Rafael Mendes. Diagrama reelaborado pelo autor, redesenho Matheus Pardal.

30. Produção dos professores da FAUS, p. 102 Pesquisa Rafael Mendes. Diagrama reelaborado pelo autor, redesenho Matheus Pardal.

31. Produção dos professores da FAUS, p. 103 Pesquisa Rafael Mendes. Diagrama reelaborado pelo autor, redesenho Matheus Pardal.

32. Produção individual dos professores da FAUS, p. 104 Pesquisa Rafael Mendes. Diagrama reelaborado pelo autor, redesenho Matheus Pardal.

33. FAUS 1973, p. 106 Arquivo Eber de Goes.

34. Resumo dos fatos ocorridos entre 1970 e 1971, p. 114 DIRETÓRIO ACADÊMICO LUCIO COSTA. Dossiê da Crise de 1972. Santos, 1972.

35. Resumo dos fatos ocorridos entre 1970 e 1971, p. 117 DIRETÓRIO ACADÊMICO LUCIO COSTA. Dossiê da Crise de 1972. Santos, 1972.

36. Aula do professor Ari Vicente Fernandes, 1975, p. 120 Arquivo Maria Dalva Orlando.

37. Símbolo da FAUS, p. 121 Imagem à esquerda: arquivo Eber de Goes; imagem à direita: redesenho do autor.

38. Escola itinerante, percurso da FAUS pela cidade de Santos, p. 125 Imagem elaborada pelo autor.

39. Desenho das peças pré-fabricadas do conjunto CECAP e construção industrializada do CRUSP, p. 127 ARTIGAS, Rosa (org.). Vilanova Artigas. São Paulo: Terceiro Nome, 2015.

40. Situação atual da FAUS e Campus Dom Idílio, p. 129 Elaborado pelo autor, desenho Dhiego Torrano.

41. Primeira versão do projeto para o prédio da FAUS, p. 130 Arquivo Biblioteca da FAUS.

42. Versão do projeto para o prédio da FAUS para a Prefeitura Municipal de Santos, p. 131 Arquivo Biblioteca da FAUS.

43. Planta do módulo estrutural e perspectiva do prédio da FAUS, p. 132 Desenhos Rafael Pereira, Milena Santos e Dhiego Torrano.

44. Plantas do pavimento térreo e 1ำ pavimento do prédio da FAUS, 1976 p. 133 Desenhos Rafael Pereira, Milena Santos e Dhiego Torrano.

45. Plantas do 2으 e 3o pavimentos do prédio da FAUS, 1976, p. 134 Desenhos Rafael Pereira, Milena Santos e Dhiego Torrano.

46. Planta de cobertura, corte longitudinal e elevação sul do prédio da FAUS, 1976, p. 135 Desenhos Rafael Pereira, Milena Santos e Dhiego Torrano.

47. Diagrama de usos e circulações do projeto executado em 1976, p. 136 Elaborado pelo autor, desenho Matheus Pardal.

48. Diagrama de zoneamento do projeto executado em 1976, p. 137 Elaborado pelo autor, desenho Matheus Pardal.

49. Maquete do prédio da FAUS, p. 138 Arquivo Biblioteca da FAUS.

50. Classificação dos elementos estruturais componíveis do Prédio da FAUS, p. 139 Elaborado pelo autor, desenho Matheus Pardal.

51. Processo construtivo do prédio da FAUS, p. 141 Diagrama: elaboração do autor e desenho Ricardson Ricardo. Fotografias: Arquivo Biblioteca da FAUS.

52. FAUS em meados dos anos 1970, p. 143 Arquivo Biblioteca da FAUS.

53. Abrahão Sanovicz, Oswaldo Corrêa e Julio Katinsky, p. 144 Arquivo Biblioteca da FAUS.

54. Conferência de Roberto Burle Marx e reunião da ABEA no atelier da FAUS, p. 151 Arquivo Biblioteca da FAUS 
55. Alunos em assembleia permanente na FAUS, p. 153 Jornal A Tribuna de Santos. 10 mai. 1977.

56. Quadro organização das ementas, 1978, e fotos do cotidiano da FAUS, p. 154 Quadro e foto à direita: Arquivo Biblioteca da FAUS. Fotografia à esquerda: Sérgio Waissmann. Fotografia no centro: Paulo Martins.

57. Cotidiano da FAUS no final da década de 1970, p. 157 Arquivo Biblioteca da FAUS.

58. Maitrejean, Artigas e Mendes da Rocha, Lobby e FAUS, p. 158 Foto, Jon Maitrejean, Vilanova Artigas e Paulo Mendes da Rocha: KEESE, Jefferson Lafaiette. Anistia na FAUUSP. p. 9. Fotos, Lobby: Arquivo Diretório Acadêmico Lucio Costa. Foto prédio da FAUS: Arquivo Biblioteca da FAUS.

59. Estudantes em frente ao prédio da FAUS, p. 162 Arquivo Fernando Arouca.

60. Cotidiano da FAUS e documento da Polícia Militar, p. 163

Fotografias: Arquivo Biblioteca da FAUS. Foto com Tony Bellotto: Sérgio Waissmann. Foto alunos no pergolado: Paulo Elias. Documento confidencial da Policia Militar: DOPS-Santos. Prontuário no 3679 . Santos, 1972.

61. Estudantes e professores em assembleia no atelier da FAUS, p. 167 Fotos de Fabio Bernils e Olegário Vasconcelos.

62. Painel do professor Mauricio Nogueira Lima, p. 167 Arquivo Diretório Acadêmico Lucio Costa.

63. Manifestação de apoio aos professores demitidos da FAUS em 1982, p. 169 À direita: Arquivo Diretório Acadêmico Lucio Costa. Passeata: Dossiê da Crise de 1982. Santos, 1982.

64. O "a" da FAUS, p. 171 Fotografias: Paulo Elias e arquivo Diretório Acadêmico Lucio Costa.

65. Oswaldo Corrêa Gonçalves em frente ao Prédio da FAUS com seus estudantes, p. 174 Arquivo Diretório Acadêmico Lucio Costa.

66. Diagrama de evolução do Curso de Urbanismo (1983) e quadros de distribuição das disciplinas (1984), p. 176 Diagrama: Henri Michel Lesbaupin. Quadros: Arquivo Secretaria Acadêmica da FAUS.

67. Estudantes desmontando as divisórias do atelier em 1983, p. 177 Arquivo Diretório Acadêmico Lucio Costa.

68. Habitafaus e Semana da Habitação, p. 178 Diagrama Habitafaus: Jornal Revista. Ed. no 7 ago/set 1984. pp. 8-9. Fotos: Arquivo Biblioteca da FAUS. Cartazes e capas revistas: arquivo do autor.

69. Pergolado e auditório da FAUS, p. 180 Arquivo Biblioteca da FAUS.

70. Reforma de 1984. Plantas do pavimento térreo e do 1ㅇ pavimento, p. 181 Desenho elaborado pelo autor em 2017, baseado nos documentos e registros disponíveis nos arquivos da Biblioteca da FAUS.

71. Reforma de 1984. Plantas do 2으 e 3ㅇ pavimentos, p. 182 Desenho elaborado pelo autor em 2017, baseado nos documentos e registros disponiveis nos arquivos da Biblioteca da FAUS.

72. Reforma de 1984. Planta de cobertura e corte longitudinal, p. 183 Desenho elaborado pelo autor em 2017, baseado nos documentos e registros disponíveis nos arquivos da Biblioteca da FAUS.

73. Reforma de 1998. Plantas do pavimento térreo e do 1 1o pavimento, p. 185 Desenho elaborado pelo autor em 2017, baseado nos documentos e registros disponiveis nos arquivos da Biblioteca da FAUS.

74. Reforma de 1998. Plantas do 2으 e 3ㅇ pavimentos, p. 186 Desenho elaborado pelo autor em 2017, baseado nos documentos e registros disponíveis nos arquivos da Biblioteca da FAUS.

75. Reforma de 1998. Corte longitudinal, p. 187 Desenho elaborado pelo autor em 2017, baseado nos documentos e registros disponiveis nos arquivos da Biblioteca da FAUS

76. Reforma de 2017. Planta do pavimento térreo, p. 188 Desenho elaborado pelo autor em 2017, baseado nos documentos e registros disponiveis nos arquivos da Biblioteca da FAUS.

77. Reforma de 2017. Plantas do 1 e e 2 o pavimentos, p. 189 Desenho elaborado pelo autor em 2017, baseado nos documentos e registros disponíveis nos arquivos da Biblioteca da FAUS.

78. Reforma de 2017. Plantas do 3으 pavimento e da cobertura, p. 190 Desenho elaborado pelo autor em 2017, baseado nos documentos e registros disponiveis nos arquivos da Biblioteca da FAUS.

79. Reforma de 2017. Corte transversal e longitudinal, e elevação frontal, p. 191 Desenho elaborado pelo autor em 2017, baseado nos documentos e registros disponiveis nos arquivos da Biblioteca da FAUS.

80. Cronologia construtiva, p. 192 Desenho elaborado pelo autor em 2017, baseado nos documentos e registros disponíveis nos arquivos da Biblioteca da FAUS.

81. Cronologia construtiva, p. 193 Desenho elaborado pelo autor em 2017, baseado nos documentos e registros disponiveis nos arquivos da Biblioteca da FAUS.

82. Cronologia construtiva, p. 194 Desenho elaborado pelo autor em 2017, baseado nos documentos e registros disponíveis nos arquivos da Biblioteca da FAUS. 
83. Relações entre espaço e pedagogia no prédio da FAUS, p. 195

Elaborado pelo autor a partir de BAROSSI, A. C. Ensino de Projeto na FAUUSP. FAU-USP, 2005. p. 97.

84. Alteração da entrada, usos e circulação do Prédio da FAUS em 2017, p. 196. Elaborado pelo autor, desenho Matheus Pardal.

85. Zoneamento do Prédio da FAUS em 2017, p. 197 Elaborado pelo autor, desenho Matheus Pardal.

86. Vistas do prédio da FAUS no contexto urbano e ambientes internos (2017), p. 198 Fotos do autor.

87. Síntese da distribuição de horas do Projeto Pedagógico da FAUS, p. 202 Gráficos elaborados pelo autor a partir do Projeto Pedagógico da FAUS, 2000.

88. Comissão Plena desenvolvendo o Projeto Pedagógico da FAUS (2000), p. 203 Arquivo do autor.

89. Organização Conceitual do Projeto Pedagógico da FAUS formulada pela Comissão Plena em 2000, p. 204 Elaborado pelo autor a partir da leitura do dossiê final.

90. Síntese da distribuição de horas apresentada pela Comissão Plena, p. 209 Elaborado pelo autor a partir do Projeto Pedagógico de Curso da FAUS, 2017-2021.

91. Forma de arborescência, p. 215 DELEUZE, Gilles; GUATTARI, Félix. Mil platôs, capitalismo e esquizofrenia. Vol. 01, 1995. p. 26.

92. Trabalho de estudante da disciplina de Plástica IV, turma do 4o semestre de 2019, p. 216 Foto: Christiane Costa.

93. Trabalho de estudante da disciplina de Plástica V, turma do 6 semestre de 2004, p. 217 Arquivo do autor.

94. Trabalho de estudante da disciplina de Projeto de Arquitetura IV, turma do 4o semestre de 2014 p. 218 Arquivo do autor.

95. Diagrama de aproximação do conceito de completude de Kant com o modo operativo do arquiteto, p. 219 Elaborado pelo autor.

96. Produção da FAUS: atelier, aulas externas, produção dos alunos, p. 221 Fotos acima e menores à direita, acima e abaixo: do autor. Foto centro e abaixo: Paulo von Poser. Demais fotos: Christiane Costa.

97. Atelier John Hejduk e Atelier FAUS, p. 223 Atelier John Hejduk: Larynx, elevação e corte. Autor Curtis Vasquez, Cooper Union, 1979. Atelier FAUS: Fotografias do autor.

98. Atelier, Laboratório de Práticas Construtivas, Maquetaria, Lavucs, p. 224 Foto canto superior esquerdo: do autor. Foto menor acima: Sebastian Beck. Fotos extrema direita/canto inferior esquerdo: Ricardo Granata. Foto meio: Christiane Costa. Foto canto inferior direito: Marcos Piffer.

99. Produção do Atelier da FAUS, p. 225 Fotos: menor à esquerda/meio/direita/embaixo: Christiane Costa. Foto menor canto superior à direita: Marcos Piffer. Demais fotos: do autor.

100. Produção do Atelier da FAUS, p. 226

Desenho e fotos: menor à esquerda/maquete a esquerda/alinhadas à direita/canto inferior à direita: do autor. Fotos: menor à direita/canto inferior à esquerda: Marcos Piffer. Foto canto superior à esquerda: Christiane Costa.

101. Localização atual dos laboratórios da FAUS, p. 227 Elaborado pelo autor, desenho Matheus Pardal

102. Quadro desenvolvido pelos professores da Sequência de Plástica em 2017, p. 228 Elaborado por Christiane Costa.

103. Atelier FAUS: trabalhos de Plástica VI e Projeto de Arquitetura II: Subtrações, p. 230 Fotografias dos trabalhos de Plástica (1a, 2a e 5ạ): Christiane Costa; fotografias dos trabalhos de P.A. (3aㅡ e 4a): do autor.

104. Percorrer e reconhecer a cidade, p. 234 Fotos: André Silva, Andrei Krichinak, Christiane Costa, Paulo von Poser. Desenho: Agnes Lucia.

105. Dique Vila Gilda, p. 235 Foto à esquerda: Andrei Krichinak. Demais fotos e desenho: Izabela Volpi.

106. Trabalhos de Curso, p. 238 Acervo Biblioteca da FAUS.

107. Trabalhos de Curso, p. 244 Acervo Biblioteca da FAUS.

108. Trabalhos de Curso, p. 246 Acervo Biblioteca da FAUS.

109. Trabalhos de Curso, p. 247 Acervo Biblioteca da FAUS.

110. Trabalhos de Curso, p. 248 Acervo Biblioteca da FAUS. 
111. Professor Hugo Segawa e Concurso CLEFA, p. 251

Foto à esquerda: Olegário Vasconcelos. Imagens à direita: X CLEFA. São Paulo: UDUAL/FAUUSP, 1983. pp. 53-60.

112. Concurso Opera Prima, p. 252 Acervo Biblioteca da FAUS.

113. Concursos, p. 254 Acervo Biblioteca da FAUS.

114. Concurso Archdaily Melhores TCs de 2018, p. 257 Acervo Biblioteca da FAUS

115. Biomimetic 24 competition, p. 258 Disponivel em: < https://www.e-architect.co.uk/competitions/24h-competition >. Acesso em: 14 fev. 2020.

116. Gate, Tuca Reinés, p. 260 Disponivel em: <http://www.tucareines.com.br/>. Acesso em: 09 jan. 2020.

117. Ano de formatura e "olhos que viram peixes", p. 261 Gráfico elaborado pelo autor. Imagem disponivel em: <http://www.goloborotko.com/\#/1>. Acesso em: 09 jan. 2020.

118. Mapa das cidades de origem dos estudantes, p. 262 Elaborado pelo autor.

119. Área de atuação como arquiteto e Livraria Cultura, p. 262 Gráfico elaborado pelo autor. Imagem disponivel em: <https://www.archfb.com/>. Acesso em: 09 jan. 2020

120. Casa no Colorado e Casa Itamambuca, p. 263 Disponivel em: <https://guimattos.com.br/>. Acesso em: 09 jan. 2020.

121. Ênfase de atuação como arquiteto, p. 264 Elaborado pelo autor.

122. Mapa do estado de São Paulo, p. 265 Elaborado pelo autor.

123. Mapa do Brasil e Mundo, p. 266 Elaborado pelo autor.

124. Formação acadêmica e "Life is a hard silk soft", p. 267 Gráfico elaborado pelo autor. Imagem disponível em: <http://www.goloborotko.com/\#/1>. Acesso em: 09 jan. 2020.

125. Instituições de pós-graduação, p. 268 Elaborado pelo autor.

126. Torneira para lavatório, p. 269 Disponivel em: <https://guimattos.com.br/>. Acesso em: 09 jan. 2020.

127. Categorias de atuação docente, p. 270 Elaborado pelo autor.

128. Map-II inked drypoint on acetate, p. 270 Disponivel em: <http://www.goloborotko.com/\#/1>. Acesso em: 09 jan. 2020.

129. Instituições de atuação docente, p. 271 Elaborado pelo autor.

130. Revista, livros e fotografia de Marcos Piffer, p. 272 Disponivel em: <http://www.marcospiffer.com.br/>. Acesso em: 09 jan. 2020.

131. If-the-storm-was-red1 2014, p. 274 Disponivel em: <http://www.goloborotko.com/\#/1>. Acesso em: 09 jan. 2020.

132. Primeiro e segundo Show FAUS, 1977/1978, p. 279 Arquivo Henri Michel Lesbaupin.

133. Avaliação de Projeto de Arquitetura IV na FAUS, p. 280 Foto do autor.

134. Estrutura do Departamento de Projeto da FAU-USP, p. 282 Arquivo Edgar Dente.

135. Estrutura do Departamento de Projeto da FAUS, p. 282 Arquivo do autor.

136. Orientação de Projeto de Arquitetura VI, 2019, p. 285 Arquivo do autor.

137. Avaliação de Projeto de Arquitetura, 2018, p.285 Arquivo do autor.

138. Avaliação de Projeto de Arquitetura V, 2018, p.286 Arquivo do autor.

139. Planos de ensino da Sequência de Urbanismo, 1983, p. 286 Elaborado por Henri Michel Lesbaupin. 
140. Entrega e avaliação do TGI em março de 2017, p. 290 Arquivo do autor.

141. Entrega e avaliação do TGI em setembro de 2017, p. 290 Arquivo do autor.

142. Entrega e avaliação do TGI em março de 2018, p. 291 Arquivo do autor.

143. Entrega e avaliação do TGI em setembro de 2018, p. 291 Arquivo do autor.

144. Entrega e avaliação do TGI em março de 2019, p. 292 Arquivo do autor

145. Entrega e avaliação do TGI em setembro de 2019, p. 292 Arquivo do autor.

146. Axonometria do Laboratório de Práticas Construtivas, p. 296 Elaborado pelo autor, desenho Matheus Pardal.

147. Proposta FAUS 2020, p. 297 Elaborado pelo autor.

148. Laboratório de Práticas Construtivas, p. 298 Elaborado pelo autor, imagem Matheus Pardal.

149. Prédio da FAUS recém-inaugurado, p. 298 Arquivo Biblioteca da FAUS.

150. Proposta FAUS 2020, p. 299 Elaborado pelo autor.

151. Diagrama dos laboratórios de produção, p. 300 Elaborado pelo autor, desenho Matheus Pardal.

152. Proposta FAUS 2020, p. 301 Elaborado pelo autor.

153. Proposta FAUS 2020, p. 303 Elaborado pelo autor.

154. Diagrama novas relações e distribuição espacial, p. 304 Elaborado pelo autor, desenho Matheus Pardal.

155. Estudantes e professores em assembleia no atelier da FAUS em 1982, p. 315 Fotos: Olegário Vasconcelos.

\section{Créditos das tabelas}

1. Programas de ensino da FAU-USP e FNA-RJ, p. 47 Reelaborada pelo autor. Dados: Disponível em: <http://www.dearquiteturas.com>. Acesso em: novembro de 2015

2. Estrutura do currículo mínimo proposto pelo MEC em 1969, p. 62 Elaborado pelo autor.

3. Sugestão para a Faculdade de Santos, p. 69 Elaborado pelo autor.

4. Professores pioneiros da FAUS, p. 92 Quadro elaborado pelo autor a partir da leitura do Relatório do ano letivo de 1970 da FAUS.

5. Diretores da FAUS, p. 105 Elaborado pelo autor.

6. Quadro para composição das comissões de integração, p. 112 Diretório Acadêmico Lucio Costa. Dossiê da Crise de 1972. Santos, 1972. p. 49.

7. Quadro síntese de áreas das sedes da FAUS, p. 125 Elaborado pelo autor.

8. Calendário de Reuniões das FAU's do Estado de São Paulo, p. 152 Elaborado pelo autor com base no comunicado das FAU's do Estado de São Paulo, Arquivo Diretório Acadêmico Lucio Costa.

9. Quadro síntese da carga horária por departamento da FAUS, p. 156 Elaborado pelos estudantes em 1979. Redesenho do autor.

10. Quadro síntese da pesquisa um exemplo de procedimento de avaliação, p. 161 Elaborado pelo autor a partir do trabalho de Noêmio Xavier. Revista Educação e Avaliação, edição no 02. jan. 1981. pp. 100-130.

11. Professores demitidos na crise de 1982 , p. 168 Elaborado pelo autor. 
12. Grade curricular e carga horária do atual PPC da FAUS, 2017-2021, p. 210 Elaborado pelo autor.

13. Grupos de pesquisas da FAUS, p. 211

Elaborado pelo autor a partir da leitura do Projeto Pedagógico de Curso da FAUS.

14. Acervo documental da UNISANTOS, p. 212

Elaborado pelo autor, fonte: Departamento de Bibliotecas - dados estatísticos até 29 de março de 2016.

15. Docentes ativos na FAUS, p. 213

Quadro: elaborado pelo autor. Dados: Departamento de Recursos Humanos da Universidade Católica de Santos.

16. Quadro de amostragem dos Trabalhos de Curso da FAUS, p. 213 Elaborado pelo autor.

17. Quadro das premiações da FAUS, p. 256 Elaborado pelo autor.

18. Atuação dos arquitetos da FAUS no setor público regional, p. 273 Elaborada pelo autor.

19. Docentes das faculdades de arquitetura de Santos, p. 273 Elaborada pelo autor.

20. Campo de atuação profissional, p. 276 Fonte dos dados: STEVENS, Garry. O circulo privilegiado. Brasília: UnB, 2003. p. 101.

21. Quadro síntese da reestruturação da Sequência de Projeto de Arquitetura, p. 283 Elaborado pelo autor.

22. Ementas das disciplinas das sequências de projeto e tecnologia, p. 287

Elaborado pelo autor. Dados: UNIVERSIDADE CATÓLICA DE SANTOS. Projeto Pedagógico de Curso - Arquitetura e Urbanismo. pp 54-100. 


\title{
APÊNDICE
}

\author{
Professores da FAUS
}

Parte integrante das diretrizes metodológicas para a verificação do problema principal dessa pesquisa, o quadro a seguir contém o registro do corpo docente da FAUS desde 1970 até 2018, abrangendo um período de 48 anos de atividades da escola. As informações aqui registradas foram obtidas a partir das pesquisas nos documentos de registro do Departamento de Recursos Humanos da Universidade Católica de Santos, da leitura das atas de plenárias da escola e dos planos de ensino disponíveis nos arquivos da FAUS, da pesquisa na Plataforma Lattes e através do depoimento de alguns professores longevos da escola. Como forma de organizar este material, foi elaborado um quadro com os 347 nomes de professores encontrados, listados em ordem alfabética, associados à disciplina ministrada, ao ano da sua admissão, ao ano do seu desligamento e a instituição da sua graduação de origem.

Entretanto, este quadro possui muitas lacunas, pois até o momento do depósito desse trabalho não foi possível encontrar a íntegra dos dados de alguns dos professores. Esse problema se deve aos seguintes fatos: nem todos os registros de contratação estão completos, alguns não constam qual era a disciplina ministrada e ou a instituição de graduação do professor. Alguns nomes aparecem nos planos de ensinou e ou grades horárias, mas não constam nos registros de contratação da universidade, o que pode estar relacionado ao programa de estágio docente que vigorou entre os anos de 1970 e início dos anos de 1980, a efetivação destes estagiários dependia de fatores, como por exemplo, desempenho didático, relacionamento com o corpo discente e com o próprio corpo docente da FAUS.

PROFESSORES DA FAUS

\begin{tabular}{|c|c|c|c|c|c|}
\hline SEQ & NOME & EIXO TEMÁTICO & ENTRADA & SAÍDA & FORMAÇÃO \\
\hline 1 & ABRAHÃO VELVU SANOVICZ & PLÁSTICA & 01/04/1970 & 1977 & FAU-USP \\
\hline 2 & ADILSON COSTA MACEDO & URBANISMO & 1989 & 1991 & FAU-USP \\
\hline 3 & ADOLPHO RUBIO MORALES & PROJETO & 01/06/1976 & 19/12/2005 & BELAS ARTES - RJ \\
\hline 4 & AJAX EPAMINONDAS DE ALMEIDA & PROJETO & 01/08/1994 & $13 / 04 / 2012$ & FAUS \\
\hline 5 & ALBERTO FERNANDO MELCHIADES XAVIER & TEORIA E HISTÓRIA & 01/08/1974 & 1986 & BELAS ARTES - SP \\
\hline 6 & ALEXANDRE C P DELIJAICOV & PROJETO & 01/05/1991 & $20 / 10 / 2004$ & BELAS ARTES - SP \\
\hline 7 & ALFRED TALAAT & PROJETO & 03/04/1973 & $23 / 06 / 2016$ & FAU-USP \\
\hline 8 & ALFREDO TEIXEIRA & URBANISMO & 24/03/1986 & 27/08/1998 & - \\
\hline 9 & ALTIVO OVANDO JUNIOR & URBANISMO & 22/05/1992 & 1993 & FAU-PUCCAMP \\
\hline 10 & ANA CLAUDIA VENTURA & PROJETO & $01 / 04 / 1993$ & $19 / 12 / 2005$ & FAUS \\
\hline 11 & ANA ELENA SALVI & TEORIA E HISTÓRIA & 04/04/1994 & ATIVO & FAU-USP \\
\hline 12 & ANA LUIZA RIBEIRO LINS & - & - & - & - \\
\hline 13 & ANA MARCIA AKAUI MOREIRA & PLÁSTICA & $02 / 04 / 2012$ & $13 / 12 / 2016$ & BELAS ARTES - SP \\
\hline 14 & ANA MARIA GONZALEZ GARCIA & TECNOLOGIA & & & FAUS \\
\hline 15 & ANA PAULA MENEGHETTI DE FREITAS & TECNOLOGIA & $02 / 05 / 2014$ & 04/08/2014 & ENG-UFSM \\
\hline 16 & ANGELA MARIA GONÇALVES FRIGERIO & TECNOLOGIA & 01/08/1978 & ATIVO & GEO-UNESP \\
\hline 17 & ANGELO SALVADOR FILARDO JUNIOR & URBANISMO & $21 / 04 / 1987$ & 19/01/2011 & FAU-USP \\
\hline 18 & ANÍBAL MARTINS CLEMENTE & DIRETOR & $01 / 02 / 1970$ & $31 / 05 / 1972$ & POLI-USP \\
\hline 19 & ANNA MARIA ABRAÃO KHOURY RHAME & TECNOLOGIA & 07/03/1975 & - & FAAP \\
\hline 20 & ANTÔNIO CARLOS QUINTAS & PROJETO & $13 / 03 / 1974$ & - & FAU-Mack \\
\hline 21 & ANTONIO CASTANHEIRA NETO & TECNOLOGIA & 07/08/1972 & - & - \\
\hline 22 & ANTONIO CLAUDIO PINTO DA FONSECA & PROJETO & 01/03/1997 & $30 / 06 / 2006$ & FAU-USP \\
\hline 23 & ANTONIO DOMINGOS BATTAGLIA & URBANISMO & 1978 & 1986 & FAU-USP \\
\hline 24 & ANTONIO EDGARD BASAGLIA & TECNOLOGIA & - & 1988 & ENG-FEI \\
\hline 25 & ANTÔNIO LUIZ DIAS DE ANDRADE (JANJÃO) & TEORIA E HISTÓRIA & 01/05/1976 & 1987 & FAU-USP \\
\hline 26 & ANTONIO MÁXIMO & TEORIA E HISTÓRIA & $01 / 06 / 1976$ & 1986 & - \\
\hline 27 & ANTONIO MELCHOR & TECNOLOGIA & 03/04/1974 & 1985 & FAU-USP \\
\hline 28 & APOENA AMARAL E ALMEIDA & PROJETO & $18 / 02 / 2010$ & ATIVO & FAU-USP \\
\hline 29 & ARI VICENTE FERNANDES & URBANISMO & 01/06/1976 & 1986 & FAU-USP \\
\hline 30 & ARMANDO DIORIO FILHO & TECNOLOGIA & 16/02/1998 & $13 / 12 / 2014$ & ENG-UNESP \\
\hline 31 & ARNALDO ANTÔNIO MARTINO & PLÁSTICA & $14 / 04 / 1970$ & 29/02/1972 & FAU-USP \\
\hline 32 & AUGUSTO MUNIZ CAMPOS & URBANISMO & $10 / 08 / 1983$ & $13 / 12 / 2017$ & FAUS \\
\hline 33 & AUGUSTO REYNOL FILHO & TECNOLOGIA & - & & IME-USP \\
\hline 34 & AVELINO RUIVO JUNIOR & URBANISMO & - & 1987 & FAUS \\
\hline 35 & AYAKO NISHIKAWA & URBANISMO & 08/03/1974 & - & FAU-USP \\
\hline 36 & BENEDITO LIMA DE TOLEDO & TEORIA E HISTÓRIA & 01/08/1972 & 28/02/1973 & FAU-USP \\
\hline 37 & BENEDITO VICENTE PADOVANI & TECNOLOGIA & $11 / 08 / 1973$ & $31 / 07 / 1975$ & - \\
\hline 38 & BENNO MICHAEL PERELMUTTER & PROJETO & $01 / 04 / 1970$ & - & FAU-USP \\
\hline 39 & BETINA & TEORIA E HISTÓRIA & - & - & - \\
\hline 40 & BONA DE VILLA & URBANISMO & $11 / 06 / 1972$ & 1985 & - \\
\hline 41 & CALIM JABUR & TECNOLOGIA & $12 / 03 / 1973$ & 1986 & - \\
\hline 42 & CANDI HIRANO & PROJETO & 23/03/1973 & - & FAU-MACK \\
\hline 43 & CARLOS ALBERTO PRATES COSTA & PROJETO & 02/09/1986 & $19 / 12 / 2005$ & FAU-UBC \\
\hline 44 & CARLOS ANTONIO FERRO & PROJETO & 19/03/1974 & $19 / 12 / 2007$ & FAU-USP \\
\hline 45 & CARLOS ANTUNES & PROJETO & 12/08/1992 & ATIVO & FAU-USP \\
\hline 46 & CARLOS AUGUSTO MATTEI FAGGIN & TEORIA E HISTÓRIA & - & - & FAU-USP \\
\hline 47 & CARLOS AUGUSTO WELKER & PROJETO & - & 1986 & \\
\hline 48 & CARLOS EDUARDO ADEGAS & TECNOLOGIA & $17 / 09 / 1983$ & $14 / 04 / 1988$ & ENG-UMC \\
\hline 49 & CARLOS EDUARDO M GOUVEIA & TECNOLOGIA & 01/03/1996 & $26 / 06 / 2017$ & 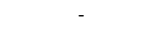 \\
\hline
\end{tabular}




\begin{tabular}{|c|c|}
\hline 50 & CARLOS ROBERTO FIGUEIREDO NOGUEIRA \\
\hline 51 & CARLOS ROBERTO MONTEIRO DE ANDRADE \\
\hline 52 & CARLOS ROBERTO PAIVA \\
\hline 53 & CARMELA LEVY KANJI \\
\hline 54 & CASSIA REGINA C MAGALDI \\
\hline 55 & CÉLIA PEREIRA MENDES \\
\hline 56 & CÉLIA SOIBELMANN \\
\hline 57 & CÉLIO CALESTINI \\
\hline 58 & CELIO PIMENTA \\
\hline 59 & CELSO PAZZANESE - POLA \\
\hline 60 & CELSO SILVEIRA QUEIROZ \\
\hline 61 & CESAR AGENOR FERNANDES DA SILVA \\
\hline 62 & CESAR AUGUSTO ALONSO CAPASSO \\
\hline 63 & CESAR BARGO PEREZ \\
\hline 64 & CESAR LUIZ MAZZACORATTI \\
\hline 65 & CHRISTIANE COSTA FERREIRA MACEDO \\
\hline 66 & CHRISTINA DE CASTRO MELLO \\
\hline 67 & CLARISSA DUARTE DE CASTRO SOUZA \\
\hline 68 & CLAUDIA MARIA BRAGA RIBEIRO \\
\hline 69 & CLAUDIO AUGUSTO Q ABDALA \\
\hline 70 & CLAUDIO JOSÉ DOS SANTOS \\
\hline 71 & CLAUDIO SCHERER DA SILVA \\
\hline 72 & CLEBER FERRAO CORREA \\
\hline 73 & CLEBER JOSÉ BONETTI MACHADO \\
\hline 74 & CLEIDE VALERI SANCHEZ FIDALGO \\
\hline 75 & CLOVIS RODRIGUES DA MATTA \\
\hline 76 & CONRADO JORGE (SILVA DE MARCO) HECK \\
\hline 77 & CRISTIANO ALCKMIN MASCARO \\
\hline 78 & CYRO ANTONIO LAURENZA FILHO \\
\hline 79 & CYRO RAPHAEL MONTEIRO DA SILVA \\
\hline 80 & DÁCIO ARAÚJO BENEDITO OTTONI \\
\hline 81 & DANIELLE (ARDAILLON) SIMÕES \\
\hline 82 & DAVID ARAÚJO BENEDITO OTTONI \\
\hline 83 & DAVID GELEHRTER DA COSTA LOPES \\
\hline 84 & DEBORA BLANCO BASTOS DIAS \\
\hline 85 & DÉCIO TOZZI \\
\hline 86 & DELCHI MIGOTTO FILHO \\
\hline 87 & DENISE GOMES CESAR RUPRECHT \\
\hline 88 & DENISE MARIA F ALCANTARA \\
\hline 89 & DORA HENRICI DE LONDOÑO \\
\hline 90 & DOUGLAS CANJANI DE ARAUJO \\
\hline 91 & EDGAR GONCALVES DENTE \\
\hline 92 & EDISON ELOY DE SOUZA \\
\hline 93 & EDITH GONÇALVES DE OLIVEIRA \\
\hline 94 & EDMILSON ROBERTO BRAGA \\
\hline 95 & EDUARDO DE JESUS RODRIGUES \\
\hline 96 & EDUARDO FONTES HOTZ \\
\hline 97 & EDUARDO TRANI \\
\hline 98 & EIDEVAL BOLANHO \\
\hline 99 & ELIANE GUEDES MAZZA \\
\hline 100 & ELIAS JORGE CURY \\
\hline 101 & ELVIRA DE ALMEIDA ALQUÉRES \\
\hline 102 & ELYSEU DE ANDRADE JUNIOR \\
\hline 103 & ERNESTO THEODOR WALTER \\
\hline 104 & EUGENIO FERNANDES QUEIROGA \\
\hline 105 & EULALIA PORTELA NEGREIROS \\
\hline 106 & EULER SANDEVILLE JUNIOR \\
\hline 107 & EURICO PRADO LOPES \\
\hline 108 & EVELYN LEVY \\
\hline 109 & FABIO EDUARDO SERRANO \\
\hline 110 & FABIO PAZZANESE FILHO \\
\hline 111 & FATIMA REGINA SANS MARTINI \\
\hline 112 & FERNANDA DE MACEDO HADDAD \\
\hline 113 & FERNANDO ALCKMIN MASCARO \\
\hline 114 & FERNANDO FRANK CABRAL \\
\hline 115 & FERNANDO JORGE REBELO SOARES \\
\hline 116 & FIORAVANTE MANCINI FILHO \\
\hline 117 & FLAVIO FRANCISCO DA COSTA \\
\hline 118 & FLAVIO MARCONDES BUENO DE MORAES \\
\hline 119 & FLAVIO MINDLIN GUIMARÃES \\
\hline 120 & FRANCISCA BARBOSA SCHURMANN \\
\hline 121 & FRANCISCO DE OLIVEIRA \\
\hline 122 & FRANCISCO FUZETTI DE VIVEIROS FILHO \\
\hline 123 & FRANCISCO LUCIO MARIO PETRACCO \\
\hline 124 & FRANCO PETRICH \\
\hline 125 & FREDERIC EDOUARD LEBOIS \\
\hline 126 & GABRIEL BOLAFI \\
\hline 127 & GENTIL PAIS DOS SANTOS \\
\hline 128 & GERALDO VESPASIANO PUNTONI \\
\hline 129 & GIANCARLO SALVADOR LATORRACA \\
\hline 130 & GIANRENATO VITIELLO \\
\hline 131 & GILBERTO BERZIN \\
\hline 132 & GILBERTO MACHADO RIZZI \\
\hline 133 & GILBERTO ORCIOLI SALVADOR \\
\hline 134 & GINO CALDATTO BARBOSA \\
\hline 135 & GRAZIELA MARQUES DE SOUZA DIAS \\
\hline 136 & GUSTAVO MAIA RODRIGUES \\
\hline 137 & HARON COHEN \\
\hline 138 & HEITOR PICCININI FILHO \\
\hline 139 & HELCIO MONTEIRO CREMONESE \\
\hline 140 & HENRI MICHEL DO AMARAL LESBAUPIN \\
\hline 141 & HENRIQUE CAMBIAGHI FILHO \\
\hline 142 & HENRIQUE NOÉ DE ALMEIDA \\
\hline 143 & HILTON FELICIO DOS SANTOS \\
\hline 144 & HSIEH WEN HSIANG \\
\hline
\end{tabular}

\begin{tabular}{|c|c|c|c|}
\hline TEORIA E HISTÓRIA & - & - & HIST-USP \\
\hline TECNOLOGIA & 1980 & 1983 & USP \\
\hline TEORIA E HISTÓRIA & 1990 & 1992 & FILOS-UNISANTOS \\
\hline URBANISMO & 01/09/1991 & $22 / 06 / 2016$ & FAUS \\
\hline TEORIA E HISTÓRIA & 01/03/1987 & ATIVO & FAU-UFBA \\
\hline TEORIA E HISTÓRIA & $12 / 03 / 1974$ & - & - \\
\hline- & $12 / 03 / 1973$ & $28 / 02 / 1974$ & - \\
\hline URBANISMO & $22 / 08 / 1973$ & 1984 & FAU-UFPR \\
\hline TEORIA E HISTÓRIA & 1978 & 1992 & FAU-USP \\
\hline PROJETO & - & - & FAU-USP \\
\hline TECNOLOGIA & $17 / 03 / 1973$ & - & ENG-Mack \\
\hline TEORIA E HISTÓRIA & $01 / 03 / 2010$ & ATIVO & HIST-UNESP \\
\hline TECNOLOGIA & $04 / 08 / 2006$ & ATIVO & FAUS \\
\hline PLÁSTICA & $02 / 05 / 2011$ & ATIVO & FAUS \\
\hline PROJETO & 09/03/1994 & $02 / 02 / 2009$ & FAU-USP \\
\hline PLÁSTICA & $14 / 02 / 2008$ & ATIVO & FAUS \\
\hline PROJETO & 1978 & 1988 & FAU-USP \\
\hline URBANISMO & 07/02/2011 & ATIVO & FAUS \\
\hline PLÁSTICA & $04 / 02 / 2013$ & ATIVO & FAU-USP \\
\hline PROJETO & 01/11/1994 & $23 / 06 / 2006$ & FAU-Mack \\
\hline TEORIA E HISTÓRIA & 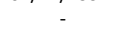 & 1985 & PEDAG-UNISANTOS \\
\hline TEORIA E HISTÓRIA & $11 / 02 / 2009$ & ATIVO & FILOS-CLARETIANO \\
\hline PAISAGISMO & $01 / 06 / 2001$ & ATIVO & UNESP \\
\hline PROJETO & 1987 & - & FAU-UBC \\
\hline TECNOLOGIA & 01/04/1991 & $15 / 12 / 2006$ & MAT-UNISANTA \\
\hline TECNOLOGIA & - & - & - \\
\hline TECNOLOGIA & 01/03/1971 & 1986 & - \\
\hline PLÁSTICA & 1983 & 1986 & FAU-USP \\
\hline TECNOLOGIA & $16 / 09 / 1972$ & - & - \\
\hline TECNOLOGIA & $19 / 02 / 1990$ & $13 / 12 / 2010$ & POLI-USP \\
\hline TEORIA E HISTÓRIA & $01 / 08 / 1972$ & - & FAU-USP \\
\hline TEORIA E HISTÓRIA & $22 / 05 / 1970$ & $28 / 02 / 1971$ & FFCL-USP \\
\hline PROJETO E URBANISMO & $29 / 04 / 1970$ & - & POLI-USP \\
\hline OBJETO & $02 / 05 / 1978$ & $16 / 06 / 2014$ & FAU-USP \\
\hline URBANISMO & 01/05/1991 & ATIVO & FAUS \\
\hline PROJETO E OBJETO & $11 / 08 / 1972$ & - & FAU-Mack \\
\hline TECNOLOGIA & $01 / 03 / 1994$ & $22 / 12 / 2003$ & ENG - UNISANTA \\
\hline PROJETO & $01 / 05 / 1996$ & $02 / 02 / 2009$ & FAU-USP \\
\hline TEORIA E HISTÓRIA & 02/09/1986 & $07 / 02 / 2008$ & FAUS \\
\hline URBANISMO & - & 1988 & - \\
\hline PLÁSTICA & $01 / 06 / 1988$ & $01 / 02 / 2011$ & FAU-USP \\
\hline PROJETO & $22 / 09 / 1987$ & $19 / 12 / 2005$ & FAU-USP \\
\hline PROJETO & 1976 & 1988 & FAU-USP \\
\hline- & 08/09/1971 & $17 / 12 / 1971$ & - \\
\hline TECNOLOGIA & $01 / 03 / 1999$ & $21 / 06 / 2010$ & POLI-USP \\
\hline PLÁSTICA & 1978 & 1986 & FAU-USP \\
\hline OBJETO & $11 / 08 / 1972$ & 1982 & FAU-Mack \\
\hline URBANISMO & $06 / 05 / 1988$ & 20/03/1993 & FAU-USP \\
\hline TEORIA E HISTÓRIA & $15 / 03 / 1973$ & 1985 & - \\
\hline URBANISMO & 1985 & 1989 & FAU-USP \\
\hline TECNOLOGIA & $02 / 10 / 1990$ & $20 / 10 / 2004$ & $\mathrm{FEI}$ \\
\hline OBJETO & 1973 & & - \\
\hline TECNOLOGIA & - & 1986 & - \\
\hline PROJETO & $13 / 11 / 1986$ & $16 / 12 / 2015$ & FAU-USP \\
\hline URBANISMO & - & & FAU-USP \\
\hline URBANISMO & 1988 & 1996 & BELAS ARTES - SP \\
\hline TEORIA E HISTÓRIA & 02/09/1986 & 01/11/1999 & FAU-PUCCAMP \\
\hline PROJETO & 1980 & & FAU-Mack \\
\hline TEORIA E HISTÓRIA & 1980 & 1985 & CSP-PUC RIO \\
\hline TEORIA E HISTÓRIA & 03/09/1982 & ATIVO & FAU-USP \\
\hline- & $17 / 03 / 1973$ & - & - \\
\hline TEORIA E HISTÓRIA & 04/02/2013 & $01 / 02 / 2016$ & ARTES-UNISANTA \\
\hline PAISAGISMO & $01 / 09 / 2016$ & $13 / 12 / 2017$ & FAUS \\
\hline OBJETO & - & - & FAU-USP \\
\hline PROJETO & $01 / 11 / 1993$ & $13 / 12 / 2017$ & FAU-USP \\
\hline TEORIA E HISTÓRIA & 1984 & 1990 & DIREITO-UNISANTOS \\
\hline TECNOLOGIA & 01/09/1992 & 30/12/1999 & FAU-USP \\
\hline TECNOLOGIA & $11 / 02 / 2008$ & $28 / 10 / 2014$ & ENG-UNISANTOS \\
\hline URBANISMO & $15 / 03 / 1990$ & $03 / 08 / 2009$ & BELAS ARTES - SP \\
\hline TECNOLOGIA & 01/03/1971 & $17 / 12 / 1971$ & - \\
\hline TEORIA E HISTÓRIA & JUL. 1973 & JUL. 1985 & HIST-UNB \\
\hline TEORIA E HISTÓRIA & $01 / 04 / 1970$ & 29/02/1972 & $\mathrm{CFCH}-\mathrm{UFPE}$ \\
\hline PROJETO & $01 / 11 / 1971$ & $30 / 05 / 1972$ & FAU-USP \\
\hline PLÁSTICA E PROJETO & $01 / 03 / 1971$ & $01 / 11 / 1986$ & FAU-Mack \\
\hline OBJETO & $16 / 04 / 1974$ & - & FAU-USP \\
\hline PROJETO & 01/03/1998 & $23 / 06 / 2016$ & FAU-UBC \\
\hline TEORIA E HISTÓRIA & 1970 & 1970 & FFCL-USP \\
\hline TECNOLOGIA & $31 / 03 / 1973$ & - & - \\
\hline PROJETO & $14 / 03 / 1973$ & - & FAU-USP \\
\hline PLÁSTICA & 01/03/1995 & $01 / 02 / 2010$ & FAU-USP \\
\hline URBANISMO & 01/10/1991 & $01 / 11 / 2004$ & IUAV-VENEZA \\
\hline TECNOLOGIA & 04/04/1994 & $23 / 06 / 2017$ & EESC-USP \\
\hline URBANISMO & - & 1988 & FAU-USP \\
\hline PLÁSTICA & $01 / 06 / 1976$ & 1982 & FAU-USP \\
\hline TEORIA E HISTÓRIA & 01/05/1993 & ATIVO & FAUS \\
\hline TEORIA E HISTÓRIA & $15 / 04 / 1974$ & - & - \\
\hline TECNOLOGIA & $07 / 02 / 2011$ & $13 / 12 / 2017$ & ENG-UNISANTOS \\
\hline PLÁSTICA & $01 / 10 / 1973$ & $30 / 01 / 1974$ & FAU-Mack \\
\hline TECNOLOGIA & $01 / 03 / 1995$ & $12 / 12 / 2003$ & ENG-UNISANTA \\
\hline TECNOLOGIA & $01 / 09 / 1981$ & $09 / 12 / 2010$ & FAUS \\
\hline URBANISMO & $16 / 03 / 1973$ & 1986 & FAU-UFRJ \\
\hline PROJETO & 1980 & 1992 & FAU-USP \\
\hline TEORIA E HISTÓRIA & $01 / 12 / 1972$ & 1973 & FAUS \\
\hline- & $24 / 03 / 1973$ & $28 / 04 / 1978$ & - \\
\hline TECNOLOGIA & $01 / 08 / 1974$ & & - \\
\hline
\end{tabular}




\begin{tabular}{|c|c|}
\hline 145 & HUGO SEGAWA \\
\hline 146 & IGOR GELEHRTER DA COSTA LOPES \\
\hline 147 & ISABEL RUAS PEREIRA COELHO \\
\hline 148 & JACQUELINE DORIS LOW-BEER \\
\hline 149 & JAIR BREGA MARCATTI JUNIOR \\
\hline 150 & JAIR PEREIRA DOS SANTOS \\
\hline 151 & JAVIER MATEO ARANA \\
\hline 152 & JERÔNIMO BONILHA ESTEVES \\
\hline 153 & JHONNES ALBERTO VAZ \\
\hline 154 & JOAO CALLEJA ALCANIZ VALENTI \\
\hline 155 & JOAO FERNANDO PIRES MEYER \\
\hline 156 & JOÃO WALTER TOSCANO \\
\hline 157 & JOAQUIM DE BRITTO COSTA NETO \\
\hline 158 & JOAQUIM MARTINS \\
\hline 159 & JON ANDONI VERGARECHE MAITREJEAN \\
\hline 160 & JORGE BASSANI \\
\hline 161 & JORGE OSVALDO CARON \\
\hline 162 & JOSÉ ANTONIO DA SILVA QUARESMA \\
\hline 163 & JOSE CARLOS LODOVICI \\
\hline 164 & JOSE CLAUDIO PANEQUE \\
\hline 165 & JOSE DE OLIVEIRA SILVA \\
\hline 166 & JOSÉ FLÁVIO CORREIA VIEIRA \\
\hline 167 & JOSÉ GABRIEL BORBA FILHO \\
\hline 168 & JOSE GUILHERME T WHITAKER \\
\hline 169 & JOSE HENRIQUE C SERAPHIM \\
\hline 170 & JOSE LUIZ NUNES ZAPIA \\
\hline 171 & JOSE MAGALHAES JÚNIOR \\
\hline 172 & JOSE MARIA DE MACEDO FILHO \\
\hline 173 & JOSE MARQUES CARRIÇO \\
\hline 173 & JOSE NAGIB MIZIARA FILHO \\
\hline 174 & JOSE RENATO SPINA MARTINS \\
\hline 175 & JOSÉ RICARDO DE CARVALHO \\
\hline 176 & JOSE ROBERTO DEBS \\
\hline 177 & JOSE ROBERTO GOMES DE SOUTELLO \\
\hline 178 & JOSÉ ROBERTO RAMOS MUSA \\
\hline 179 & JUAN CABELLO ARRIBAS \\
\hline 180 & JUAN VILLA MARTINEZ \\
\hline 181 & JUAREZ RAMOS DA SILVA \\
\hline 182 & JULIO CAMARGO ARTIGAS \\
\hline 183 & JÚLIO ROBERTO KATINSKY \\
\hline 184 & KALIL ABRAHÃO \\
\hline 185 & KASUO SAKURAI \\
\hline 186 & KLARA ANNA MARIA KAISER MORI \\
\hline 187 & KOJI FUJISAKA \\
\hline 188 & LEILA REGINA DIÊGOLI \\
\hline 189 & LENA COELHO SANTOS BODANZKY \\
\hline 190 & LENIMAR GONCALVES RIOS \\
\hline 191 & LEVI BUCALEM FERRARI \\
\hline 192 & LOYDE VIEIRA DE ABREU HARBICH \\
\hline 193 & LUCIANO BARBANTI \\
\hline 194 & LÚCIO FLORO GRAZIOSI \\
\hline 195 & LÚCIO GOMES MACHADO \\
\hline 196 & LUIGI VILLAVECCHIA \\
\hline 197 & LUIS BATTAGLIA \\
\hline 198 & LUIS FINGERMANN \\
\hline 199 & LUÍZ ALFREDO HIEHL GALVÃO \\
\hline 200 & LUIZ ANTONIO RECAMÁN DE BARROS \\
\hline 201 & LUIZ CARLOS DAHER \\
\hline 202 & LUIZ CÉLIO BOTTURA \\
\hline 203 & LUIZ DE PINEDO QUINTO JUNIOR \\
\hline 204 & LUIZ FERNANDO DE ALMEIDA \\
\hline 205 & LUIZ GONZAGA MONTANS ACKEL \\
\hline 206 & LUIZ LAURENT BLOCH \\
\hline 207 & LUIZ OTÁVIO DE SOUZA ZAMARIOLLI \\
\hline 208 & LUIZ PANZOLDO NETO \\
\hline 209 & LUIZA NAOMI IWAKAMI \\
\hline 210 & MANOEL JOAQUIM FILIPE \\
\hline 211 & MANOEL LEMES SILVA NETO \\
\hline 212 & MARCELO ANTONIAZZI \\
\hline 213 & MARCELO MORATO \\
\hline 214 & MARCIA APS \\
\hline 215 & MARCIA HALLULI MENNEH \\
\hline 216 & MÁRCIA LUCIA GUILHERME \\
\hline 217 & MARCIA MARIA BENEVENTO \\
\hline 218 & MARCIA PEINADO ALUCCI \\
\hline 219 & MARCIEL PEINADO \\
\hline 220 & MARCIO BRASIL \\
\hline 221 & MARCIO LUCAS GIMENEZ MAZZA \\
\hline 222 & MARCO ANTONIO LANCA \\
\hline 223 & MARCOS ASSIS PIFFER \\
\hline 224 & MARCOS DE AZEVEDO ACAYABA \\
\hline 225 & MARCOS JOSÉ CARRILHO \\
\hline 226 & MARCOS MARI BARRETO \\
\hline 227 & MARCUS LIMA \\
\hline 228 & MARIA ARGENTINA O BIBAS NARUTO \\
\hline 229 & MARIA BEATRIZ ALVES MEIRA \\
\hline 230 & MARIA CECÍLIA LUCCHESE \\
\hline 231 & MARIA CRISTINA TUZZOLO VIDALLER \\
\hline 232 & MARIA CRISTINA GARCIA \\
\hline 233 & MARIA FERNANDA BRITTO NEVES \\
\hline 234 & MARIA HELENA M BARROS FLYNN \\
\hline 235 & MARIA JOSÉ PAIVA DE PAULA \\
\hline 236 & MARIA LUCIA REFINETTI MARTINS \\
\hline 237 & MARIA LUIZA MACHADO JATOBÁ \\
\hline 238 & MARIA RITA FIGUEIREDO GODOY \\
\hline
\end{tabular}

\begin{tabular}{|c|c|c|c|}
\hline $\begin{array}{c}\text { TEORIA E HISTÓRIA } \\
\text { OBJETO }\end{array}$ & MAR. 1982 & DEZ. 1987 & $\begin{array}{l}\text { FAU-USP } \\
\text { FAU-UNB }\end{array}$ \\
\hline PAISAGISMO & 01/07/2001 & $11 / 05 / 2006$ & FAU-ESBAL \\
\hline URBANISMO & SET. 1985 & MAR. 1988 & FAU-USP \\
\hline TEORIA E HISTÓRIA & - & - & HIST-UNISANTOS \\
\hline TECNOLOGIA & MAR. 80 & AGO. 85 & MAT-USP \\
\hline TEORIA E HISTÓRIA & - & - & - \\
\hline PROJETO & - & - & - \\
\hline TECNOLOGIA & 01/03/2012 & ATIVO & UNITAU \\
\hline TECNOLOGIA & 01/04/1993 & ATIVO & MAT-UNISANTOS \\
\hline URBANISMO & 21/04/1987 & 04/06/2010 & FAUS \\
\hline PROJETO & 01/03/1971 & 1988 & FAU-USP \\
\hline TECNOLOGIA & 05/09/1983 & $01 / 02 / 2008$ & FAUS \\
\hline TECNOLOGIA & 09/03/1974 & - & ENG-Mack \\
\hline PROJETO & 1978 & 1984 & FAU-USP \\
\hline TEORIA E HISTÓRIA & 01/04/1996 & $14 / 02 / 2006$ & FAU-USP \\
\hline PROJETO & 1975 & 1988 & FAU-USP \\
\hline URBANISMO & 1976 & 1985 & FAU-USP \\
\hline PROJETO & 01/11/1982 & $19 / 12 / 2005$ & FAUS \\
\hline PROJETO & 13/11/1986 & $13 / 12 / 2017$ & FAUS \\
\hline TECNOLOGIA & 01/09/1971 & ATIVO & - \\
\hline TECNOLOGIA & & 1986 & - \\
\hline TEORIA E HISTÓRIA & 01/03/1971 & 30/04/1972 & FAU-USP \\
\hline PROJETO & 01/11/1993 & $20 / 12 / 2011$ & FAU-USP \\
\hline TECNOLOGIA & 01/04/1993 & $01 / 02 / 2010$ & ENG-UNB \\
\hline TECNOLOGIA & 28/03/1990 & $12 / 12 / 2008$ & - \\
\hline URBANISMO & 01/05/1982 & $01 / 11 / 2004$ & FAU-Mack \\
\hline PROJETO & $13 / 03 / 2003$ & ATIVO & FAUS \\
\hline URBANISMO & $02 / 08 / 2010$ & ATIVO & FAUS \\
\hline TECNOLOGIA & 01/03/1996 & $01 / 08 / 2012$ & ENG-FAAP \\
\hline TECNOLOGIA & $02 / 02 / 2015$ & $13 / 12 / 2017$ & UNISANTA \\
\hline OBJETO & - & 1985 & FAU-USP \\
\hline URBANISMO & 01/04/1993 & $20 / 10 / 2004$ & - \\
\hline OBJETO & 09/08/1973 & $22 / 06 / 2016$ & FAU-USP \\
\hline EDUCAÇÃO FÍSICA & - & - & - \\
\hline PROJETO & $15 / 08 / 2016$ & ATIVO & UPM-ESPANHA \\
\hline PROJETO & 23/04/1975 & 1986 & \\
\hline TECNOLOGIA & $01 / 03 / 2014$ & ATIVO & ENG-UNISANTA \\
\hline PROJETO & 01/11/1982 & $01 / 08 / 2006$ & FAU-USP \\
\hline OBJETO & 01/04/1970 & 1977 & FAU-USP \\
\hline TECNOLOGIA & 23/09/1972 & - & - \\
\hline URBANISMO & 11/04/1975 & 1985 & - \\
\hline URBANISMO & - & 1986 & FAU-USP \\
\hline TECNOLOGIA & 28/04/1973 & - & ENG-Mack \\
\hline TEORIA E HISTÓRIA & 02/04/1990 & ATIVO & FAU-UBC \\
\hline TEORIA E HISTÓRIA & 02/05/1974 & 1985 & - \\
\hline URBANISMO & 04/04/1994 & ATIVO & FAUS \\
\hline TEORIA E HISTÓRIA & 01/03/1997 & 30/12/1999 & FCLAR-UNESP \\
\hline OBJETO & 01/03/2012 & $11 / 03 / 2014$ & PUC-GOIÁS \\
\hline TECNOLOGIA & 01/08/1972 & $31 / 07 / 1974$ & - \\
\hline TEORIA E HISTÓRIA & 09/04/1973 & - & TEOLOGIA \\
\hline TEORIA E HISTÓRIA & $12 / 03 / 1973$ & 1985 & FAU-Mack \\
\hline URBANISMO & 1971 & - & - \\
\hline URBANISMO & - & - & - \\
\hline URBANISMO & $15 / 03 / 1980$ & $01 / 11 / 2004$ & - \\
\hline- & 01/03/1971 & $29 / 02 / 1972$ & - \\
\hline TEORIA E HISTÓRIA & 01/03/1987 & 01/03/1992 & FAU-USP \\
\hline TEORIA E HISTÓRIA & 01/03/1971 & $30 / 04 / 1972$ & FAU-USP \\
\hline TECNOLOGIA & $16 / 03 / 1973$ & 1988 & ENG. AGRI. - FEAA \\
\hline URBANISMO & 22/05/1992 & $19 / 12 / 2005$ & FAU-USP \\
\hline TEORIA E HISTÓRIA & 02/04/1990 & $21 / 08 / 2006$ & FAU-PUCCAMP \\
\hline URBANISMO & - & - & - \\
\hline PROJETO & - & - & FAU-Mack \\
\hline OBJETO & - & - & - \\
\hline TEORIA E HISTÓRIA & - & - & - \\
\hline URBANISMO & 01/03/1994 & $01 / 02 / 2016$ & FAU-USP \\
\hline TEORIA E HISTÓRIA & 01/03/1995 & $07 / 12 / 2010$ & - \\
\hline URBANISMO & 01/03/1990 & 01/04/1994 & FAU-USP \\
\hline URBANISMO & - & 1986 & FAU-USP \\
\hline OBJETO & 04/08/2014 & $30 / 06 / 2017$ & FAU-USJT \\
\hline TECNOLOGIA & $01 / 03 / 2010$ & ATIVO & FACUL. FRANCISCANA \\
\hline PAISAGISMO & $15 / 03 / 1993$ & $28 / 06 / 2011$ & FAU-Mack \\
\hline URBANISMO & 1978 & 1986 & FAU-USP \\
\hline PLÁSTICA & 01/05/1991 & $14 / 03 / 2005$ & FAU-USP \\
\hline TECNOLOGIA & - & 1986 & - \\
\hline PROJETO & 1982 & 1986 & FAUS \\
\hline TECNOLOGIA & 01/05/1991 & $16 / 11 / 2015$ & FAUS \\
\hline TEORIA E HISTÓRIA & - & 1986 & - \\
\hline URBANISMO & 21/04/1987 & $01 / 12 / 2016$ & FAUS \\
\hline PLÁSTICA & 04/08/2006 & ATIVO & FAUS \\
\hline PROJETO & 02/04/1971 & $31 / 07 / 1983$ & FAU-USP \\
\hline TEORIA E HISTÓRIA & - & - & FAU-UFPR \\
\hline OBJETO & 04/08/2014 & $22 / 06 / 2017$ & FAUS \\
\hline PROJETO & 01/03/1987 & $14 / 02 / 2006$ & FAU-USP \\
\hline PLÁSTICA & 02/09/1976 & $19 / 12 / 2005$ & FAU-USP \\
\hline PLÁSTICA & 01/04/1995 & $10 / 07 / 2006$ & FAU-USP \\
\hline TEORIA E HISTÓRIA & 1986 & 1987 & FAU-PUCCAMP \\
\hline TECNOLOGIA & ago/03 & ATIVO & ENG - MAck \\
\hline TECNOLOGIA & 01/10/1994 & 01/02/1999 & - \\
\hline TECNOLOGIA & $01 / 08 / 2007$ & ATIVO & FAUS \\
\hline PROJETO & $02 / 05 / 1978$ & $13 / 12 / 2017$ & FAU-USP \\
\hline TEORIA E HISTÓRIA & 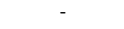 & (2. & - \\
\hline URBANISMO & & & FAU-USP \\
\hline TEORIA E HISTÓRIA & 20/04/1999 & $11 / 12 / 2006$ & FFCL-UNISANTOS \\
\hline PROJETO & $01 / 08 / 2006$ & $16 / 12 / 2008$ & FAUS \\
\hline
\end{tabular}




\begin{tabular}{|c|c|}
\hline 239 & MARIA TERESA KERR SARAIVA \\
\hline 240 & MARILENE NASCIMENTO GOMES \\
\hline 241 & MARINA DE CAMARGO HECK \\
\hline 242 & MARINA DONELLI \\
\hline 243 & MARIO EDUARDO SHIRAICHI \\
\hline 244 & MARLIO RAPOSO DANTAS \\
\hline 245 & MASSASHI RUY OHTAKE \\
\hline 246 & MAURICIO AZENHA DIAS \\
\hline 247 & MAURÍCIO NOGUEIRA LIMA \\
\hline 248 & MAYUMI WATANABE SOUZA LIMA \\
\hline 249 & MICHAIL LIEDERS \\
\hline 250 & MIGUEL GUKOVAS \\
\hline 251 & MIGUEL MATECC \\
\hline 252 & MILTON NASCIMENTO MARCELLOO \\
\hline 253 & MILTON VILHENA GRANADO JUNIOR \\
\hline 254 & MONICA ANTONIA VIANA \\
\hline 255 & MORACY AMARAL E ALMEIDA \\
\hline 256 & MURILLO DE AZEVEDO MARX \\
\hline 257 & NÁDIA SOMEKH MARTINS FERREIRA \\
\hline 258 & NELIO CESAR BORGOMINI \\
\hline 259 & NELSON ACHCAR \\
\hline 260 & NELSON TREZZA \\
\hline 261 & NEY CALDATTO BARBOSA \\
\hline 262 & NIEL LEONEL CORRÊA \\
\hline 263 & NILTON RICOY TORRES \\
\hline 264 & NÔEMIO XAVIER DA SILVEIRA FILHO \\
\hline 265 & ODILEA HELENA SETTI TOSCANO \\
\hline 266 & ORPHEU ENNIO ZAMBONI \\
\hline 267 & OTAVIO SAITO \\
\hline 268 & OSWALDO CORREA GONCALVES \\
\hline 269 & PAULA GORENSTEIN DEDECCA \\
\hline 270 & PAULA RODRIGUES DE ANDRADE \\
\hline 271 & PAULO BARROS \\
\hline 272 & PAULO CARLOS LACRETA \\
\hline 273 & PAULO CESAR AMBROSIO \\
\hline 274 & PAULO DE MELLO BASTOS \\
\hline 275 & PAULO DE MORAES \\
\hline 276 & PAULO EDUARDO B PIGNANELLI \\
\hline 277 & PAULO FERNANDO VON POSER \\
\hline 278 & PAULO SERGIO DE SOUZA E SILVA \\
\hline 279 & PEDRO FERREIRA \\
\hline 280 & PEDRO MANUEL RIVABEN DE SALES \\
\hline 281 & PEDRO PAULO DE MELO SARAIVA \\
\hline 282 & PERCIVAL BROSIG \\
\hline 283 & RAFAEL PAULO AMBROSIO \\
\hline 284 & RAYMUNDO DE PASCHOAL \\
\hline 285 & RENATO ARNALDO TAGNIN \\
\hline 286 & RENATO CARRIERI JUNIOR \\
\hline 287 & RENATO LUIS MARTINS NUNES \\
\hline 288 & RICARDO AUGUSTO DE MELLO GRANATA \\
\hline 289 & RICARDO COSTA GALVANESE \\
\hline 290 & RICARDO MOREIRA SOARES \\
\hline 291 & RITA DE CASSIA VAZ ARTIGAS \\
\hline 292 & ROBERTO FRANKLIN RONDINO \\
\hline 293 & ROBERTO HAGE CHAIN \\
\hline 294 & ROBERTO JOAQUIM DE OLIVEIRA \\
\hline 295 & ROBERTO LOEB \\
\hline 296 & ROBERTO MACHADO DE ALMEIDA \\
\hline 297 & RODRIGO BROTERO LEFÉVRE \\
\hline 298 & RONALDO DE SOUZA BARCALA \\
\hline 299 & RONALDO DUSCHENES \\
\hline 300 & ROSA ARTIGAS \\
\hline 301 & ROSANA DENALDI \\
\hline 302 & RUDOLF HERMAN HENRI YSEBIE \\
\hline 303 & RUY EDUARDO DEBS FRANCO \\
\hline 304 & RUY SARDINHA LOPES \\
\hline 305 & SAMUEL SZPIGEL \\
\hline 306 & SANDRA MARA ORTEGOSA \\
\hline 307 & SARA FELDMAN \\
\hline 308 & SELMA DOS SANTOS SEVA \\
\hline 309 & SEMI AMMAR \\
\hline 310 & SERAFIM CARLOS DIAS POUZA \\
\hline 311 & SÉRGIO DE SOUZA LIMA \\
\hline 312 & SÉRGIO FERRO PEREIRA \\
\hline 313 & SERGIO MOLLICA JUNIOR \\
\hline 314 & SERGIO NOVITA FORTIS \\
\hline 315 & SERGIO REGIS MOREIRA MARTINS \\
\hline 316 & SILVANA MARIA ZIONI \\
\hline 317 & SILVIA FERREIRA SANTOS WOLFF \\
\hline 318 & SILVIA MARIA FERREIRA RAMOS \\
\hline 319 & SYLVIA FISCHER \\
\hline 320 & SONIA VILAR CAMPOS \\
\hline 321 & SUNAO KISHI \\
\hline 322 & TELÉSFORO GIORGIO CRISTOFANI \\
\hline 323 & TEREZINHA AYUB PELIZZARI \\
\hline 324 & THAIS APARECIDA SOARES ROSSI \\
\hline 325 & THEREZINHA BANEVICIUS \\
\hline 326 & TOMIO TANAKA \\
\hline 327 & UBIRAJARA MOTTA LIMA RIBEIRO \\
\hline 328 & UBYRAJARA GONÇALVES GILIOLI \\
\hline 329 & VALERIA DE ROGATIS LEBOIS \\
\hline 330 & VANIA MOURA RIBEIRO \\
\hline 331 & VERA LUCIA DOMSCHKE \\
\hline
\end{tabular}

\begin{tabular}{|c|c|c|c|}
\hline $\begin{array}{c}\text { PLÁSTICA } \\
\text { TEORIA E HISTÓRIA }\end{array}$ & 1991 & $\begin{array}{l}1991 \\
1986\end{array}$ & $\begin{array}{l}\text { FAU-Mack } \\
\text { FAUS }\end{array}$ \\
\hline TEORIA E HISTÓRIA & $14 / 04 / 1970$ & $28 / 02 / 1971$ & FFCL-USP \\
\hline OBJETO & 1971 & - & FAU-USP \\
\hline TECNOLOGIA & $01 / 08 / 2006$ & $30 / 06 / 2010$ & FAUS \\
\hline PROJETO & 04/04/1972 & 09/06/1972 & FAU-Mack \\
\hline OBJETO & $01 / 04 / 1970$ & $30 / 07 / 2008$ & FAU-USP \\
\hline PROJETO & 01/05/1996 & $20 / 12 / 2011$ & FAUS \\
\hline PLÁSTICA & $22 / 03 / 1973$ & 1985 & FAU-Mack \\
\hline TECNOLOGIA & 01/04/1970 & 01/09/1971 & FAU-USP \\
\hline OBJETO & $11 / 08 / 1972$ & 1976 & \\
\hline OBJEIO & 14/04/1986 & $16 / 09 / 2007$ & FAU-USP \\
\hline TECNOLOGIA & 01/10/1976 & ATIVO & POLI-USP \\
\hline TECNOLOGIA & - & 1988 & - \\
\hline TECNOLOGIA & - & - & - \\
\hline TECNOLOGIA & - & 1987 & - \\
\hline URBANISMO & 01/03/1995 & ATIVO & FAU-PUCCAMP \\
\hline PROJETO & 09/08/2012 & ATIVO & ESCOLA DA CIDADE \\
\hline TEORIA E HISTÓRIA & $01 / 08 / 1972$ & 28/03/1973 & FAU-USP \\
\hline TEORIA E HISTÓRIA & MAR. 1987 & MAR. 1989 & FAU-USP \\
\hline TECNOLOGIA & - & 1986 & - \\
\hline TECNOLOGIA & 01/09/1974 & 1986 & MAT-USP \\
\hline URBANISMO & $24 / 05 / 1974$ & $17 / 12 / 2015$ & FAU-USP \\
\hline TEORIA E HISTÓRIA & 10/03/1997 & ATIVO & FAUS \\
\hline TECNOLOGIA & 03/07/1972 & - & - \\
\hline URBANISMO & - & 1986 & FAUS \\
\hline PROJETO & 1976 & 1982 & FAU-Mack \\
\hline PLÁSTICA & $16 / 08 / 1972$ & 1985 & FAU-USP \\
\hline & 20/04/1970 & 17/12/1971 & \\
\hline PROJETO & $01 / 03 / 1987$ & $30 / 12 / 1999$ & FAU-USP \\
\hline PLÁSTICA & - & - & FAU-USP \\
\hline PROJETO E URBANISMO & $01 / 04 / 1970$ & $28 / 08 / 2005$ & POLI-USP \\
\hline PROJETO & $01 / 04 / 2013$ & $30 / 06 / 2013$ & FAU-USP \\
\hline TEORIA E HISTÓRIA & $02 / 02 / 2015$ & $13 / 12 / 2017$ & FAUS \\
\hline PROJETO & - & - & - \\
\hline TECNOLOGIA & - & 1988 & FAUS \\
\hline TECNOLOGIA & 21/09/1987 & $19 / 12 / 2011$ & E. ENG. MAUÁ \\
\hline PROJETO & $01 / 08 / 1978$ & $19 / 12 / 2005$ & FAU-USP \\
\hline TECNOLOGIA & $14 / 02 / 2008$ & $14 / 12 / 2015$ & FAUS \\
\hline PROJETO & 01/04/1996 & $02 / 02 / 2009$ & FAU-USP \\
\hline PLÁSTICA & 02/09/1986 & ATIVO & FAU-USP \\
\hline URBANISMO & $21 / 08 / 1971$ & 1986 & - \\
\hline- & - & - & - \\
\hline URBANISMO & $22 / 05 / 1992$ & $01 / 02 / 2005$ & FAU-USP \\
\hline PROJETO & $01 / 08 / 1990$ & $01 / 11 / 2004$ & FAU-Mack \\
\hline PROJETO & $14 / 03 / 1973$ & $31 / 07 / 1976$ & - \\
\hline URBANISMO & $03 / 08 / 2015$ & ATIVO & FAU-UNESP \\
\hline URBANISMO & $13 / 03 / 1973$ & - & FAU-Mack \\
\hline URBANISMO & $24 / 03 / 1986$ & $01 / 11 / 2004$ & FAU-UBC \\
\hline PROJETO & 1982 & 1995 & FAUS \\
\hline OBJETO & 1971 & - & FAU-USP \\
\hline OBJETO & $01 / 08 / 2014$ & ATIVO & FAU-FAAP \\
\hline TEORIA E HISTÓRIA & $01 / 05 / 1992$ & ATIVO & FFCL-UNISANTOS \\
\hline- & - & - & - \\
\hline PROJETO & - & - & FAU-USP \\
\hline OBJETO & 1979 & - & FAU-USP \\
\hline OBJETO & 01/08/1996 & 19/12/2012 & FAU-UBC \\
\hline PROJETO & 01/08/1979 & $07 / 12 / 2010$ & FAUS \\
\hline TECNOLOGIA & $13 / 04 / 1970$ & $17 / 12 / 1971$ & FAU-MACK \\
\hline PROJETO & $17 / 08 / 1973$ & $12 / 08 / 2006$ & FAU-MACK \\
\hline TEORIA E HISTÓRIA & 01/04/1970 & 28/02/1971 & FAU-USP \\
\hline TECNOLOGIA & 2013 & ATIVO & ENG - UNISANTA \\
\hline TECNOLOGIA & 14/04/1970 & 29/02/1972 & FAU-USP \\
\hline TEORIA E HISTÓRIA & - & - & FFLCH-USP \\
\hline URBANISMO & 01/04/1995 & $04 / 12 / 2008$ & FAUS \\
\hline TEORIA E HISTÓRIA & 07/04/1973 & - & - \\
\hline TECNOLOGIA & $10 / 02 / 2014$ & $16 / 12 / 2015$ & FAUS \\
\hline TEORIA E HISTÓRIA & - & - & FFLCH-USP \\
\hline PROJETO & $01 / 12 / 1975$ & $22 / 12 / 2003$ & FAU-MACK \\
\hline TEORIA E HISTÓRIA & $21 / 04 / 1989$ & $17 / 05 / 2000$ & FAU-USP \\
\hline URBANISMO & MAR. 1986 & DEZ. 1986 & FAU-MACK \\
\hline TECNOLOGIA & 01/09/1991 & $22 / 05 / 1998$ & - \\
\hline TECNOLOGIA & $14 / 04 / 1972$ & 20/06/1998 & - \\
\hline TECNOLOGIA & $04 / 04 / 1994$ & ATIVO & FFCL-UNISANTOS \\
\hline TECNOLOGIA & 01/04/1970 & 28/02/1971 & FAU-USP \\
\hline TEORIA E HISTÓRIA & $01 / 08 / 1970$ & 28/02/1971 & FAU-USP \\
\hline TECNOLOGIA & - & 1988 & - \\
\hline TECNOLOGIA & 01/08/1974 & $22 / 12 / 2009$ & ENG-MACK \\
\hline PLÁSTICA & 1986 & 1994 & FAU-USP \\
\hline URBANISMO & 1986 & 1990 & FAU-USP \\
\hline TEORIA E HISTÓRIA & - & - & FAU-MACK \\
\hline TECNOLOGIA & - & - & FFCL-UNISANTOS \\
\hline TEORIA E HISTÓRIA & 1979 & - & FAU-USP \\
\hline URBANISMO & - & - & FFCL-SM \\
\hline TECNOLOGIA & $14 / 08 / 1972$ & $07 / 02 / 2008$ & FAU-MACK \\
\hline PROJETO & $15 / 04 / 1970$ & 1991 & FAU-MACK \\
\hline TEORIA E HISTÓRIA & $17 / 09 / 1985$ & $23 / 07 / 2013$ & PUC-SP \\
\hline TEORIA E HISTÓRIA & 04/04/1972 & $28 / 03 / 1973$ & USP/FAFI \\
\hline URBANISMO & $01 / 06 / 1976$ & 1988 & FAU-USP \\
\hline OBJETO & $30 / 08 / 1972$ & - & - \\
\hline PROJETO & 1978 & - & FAU-MACK \\
\hline PROJETO & $21 / 06 / 1972$ & 1986 & FAU-USP \\
\hline OBJETO & $01 / 03 / 2012$ & $23 / 06 / 2016$ & FAU-UBC \\
\hline TEORIA E HISTÓRIA & - & - & FAU-UFPE \\
\hline PROJETO & 01/05/1991 & $30 / 06 / 2006$ & FAU-USP \\
\hline
\end{tabular}




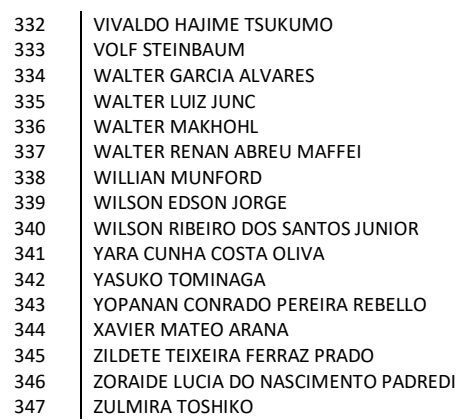

\begin{tabular}{c|c} 
PLÁSTICA & $01 / 11 / 1971$ \\
TEORIA E HISTÓRIA & $04 / 04 / 1972$ \\
TECNOLOGIA & $01 / 04 / 1983$ \\
TECNOLOGIA & - \\
PROJETO & $02 / 04 / 1975$ \\
PROJETO & $01 / 06 / 1976$ \\
URBANISMO & $04 / 04 / 1972$ \\
URBANISMO & $28 / 08 / 1971$ \\
TEORIA E HISTÓRIA & AGO. 1979 \\
URBANISMO & $10 / 08 / 1983$ \\
URBANISMO & 1977 \\
TECNOLOGIA & $17 / 03 / 1973$ \\
TEORIA E HISTÓRIA & $15 / 03 / 1973$ \\
TECNOLOGIA & $05 / 03 / 1990$ \\
TECNOLOGIA & 1986 \\
- & -
\end{tabular}

\begin{tabular}{c|c}
1986 & - \\
$18 / 03 / 2009$ & FFCL-USP \\
$19 / 12 / 2005$ & UNICAMP \\
- & - \\
1988 & FAU-UNB \\
DEZ. 1994 & FAU-MACK \\
- & - \\
$29 / 02 / 1972$ & FAU-USP \\
DEZ. 1986 & FAU-USP \\
$10 / 03 / 2000$ & - \\
1988 & FAU-USP \\
1993 & ENG - MACK \\
- & - \\
$28 / 03 / 2011$ & ENG - UNISANTA \\
- & FFCL - OC \\
- & -
\end{tabular}

\section{Roteiro das entrevistas com os professores das FAUS}

As entrevistas com os professores da FAUS constituíram um dos instrumentos metodológicos utilizados para verificação do problema principal dessa pesquisa. Esses depoimentos foram gravados em áudio, transcritos na íntegra para a forma de texto e, posteriormente, convertidos da linguagem verbal para a linguagem literária na forma de resenhas, com pleno compromisso de interpretação fiel ao pensamento do entrevistado. ${ }^{1}$

Vale destacar os depoimentos dos dois professores fundadores da FAUS, essenciais para a reconstituição dos mecanismos ideológicos, políticos e pedagógicos que permeavam o universo profissional e acadêmico da arquitetura nos anos de 1970. De um lado, o depoimento do professor Julio Katinsky que traz à luz um pouco mais da visão e postura do grupo de docentes vinculados à ideologia de Vilanova Artigas. Por outro lado, a entrevista do professor Orpheu Zamboni oferece um importante panorama sobre a curta, porém radical atuação do grupo do professor Sérgio Ferro na FAUS. Estas duas entrevistas somadas aos depoimentos dos professores Edgar Dente, Edison Eloy, Jon Maitrejean e Sérgio Novita fornecem valiosos subsídios para uma importante reflexão no campo do ensino de arquitetura e sua abrangência social e seus reflexos na cidade de Santos e região.

\begin{tabular}{l|c|c|c|c}
\hline PROFESSOR ENTREVISTADO & DATA & HORA & LOCAL & TRANSCRIÇÃO \\
\hline JÚLIO ROBERTO KATINSKY & $23 / 05 / 2016$ & $11 \mathrm{~h}$ & FAU-MARANHÃO & C. COSTA \\
ORPHEU ZAMBONI & $06 / 06 / 2016$ & $17 \mathrm{~h}$ & ESCRITÓRIO DO ENTREVISTADO & C. COSTA \\
JON MAITREJEAN & $01 / 07 / 2016$ & $15 \mathrm{~h}$ & RESIDÊNCIA DO ENTREVISTADO & J. M. MACEDO FILHO \\
EDISON ELOY & $13 / 07 / 2016$ & $18 \mathrm{~h}$ & SEDE DO CAU-SANTOS & J. M. MACEDO FILHO \\
SÉRGIO NOVITA FORTIS & $22 / 09 / 2016$ & $14 \mathrm{~h}$ & CAFÉ EM SANTOS & J. M. MACEDO FILHO \\
EDGAR DENTE & $08 / 03 / 2017$ & $16 \mathrm{~h}$ & ESCRITÓRIO DO ENTREVISTADO & J. M. MACEDO FILHO \\
& & & \\
\hline
\end{tabular}

Sobre ensino e abrangência social foram elaboradas as seguintes questões:

1. Como um dos professores fundadores da Faus, em sua opinião, essa escola foi capaz de alterar o perfil cultural da cidade de Santos?

\section{A cidade pode moldar o perfil da escola? E o edifício?}

Sobre ideologia e política foram elaboradas questões, a partir da leitura de documentos que demonstram processos de crise a partir de visões antagônicas de dois grupos oriundos da FAU, o grupo de Vilanova Artigas e o grupo de Sérgio Ferro:

3. No momento da fundação da escola no final de 1969, por seus docentes serem em sua maioria da FAU, existiu alguma ideia de continuidade ideológica e política, então praticada na FAU, ou a FAU Santos foi vista como um campo expandido a ser experimentado?

4. O fórum de 1968 da FAU se refletiu neste processo? Artigas e a vertente do desenho? Ferro e a vertente da luta armada?

5. Qual foi o papel dos alunos de Santos nesse processo?

\footnotetext{
${ }^{1}$ A experiência pessoal do autor como pesquisador no NAPPLAC - Núcleo de Apoio à Pesquisa Produção e Linguagem do Ambiente Construído, coordenado pelo professor Miguel Pereira, foi fundamental para o estabelecimento de critérios metodológicos para o preparo, seleção, coleta, tratamento e finalização das resenhas dos depoimentos dos professores da FAUS. A pesquisa do NAPPLAC resulto na seguinte publicação: PEREIRA, Miguel Alves (org). Sobre arquitetura brasileira e ensino na virada do século. Vol. I. e Vol. II. São Paulo: FAUUSP, 2008
} 
Arquitetos da FAUS

Além da pesquisa bibliográfica e documental, foi desenvolvida uma enquete composta por onze questões, sendo algumas do tipo objetivo (múltipla escolha) e outras do tipo dissertativo, cujo objetivo, foi mapear alguns egressos da FAUS, Apesar de configurar uma sondagem com pouco rigor metodológico, pois além de não possuir segmentação por grupos, a média das opiniões reflete somente o parecer daqueles que responderam às questões, no âmbito desta pesquisa, cumpriu seu objetivo. Segundo as professoras Dra. Any Bernstein e Dra. Riva Roitman, as enquetes diferenciam-se de pesquisas tanto pela metodologia utilizada quanto pelos objetivos, embora ambos exijam planejamento cuidadoso e seleção de instrumentos adequados para que se torne possível gerar resultados analisáveis e conclusivos. Uma enquete consiste do levantamento de opiniões e/ou percepções representativas de um grupo sobre um assunto de interesse geral que envolve um número restrito de entrevistados, podendo extrapolar para um grupo maior, tem a finalidade de elucidar uma questão para colocá-la dentro de um contexto de interesse geral. ${ }^{2}$

De maneira resumida, podemos esquematizar o quadro das questões como segue abaixo:

- Questões número 1, 2 e 3 - sobre identificação

- Questões número 4, 5, 6 e 7 - sobre atuação profissional

- Questões número 8 e 9 - sobre especialização acadêmica

- Questões número 10 e 11 - sobre atuação acadêmica

O questionário foi apresentado da seguinte forma:

1. Nome completo

2. Ano de formatura

3. Cidade de origem quando se matriculou na Faus (campo para preencher qual cidade)

4. Atua na área de arquitetura e urbanismo? [ ] sim [ ] não

5. Área de atuação como arquiteto

- Esfera pública

- Iniciativa privada

6. Ênfase de atuação

- $\quad$ Projeto de edificações

- Projeto de urbanismo

- Projeto de interiores

- Projeto de paisagismo

- Projeto gráfico

- $\quad$ Projeto do objeto e mobiliário

7. Cidade em que trabalha ou trabalhou (campo para preencher qual cidade)

8. Formação acadêmica

- Graduação

- Extensão

- Especialização latu sensu

- $\quad$ Stricto sensu: Mestrado

- Stricto sensu: Doutorado

- $\quad$ Stricto sensu: Pós-Doutorado

- $\quad$ Stricto sensu: Livre Docência

9. Instituição (ões) de ensino da pós-graduação (campo para preencher qual Instituição(ões)

10. Leciona ou lecionou

- Não

- $\quad$ Nível técnico

- Nível superior: Graduação

- Nível superior: Pós-graduação

11. Instituição (ões) de ensino que leciona ou lecionou (campo para preencher qual Instituição(ões)

${ }^{2}$ BERNSTEIN, Any; ROITMAN, Riva. O que você precisa saber para realizar uma enquete. In Revista Educação Pública, Edição no 07. Mar. 2016. 


\section{Livros para lavratura dos termos de colação de grau da FAUS}

Composto por dois livros, o registro dos arquitetos formados na FAUS teve início em 04 de maio de 1976 e, desde então, tem sido feito manualmente pelos secretários ao longo dos anos. Esse fato trouxe alguma dificuldade na leitura de alguns nomes, em alguns casos foi necessário pesquisar em portais de busca na internet, obtendo assim os nomes corretos.

O universo dos arquitetos da FAUS está organizado por ano e por turmas, o regime inicial da escola era semestral e vespertino com abertura de vestibulares duas vezes por ano, a partir de 1996, o vestibular passou a ser anual, mas a organização se manteve semestral. A partir dos anos 2000 a universidade abriu a primeira turma no período noturno, preocupada pela crescente perda de novos alunos que, por trabalharem, não podiam estudar à tarde. $O$ período vespertino foi mantido para os alunos já matriculados, mas não foram abertas novas turmas. Estrategicamente, com o objetivo de não perder espaço, a universidade abriu uma turma no período matutino, estes três regimes funcionaram juntos até que a última turma vespertina se formasse e, a partir de então, a FAUS oferece seus cursos nos horários da manhã e noite.

Portanto, a lista a seguir está organizada por ano e por turmas, a partir da 51a turma surge a divisão entre vespertino e noturno, no entanto, em 2007 essa divisão desaparece e as turmas são classificadas somente por ano. Ao final de cada turma é possível observar a quantidade total de alunos [T], e sua organização por gênero, homens [H] e mulheres [M]. Além disso, os nomes dos arquitetos que responderam o questionário estão destacados.

1974 1a tURMA Ajax Epaminondas de Almeida, Antonio Carlos Oesi Penteado, Ary Penna da Camara, Augusto Muniz Campos, Avelino Ruivo Junior, Claudio Kanji, Daysi Figueira, Denise Junko Higa, Eliani Alves de Carvalho, Eneida Regina Belluzo Godoy Heck, Eudes de Mello Campos Junior, Francisco Humberto de Viana, Henri Chalabi, Inocêncio Carvajal Jimenez, Jefferson de Andrade e Silva Filho, Luciana Mangotti Silvie, Lucino Alves Filho, Luiz Carlos Batalha, Luiz Gonzaga Montans Ackel, Maria da Graça Arnus Koelle, Maria Teresa Ramasini Furiuti, Maria Tereza Silva, Newton Issao Okida, Paschoal Grande Neto, Renato Satriano, Roberto Joaquim de Oliveira, Rodion Cracél Junior, Ronaldo Parisi, Silvio Alfredo Havas, Vera Regina Ramos e Castilho Badke. T. 30|H.21|M.9. 1975 2a TURMA Adriana Eboli, Alfredo Teixeira, Ana Rosa Sherer, Anita Mabia de Araújo Siqueira, Bolivar Montenegro Junior, Carmela Levy, Carolina Maria Pozzi de Castro, Cornelia Chatarina Schliemann, Cristina Dias e Santos, Décio Roberto Ambrozio, Deise Meire Fulini Modica, Egle Neuberger Cota, Eliete Barbosa de Luna Freire, Elias Nahas Neto, Fernando Augusto Barros Betarello, Francisco Baffa Netto, Francisco José Fernandes Mareiano, Germano Gareia Agnelli, Gilberto Motomu Yoshimoto, Hilda Fumiko Kussano, Ivaldo Isao Ueno, Jayme Gabriel Filho, José Antonio Bergamin, José Arduin Filho, José Carlos Ludovici, José Claudio Paneque, José Gabriel da Silva, José Gatti Junior, Laudelino de Carvalho Neto, Lenimar Gonçalves Rios, Lucio Leal, Luiz Henrique da Silva Villaça, Luiz Nelson Colombo Barbosa, Marcelo Raia Falei, Marciel Peinado, Marco Polo Maraucci, Margarida Ferreira dos Santos, Margarida Mincherian, Maria Cristina Rosa Viera, Maria Estela de Almeida Neves, Maria Francisca Moraes de Oliveira, Maria Ignez Maricondi, Mariangela Erschfeld Alves de Brito, Mario Leidinger, Marta Rosolino, Milton Esteves Junior, Neide Marcigaglia da Cunha, Neira Pereira, Newton Domingues Corradi, Paulo Cesar Parri, Pedro Augusto Pompeo Motta, Regina Antonieta Lopes, Renato Carrieri Junior, Rui Waetge, Sidney Rossi, Weliton Ricoy Tôrres T. 56|H.32|M.24. 1976 3a TURMA Ana Cristina Guedes Pereira, Antonio Claudio Brito Offa, Aristides Pinheiro Neto, Carlos Eugênio Salemme, Catarina Tami Tarasaka, Edelcio Fagnani Sanches, Eduardo Sabatini, Fernando Antonio Pires, Heloisa Hunold Martins Neto, Hugo Antonio Rodrigues Bras, John Peter Allenby, José Afonso Bottura Portucarrero, José Guilherme Simon Battisti, José Antônio Ridenti, José Geraldo Branco Costa, José Roberto Arduin, José Luiz Magri Mendonça Uchôa, José Roberto Martinho de Castro, Lezio Cardoso, Liomar Valentini, Luiz Alberto Monteiro Arcuri, Luiz Carlos Gomes, Luiz Maurilio Garcia Freire, Luiz D’Alkimin Alves Ferreira, Luiz Antonio Fontes Novoa, Marco Otávio Baruffaldi, Marcia Botelho Rizzo, Maria Angélica Tamada Fernandes, Maria Isabel Guedes Pinto Teixeira, Maria Rita Bordini, Mauro Nunes Mazetto, Mauro Eiji Morita, Nelson Zacarias Aristakessian, Ney Aguiar de Assis, Roberto Spinelli, Renato Silveira da Motta, Ruth Gabriele Rodrigues, Ruy Lessa de Oliveira, Sandra Maria Ramos, Selma dos Santos Sevá, Sonia Mesquite, Suzana Maria Garcia, Sylvio Caramaschi, Sylvio de Souza Nogueira, Suely Galhardo

Peinado, Vlasta Caric. T. 46|H.31|M.15. 1977 4a TURMA Adelino Lobo, Agostinho de Souza Hernandes, Alcides Sauerio Blois Junior, Ana Lucia Ribeiro Monteiro, Ana Maria Izzo, Ana Maria Maia Rodrigues, Annie-Claude Christine Bouchek, Antonio di Francesco, Antonio Marcos Amorim da Silva, Armando Sinkovitz, Célia Gerra, Claudia de Stefani, Corinto Luis Riberio, Cornélia Catharina Selliemann, Djalma Fontes de Souza, Dirceu Marçal, Elaine da Rocha Silva, Eliana Pozzi da Cunha, Etulain Américo Cartolano Junior, Gerson Ferrari, Gilberto di Capodarso Cará, Irene Maria Nogueira Lopes, Italo Constanzo Luiz Otta, José Carlos Alles, José Eber de Góis, Leopoldo Galembeck Butkiewicz, Luiz Antonio Ocsi Penteado, Luiz Antonio Senna Patúcio, Luiz Eduardo Bruno de Carvalho, Manoel Paiva Félix, Manoela Dias Pires de Almeida, Márcia Helena Goldsmid Galvão, Marcos Szafir, Maria Angela da Graça Pelosi Ambrózio, Maria da Conceição Pouzo Ferreira, Maria José Carneiro Muniz, Maria Lucia Bernardes Vasques Lopes, Maria Rosangela de Oliveira, Maria Tereza de Matos Myre Dores, Mario Dias de Aguiar Neto, Mario Lourenço de Azevedo, Mariluci da Silva Ruivo, Marjorie Nicolas Paz Cardoso, Malta Inês Moral Miller, Newmar Meirelles, Paulo Roberto Cortês, Ricardo Pirondi Gonçalves, Ricardo Tadeu Mascaro e Silva, Ruth Maria Bonilha Macedo, Rogério Cicero Pietropaolo, Sandra Maria Lazxuri, Santiago Gonzalez Arias, Sergio Barros Barletta, Sérgio de Oliveira, Suzerlei Domingues de Carvalho, Sylvia Mara Rodrigues Teixeira, Teresa de Fátima Grassano Borges, Tibor Geza Hary, Vera Helena Pinha da Rocha e Silva, Verônica Carolina Nagy, Walderez Clept, Walter Claudino Herculano, Wanderley Vasconcellos Amadio. T. 63|H.34|M.29. 1978 5a TURMA Ademir de Oliveira Neves, Adhemar Carlos Pala, Ana Maria Gonzalez Garcia, Angelo Garcia Filho, Antonio Cesar de Oliveira Brito, Antonio Henrique de Pace, Carlos Sérgio Britto de Castro, Carmela Lombardo, Claudia Sylvia Filgueiras Leal, Claudio Paes Rodrigues, Elizabeth Dealis Bernardo, Elza Nazaré laureano, Eurindo Pereira Braga Alvarez Perez, Eva Blanco Perez, Flora Iglesias Calvino, Helena Ladeira Werneck, Hoover Rodrigues Frade, João Carlos Marques Athanes, José Augusto Santana, José Oswaldo de Oliveira Valente, Júlio Alberto Rodrigues Marques, Lidia Ventura Regis, Ligia Maria Martins, Luis Antonio Rosa, Marcia Martins Silva, Marco Antonio Damim da Silva, Maria Aparecida Guerra Ruivo, Maria Celia lervolino, Maria José Salvadori Console, Maria Regina Godinho de Andrade, Mario José Buzolin Persona, Marly Alvarez Cimino, Mauro Maciel Junior, Miriân Kuehni Castro, Nelson Aparecido da Costa, Olavo Thadeu Fermoseli Câmara, Paulo Eduardo Roland de Silveira, Raymundo Corrêa da Silva, Reinaldo Amiky, Silvana Leme, Silvia Helena Duarte Vaz, Sonia Irani Chinzarian, Tania Correia Lima Macêdo, Telma Valença Sant'Anna, Vania Marçal Nunes Garcia, Valeria Ribeiro Reis, Vera Lucia Dias Gonçalvez, Wilson Takeshi Matsuora, Wilson William Bunduki, Zilda Maria Alves Matheus. T. 47|H.20|M.27. 1979 Denise

Maria Fusichini de Alcântara, Marlene Aparecida Ferraz Casado. T. 02|H.00|M.02. 1980 6a tURMA Afonso Jorge Assumpção, Ana Elena Lampieri Pinto Laranjeira, Ana Maria de Mello Ferreira, Ary Roberto Guimarães Gutierres, Aydar Tozzi Campos Filippe, Bechara Aziz Ibrahim, Carlos Alberto Martins, Carlos Rodriguez Gomez, Carmen Lydia Nogueira Rocha e Silva, Claudio Corrente, Denis Wagner Resmini, Dulce Maria Vianna de Andrade, Edméa Fioretti Mateu, Edna Estevam Menzio, Eduardo Parente, Elizabeth Scanho Marques de Queiroz, Fernando Medeiros Gaspar, Flavio Luiz Marcondes Bueno de Moraes, Flávio Siquieroli Cavaton, Francisco Armando Salles, Heidy de Moura, Homero Cavalhieri, Jaques Mendel Richter, João Fernando Pires Meyer, Joaquim de Britto Costa Neto, José Henrique Leme, José Olympio de Castro Neto, Kalil Antonio Alcantara Ferran, Lélio Marcus Munhoz Kolhy, Luiz Alberto Batista, Luiz Alberto Silveira, Luiz Augusto Ferraz do Amaral, Luiz Carlos Dempsey, Marcia Picarelli Meyer, Marco Antonio Baquedano Pontes, Marco Antonio Lança, Maria Adelina Kannebley Bitencourt, Maria Amélia Devitte Ferreira de Azevedo, Maria Aparecida Monteiro, Maria Cristina Esteves, Maria Dalva Orlando, Maria Del Carmen Villamarin Gomez, Maria Lucia de Paiva Ferreira Vaz, Maria Luiza Carromeu, Maria Marta Roda Domingues da Silva, Maria Salete de Lucia, Mary Suplicy Cornway, Monica de Almeida, Nancy de Araújo Teixeira, Nelson Tapxure, Olivia Saraiva Valdívia, Oswaldo Luiz Taroni Filho, Paulo Roberto Basso, Roberto Garkisch, Reinaldo Cursino Negrini, Ricardo Leite Filho, Rosilene Maria de Toledo Marciano, Silmara da Silva Nunes Penteado, Sonia Maria Luz de Alencar, Sylvia Greco de Assis, Sylvia Maria Mendes de Moraes, Telma Ligia Lazarini, Valter Eduardo Foschini Pinto, Vera Pereira Leite, Walter Catarino Antunes, 
Wladimir das Neves, Ylidia Bolzan Mansur, Maria Fernanda Martins Pires de Almeida, Oswaldo Polizio Junior. T. 69|H.38|M.31. 1980 7a TURMA Airton Carrilho Trevisan, Ana Lucia Borges Gomes, Ana Maria Marçou, Carlos Alberto Monteiro Fernandes, Daniela Buscaroli, Darnei Candido, Eunice Bergamaschi de Cara, Edith Gomes Pinto, Eliana Lourenço Tucci, Fátima de Oliveira Ramos, Fernando de Avilla Zerbini, Gisela Carvalho Fonseca, Hamilton Luiz da Costa Junior, Hugo Santos Silva Neto, João Carlos Baptista Campos, João Carlos Ribeiro, José Carlos Lopes Rodrigues, José Roberto Pires de Almeida, Kátia Regina Calleizzi de Almeida, leda Maria Pinto de Oliveira, Luiz Antonio de Paula Nunes, Luiz Carlos Ribeiro Marques, Maria Augusta Buiton, Maria Bernadette Nascimento Cury, Maria Cecília Carbonari, Maria Cristina Amado Coelho, Maria Fernanda Kaizer Barreiros, Maria Matilde Ribeiro dos Santos, Maria Rita Silveira de Paula, Marcia Fortes de Souza, Marilene Lourdes de Oliveira, Marília Paiva, Mario Aloísio Grossi, Mario Luiz Silvério, Marcia Regina Rocha, Odete Souza Padeiro, Ondina Maria Lourenço, Ornella Regina Flandoli, Oswaldo Schuch, Paulo Cesar Brida, Pedro Antonio Gonçalves Leiva, Roberto Campos Rolim, Roberto Corrêa Saviello, Roselene Wuilleumier, Simone Larrubia, Tânia Martinho, Themis Dias de Fernandez, Thereza Cristina Arruda de Paula Leite, Vitor Iglezias Cid, Wilson Roberto Campos Motta, Zuleica Yoshiko Morimoto. T. 51|H.21|M.30. 1981 8a TURMA Adalberto Ferreira da Silva, Adalgisa Maria Silva de Oliveira, Adriano Ranzani, Aldo Pereira de Carvalho, Ana Paula Pinto Silveira, Andrea Maria Passareli, Bernadette Sandoval Lamardo, Carlos Augusto Botelho Mariani, Cassio Guerra Oliveira Leite, Claudete Aparecida Julio, Celia Regina Martins, Daniel Passos Proença, Denise Macchi, Dimas Valfrido de Almeida, Elaine Magda de Marchi, Eliana Maronna, Eneida Xavier Engelbretti, Evana Clecia Lisboa Sutelo, Fatima Alves do Nascimento Roda, Fausto Mendes Fogaça Junior, Gerson Palazzo Ribeiro, Gisele Mandarino, Heitor de Paula Garcez Filho, Hilda Aparecida Avilez, Hosmany Rosa Vieira, Jaime Henrique Caldas Pereira, Joana Maria Pereira Roge, João Fernando Rolim Coutinho, João Fonseca Teixeira, Jorge Cody, Jorge Mattar Filho, Juvenal João de Oliveira Diniz, Kensin Higa, Leila Aparecia Abe, Lisete Sierra Lopes, Lucia Balula, Luciano Ricardo Azevedo Roda, Lucimar Pergolizzi Moraes de Oliveira, Luiz de Oliveira Martins Alves Junior, Luiz Umberto Pereira de Araújo, Marcia Terezinha Pavan, Marcia Ramos de Oliveira, Marcio Geraldo da Silva, Marco Antonio de Oliveira Vallada, Marcos Arruda Bertani, Marcos Gaban, Magda de Fatima Buzzo, Mirian Filgueiras Baldotto, Nancy Carbone, Odila Cristina Bernardo de Guimarães, Oscar Alves Capella Filho, Regina Fleury de Aguiar Pupo, Regina Maria dos Santos Lourenço, Ricardo Valery Sanzy, Robson Papaleo, Rosana Hasan, Rose Ane Scatt, Sandra Simões Jorge, Selma Eliana Pinho de Paiva, Sérgio Marin de Oliveira, Shedd Pegáz, Sônia Miranda Fortes, Tarcísio José Maia de Souza, Valdemar Mozena Filho, Walter Nogueira Prado, Wilson Carlos de Fiori. T. 66|H.34|M.32. 1982 9a TURMA Adalberto Montiani Ferreira, Alexandre Fücher, Ana Maria Matias, Angela Yuriko Motisuki, Antonio Fernando Fadel Cerezini, Aparecida de Oliveira Braga, Carlos Augusto Setfani, Carlos Eduardo Hallite, Carmen Silvia Valente Leite, Carlos Sergio Pereira Mazzetti, Dalton Pires Rodrigues, Denis Rodrigues de Carvalho, Dina Betty Roth Melaragno, Edilce Campelo Rodrigues, Elias Carlos Daccache, Elza Maria Saviello Define, Fernanda Coelho e Mello Pimentel, Fernando Chiavassa, Gilmar Barros, Henrique Noé de Almeida, Jane Barbosa Machado, Joyce Maria Thon de Araújo Duarte, José Antonio Reinés, José Luiz Pires Rodrigues, José Marcio da Costa Couto, Laura Hiroko Seguchi, Lísias Donádio Mourão, Lucia de Castro Veras Macchi, Luiz Alberto Xavier Mangueira, Magali de Oliveira Pinto, Márcia Amazonas Duarte de Avelar Fioresi, Marco Antonio Gonçalves do Carmo, Maria Cristina Blanco, Maria Fernanda Britto Neves, Maria Isabel Justo Nadaletto, Maria José Gomes Ribeiro, Maria José Santos Duarte, Maria Teresa Brandão Marques de Oliveira, Maria Teresa Franchi, Mariclé Ortega Xavier de Araújo, Marilene Nascimento Gomes, Miguel Fernando Maximiliano Maria Baron Von Behr, Mirian Dondon Salum, Paulo Carlos Lacreta, Paulo Rodrigues Pinotti, Rosana Giovannetti Moliterno, Rosana Murinelly Gomes Spinola, Rosane Ferreira, Sergio Luiz Farina,

Sheila Goloborotko, Sidnei Paulo Diana, Silvia Correia Gomes, Teresa Cristina Angrisani Garcia. T. 53|H.23|M.30. 1982 10a TURMA Adelino Gonçalves de Oliveira Neto, Alexandre Carneiro Leão, Ana Maria Bernardi, Antonio Calil Daher, Antonio Pedro Gonçalves Leiva, Benny Goldvasser, Carlos Alberto Rodrigues da Silva, Carlos Alberto Vida Gala, Cleisa Bernardes Godoy, Cristiane Vaz Domingues, Denise Carvalho, Eliege Ribeiro, Eduardo Alves de Oliveira, Elaine Sant'Anna Martins Brabo, Eufêmia Ramirez Llopis, Fabio Maracci Formoso, Fabio Silveira Bernils, Gerson Wandenkolk da Cunha, Henrique Ivo Meschini, Ida Cardoso, Iná Uehara, João Tugio Matsuda, José Antonio de Andrade Dias da Silva, José Haroldo Pierry Filho, José Roberto Baraú na Filho, Kelli Arruda, Lucy Rumi Katsuragawa, Luiz Roberto Peel Furtado de Oliveira, Luiz Vieira de Carvalho Neto, Luz Divina Vieitez Garcia, Marcia Cristina Amaral Serra, Maria Elisa de Melo, Maria Inês Rocha, Marcos Antonio de Barros, Marizélia Coregliano, Marta Maria Cardoso, Mauro Scazufca, Milton Carlos de Souza Nogueira, Myrian de Carvalho e Melo, Paulo Sergio Silva, Pedro Alvarenga Neto, Ronaldo Ramos da Silva, Rosely Maria Bordieri de Barros, Rubens Pereira Monteiro, Sandra Maria Ferraz Tedesco, Sérgio Fernando Luiz, Sonia Maria Freire Pimenta, Sonia Regina Campagner, Soraia Tavares de Almeida, Suzana Pereira de Souza, Vania Esbizaro Rodrigues, Vania Tapias Canteras, Vicânia Maria Lourenço dos Santos, Zuleika Maia. T. 53|H.26|M.27. 1983 11a TURMA Antonio Carlos Rossi, Ary Aps Junior, Bartira Mendes de Campos, Carlos Alberto Vida Gala, Claudia Faria Godinho Viana, Clayton Gonzalez Gomes Carolino, Danilo Nicodemos de Jesus, Debora Maria Casarim Arcieri, Dejair Santos Soutos, Delcides Regatieri, Denise Pereira Gil, Dirceu Dias de Lima, Edison Jorge de Moraes, Eduardo Lauand Sobrinho, Eliana Mercês Blaschi, Estevam Souto Neto, Fernando Brandão Tena, Fernando Maricondi, Geraldo Souto Serrão, Hannelare Ferdinanda Mrkvicka, Hélio Yamamoto Serizawa, Heloísa Ribeiro de Aguiar, Hilton Mishima Kubata, Iris Geiger da Silva, Ivan de Freitas, Joel Aparecido Pereira, José Alberto Gomes, Keila Micadei de Camargo, Ligia Maria dos Santos Carvalho, Lucia Helena da Silva, Lucila Mara Sbrana, Luiz Ferrari de Ulhôa Cintra, Manoel Lacerda Pinto Neto, Marcelo Antonio Nogueira Prado, Marcelo Fukuda Pereira, Marcia Portella Perrone, Marcos Machado Capella, Marcia Angélica Domingues Villar, Maria Angélica Monteiro Costa, Maria Cecília Guerra Passarelli, Maria Claudia Affonso dos Santos, Maria Cristina Strini Piedade, Maria Lucia Castelo Branco Zanetta, Maria Lucinda Cavanha, Marli dias de Oliveira, Mario Sérgio Longo, Mariana Rosina Chirico Ardita, Marisa Alvarez de Azevedo, Marisa Gerais de Camargo Rangel, Monica Lorenzan Mollica, Nelson Reis Fumagalli, Paulo Agostinho Simões Vieira Gameiro, Paulo de Moraes, Regina Vitória Soares Garcia Fernandes, Reinaldo dos Santos, Renato Bragetta Camargo, Ricardo Andrade Thomaz da Cruz, Ruy Eduardo Debs Franco, Sandra Maria Oliveira dos Santos, Sandra Paioletti Moura, Sergio Dantas Miranda, Sergio Gazal, Sergio Weissmann, Silvana Hervelha Quintas, Susanne Bartlewski, Thomas José Michaelis, Ubirajara Teixeira Moretti, Vicente Antonio Filgueiras Parmigiani, Yedda Cristina Moreira, Yoneko Arakaki. T. 70|H.38|M.32. 1983 12a TURMA Alda Emilia Machado Tondelli, Aloísio Candido de Paula, Ana Lucia da Rocha Mendonça, Ana Rita Vergara Gomes, Carlos Alberto Franco Zmyslowski, Carlos Eduardo da Nova Machado, Carmem Monzu Sanchez, Carmem Silvia Froelich Cambaúva, Celeste Rodrigues da Silveira, Dulceny Cerqueira Leite, Eduardo Vallejo Parada, Elaine Silveira, Fabio Luiz dos Santos Pereira, Helena Gonçalves Francisco, João Cesar de Lucas, José Claudio de Souza, José Luiz Gomes de Assis, José Renato Pinheiro Sérgio, Lourdes Valente de Almeida e Silva, Lucia Pires Castanho Valente, Luiz Carlos Moscatelli, Manoel Rodrigues Gonzalez, Marcelo de Oliveira Morozetti, Marcio Augusto Ciaffrei, Maria Beatriz Coury, Maria Beatriz Machado Leão, Maria Cleide Therezinha Méssi, Maria Cristina Chirico Carregosa, Maria Luiza Rodrigues Homem de Bittencourt, Maria Stella Dias Penha, Maria Teresa Stefan, Marília Gléria Sircili, Milton Martins de Lara Junior, Newma Bittencourt Pereira, Paulo Celso Marcondes de Salles, Paulo Cesar Martins da Silva, Paulo Silva Leite Flores, Rosana do Nascimento Vicente, Rosemary Alonso, Sidmar Pinheiro de Souza, Sidney Roberto Hyppolito, Silvia Regina Dantas, Siomara Gonzalez Gomes, Sônia Ludovino Cherbino, Suely Aparecida Vicente, Sylvia de

Moraes Blanco, Taina Mara Caetano Abdo, Wagner Antonio de Oliveira Ramos, William Rodrigues dos Santos. T. 49|H.21|M.28. 1984 13a TURMA Albano Soares Martins Junior, Amira Fares Kabbara, Ana Lucia Cerqueira Pimenta, Angelito Garcia Gonzalez, Arnaldo Guimarães Gonçalves, Caetano Valentim Martire Filho, Carlos Eduardo de Carvalho e Silva Finochio, Cesar Luiz Corrêa da Costa, Ciro Rodrigues de Araújo, Claudia Maria de Albuquerque, Edmir Mantellatto, Edna Naomi Unten, Eliana Monteiro Cruz, Fabio Monteiro da Rocha Franco, Fernando Antonio da Silva Suckow, Fernando Roberto dos Santos Henrique, Geraldo José Simplício dos Santos, Hélio Abramides, Henrique Patriani Frasson, Jacques Moraes da Costa, Janete Tavares, José Augusto Sciotto, José Costa de Oliveira Filho, Laerte Sakai, Leopoldo José Pellico, Lilian Alvarez Lima, Lucrécia Nitti, Luiz Fernando da Silva, Luísa Amélia da Costa Alves Feijó, Luísa Helena da Costa Alves Feijó, Luiz Carlos Tenório Acosta, Marcelo Moreira Helou, Marcia de Almeida Motta, Marcia Negreiros Feitosa, Marcos Fregnani Martins, Marcos Frugolli, Maria Aparecida Vango, Maria Cecilia Martins de Souza, Maria de Fátima Quadros, Maria Luisa Marques Alegria Ferreira, Maria Tereza Regina Leme de Barros, Marly Kaminskas Fernandes, Marta Eunice Costa Pereira, Mauro Antonio di Francesco, Mauro Guedes de Andrade, Maysa Gomes Ramos, Monica Almeida Peña, Monica Lorenzon Mollica, Oscar Ribeiro Filho, Paulo Roberto Elias Ferreira, Paulo de Tarso Montanaro, Rosa Emília Marques Pavan, Rosana Attini Palmieri, Rosangela Varlesi, Rosimara Penha Sarti, Ruy Manoel Alves dos Santos, Samuel Ribeiro Junior, Sérgio Caetano Bardelli, Sérgio Suster, Silvia

Gonçalves Arruda, Sylvio Zanelato Filho, Sonia Fumi Yamagata, Sueli Martins Plum. T. 63|H.34|M.29. 1984 14a TURMA Alvamar Cardoso de Oliveira, Amauri Augusta, Caetano Greco Junior, Carlos Antonio Santos Pardal, Carlos Lutuvino, Claudio Gimenez Filho, Claudio Novaes, Cristina Costa, Débora Paro, Deise Dias de Oliveira, Edeli Verotti Martins Coutinho, Edson Luís da Costa Sampaio, Edward William Kronig Wander, Eliane Christina Marani, Eliane de Souza Queiróz, Francisco Sanches, Gisele Rita Cardoso, Gladis Anauate, Hamilton Affonso Grimaldi, Heidy Diana de Almeida Notter, Herlene Sá de Almeida, Hilda Teruko Anzai, João Almeida Cardoso Filho, João José Dalcim, José Leonam Mendonça, José Roberto de Souza, Katia Soares de Almeida, Luis Eduardo Rivas, Luiz Francisco de Paiva Martins, Luiz Henrique Rodrigues Zanetta, Marcia de Britto Calzado, Marcia Marcondes Sodré, Maria Amélia Pereira Alves, Maria Cecilia Torres, Maria Inês de Toledo Cesar, Maria Lucia Castelo Branco, Maria Lucia Coffani dos Santos, Maria Luiza de Barros Gonçalves Nassif, Maria do Rosário Faria Villela, Maria 
Rita Nogueira Baldi, Marisa Murta, Milton Yukio Ozawa, Monica Aparecida Mendes Cardoso, Neréa Massini, Renata Martins de Carvalho, Romano Venturin Junior, Roseli Fonseca Saviello, Sandy Claudio Bispo Junior, Silvana Soares Martins, Simone Paschoali Schumacher, Solange Venturelli Helú, Thais Heleno Lopes. T. 52|H.21|M.31. 1985 15a TURMA Adhemar Dizioli Fernandes, Aguinaldo Monteiro da Costa Fonseca, Alba Maria Guerra Kannebley, Albino José Soares da Cunha, Álvaro da Silva, Amaury Mendonça Junior, Ana Alice Pancini, Ana Elisa Gabos, Ana Luiza Borja Ribeiro Lima, Anderson José Ulian, André Luiz Destro Peres, Antonio Carlos Forioni, Antonio Claudio Rodrigues dos Santos, Antonio Ferreira Pires, Antonio Sergio Galego, Aristides Tadeu Paulino, Beatriz Martins Mendes Ferreira, Bechara Abdalla Pestana Neves, Beni Skitnevsky, Carlos Carmelo de Benedetto, Carlos de Andrade Ungaretti, Ciro Augusto Pereira, Claudio Augusto Tise da Cunha, Cristiane de Lima Souza Flórido, Cristina Ibrahim Ribas, Cristina Soares de Oliveira, Debora Paro, Denise Longhi Farina Marcondes Pereira, Edison Gloeden, Edna Margarida Marques de Almeida, Eduardo Tsutomu Asahara, Eliane Garcia, Elisabete Miranda Galleão, Eric Guimarães Crispin, Eugenio Lara, Feris Jorge Bou Anni, Fernando Faria de Castro Brandão, Fernando Gregório de Oliveira Pereira, Flavio Sano, Gisela Vasconcelos Monteiro, Guacymar Mazzarielo, Jaime Fernandes Mendes, José Antonio da Fonseca, José Antonio Varanese, José Eduardo de Carvalho Borges, José Israel de Oliveira Pinto, José Marques Carriço, Juarez José Bulhões da Silva, Júlio Guilherme Lacerda Pistori, Leonarda Elizabeth Chirico Ardito, Lindolfo Tomiyoshi Miura, Lucia Maria da Silva Lia, Lucienne de Almeida Cavaco, Marcelus Eduardo Teixeira Freschet, Marcia Cristina Medeiros de Freitas, Marcia Fugiko Kotaki, Marcia Otoni Avelin Marchi, Marcos Vitor dos Santos Pereira, Marcus Cortines Lasce, Marcus Vinicius Paioletti Martins Costa, Maria Cristina Amaral de Bulhões Marcial, Mario Emilio Luppi, Mauricio Ferreira Koyama, Milton Massayoshi Shimizu, Miriam Regina Canteras di Matteo, Nelson Tsutomu Ota, Nilton Roberto Antunes Faria, Orlando Silva Filho, Octavio de Siqueira Ferreira, Paulo Lara Paes de Barros, Paulo Sergio Gambini, Renata Henrique Prado Leite, Renata Teixeira Affonso, Renato Narkevitz, Ricardo Caseiro Duarte, Ricardo Muniz Faulin, Rita de Cassia Cavani, Rivaldo de Abreu Serrão Junior, Rubens da Silva Mano, Sidney Ferreira, Silvia Regina Tavares Silva, Umberto Sarris Mateus, Wagner Ortega. T. 83|H.57|M.26. 1985 16a TURMA Airton dos Santos, Aleumar Montich da Silva, Ana Maria dos Santos, Antonio Roberto Simões Ventriglia, Carlo Rangel Desinano, Carlos Alberto Corulla, Carlos Alberto Ferreira Fontes, Carlos Eduardo Devienne Ferraz, Debora Blanco Dias Figueiredo, Denise da Silva, Elenice Aparecida Taniolo, Eloá Irene Lima Cecchetti, Estevam Camilo Bueno da Costa, Fabio Camillo, Fábio Vital, Flavia Augusta Peres de Oliveira Bazaneli, Francisco Arnaldo da Silva Neto, Helder Clemente Ribeiro, Helio Hideyuki Gondo, Herbert Betman, Ilka Brigitte Rauert Celeghin, Jarbas Barbosa de Oliveira Junior, João José Ozores, Joira Maria Ferreira da Cruz, José Accacio de Barros Neto, José Maria Martins, Katja Lauber, Leomar Annunziata, Lucia Fernandes Cardoso de Pinho, Luciana Jorge Zion, Luiz Otávio Foster, Luiz Alberto Hamen, Luiz Paula Souza de Anhaia Mello, Luzdalma Parreira de Souza, Marcelo Dias do Couto, Maria Celeste Canário Lélles, Maria Celina Peres Fernandes, Maria Clara de Assis Rufino Gnecco, Maria Fernanda Pinheiro de Mello, Maria Olide Leal Botelho, Marina Pereira da Silva, Marina Sheetikoff, Marlu Conceição Fragoso, Mario Carvalho Lima Neto, Maristela Beraldi, Maruem de Castro Hatem, Mauricio Azenha Dias, Mauro Luiz Prata Garcia, Melba Peres Nadais, Miguel de Almeida Matos, Nanci Cardoso, Nivaldo Yoshihiro Nozoie, Olegário Vasconcelos Pereira Junior, Patricia Zuliani Marcondes, Paulo Adolfo Corte Real Garcia, Paulo Roberto Ramos Ankerkrone, Pedro Tolentino Marcondes Fiorano, Petronio Caldas Barão, Romeu Patriani Junior, Rosana Roberto, Rosana Zito da Silva Luciano, Selma Olson Granata, Suzete Ferreira da Costa, Telma Conceição Tangary Elias, Valdemir Caulada da Silva, Valéria Fernandes Francisco Miranda, Wilson da Silva Cruz. T. 66|H.34|M.32.

1986 17a TURMA Aguinaldo Secco Junior, Alberto José da Motta Neto, Ana Lucia Duarte Pereira da Cruz, André Vitor Lyra Martins, Barbara Regina Murano, Carlos Eduardo Arantes Cavalleri, Carlos Roberto Xavier Zundt, Cátia Elisabete Dias Ferreira dos Santos, Cesar Bargo Peres, Claudia dos Reis Franco, Claudia dos Santos Ferreira, Claudio Weizmann, Dimitri Papadopoulos Junior, Domingos José Casemiro Martins, Edneia Maria Fortunato de Souza, Elaine Soffredi, Elídio de Jesus Toito, Fernando Garcia Simon, Fernando José Arouca, Flávio Mendes Carrer, Gerson Crozariollo Filho, Gino Caldatto Barbosa, Gisele Garrido, Gisele Maria Murari, Guilherme de Souza Paula, Guilherme Silvestre Morales, Helena Quintana Minchin, Hélio Gardinalli, Irene Cardoso Magalhães, Jamil Curi Filho, Jaqueline Fernandes Alves, João Batista de Vasconcelos Junior, Jorge Luiz Valente, José Roberto de Souza Davatz, Leila Magali Zanardi, Lucia Maria de Mello, Luiz Afonso Monzillo, Marcia Augusta Alonso dos Santos, Marcia Regina de Moraes, Maria Angélica Campello Pasin, Maria Cecilia Pfeifer Inforzato, Maria Cristina Salvador de Carvalho, Maria Emília Pollo Sabio, Maria Estela Zanandrea Tiveron, Maria Luiza Breda de Figueiredo, Maria Monica Placer, Monica Ferreira da Costa, Monica Simões de Aguiar, Naicir Correa Rebelatto, Paulo Ricardo Gomes da Silva, Percival Cardoso, Rogério Bessa Gonçalves, Rogério Montes Bardelin, Rosa Maria Miraldo, Silvana Carneiro da Cunha Mauro, Sonia Antzuk, Sonia Mara Grispino Soffredi, Tania Regina Gaidarji, Vania Felfele,

Yarima Ranir Maro, William Norberto Aloise. T. 61|H.28|M.33. 1986 18ª TURMA Ana Claudia Carloni, Andrea Bergamaschi Nogueira, Angela Martins Vaz, Berenice Pereira, Carlos Alberto Alves de Freitas, Celia Regina Apene, Claudia Inês Nouer, Cristina Faro Soares, Debora Luise de Castro Silva, Delcimar Marques Teodózio, Denise Mendes Thomaz, Dino de Castro Pimentel, Elieser Pardo dos Anjos, Fernado Romboli, Heráclio Ferreira da Fonseca, Iriana Steiner Gomes de Moura, Isa Dello Strologo, José Alberto Torres, José Luiz Nascimento Barreiros, Julio Romero de La Iglesia, Leandro Buzatto Amaral, Leonel de Oliva, Liliane Fernandez Mayo, Lucia Helena Menezes Weingrill, Luis César Garrucho Varella, Luis Mariano Vila Iglesias, Marcia Regina de Carvalho Guidini, Marcos Assis Piffer, Maria Aparecida Barreira, Mauro Barros Fernandes, Miriam Aparecida Brizueña Cansian, Melci Barros Maia, Otavio da Rós Neto, Patricia Corsi, Paulo Eduardo Silva Langeani, Regis Jardim Cavariani , Roberto de Mattos Ribeiro Nogueira, Roberto Silverio Junior, Rosana Denaldi, Rosangela Candido Salgueiro, Rosangela Pereira de Araújo, Rose Cristina Mustafá, Rosely Rodrigues, Sandra Maria Souza Garcia, Sibila Raquel Silva Pesce, Silvana Santaella Gregolin, Sueli

Batista Martins, Tanya Diniz Borges Figueira de Mello,Teresinha de Jesus Gravato, Toshio Totake. T. 50|H.21|M.29. 1987 19a TURMA Aglair Garcia Quaresma, Alexandre Santi Casasco, Ana Claudia Salles Campbell, Ana Claudia Ventura, Carlos Eduardo Pereira de Marais, Cecília Helena Andrade de Almeida, Cesar Augusto Alonso Capasso, Claudia Lopes Jacoponi, Claudia Regina Medeiros Cardoso, Clementina Fernandes Rio, Cristina Ferraz Rodrigues, Cristina Langerfeld, Cicero Lermann Dutra, David Aly Neto, Debora Regina Stange Augusto, Eduardo Lopes Villas Boas, Eliana Kazue Fuji, Eliane Gouvea Lousada, Eni Zimbarg, Euzébio Fortran Junior, Everton Briques, Guilherme Penteado Mattos, Ilka Lilian Allen, José Garcia Mendez, Katia Ribeiro Seabra, Laurete Giaquinto Pissolati, Leda Maria Pinheiro Nardella, Lilian Patricia Alves Gambini, Lucy Mendes de Souza, Luiz Fernando dos Reis, Manoel dos Santos Neto, Maria José dos Santos, Margarida Maria Monzoni Prestes, Maria Silvia Alcover de Moura, Maria Valeria Affonso dos Santos, Maria Valquiria de Souza Barbosa, Maria Teresa Pereira Antonini, Marilu Lopes Santos, Marina Mendes de Campos, Marina Paiva de Mattos, Miriam Guarino Mendes, Monica Ramazzotto Calçada, Nelson Gonçalves de Lima Junior, Neusa Shimura, Nilo de Mello Chaves Junior, Paulo Roberto del Santo, Regina Moura Soares de Novaes, Ricardo Laurentino Vasconcelos, Ricardo Moreira Soares, Rita de Cassia Furlan, Rogerio Stumpf Möller Falcão, Roseane Aparecida Costa, Selma Perdigão Batbugian, Sergio Alexandre da Silva, Sonia Liberati, Susana Aparecida Torita, Susana da Silva Campos, Syllas Martins Junior, Tarcísio Galvão Rojas, Venâncio Ferraz de Conde,

Vinícius Nogueira Delhaye, Walter José Lavandeira Galindo Decker, Welton Silva dos Santos, Wilson Flavio dos Santos. T. 64|H.27|M.37. 1987 20ä TURMA Alberto Grimaldi, Ana Cândida Alves da Costa, Ayrton Silva Affonso, Carlos Alberto Cappatto, Carlos Roberto Cavalcanti Dutra de Aguiar Faria, Eduardo Soranz, Francisca Claudia Braga, Hamilton Barbosa Braga, Jaime Mosanés Ceriola, José Rafael Araújo Lima Amato, Juan Marcial Menacho Fria, Laís Dias, Margareth Matiko Uemura, Maria Emília Marques, Maria Teresa Rios Olivares, Marise Céspedes Tavolaro, Miriam Catalina Escobar Salguero, Najla Jorge Lucresia, Reginaldo Luiz Nunes Ronconi, Renata Milanesi, Reynal Ramos Rost, Ricardo Garboni, Ronaldo Wilson Baptista Filho, Sergio Alberti Cascino, Valeria Bastos

Valero, Wilson Spinardi Junior. T. 26|H.15|M.11. 1988 21a TURMA Airton dos Santos, Ana Claudia Brandão Sanches, Ana Lucia Collet de Toledo Teixeira, Ana Lucia Dias de Andrade, Ana Luiza Marcello Frangipani, Ana Virginia Paes Musa, Angeles de Jesus Blanco Lón, Antonio Dacosta Fernandes, Bianca di Luccia, Carlos Eduardo Albrecht Miño, Claudia dos Santos Góes, Cleomar Lousada Ribeiro, Dante Trevisani Junior, Denis Murilio Maricato Junior, Denise Fraga de Oliveira, Denise Helena Gonçalves, Dinah Bacchi Neves, Fernando Rodrigues Alves Pardal, Fernando Shirahama Inforzato, Glaucia Tinoco Santos, Haroldo José Kinder, Hernani Melquiades de Lima, Ivone Faddul Alves, Jacqueline Maria Torres Paro, João José Gonzales Lizano, José Luiz Ferreira Navarro, Lisnei Brejão, Lucia Pucca, Luis Carlos Pulici, Magali de Souza Rocha, Mara Silvia Carvalho, Marcia Helena Rusni, Marcia Yumi Miyazi, Marcelo Prado Leite Mattar, Marcos Antonio Feliciano, Marcos Yukio Sato, Margarete Vechiez, Maria de Fátima Lopes de Carvalho, Maria Fernanda Sala Minucci, Maria Renata Camargo Guimarães de Melo, Marisa Bergamasco, Marta Lopes de Souza, Marta Menzen Campos, Mirian Aparecida dos Santos, Neide de Almeida, Ney Caldatto Barbosa, Renato Caetano de Jesus, Ricardo Munhoz, Roberto Teixeira Campos, Rosana Baraldi de Figueiredo, Sandra Mara Monteiro Vidal, Sergio Augusto Vaccari, Silvia Faria, Sueli Martins, Teresa Cristina de Veiga e Souza, Vera Lucia Simões, Viviane Zanetti. T. 56|H.20|M.36. 1988 22a TURMA Ana Claudia Gonçalves de Siqueira Balbino de Moraes, Ana Lucia Agustini Scarlatti, Ana Lucia Graziano, Carmen Silvia Ruiz, Cassia Regina Amadeo Tamburrino, Catharina Christina Teixeira, Cristina Cecília Malzov, Edison Rodrigues de Araújo, Flavia Fernandez Leite Cesar, Gisela Pagani, Isabel Cristina Rodrigues Peres, Isabe Eugênia Cançado Alcolea, João Jaime de Carvalho Almeida Filho, José Antonio Lampreia Baião, José Aparecido Monteiro, Marco Antonio rocha Machado, Marco Aurélio Roberto Lora, Maria Aparecida Matheus, Maria Cecília da Silva Lopes, Maria Stella Evangelista dos Santos, Marli Carmen Mendes Rodrigues, Marly Shinzato, Neide Trindade Bento, Osmar João Soalheiro Junior, Raimundo José Pimenta Araújo Filho, Rosely Vaz Feijó, Sandra Regina Hitomi Adati, Sergio 
Alexandre da Silva, Silvana Lucia de Araújo Col, Tais Marrom, Walid de Castro Hatem. T. 31|H.10|M.21. 1989 23a TURMA Adriana Hjertquist Carneiro, Agnes angélica de Carvalho, Alda Maria Pereira de Araújo, Ana Paula Alcântara Romualdo, Ana Paula Monteiro, Andrea dos Santos Ursini, Andrea Telenta Grossi, Antonio Carlos Soares de Almeida, Carmen Silvia Romero Villacroce, Cezar Augusto Santana, Cléia Moura da Silva, Cristina Botarelli, Denise Terezinha da Silva Medeiros, Égle Cócca de Nóbrega Umbujeiro, Eliane Habib, Emmanuela Silva Nunes de Oliveira, Fabio de Giovani Segabinazzi, Fernando Augusto Varga, Fernando Gallotti Bonavides, Fernando Pinho Vallada, Inez dos Santos Gossi, José Olavo Jucá Araújo Neto, Laura Matilde Coelho Capasso, Lidia Mara Rodrigues de Souza, Lincoln Vaz Cid, Mara da Glória Gonzaga, Marcelo Reverendo Vidal Akaui, Marcia Arruda, Marcio Brasil, Marcos da Cruz Lopes, Maria Civita Mangiocca Girardi, Maria Isabel Garcia, Maria Julia de Arruda Arsky, Marisa Ribeiro Leal, Mozart de Araújo Junior, Nelson de Almeida Cardoso Junior, Paula de Barros, Paula Maria de Oliveira Costa, Paulo Sergio Pitta Virga, Richard Pieper, Rita de Cassia Kalume, Rogério de Lira Queiroz, Roberto de Medeiros Borges,

Ronney Van Opstal Martins da Costa, Simone de Amorin Ferrauche, Sueli Martins dos Santos. T. 46|H.18|M.28. 1989 24a TURMA Adriano de Brito Bertozzi, Ana Paula Marques, Cesar Augusto dos Santos Scudeller, Claudia Maria Quintana, Eduardo Maggi Novoa, Edmundo Castilho Junior, Elenice Orlanda Manreza, Eliane Marques da Silva, Fabio Cafaro Alexandre, Fabio Luiz Rienzo Varella, Fabio Vokurka, Guilherme Onofre Mazza Dourado, Jeferson Bünder, João Eduardo Rodrigues de Oliveira, José Eduardo Oliveira, Júlio Fernando de Souza Martins, Luiz Valdir Soares Coelho, Márcia Isabel Nascimento Teixeira, Marcelo do Amaral Gonçalves, Maria Alice Bittar, Maria Augusta Consiglio, Martha Torres, Monica Therezinha Bartié, Paulo Eduardo Branco, Perola Mota Zanotto, Renato Luiz Benedito, Roberto Rossi, Rosemeire Fernandes Nunes Ali, Silvia Regina Basso, Simone Maria Perlatti Martins, Suzete Petrasoli. T. 31|H.17|M.14. 1990 25a TURMA Antônio Cesar Ablas de Freitas, Auster Ruzante Filho, Carla Refinetti de Lauro, Celia Cristina Madeira de Souza, Claudia Maria Pereira, Fabio Bustani Carrijo, Georgia Linhares Martins, Lazaro Tribst Junior, Leonardo Sorbello Junior, Lilian Diniz Ferreira, Luigi Humberto Caffarello, Luiz Eduardo Mauro Terra, Marcelo da Silva Agosto, Marcos Ronaldo Prado Ranzani, Maria da Glória Rosa da Silva, Maria Dolores Zaya Amaro, Mariliza Fontes Pereira, Marilza Lopes Pancotti, Mohamed Antonio de Lima Ali, Nelson Santos Dias, Pierre França Corrêa, Raonda Mohamad Assaf, Ricardo Porto da Costa, Ricardo Zanoli, Silvio Curado Coelho, Soraya de Castro Hatem, Valeria Faria. T. 27|H.15|M.12. 1990 26a tURMA Angela Sofia Garcia Luca, Claudia da Costa Afonso, Claudia da Silva Angerami, Claudio Henrique Britto Fumes, Cleres Sesmilo Peron, Debora Aparecida Fusetti, Eliana Dalla Ono, Glaucia Regina dos Santos, Henrique Rangel Leal Quartin, Katia Marinho Hembik, Luciana Ventura Pereira, Luiz Fernando Felix de Paula, Marcelo Américo de Santana, Marcia Orlando, Mauricio Arradi, Mercedes Apaza Mayta, Patápio da Silva Souza, Roberta Soares dos Santos. T. 18|H.06|M.12. 1991 27a TURMA Alexandre Cesar de Oliveira Brito, Ana Cristina Peralta, Ana Paula Domenciano, André Luís Avelar Rua, Athea Aparecida Palladino, Christiane de Primo Franceschini, Eduardo Cisne Moreira, Eloisa Alves Serrão, Fabio Marques Swartele, Flavia Neves Dantas, Franco Antonio Brunelli Linares, Gilberto Espinoza Moreira, Gildo Alves de Barros, José Álvaro de Menezes Neto, Luciano Fernandes Martinho, Luiz Felipe Buchmann de Gerais Rangel, Mara Merlini Bagagiolo, Marcelo Bolzan Domingues, Maria Civita Mangiocca Girardi, Marcia Pinto de Camargo, Marilena Villa Nova Spaziani, Ney Vaz Pinto Lyra, Norma Cristina Cavalcanti Viana, Paula Renata Badan Martins, Reinaldo Fernando Godinho Junior, Renata Freijó Rodriguez, Ricardo Senegali Gomes, Silvia Helena Ribeiro Brandão e Carvalho, Simone Di Giocarmo, Sonia Maria Rosignoli Moura, Suely Cristina Pestana Ferreira, Sylvia Maris Boerner Ribeiro Porto, Synval Antonio Barreiros Bitencourt, Thais Helena Andrade Simões

Álvaro, Valeria Aparecida Abreu Branco, Vera Lucia Dantas, Xenia Aliucha Guimarães de Godoy. T. 37|H.15|M.22. 1991 28a TURMA Archille José Brichese, Álvaro Artur de Castro Silva, Antonio Valmor Correia, Elcio Ragazzini, Fernando Nacarato, Luiza Helena Scarpa Mehl, Marcelo de Oliveira Montoro, Marli Mendes de Araújo, Patrícia Barreira Lambert, Patrícia de Toledo Ribeiro, Paulo Lopes de Oliveira, Ricardo Ferraz, Rosana Carla Gonçalves, Solange de Sousa Barreiros, Zélia Mirtes Luz e Calil. T. 15|H.08|M.07. 1992 29a TURMA Alberto da Silva Ramos Arruda, Ana Paula de Figueiredo, André Luiz da Silva, Andréa Ribeiro Gomes Franco, Carla Cristina Derbedrassian Dias, Carlos Roberto Stelluto Jacob, Carlos Roque Barbosa de Jesus, Carolina Ponte Ferrari, Christine Vasquez Iglesias, Claudia Ferreira Merino, Creusa Salete Oliveira Marra, Denise Padilha Lotito, Dircelene Pedroso de Oliveira, Eduardo Hiroshi Mori, Elenir Nascimento de Souza, Eliana de Abreu Bellini, Franque de Santana Pereira da Silva, Gelson Carlos Damasceno, Gerson Belucci, Gláucia da Silva Soares Novaes, Grace Fleming de Oliveira, Jandara Jardim Barros, José Afonso Freitas Alves Feitosa, Juliana Fernandes Abad, Kleber Pereira Faria, Maria do Carmo Aléo, Maria Dolores Sanches Bastos, Maria Luiza dos Santos, Marta Moura Ribeiro, Miriam de Matos, Mônica Calçada Saad, Nelson Mattos da Silva Junior, Paulo César Mendes Monteiro, Renata Tagliari Franze, Ricardo Augusto Rosa Martins, Roberto Noronha de Rezende, Sérgio Ricardo Bonito, Viviane Comitre Gibertoni. T. 38|H.15|M.23. 1992 30a TURMA Adriana Dias Gavaldão, Alda Sueli Dias dos Santos, Ana Cristina Teixeira Dias, Andrea Campos Genovese, Carla Andrea Dias, Carlos Eduardo Ferrari, Carlos Federico Spago, Carlos Francisco Lopes Fernandes, Debora Consolini, Edison Fernandes, Edna Lucia Vendrame, Emerita Ara Cebollada, Gustavo Antonio Schliemann, Katia Lucas Rosa, Leticia Poço, Loredana Fantozzi Giorgetti, Marcelo Antonio Paulo Varella, Marcelo Claret Paiva dos Reis, Maria Cecília de Barros Saggese, Maria Luiza Zanatta, Maria Pilar Ara Cebollada, Maristela Susuki, Norival Bouças Junior, Renilda dos Santos, Ricardo Cuminale, Rogério Cruz Samenho, Roseli Duarte, Rosemeiri Leão Sividanes, Sergio Gonçalves Proença, Sylvio Carneiro de Farias, Toniamari Rodrigues Leme, Valmir Vieira. T. 32|H.13|M.19. 1993 31a tURMA Adriana Pastori, Adriane Angeli Pelosini, Alexandre Vitta Honigmann, Ana Claudia Andrade Costa, Ana Lucia Camargo Castro, Ana Lucia de Andrade Coelho, Carmen Lúcia Reis Peres, Claudia de Carvalho Alves, Claudinei Vital da Silva, Cláudio Andrés Valdivia Arriagada, Daniela Martin Gradella, Denise Della Paschoa, Edson Luiz Nardo, Elga Serodio Simionato, Fabio Coutinho, Fabio de Oliveira, Flavia Petrossi Rosa, Francisco de Assis Godoy Moreira Young, Heraldo Yogi Yshida, Inês Kazuko da Silva, Jorge Luís Lopes, José Domingos Gonçalves, Liliana Guimarães Gomes, Luciane Amante, Magno Rodrigues Junqueira, Marcia Cristina de Souza, Marcia Cristina Monteiro Manhani, Maria Cecília Mendes da Silva, Maria Conceição de Oliveira Kloppel, Maria Helena Silveira, Maria Inês Sousa Hahn, Mariella da Luz Quirino, Patrícia de Souza Hemari, Ricardo Andalaft, Rinaldo Tessuti de Lucca, Robson Carvallho de Oliveira, Rogério da Rocha e Silva Mandetta, Rosy Cristina Maia de Souza, Samuel Adesida Adesunloye, Silvana Luiz de Souza, Silvia Cristina Figueirôa Pereira, Simone Brajato, Tânia Adam, Valeide Vieira Elias Cruz, Valeria Bertolozzi, Wagner Lopes. T. 46|H.17|M.29. 1993 32a TURMA Andréa Assumpção Mendes, Andréa de Sá Sega, Antônio Manoel de Carvalho Filho, Betina Alves de Campos, Clayton Akira Naka Neto, Cristiane Mimesse Prado, Danilo Villin de Campos, Edmir Luchesi Marinho, Elaine Mauro, Erika Mendonça Britto Passos, Fabio Petracco, Fernanda de Macedo Haddad, Isabel Cristina Pires, Katia Minioli Bignardi, Liara Ferras Conte Aps, Liliane Fraga Moreira Belin, Marcelo Guizzo, Maria Imaculada de Souza Lara, Maria Rita Figueiredo Godoy, Maristela Alexandroni, Mauricio Ferrante Veloso, Mauro Sergio da Silva Martins, Nelson França Junior, Nilze Silva Faconti, Regina Helena Gomes Richieri, Renata Luiza Albiero, Ricardo Lima Oliveros, Ricardo Maluf Chaim, Vanessa Lombardi D’Abreu Macedo, Vera Lucia Theodorico Gomes. T. 30|H.11|M.19.

1994 33a tURMA Ana Maria Bigliazi, André de Freitas, André Luiz de Freitas Marzabal, Andréa Adamo, Antonio Carlos Gomes dos Santos, Carla Arigón Fellipi, Carmen Andrea Munhoz Perez, Christina Vasconcellos, Claudia Adelina Tamblay Arancibia, Claudia Mendes Pereira, Claudia Teixeira Nunes, Edgar Gouvêa Junior, Eduardo Moreira Dardaqui, Gilson Braga, Gisella Nogueira Rangel Pestana, Ivana de Moura Villaça, Katia Gomes Pinto Rodrigues, Lesko de Araújo, Lilian Maracini, Lilian Varela de Souza Villar, Marcelo de Lara Peixoto, Marcia Maria Gouvêa de Azevedo, Marcio Shoji Nishinaka, Marco Fúlvio Amado Ribeiro, Maria Carolina Nunes Conceição, Michele Masutani Munhoz, Mônica Rodrigues Rosendo, Paola Andrea Riquelme Lopez, Ricardo Pupo Ferreira, Rogério Nakakubo, Sandra Denise Landre, Sidney Piochi Bernardini, Valéria Cristina Jacomette, Valter Peres Filho, Vanessa Fernandes Vellani, Vania Neide de Araújo Magalhães. T. 36|H.14|M.22. 1994 34a TURMA Alessandra de Oliveira Henriques Paulo Bergamo Boteon, Alessandra Gonçalves Nunes Mantovani, Ana Vitória Cardoso, André Folganes Franco, Andrea Franco Coelho, Andrea Nogueira Lopez, Andréia Grassi Marcolin, Angélica Peres Lopes Reis, Célia Ribeiro de Freitas, Cynthia Maria Fiorini Santos, Fernando Alonso Garcia, Gleice Fiorante, José Francisco Alvarez Gonzalez, Luciana Trizzini Refundini, Luiz Augusto Maymone de Azevedo, Marcos Mari Barreto, Maria Ligia Dalla Torre, Maria Paula Dias Cunha, Maria Renata Machado Stellin, Meire Ane de Souza Silveira Corrêa, Meren Lilia de Jesus, Patrícia Ferreira Fourniol, Paula Piccinini de Azevedo, Paula Vanessa Pereira de Sousa, Raquel Nicolau de Lima Oliveira, Regina Helena Vieira Santos, Roberta Alvares Alípio, Roberto Carvalho de Abreu Prado, Roberto D'Allevo, Rogério Harmitt Machado, Silvia Abujamra, Silvio Cesar Ribeiro Gonçalves, Sionéia Hernandes Ferreira, Uliana Inês Maida. T. 34|H.09|M.25. 1995 35a TURMA Adriana Corrêa Pinto, Alessandra Galante Loureiro, Alexandra Dias Gavaldão, Aliandra Carla Neves, Ana Clara Gomes, Anna Beatriz Carvalho da Silva, Andrea Cardilli Ballo, Andrea Oliveira de Souza, Anelise Marinheiro Centeno, Angela de Mello e Silva Assumpção, Antônia Maria Barbosa Felix, Caio Esteves Ribas, Carlos Eduardo Azevedo Passos, Carlos Humberto Pegoraro, Cerise Goldman Batistic, Christiane de Mello Lopes, Ciro Luiz Henrique de Oliveira, Cristiana Pieroni Louzada, Cristina Aparecida Saijo, Daniela Silveira, Eliana Rucci, Elker Herrero dos Santos Pinto, Erika Adelaide Carrera, Evelyse de Oliveira Cravo, Fabio de Almeida Figueira, Fabio Luiz Armínio, Jaqueline Stankovits Mathias de Souza, Jaqueline Vanderci Francisco, Jennifer Abreu, José Ricardo Freire dos Santos, Katia Cristina de Souza, Katia Mitie Yamauti, Luciana 
Lourenço Ballio, Luciana Michael Ferreira de Mello, Luiz Claudio Weinfurter Lima, Marcelo Lima Peron, Marcia Cristina de Matos, Marcia Maria Saraiva Luzano, Marcia Ricardo Minardi Alves, Maria Teresa Augusto, Marisa Tedesco Bettoni, Monica de Fatima Miller, Nicole Duarte Pinheiro, Patrícia Aparecida Alba de Araújo, Patrícia de Campos Valadares, Paula Albino, Priscila Cavanha, Priscila Melhado, Renato de Mattos Ribeiro Nogueira, Rodolfo Nakakubo, Simone de

Souza Alexandre, Viviane Rosa Rodrigues, Zuleica Maria Castex Aly. T. 53|H.12|M.41. 1995 36a tURMA Adriana Apicella Penteado, Adriana de Souza, Alessandra Maura de Almeida Bortoto, Alessandra Schimidt Guolo, Andréa Maria Gomes, Benigno Pestana Puga, Carina González Sousa, Christiane Amorim Alexandre, Claudia Aparecida Lopes Blanco, Claudia Elaine de Oliveira Meda, Cybelle Croce Rocha, Edgar Pistelli Nogueira, Fabiano Cervera, Katia Regina Cardoso Carvalho Freire, Lucia Helena Armani, Luciana Dias, Luciana Jeronymo Ferreira, Luciane Beck, Marcelo Alexandrino, Marcelo José Cardoso da Silva, Marcelo Ribeiro Feliciano da Silva, Maria das Graças Neves de Jesus, Marilys Hassanet, Marise Harue Hirose Hashimoto, Mônica Fazion, Pamela Soledad Pena Hurtado, Paula Luciene Candeira, Regiane Fuoco, Reinaldo Morgante Ferreira, Renata Argenton, Roberta Christina Veras de Souza, Rodrigo Roman, Rosemeire Teixeira Frias, Vanessa Cristina Teixeira dos Reis, Vanessa Morgante de Alencar. T. 35|H.08|M.27. 1996 37a TURMA Adriana Rodrigues, Alessandra Tranjan Souzedo, Alexandra Salles Maria de Macedo Rego, Alexandre Espindola, Alexandre Straub, Audrey Marques, Carlos Alberto Ferro, Claudio José Cesarini, Daniela Ferramenta Silva, Daniele Maria Murari, Daniella Pellegrini Bertoncini, Denise Alvares Gerstenmayer, Elizabeth Centeno Ferraz, Erika Tiemy Kawakami, Etelvina Augusta Naclério Baptista, Fabio Luiz Cahn Ponciano, Frederico da Costa Marins, Gisele Aparecida Corrêa, Haroldo Borille, José Ignacio Cespedes Jimenes, Katia Dolabella Ferreira Luz, Lídia Maria Esperança Pousada, Luciana Rufino, Luiz Augusto Viva Nascimento, Maria Helena Pereira de Sá, Marcia Mandaji, Maria Fernanda Soares Valdez, Mayra Barba de Freitas, Pablo Andrés Contreras Pizarro, Pablo Artura Cespedes Jimenez, Pacita Lopez Franco, Patrícia Ferreira da Costa, Patrícia Napolitano Ribas, Paula Marcia Rodrigues Mendonça, Renata Francisco Valeiro, Ricardo dos Santos Ferreira, Sergio Boscoli, Suely Fernandes de Andrade, Tupy Rodrigues Cunha, Umberto Sergio Donato Fornos, Valeria de Araújo Faria, Vinicius de Almeida Martins. T. 42|H.16|M.26. 1996 38a TURMA Alfredo Pissinato Júnior, Angela Lacconi, Anna Margarethe Luber, Caio Marco de Stefano, Cibele Marçola, Cíntia Silva Teixeira, Dalto Cruz Stipanich Elaine Cristina Fanzolini, Eunice Frederick Papadopoulos, Flavia Onofre das Neves, Gustavo de Araújo Nunes, Hiu Hiun Wei, Jerônimo Amâncio da Silva, João Paulo de Freitas Neto, Liamara Terra Bento, Lucia Alves Martins, Luciana Reis Palermo, Lucy Mary Magalhães Vieira, Luiz Fernando Joaquim Perez, Marcelo Aparecido Ferreira de Araújo, Mario Roberto Pinto Júnior, Naomi Iraha, Patrícia Karla Martins, Paulo Roberto Negreiros Negrini, Paulo Eduardo Ferreira Gonzalez, Renata Dias dos Santos, Renata Faconti D’Angelo, Rita Veronezi, Rodrigo Alexandre de Barros Carvalho, Viviane Homem de Mello. T. 30|H.12|M.18.

1996 39a TURMA Adriana Freitas Rachid, Altemar Lima, Ana Carolina Martins Bertoldi, Ana Paula Haiek, Analuisa de Faria Antezana, Anderson dos Santos Tiezzi, Claudia Chrystina Kozemekin Kato, Décio Antonio de Castro Melo, Douglas Parra, Érika Ratzka Formiga, Fabiano Gomes Taleb, Fabíola Vidal Figueiredo, Luciana Cabral de Castro, Luciana Silva Mendes, Luciene Machado, Márcia Cristina Ribeiro Alves, Raquel Andrade Coelho, Regiane Monteiro Santos, Renata Brenneken Duarte, Renata Sioufi Fagundes dos Santos, Rodrigo Zaniolo Alvaro da Costa, Rogério de Oliveira Santos, Sandra Helena Soares Barreto, Silvia Alessandra Augusto Duarte, Sylmara Cremonini Jacob, Valéria Tournillon Costa, Walter Fernando Paixão de Assis D’Antonio. T. 27|H.08|M.19. 1997 40a TURMA Adriana Bueno Leite, César Boletta Lopes, César Henrique de Godoy Gomes, Clarisse de Fátima Ferreira, Cláudio Porsé Cleis, Denise Delpoio, Eliana Cristina Jeronimo Ferreira, Ivete Warigoda, Leticia Urbini Arenghi, Lucia Maria Fernandes Simões da Silva, Maria Eugenia Luvisotto, Maria Isabel de Souza Graffúnder, Orlando Marques da Silva Júnior, Patrícia Mara Juliani Mellilo, Roberta Gomes Péres, Rodrigo de Lima Maransaldi, Simoni Okamori, Valéria Lúcia Real Paglioni, Vanessa Santana de Farias. T. 19|H.05|M.14. 1998 41a tURMA Adriana Alves Ribeiro, Adriana Avanci, Adriana de Almeida Rodrigues, Adriana Dias Dieguez, Alcides Trauzola Filho, Ana Cristina Koromizato, Andréa Moreira dos Santos, Claudio dos Santos Silva, Daniela Ferreira Flores Oliveira Santos, Daniella Vian Matavelli, Douglas Carvalho, Eduardo de Albuquerque Nogueira, Elionai Maria dos Anjos, Emerson Aires Melro, Fabio Carvalho Brandão, Fábio Lourenzon do Espírito Santo, Fernanda Dias da Cruz, Fernanda Faria Meneghello, Fernanda Ravani Beneti, Guilherme Ribeiro de Carvalho, Haroldo Resende Rossi, Hélio Nishikuma, Jaime Gomes Calixto dos Santos Junior, Kátia Maria Pereira Sousa, Luiz Alexandre Dias da Silva, Marcelo Sikorski Nunes, Maria Carolina Montenegro Castelo, Marta Elizabeth Yañez Guzmán, Maurício Nascimento Ferreira, Patrícia Santelli Mestieri, Paula Regina de Souza Ferreira Pinto, Regiane Rodrigues Vieira, Regis de Oliveira Campos, Renata de Brito Santos, Ricardo de Santana Torres, Riccardo Frederico Testi, Roberta Gonçalves Christo, Viviane de Oliveira Vaz, Wandemberg Naves Oliveira. T. 39|H.18|M.21. 1998 42a TURMA Adriano Gonçalves Nogueira, Ana Paula Ferreira Quinto, Christiane Nascimento Costa Ramos, Cristiane Faria Fernandes, Daniela Gonçalves Marques, Daniela Rodrigues Quintas, Daniela Vitoriano Olivan, Denise Costa Junqueira, Elena Olaszek, Fernanda Rocha D’Elia, Gisele Lobo Vianna, Heloisa Helena de Melo Ferreira, Henrieth Flávia Aires Veiga, Isabel de Jesus Araújo Lemes, Luciana Gouvêa de Figueiredo Guedes, Luciane de Araujo Keskissian, Lumi Okimasu, Maria Paula Delfino Coelho, Marcela Rezek Barbosa, Marcelo dos Santos Rodrigues, Melissa Pinheiro Topp de Souza, Orlando Gonçalves Faya Junior, Patrícia Miranda Rodrigues, Simone Muralis, Tatiana Yamaúti, Vanessa Rampazo Trentin, Vânia Coelho Parente dos Santos. T. 27|H.03|M.24. 1999 43a TURMA Alexandre de Aguiar Siqueira, Aline Cristina Palmieri, Aline Stern Pinto, Ana Cristina de Paula Mazzetti Armesto, Ana Lucia Kimura, Andrea Ferreira Quaglia, Beatriz Godinho de Andrade, Carla Camargo Gardenal, Carla Regina Videira Marques, Carolina Christhina Velloso Mendes, Claudia Herrero, Cláudia Maria Pereira, Cláudia Roberta Magalhães Vieira, Christiane Avelino, Denis Fabrisio de Oliveira Selymes, Elena Pajon Gonzalez, Erika Zancaner Arvati, Fabiane Holter Lavandeira, Flavia Alves Gonçalves Lins, Jefferson Nery Alvarenga, Jorge Eduardo Gonçalves e Gonçalves, Leila Elias Azar, Licia Corchs Carneiro, Ligia Terumi Ono, Lilian D’Ambrósio, Lourdes Ferauche Seguin, Luciana Pinheiro de Melo, Marcelo Fazzio Barsotti, Marcia Alves Martins, Marcos Cesar Silva Rodrigues, Maria Angélica Giani França Amaral, Maria Rita Torres Antonascio, Michele Lingh, Odilon dos Santos Pereira Junior, Paula Adriana Fernandes Ferraz, Paulo Alexandre Ramires José, Paulo Eduardo Magalhães Bonifácio, Pedro Luiz Zille Porto de Oliveira, Priscila Molina Sansone, Queiti Aparecida Magalhães, Ricardo Henrique Velasco Rodrigues, Ricardo Netto Nogueira, Richard Pereira Meneses, Roceli Luizi Rapini, Rubia Mara Gois Couto, Sheyla Regiane de Melo, Silmar Silva de Paulo, Silvia Barrote Palmieri, Simone Espinar de Camargo, Viviane Padredi Matias,

William dos Santos Guedes. T. 51|H.15|M.36. 1999 44a TURMA Angélica Aparecida Bechelli, Aristides Damásio Barbosa Junior, Bertoldo Rosa Carneiro, Claudia Cecilia Cid Pedraza, Cristina Baralle Fangiulli, Daniela de Araujo, Egle de Almeida Salgarella, Eduardo Lisbôa Rosa, Elcio dos Santos Moreira, Erika Hembik Borges, Fabiana Feiga Maniov Levin, Fabiana Laurindo Peixoto, Fabricio Fernandes Correia, Fabricio Renato Dominguez Duarte, Julieta Romão Murad, Luiz Fernando Corrêa da Silva, Manuel Carlos Rodrigues Carvalho, Marcelo André Gollegã Soares, Marcelus Condé, Marcus Vinícius Cardoso, Maria Aurélia Dias Gagliardi, Milene Furigo, Patrícia Veloso D'Andréa, Paulo Eduardo Carvalho Miranda, Renata dos Santos Reis, Renata Salgado, Roberta Lozada Costa, Rubens Gonzalez Castanho Junior, Sérgio Carlos de Aquino Gandra Filho, Sueli Zonari Martines, Vanessa Carvalho de Jesus. T. 31|H.14|M.17. 2000 45a TURMA Adriana Malas Zican, Adriel Fernandes Passos Neto, Ailton Fernando Babugia, Alexsandro Ferreira, Alfred Dutzmann, Ana Carolina Carminato Duarte dos Santos, Ana Lucia Santos Rabêlo, André Luiz de Sousa Cappra, André Mattos Lobão, Andréa Pereira, Andressa Gomes de Almeida, Ângelo Marcos Ramires Alba, Beatriz de Aguiar Barbosa, Bianka Juliana Alexandre, Cibele Marques Rosa D'Agrella, Cintia Viana Rodrigues, Cirlei Aparecida Pereira dos Santos, Cláudia Alba Kucko, Cristiane Corrêa, Daniel de Oliveira Pereira, Daniela Marani, Daniela Rodrigues Cervantes, Danielle Luz do Amaral Bastos Peroba, Eloy Bernardo Nascimento Nogueira, Evanir Silva de Lima, Fernanda Figueiredo Bittencourt, Gabriele Betke Prado, Gisele Janaina Chagas Gonçalves, Giuliano Scatena, Glauce Helena Fernandes Erminda, Hélio Souza de Oliveira, Ivan Braga Andriani, Ivanise Graziela de Souza, José Alexandre de Oliveira Esteves, José Maria de Macedo Filho, Liliane Louzada Lamela, Luciana Neres, Magda Carlos Francisco, Marcelo David de Aquino Viana, Marcelo Reis de Barros Fernandes, Marcos Paulo Barbosa, Maria Eugênia Carvalho de Oliveira, Maria Fernanda Gonzalez Ferreira, Melissa Perrota Souza Bento, Nataly de Jesus Santos, Natasha Mendes Gabriel, Patrícia Gomes de Souza, Priscila Mutter, Ricardo Augusto de Oliveira, Rodrigo Salvador da Costa Diogo, Rogério Gama de Abreu Macedo, Simone Hideko Tsuchiya, Tiago Angelini Morgero, Viviane Alves Rego. T. 54|H.21|M.33. 2000 46a TURMAAdriana Domingos, Daniel Silva Teixeira, Eralda Lucrécia Mendes, Fabiana Silva De Oliveira, Fernando Jamar De Queiroz Rodighieri, Karla Janaina De Melo Almeida Cunha, Leila Pavanelli Truffe De Oliveira, Lindiane Da Silva, Maria Isabel De Almeida Camacho De Oliveira, Ricardo Ara Cebollada, Roberta Camargo Borges, Rodrigo Rubido Alonso, Simone Pedalini Marzionna, Wanessa Américo Gomes. t. 14|h.04|m.10. 2001 47a TURMA Ana Cristina de Aquino Cesário, Ana Lúcia Passarelli Souza, Ana Paula Chiarella Young, André Albuquerque Santana, André Luiz Lima Lopes, Bianca Pellegrini de Oliveira, Camila Padim Mourão, Carla Neves Weishaupt, Cassiano Eduardo Macêdo, Christian da Silva Gonzaga, Christiane Costa Ferreira, Clarissa Duarte de Castro Souza, Claudete Souza de Oliveira, Claudia Aparecida Ferrer Martines Spádafora, Cristiane Pierrotei, Cristiane Simões Gameiro Guedes, Cristina Imay, Cynthia Regina de Araújo Evangelista dos Santos, Daniele Lopes Fernandes, Daniella Franco de Nicola, Duarte Gil Gouveia da Silva Junior, Elaine Cristina de Freitas, Fabiana Costa Silva, Fabiana Fonseca Gomes, Flávia Lins de Oliveira Nogueira, Flávia Saldon, Flávia Vendramini de Souza, Gisele Midori Kuwabara, Jimena Rachel Sanchez Acosta, João Roberto Ribeiro Camarneiro, Juliana 
Gonçalves Fefim, Leandro Solovjovas Santos, Luiz Eduardo Gonçalves, Luiz Eugênio de Aragão Ciampi, Marcel Budau Ferreira, Marcela Millás Fracaro, Marcus Paulo Giacomíni Soares, Marcus Vinícius Corrêa, Marduc Antipas Gonçalves Rodrigues, Maria Cecília Yamamoto Peres, Maria Cristina Cândido Fonseca, Mariana Guauche Motta, Patrícia Françoso Corrêa, Pedro Henrique de Carvalho Rodrigues, Renata Imafuku Balsamão, Renato Fernando Mascarenhas Pegoretti, Roberta Lopes Moledo, Rodrigo Franco Pinto, Roger Improta Guerra Martins, Silvana Alves Spina de Cristo, Talitha Mathias Cereto, Vanessa França Baísi. T.

52|H.17|M.35. 2002 48a TURMA Alessandra Benite Toledo, Alessandro Cardoso Lopes, Aline Thelma Pereira de Lima Lopes, Ana Paula Veras de Paiva, Bianca Rocha Rodriguez, Cristiane de Oliveira Casella, Cristiano Teixeira Sidoti, Daniel Nascimento Bredariol, Daniela Ferauche, Daniela Pereira de Araújo, Daniela Santana do Nascimento, Denise Higuchi, Erika Sahêki, Fabiano Garrote Torresan, Fabio Correa Prado, Fabio Ercolin, Fabrício Menezes de Paula, Felipe Lagnado Cremonese, Flávia Blanco Paneque, Francine Moreira Arantes, Gabriela Kechichian Alonso, Giuliana Fiszbeyn, José Eduardo Fernandes Magalhães, Juliana Dias Boehm, Luciana Muniz Valpreda, Luis Fernandes Moreira, Marcelo Ribeirão de Freitas, Marcio Mendes de Freitas, Maria Gabriela de Lucca, Neander Shimizu, Noele Megumi de Sandre, Paula Rodrigues de Andrade, Peter Masuo Kawamura, Raphael Antunes Vaz, Renata Feitoza Nascimento, Roberto de Toledo Moraes Amiralian, Roberto Paulino Junior, Rodrigo Asenjo Blanco, Ronald Couto Santos, Sheila Cristina Coelho dos Santos, Sheyla Andrade Vieira, Sônia Fernandes Borges dos Santos, Suzi Mika Mitsunaga, Thiago Antonio Silva, Thiago Costa de Lima, Valmor Bento Zanoni Junior, Vanessa Rodrigues Aguiar, Victor Roquete Maia. T. 48|H.23|M.25. 2003 49a TURMA Adão Antonio Ribeiro Junior, Adriana de Marchi Gonçalves, Alessandra Nadalin Pereira Simonian dos Santos, Aline Azevedo Nobre Rasteiro, Ana Claudia Leite Marinho, Andrea Jacob Laurindo, Angélica Iraha Cardoso, Antonio Carlos dos Santos Junior, Armando Marconi Netto, Bruna Zager, Carina Simões Pereira Nogueira, Carolina Nobiling, Cintia Pereira de Santana, Cristiano de Campos Gil, Daniel de Moraes Cardozo, Daniel Massagiro de Carvalho Yamaoka, Daniela Igarashi, Daniela Monteiro Costas, Danielle Alves da Rocha Garcia Morad, Danilo Teixeira da Silva, Debora Cristina Bellatini, Elaine Camargo Martins, Elisângela de Souza Silva, Ellen Novo Fernandes, Erika Baptista Kuhn, Erika Rodrigues Uchoa, Erika Diaz Avilés, Everton Cesar dos Santos Silva, Fernanda Machado Bezerra, Fernanda Tomassis Morros, Flavia Xavier Gomes, Gabriella Postiglione Cavichioli, Gilson Bastos Simões, Guilherme Bentes Vianna, Jorge Luis Cavalcante dos Santos, Juliana Alba Ozores, Juliana Ayub Pelizzari, Juliana Pestana de Azevedo, Leonardo Silva Menezes, Leonora Gomes Pinheiro, Lincoln Santana de Oliveira, Marcelo Gouveia Trevisan, Maria Lúcia Mafus, Merin Fujiuana Arrastia, Nicole Sanchez, Nizomar Gonçalves Junior, Pablo Luiz Marchi Palma e Silva, Paula Khoter, Paula Venônica Sanseverino de Carvalho, Paulo Marcel Factori Camargo, Priscilla Vasconcelos Cintra, Roberta Nunes Gonçalves, Rodrigo Soares de Novaes, Rosane Borowski Gonçalves, Sandra Ávila Mendanha. T. 55|H.18|M.37. 2004 50a TURMA Alexandre Livramento Remédio, Ana Lucia Veras de Paiva, Ana Maria Fernandes Cooke, Andreia Vieira dos Santos, Bruna Raccioppi, Caroline Cristina Moreira da Silva, Cristiano Vieira da Silva, Danielle Barbosa Silva de Carvalho, Douglas Elias da Costa, Eduardo Andre Gerardi, Erika Domingues da Costa, Fernanda Siqueira Soares, Gustavo Abreu Raimundez Alvarez, Horácio Pinheiro Filho, Juliana Ferreira dos Santos, Kathia Regina Barros Bico, Keity Chrystin Seheik Ciccacio, Lucas Gratão Faconti, Luciana Bicalho Mendes Vinagre, Luciana Reis Fernandes, Maria Castelo Branco, Marcelo da Silva Tavares, Marcos Barga Ribeiro, Mariana Barreto, Mariana de Oliveira Rodrigues, Mario Eduardo Shiraichi, Marlene de Lima Saguir, Nei Anderson Salem Pereira da Silva, Patrícia Gonçalves dos Santos, Patrícia Regina Gomes de Lima, Priscila Dias Malvaccini, Priscila Franceze Martins, Priscila Daibert Moncorvo de Castro, Rafael Raimona Barbosa, Renata Caichjian, Renato Amaral Siqueira, Ricardo Lima Moreira, Ricardo Pereira Ramos, Rodrigo Campos Correa, Rodrigo Hojas Gimenis Mariano, Rosane Aparecida Ribeiro Occhiuto, Sergio Camargo da Maria Aveiro, Simone Yuri Iwai, Tais Araújo Thomaz Bechara, Tathiana Pereira de Souza Azevedo, Tatiana Benicio Martim, Thais Polydoro Ribeiro, Thalita Bulbarelli Miguel, Thiago Cepeda Marta, Verena Huke Bellintani, Vitor Gemio Ferreira, Yoanna Simonsen Rapakulias, Vanessa de Souza Gianetti. T. 53|H.20|M.33. 2005 51a TURMA - VESPERTINO Ana Dias Baptista Navarrete, Adriana Fenerich Correa Romão, Alessandra Carpentieri de Oliva, Ana Lucia Cerri Pires Tamagnini, Andréa Moretto Galvão, Beatriz Von Kruger Toledo, Élvio Borba de Lima, Felipe Torelli Alexandre, Gláucia de Deus Marques, José Paulo Mauro Pacifico Bordin, Juliana Gonçalves Di Gregório, Letícia Nunes Campos, Márcia Rosa Canizares Tank, Noele Lança Martins Ferreira, Patrícia Fernandes Senra, Patrícia Miyuki Oshiro, Pedro Costa Barroso, Priscila Nunes de Vivo, Rodrigo de Miranda Silva, Sylvia Helena Moreira Bueno, Thaís Cristina Negrão. NOTURNO Adriana Maria Fraga Lopes, Alexandre Ferraz de Oliveira, Ana Letícia Gonçalves Batista, Caio Sanches Delphino, Camila Ribeiro Bugada, Camila Terumi Takahashi, Carlos Adel de Freitas, Carlos Augusto Roque, Christian Aguiar Barbosa, Claudia Jardim Meireles de Mello Chaves, Daniel de Lima Duarte, Daniel Torres Vieira, Danielle Sales Galvão Santos, Danilo Rotondo Silva, Diego Costa Rozo Guimarães, Elias de Souza, Fabiana do Rego Vasconcelos, Fabrício Silva Novaes, Gisela Lopes Péres, Gisele Martins Fernandes Gonçalves Pires, Glaucus Renzo Farinello, Leandro Santos Alejandro, Lygia Trielli Paiva da Silva, Marcelo de Jesus Diegues, Marcos Ramos, Maurício Nunes Veiga, Paola Bottino, Raphael Moreira Varjão, Ricardo Maia

Hernandez. T. 50|H.21|M.29. 2006 52a TURMA - VESPERTINO Adriana de Fátima Andrade, Dayana Pizzini Soares, Diego Larocca e Silva, Edson Reinaldo Neno Manzon, Elaine Reis e Silva, Elza Neide Castro Correia, Fernando Miguel Farinella, Fernando Morilhas, Henry Carlos Jacob, Iris Ferraz Margarido, Isabela Silva Faconti, Jandaia Melques Fernandes, Letícia Paiva Lopes, Lidiane da Silva Marote, Ligia Ferreira de Souza, Lívia Mello Scapuccin, Mariane Mazzariello Damante, Michelle Benite Toledo, Priscila Guedes do Prado, Tatiane de Abreu Imakawa, Thaís Frota e Silva. NOTURNO Adriana da Cruz Zanotti, Amanda Ferreira Cardoso de Souza, Amanda Garcia Chiou, Ana Carla Cubas de Almeida, Bruno Silva Lima, Camila Rospe, Caren Martins Barroso, Carina Rodrigues Vazquez, Caroline de Almeida Martins Duarte, Claudia Alessandro Santiago, Cristianne de Freitas Cordeiro, Cristina Capra, Daniel Wurglitsch, Diego Procópio Armesto, Dulciene Martins de Souza, Fabrício Pereira Cruz, Felipe Rodrigues Afonso, Fernando Lamberti Pinto da Silva, Jean Lima Masumoto, Juliana Rosa Cabral, Marcela de Carvalho Oliveira, Marcella Tavares Farinazzo de Mello, Marcus Vinícius Afonso Marques, Marcus Vinícius Gonçalves Junior, Mario Ferreira de Oliveira, Maurício Roger Mendes, Noelle Uvinha, Pedro Caetano da Silva Lopes, Priscila Patrocínio Simões, Rafael Ferreira Lima Paulo, Raquel Mota dos Santos, Rechilde Bonifácio, Renata Pinho D’Eugênio Mainardi, Ricardo Pires Soares Filho, Roberta Zannin Rosas, Rodrigo Luiz da Silva, Rubia Kaori Higa, Tathiana de Noronha Prieto, Thiago Amado Veiga Calvo Batista, Tiago de Oliveira Caligiuri. T. 61|H.22|M.39. 2007 53a TURMA Adriana Tiemy Eihara, Alexandra Medeiros Martins, Ana Luísa Vasconcelos dos Santos, Angela Mieko Nakamoto, Barbara Vendrami Rimi, Bianca Bueno Lopes, Bruno Barbieri Canepa, Bruno dos Santos Neves, Bruno Pavan Tavano, Camilla Rodrigues Gonçalves, Cristiano Gomes Pestana, Daniela Silveira Alves da Rocha, Dina Pita de Jesus, Edward Antonio Gavião Lima Junior, Felipe Assaf Navarro Ayub, Felipe Martins de Oliveira, Fernanda Neder de Souza, Fernando Gagliardi, Flavia Ferreira dos Santos, Gabriel Sperandelli Fontes, Leila Lemos Novais, Leonardo Correia Campos, Lídia Faria Ribeiro de Barros, Lucas Ruas Amado, Luciana Capucci de Oliveira, Luciana Silva Vaz, Luciano Fonte Rabelo, Manuela Soffredini Faim, Marcela Lamonato Bastos, Marcelo Costa Choukri, Marielle de Paula Calesco, Marina Otávia Rayis, Mario Marcos Alves Teixeira, Natalia Correa Neves, Omar Yassin Moubarec, Patrícia Lourenço Alves de Camargo, Rachel Mariah dos Santos, Rebeca Rebouças Prisco de Souza, Regina Círio de Araújo Duarte, Roberta Ferreira Sales, Roberta Maria Brito de Almeida, Rodrigo Menescal Souza, Rogerio Tsuyoshi Tamaki, Samantha Fonseca Sasaki, Sthefânia Rosas Candido Rodrigues, Thais Mariana Fernandes, Thiago Gonçalves de Novaes , Vanessa Hubert, Veridiana

Nobre Lopes Teixeira, Verônica de Oliveira Proença, Victoria Salete Garbero. T. 51|H.18|M.33. 2008 54a TURMA Adriana Santa Rosa Alves, Ana Carolina Conceição, André Comitre Neto, Bruno Fernandes Meira, Carlos Lineu Pupo de Oliveira, Cassia Neves Teixeira, Cintia Martins Pestana, Danilo Louveira Paulino, Ede Antonio Bresolin, Edmilson Fonseca da Silva, Eduardo Gonçalves Giorno, Elizabeth dos Santos Giacomini, Erique José Vaz, Fabrício Forganes Santos, Francisco Antônio Thomarelli Spignardi, Gabriel Garcia Barreiros, Guaíra Celi Maia, Guilherme Henrique Adão Thomé Silva, Jader Magno Ribeiro Ferreira, Janaina Santos Comersani, Juliano Reis Fernandes, Leonardo Figueiras de Carvalho, Lívia Salles de Godoy, Liz Dias de Campos, Manoel Carvalho de Araújo, Marcelo Gomes de Nascimento, Marco Antonio Beannucci, Mariana Barbieri Pagani, Mario Britto Passos Gerson, Moysés Barbosa da Silva, Nádia Fratantonio, Patrícia Silva Salgoso, Rosângela de Oliveira, Suelen Dias Roedel, Vanessa Fernandes da Costa, Vanessa Santos Pissolati, Vitor Alexandre da Silva. T.

37|H.21|M.16. 2009 55a tURMA Amim Thomas Taves Jundi, Ana Carolina Marques de Araújo, André de Camargo Simonian, Ariane Lopes Santana, Bruna Alessandra de Lucia Baquedano, Bruno Roberto de Almeida Batista, Camila Leandro Moreno de Figueiredo, Carla Domingues Rodriguez, Carla Mara Marques Torci, Carlos Artur Viana da Silva, Carolina Fassina Oliveira, Claudio Cruz Almeida, Dalila Shibata Requel, Daniel Matos Barros, Eliza Fioravante Pelloso, Fabrício Ferrarez Confort, Fernanda Mota Chaves, Fernanda Stelzer Nogueira Mucci, Gabriela Vieira dos Anjos da Silva, Isabella Cardoso Panucci, Johnny Gomes Teodoro dos Santos, Juliana Lara Wiermann Celeghin, Laís Medeiros de Araújo, Leilane Neméth Nagy, Marcelo Veras Ferruccio, Marcos Paulo Cordeiro Santana, Maria Carolina Simas Simões, Mayara Menescalco Moran, Nathália Manzano Afonso, Paulo Henrique Brant de Carvalho Ferranti, Patrícia Magalhães Gonzalez, Priscila Batista de Menezes, Priscila Porto Bragança Tavares, Roberta dos Santos Martins, Sandra Regina Oscalis Martins, Suzanne dos Santos Franck, Talita Duarte França, Viviane Morelli da Silva T. 38|H.11|M.27. 2010 56a TURMA Alexandre dos Santos Zecchin, Aline Miranda da Silva Bonfá, Ariadne Ferreira Penna dos Santos, Aritai Machado Pinto, Bruno Molinari Campos, Camila Martins Sansivieri, Carolina Crocelli Souza Lins, Clarissa Alves Francisco, Daniele Scarlate Barros, Daniella Romani Vidal, Diego Santos Carvalhinho Lopes, Eliza Matias Amon, Fabrício Mendrot Pinho Pereira, Flávia Gambôa Correia, 
Gabriela Sousa Chagas, Hanaí de Mello Gomes, Helena Aparecida Peres Rodrigues, Heraldo Mesquita Prado, Juliana Kovalevski Bento Porto, Kely Picado Oliveira, Laila Apene Feitosa, Leandro Ramos Figueiredo, Leonardo Isaac Nishimoto, Letícia Kanashiro Cardozo, Luana Rossi Dias, Mariana Abussamra Vianna de Lima, Mariana Paiva Lobato Bozza, Mauro Olímpio Menezes da Silva, Munique Varela Lucena, Natalia Santos de Paula Leite, Náthali Domingos Nunes da Silva e Silva, Nicole Moreira Morgado, Nilson Marques Matos, Patrícia Akemi Iraha, Patrícia Waldomiro Silva Esteves, Pedro Augusto Assaf Navarro Ayub, Pedro Nuno Alegria Canton, Priscila Afonso Mendes, Rafael Taboranski Silva, Rafaelly Mangifeste Vianna, Raphael Gomes Monteiro Soriano de Oliveira, Raquel Figueiredo Alves, Raquel Quintas Saraiva, Raquel Villar Arasaki, Renan Carneiro Freire Mazzaro, Susan Caroline Dão Pereira, Thiago de Mello Gonçalves. T. 47|H.16|M.31.

2011 57ạ TURMA Alda Paulina dos Santos, Amanda Mehanna Khamis, Amanda Monteiro Balio Marques, Ana Luisa Lopes Sangueirosa Augusto, André Felipe Helu Martorelli de Luccas Lima, Bárbara Correia Saraiva, Carlos Augusto Novita Faria Jacquet, Caroline Elkis, Cláudio dos Santos Lima Ferreira, Erika Socorro Novais, Isabela Delgado Moreira Velzi, Juliana de Amorim Corrêa, Karina dos Santos Assis, Kátia Garcia Lesk, Kauê de Oliveira Antonio, Leandro Alves dos Santos, Linda Mattoli, Marcela Sion Pardal, Marcos Vinicius Nascimento da Silva, Marcus Vinícius Bezerra Leite, Mariah Rocha Peruzzo, Marcella Araújo Rached Mariana Barbosa da Silva, Mariana Vila Nova Xavier Villela, Mariana Victor de Faria, Milena Lopes Magalhães, Paula Buoro Joaquim, Paula Emy Aquino, Renata Braga Bendito, Renata Coutinho Marques Rodrigues, Rodrigo Carvalho Pereira, Rodrigo França da Silva, Soraya Silva da Luz, Tarso Roberto da Silva, Tatiane Pinheiro Silva, Tomás Leme Simoni, Vinícius Ismerim Santos de Lara, Vivian Miranda da Silva, Washington Aparecido Barbosa Silva. T. 39|H.13|M.26. 2012 58a TURMA Adriana Gonçalves Martins, Alexandre de Souza Aguia , Aline Fernandes de Sá Jorge, Aline Oliveira Farias, Ana Paula Dubas, André Farias Cavaco, Beatriz de Almeida Ramos Sonnenhohl, Bruna Luchese Baptiste, Camila Peres Lopes, Carina Claro Natarelli, Carla de Pinho Mendanha, Chadia Caled Ali, Cibele Cecily Silva de Araújo, Cintia Miyahira, Daniela Braga Pereira de Carvalho, Danielle Talamo Fontaneta, Denis Ferri da Silva, Dhiego Magalhães Torrano, Douglas Alexandre Ribeiro Silva, Fabio Luiz de Souza Carlos Junior, Guilherme Ribeiro Morganti, Karoline Campos Martins, Kaue Toyama Morozetti, Kevan Carvalho Fonseca, Ludmyla dos Santos Leôncio Silva, Luma Cristina Barbosa Serrachioli, Marcela Mazzonetto Medeiros Fonseca, Marcella Ornellas Torres, Marcelo Roberto Pucciarello, Marilia Fernanda Ferreira de Oliveira, Mayra Serrano de Barros, Otto Theodoro Pupo de Moraes Neto, Paulo Eduardo de Oliveira Andrade, Paulo Roberto Santos Petrucci, Pedro Ribeiro de Castro Matheus, Quirino Alves Carneiro Neto, Raphael Marques Graça Lopes, Riad Yassin, Roberta de Castro Souza, Robson Libório Lemos, Samara Nishino Bueno de Freitas, Suellen Carvalho de Sousa, Tarcísio Mateus, Thais Caldeira Brandt Almeida, Thiago Telhado dos Santos, Yves Danillo Bocutti. T. 46|H.21|M.25. 2013 59a TURMA Alles Godoy Maia Mallegri, Ana Claudia Louzã Mathias, Bruna Alipio Laiz, Caio Gonzalez dos Santos Carolino, Camila Rodrigues Martinez, Carolina Prudente dos Santos Fiuza, Caroline Martins Tavares da Silva, Caroline Rodrigues Lucas, Catarina Fonseca Barbosa, Cibele Correia de Sousa, Cleber Telles Lima, Elaine Fratini, Elis Daniela de Oliveira, Felipe Xavier da Silva, Flávia Moreira Xavier, Franciele Alves dos Santos Medina, Gabriel Martins Colombo, Gabriella Pereira Macia, Guilherme Mendez Freire dos Santos, Henrique Lacerda de Menezes, Jacqueline Costa Nunes dos Santos, Juliana Duarte de Lima, Juliana Pete Silva, Karina Martins Carvalho Rodrigues, Lenon Scarpa, Marcela Michaelis Carballido Dominguez, Marcela Pelosi de Almeida, Marcelo Gomes Galdino, Maria Eduarda Salles de Oliveira, Mariana Leite Monteiro, Matheus Santa Cruz, Osmar Alves de Moura Junior, Paula Tedesco Sampaio, Paulo Luvizoto Sampaio, Rafael Carvalho Iplinsky, Rafael Mlatisoma de Andrade, Raffael Farias de Souza, Rafael Rodrigues de Freitas Miranda, Raquel Germano Ferreira, Swell Troisi de Savoia, Taynã Daval, Valeria Takagochi, Vinicius Moreira Domingues, Wlysses Sousa

Ruiz, Yasmin Alonso Rua. T. 45|H.19|M.26. 2014 60 a TURMA Adriana Lamoglia Barbieri Alcântara, Amanda Bontempi Batista, Amanda Fonseca de Moraes, Beatriz Cavalcanti Matos, Bianca Simões Corrêa, Bruno Schmelzer de Souza, Carlos Eduardo Justos da Silva, Danilo Barbosa Morais, Elaine Cristina Fernandes Prior, Everthon Eduardo de Andrade, Fábio Hás Moscariello, Felipe Benedito Simões, Felipe Cagno Lovecchio, Gabriel Pires de Camargo Curti, Gabriela Kotur, Helton Matias da Silva Sousa, Igor Morais Silva, João Daniel Ribeiro Nogueira, Jason Adriano da Silva, Jorge Paulo Antunes de Oliveira, Juliana de Matos Santos Braga, Letícia Felipe Pérsico, Letícia Medeiros de Araújo, Luis Roberto de Medeiros Oshiro, Marcela Lourenção Cortez, Maria Clara de Faria Fernandes, Maria Thereza Vazquez Pimentel, Mayara Zambelli Silvino, Milena Jesus dos Santos, Patrícia Mendes Borges, Paula Corsi Mariano, Paula dos Santos, Pryscila Zahi Zeitani, Rafael Pereira, Renata Castanheira Cunha Mendes, Rita Rodrigues Roriz, Roberta Haruê de Oliveira Kuratani, Sabrina Fernanda de Araújo, Taís Ribeiro Capella Francisco, Thainá Rodrigues Xavier da Costa, Thamyris Albuquerque Vasconcelos, Tuanny Suemy Mendes Moria, Vivian Terni de Mello. T.

43|H.15|M.28. 2015 61a TURMA Aline Melo de Abreu, Alisson de Jesus Santos, Amanda Ramirez Penteado, Ana Paula Rosa Pereira, André Luiz Pereira da Silva, Andressa Torres Veiga, Ariane Teixeira Tabosa, Barbara Letícia Amir Bahmad, Beatriz Dias de Souza, Bianca Silva dos Santos, Bruno Cabaleiro Brito, Camila de Freitas Leal Madeira, Carolina de Medeiros Lopes, Cassia Pugliese Piccolo, Cassio Fialho, Claudia Laurindo Villela, Danielle Dias Costa, Drielle dos Santos Lima, Elis Lima dos Santos, Felipe Daveis Malavasi, Fiama Evangelista da Costa, Gabriela Caporossi, Gabriela Jaques Martins da Silva, Henrique Souza Bernal, Jaqueline Bezerra da Silva, Jéssica Aparecida Rampim de Santana, Jéssica Reis da Conceição, João Guilherme, Karem Amaro Pimentel, Laryssa Fernanda Silva Pereira, Luisa Leme Simoni, Luiza Assis das Chagas, Luma Rafaela Salivar, Marina da Costa Laranjeira, Mayara Costa de Ulhoa Cintra, Micke Pimentel, Mirian Fernanda Alves, Naira Curado da Silva, Nathalia Cristinna Pinheiro Barros, Olivia Peralta Miranda de Carvalho, Osvaldo Abreu da Silva, Rayssa Modé Ferreira, Romulo Teixeira Miguel Machado de Oliveira, Sabrina Coelho Antunes, Silie Regina Takeuti Riciluca, Tainá de Sousa e Sousa, Tamyris Carolina Gomes Fernandes, Tânia Neves Teixeira, Thiago Vieira Carvalho, Taynah Spinola Francisco, Victoria Ferreira Rodrigues, Vitória Tavares Pessoa. T. 52|H.11|M.41.

2016 62a TURMA Amanda Merighi Bastos, Amanda Nobrega dos Santos, Andrea Hassan Zoghaib, Anna Elis Gomes Vilaverde, Arthur Souza Rodrigues, Bruno Alvarez de Lima, Camila Bastouly, Camila de Almeida Macedo Sarabando, Camila Slongo Mrozinski, Ciro Barbosa Mariano, Dandhara Lemos Pinto, Deborah de Campos Fontes, Desyrée Christine da Silva Gomes, Gabriel Augusto de Araújo Cortez, Gabriel Menezes de Souza, Jéssica Paulos Tavares Paraduça, Juliana Toriglia, Leonardo da Silva Amado, Livia Hidd Vasconcelos, Lívia Silvares Lotito, Luany Costa do Carmo, Lucas de Oliveira Cliquet, Luís Gustavo Cabral Souza Silva, Luiz Guilherme Varela Alves, Maria Fernanda Duarte Marques, Mariana Silva Fagundes, Marjory Tunisi Araia, Pérside da Silva Oliveira, Priscila Silva de Oliveira, Raphael Sakai Mendes, Renato Trocoli Rodrigues, Sérgio Silva de Oliveira, Sonia Aparecida dos Santos, Tatiane da Silveira Rocha Santos, Thais Ribeiro Vequione, Thamyris Pereira Gomes, Valmir Tavares Junior, Vanessa da Silva Paz, Vitória Regina Lopes Mendes, Viviane Mancilha Franchi, Walter Barroso Neto, Wanderson Alquimin. T. 42|H.15|M.27. 2017 63a TURMA Amanda Guerra de Oliveira Andrade, Bianca Teixeira Cavalhieri, Demontier Meireles Vasconcelos, Felipe Lobo Domingos da Silva, Helena Alejandra Sviaghin Coelho, Luiza Rodrigues de Padoan, Rachel Grandi de Freitas, Raphael dos Santos Silva de Paula, Rebeca Lucas Ribas, Rodrigo Cabral, Vinícius Araújo de Oliveira. T. 11|H.05|M.06. 2017 64a TURMA Allan Rodrigues Virga, Ana Beatriz Alonso de Oliveira, Ana Caroline Gonçalves da Silva, Andréa Toth Teixeira, Andressa Carvalho de Oliveira Xavier, Beatriz Correia dos Santos, Beatriz da Cruz Barros Fonseca, Carolina da Conceição Alfredo Rijo, Carolina de Souza Ventura, Catarine Castro Rosendo Datoguêa, Edson Felipe Monteiro Gonzalez, Fábio de Souza Ventura, Flávio Henrique Moura Morello de Quadros Vecchi, Gabriel Grilo Pestana Bittar, Giovana Nayumi Miyashiro, Henrique Ribas dos Reis, Ingrid Lopes Costa, Izabela Volpi Fernandes Aguiar, Juliana Fernandes dos Santos, Juliana Melo Moraes Lima dos Santos, Karen Christine Nogueira, Karen Nunes da Silva, Larissa de Souza Varaschin, Leticia Cruz da Invenção Silva, Lucas Avona de Carvalho, Marcos Sousa Santiago, Mariane de Alencar Prado, Marilia Jordão Martins, Marina Fernandes Quintana, Maurício Zati, Mayara Gomes da Silva, Milena Ricciotti Cardoso, Miriam Pestana Alves, Nathalia Morais da Costa Marques, Paloma Domingos Nunes da Silva Ribeiro Fontes, Pamela Pacheco Guilherme, Patrícia Guimarães da Silva, Pedro Andriani, Pedro Matsumoto França, Rafaela Batisti Justo, Soliana Pereira da Silva, Steffani Cadete Aud, Talita Coelho Pereira Fernandes, Thais Heitor Valente Vieira, Thalita da Silva Lima, Thiago Viola Coscarelli. T. 46|H.12|M.34 


\title{
ANEXO
}

\author{
Oração do Paraninfo
}

Segue a transcrição na íntegra o discurso de paraninfo da primeira e segunda turma de formandos da FAUS em 1976, respeitada a grafia da época, esse documento ficou conhecido como "Oração do Paraninfo", constitui o principal registro disponível do período de gestação, fundação e início de atividades da FAUS.

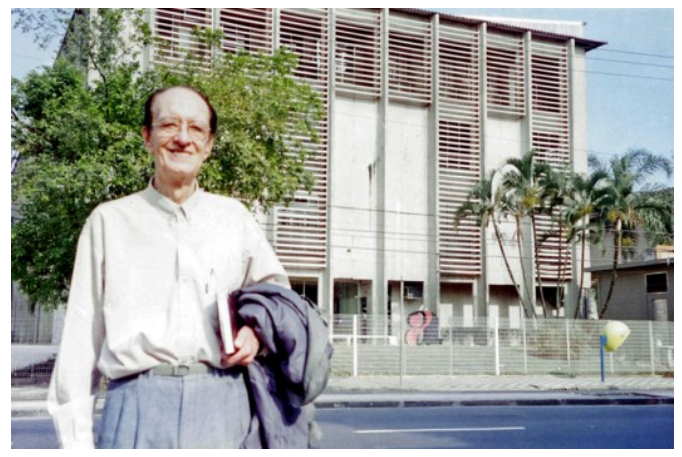

Oswaldão diante da FAUS em 2004. Arquivo Gino Caldatto.

FACULDADE DE ARQUITETURA E URBANISMO DE SANTOS

(Colação de grau da 1a e 2a turma da FAUS - 04/05/1976)

Oração do Paraninfo

A idéia da creação de uma Faculdade de Arquitetura ocorreu em 1969 em consequência da existência nessa época, em nossa cidade natal - Santos, bem como nos munícipios vizinhos, de um surto de desenvolvimento territorial urbano, social e econômico marcante e da instrumentação para controlar esse desenvolvimento, recentemente creada em Santos pelo Prefeito Municipal de então, Eng.o Silvio Fernandes Lopes com a promulgação do Plano Diretor da Cidade e, 1968. Trocamos idéias com o Arq. Aníbal Martins Clemente antigo Presidente do Núcleo de Santos do Departamento de São Paulo do Instituto de Arquitetos do Brasil e naquela ocasião presidente da PRODESAN, empresa pública incumbida de pôr em execução o Plano Diretor. Os arquitetos propuseram ao Senhor Bispo, presidente da Sociedade Visconde de São Leopoldo, a creação da FAUS sob a égide desta mantenedora que se mostrava, como entidade de ensino superior, mais categorizada para conter uma Faculdade de Arquitetura. O Presidente da Sociedade quis conhecer primeiro a opinião do Instituto de Arquitetos do Brasil - Departamento de São Paulo.

O órgão de classe dos arquitetos em nosso Estado havia recentemente firmado posição, face ao início do surto de creação de Escolas de Arquitetura, enviando ao Reitor da Universidade de São Paulo, extenso ofício esclarecendo como os arquitetos viam a creação de novas Faculdades, posicionando-se contra a proliferação indiscriminada de Escolas, mas favorável inteiramente a creação de Escolas, capazes de ministrar o ensino em alto nível e corresponder aos reclamos do desenvolvimento do país.

Esta posição era e é a posição dos arquitetos que pensaram a Faculdade de Arquitetura de Santos. A responsabilidade era de: crear, não uma Escola a mais, porém sim a Escola capaz de ministrar o ensino, voltado para os altos interesses do país, preocupada com os problemas nacionais, e propondo soluções para os problemas do desenvolvimento da região e prestando serviços a coletividade local.

O elenco de arquitetos convidados a formar o embrião, que deu vida a Faculdade garantiu esse propósito. À reunião histórica de fundação da FAUS estiveram presentes os arquitetos Julio Katinsky, Abrahão Sanovicz, Benno Perelmutter, Mayume Watanabe Souza Lima, Rodrigo Brotero Lefèvre e Gabriel Bolaffi. Com o voto de confiança expresso pelo presidente da Sociedade Visconde de São Leopoldo e grande entusiasmo foram tomadas as primeiras medidas necessárias e suficientes para instalação e funcionamento da Faculdade. A instalação inicial foi feita em dependências da Sociedade Visconde de São Leopoldo no prédio atualmente ocupado pela Faculdade de Filosofia. A seguir, rumamos para o Rio de 
Janeiro, Monsenhor Manoel Pestana, Aníbal Martins Clemente e eu para obter a autorização do Conselho Federal de Educação. Vários dias se passaram de muito trabalho e perseverança para conseguir do Conselho Federal de Educação, ainda naquela cidade, a autorização para funcionamento, que se consumou pela aprovação em plenário do voto favorável do relator, Conselheiro Flavio Suplicy de Lacerda.

O primeiro exame vestibular de caráter inusitado para alguns, inovador para outros, realizou-se em dependências da Escola Escolástica Rosa. Os 70 alunos da 1a turma tiveram aula inaugural proferida pelo agora saudoso arquiteto Luís Saia na FAFI. Em seguida iniciávamos o percurso de instalações deixando as dependências da FAFI e passando para um pavilhão atrás do prédio principal a Av. Ana Costa, seguindo de novas instalações em 1971 à Av. Senador Feijó, no segundo andar e em 1972 no terceiro andar do Colégio Santista, sem direito a elevador e finalmente prédio próprio que agora ocupamos ao lado de nossa co-irmã Faculdade de Direito, com o reconhecimento da Escola.

O entusiasmo e o interesse de alunos e professores permitiram essa longa caminhada para chegarmos com sucesso à sede atual, que as duas primeiras turmas, pioneiras que foram em 1970 e 1971 só conhecem agora e da qual desfrutarão certamente já com o título de Arquitetos, seja como professores ou como estudiosos de cursos de pós-graduação e outros que vierem a se realizar.

Reconhecimento da Escola. Poucos poderão imaginar o valor do seu significado para os que ora se formam e para o corpo docente e dirigente da Escola.

Significou a necessidade de prédio próprio com espaços enormes para ateliers e outras instalações apropriadas ao ensino da arquitetura e urbanismo. Significou entusiasmo e sacrifício dos dirigentes da S.V.S.L., da FAUS, dos professores e alunos. Desde a compra do terreno em época difícil, pela Sociedade Mantenedora, do empréstimo para construção pelo Governo do Estado através da Caixa Econômica do Estado de São Paulo, até sua execução em pré-moldados, que por isso mesmo deveria ser rápida e foi demorada. A elevação diária do custo da construção se tornava sem efeito os orçamentos sucessivos. Foi necessário reforço do financiamento inicialmente concedido. Nessa oportunidade foi decisiva a atuação junto ao Governo do Estado do Eng.o Silvio Fernandes Lopes, antigo prefeito de Santos, membro da S.V.S.L. e grande amigo da Faculdade.

Somente em 1975, executado o prédio, que agora ocupamos, mas não está concluído, tivemos condições de reivindicar o reconhecimento. A primeira turma de alunos termina o curso em dezembro de 1974 e aguarda confiante, mas ansiosa esse reconhecimento. A segunda turma (dez. 1975) se junta a primeira na expectativa que é de todos, confiante, mas preocupada. Grande é o trabalho das administrações da S.V.S.L. e da FAUS na montagem do processo, seu encaminhamento e acompanhamento. O processo chega ao estágio final depois da vistoria da Comissão Verificadora, composta pelos arquitetos David Ferreira Lima e Frederico Rosa Borges de Holanda. Será relatado pelo Conselheiro Edson Machado de Souza, diretor do DAU. Ele promete para janeiro na semana em que está reunido o Conselho, segue, porém, com o Ministro Ney Braga para o Norte e não volta em tempo hábil. Fica para a sessão de fevereiro. Nos dias de fevereiro que antecedem a sessão, foram mobilizados os contatos e relações de todo tipo e escalão no sentido de que o relator não protelasse mais a inclusão na pauta do processo do nosso reconhecimento, que finalmente acontece no dia 12 de fevereiro de 1976. Terminou a jornada? Tudo resolvido? Nada disso. Falta a remessa ao MEC para encaminhamento, ao gabinete do Ministro para homologação do decreto respectivo. $O$ tempo passa e uma data limite aparece: 15 de maio para os formando que já trabalhando junto a entidades do poder público não poderão ser contratados depois dessa data em decorrência da lei eleitoral. Reinicia-se, então, com mais ímpeto, a corrida contra o tempo. Contato com o Presidente do CREA-6a Região, Eng.o Máximo Martins da Cruz, que se prontifica a identificar os formandos, porém, condiciona a entrega de carteiras profissionais à Colação de Grau.

Viaja-se a Brasília, mais vezes. O processo está no gabinete do Ministro para homologação. Os formandos também se mexem e telefonemas de Silvio Havas e Sergio Wagner a elementos do gabinete são feitos. Nós também telefonamos e pedimos. É dia 9 de abril. Encontramos em Brasília Athiê Jorge Coury, deputado federal e membro da S.V.S.L. Seu escritório na Câmara é sucursal de Santos. Ele assume as rédeas finais da tramitação e com pertinência e dedicação, nos transmite na quarta-feira santa (dia 14) a notícia de que o decreto havia sido assinado naquele dia pelo Presidente da República e seria publicado no Diário Oficial da segunda-feira dia 19, o que realmente aconteceu. Termina assim uma luta árdua e longa de providências e procedimentos.

Agora mais tranquilos e dependendo de nós mesmos, finalmente realizamos esta primeira colação de Grau de diplomados pela FAUS de Santos.

Este depoimento faz-se necessário para registro da história da nossa Faculdade.

Presença na Baixada Santista.

O Acerto da creação de uma Faculdade de Arquitetura e Urbanismo em Santos, pólo de desenvolvimento da Baixada Santista é comprovado pela procura cada vez maior da mocidade estudiosa, presente aos exames de vestibulares. Por outro lado, a solicitação e demanda, seja por parte da iniciativa privada, seja por parte do poder público, do concurso de nossos estudantes, para utilização de seu conhecimento, ainda em fase de formação, em prestação de serviços da sua futura especialidade, dizem do acerto daquela decisão. Hoje a Faculdade de Arquitetura e Urbanismo de Santos já constitue um patrimônio, não só da cidade, mas da região e do Estado. Como elemento ativo da cidade está em condições não só de prestar serviços a sua comunidade, mas também reivindica o direito de emitir opinião sobre os seus destinos.

Meus caros colegas arquitetos: 
É importante acentuar agora o significado do título que acabais de receber. O que significa ser arquiteto. No nosso entender significa preocupar-se com o seu semelhante e dedicar-se dentro de nossa atuação profissional a resolver os problemas das cidades, das casas e das coisas, melhorando as condições de vida daqueles que usufruirão ou sofrerão as consequências de nossa intervenção como arquitetos no meio ambiente, hoje cada vez mais conturbado e poluído pelo próprio homem e já pondo em risco, a sua sobrevivência.

A sociedade cada vez mais se conscientiza da contribuição que pode receber deste profissional - o arquiteto. Entretanto ainda depende muito de nós faze-la conhecer a gama cada vez mais ampla de nossa faixa de atuação. 0 arquiteto não é somente elemento capaz de propor soluções aos problemas da cidade, das casas e das coisas, mas um elemento pensante preparado para discutir a própria colocação do problema. E tem, como cidadão participante de uma comunidade e do processo de desenvolvimento do país, uma opinião valiosa para seu equacionamento.

É por isso mesmo que a classe dos arquitetos estruturada em várias entidades, cuida não somente dos problemas de classe, mas também procura discutir e equacionar corretamente os problemas nacionais e encaminhar suas soluções. Cincoenta anos de existência do Instituto de Arquitetos do Brasil atestam nossa afirmação. Nestas cinco décadas o I.A.B. teve ocasião de participar de muitos eventos e realizar pronunciamentos válidos para o interesse nacional.

Poderemos dar o testemunho de alguns que nos ocorrem neste instante: o 10 Congresso Brasileiro de Arquitetos realizado após a 2a Grande Guerra Mundial em 1945, em São Paulo, se preocupou com o destino dos abrigos anti-aéreos exigidos nas edificações de então. No Governo do Presidente João Goulart, através do Seminário de Habitação e Reforma Urbana, os arquitetos apresentaram sua contribuição para a reforma urbana. No Governo do Presidente Castelo Branco, ao se crear o Banco Nacional de Habitação o parecer dos arquitetos foi discutido na Câmara Federal. Mas a visão dos arquitetos não acaba no plano nacional. No âmbito internacional o relacionamento dos arquitetos se faz acima da política dos países, conforme atesta a existência da Federação Pan Americana de Arquitetos que congrega os arquitetos de todas as Américas [6], e a União Internacional de Arquitetos U.I.A., cujo trabalho internacional se faz sem distinção de língua, ideologia ou sistema político de cada país, voltada que está para a melhor condição de vida do homem no ambiente que ele organiza.

Além do seu Instituto, os arquitetos mais recentemente possuem como outro instrumento de ação e trabalho, os Sindicatos de Arquitetos em âmbito nacional e os sindicatos regionais implantados em vários estados. Sua atuação na defesa da classe, ombro a ombro com o Instituto, é uma garantia do procedimento correto entre os arquitetos e seus clientes. Para cobrir a área do ensino, no relacionamento entre as Escolas e aprimoramento da formação profissional, no instante em que estão implantadas 30 escolas de arquitetura no país, foi fundada em novembro de 1973 a Associação Brasileira de Escolas de Arquitetura, ABEA, que no curto espaço de dois anos e meio já promoveu encontro entre professores em todas as áreas do ensino da arquitetura, bem como cursos de aperfeiçoamento dos quadros docentes propugnando pela elevação do nível de ensino em caráter nacional, minimizando as diferenças regionais, com a troca de informações e de experiências.

Finalmente, a política de relacionamento entre as Escolas de Arquitetura e o Ministério da Educação e Cultura culminou com a criação pelo MEC, através de portaria ministerial, da Comissão de Ensino de Arquitetura e Urbanismo (CEAU), cuja instalação se deu nos dias 8 e 9 de janeiro de 1974. Cabe a esta Comissão recolher subsídios das escolas de Arquitetura e Urbanismo, levantar dados, examinar currículos e ser interprete junto ao órgão público das reivindicações e necessidades das escolas, enquanto ligadas a política de ensino superior do país.

Ao terminar esta longa, mas necessária digressão, agradecendo a honra com que fui distinguido, escolhido que fui por unanimidade dos formandos, de 1974 e 1975 para seu paraninfo, declaro que aceitei esta distinção levando em conta que representamos neste instante a imagem do professor e do administrador, e que a mocidade de hoje, como sempre, por mais irreverente que seja, sabe discernir, reconhecer e tomar posição perante aqueles que como nós, participaram do processo de sua formação acadêmica, no decorrer do qual, atitudes foram tomadas convergentes umas, divergentes outras, porém sempre com lealdade, correção e espírito aberto.

Meu conselho final:

Pautai a vossa conduta e atuação como cidadãos e como arquitetos pelos mesmos princípios que regem os objetivos de nossa Faculdade: que reza no artigo cinco do seu regimento: para alcançar seus objetivos, a Faculdade reger-se-á pelos princípios de liberdade de investigação, de ensino e de expressão, manter-se-á fiel aos requisitos de método científico e estará sempre aberta, com o objetivo de estudo e pesquisa, a todas as correntes de pensamento científico e cultural.

Felicidade a todos vocês e muito obrigado 